\title{
OPTIMIZATION OF ORGANIZATION AND LEGAL SOLUTIONS CONCERNING PUBLIC REVENUES AND EXPENDITURES IN PUBLIC INTEREST
}

(CONFERENCE PROCEEDINGS)

\author{
EDITORS: \\ EWA LOTKO
}

URSZULA K. ZAWADZKA-PĄK MICHAL RADVAN 
Optimization of Organization and Legal Solutions concerning Public Revenues and Expenditures in Public Interest

(Conference Proceedings) 

Optimization of Organization ANd Legal Solutions CONCERning Public Revenues and Expenditures in Public Interest

(Conference Proceedings)

\section{EDITORS:}

EWA LOTKO

Urszula K. ZawadzKa-PĄK

Michal Radvan

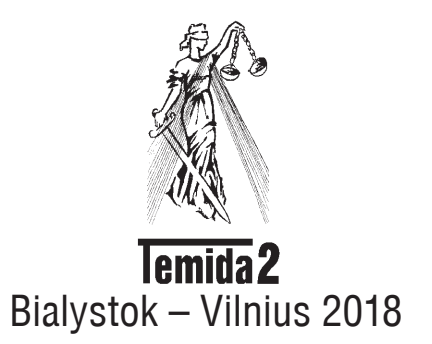




\title{
Advisory Board:
}

Members from University of Białystok: Emil W. Pływaczewski, Stanisław Bożyk, Adam Czarnota, Leonard Etel, Ewa M. Guzik-Makaruk, Adam Jamróz, Dariusz Kijowski, Cezary Kosikowski, Cezary Kulesza, Agnieszka MalarewiczJakubów, Maciej Perkowski, Stanisław Prutis, Eugeniusz Ruśkowski, Walerian Sanetra, Joanna Sieńczyło-Chlabicz, Ryszard Skarzyński, Halina Święczkowska, Mieczysława Zdanowicz.

Other Polish members: Marian Filar, Edward Gniewek, Lech Paprzycki.

Foreign members: Liliya Abramchik, Vladimir Babčak, Renata Almeida da Costa, Chris Eskridge, Jose Luis Iriarte Angél, Marina Karasjewa, Bernhard Kitous, Martin Krygier, Petr Mrkývka, Marcel Alexander Niggli, Andrej A. Novikov, Sławomir Redo, Bernd Schünemann, Sebastiano Tafaro, Wiktor Trinczuk, Keiichi Yamanaka.

Editor-in-Chief: Jerzy Banasiuk

Cover design: Jerzy Banasiuk

Publisher: Temida 2, Faculty of Law, University of Białystok

(C) 2018 Center for Information and Research Organization in Public Finance and Tax Law of Central and Eastern European Countries and The University of Bialystok.

ISBN 978-83-65696-08-3

DOI 10.15290/oolscprepi.2018

\author{
Temida 2 \\ Mickiewicza 1 \\ 15-213 Białystok, POLAND \\ Tel.: (+48) 857457168 • Fax: (+48) 857406089 \\ temida2@uwb.edu.pl \\ www.temida2.uwb.edu.pl
}




\title{
Table of Contents
}

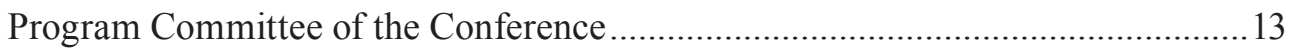

Local Organizational Committee of the Conference................................................. 14

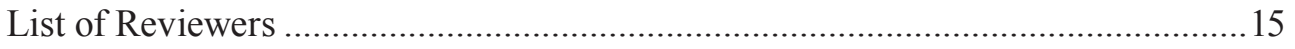

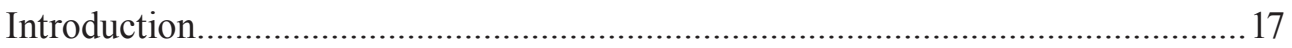

CHAPTER 1

\section{ESSENCE OF FINANCIAL PUBLIC INTEREST}

\author{
SECTION 1.1 \\ NOTION OF FINANCIAL PUBLIC INTEREST
}

VLADIMÍR BABČÁK

Public Financial Interest in Slovak Republic (Certain Reflections). .25

$$
\text { Igor Bartsits, Elena Chernikova }
$$

Public Interest in Russian Financial Law and Modern Legal Science

\section{LiLIYA ABRAMCHIK}

Public Interest in Financial Law of The Republic of Belarus:

Theory and Practice.

\section{Michael Kohajda}

Public Interest in Financial System Law .63

Witold ModZELEWSKI

Public Financial Interest in Polish Tax Law .73

SECTION 1.2

PREMISES OF FINANCIAL PUBLIC INTEREST

Jolanta SzoŁno-Koguc

Rationality as a Basic Condition for Public Finance Reform .85

\section{Yulia GoRosh}

Protection of Public Finance Interests in Terms of Public Finances Management. 
Social Interest in Financial Regulation and the Constitutional Principles 105

Piotr Woltanowski, Róża KosińsKa

The Possibilities and the Practice to Protect the Public and the State's Fiscal Interest by the Constitutional Tribunal

CHAPTER 2

\title{
PROTECTION OF PUBLIC INTEREST IN FINANCIAL LAW
}

\author{
SECTION 2.1 \\ PUBLIC FINANCIAL INTEREST AND EUROPEAN UNION
}

\section{MARCIN TYNIEWICKI}

Protection of the European Union's Public (Financial) Interest in Normative Budgetary Principles

\section{Anna Reiwer-KalisZewska}

The Impact of the Traditional Own Resources on the Budget of the European Union

\section{AdAM P. CHOCIEJ}

Selected Issues on the Protection of the European Union's Financial Interests .... 157

$$
\text { Joanna Czapska, Piotr Woltanowski }
$$

The System of EU Financial Interest Protection under the Common Agricultural Policy Based on the Example of the Payments Related to the Area

AdRIÁn POPOVIČ

Initiatives in the Area of the Financing of the EU Budget in the Context of Environmental Protection.

$$
\text { Maciej Tokarski, Pawee Kufel }
$$

The Role of the Financial Engineering Instruments in the Allocation of EU Funds - the Results of the Research Based on the Example of the Kuyavian-Pomeranian Voivodship 


\section{Oksana Muzyka-Stefanchuk, Nataliya Guberska}

Public Interest in Budget Legal Relations - Ukrainian European Aspect

\section{Marta PostuŁa}

Ten Years of Performance Budget Implementation in Poland

- Successes, Failures, Future 243

\section{Aleksei G. Paul}

Performance Budgeting and Medium-Term Financial Planing in the Russian Federation

\section{ELENA Kireeva}

Public Interests Provision in the Activities of Control and Accounts Bodies of the Subjects of the Russian Federation

\section{RADIM BOHÁČ}

Revenues and Expenditures of Public Budgets in the Czech Republic Related to Gambling .281

\section{Barbara Roszkowska-Mądra, Elżbieta Zalesko}

Sources of Financing Public Goods in Polish Agriculture 291

SECTION 2.3

PROTECTION OF PUBLIC INTEREST IN SPECIFIC ISSUES OF FINANCIAL LAW

Hana Marková

Municipalities and the Solution of Expenditure in the Public Interest and Indebtedness.

Urszula K. ZawadZKa-PĄK

Model of Public Accountability for Public Debt Reduction in Public Interest ..... 313

Katarzyna WóJTOWicz

Sub-National Constraints of Fiscal Policy-Review of the Experiences of Selected Countries 
Table of Contents

StanisŁaw Pilżys, Robert Aliukonis

Budget Deficit and Public Debt in the Baltic States in 2010-2015.

\section{Eva TomÁšKovÁ}

Optimization of Pension Companies in the Czech Republic

\section{Michą MariaŃSKI}

Optimization of Public Income and Expenditure in the Social Interest and the Development of Local Companies in French Law

JoHAN SCHWEIGL

Central Bank Digital Currency - the Latest Challenge for the Theory of Monetary Law ..... 385

\section{KRYSTIAN JASZCZYK}

Public-Private Partnership in Terms of the Contract for the Construction of District Hospital in Żywiec as an Example of Optimization in the Public Interest 391

ANDRZEJ TOKARSKI

The Phenomenon of Bankruptcy of Enterprises in the Polish Economy in the Years 2008-2015.

\section{CHAPTER 3}

\section{PROTECTION OF PUBLIC INTEREST IN TAX LAW}

SECTION 3.1

PROTECTION OF PUBLIC INTEREST IN GENERAL ISSUES OF TAX SYSTEM AND FISCAL ADMINISTRATION

Leonard Etel, Mariusz Popeawski

Weighing the Interest of the Obliged and the Public Interest in the Polish Tax Law.

\section{MÁRIA BujŇÁKovÁ}

Tax Law and its Impact on the State Budget

$$
\text { Aleksander Kostyukov, Kirill Maslov }
$$

The Role of National Fiscal Security and Tax Sovereignty in Collection of Taxes 
Katarzyna Święch - KuJAwsKa

Premises of Granting Reliefs in Payment of Tax Liability 461

\section{Matgorzata Ofiarska}

A Poviat Governor as a Party to the Agreement Transferring the Ownership of Objects and Property Rights to the State Treasury or a Local Government Unit in Exchange for Tax Arrears

\section{ZBIGNIEW OfIARSKI}

Public Interest as a Positive Condition of Applying Reliefs in Payment of Non-Tax Public Law Liabilities to State

\section{EWA LOTKO}

Tax Motivation as an Instrument Protecting Public Financial Interest 509

WoJCiech Morawski

The Tax Rulings - the Conflict Between the Principle of Legality and the Principle of Legitimate Expectations 521

Natalia A. Soloveva

Transformation of Direct and Indirect Taxation's Correlation as a Necessary Condition for Social and Economic Development of the State 533

ElżBieta A. AmbrożeJ

Protection of the Public Interest and the Taxpayer's Interest as the Goal of Tax Advisory in Poland

\section{KRZYSZTOF TESZNER}

The National Fiscal Administration - Challenges and Expectations .563

JoZEF SÁBo

The Reasoning about Evidence in Tax Matters

$$
\text { Piotr Woltanowski, Róża Kosińska, Joanna Czapska }
$$

Protection of Rights of Taxpayers That Are Not Defined as Physical Persons in Poland

\section{Ewa KoniuszewsKa}

Referendum for Self-Taxation as a Form of Participation of Commune Residents in the Shaping of its Revenues 
New Challenges and Perspectives in Customs Law 615

SECTION 3.2

PROTECTION OF PUBLIC INTEREST IN INCOME AND SALES TAXES

\section{ARtur Mudrecki}

The Principle of Proportionality in Value Added Tax

\section{Zuzana Marethová, Petra Snopková}

Electronic Registration of Sales in the Czech Republic - Theory and Praxis

\section{KATARZYNA KOPYŚCIAŃSKA}

"Pre-Factor" in the Tax on Goods and Services .665

\section{ERNeST GinC}

Structure of National Sources of Financing of Road Infrastructure in Lithuania.

\section{Roman VyBíRAL}

Public Interest in Taxation of Professional Sportsmen in the Czech Republic

$$
\text { MichAL LišKA }
$$

Formal Values of Law with Emphasis on Recent Case Law of the Taxation of Athletes

\section{Marie KarfíKová}

Optimization of Public Revenues and Expenditure

Michal Radvan

Czech Tax Heaven for Sportsmen

\section{WiesŁaWA Miemiec}

Depreciation Methods and Rates as an Instrument of Optimization of Direct Taxes 


$$
\text { IvANa ŠTIEBEROVÁ }
$$

Few Notes on Measures to Prevent Tax Evasion

and Tax Fraud - What Is the Interest of Society?

Miroslav Štrkolec

Security Measures in Tax Administration as a Tool to Eliminate Tax Evasions

$$
\text { Karolína Č́rvena, Anna Románová }
$$

Economic-Political Causes of Tax Evasion (Theoretical Background) 767

RICHARD BARTES

Juridical Institute of "Fiscal Repentant" 



\section{PROGRAM COMMITTEE OF THE CONFERENCE}

Prof. Jan GŁUCHOWSKI - Chair - Nicolaus Copernicus University in Toruń and WSB University in Toruń, Poland

Prof. Liliya ABRAMCHIK, Janka Kupala State University of Grodno, Belarus

Prof. Hrvoje ARBUTINA, University of Zagreb, Croatia

Prof. Vladimir BABČAK, Pavol Jozef Šafárik University in Košice, Slovakia

Prof. Maria BUJŇAKOVA, Pavol Jozef Šafárik University in Košice, Slovakia

Prof. Elena CHERNIKOVA, Russian Presidential Academy of National Economy, Russia

Prof. Leonard ETEL, University of Bialystok, Poland

Prof. Ruslana GAWRYLUK, Chernivtsi Yuriy Fedkovych National University, Ukraine

Prof. Jadwiga GLUMIŃSKA-PAWLIC, University of Silesia, Poland

Dr. Gábor HULKÓ, Széchenyi István University, Hungary

Prof. Marie KARFIKOVA, Charles University in Prague, Czech Republic

Prof. Aleksander KOSTYUKOV, Dostoevsky Omsk State University, Russia

Dr. Michal KOZIEŁ, Technical University of Ostrava, Czech Republic

Prof. Hana MARKOVÁ, Charles University in Prague, Czech Republic

Prof. Wiesława MIEMIEC, University of Wrocław, Poland

Prof. Petr MRKÝVKA, Masaryk University, Czech Republic

Prof. Zbigniew OFIARSKI, University of Szczecin, Poland

Prof. Piotr PACZURBICKI, Yuriy Fedkovych Chernivtsi National University, Ukraine

Prof. Krystyna PIOTROWSKA-MARCZAK, WSB University in Toruń, Poland

Prof. Barbara ROSZKOWSKA-MĄDRA, University of Bialystok, Poland

Prof. Eugeniusz RUŚKOWSKI, University of Bialystok, Poland

Prof. Marina SENTSOVA, Voronezh State University, Russia

Prof. Bronius SUDAVIČIUS, Vilnius University, Lithuania

Prof. Mieczysława ZDANOWICZ, University of Bialystok, Poland 


\section{LOCAL ORGANIZATIONAL COMMITTEE OF THE CONFERENCE}

Dr. Urszula K. ZAWADZKA-PĄK

Dr. Ewa LOTKO

Dr. Piotr WOLTANOWSKI

Mgr Robert ALIUKONIS

Mgr Patryk ZABROCKI

Łukasz PRESNAROWICZ 


\section{LIST OF REVIEWERS}

ABRAMCHIK Liliya, Janka Kupala State University of Grodno, Belarus AMBROŻEJ Elżbieta, Higher School of Finance and Management in Bialystok, Poland

BABČÁK Vladimír, Pavol Jozef Šafárik University in Košice, Slovakia

BENDE-SZABO Gabor, Széchenyi István University, Hungary

BOGOVAC Jasna, University of Zagreb, Faculty of Law, Croatia

BOHÁČ Radim, Charles University in Prague, Czech Republic

BRZEZICKI Tomasz, Nicolaus Copernicus University in Toruń, Poland

BUJŇÁKOVÁ Mária, Pavol Jozef Šafárik University in Košice, Slovakia

CAKOCI Karin, Pavol Jozef Šafárik University in Košice, Slovakia

CZUDEK Damian, Masaryk University, Czech Republic

ČERVENÁ Karolína, Pavol Jozef Šafárik University in Košice, Slovakia

ČUNDERLÍK L’ubomír, Comenius University in Bratislava, Slovakia

DOWGIER Rafał, University of Bialystok, Poland

FRANZSEN Riel, University of Pretoria and African Tax Institute, Republic of South Africa

GŁUCHOWSKI Jan, Nicolaus Copernicus University in Toruń and WSB University in Toruń, Poland

JANOVEC Michal, Masaryk University, Czech Republic

KARFÍKOVÁ Marie, Charles University in Prague, Czech Republic

KOHAJDA Michael, Charles University in Prague, Czech Republic

KOSTYUKOV Aleksander, Dostoevsky Omsk State University, Russia

KOZIEŁ Michal, Technical University of Ostrava, Czech Republic

LEMONNIER Mariola, University of Warmia and Mazury in Olsztyn, Poland

LISZEWSKI Grzegorz, University of Bialystok, Poland

LOTKO Ewa, University of Bialystok, Poland

LUBIŃSKA Teresa, University of Szczecin, Poland

MARIAŃSKI Michał, University of Warmia and Mazury in Olsztyn, Poland 
MASLOV Kirill, Dostoevsky Omsk State University, Russia MORAWSKI Wojciech, Nicholas Copernicus University in Toruń, Poland

MUZYKA-STEFANCZUK Oksana, Taras Shevchenko National University of Kyiv, Ukraine

NECKÁŘ Jan, Masaryk University, Czech Republic

PAPOUŠKOVÁ Zdenka, Palacky University, Czech Republic

PAUL Aleksei, Voronezh State University, Russia

PEST Przemysław, University of Wrocław, Poland

POPŁAWSKI Mariusz, University of Bialystok, Poland

REIWER-KALISZEWSKA Anna, University of Business and Administration in Gdynia, Poland RUŚKOWSKI Eugeniusz, University of Bialystok, Poland

SÁBO Jozef, Pavol Jozef Šafárik University in Košice, Slovakia

SARTORI Nicola, University of Milano-Bicocca, Italy

SCHWEIGL Johan, Masaryk University, Czech Republic

SENTSOVA Marina, Voronezh State University, Russia

SHUPITSKAYA Aksana, Janka Kupala State University of Grodno, Belarus

ŠIMONOVÁ Jana, Academy of the Police Force in Bratislava, Slovakia

SOLOVEVA Natalia, Voronezh State University, Russia

ŠTRKOLEC Miroslav, Pavol Jozef Šafárik University in Košice, Slovakia

TOMÁŠKOVÁ Eva, Masaryk University, Czech Republic

TYNIEWICKI Marcin, University of Bialystok, Poland

VYBÍRAL Roman, Charles University in Prague, Czech Republic

WÓJTOWICZ Katarzyna, Maria Curie-Skłodowska University in Lublin, Poland

WOLTANOWSKI Piotr, University of Bialystok, Poland

ZAWADZKA Patrycja, University of Wrocław, Poland

ZAWADZKA-PĄK Urszula K., University of Bialystok, Poland

ZUNIC KOVACEVIC Natasa, University of Rijeka, Croatia 


\section{INTRODUCTION}

Before 1990's the cooperation of financial experts from Central and Eastern Europe countries had, among others, a formula of scientific symposia organized every 2 years by the particular countries of the region. The last of them took place in May 1991 in Opatija (Croatia). The socio-economic and political transformations of the 1990s interrupted this cooperation. However, the need for its establishment and institutionalization continued in academic circles, which is why on 6 September 2002 the founding meeting of the Association Center for the Research on the Public Finances and Tax Law in the Countries of Central and Eastern Europe (in short "Center") was held in Bialystok (Poland).

The Center Association inspires and conducts joint conferences and research, assists in their implementation, collects and makes available information on the Members' scientific initiatives, cooperates with governmental and non-governmental organizations. An important aim of the Association is to promote European standards in the field of public finance and tax law in Poland and the other countries represented by the members of the Association as well as the exchange experience with other countries. The Association brings together ca. 300 members - the representatives of legal, economic and public management science as well as public sector practitioners - from 14 European and Asian countries (Poland, Russia, Czech Republic, Slovakia, Lithuania, Belarus, Hungary, Ukraine, Kazakhstan, Croatia, Bulgaria, Moldova, Romania, France). The "Center" autonomous organizational unit is the All-Russian branch of "Center" functioning since 2008 at the Voronezh State University.

One of the basic ways that the mission of the Association "Center" is fulfilled is through the organization of annual international scientific conferences, which have become a forum for the exchange of ideas, the findings of scientific research and the experience of scientists from several dozen academic centers of Europe and Asia. It seems that the differences in legal systems and regulations in the field of public finance in the 14 countries, which the board members come from, promotes creative discussion at the conferences and the elaboration of effective solutions to problems that exist in practice. The multiplicity of points of view and the variety of solutions analyzed by scientists is a significant value that the Association has brought to the development of the science of financial law in this part of the world for 16 years. 
So far, 16 international scientific conferences of the "Center" have been held (Bialystok 2002, Brno 2003, Vilnius 2004, Košice 2005, Grodno 2006, Voronezh 2007, Paris 2008, Lviv 2009, Prague 2010, Győr 2011, Bialystok 2012, Omsk 2013, Mikulov 2014, Štrbské Pleso 2015, Bialystok 2016, Vilnius 2017), the next one will be held in Prague in 2018. In consequence, so far, 15 monographs have been published that are the result of annual international conferences, i.e.:

- Ruśkowski, E. (ed.): The Budget Deficit and the Public Debt in the Selected European Countries, Bialystok: Publisher of WSFiZ in Białystok, 2003.

- Radvan, M., Mrkývka, P. (eds): Financování územní samosprávy ve sjednocující se Evropě (Financing Territorial Self-government in a Unifying Europe), Brno: Publisher of the Faculty of Law of Masaryk University in Brno, 2005.

- Miškinis, A., Ruśkowski, E. (eds.): Problems of Financial Law Evolution in Central and Eastern Europe within Integration Processes, Wilno-Bialystok: Temida 2, 2004.

- Current Questions of Efficiency of Public Finance, Financial Law, and Tax Law in Countries of Central and Eastern Europe, Koszyce: Publisher of the Faculty of Law at the University of J.P. Safarik in Košice, 2005.

- Guszczyn, I. (ed.), Zhuk, M., Abramchik, L., Ruśkowski, E., Kosikowski, C., Etel, L. Głuchowski, J., Mrkývka, P., Sentsova, М.: Финансовое правотворчество и правоприменение в государствах Центральной и Восточной Европы (Financial Lawmaking and Law Enforcement in the States of Central and Eastern Europe), Grodno: Publisher of Grodno State University, 2006.

- Sentsova, M. (ed.): Modern Problems of Tax Law Theory (Современ- ные проблемы теории налогового права), Voronezh: Publisher of the Voronezh State University, 2007.

- Ruśkowski, E., Tyniewicki, M. (eds.): Basic Problems of Public Finance Reforms in the 21st century in Europe, Białostockie Studia Prawnicze (Bialystok Legal Studies), no. 5 (2009).

- Ruśkowski, E., Zawerucha, I. (eds.): Public Finance and Financial Law in the context of Financial Crisis in Central and Eastern Europe, Bialystok-Lviv: Temida 2, 2010.

- Boháč, R. (ed.): Current issues of finance and financial law from the viewpoint of fiscal and monetary promotion of economic growth in the countries of Central and Eastern Europe after 2010 (Актуальные проблемы финансов и финансо-вого права с точки зрениа фискального и монетарного поощрения хоэяйственного роста в странах Средней и Восточной Европы после 2010 года), Prague: Wydawnictwo Leges, 2010. 
- Hulkó, G., Patyi, A. (eds.): Public finances - Administrative Autonomies, Győr: Publisher of Univerity in Győr, 2012.

- Ruśkowski, E., Stankiewicz, J., Tyniewicki, M., Zawadzka-Pąk, U.K. (eds.): Annual and Long Term Public Finances in Central and Eastern European Countries (Годовое и многолетнее планирование в публичных финансах стран Централь- ной и Восточной Европы, Bialystok: Temida 2, 2013.

- Kostukov, A.N. (ed.): Problems of Application of Tax Law in Central and Eastern European Countries (Проблемы налогового правопри- менения в странах Центральной и Восточной Европы), Omsk: Publisher of State Omsk University, 2013.

- Mrkývka, P. (ed.): System of Financial Law - General Part, Brno: Publisher of the Faculty of Law of Masaryk University in Brno, 2015; Radvan, M. (ed.): System of Tax Law, Brno: Publisher of the Faculty of Law of Masaryk University in Brno, 2015; Blažek, J. (ed.): Financial Markets, Brno: Publisher of the Faculty of Law of Masaryk University in Brno, 2015.

- Babčák, V., Románová, A., Vojníková, I. (eds.): Tax Law vs. Tax Frauds and Tax Evasion, Košice: Publisher of the Faculty of Law at the University of J.P. Safarik in Košice, 2015.

- Etel, L., Popławski, M. (eds.): Tax Codes Concepts in the Countries of Central and Eastern Europe, Bialystok: Temida 2, 2016.

Members of the "Center" take an active part in the Days of Law at the Masaryk University in Brno organized since 2007, as well as in international scientific conferences organized by Michał Rőmer University in Vilnius, Pavel Josef Šafárik University in Košice, Yanka Kupala Grodno State University in Belarus and the Voronezh State University in Russia.

The results of the scientific research of the "Center" Members are presented in the form of comparative scientific monographs, especially on an international scale. So far, about twenty such monographs have been published, issued at the initiative or with the participation of the Association. Monographs analyze selected issues of financial and tax law in the countries of Central and Eastern Europe. The following publications can be mentioned only as an example:

- Etel, L. (ed.): Europejskie systemy opodatkowania nieruchomości (European Real Estate Taxation Systems), Warszawa: Wydawnictwo Sejmowe, 2003.

- Ruśkowski, E., Dolnicki, B. (eds.): Władza i finanse lokalne w Polsce i krajach ościennych (Local Authorities and Finance in Poland and Neighboring Countries), Bydgoszcz-Bialystok-Katowice: Branta, 2007. 
- Popławski, M., Šramková, D. (eds.): Legal Sanctions: Theoretical and Practical Aspects in Poland and the Czech Republic, Brno: Publisher of the Faculty of Law of Masaryk University in Brno, 2008.

- Sentsova, M. (ed.): Tax and Budget law: Modern Problems of Property Relations, Voronezh: Publisher of State University in Voronezh, 2012.

- Ruśkowski, E. (ed.): Stankiewicz, J., Tyniewicki, M., Zawadzka-Pąk, U.K., Roczność i wieloletniość w finansach publicznych (Annuality and Multiannuality in Public Finances), Warszawa: Lex a Wolters Kluwer business, 2014.

The Association publishes two own journals in the form of yearbooks presenting the papers in English or Russian. Since 2008, the "Annual Center Review" has been published by the "Center" together with the Law Faculty of the University of Bialystok. In 2016, an additional issue of the "Annual Center Review" was published devoted to the principles and problems of evaluation and dissemination of the scientific achievements of the Association's members. In turn, since 2010 the "Public Finances and Tax Law" issued by the "Center" and the State University of Voronezh has been published. In addition, the "Center" supports the organizational structure of the international scientific journal "Public Governance, Administration and Finances Law Review" published in Budapest since 2015 by Wolters Kluwer (Hungary).

Thinking about the scientific future, the Association pays a lot of attention to the scientific development of young scientists, the results of their research are published, among others in the "Annual Center Review". With a view to them, the Seminar for Ph.D. Students and Young Researchers was initiated as a part of the annual conference that was held in Vilnius in 2017. In addition, the Association undertakes the task of inspiring double doctorates. In 2015, two such defenses took place as a result of the scientific cooperation of the University of Brno and the University of Bialystok. Currently, the "Center" work on next double doctorates.

More information about the Association and its activities can be found in the Center Scientific Bulletin, edited by E. Ruśkowski, P. Mrkývka, J. Stankiewicz, P. Woltanowski, E. Lotko, Bialystok: Center, 2017, 272 pp., available at the website of the Association (www.ciob.pl).

\section{$* * *$}

The book contains papers sent for the XVI annual international conference of the "Center", which took place in Vilnius in September 2017. The main theme of the conference was the optimization of organization and legal solutions concerning public revenues and expenditure in the public interest. The articles analyzing the 
mutual relations between broadly understood public revenues and expenditure and public interest from the legal, economic and managerial point of view were invited to the publication.

Public interest-based theories are imprecise because the subject of these theories is an ideal rather than a discrete construct. The concept of public interest is sometimes identified with public values, however, the most important distinction between these two concepts is that the "public interest" is the ideal, whereas the "public values" have specific, identifiable content.

This publication is a unique approach to the subject of public revenue and expenditure as so far in Western literature the public interest analysis was conducted within the broadly understood science of public administration, in which legal science does not play an important role. On the one hand, due to the dominance of research on public administration in CEE countries by legal science, and on the other hand, due to the fact that representatives of legal sciences from this geographical area open to issues of public interest, going beyond strictly legal scope of the research, this publication is an important step towards building scientific bridges between representatives of legal scientists from the CEE countries and representatives of public administration and public management scientists from Western countries.

The book consists of three parts. The first one, having the introductory and definitional character present the essence of financial public interest. The second part contains studies on the protection of public interest in the financial law, while the third part discusses the issues of protection of public interest in the tax law.

The first part presents issues of the concept and premises of the public financial interest. The second part presents the issues of the public financial interest of the European Union, the public interest in the budgetary law as well as the protection of the public interest in specific issues of the financial law. In turn, the third part discusses the issues of the protection of the public interest in general issues of the tax system and fiscal administration, the protection of public interest in income and sales taxes, as well as the impact of tax optimization on the public interest.

The published articles have been subjected to a double, and in some cases, triple, blind review. 

CHAPTER 1

ESSENCE OF FINANCIAL PUBLIC INTEREST

SECTION 1.1

NOTION OF FINANCIAL PUBLIC INTEREST 



\title{
PUBLIC FINANCIAL INTEREST IN SLOVAK REPUBLIC (CERTAIN REFLECTIONS) ${ }^{1}$
}

\author{
VLADIMÍR BABČ́́K $K^{2}$
}

\begin{abstract}
The contribution deals with issues concerning public financial interest (with emphasis to conditions in the Slovak Republic). These issues are inherently connected with the notion of the private and the public interests. The opposite character of different kinds of interests manifests itself predominately in issues concerning taxation. Author's opinion is that contradictory positions of taxpayers and the state/municipalities in tax matters reflect opposite nature of private and public interests. Abovementioned topic, which is very interesting, is difficult to analyze since various scientific disciplines describe the general notion of interest differently (for example psychology, sociology or pedagogy). The Author describes the notion of interest as the specific focus of an entity: concentrated attention to the certain thing, the certain activity or certain social relations. With that regard, the Author draws the conclusion that political interests are on the top of the hierarchy of interests in the society while economic interests are realized through them.
\end{abstract}

\section{Keywords}

Notion of interests; public interest; private interest; tax law; financial law; taxation and enforcement of interests

\section{JEL Classification: E62, K00, K34}

1 This article presents a partial output of grant project VEGA n.1/0375/15 "Tax evasions and tax frauds and legal possibilities of its prevention (by institutes of tax law, commercial law, and criminal law)".

2 Professor for Tax law, Head of the Department of Financial Law, Tax Law and Economics at the Law Faculty of Pavol Jozef Šafárik, University in Košice since the establishment of the department in 2001 (formerly called the Department of Financial Law and Tax Law). He is generally regarded as the founder of so-called "Kosice school of tax law", which promotes the independent and autonomous status and operation of the tax law within Slovak tax system. He is the author of seven monographs issued in national publishers, co-author of the four monographs published abroad, the author of the twelve university textbooks in the field of financial law and tax law, the author of 47 abroad published scientific studies and contributions to conferences, the author of 54 scientific studies and contributions to domestic scientific conferences, etc. He is a member of Information and Organization Centre for the Research on the Public Finances and Tax Law in the Countries of Central and Eastern Europe. Contact email: vladimir.babcak@upjs.sk. 


\section{Introduction}

Our opinion is that the fiscal interest of the state, as well as the fiscal interest of self-government bodies, has priority among public interests of the state, although this fact is not often empathized. It should be noted (with certain reservation) that described hierarchy of public interests are prevalent mainly in modern states. During the realization of tax law relations and financial relations, the abovementioned fiscal interests are transformed/ incorporated into specific economic policies of the state (containing as their integral parts financial and tax policies).

With that respect, both state and self-government bodies (from the standpoint of the pursuit of public fiscal interest) are primarily concern about financial and tax legal relations. This result from the fact that the achievement of revenue goals that are set in the state budget/municipally budgets (according to specific territorial and temporal conditions) is necessary for the effective realization of the state functions. The executive power branch (mainly state government) in order to gain financial resources prefers the increase in tax rates (or introduction of new tax measures with similar effect) over cuts in budgetary expenditures. As an argument/excuse for that approach the governments often use "standard" excuse that high level of expenditures serves the interests of the general public. It is regrettable that cuts in expenditure are not to the wider extent used to achieve the rational balance between expected revenues and necessary expenditures of the state. It would be the oversimplification to conclude that abovementioned situation only concerns the Slovak Republic.

In dealing with issues concerning public fiscal interest, we need to tackle several questions like:

- what could be regarded as public interest/how could public interest be defined; from which sources does the public interest arise, how is the perception of public interest shaped by government policies and finally, how could be public interest pursued within actual social condition existing within the certain state;

- what is the purpose of public interest and in what cases does it actually serve only as an excuse/argument for people in government pursuing their private/political-power interests (or for interests and economic ambitions of oligarchs and lobbying groups);

- which issues belong exclusively either to the category of private interests or to the category of private interests;

- how to described vague and interdisciplinary notion of public financial interest; 
- which criteria should be used in the assessment of public fiscal interest in Slovak Republic as an EU member state (which membership lasts for 13 years).

It should be noted that aforementioned questions are related to the notion of public interest as described in the contemporary theory of democracy, which teaches that every government decision should closely follow interests of the general public. It should be further noted those terms: "policy/policy decisions" and "public interest" is broad notions that could have the different meaning for different individual economic entities or social groups. Also, varieties of methods are used by different scientific disciplines in approaching questions: whether the certain issue is in public interest or whether certain policy truly promotes the public interest. Such situation is further complicated by the fact that public interest sometimes loses its importance in the realization of state policies in spite of its previous key importance in the policy-making process of these same policies.

In modern democracies, collective decisions are made by referendum and elections. Therefore each policy decision, in theory, should reflect the will of the majority of the population. From this follows that public interest by definition and according to scholarly literature should maximize benefits to a large number of people. Stated conclusion is based on the doctrine of economic individualism, which stresses the primary importance of private interests. In that conceptual framework, the change in perception of the notion of private interests affects the notion of "public interest" (Ivanovič, 2015) as well (which is changing accordingly).

\section{Description of Various Kinds of Interests and of Interaction between Public and Private Interests}

There is a saying: "money rules the world". Majority of people accept stated opinion as a priory true and they do not think about its further implications. Similarly, people react to the question: "who rules/controls the money". Only hardly one could be imagined such state of affairs in which the circulation of money would be totally independent of any other causes. Potential proponents of such possibility could counter this position by the truism that "money brings money (even bigger money) in time". But this is not a valid argument since the increase in any monetary supply does not result from independent "self-circulation" of money. The modus vivendi for growth in monetary mass during time should be therefore described rather by something/someone else than by the money themselves.

There is an evident answer to the question: "who causes the circulation of money". Without the need to look further into that question it is apparent that banks are 
actually entities affecting and causing the circulation of money in the economy. However, the similar simple answer is not satisfactory for the second part of the question: "what causes the money to circulate".

Various possible answers to that question have been proposed, however, in my opinion, the main factors that create the circulation of money in an economy are public and private interests (and therefore interests subsequently shape the very nature of the global economy). With that in mind, we can describe the general notion of interest as the specific focus of an entity: its concentrated attention to the certain thing, a certain activity or certain social relations. My reason for using term entity instead of a person is that the interests do not concern only natural persons but also various other legal subjects (bodies) as well. Naturally, every scientific discipline, which has interests as an object of study, defines them differently.

In my opinion, each interest is a special type of motivational factor. Interest also functions as a global phenomenon that is expressed in a variety of forms according to different social conditions. Each scientific discipline that is studying interests, offers a different classification of interests according to different criteria. Therefore, we may recognize various distinct classifications of interests in psychology, pedagogy or sociology etc.

The most suitable classification of interests divides the interests into two large groups/classes - the class of public interests and the class of private interests. This classification accurately describes the dichotomy between:

a) public and private social spheres,

b) two economic sectors - public sector and private sector ${ }^{3}$

c) public and private finances,

d) public and private law,

e) public and private administration.

The dichotomy of social phenomena listed under para. a) till e) is prima facie apparent. We can ask whether public interests and private interests are in symbiotic/ synergic interaction or whether their distinct features cause them to be antagonistic. With this respect, the founder of the classical economics A. Smith proposed the notion that the harmony in public and private interests could be achieved (Smith, 1997). If he had been alive today, he might have reconsidered his view (if that had that are: public sector, the private sector and third sector (Klimovský, 2014:95-120). However, I do share the view of R.A. Musgrave, of the division of economy into two main sectors: public sector and the private sector. Cooperation between these two sectors is essential for the economy to perform effectively (Musgrave, Musgreová, 1994: 4). 
been the case, his four tax cannons of taxation would have had to wait until their much later discovery).

I am still convinced that to achieve significant development in economic and social relations the symbiotic/synergic interaction between public and private interests must be the highest that is possible. However, in order to achieve that kind of interaction between various interests, the political compromise between the governments, representatives of employers and representative of employees concerning tax and financial matters is of paramount importance.

The above-mentioned classification of interests into the class of public and class of private interests has certain disadvantages since similar classification could be made only in the theoretical and abstract sense. Furthermore, it is highly difficult to classify actual social phenomena exclusively either as private or as public interests (we may mention our reservations towards efforts to do similar classification).

Actual interests manifest themselves in the outside world mainly as political interests. The politics is by definition a tool for enforcement/pursuit of interests. That is the case whether it comes to economic policy, social policy or any other policies; tax policy, the policy of fees, financial policy etc. with no exceptions. The political interests should represent the will of the majority of people who cast their votes in favor of the winner of the election. Therefore the political interests might be in reality very far from actual public interest: the winner/winners need only to successfully persuade the electorate that his/their campaign promises do represent public interests. With that regard, it is not very important whether the winner/ winners is honest with his/their campaign promises or the winner/winners only use his/their promises to sway the election in his/their favor. We are convinced that even if the latter is true, the winner could repeat his success in future elections: which leads to the conclusion that the saying "the voice of the people is the voice of God" is not so true after all.

Also, we must keep in mind that voters are prone to forget (which is often exploited by politicians). In many cases, the notion of "public interest" is used only as a pretext for populist while pursuing their own interests or interests of business groups. On the other hand, if an individual person, social groups, and other political actors do not only follow their private interests, they could be instrumental in the pursuit of public interest.

We may often encounter policy position, which seems to represent public interests, however, in truth, it is only put forward under influence exerted by lobbying organizations, business groups et Cetera. In this case "public interest" in reality stands for private interests of various groups that are working from behind. These private interests (under the cloak of "public interest") root itself into the legal 
regulations and laws (legal acts) reshaping/changing the true essence of public fiscal interest. As a result, private parties secure for themselves economic advantages and achieve monetary profits. Money, which aforementioned groups obtain after this manner, makes their influence in society even stronger. Therefore in my opinion, in the chest of politics beats a heart made of purely economic interests in the situation when politics serves interests of general public and also in situations when it serves interests of business groups. The highest achievement for every kind of interests is to gain political power, which leads to its prevalence in economic power. Therefore the view which sees politics in close proximity to economic interests seems to be accurate. With that regard, the political interests often stand above both the law and justice. This brings us to the central problem: the role of interests in fiscal relations and finally in tax law relations.

\section{Public Fiscal Interest and its Realization (Pursuit) in the Slovak Republic}

To understand the role of various kinds of interests in fiscal relations/tax relations, it is necessary to understand functions, goals, and values, upon which these relations are based. Different subjects view differently issue of compliance in taxation. Tax law is built upon the conflict of interests of entities obliged to pay taxes and of those who are entitled to receive tax revenue.

Fiscal relations and especially tax law relations have always been marked by the contradiction between public interests of state/municipalities and private-economic interests of persons who are obliged to pay taxes (taxpayers). These interests collide especially during the period before the deadline for the submission of the tax return. The interest of the state is to maximize tax revenue. The taxpayers aim for the opposite outcome and regard taxes as the infringement of their right to own property that results in the violation of their personal liberty. The state/municipality impose levy without any direct consideration of the added value, income or property which belongs/is produced by taxpayers. Therefore I think the taxpayers have natural right to reduce (Babčák, 2015: 69) to the smallest possible amount their final tax burden since taxation restricts their fundamental human rights.

Tax administrators and second instance authorities should enforce public interests of the state and municipalities in tax administration. Furthermore, they should protect public interests in tax relations and serve as forbearers and representatives of aforementioned interests. 
These kinds of public interests are monetary by nature. Fiscal interests are expressed in financial regulations and especially tax law regulations. The main body of these legal acts is enacted by parliament and therefore consist mainly of laws (tax laws).

Tax regulations (tax laws) should clearly and persuasively follow public fiscal interest without overtaxing the taxpayers (the over-taxation impose inappropriate tax burden upon taxpayers and does not bring positive effects on national economy). By setting appropriate condition with respect to the taxation, public fiscal interest can be fulfilled. Tax regulations are shaped by conflicts between various kinds of interests (concerning property, religion issues, nationality etc.). Therefore it is the role of tax law to prevent excess in conflicts in tax matters. If the division between various kinds of interests becomes wider the legislation process in tax matter will become more difficult.

We could ask whether tax laws (acts) have some discretion towards limits of the taxation. The natural level of tax burden does exist in every society and it should not be exceeded by the state. Otherwise, taxpayers either would not be able to pay their taxes or doing so they would undermine their source of income and diminish their personal property (Kosikowski, 2014: 10). With that in mind, some Authors (Schultzová, 2015: 20) stress the importance of the so-called sensitive level of the tax burden. That level of tax burden both enhance the effectiveness of tax administration and also motivate taxpayers to do business or to seek new job opportunities.

In the past, the excess in the level of the tax burden was considered to be sinful; however contemporary world does no longer accept this view and therefore taxpayers are prone to sophistically evade paying their taxes. With that respect, Slovakia is trying to tackle the tax evasion (avoidance) by various actions adopted under the OECD's BEPS guidelines (Action Plan on Base Erosion and Profit Shifting ("BEPS")) and EU's action plan ATAP (Commission: COM (2016) 23 final).

The actual role of public interest in tax relations depends on following factors/ effects:

- The fact that taxes are regulated by law and power to tax always emanates from the public authority. Therefore the tax regulations demonstrate their link to public fiscal policy by such characteristics as specific methods of legal regulation; distinct tax principles, specific delimitation of competence between the tax administrators, distinct kind of various tax measures and various kinds of systematic/unsystematic tax measures that may be enacted if it is necessary.

- The tax regulations are often very complicated which is made only worse by an annual increase in a number of paragraphs and pages per legal tax acts, 
this is especially true about laws concerning income tax and value-added tax. This is quite clear from the comparison with the first tax code (Act on Income Taxes) which had only 25 pages of text and 43 paragraphs when it came into effect while 51 pages of texts at the time of its repeal.

- The legislator who intends to lay down strict and precise tax rules often encounters opposition from taxpayers.

- The number of taxpayers obliged to pay different kinds of taxes could be expanded through local inquiry and investigation activity performed by tax administrators.

- There are several unanswered questions on how to effectively secure public/ private interests in tax law relations. Without answering these questions we cannot draw the conclusion about true nature of interests protected by tax legislation. Only some of these questions I shall describe below:

- Do the structure of Slovak tax legislation and the structure of legal acts of the EU - their philosophical framework - serves the public interest or do they serve the private interests?

- Have the private interests (that is to say political-economic interests) rooted into public fiscal interest because of the abovementioned connection between politics and economics and between political and economic interests? All of these factors also affect relations between the EU and its member states: each of the member states pursuits his own "private" interest (metaphorically speaking) and the EU pushes for "public interests" of the whole block. While the EU proclaims to protect fairness (which includes fairness in tax competition) and to promote good governance in tax matters, some EU member states may still be considered tax heavens. I know that the tax professionals are well aware of states I, which I am speaking about, therefore I will not herein list them by their names. We may further ask, what actions have the EU actually made to tackle the tax havens inside its territory and were they effective? In fact, there have been not many such initiatives besides few proposals for new directives and some Commission communications. The fairness in tax matters has become agenda of the EU only during past several years because of a huge increase in cases of international tax avoidance and tax evasion (Commission: COM (2015) 302, Commission: COM (2016) 23).

- When legislator chooses to prefer one of two main principles of taxation either principle of tax fairness or principle of economic efficiency - does he follow either the private interests or public interests? The choice between tax principles is a typical example in which public interest and private interests overlap. In Slovakia, the revaluation of leading tax principles often 
occurs due to change of government, when tax policy and public interest is redefined by political party/parties forming a new government. Because of political struggle, the real economic needs of the state and public fiscal interest often become less important.

- Does granting state aid (Act on State Aid), providing investment incentive (Act on Subsidies to Investment), supporting stimulating measures for research \& development (Act on Stimulus to Research and Development) or conferring any other advantages by the state enhance public interest, or do these fiscal tools serve "in disguise" the private interests of big foreign business companies? If the latter is true, private interests will inevitably root more widely into public fiscal interest. On the other hand, abovementioned fiscal tools may attract foreign capital and strengthen international tax competitiveness of the state. In Slovakia, well-known cases of "state aid" concerned US Steel, various automobile manufacturers as Volkswagen (VW), PSA Peugeot Citroën, KIA Motors and the most recent case concerns Jaguar Land Rover et $\mathrm{al}^{4}$. On the other hand, small and mediumsized enterprises (hereinafter "SMEs") are often overlooked. Their true importance for public fiscal interest is not taken properly into consideration, as though SMEs did not perform any activities that would serve public interests (the assessment of their overall contribution is one-sided and based solely on their private interests).In fact, it is quite the opposite. According to statistical data gathered for the year 2015, SMEs accounted for $99.9 \%{ }^{5}$ of all businesses also SMEs served as employers for $71.8 \%$ of active work-force and created $55.1 \%$ of added value produced in that year (Analysis of SMEs).

Furthermore, there is a question, how to evaluate the shift in taxation from direct to indirect taxes. This shift has occurred as result of Slovak republic joining the EU and it has had a profound impact on the fiscal decentralization in Slovakia. With that respect, we can ask, which interests - public or private - were actually pursued by that significant change in tax policy? My opinion is that there are more reasons behind shift towards indirect taxation than are officially admitted by the government. The official reason in favor of indirect taxes is that the indirect taxation feels psychologically less painful than direct taxes. If that was the only reason, the shift in Slovak tax policy would be the clear manifestation of public interest. However, the situation looks different after we take into account that the shift has helped corporations, especially big businesses to further lower their tax

\footnotetext{
4 The state aid including state tax reliefs was granted to $\mathrm{VW}$ at 17.12 .2008 . With that regard automobile manufacturer, VW had promised until the year 2012 to employ 760 people. That was reflected in tax relief of 2,9 mil. EUR (in the year 2010), 5 mils. EUR (in the year 2011) and tax relief of 6,4 mil. EUR (in the year 2012). Business was actively conducted by 387076 self-employed people. The number of active companies (limited liability companies and joint stock companies) at the end of the year 2015 was 235380 . The annual increase in the number of companies was of 4200 companies (reaching 1.8\%) (www.indexpodnikatelia.sk).
} 
burden, which has been steadily decreasing since the year 1993 (with the exception of one short period of time) ${ }^{6}$. Still, I am not denying that private companies may improve public fiscal interest sometimes even in situations when they pursue private interests. Indeed, the shift of tax policy towards indirect taxation enables the state to achieve revenues without setting high-income tax rates (after all, the creation of revenues is the sole importance of tax system).

I am convinced that all changes in tax regulations should be motivated by public interest and well-being of society as a whole. However, what we should think about the change of tax legislation that negatively affects the legal certainty of taxpayers? Ultimately, that kind of changes goes contrary to the very essence of public fiscal interest and weakens the private interests of businesses sector.

Tax law should guarantee for its addressees' certainty and the legality when it comes to the imposition of tax obligations as well as in conferring the rights. Furthermore, tax law should always avoid creating uncertainty that might affect decision-making process of taxpayers. That kind of changes creating uncertainty especially for business environment clearly goes against the public fiscal interest. Even though the modern world is plagued by tax evasions and tax frauds, stated principles of legal certainty and legality remain essential for tax law.

Every state resp. the international body should seek effective measures to tackle tax evasion, but these measures must be in accordance with these tax principles. It may be noticed that according to European tax survey which was conducted by Deloitte in the year 2015 , almost $40 \%$ of responders chose legal certainty as for the key factor in the building of trust towards tax administration (Deloitte, 2016: 5). I suppose that all tax professionals would agree that trust of taxpayers in tax administration promotes public fiscal interest.

The concept of taxes as compulsory payments is based on the theory of the burden - imposed (forced) unilaterally upon an individual by the state. The taxpayers are required to pay taxes event though it goes contrary to their own private economic interests. This creates tension between private interests of the taxpayers on the one hand and public interest of the state/municipalities on the other. With that regard, it may be further mentioned that each tax regulation enacted by public bodies are binding legal act whether it has or has no any moral status (characteristics).

General view of taxpayers is that the tax obligations are unwanted burden forced upon them against their will. That attitude only deepens when the state manages the

6 In the time period between years 1993 till 2000, the tax rate of corporate income tax was 40\%, from the year 2000 it was lowered to $29 \%$, from 1.1 .2002 it was lowered to $25 \%$, from 1.1 .2004 it was lowered one more to $19 \%$; from the year 2013 tax rate was finally rise to $23 \%$. Actual tax rate $22 \%$ has been in force since the year 2014 and proposal for the lowering of the tax rate to $21 \%$ is now seriously considered. 
tax revenues contrary to principles of economy, efficiency, and effectiveness. With that respect we may provide some examples: the overpricing of tenders, the low quality of work performed by persons to whom the contract is awarded in tender, corruption in tendering process, the involvement of brass plate' companies in public financial relations, the high administrative burden, the granting of state aid primary to foreign investors etc. When business environment due to publicity of corruption scandals lost its trust in public authorities the tax discipline/tax morale it negatively affected. These cases cause huge loss resources that belong to the state, but people in power manage budgetary resources as if they were their own private property.

I am convinced that the tax morale/tax discipline would improve if the general public had more confidence in the sound financial management of the state. If it was the case, taxpayers might view taxation more like an unwritten contract between taxpayers and the state than the unwanted burden imposed unilaterally upon them. To make this change in taxpayer's attitudes, the state should stop its support for individuals who willingly does not work and obtain their income only as state benefits and to start using revenues primarily/exclusively for social goods.

In many cases, the politics/political nominees "hide" themselves behind their posts in administration thus avoiding monetary sanctions for the damage they make to public fiscal interest (by their decisions which they had ostensibly adopted to "promote" public interest). There is nobody among scientific community who would believe that any case of damage incurred by budgetary resources has anything in common with the public interest. Damages for lost budgetary resources may be recovered, through the introduction of new tax instruments - similar to tax licenses - targeting persons who are liable for loss in those resources.

Discussed topics besides legal, economic and political issues also concern variety of questions about ethics in taxation, tax moral/tax discipline and psychological aspects of taxation, however, they go beyond the scope of this article.

\section{Conclusions}

The dynamic relationship between public and private spheres (zones of interests) affects the pursuit of private/public interests in actual social circumstances. Various distinctions between private and public interests affect relations between two main areas of law namely relations between private law and public law.

The social importance of the law is indeed undeniable, but the law sometimes does not achieve desired results in actual social interactions. The law has become seriously infected by economic interests of political parties, lobbying organizations, 
business community even by populists seeking to attract voters (Babčák, 2012: 355). This may be considered new characteristics of contemporary law. While the law it is still created through democratic means/processes, its actual application in many instances diverges from legal principles to the law often ceases to serve the interests of the majority of the population. The law often comes under the influence of various s groups and more often under the influence of politicians with close ties to "big business". What are the implications of such situation? In many cases, private and public interests have become so intertwined than to discover their true nature is nearly impossible. Moreover, the law had lost one of its key attribute that is the ability to successfully prevent future social and economic disruptions by the anticipation of social development. We must face the fact that these unfortunate circumstances have befallen also the tax law.

\section{References}

Babčák, V.: Daňové právo na Slovensku (Tax law in Slovakia), Bratislava: EPOS, 2015.

Babčák, V.: Finančné zákonodarstvo v "službách" stabilizácie a rozvoja slovenskej ekonomiky (Financial law in "services" of stabilization and development of Slovak economy), in: Právo, obchod, ekonomika II., zborník vedeckých prác (Law, Commerce and Economy II, scientific proccedigs), Praha: Leges, 2012.

Klimovský, D.: Základy verejnej správy, druhé, prepracované a doplnené vydanie (Basics of public administration sec. ed.), Bratislava: Wolters Kluwer, 2014.

Kosikowski, C.: Granice opodatkowania - główne problemy (Boundaries of knowledge - main problems), Studia Juridica Cassoviensia no. 2 (2014).

Musgrave, R.A., Musgreová, P.B.: Veřejné finance $\mathrm{v}$ teorii a praxi (Public finances in theory and practise), Praha: Management press, 1994.

OECD: Action Plan on Base Erosion and Profit Shifting, 2013.

Schultzová, A. et al: Daňovníctvo (daňová teória a politika I) (Taxation (theory of taxation and tax policy I)), Praha: Wolters Kluwer, 2015.

Smith, A.: An Inquiry into the Nature and Causes of the Wealth of Nations, Chicago: University of Chicago Press, 1977.

Analýza stavu malého a stredného podnikania (Analysis of SMEs). www.hsr.rok ovania.sk.

Deloitte: European Tax Survey. Transparency, simplification and collaboration. www2.deloitte.com.

Ivanovič, D.: Teória demokracie a koncept verejného záujmu (Theory of democracy and a concept of public interest), Bratislava: e-Polis.cz, 2015.

EU: Communication from the Commission to the European Parliament and the Council form date 28.01.2016 on Anti-Tax Avoidance Package: Next steps towards delivering effective taxation 
Public Financial Interest in Slovak Republic...

and greater tax transparency in the EU (ATAP, Anti-tax avoidance package) no. COM (2016) 23 final.

EU: Communication from the Commission to the European Parliament and the Council, A Fair and Efficient Corporate Tax System in the European Union: 5 Key Areas for Action. COM (2015) 302 final.

EU: Communication from the Commission to the European Parliament and the Council, AntiTax Avoidance Package: Next steps towards delivering effective taxation and greater tax transparency in the EU. COM (2016) 23 final.

SK: Act no. 286/1992 Coll., on Income Taxes, as amended.

SK: Act no. 231/1999 Coll., on State Aid, as amended.

SK: Act no.561/2007 Coll., on Subsidies to Investment, as amended.

SK: Act no. 185/2009 Z. z., on Stimulus to Research and Development. 



\title{
PUBLIC INTEREST IN RUSSIAN FINANCIAL LAW AND MODERN LEGAL SCIENCE
}

\author{
IGOR BARTSITS ${ }^{l}$, ELENA CHERNIKOVA ${ }^{2}$
}

\begin{abstract}
The article is devoted to one of the fundamental issues in legal science and theory of financial law in particular. In the context of globalization and expansion of legal regulation the issue of safeguarding public interest is becoming more and more urgent. The choice of adequate directions, goals, and mechanisms of legal impact on social and economic relations is determined by public interests. The Authors give thorough consideration to the concept of the public interest in the Russian legal doctrine, the aspects of its development in modern legal science, as well as the necessity to safeguard it in public expenditure. Preserving public interest is substantiated as the basic principle of public administration and legal regulation of finance. According to the Authors, this kind of approach facilitates successful achievement of the strategic goals of the country and optimization of public finances administration.
\end{abstract}

\section{Keywords}

Public interest; legal science; financial law theory; statutory regulation; legal regulation of finances

\section{JEL Classification: D63, K34, K40}

1 Professor, Doctor of Juridical Sciences, Director of the Institute of Public Administration and Management of the Russian Presidential Academy of National Economy and Public Administration, Honoured Lawyer of the Russian Federation, Moscow, Russia. Contact email: in.bartsits@migsu.ru.

2 Doctor of Juridical Sciences, Candidate of Economic Sciences, Head of the Department of Legal Regulation of Economy and Finances at the Institute of Public Administration and Management of the Russian Presidential Academy of National Economy and Public Administration, Moscow, Russia. Contact email: ev.chernikova@ migsu.ru. 


\section{Introduction}

Modern life keeps offering new challenges to individuals, to the society and the state. Social development makes it clear that it is not such achievements of the civilization as freedom or market or property or public order as such that we value, but some positive, humane achievements and consequences of social, political, economic and other kinds of character that are attractive for the whole or, at least, for the vast majority of the society. There cannot be a goal of just building democracy or developing the market economy without any further definitions and specifications, because the idea of them is too different in different areas of the world, and they are implemented in various forms and versions. In this article, the Authors single out and suggest sharing opinions on two main issues - the place and role of "public interest" in the legal doctrine and legal regulation of finance and ways to optimize the administration of public expenditure. To our mind moving along the marketled way combined with democracy implies that safeguarding public interest is the fundamental principle of legal regulation of finance.

\section{On Significance of Public Interest for National and State Economy, its Role in Expenditure and Revenue of Russia}

E.N. Berendts was able to give a clear explanation of the essence of the concept of the public interest in his fundamental work "Russian Financial Law" (Berendts, 2014: 14-15). The well-known Russian legal scholar wrote: "Present-day state economy is run not for the sake of narrow, ephemeral, selfish goals of the persons that manage it, but for the sake of goals of higher level, for the interests of the whole people united as a state, as a moral, spiritual being that consists not only of the people living in a particular year or a period of time in the territory of the given country and under the given government; as a link connecting the past and coming generations by one origin, common historical past, language, culture, and the awareness of this commonness". The given goal of protection of the public interest in the economic activity of the state and its expenditure of public finances sounds modern and relevant not only for today's model of economic development of a particular country but of the world.

As we know, the decisions of the state power are legitimized by the rules of law in the form of legal regulation. The basis of the economic activity of the state is formed by the rules of financial law, and it is them that provide for the state management via the budget, i.e. the main public monetary fund. It is important to observe the principle of safeguarding the public interest in the course of its spending. One should note here that the significance of the given principle has also been pointed out in the 
theory and practice of Russian legal financial science. Famous Russian statesman M.M Speransky suggested "establishing the principle of rational expenditure of state funds and correlating expenditure with receipts as one of the key rules of budget administration in 1810 in his Financial Plan, which in fact was a project of dramatic financial reforms in the area of currency circulation, credit and budget". In the introduction to his Financial Plan, M.M. Speransky noted that any state whose expenses keep growing annually while its gains keep decreasing is bound to go into debts. Even the most useful activities that are carried out in debt or require an extraordinary effort and distress for finances will harm the state considerably. The only exception is war. The general principles in the first part of Financial Plan are worth special attention and sound particularly modern. The general rule for state affairs is the following: all great endeavors require work, firmness, and patience. The key distress for finances is disproportion of expenditure and receipts. There are two ways to restore the proportionality: decrease the expenditure or increase the receipts. It is interesting to note here that in case of decreasing the expenditures it is suggested that all the necessary ones should be preserved, all the useful ones should be postponed, and all the unnecessary ones should be stopped (At the onset of financial law, 1998: 35-37).

Preserving public interest in the administration of public finances is an ancient postulate of philosophical nature. Being economical when dealing with one's people's means is an evangelical truth that is quite resonant with the idea of safeguarding the public interest in the financial and economic activity of the state and state management in general. In this respect we would like to emphasize the point that seems conceptual for the development of financial law, since it is its rules that ensure the legitimacy of the authorities' actions: it is the necessity to define and enshrine legislatively the principle of safeguarding public interest in public finances administration, which will allow one to enhance the efficiency of legal and financial regulation.

\section{On Benefits of Safeguarding Public Interest in Financial Activity of State in Russian and Modern Legal Theory}

Integration and globalization of public relations, market development and the development of new technologies in it, the emerging digital economy and the processes connected with it - all of it reinforces the role of financial law in general. In fact the instrument of regulation of finances, and public finances in particular, is financial law. One should note here that financial law both as a science and as a branch of law has always contained three elements: legal, political and economic. They are all inseparably interconnected and interdependent. Professor of the 
Demidov legal lyceum I.T. Tarasov wrote about this characteristic of financial law in 1889: "The legal, political and economic elements of financial law are inseparable. The analysis of laws of economic phenomena and the analysis of legal norms that determine the sphere of state economy go hand in hand in it. This science does not only teach what is there and why it takes place, but also what is congruent with economic laws, with the meaning and goal of the state and with the ideas of truth and justice" (Tarasov, 1889: 6-7). It is this comprehensive approach and creative attitude of Russian legal scholars that allowed one to establish the idea of safeguarding public interest in public finances administration. The "common good" the achievement of which as a goal is at the basis of the realization of the given principle is "nothing but a combination necessary for the joint development of many private interests. All the society with all its institutions is the body of common good - in accordance with the way it is understood at this period of time and in this particular place" (Muromtsev, 1879: 186-201). The issue is not just theoretical, but practical, too. A spectacular example of this is VAT, one of the largest and best collected taxes in Russia in its interconnection with the development of the material and financial resources of subsidized subjects and local government. Referring this tax to the regulating revenues allows local small and medium businesses to develop. Allocating a percentage of the regulating revenue from a higher rank budget to a lower one gives considerable advantages to public administration. The VAT is formed in the sphere of services and trade that are provided everywhere, so allocation of the percentage of these proceeds can be made everywhere. Regional and local authorities receiving the percentage of money to the budget will be directly interested in extending the number of taxpayers via creating favorable conditions for the development of the small and medium business. And as we know, it is a stable platform for any economy and a middle social class of a harmonious society. This model of budget equilibrium has been repeatedly offered by well-known Russian scholars in the sphere of financial law (Gorbunova, 2017: 314-320). Observing the principle of safeguarding public interest in the process of legal regulation of finance and its legal enshrinement in particular, e.g. in the Budget Code, to our mind would facilitate the solution of the problem of budget balance, establishing budgetary equilibrium, which is not a new issue in the theory of financial law.

\section{Public Interests in Russian Legal Doctrine and Public Finances}

The following researchers worked on the issues of public interest in modern legal doctrine:

- Sergey Sergeyevich Alekseyev (1924-2013), a prominent Soviet and Russian legal scholar, Author of monographs "Philosophy of law: history and 
modernity, issues, trends, prospects" (1999); "The ascent to law: search and solutions" (2001), "Selected works" (2003);

- Yury Aleksandrovich Tikhomirov, a prominent scientist, a legal scholar, Author of the monographic textbook "Law, forecasts and risks" (2017);

- Gennady Vasilyevich Maltsev (1935-2013), honored worker of science, corresponding member of the Russian Academy of Science, expert in the field of theory of state and law, Author of monographs "Social grounds of law" (2015), "Cultural trends in law" (2015), "Moral ground of law" (2015); researcher of the issues in the dynamics of legal consciousness, legal culture and legal traditions.

Based on the works named above, we take the liberty to note that public interest and the common good are philosophical and legal categories and are permanent landmarks in legal regulation, as they are aimed at positive results that are valuable and attractive for the whole or the vast majority of the society. Under the conditions of growing volume of legal regulation the given position is important for the legal and financial regulation and for the public finances expenditure in particular. State management in the form of legal regulation must be carried out observing the principle of safeguarding the public interest. Chairman of the Constitutional Court of the Russian Federation, V.D. Zorkin in his monograph "The Civilization of law and development in Russia" notes that regularity should look out for the public interest" (Zorkin, 2016: 196-198). It is unacceptable to adjust the attitude to law to the interest that is characteristic of the governor, the ruling circles, one particular stratum (Tikhomirov, 2017: 5). In terms of public spending, the given statement is particularly valuable, as "public spending is based on the necessity to realize public interest, the basis of which is the need for social integration. The given need is recognized by the state and ensured by law, and its satisfaction guarantees the existence and development of the corresponding social community" (Tikhomirov, 2008: 140-141).

\section{Russian Legal Scholars and Statesmen, Researchers of Concept of Public Interest}

Our attempt to reinforce the category of "public interest" in modern theory and practice of legal regulation of finances allows one to pay more attention to the research and application of the concept by Russian legal scientists and statesmen. The concept of "public interest" has been explored in Russian legal theory for the last 200 years. Famous Russian scholars who carried out research of the given philosophical and legal category are Mikhail Mikhailovich Speransky (1772-1839), an outstanding Russian reformer and Author of the famous "Plan of Finances"; 
Sergey Andreyevich Muromtsev (1850-1910), Author of the research "Definition and general division of law", professor of Moscow University; Eduard Nikolaevich Berendts (1860-1930), Russian lawyer, doctor of financial law, professor of Tartu University, Author of the first consistent description of the main institutes of financial law of the Russian empire - "Russian financial law". The lectures read in the Imperial School of Justice; Lev Iosifovich Petrazhitsky (1867-1931), a prominent Russian and Polish legal scholar, Author of monograph "Introduction to the study of law and morality: emotional psychology"; Vladimir Nikolaevich Kokovtsev, a prominent statesman, Russian minister of finance of 1903-1914, Author of "From my past. Memories of 1911-1919" (1991); Sergey Yurievich Vitte (1849-1915), an outstanding Russian statesman, Author of the textbook for the royals "Compendium of lectures on the national and state economy" (2011), in which he gave thorough consideration to the key economic concepts, categories of economic theory, events and fact of economic policy, key problems of economy and finances of that historical period in Russia. At present we more and more often turn to our history, study the works of legal scholars of the past, economists and statesmen, which is for a reason. Today, when Russia is looking for the points of economic growth and developing the potential of the country, the experience of the past generations is more important than ever. Innovations in the sphere of administration of public finances do not always lead to a boost in the economic development. "There is no other sphere that is less amenable to innovation than financial administration, where all kinds of unsuccessful experiments would manifest their harmful impact as fast as in the sphere of finances. That is why there's just one task for us - no matter how boring it might sound and how desirable it might be to replace it with something more lively and rewarding - there is a need to live within one's means" (Kokovtsev, 1991: 425-430). Apologist of the policy of budgetary equilibrium, V.N. Kokovtsev believed that there is only one policy in financial affairs - the policy of budgetary equilibrium. Covering the expenses with ordinary income, it is this policy that is at the core of financial and overall economic well-being of the state. This policy is not advantageous and it is not accompanied by big promises or generous prophesy, but it reminds one of that inconspicuous work of stone mason who works under the ground and lays the foundation, choosing each stone painstakingly and being aware of the fact that the foundation must be broad and deep. He does it "being aware that only on this broad and deep foundation one can build a solid building of the financial and economic development of the country capable of taking Russia along the path of strengthening and prosperity" (Kokovtsev, 1991: 427). It is not by incident that we drew your attention to the views of Russian statesmen on the issues of legal administration of finances. It is our earnest conviction that all of this sounds very modern and relevant. To enhance legal regulation of finances one should try and develop everything valuable that had been done by our predecessors in legal theory and the science of financial law. 


\section{Conclusions}

It is a well-known fact that legal regulation may not only facilitate the economic and social development of the state but hamper it, too. It is important to determine the basics, the principles of legal regulation. Based on the grounds mentioned above and on the historical traditions in the development of Russian legal doctrine we consider the principle of safeguarding the public interest in public finances administration to be fundamental for the legal regulation of finances. As our first conclusion, we may note that the principle of safeguarding public interest is fundamental for legal financial regulation and public finances administration. Based on the given principle the growth of state expenses is firstly covered by the growth of state receipts originating from the development of the productive power of the country and, secondly, from raising taxes.

We believe that the second important point here is that in the course of optimization and administration of public finances one should proceed from the public interest and obligatory observation of the principle of budgetary equilibrium and balance.

The third conclusion is that the concept of "public interest" is a philosophical and legal category, dating back to the concept of "interest" and the goal of reaching the "common good".

All the questions raised in the article are caused by the necessity to enhance the system of public finances administration and their organization. As a rule, in the course of transformations, and mainly in the sphere of economy and finances, there are two extremes: excessive regulation of financial instruments and economic mechanisms that want more freedom, or absence of necessary legal support. As for the first case, one can proceed from the principle formulated by our predecessor, V.N. Kokovtsev: "One needs the freedom that allows you to do your duty, to work and be sure of the results of one's work (...) When work penetrates each and everyone, from top to bottom, when everyone is sure that the results of their work belong to them (...), then there will be the order that is the basis of law" (Kokovtsev, 1991: 430). The research of the problems in the legal regulation of finances, including the development of the principle of safeguarding public interest proceeds from the key goal of the Russian state - building the society of well-educated and healthy people with a high level of material security and the state with the market economy and a social face. Since it is possible to realize only via finances, it is only fair to demand their comprehensive and integrated regulation. Economic and social processes cannot be uncontrollable, and they are regulated first and foremost with the help of the norms of financial law. 


\section{References}

Alekseyev, S.S.: Философия права: история и современность, проблемы, тенденции, перспективы (Philosophy of law: history and modernity, problems, trends, prospects), Moscow: Norma, 1999.

Alekseyev, S.S.: Восхождение к праву: поиски и решения (The ascent to law: search and solutions), Moscow: Norma, 2001.

Alekseyev, S.S.: Избранное (Selected works), Moscow: Statut, 2003.

Berendts, E.N.: Русское финансовое право (Russian financial law), Moscow: Rior Infram, 2014.

Gorbunova, O.N.: Избранное (Selected works), Moscow: Russian State University of Justice, 2017.

Gorbunova, O.N.: Финансовое право и финансовый мониторинг в современной России: научнопопулярная монография (Financial law and financial monitoring in modern Russia: popscientific monograph), Moscow: Elit, 2012.

Kokovtsev, V.N.: Из моего прошлого. Воспоминания 1911-1919 (From my past. Memories of 19111919), Moscow: Sovremennik, 1991.

Maltsev, G.V.: Нравственные основания права (Moral grounds of law), Moscow: Norma, 2015.

Muromtsev, S.A.: Определение и основное разделение права. Исследование Сергея Муромцева, профессора Московского Университета (Definition and division of law. Research by Sergey Muromtsev, professor of Moscow University), Moscow: Tipografia A.I. Mamontova i Co., 1878.

Petrazhitsky, L.I.: Введение в изучение права и нравственности: Эмоциональная психология (Introduction to the study of law and morality: Emotional psychology), Moscow: Lenand, 2015.

Tarasov, I.T.: Очерк науки финансового права: Введение. Конспект лекции (Outline of the science of financial law: Introduction. Compendium of lectures), Yaroslavl: Tipo-litogr. G.V Falk, 1889.

Tikhomirov, Y.A.: Современное публичное право (Modern public law), Moscow: Eksmo, 2008.

Tikhomirov, Y.A.: Право, прогнозы и риски (Law, forecasts and risks), Moscow: Infra, 2017.

Vitte, S.Y.: Конспект лекций о народном и государственном хозяйстве, читанных его императорскому высочеству великому князю Михаилу Александровичу в 1900-1902 годах (Compendium of lectures on national and state economy read to his imperial highness grand duke Mikhail Aleksandrovich in 1900-1902), Moscow: Yurait, 2011.

У истоков финансового права (в серии «Золотые страницы российского финансового права»), At the onset of financial law ("Golden pages of Russian financial law" series), Moscow: Statut, 1998.

Zorkin, V.D.: Цивилизация права и развитие России (Civilization of law and development of Russia), Moscow: Infra, 2016. 


\title{
PUBLIC INTEREST IN FINANCIAL LAW OF THE REPUBLIC OF BELARUS: THEORY AND PRACTICE
}

\author{
LILIYA ABRAMCHIK ${ }^{1}$
}

\begin{abstract}
In the scientific work the analysis of interaction and boundaries of public and private interest in financial law, from the point of view of both doctrine and law enforcement, was carried out. The absence of public interest concept in financial, budget, tax legislation of the Republic of Belarus was paid attention to. It was suggested that the concept of public interest should be enshrined in financial law at the statutory level. The following works of scientists in the field of financial, tax and budget law served as methodological basis for writing the work: E.Yu. Gracheva (2014), Yu.P. Gavrilchenko (2016), M.V. Karasev (2006), Yu.A. Krokhina (2012), S.K. Leshchenko (2008), O.A. Nogina (2012), A.A. Pilipenko (2006), N.A. Povetkina (2015), N.A. Sheveleva (2009), E.V. Chernikova (2016), and others. In the research process both general scientific and particular methods were used: synthesis and analysis, collection and generalization of different points of view of scientists, comparative, system, comparative legal, logical-juridical, structuralfunctional analysis.
\end{abstract}

\section{Keywords}

Public interest; budgetary activity; financial law; tax law; private interest; tax administration

JEL Classification: K34, K39, D63

1 Candidate of Juridical Sciences, associate professor, Educational institution Yanka Kupalthe state University of Grodno, Doctoral (higher doctorate degree) candidate of Saint Petersburg State University, author of more than 100 scientific works. Contact email: lilia_abramchik@mail.ru. 


\section{Introduction}

The aim of the law is to provide stability of social relations by ensuring the balance of public and private interests. The relevance of the raised issue is determined by the following factors:

- firstly, by the objective need for theoretical comprehension and enshrinement in the Belarusian legislation of the principle of balance of public and private interests as a regulator of relations in the "state-society" system as the most important condition for stable democratic development of society and the state;

- secondly, by the need for legislative enshrinement of "public interest" concept and features of public interest in financial law;

- thirdly, by the search for conditions and ways to harmonize the spheres of public interests, state and private interests, boundaries of their satisfaction and limitation;

- fourthly, by the solution of the problems of doctrinal development and the legal-regulatory consolidation of fundamentals, ensuring compliance with this principle in all areas of legally significant activity.

In the national and foreign scientific literature there are a number of works devoted to certain aspects of the problem of observing the balance of public and private interests. The issue was addressed by: S.S. Alekseev (1995), T.S. Boiko (2011), A.V. Bryzgalin (1997), G.A. Vasilevich (2005), V.A. Vitushko (2001), E.Yu. Gracheva (2014), Yu.P. Gavrilchenko (2016), O.S. Ioffe (19750), M.V. Karaseva (2006), Yu.A. Krokhina (2014), S.K. Leshchenko (2008), A.V. Malko (2014), V.A. Maltsev (2011), M.N. Marchenko (2015), O.A. Nogina (2012), A.A. Pilipenko (2006), N.A. Povetkin (2015), A.M. Rabets (2016), L.N. Ryabtsev (2013), Yu.A. Tikhomirov (1995), N.A. Sheveleva (2009), G.F. Shershenevich (1995), E.V. Chernikova (2016) and others.

However, until now there is no clear understanding of the ways and means for ensuring the balance of public and private interests in various areas of legal regulation, including in the field of financial law. Legal science needs specification and concretization of theoretical positions on a number of issues relating to the concept under investigation.

In the research process both general scientific and particular methods were used: synthesis and analysis, collection and generalization of different points of view of scientists, comparative, system, comparative legal, logical-juridical, structuralfunctional analysis. 


\section{Theory of Public Interest in Financial Law}

The social value of law lies in the fact that it is designed to regulate the widest range of social relations, both from the point of view of social interest and for the sake of fulfilling public interests. In the legal literature public interests are fairly divided according to different grounds: economic, related to the production, distribution and consumption of financial resources, material wealth; political, underlying the management of the state, implementation by the state power of its functions; spiritual, connected with spiritual values, products of spiritual creativity - morality, science, art; social (Tikhomirov, 1995).

The state is the fundamental participant of public relations, the specificity of legal status of which consists in determining, acquiring of its legal personality, establishing of legal regulation method (imperative or dispositive) of one or another legitimate interest, the ways of their protection, sanctions, the limits of their implementation. Therefore, the purpose of the law is in balancing of interests in society, in finding a compromise between them through relevant regulatory legal acts that serve as the means of external expression of public interest, and in provision of a mechanism for their implementation.

In the Preamble of the Constitution of the Republic of Belarus, the main ideas, and principles, by which people and power should be guided them in the process of state-building and social development, are formulated. It is responsibility for the current state and the future of Belarus; awareness of being a full-fledged subject of the world community, an inalienable right to self-determination; reliance on the centuries-old history of the development of the Belarusian statehood; the assertion of the rights and freedoms of every citizen; ensuring civil consent and unshakable foundations of democracy and the law-governed state. The second section of the Constitution of the Republic of Belarus "Individual, society, state" fixes personal, political, socio-economic and cultural rights and freedoms of citizens, defines the duties of citizens, the state's responsibility to society and individual, its responsibility to provide material guarantees and opportunities for the full exercise of rights and freedoms of citizens. Therefore, the state becomes a speaker of public interest when implementing its activities. A particular difficulty in the process of implementing financial activity of state, or more precisely, in the process of raising, distributing and using of funds and setting its goals, is the procedure of determining what interests at a certain point in time can obtain a legal regime of state regulation for the sake of fulfilling public interests. The main directions of social and economic development of the Republic of Belarus for 2016-2020 contain tasks that need to be realized from the point of view of public (social) interest (The set of measures for 
the implementation of the main directions of socio-economic development of the Republic of Belarus for 2016-2020).

The realization of state interests is possible through the actions of the state itself represented by appropriate authorities and also through the activity of other subjects, including tax authorities, banks, insurance companies, as a special type of legal entities, state institutions, unitary enterprises, state corporations, and in other ways. The most important is the ability of a public subject to express public interest through an integrated system of administration and, in our opinion, particularly tax administration, since the largest number of concerned parties are affected. It is important here to be able to maintain the balance, the boundaries of public and private interests.

Having examined various scientific doctrines, we became convinced that the very concept of public interest is controversial: the content of homogeneous public interests does not always coincide, and homogeneous interests themselves do not always form a commonality. For instance, Yu.A. Tikhomirov writes that public interests as a concentrated expression of general social needs and aspirations act as a backbone phenomenon and from the legal point of view is characterized by certain regulatory features by fixing its priority, establishing order and guarantees of provision, fixing the ways of protection and measures of responsibility. The common generic concept of "public interest" is combined with specific normative concepts - "interests of society and state", "national security", "common interests", "interests of nations, peoples, population", "general economic interests", "interests of ecological well-being" "regional and local interests", "corporate interests". In his opinion, public interest, in its concentrated form, is enshrined in the Constitution and serves as a legal basis for all branches of law, being at the same time an object of reflection and enshrinement in the private law branches (Tikhomirov, 1995). Professor L.N. Ryabtsev and D.V. Gvozdev point out that public interests are subjective interests, the implementation of which is entrusted to the state represented by its apparatus. At the same time, the security is a subjective need, which is realized through the implementation of law enforcement function (Ryabtsev, Gvozdev, 2013: 145). Therefore, public interests are the interests of society and state. We should agree with the definition of public interest, suggested by Yu.A. Tikhomirov - "a general social interest that in a concentrated form reflects the entire spectrum of interests in society" (Tikhomirov, 1995).

It is important for us to determine the nature of public interest in financial law. To define whether it meets the long-term needs of society. Despite the fact that the concept of "public interest" is not enshrined in financial legislation, the components of public interest of state are not only enshrined in the regulations of financial legislation, but the Constitutional Court of the Republic of Belarus 
in a number of acts emphasizes the public interest of the state. For example, the Constitution, fixing the duty of citizens of the Republic of Belarus to participate in the financing of public expenditures by paying state taxes, duties and other payments, does not directly provide for a legal mechanism for the fulfillment of this duty. The Constitutional Court, when reviewing regulatory legal acts in the sphere of tax legislation, expressed legal positions, the essence of which is that a constitutional obligation to pay taxes has a special public legal nature, conditioned by the public legal nature of state and state power; taxes, duties, and fees are a prerequisite for the existence of any state, so the obligation to pay them applies to all taxpayers as an unconditional requirement; tax payments are the main source of revenue part of the budget and the most important guarantee of national interests protection in the sphere of financial activity; only if the budget is sufficiently filled with funds, state is able to carry out its functions and solve its tasks (Constitutional Court no. P-412/2009, Constitutional Court no. P-962/2014, Constitutional Court no. P-1017/2015, etc.). When investigating the financial activities of the state, Yu.A. Krokhina acknowledges that it is public in nature, since it provides the flow of funds in the interests of the whole society (Krokhina, 2014: 67).

However, public interests may coincide with the interests of the state and in this case become a part of state interests. In other occasions, the state may allow their implementation in the framework of lawful activities or may fight against them, establish a ban on their implementation. In a number of cases the state from the perspective of the long-term interests of society, tasks concerning the development of certain spheres of public activity, promotion of economic stability and social progress may realize its state interests, sometimes not shared by society. For example, the state may implement so-called unpopular measures, for instance, increase tax rates, reduce tax exemptions, introduce new fees, etc. Thus, not every social interest can become an interest for the state. But it is public interest in financial law that is aimed at the benefit of society and the development of the state.

While carrying out financial activities, the state simultaneously acts as both a subject of public authority and the owner of its own (state) property, therefore public interest recognized by state and secured by law serves as a condition and guarantee for the existence and development of state itself. Without financial resources, it is impossible to ensure the implementation of functions of the state. Public interest should act as a guarantor of the society development. Thus, it is possible to give the following definition of the concept of "public interest in financial law": social interests recognized by the state, expressed in the rules of financial law and provided with the mechanism of state coercion allowing the development of society and the state. Thus, the diversity and multiplicity of functions performed by modern states as well as the incoherence and 
inconsistency of the goals of various state policies (tax, budget, social, scientific and others) cause plurality and diversity of public interests.

\section{Public Interest in Budget Law}

Legal regulation of budgetary relations is an important task and, along with problems of legal regulation of public and private interests, belongs to one of the acutest problems of the world community, requiring study and solution in each state. At the same time, to protect its own interests, the state legislatively fixes funds that allow it to regulate budgetary relations, providing for its own property interests, property and non-property interests of its citizens. All this is an expression of interests of state and other public subjects. Therefore, for the objective of our research we will proceed from the theoretical provisions of the previous chapter that at the present time it is public interest of the state that is traced through proprietary rights: the right to finance - money, the right of state and municipal property, and also a number of non-proprietary interests express public interests in budgetary sphere. Budget law is the aggregate of legal rules governing relations that arise between subjects of budgetary legal relations in the process of income generation, its distribution and use in the budgetary system of the Republic of Belarus, implementation of state and local borrowings, regulation of state debt as well as relations between subjects of budgetary legal relations in the budget process. Budget control is an important direction in the public interest of the state.

It is public interest in the budget law that allows its citizens to receive necessary benefits from the state through the performance of functions by state bodies. The state, by establishing legal rules reflecting certain interests, enables the subjects of budget law to acquire necessary legal means for the realization of their subjective rights, which ensures a combination of public and private interests. In the norms of the Budget Code of the Republic of Belarus, budget obligations are fixed as expenditure obligations received and accepted by the recipient of budgetary funds and (or) subjected to execution in the corresponding financial year from the funds of the corresponding budget (Budget Code, Art. 2). The state guarantees financial security through expenditure obligations - obligations of the Republic of Belarus, the administrative-territorial unit of the Republic of Belarus or the recipient of budgetary funds acting on their behalf, determined by the Law of the Republic of Belarus, Act of the President of the Republic of Belarus, the agreement concluded on behalf of the Republic of Belarus, its administrative-territorial unit, the resolution of the Government of the Republic of Belarus, the decision of the local Council of Deputies, local executive and regulatory body, to provide a resident and (or) non-resident of the Republic of Belarus with funds from the relevant budget 
(Budget Code, Art. 1/461). At the same time, budgetary allocations are directed to the social provision of the population, provision of social payments to citizens or purchasing of goods, works, services in favor of citizens to ensure their needs in order to implement social support measures for the population, to realize socially significant state programs.

Thus, state assumes public obligations - expenditure obligations of public-law entity, determined by law, other regulatory legal act, to a natural or legal person, another public-law entity, subjected to enforcement in the amount established by the relevant law, other regulatory legal act or having a method for determining it, established by a corresponding act (calculation, indexation).

It should be noted that the subjects of budget law have a very definite interest in using budgetary funds for the benefit of the development of society and each individual. Social, economic and other common needs are recognized as social and public in the analyzed situation. The state in this interpretation acts not as an independent subject of social relations, but only as a representative of the interests of society, Authorized to perform functions through budgetary activities in general. At the same time, one should not forget and bear in mind that when resolving disputes, that it is necessary to accurately qualify the norms that are subjected to direct application for the implementation of public and private interests in the budget law.

\section{Public Interest in Tax Law of the Republic of Belarus}

Taxes, being an attribute of state, in addition to the fact that they touch the foundations of the constitutional order of the state, they also concern the entire system of human and citizen rights and freedoms. The inviolability of private property, protection of human rights and freedoms enshrined in the Constitution determines the importance of tax law from the position of both public and private subjects. Modern tax law comes not only from public interests of the state through the implementation of fiscal tasks but also from the private interests of natural and legal persons participating in civil circulation through tax incentives. Since tax regulation is mainly fiscal in its nature, taxation is characterized by giving priority to public interests over private ones. Legal principles of a tax system of a particular state fully reflect correlation of private and public interests.

In the tax law science it is not only issues of correlation between private and public interests, but primarily the concepts themselves approach to their definition that causes discussion. As a theory of law (Karaseva, 2006) the tax law expresses different points of view regarding the content of the concept of public interest. Khimicheva N.I. pointed out that private interests lie in: reducing of tax burden; 
return of taxes in the form of social benefits; protection of property rights of a private subject; application of tax legislation in the most beneficial way for a taxpayer; fair consideration of tax disputes; providing complete and reliable information on tax legislation; observance of tax secrecy (Khimicheva, 1997: 102).

The interests of the private and public subject in tax sphere can be classified according to various grounds. For example, the interests of individuals - according to status in tax legal relations of a private subject that bears such interest (taxpayers, tax agents, persons on whom the duties of a taxpayer are imposed, persons participating in tax control procedures, taxpayer representatives, tax authorities, customs authorities, etc.); according to the compliance of interests with legislation (legal and illegal); according to types of needs to which they are directed (property, non-property, own needs, need of others, group and individual needs, etc.); according to the duration of their existence (long-term or temporary ("momentary")); according to their connection with other interests of a subject. Some of the private interests may be "unique", i.e. they are inherent only to a particular single subject-bearer, or "universal" i.e. they are inherent to several or all categories of the subject. For example, private property interests related to obtaining of property benefits from the performance of tax agent duties are absent in the correspondent subjects (tax agents) obliged to calculate, withhold and transfer taxes to the budget, as well as banks that carry out transactions to transfer taxes to the budget are that are obliged to report on the opening or closing of taxpayers accounts; in subjects obliged to transfer information to the tax authorities about registration of certain rights or transactions made by a taxpayer.

A comprehensive study of public interest in tax law will not be complete without an analysis of tax legislation principles. Principles of law - objective properties of law, which are rooted in its content. They reflect the laws of social development, the needs of society in legal regulation. In the opinion of T.S. Boyko, "the principles of regulating of tax relations are fundamental elements that reflect the objective laws of tax relations" (Boiko, 2011: 74). In the frame of this work, the following constitutional principles, which are reflected in the principles and rules of tax legislation, are of the greatest interest:

- the principle of recognition of human and citizen rights and freedoms as the highest value and the principle of their observance and protection by the state (Art. 2 of the Constitution of the Republic of Belarus);

- the principle of the social character of the Belarusian state (Art. 7 of the Constitution of the Republic of Belarus) defines the duty of the state to pursue a certain social policy and bear responsibility for decent life of citizens, regardless of ability to participate in socially useful work (Boiko, 2011: 75). The principles play the role of reference points in legislation formation. An 
emerging legal idea, in a number of cases, is developed in the form of a principle that influences the development of law.

In the future, the legal principle is translated into the rules of legislation. Thus, in the opinion of M.V. Arakelova, "the shift in the balance of interests of private and public subjects towards equality, originally emerged as a legal idea, which then began to find expression in the rules of tax legislation" (Arakelova, 2015: 42).

As one of the manifestations of this trend, one can name the norm from paragraph 7 of Art. 3 of the General Part of the Tax Code, which specifies that "in case of ambiguity or vagueness of tax legislation provisions, state bodies and officials shall make decisions in favor of payers" (Tax Code). While investigating general issues of tax legislation, it is necessary to take into account that its most important tasks are: protection of the property rights of taxpayers from unlimited (in principle) claims of the state and maintaining the balance of public and private interests of tax relations subjects. The very emergence and development of tax legislation are associated with the democratization of society, with the idea of a law-governed state. Principles of justice are becoming more characteristic to Tax law as part of the Belarusian legal system.

The principle of justice is traditionally regarded as the most important. Universal justice is unattainable if we evaluate the event and the phenomenon behind it from the point of view of each participating subject. Speaking about tax relations, those that most corresponds to the balance of interests currently existing in society should be recognized as fair. Public relations, interests of public and private subjects, rules of tax legislation as a result of mutual influence in each period of time tend to the most optimal, to their equilibrium state, which for various reasons is not achieved.

The principle of justice is closely related to the principle of proportionality of taxes, which lies in the optimal balance of budget filling and unfavorable tax consequences for a taxpayer. This principle can also be formulated as a principle of balance of private and public subjects' property interests. This important principle designed to link, coordinate fiscal and stimulating interests of private and public subjects is not adequately reflected in the current tax legislation (Bryzgalin, 1997: 6).

The principle of proportionality could be manifested in the regular specification of tax rates, alongside with the adoption of the law on the budget for the next year, based on the forecasts of the country's economic and social development (Grigorieva, 2009: 32). It should be noted that the principles of tax and budget law are closely connected to tax and budget laws within the framework of the financial law. For example, the principle of proportionality of taxes is related to the principle of the balance of budget, budget legislation, suggesting that the number of budgeted 
expenses should correspond to the total amount of budget income (Art. 8/4 of the Budget Code of the Republic of Belarus) (Budget code).

In accordance with the principle of the public purpose of paying taxes and fees, taxes are established to ensure the solvency of public authorities subjects and should have socially billable character. The state cannot have needs that are different from the needs of society and spend tax revenue for these purposes. This principle develops a provision on the social character of the state, the policy of which is aimed at creating conditions that ensure a decent life and free development of a person, state support for the family, disabled people and elderly citizens, etc. This principle demonstrates the inseparable link between tax legislation and budget legislation within the framework of a single branch of financial law. It is within the budgetary process that deputies, representatives of taxpayers, determine the plans for spending budget funds, control the implementation of budgetary assignments by the executive authorities (Abramchik, 2013: 130).

The principle of the public purpose of paying taxes involves finding a balance of interests of private and public subjects. The property interest of all members of society is embodied in the duty to pay taxes. Therefore, the state has the right and is obliged to take measures to regulate tax legal relations in order to protect the rights and legitimate interests of not only taxpayers but also other members of society. The implementation of the principle of public purpose also implies the consent of a private subject to introduction of tax and his participation in control over the expenditure of funds.

The principle of equal tax burden or the principle of equality is realized in tax legislation not as payment of taxes in the same amount, but as the economic equality of payers and is expressed in the fact that the actual ability to pay tax on the ground of comparison of economic potentials is taken as a basis. The principle of the equal tax burden is to balance public and private interest and to take into account taxpayers economic status to the fullest extent without violating legal equality of taxpayers.

The principle of limiting of specialization of taxes should also be noted. As a general rule, the tax is not intended for targeted expenditure. This is one of the conditions for the stability of the state budget and guarantees that the state fulfills its functions. Target taxes are not completely excluded, but their establishment must be conditioned by significant goals. To introduce a targeted tax, it is necessary to justify, from the constitutional point of view, the need for financing a specific event precisely at the expense of targeted deductions, but not from other sources (Poroshkova, 2007: 59). 
The legal principle of parity of interests of the state and taxpayers is of particular interest (the principle of parity of interests). The essence of this principle is to establish the balance between economic interests of the state and a taxpayer. The principle of parity of interests is based on the idea of smoothing contradictions between interests of the state and taxpayers, which are manifested in the fact that the state seeks to receive as much tax revenue as possible, and the taxpayer to pay as little taxes as possible, as he seeks to save as much income as possible for economic and social development. In these conditions, there is a need to find ways to smooth economic contradictions and highlight the importance of publicity of interests.

Economic equalization of public interest of the state and taxpayers is also carried out through tax administration. Even a slight violation of the balance of these interests leads to a violation not only in the field of taxation but also to causing damage to the state financial (budgetary) activity. It should be noted that in the legal literature judgments have already been expressed that with the adoption of the Tax Code the shift of the balance of rights between public and private subjects towards the latter has become clear.

As an example of the manifestation of the trend of shifting the balance of interests towards a private subject one also should note the fact that the Tax Code of the Republic of Belarus formulates requirements addressed to legislative and law enforcement bodies when adopting and interpreting legislation on taxes and fees. When establishing the requirement to the legislator that the acts of tax legislation should be formulated in the way that everyone knows exactly what taxes (fees), when and in what amount one should pay, the consequences of non-compliance with this requirement are immediately determined: in case of ambiguity or vagueness of the requirements of acts of tax legislation state bodies and officials should make decisions in favor of payers.

Thus, the presumption of the taxpayer's rightness is legislatively determined, when doubts, contradictions, and ambiguities in acts of legislation on taxes are unrecoverable. The implementation of this presumption should allow providing protection of property rights and interests of a taxpayer (Pilipenko, 2006). Since the public interest of all members of society is embodied in the constitutional duty of a taxpayer, the state is not only entitled, but also obliged to take measures to regulate tax relations.

In the opinion of the Constitutional Court of the Republic of Belarus, the types of administrative penalties, the size of the fine, imposed by the Law, allow the enforcers to assign appropriate penalty taking into account the nature and harmful consequences of the committed administrative violation, the circumstances of its commission. The change in the legislative regulation of administrative responsibility 
for violation of procedure of income and property declaring give evidence of legislation liberalization in the field of declaring and is aimed at implementation of the principle of humanism. Ensuring of taxpayers' fulfillment of their constitutional obligation to participate in the financing of public expenditures by paying state taxes, the obligation of natural persons to comply with the requirements of the Declaration law will be exercised through other leverages without bringing these persons to administrative responsibility (Art. 12/1 and Art. 12/7 of Declaration Law). In addition, the Constitutional Court believes that legislator strengthens legal basis for encouraging natural persons to act in compliance with the law, that is expressed in the timely performance of their duties under the Constitution and legislation, which takes into account the interests of society and the state.

From the revealed constitutional and legal sense of the Law, it follows that its provisions are aimed at clarifying of legal regulation in the field of income and property declaring, specifying the rights and obligations of natural persons when declaring income and property at the request of tax authority, process of control activities implementation in this area and are based on the principles and norms of the Constitution. In our opinion, it is necessary to single out the criteria of public interests that are significant from tax and legal point of view, which must be taken into consideration and be settled by tax law. At the same time, not only legally qualified and competent subjects but also procedures, as well as terms for their implementation, should be identified.

\section{Conclusions}

The research carried out led to the conclusion about the necessity of legislative consolidation of the concept of "public interest" in the financial law, defined as social interests recognized by the state, expressed in the rules of financial law and provided with the mechanism of state coercion allowing the development of society and the state. The diversity and multiplicity of functions performed by modern states as well as the incoherence and inconsistency of the goals of various state policies (tax, budget, social, scientific and others) cause plurality and diversity of public interests. Public interest in tax law is manifested in the desire of subjects of tax relations to ensure their legitimate realization, to implement actions aimed at meeting the needs, protecting their rights, receiving material and other benefits, and fulfilling the duties assigned to them by the Constitution of the Republic of Belarus and tax legislation.

Often a particular interest, not explicitly named, is realized in the norms of legislation. However, interest can be embodied in tax legislation. The interdependence of public and private interests leads to the fact that it is difficult or even impossible to 
determine the only subject of a particular interest. Public interests include interest in maintaining a single economic space; interest in the protection of public subject property rights; interest in sharing of tax powers.

It is necessary to find a balance between public and private interests, which include: interest in reducing of tax burden; in return of taxes in the form of social benefits; in protection of property rights of a private subject; in application of tax legislation in the most beneficial way for a taxpayer; in fair consideration of tax disputes; in providing complete and reliable information on tax legislation; in observance of tax secrecy. The use of constitutional principles makes it possible to implement in practice the protection of private property in the implementation of tax relations, to confirm the priority of protection of taxpayer interests while observing the interests of a public subject, to ensure legitimacy in tax legal relations. The analysis carried out showed that tax legislation reflects a trend consisting in shifting of the balance of property interests of public and private subjects of tax relations towards their equality. In this regard, it seems necessary to fix in the Tax Code of the Republic of Belarus, among the main principles of the legislation on taxes and fees, the principle of parity of public interest, which allows achieving harmony in the financial provision of social development.

Since some public interests are not common to all members of society, the complete coincidence of public and social interests is an idea that is not achievable in reality. In tax law, the basic public interest predetermining its system is fiscal interest. At the same time, there are additional public interests, as well as social interests having a general legal, general social significance, that should be taken into account when implementing legal regulation of taxation. For example, for tax law among additional interests and those of general legal significance one can name: the existence of a law-governed state, the priority of universal values; equality and justice; state integrity and security and many others.

\section{References}

Abramchik, L.: Конституционные основы налогового права в Республике Беларусь (Constitutional fundamentals of tax law in the Republic of Belarus, Value paradigm of the Basic Law of the Republic of Belarus), Minsk: BSU, 2013.

Alekseev, S.S.: Теория права (Theory of law), Moscow: BEK, 1995.

Arakelova, M.V.: Баланс частных и публичных интересов при альтернативном разрешении споров, возникающих в налоговых правоотношениях (Balance of private and public interests in alternative resolution of disputes arising in tax legal relations), Финансовое право (Financial Law) no. 11 (2015). 
Boiko, T.S.: Реализация конституционных норм и принципов в налоговом законодательстве Республики Беларусь и решениях Конституционного Суда Республики Беларусь (Realization of constitutional norms and principles in tax legislation of the Republic of Belarus and decisions of the Constitutional Court of the Republic of Belarus), Веснік Канстытуцыйнага Суда Рэспублікі Беларусь (Bulletin of the Constitutional Court of the Republic of Belarus) no. 1 (2011).

Bryzgalin, A.V.: Справедливость как основной принцип налогообложения (Justice as the main principle of taxation), Финансы (Finances) no. 8 (1997).

Chernikova, E.V.: Несколько слов о налоговом патриотизме (A few words about tax patriotism), Современное право (Modern law) no. 4 (2016).

Gavrilchenko, Yu.P.: Правовое регулирование сбережений населения. Теория и практика (Legal regulation of population savings. Theory and practice), Saarbrucken: LAP Lambert Academic Publishing, 2016.

Gracheva, E.Y.: Государственный финансовый контроль как важнейший инструмент обеспечения публичных интересов в условиях рынка (State financial control as an essential tool for ensuring public interests in the market conditions), Вестник университета имени О.Е. Кутафина (МГЮА). Выпуск “Финансовое право” (Bulletin of the University named after O.E. Kutafin (MSAL). Issue "Financial law") no. 4 (2014).

Grigorieva, E.N.: Классификация принципов налогового права (Classification of tax law principles, Actual problems of economic development of the Republic of Belarus and its legal regulation), Minsk: BSEU, 2009.

Gvozdev, V.D., Ryabtsev L.N.: Интересы в праве: теоретические проблемы определения сущности и критериев классификации (Interests in law: theoretical problems of determining the nature and criteria of classification), Право в современном белорусском обществе (Law in contemporary Belarusian society), Minsk: Center for law and pravofinansi. REP, 2013.

Ioffe, O.S.: Обязательственное право (Law of obligations), Moscow: Legal literature, 1975.

Karaseva, M.V.: Современные проблемы построения системы финансового права (Modern problems of financial law system building), Правоведение (Jurisprudence) no. 3 (2006).

Khimicheva, N.I .: Налоговое право (Tax Law), Moscow: BEK, 1997.

Krokhina, Yu.A.: Финансовое право России (Financial Law of Russia), Moscow: Norma, 2014.

Krokhina, Yu.A.: Современные вопросы предмета финансового права (Current Issues of the Subject of Financial Law), Финансовое право (научно-практический журнал Украины), Financial Law (Scientific and Practical Journal of Ukraine) no. 1 (2012).

Leshchenko, S.K.: К вопросу о понятии международного налогового права (On the concept of international tax law), Промышленно-торговое право (Industrial and trade law) no. 5 (2008).

Malko, A.V. (eds): Правовая политика России (общетеоретические и отраслевые проблемы) (Legal policy of Russia (General theoretical and branch problems)), Moscow: Yurlitinform, 2014. 
Public Interest in Financial Law of the Republic of Belarus: Theory and Practice

Maltsev, G.V.: Социальные основания права (The Social foundations of law), Moscow: INFRA-M, Norma, 2011.

Marchenko, M.N.: Теория государства и права (Theory of state and law), Moscow: Publishing House Prospect, 2015.

Nersesyants, V.S.: Общая теория права и государства (General theory of law and state), Moscow: Norma, 2004.

Nogina, O.A.: Государственные внебюджетные фонды в составе бюджетной системы России:проблемы правового регулирования (State extra-budgetary funds within the Russian budget system: problems of legal regulation), Moscow: Statut, 2012.

Pilipenko, A.A.: Теоретико-прикладные аспекты реализации принципа справедливости в налоговом праве (Theoretical and applied aspects of the implementation of the principle of justice in tax law), Духовность, общество, личность, государство (Spirituality, society, personality, state) no. 1 (2006).

Povetkina, N.A.: Бюджетное законодательство Российской Федерации: перспективы развития (Budget legislation of the Russian Federation: prospects for development), Финансовое право (Financial law) no. 9 (2015).

Poroshkova, T.A.: Меры и способы защиты публичных интересов в налоговых правоотношениях (Measures and ways to protect public interests in tax legal relations), Налоговые споры: теория и практика (Tax disputes: theory and practice) no. 9 (2007).

Rabets, A.M.: Соотношение частных и публичных интересов в сфере государственной поддержки семьи в Российской Федерации (The correlation of private and public interests in the sphere of state support of family in the Russian Federation), 2016. www.naukarastudent.ru.

Shershenevich, G.F.: Учебник русского гражданского права (The Textbook of Russian civil law), Moscow: Spark, 1995.

Sheveleva, N.A.: Баланс частных и публичных интересов (Balance of private and public interests), Конституция Российской Федерации (The Constitution Of The Russian Federation), Moscow: Norma, 2009.

Spector, E.I. (eds.): Публичные и частные интересы в финансовом праве (Public and private interests in financial law), Moscow: Norma, 2011.

Tikhomirov, Yu.A.: Публичное право (Public Law), Moscow: Publishing House BEK, 1995.

Vasilevich, G.A.: Конституция Республики Беларусь: научно -практический комментарий (The Constitution of the Republic of Belarus: scientific and practical comment), Minsk: State Institute of Management and Social Technologies of the Belarusian State University, 2005.

Vitushko, V.A.: Теория механизма правового регулирования экономических отношений (Theory of the mechanism of legal regulation of economic relations) Doctor (higher doctorate) Thesis, Minsk: Belarusian State University, 2001.

Zapolsky, S.V.: Дискуссионные вопросы теории финансового права (Discussion questions of the theory of financial law), Moscow: Eksmo, 2008. 
BY: Constitution of the Republic of Belarus of 24 November 1996.

BY: Act no. 412-3/2008 - Budget Code of the Republic of Belarus.

BY: Act no. 1660-3/2002 - Tax Code.

BY: Resolution of the Council of Ministers no. 18/2017, A set of measures to implement the main directions of social and economic development of the Republic of Belarus for 2016-2020.

BY: Decisions of the Constitutional Court of 23 December 2009 no. P-412/2009.

BY: Decisions of the Constitutional Court of 24 December 2014 no. P-962/2014.

BY: Decisions of the Constitutional Court of 28 December 2015 no. P-1017/2015. 


\title{
PUBLIC INTEREST IN FINANCIAL SYSTEM LAW'1
}

\author{
MICHAEL KOHAJDA
}

\begin{abstract}
This paper deals with issues related to public interest and financial system. He brings several general arguments regarding the actual legal regulation of financial system, asks about reasons for such detailed regulation and discovers the public interest in financial system law. In addition, the author defines the term "financial system" and "financial stability" in the paper because there can be found a lack of their broadly accepted definition in recent legal scientific literature, therefore the author offers his own definition of these terms. In the middle part of the paper, there can be found several important reasons in behalf and against the actual high level of legal regulation of the financial system. In concrete, namely a high level of risk, a high profitability of undertaking business in financial services, an asymmetry of information in the relationship between a financial institution and its client, a protection of clients, restriction of the competition of financial institutions or costs of regulation requirements fulfillment are mentioned and analyzed.
\end{abstract}

\section{Keywords}

Financial system; financial stability; legal regulation

JEL Classification: K22, K34, K39

\footnotetext{
1 This paper has been elaborated within the programme "PROGRES Q02 - Publicization of Law in the European and International Context" which is realized in 2018 at the Faculty of Law of the Charles University. 2 Associate Professor for Financial Law and Financial Science, Department of Financial Law and Financial Science, Faculty of Law, Charles University, Czech Republic. The Author specializes in financial system law, capital market law and banking law. He is the author or co-author of 5 books and more than 40 reviewed articles in prestigious journals.orcid.org/0000-0001-7235-0921. Contact email: kohajda@prf.cuni.cz.
} 


\section{Introduction}

The financial system is a branch of social life that is broadly and in detail regulated by law. But the question what the reason for such level of regulation is can be asked. This question is more important when an existence of the public interest is analyzed in different branches of law comparing the importance of legal relationships in such branch for the public. According to opinions of many Authors the actual progress in legal regulation of the financial system is determined by the complexity of the financial services and the relationships between financial institutions and their clients (Cooley, 2010: 73).

It can be found surprising why the field of demand and supply for financial assets shall be regulated in such broadway. Where else than in this branch shall the invisible hand of the market (i.e. autoregulation) take effect? But in the real world, this concept does not prevail, and it shows just as a theoretical and not relevant idea, on the contrary, practical experiences ask for detailed legal regulation of financial system for many reasons and the public interest is one of the most important ones.

The general need for the existence of binding rules of behavior in the financial system arises from the fundamental fact which can be also found in all other branches of social life, i.e. the fact that in the financial system subjects enter social relationships which must be regulated by legal rules for their functionality and public enforceability. Respecting the complexity of legal relationships in the financial system and general inequity of subject entering legal relationships in knowledge and possession of information, it is necessary to put public law requirements onto the primarily private law relationships that in the financial system are not much different comparing to any other, ordinary private law relationships in general social life. The public law regulation establishes second, the upper layer of legal regulation above the fundamental private law regulation of legal relationships, the second layer contains much detailed regulation which is usually composed by mandatory legal rules regulating rights and duties in the concrete legal relationship. It is important to realize that in fact in relationships in the financial system there cannot usually be found proper equity between subjects which, in general, is the fundamental principle of private law relationships, therefore the secondary regulation by public law is needed.

The example of a concrete public interest can, of course, be brought from the conduct of business regulation in the financial system (it shall be mentioned that the public interest can be also found in the prudential regulation of the financial system). The mentioned inequity is, for example, obvious in the relationship between the financial institution and its possible client who is the natural person not undertaking any business. There is no equity there regarding the amount of information, 
therefore there is very small possibility of the possible client to make an informed decision according to real will. The financial institution has expert knowledge, high practical experience, and ability. On the contrary, the possible client has nothing of this but usually has a necessity to enter the relationship with a financial institution (for example he needs to have a payment account). In fact, such possible client must choose among several concrete financial institutions on the local market, but every of them starts negotiation process with a previously prepared agreement of concrete content, very often so-called form agreement, and it does not allow to negotiate about any particular provision of it, the possible client can only decide to accept the prepared agreement or to refuse it and try to find out other financial institution (which unfortunately probably will offer him very similar agreement conditions as the previous one). In fact, the possible client has no real choice and he will sooner or later accept an offer of a financial institution because he needs a concrete financial service.

On the other hand, it must be admitted there is no other reasonable possibility of financial institution's position because of legal regulation of its behavior as well. An allowing of negotiation with every person who is interested in its financial services would mean high costs because it would require quite complicated and formal process of approval of every made change to fulfill all requirements of legal regulation on internal process inside the financial institution. The aim of the public legal regulation is not to change the process between a financial institution and its possible or existing client, but to set conditions that will adjust the unequal position between them to allow establish a fair legal relationship.

\section{Financial System as Legal Term}

When the term "financial system" was already mentioned several times, it is necessary to bring a definition of it, at least for the purpose of this paper. The term is quite broadly used in the legislation of the European Union and its member states, but (and it can find out as a relative surprise) there is no real legal definition of it. Only exception is the Regulation (EU) no. 1092/2010 of the European Parliament and of the Council of 24 November 2010 on European Union Macro-prudential oversight of the financial system and establishing a European Systemic Risk Board that in Art. 2 defines the financial system as all financial institutions, markets, products and market infrastructures - but this cannot be considered as enough indepth definition of this term.

When it is being looked for the meaning of the term "financial system" it shall be started in economics because in this case law follows the economics, it regulates economic phenomenon. Therefore, for reaching the definition it is important 
to briefly describe functions that shall be fulfilled by the financial system in the economy. The primary aim of the financial system is to allow to treat with financial assets in different forms. The relatively redundant financial assets are collected and deposited through financial institutions with the aim to do not let them stay at the subject with their surplus. These financial assets do not be usually kept in their original form, but they are transformed into a form of accounting records with the simultaneous use of the same assets in the original form for different purposes, mainly for the purpose of lending. The monetary assets can be changed for financial or real investment instruments. This deposition of redundant financial assets through the financial system shall protect them from depreciation, or (in better case) it shall bring their appreciation in time. The financial system shall offer a general protection against a sudden depreciation (a loss) as well enabling dislocation of assets in place or object.

Another important function of the financial system is a mobilization of money, particularly an enabling of payment services, i.e. settling financial transaction through the transfer of monetary value, that is organized by the public (usually a central bank) or private (financial institutions) subject. This function is very important one which differs the financial system from financial markets that particularly enable investment of redundant financial assets.

These functions of the financial system are important not only from a perspective of private subjects, natural persons or commercial entities but from a perspective of public subjects including a state itself as well. Every state is very dependent on properly functioning financial system from the budgetary incomes point of view, the state gets obligatory levies through it, from the credit financing point of view, the state borrows financial assets in the financial system, or from the budgetary expenses point of view, the state distributes financial assets to relevant subjects or makes payments for acquired goods or services through the financial system.

Every system consists of elements and relationships among them. In case of the financial system, subjects can be considered as elements (subjects having redundant financial assets, subjects with the need of financial assets, subjects allowing and organizing transfers of such financial assets and subjects acting as oversight authorities) and these subjects enter legal relationships according to general binding legal regulation.

In summary and particularly, the financial system can be defined as the sum of all kinds of financial markets including their subjects who meet with their demand for and supply of disposable financial assets and subject who provide their financial services mainly for the previously mentioned subjects and the relationships among them, at the same time in summary these subjects and financial services provided 
by them create infrastructure enabling constitution, change and termination of legal relationships concerning a treatment with financial assets (deposit, transfer, exchange for instruments traded on markets, lend to others etc.) as their object and the sum of these relationships shall be included into the financial system as well. Further, authorities of secondary regulation and supervision, mostly public origin authorities, who use their powers to produce legal regulation, to decide in individual cases and to compare behaviour required by legal regulation with actual behaviour of concrete subjects with possible subsequent inference a penalty from a breach of legal regulation shall be included in the financial system as well.

\section{Financial System Stability as Public Interest}

The most important reason for legal regulation of the financial system in actual quantity and quality of legislation consists in the interest of a state in wellfunctioning, sound, healthy and stable financial system that has lack of negative deflections caused for example by the bankruptcy of more important financial institutions or dysfunction of infrastructure used for financial services.

Financial institutions, mainly the biggest of them as banks, insurance companies or fund management companies, can impact the whole financial system by their behavior. It is necessary to realize that the well-functioning financial system is the fundament of the economy of each economically developed state, therefore the well-functioning financial system is the economic and legal interest of every state and the state protects the financial system by its best possible legal regulation. The public interest can be in general found in the financial system as the aim to do not allow subjects included in the financial system to behave just according to their will, but to regulate their behavior to reach a protection of the financial system and all subjects within.

As was mentioned in the introduction, the legal regulation of financial system can be differed into two parts according to two main aims of such regulation, i.e. regulation of conduct of business requirements and prudential requirements, public interest can be found in both, but general aim of the public interest in the financial system is the stability of the system itself, i.e. the financial stability.

The term "financial stability" is not legally defined, but broadly used in the legislation of the European Union as well. The financial stability can be found as the situation in the financial system when the financial system fulfills its abovementioned functions properly, without any serious malfunctions or undesirable results for the actual or future development of the economy and when it is resistant to any serious problems. 
It is a usual aim of central bank's or any relevant authority's activity to reach and maintain the financial stability besides its other main aims, but some authors are quite skeptical about real action readiness in this field. For example, Goodhart called the Bank of England's commission that was responsible for issues related to the financial stability as "talking shop" (Goodhart, 2009: 31).

According to Theissen the term financial stability can be interpreted many ways, but he connects this term mainly with stability of banks and founds it as caring about prevention of risk of infection in case of run on bank that does not put just such bank in jeopardy but can be a threat for other banks and all system too (Theissen, 2013: 46). And for example, Crockett defines the term of financial stability as a situation when financial institutions and markets are able to mobilize savings, offer liquidity and allocate investments effectively without any disruptions (Crockett, 2003: 44).

\section{Selected Aspect of Financial System Regulation}

There can be found several relevant reasons for a broad regulation of the financial system. A potentially high profitability of services provided as the business in the financial system can be found as one of them. It is necessary to realize that money of customers is directly handled by financial services providers and it is very easy to transfer money all over the world in our highly globalized world or it is possible to invest a huge amount of money by one click on keyboard and to lose them.

The potentially high profitability of financial services attracts even subject who are not lead by positive intentions of hones business but by crooked thoughts for quick getting rich. Therefore, a stricter legal regulation of entrance to the financial system and providing of financial services shall be imposed, especially requirements of authorization on subject or requirements on capital used for establishment of such business. Other very relevant reason in behalf of a strict legal regulation of financial institutions' activity is an asymmetry of information in the relationship between a financial institution and its client. Asymmetry of information can be defined as a situation when theoretically equal parties of legal relationship dispose of the diametrically different sum of information necessary for the decision about such legal relationship, this difference can be in quality or quantity of such information. When a person, especially a consumer, enters into a legal relationship with a financial institution his contractual partner is very well equipped with knowledge, experience, professional staff or advisers. Therefore, the theoretical civil equity of contractual parties is not reflected in practice. The public legal regulation shall equalize this inequality between the parties by enforcement of obligatory contractual conditions in rights and duties of such legal relationship, by enforcement of a financial institution to provide its client relevant and understandable information 
regarding to the legal relationship or providing a client by concrete contractual rights in his favour, for example a right to terminate the contract in concrete period after its conclusion or a right to use a mechanism existing to protect rights of clients (e.g. deposit insurance scheme).

Without the public legal regulation that is a superstructure of private legal regulation as the base for legal regulation of mutual rights and duties between a financial institution and a client, it would not be fulfilled even fundamental principles of private law, especially the principle of equality of contractual parties. Furthermore, for example, Gray and Hamiltons say (2006: 199) that in case of consumers their bad decisions, if and which financial services are suitable for them, arise under influence of lack of relevant information; often the lack of relevant information is the reason why consumers do not use concrete financial service at all. The related reason for broader legal regulation in the financial system is the protection of clients (or in narrower meaning consumers).

Gleeson's opinion in the branch of banking can be considered as appropriate for all financial system (Gleeson, 1999: 6) - banks do not act in behalf of their clients but enter with them business relationships (e.i. trade with them for the creation of profit). And the financial system is based on trust of clients in the sound functioning of the financial institutions and financial system that they are part of. Carnell, Macey a Miller appositely state (2013: 291) that for long ages there was only one binding rule in banking protecting clients - the ban of usury. But this minimalistic regulation is already overcome and nowadays we are in the completely opposite situation where banking, as well as the rest of the financial system, is overregulated. According to Bonneau (2014: 330) the protection of client is rationalized not only by his weaker position as a party who shall be protected but its aim can be found as improvement of client's confidence into the financial system and financial institutions, because only with this confidence the system can be more effectively functioning. Particularly the European Union single system where the financial services are provided over borders and concrete financial institutions do not have to be well known in a country of financial service providing (and therefore not enough credible, because in general people do not trust thinks they do not know), and without proper legal regulation and following supervision the confidence into unknown institution shall not have to be sufficient to let these financial institutions compete with local financial institutions on fair market.

On example of banking, it is possible to illustrate the importance of client's confidence for sound functioning of the whole system. The business activity of commercial bank is based on voluntary deposits of the public, the gained financial assets are further lent for higher interests that are paid to depositors whose financial assets are used. Furthermore, it is typical for banks that the financial assets are 
borrowed from depositors for short time period but borrowed to bank's debtors for the long time period, this time imbalance cannot be found in different kinds of business than banking. For this functioning of banking, it is necessary that the depositor have adequate confidence in banks to provide them with their money, not to keep them at home or to invest them in another way. In this situation, the quite broad legal regulation of the relationship between depositor and bank takes place with the aim to increase depositors' confidence. This aim can be reached by several ways. One of them is a limitation of subjects allowed to accept the deposits from the public, requirements of the fulfillment of more strict conditions to run a business as a bank can be the second one. This legal regulation is usually supplemented by a special regulation of the situation when a bank is not able to pay back the accepted deposits, e.g. by a creation of deposit insurance scheme.

In case of the Czech Republic, actual system of deposit insurance scheme (which is harmonized in all EU countries) is so generous that it covers the majority of existing deposits from the public (it ensures to recover $100 \%$ of deposits by the limit that is higher than the majority of existing deposits from the public). It is even so generous that it can distort a basic investor's triangle - to eliminate a risk of the non-returning deposit back. A depositor who knows this fact, therefore, can only choose among interest that is offered by banks. This could be an example where it can successfully be doubted correctness of legal regulation of such social relationships. Now, it can be mentioned several reasons against this high level of legal regulation of the financial system, i.e. negative aspects of such regulation. One of the fundamental reasons against the actual level of regulation is a restriction of the competition of financial institutions or subjects willing to undertake business in financial services. It is necessary to agree with Goodhart (Goodhart, 2012: 321) that if the regulation of financial system shall be effective it simultaneously imitates regulated subjects in achieving of preferred and unlimited position and often decreases their profit and has the bad influence on their capital. In his different work (Goodhart, 2009: 101) can be found the conclusion that regulated subjects willing to reach a protection of their business look for any possibility how to enter non-regulated areas of similar activity to use more profitable opportunities.

Restriction of competition is mainly caused by strict requirements of the entrance of business subjects into providing of financial services. Usually, there are more strict conditions regarding a minimal capital, personal and technical apparatus or establishing of internal processes. Sources of capital are examined very often as well to find out a real owner of the subject or to eliminate a risk of criminal activity or terrorism origin of the financial assets. Because the fulfillment of such criteria is usually very complicated and demanding the entrance into the business is restricted just on several subjects who later do not have to have, especially in small 
economies, stronger motivation to compete on the market of financial services. In case of the EU, this negative can be overcome by cross-border provision of financial services which is very common activity in this area where a concept of the single European passport for financial services exists.

It shall be mentioned that there can be found different opinions on the relationship between legal regulation and market competition. According to Crockett (Crockett, 2003: 55), well-functioning market environment in the financial system shall eliminate badly functioning financial institutions or markets and at the same time to stimulate development of prudential and effective practice. Another negative aspect of broad legal regulation of the financial system relates to the market competition, this aspect consists of the high cost of fulfillment of requirements stated by such regulation.

The fulfillment of the very high number of legal regulation costs regulated and supervised subject high amounts of money. It comprises a necessity to set up all processes, to prepare contractual documentation etc. according to regulation requirements, later to fulfil continuous information obligation towards a supervisory authority or authorities that on their basis and after their evaluation find activity of supervised subject as according, or against the legal regulation and possibly deduce other conclusions (sanctions, penalties etc.). Resultant amount of information obligation of the financial institutions undertaking their business in several branches of financial system depends on the used model of institutional organization of the financial system supervision, i.e. number and system of supervisory authorities.

The connection between costs and the market competition in the financial system can be considered even in more concrete aspects. The caused costs for the fulfillment of regulatory requirements are included into the price of financial services by financial institutions and the price is (of course) paid by clients of such financial institutions (or they are calculated as cost and have an impact to interest paid to depositors). Different branches of business or concrete financial services legally not regulated in such way gain an advantage of lower costs and can be provided for lower prices or bring higher interests. Therefore, even traditional financial institutions try to discover how to avoid concrete legal regulation and to create similar financial services or schemes that would bring advantages for customers, profit for the institution but would not belong under the regulation.

\section{Conclusions}

The main aim of this paper was identified a public interest in the financial system law. The public interest is the immanent component of every legal regulation 
because otherwise any concrete relationship would not be regulated by law if it was an interest just of an individual.

The general and the most important public interest in the financial system regulation and simultaneously the most important aim of this regulation is the stability of the financial system itself. The stability has many aspects and an aim to reach it can be found in the regulation of majority of legal relationships in the financial system.

\section{References}

Bonneau, T.: Régulation bancaire et financière européenne et internationale (European and international banking and financial regulation), Brusel: Bruylant, 2014.

Carnell, R.S., Macey, J.R., Miller, G.P.: The Law of Financial Institutions, New York: Wolters Kluwer Law \& Business, 2013.

Cooley, T. et al.: Consumer Finance Protection, in: Acharya, V., Cooley, T.F., Richardson, M., Walter, I. (eds.), Regulation Wall Street: The Dodd-Frank Act and the New Architecture of Global Finance, New York: Wiley, 2010.

Crockett, A.: Strengthening financial stability, in: Booth, P., Currie, D. (eds.), The Regulation of Financial Markets, London: The Institute of Economic Affairs, 2003.

Gleeson, S.: Financial Services Regulation: The New Regime, London: Sweet \& Maxwell, 1999.

Goodhart, C.A.: The Regulatory Response to the Financial Crisis, Cheltenham: Edward Elgar, 2009.

Goodhart, C.A.: The boundary problems in financial regulation, in: Barth, J.R., Lin, C., Wihlborg, C. (eds.), Research Handbook on International Banking and Governance, Cheltenham: Edward Elgar Publishing Limited, 2012.

Gray, J., Hamilton, J.: Implementing Financial Regulation. Theory and Practice, Chichester: John Wiley \& Sons, 2006.

Theissen, R.: Are EU Banks Safe? Hague: Eleven International Publishing, 2013. 


\title{
PUBLIC FINANCIAL INTEREST IN POLISH TAX LAW
}

\author{
WITOLD MODZELEWSKI
}

\begin{abstract}
The paper describes the backgrounds and presents critical postulates to the Legislator, which altogether form the indispensable premise, indeed the foundation, for the defense of our country's interests. First, to eliminate the secret lobbying in the law-making process. Every expert must be bound to reveal in public whether he has a conflict of interest, under legal responsibility. Second, all and any links between public authorities and the tax business specializing in "aggressive tax planning" must be severed. Three, an investigation committee ought to be set up, tasked with investigating into all the pathologies identifiable in the regulations development process in respect of VAT as well as the other taxes (excise tax and income tax, in particular), where the losses are no less severe, or even severer, compared to the income gained. So far, the constitutional system of Poland has not opposed the degradation of the establishment, interpretation, and application of substantive tax law - a matter of so high importance for the financial interest of the State.
\end{abstract}

\section{Keywords}

Tax law; public interest; Poland

\section{JEL Classification: D63, H24, K34}

\section{Introduction}

Public financial interest is usually defined intuitively: its content and purpose are for the public levies system to ensure non-reimbursable income sufficient to cover the indispensable and reasonable public spend and debt servicing (if any). In tax-

1 President of the Institute of Tax Studies. Professor of the Faculty of Law and Administration at the University of Warsaw. In 1992-1996 Vice-Minister of Finance responsible for the reconstruction of the Polish tax law system. During his term, tax on goods and services and excise tax, labeling of excise goods, investment reliefs in income taxes, regulations on taxpayers identification were introduced. Academic lecturer at the University of Warsaw, the Warsaw School of Economics and other universities. The Author and Co-author of over a thousand books and articles devoted mainly to taxes and tax law. Tax Advisor and Legal Advisor. Contact email: biuro@isp-modzelewski.pl. 
law terms, the content of public financial interest is strictly defined. Specifically, the provisions of a tax law are compliant with public financial interest whenever:

- substantive tax law (detailed section) proves to be sufficiently fiscally efficient;

- the general section of tax law (substantive and procedural) ensures efficient assessment and enforcement of tax arrears whilst also eliminating tax escape;

- a repressive tax law ensures a proportional system of penalties, with a preventive (deterring) effect.

I will herein refer to the first of these issues. Substantive tax law is concordant with public financial interest only when it proves sufficiently fiscally efficient this being a measurable phenomenon, comparable in time. The annual analytical indicators useable in the assessment of efficiency are the following:

1) the share of the amount of net tax paid ${ }^{2}$ in the total taxed tax bases;

2) the share of the amount of net tax paid in the total sum of tax bases (taxed and exempt from taxation due to tax exemptions and reliefs applied);

3) the share of the total amounts of net tax paid in the estimated amount of due/ output tax (tax loophole);

4) the share of the total amounts of net tax paid in the total balance-sheet revenues from taxpayers (in their entirety);

5) the ratio of the total amounts of net tax paid to the amount of tax arrears due thereto (interest excl.);

6) the share of total refunds in gross proceeds;

7) the ratio of the total amount of net tax paid to the estimated cost of its collection.

The most synthetic indicator is the annual share of the amounts of tax paid in the GDP and the increase/decrease trend in this share. This measure allows comparing the fiscal efficiency of individual taxes in time and in the international scale.

Obviously, the fiscal efficiency of a tax depends not only on the condition of the substantive tax law, since there have appeared (and still are appearing) escapes from taxes with use of apparent or real action, as well as deliberate or unconscious disregard of fiscal obligations. The most useful measure reflecting the tax escapes is the share of the amounts of tax paid in the estimated due (output) tax. 
Substantive tax law established in the financial interest of the State has to maximize the fiscal targets measured with use of analytical (items 1 to 7) as well as synthetic measures. In case the measures applied show a deteriorating profile of the tax, the reasons for this need being identified; in the first place, the provisions in the tax law must be identified which have enabled or facilitated the tax escape, or directly result in a gap-in-the-law. Change in legal regulations is, namely, the simplest and the least expensive means of protecting the State's financial interest. In most contemporary cases of the decreased fiscal efficiency of individual taxes, it is this particular factor that was of decisive or fundamental importance. As it follows, each particular tax ought to be analyzed, on an ongoing basis, in the light of the aforesaid measures, in order to identify the reason behind changes occurring in its fiscal efficiency and formulate de lege ferenda postulates.

\section{Problems of Creating, Applying and Interpreting Tax Law}

The above considerations are related to the assumption that substantive tax law is developed on a bona fide basis, and the legislator is unwaveringly driven by the financial interest of the State. Yet, even a cursory observation of the evolution of the Polish tax law in the last decade challenges this argument, for creating a tax law contrary to the public interest is a known phenomenon, commented on by publicists. In parallel, a depreciation of the materiality of the fiscal purpose of making the tax law, or even a fading of this purpose, has continued over many recent years. The reasons behind the process are rather complex but commonly perceptible; they include:

- an atrophy of the state awareness of the essential part of the political class, who tend to treat power as a trophy enabling to pursue one's private goals;

- lobbying that aims at creating a tax law in the interest of those who are reluctant to pay taxes;

- tax business, including "international" tax business, which contributes to the making of tax provisions in order to make money on them.

In the traditional narrative on the substantive tax law, the belief prevails that such law is formed to satisfy the financial interest of the State. Is it not, however, a matter of an idealized past? In our country, this law is, in its material aspects, "settled" (as simple as that). One can "fix", or "settle", the content of a regulation, its interpretation, or method of application (including no option to apply it). Not being 
inventive, anyone who deals with this field knows it and can quote any number of examples. ${ }^{3}$

What does such "fixing" of instituted law look like, at a closer glance? Let us first take a look at the legislation process. In order to adopt the demanded regulation, it is necessary to use the services of a specialized legislation business, which include the following steps:

- first, a draft of the (set of) regulation(s) or normative act is, obligatorily, compiled by (unknown/unidentified) private legislators;

- next, "free mass media" come into play, criticising the solutions in place and giving arguments in support of the need for a change;

- then, the floor is given to men of authority, who propose "scientific" or "professional" justifications for the proposed alteration;

- at the subsequent stage, the proposed project is stealthily put on the appropriate official's desk - which is, where the legislative process formally begins.

This is followed by a formal legislative procedure, which is fully "transparent" and "clear": the draft needs to be protected against getting "tripped up" by someone, mostly, by accident. Such a scenario is not quite plausible, though, for the procedure in question is pointless (save for rare exceptions to the rule): only the drafts with a formal placet tend to be adopted.

In all fairness, it should be remarked that it has not always been so. Years ago, in the early 1990s, draft pieces of legislation concerning substantive tax law were written in this country by loyal officials under the strict supervision of their superiors of expertise; politicians had some taxation concepts which they ordered their reports to implement, whilst there was virtually no legislative business existing. We have witnessed its rapid development only in the present century, in connection with Poland's entry into the European Union. The business in question has been operating under the patronage of liberals, left- and right-oriented alike.

This is how an essential portion, if not a majority, of (detailed) substantive-tax-law regulations, are made in Poland - not in the financial interest of the State, which

3 This is not a sort of knowledge to be accepted by any of the "opinion-making media" (as they call themselves). When I was recently invited to take part in a discussion on the "domestication" of banks, I repeated the unquestionable argument that all the regulations of the banking law of material importance have been designed by the banks themselves (which none of the disputants opposed). My argument was not quoted in the media, for it exceeded the confines of the correctness "in force". Polish mass media speak in terms of Mr. Balcerowicz's categories, which depict a simple world: there are evil politicians/officials and there are good banks. All this in spite of the fact that all the banks of importance are governed by former or present politicians or former officials. This is what a politician says, twice a Deputy Minister, who has utterly lost the election, together with his political party. 
otherwise should be an obvious thing as far as the financial law is concerned. ${ }^{4}$ This fact, regrettably, affects in an extremely destructive fashion the awareness especially, the legal awareness - of taxpayers who have to subject themselves to the solutions governed by vested interest.

"Fixing" an appropriate interpretation of the regulations is a much easier thing to do. Suffice it to submit a deliberately partitioned set of applications for interpretation, to make the competent authority disoriented. With the "deal" thus "hammered out" a series of favorable views formally approved - the applicant puts them together and then applies again, now for confirmation of the whole "taxpayer-friendly" concept. Everybody knows about it, the issue is debated in public - usually, to no response from the Minister of Finance, for he (whoever is in office) has actually been taking part in these dealings for years now.

The making of legislation can, of course, be influenced in a more sophisticated manner. Thus, one holds a conference - a scholarly one, to be sure - and invites experts (who would surely never make the slightest mention of their own "business" affiliation), "international" counseling business, judges, officials, and journalists. As a result, "representative" views are produced, which (this is for certain) coincidentally have nothing to do with the State's financial interest. The ranks of this business, let us add, have been for years been supplied with herds of civil servants formerly working for the Ministry, which apparently crowns their careers.

All the formal actors of the legislative process leading to the formation of substantive tax law (in its detailed section) - that is, the Ministry of Finance, the Government, the Sejm and the Senate (i.e. the lower and the upper house of the Parliament), and the President of the Republic, only make up a curtain behind which the one who actually governs the process operates. None of these actors are perhaps willing to know what they participate in, or maybe they really are not aware of what is going on. ${ }^{5}$

The tax business has often been an intermediary in the compilation of tax regulations. What I mean is the foreign as well as domestic business, to be sure - the latter being involved in lobbying activities for years. The business has grown fullfledged, capable of earning giant money, unattainable in any other circumstances

4 More importantly, even in public utterances concrete regulations, or even laws, are referred to by their nicknames based on the names of the companies in whose interest the regulation/law has been "settled".

5 I have warned our Dear "All Saints" many a time that any regulations thus fabricated will be to the sheer detriment to public finance: their actual authors act solely in their own interest, in their eagerness to make money taking advantage of the legislator's naivety. My letters were passed by in silence, as a rule - though even more frequently I was given a somewhat vague tint that "there's more money to remain in the taxpayer's pocket", for "the less tax, the better". Such a canonical liberal concept has proved damaging to the Polish fiscal system over the recent ten years or even longer; a concept that has, unfortunately, already appeared somewhere at the background of the new Government whose official idea has been to improve on ("tighten") the tax system, basically supported by their voters. 
and, primarily, has entered political and clerical circles. It prevails in the trade media as well, interpreting the regulations in magazines, awarding prizes to themselves for successes in counseling, and acts as the only expert in tax policies (the "newspaper experts"). Lobbying is, of course, a legal activity and nobody can be punished for it. Tax regulations should be written by politicians observing public interest, whilst no expert should ever find himself in a conflict of interest - such as, for instance when dealing on a daily basis with tax optimization using the "Luxembourg agreements".

We all basically tend to (legitimately) criticize the way the legislative process goes; in tax legislation, one can speak of multiple pathologies appearing. It is not known who compiles drafts which are subsequently adopted by the Sejm, with no verification or afterthought at all. All this takes place in a distorted ambiance of suspicions of lobbying, the omnipotence of nameless officials, and conspiracy of so-called experts who often represent the interest of the tax business. It is high time now to (re)think how to rationalize and heal the process of making substantive tax law - and, primarily, how to try and outline its major non-political principles so as to protect the State's financial interest. Contrary to the appearances, there exist certain specific rules governing the process, although some of them are the emanation of the general principles of reasonable legislation. Analysis of the legislation path of most of the essential tax laws or acts (introducing new taxes or amending existing regulations) leads to describing the process under discussion in the following general terms:

- Most of the substantive or content-related alterations in a draft emerge at the initial stage, in the course of the (not-quite-transparent) "inter-ministerial consultations" which, contrary to the name, extend to an extremely large (and undefined) number of attendees/contributors.

- Clerical opportunism tends to be predominant when it comes to "putting the draft together", according to the rule describable as "submitted by someone - nobody else is against - let us keep it then".

- Any official opinions on the submitted drafts are formal or outright seeming: such opinions appear in excessive numbers and thus are probably read by no-one. The more contradictory they are, the (horror!) "better", which, in objective terms, renders any ex-post control of the process unfeasible.

- The role of anonymous compilers/editors, who give a set of regulations/ law a formal shape (at the working stage and conclusively), is prevalent. Genuine knowledge of taxes and taxation is alien to them, as a rule. While they are not to blame for the latter, given the circumstances of no leading idea present, or purpose of most of the regulations concerned, both a welland ill-constructed "piece of furniture" gets incessantly polished, since the 
"governing rule" says that it is the quality of varnish that counts and matters most.

- Immateriality of tax knowledge (not to be confused with knowledge of taxlaw provisions/regulations) has not bothered anybody over the years: once the draft's Author remains nameless, and there is no-one to embrace the problem in its entirety, there is room open for anybody whoever should like to add or thrown something in, whilst (not infrequently) remarking that s/ he has no knowledge of taxes. In any case, nobody would resolutely stand in defense of his/her proposal, to avoid suspicion of self-interest.

- As a rule, there is no-one to know where the regulations originally came from and how those corruption-generating regulations or those turning into a source of income for the chosen few (those to "reap the harvest") have been added. I have repeatedly endeavored to investigate who on earth has written all these privileges that have led to the fiscal degradation of what is presently the corporate income tax - to no avail, though: the solidarity of the Authors of such projects is, well, "enviable".

- Most of the process's participants are in tacit agreement that they should adopt ostensible solutions: everybody knows that the idea is of no value or will remain a dead letter - one example being the "tax credit" for those starting a business (a game of deception).

Establishment, interpretation, and application of substantive tax law (in its general section) is critical to ruling a democratic country. Almost every aspect of these processes are public by nature: the creation of the law, controlling the taxpayers, decisions issued by Government administration, case-law and judicial decisions. Taxes ought to be formed by those in power, on an exclusive basis; they should be created in the State's financial interest, which is not contrary to the need to protect private interests - obviously, within the confines of the law and in accordance with its purpose. The necessity of particular protection by the employer, the administration, and courts-of-law of taxpayers' private interests has been emphasized for years, it sometimes being ignored that what is essential to taxes if reasonably comprehended - is that public interest is contrary to private interest and that the former takes primacy over the latter. When the public opinion learns that the first twenty-five years of what is referred to as the transition ends up with a high and incessantly growing public debt and decreasing tax income, in spite of an economic growth, the question is worth posing: What is going on around here? Taxes are present in the media on a daily basis, with hundreds of thousands of legal problems being analyzed with deliberation. Since we give so much attention to them and put so much effort in them, why is it going so bad then? When one gets into the details, though, it becomes apparent that something is wrong with it, and our embarrassment is quite an expectable response. Why? Because all this gigantic 
effort to create, interpret and apply taxes is a sort of "the idle running" - or, is merely detrimental to the State's financial interest. The fact that crypto-lobbyists report on draft laws to Sejm committees is no more astonishing to anybody. A worse thing is that creating the law as it does not lead to solving most of the problems which only the public authority may, and indeed should, address. In an attempt to answer why this is all so, I propose the argument that across the crucial 'segments' of wielding fiscal authority - i.e. legislation, the pragmatics of tax administration, and the judicature - we have been dealing, for long years now, with something I describe as the escape from the ruling.

The phenomenon manifests itself as follows:

- Tax legislation tends to create legal regulations or such that directly implement interests quite distant from the State's financial interest, or, deliberately refuses to deal with the issue which otherwise is the declared object of this same regulation. The tax administration practice multiplies its "own" interpretative doctrines, splits hairs, all too often maltreating what the legislator has produced, and thereby only deepening the state of uncertainty and lostness.

- The judicature has become thoroughly unpredictable: they are finding multiple ways to remove problems from themselves and, primarily, pass verdicts that can resolve nothing - as confirmed by the long-known adage which says, "God moves in mysterious ways - and so do courts-of-law."

The actors have come to a peculiar excellence in playing these roles: a weird regulation is soon overgrown with dozens of contradicting views, which are subsequently "cherished" and "developed" in an endless serial of convolutedness and embroilment. The question, "Why it is so?" is a different story, though.

I will hereby try to sketch out a few, rather known, factors. First, in the last dozen-orso years, there is no-one to have built any positive tax doctrine of our State. On the contrary: much has been done to propagate demoralization in this regard. Second, since long ago, there has been no "tax policy" in place in this country, which would have been implemented by political parties and Governments. Politicians are not keen on taxes, considering them a boring topic, or even dangerous to their image. Third, there are no positive benchmarks in place which could be referred to in the everyday practice of ruling tax issues. What the EU practice has contributed to our household (obscure directives, decision-making indolence, contradictory verdicts of EUCJ) is something probably even worse than our domestic "accomplishments". Fourth, the "privatization" of the development of tax regulations that emerge within the magical triangle, officials - lobbyists - experts is death-dealing for the very 
essence of tax law. The latter must be made in public interest, and only politicians can stand in its defense.

\section{Conclusions}

Among the very basic and undisputable obligations of any Polish public authority is to act in the interest of our country, in line with the Constitution of the Republic of Poland. This has not always been so, in a more or less remote past - and not only. The recent toleration of mass-scale taxation avoidance, including value-added tax refund frauds, has given an example of atrophy of the tax system and was, primarily, an instance of violation of the country's constitutional order. Is avoidance of taxation, creation of "optimizing structures", issuance of fictitious invoices for some never-provided services part of civic freedoms? Can the public authorities shun their duty to eradicate such occurrences? As we know, we live under the dictate of a liberal correctness with its predominant view whereby the worse it goes with taxes, the better; for the "smaller", worse-paid and more incompetent state is - well, all the better, as then it "would not be able to hinder the unrestrained development of entrepreneurship". A liberal mindset clearly would not adopt the argument that there would be nobody to pay those equally low and simple taxes when the state is weak, and when an unrestrained latitude might (and, certainly would) be an advantage for bandits and thieves (including those wearing expensive suits) as well as for foreign inimical countries ("foreign" would normally mean "inimical" in this regard) to destroy ours, and bleed it white. Hence, I should like to put forth (as many as) three critical postulates to the Legislator, which altogether form the indispensable premise, indeed the foundation, for defense of our country's interests:

- Eliminate the secret lobbying in the lawmaking process. Every expert must be bound to reveal in public whether s/he has a conflict of interest, under legal responsibility.

- All and any links between public authorities and the tax business specializing in "aggressive tax planning" must be severed.

- An investigation committee ought to be set up, tasked with investigating into all the pathologies identifiable in the regulations development process in respect of VAT as well as the other taxes (excise tax and income tax, in particular), where the losses are no less severe, or even severer, compared to the income gained.

So far, the constitutional system of Poland has not opposed the degradation of the establishment, interpretation, and application of substantive tax law - a matter of so high importance for the financial interest of the State. 

SECTION 1.2

PREMISES OF FINANCIAL PUBLIC INTEREST 



\title{
RATIONALITY AS A BASIC CONDITION FOR PUBLIC FINANCE REFORM
}

\author{
JOLANTA SZOLNO-KOGUC
}

\begin{abstract}
Rationality of public finance is impossible without a clear model concept of the state, its role and consequent scope of public tasks realized (main research hypothesis). Unfortunately, due to the lack of an unambiguously accepted and consistently implemented vision of the state, both the socio-economic shifts and the attempts to reform the public finance sector throughout the transformation process in Poland have been characterized by a far-reaching lack of cohesion - governments and parliaments have changed, political doctrines have changed, individual manifestos have turned out to contain internal contradictions. And although there has been a constant element of rationalizing public spending, and improving the state's finances, the actions taken have turned out to be rather ineffective, and any results they do have are temporary and illusory, usually subordinated to current economic and political aims (supplementary hypothesis). The aim of this article is to analyze the nature and selected aspects of rationality in public finance, taking into consideration the structural, procedural and stream levels of reforms carried out in the Polish public finance system. It will concentrate on an attempt to answer the question of whether making efforts at reform have effectively realized the requirements for the rationality of public finance.
\end{abstract}

\section{Keywords}

Rationality; public finance; public finance sector; public funds; public expenditure

\section{JEL Classification: H11, H61, P43}

1 Professor for Economics, Head of the Public Finance Department, Faculty of Economics, Maria CurieSkłodowska University in Lublin, Poland. Expert in the field of public sector finances, author of over 120 publications on the organization and functioning of public sector finances, financial management of local authority institutions, taxes and the tax system, author of numerous research and implementation projects. Member of the Center for Information and Research Organization in Public Finance and Tax Law of Central and Eastern European Countries. Contact email: jszolno@hektor.umcs.lublin.pl. 


\section{Introduction}

The requirement for rationality has inspired and continues to inspire efforts at reform with regard to the management of public finance. It should be noted that rationality of public finance is impossible without a clear model concept of the state, its role and consequent scope of public tasks realized (main research hypothesis). public finance is, after all, an instrument for executing public authority, and reforming them does not achieve the intended rationalizing effect if they are not properly correlated with socio-economic intentions. Rationality of public finance is thus inherently connected with a clearly articulated and realized a vision of the state. Unfortunately, due to the lack of an unambiguously accepted and consistently implemented model of the state, both the socio-economic shifts and the attempts to reform the public finance sector throughout the transformation process in Poland have been characterized by a far-reaching lack of cohesion - governments and parliaments have changed, political doctrines have changed, individual manifestos have turned out to contain internal contradictions. And although there has been a constant element of rationalizing public spending, and improving the state's finances, the actions taken have turned out to be rather ineffective, and any results they do have are temporary and illusory, usually subordinated to current economic and political aims (supplementary hypothesis).

The aim of this article is to analyze the nature and selected aspects of rationality in public finance, taking into consideration the structural, procedural and stream levels of reforms carried out in the Polish public finance system. It will concentrate on an attempt to answer the question of whether making efforts at reform have effectively realized the requirements for the rationality of public finance. The research hypotheses indicated above have been subordinated to this problem, as has the research method used, which covers analytical and conceptual studies. The inspiration to tackle this question came, among other sources, from publications by C. Kosikowski (2004, 2011), S. Owsiak (2005) and A. Pomorska (2002), as well as by J.M. Buchanan (1997), J.M. Buchanan and R.A. Musgrave (2005) and V. Smith (2013). The article constitutes a continuation of research conducted over many years by the same Author into the system of public finance, the need for and directions of its rationalization.

\section{Essence of Rationality}

Rationality means basing actions on scientific motives or principles - a rational action is a wise, judicious action which is in accordance with the knowledge one possesses (Latin ratio - mind, rationalis - rational) (Słownik wyrazów 
obcych, 1980: 621-622). In psychology, rationality is connected with actions taken purposefully, as opposed to impulsive or reflexive actions. The sociological approach assumes that a rational entity is guided by the hierarchy of values or preferences espoused by a given social community (Pypeć, 2004: 17). Finally, from an economic point of view rationality is considered in the context of the realization of the defined goals of an action by the managing entity. Rationality of management means human activity consistent with the state of knowledge of the surrounding reality, enabling the best social and economic results to be achieved (Owsiak, 1983: 13). Rationality of management is inextricably linked with effectiveness. Effectiveness is a narrower concept, in the economic sense it takes into account the balance of efforts and results, and not all of these, and not in every situation, can be measured and expressed in monetary terms. This is particularly important in the context of managing public funds - indeed, they are allocated not so much for a direct economic effect as for the public good (interest). Rationality thus means not just effectiveness, but also the social justice aspect (Wilkin, 1997).

In the economic sense, two models of rationality can be differentiated instrumental rationalization understood as striving to increase the extent of activity while simultaneously improving its effectiveness, and teleological rationality, which is expanded to cover the judicious shaping of goals (Leśkiewicz, 1994: 58). The first model concerns the optimum breakdown of available funds for realizing a defined goal, in light of the subject's knowledge. The second model involves ensuring that actions are consistent with the existing regulations and recognized standards, which is crucial with regard to public finance. The supply of public money is, by definition, limited (there are limits to both taxation and public debt), so public spending must therefore also be limited. Rationality of public finance is thus not expressed exclusively in the size of public spending, as this parameter does not provide an adequate basis to assess activity financed from public funds, particularly in the context of the better adaptation of the extent and standard (quality) of this activity to the needs of a given community. This rationality is more likely to lead to an evaluation and choice of goals, and to the formation of a structure of public spending allocated to achieving those goals.

Rationality of public finance can be considered at both the macro- and microeconomic level. The macroeconomic view of rationality refers to the appropriate division of public funds and means both the appropriate level of state income and expenditure (particularly in relation to GDP) and their optimal internal structure. The macroeconomic approach is thus related to the problem choosing which goals and tasks are to be financed from public funds. Hence the most important criterion for rationalizing public finance becomes that of effectiveness (rationalization of choices). Macroeconomic rationality of public spending, and therefore of the entire 
system of public finance, is relative in nature. It can be considered in the context of the funds necessary to realize public tasks. First, though, the appropriate scope and size of those tasks should be established, and only then the expenditure (understood as the involvement of defined financial resources) for their realization, not the other way round. This is the only way to justify the creation and financing of a nonbalanced budget.

The microeconomic approach, on the other hand, concerns rationalization at the level of public sector entities and institutions directly involved in the process of collecting and spending public funds. In particular, this involves showing which organizational/legal forms are conducive to rational management of public money and to the optimal adaptation of resources to tasks. The basic criterion for rationalization understood in this way is effectiveness, particularly in the context of seeking savings in expenditure while achieving comparable effects. Here it should be noted that a full tally of expenditure and effects entails many practical difficulties - to the extent that expenditure is stipulated in the budget and financial plans of entities, the effects are usually difficult or indeed impossible to measure, and often with a significant delay (Owsiak, 1983: 206).

These two approaches, the macro- and micro-economic, are closely connected and mutually conditioned. It is difficult to speak of the rationality of financing individual entities and units of the public finance sector without simultaneously ensuring the rationality of the division of resources for particular areas and tasks. Success can only be achieved if these are treated together. It is worth noting that financial doctrine is dominated more by the macroeconomic approach, which shows the context and consequences of political choices (Buchanan, 1997; Buchanan, Musgrave, 2005). In practice, however, the most commonly occurring requirements are on the micro-economic scale, concerning the financial management of specific public institutions, but their isolated nature does not, unfortunately, guarantee rationality on a macro, systemic scale.

\section{Rationality in Light of the Principles of Public Finance}

Rationality of public finance is often displayed in the form of theoretical recommendations referred to habitually as financial principles, which essentially constitute recommended requirements or templates of learning, aimed at practical application, elaborated on the basis of previous experience. These firstly and most broadly covered the system for collecting public impositions, creating a catalog of fiscal principles (Gomułowicz, 2001), and budget management, thus creating a catalog of budgetary principles. Budgetary principles have been developed, and 
indeed still are, in European financial thinking ${ }^{2}$, in particular, French, German and Polish. Less importance is ascribed to these in the English-speaking world, including the USA, where rationality of managing public money is connected more with a certain degree of flexibility of action, as well as with the greatest possible optimization of choices made (Musgrave, Musgrave, 1976: 7; Gaj1, 1993: 90-91; Szołno-Koguc, 2009: 25). It is worth stressing the significant diversity of views with regard to both the essence and nature of budgetary principles and their content. It is not unusual for the doctrine to stress that it is only the ideas from which the principles stem that remain relatively constant, while their specific development has been and continues to be subject to modifications during particular periods of development of budget management. The content of the principles changes depending on the circumstances, place and time, as well as the opinions of individual Authors writing about the budget and budget system, as they represent different schools of economic and legal thought.

The literature contains many catalogs of budgetary principles, often with no overlap between them. It is worth noting, though, that when examined more deeply this lack of cohesion often turns out to be purely superficial, with analogous ideas given different names (Kosikowski, 2004: 32). Catalogs of budgetary principles also vary considerably in terms of the number and also nature of values identified. Many of the principles they postulate can apply not only to the budget and budget management but to the state's entire political, social or economic system, as every action should involve following normative rules of legality and reliability. The principles of clarity, economy, precision, and realism, which are also widely applied in various enterprises, should apply to every effective effort.

The catalog of most commonly formulated budgetary principles per se should include the principles of universality, unity, specificity (including the principle of specialization), annuality, balance, antecedence, openness, transparency, reliability, and feasibility (Szołno-Koguc, 2007: 27; Szołno-Koguc, 2005: 129-144).

Due to the distinct evolution of opinions on the doctrines of finance and financial law towards a global and comprehensive treatment of public financial management, attempts are increasingly being made to develop the traditional budgetary principles into general rules applying to the public finance system as a whole (Pomorska, 2002: 6). Among the many postulates currently emerging, particularly noteworthy on the road towards rationality are benchmarks applying to the following areas organization of the public financing sector (structural rationality), procedures for gathering and disbursing public money (procedural rationality), and the actual flows as the classical principles and accountability, transparency, stability (predictability), performance (efficiency, economy, effectiveness) as rules considered modern (OECD, 2004: 132-150). 
of money gathered and used for public needs (flow rationality) (Szołno-Koguc, 2009: 17-22). The realization of the recommendations shown in the above scope should be comprehensive in nature, combining all the levels mentioned, but could assume a gradual, partial character displaying either the structural, procedural or flow aspect.

\section{Structural Rationality of Public Finance}

Changes to structures should first and foremost bring about far-reaching and consistent institutional orderliness, including the elimination of anachronistic organizational forms, along with verification of the legal-organizational character of the rest. It is worth pointing out that the reform of 2009 ultimately resulted in only a partial liquidation of state budget-funded entities, leaving such institutions to remain at local authority level, while the abolished ancillary enterprises were in numerous cases replaced by real ephemera in the form of public sector institutions (Szołno-Koguc, 2011: 149-158). State Forests remain outside the public finance sector as an important institution carrying out essential tasks in the field of forestry, the organizational-legal status of the Farmers' Social Security Fund remains unclear.

It is essential to make a clean break from the principle of solving problems using institutionalization itself - the fact that an existing agency or office will continue or a new one is to be created does not automatically mean that a given task will be realized effectively or the situation in a particular area of social or economic life will improve. Such action limits the allocation of public funds and reduces the flexibility of financial management. Restructuring actions implemented successively do, however, constitute an excellent opportunity to review the existing organizational units in terms of the tasks they realize, the efficiency and effectiveness of their use of public funds.

Ensuring the proper institutional framework for the public finance sector in Poland requires constant verification of organizational solutions, increasingly general use via the ESA system of the idea defining affiliation to the general government sector taking into account the functions realized by given institutions as well as the way they are financed. ${ }^{3}$ Changes which lead in this direction are an expression not only of the need to adapt the public finance sector to EU standards but also of the aspirations to improve openness and transparency, to meet the requirements of the

3 ESA (European System of Accounts) - the European system of national and regional accounts adopted in 1995 (ESA-95), modified in 2010 (ESA 2010). The ESA standard indicates two criteria - redistribution of the national income and wealth as the basic activity of a given entity, and additionally the $50 \%$ rule (i.e. less than $50 \%$ of production costs are financed from sales income/revenue). 
effective management of public funds. Also important is consistency in introducing new solutions, consistency of the regulations adopted in this field with other legislation to avoid doubts regarding interpretation, whether and to what extent a given organizational entity using public money to carry out public tasks creates the public finance sector. A secondary aspect is a matter of whether and to what extent that entity is connected financially with the budget of the state or local authorities as basic institutions of a legal-financial character, serving to redistribute public funds.

\section{Procedural Rationality of Public Finance}

Procedural changes refer, among other things, to proper management of public funds, they include in particular spending in a deliberate and economical manner, maintaining the principles of obtaining the best effects from given expenditure or the optimal choice of methods and means to achieve the goals set. Unfortunately, both the Public Finance Act and other legislation lack an explanation of what it means to spend public money in a deliberate and economical way. The use of public funds should undoubtedly serve to realize the goals and tasks of socio-economic policy. This is a highly general statement, though, which is difficult to verify in practice if the goals and tasks mentioned are not subject to defined measurements allowing for a reliable and objective assessment of whether and to what extent the costs incurred contributed to their realization. A statutory provision by itself, without a properly developed system for defining goals and tasks both in a qualitative and, as far as possible quantitative (measurable), structure, and monitoring of their realization, and on this basis controlling the desirability of spending increases, has little in common with actual rationalization of public finance management. In English-speaking countries, the principle of desirable and rational public spending is expressed in the $3 \mathrm{E}$ rule - economy, efficiency, and effectiveness. These criteria are taken together to control the VFM effect - value for money (Zdasień, 2001: 2).

To improve the effectiveness and efficiency of managing public funds, the reorientation which has been underway for several years from administrative sending to management in the context of the task-oriented system is of key significance. A task-oriented budget can and should be implemented by every institution of the public finance sector, not only at the level of state administration but also by local authorities - each of them realizes defined tasks on behalf of the national, regional or local community, spends public money and it is important that they do so in the most effective way possible, taking into account elements optimizing the costs incurred. The task-based formula assumes that before expenditure is planned for financing defined budgetary tasks, it is necessary not only to verify what specifically is expected to be done, what kind of enterprise, 
why and what the public authorities want to achieve through this, how they want to do it, whether and to what extent the non-public sector is taken into account, how much it will cost and how much public money this entails, but above all how the effects of the undertaking can be measured. A task-based approach to planning, executing and controlling the budget also improves the openness and transparency of management of public funds.

It is worth noting that a task-based budget concept requires the rules of budget recording to be modified and adapted to international standards, including the implementation of accrual accounting. The illusion of a low budget deficit would finally vanish - there would be more limited possibilities to manipulate its extent by delayed payments, or creative spreading of payments resulting from separate legislation into different categories, as being financed supposedly by revenue from the privatization of Treasury or local authority assets, but in practice (due to these expenses massively exceeding privatization revenue even at the planning stage) by money obtained from treasury bills and bonds, thus increasing the already substantial public debt. Is this open and transparent, and above all consistent with sensible financial management?

The budgetary system should allow for clear delineation of the "own" expenditure of state bodies and the organizational units subordinate to them from redistributive transfers, operational expenditure, and capital expenditure, particularly on investment, with the possibility to indicate the source of financing in the latter cases (own, EU, foreign). Without an appropriate division in this area which does not violate the classical principle of budgetary unity, it is impossible to assess whether and to what extent the increasing public debt is a result of the increasing scale of prodevelopment investment, or of the ongoing maintenance of the state administration.

The full formula of a task-based budget also requires the creation of an accounts record system which would enable calculation of the actual costs of carrying out tasks, both direct and indirect costs, taking into account the consequences of any abandonment or interruption in its realization.

A necessary condition for the proper functioning of the public finance sector is properly working control of the acquisition and expenditure of funds by public sector entities. An analysis of prior practical experiences in this field gives rise to doubts, particularly with regard to the criteria of the checks conducted and the possibility to use these as the basis of a full evaluation of the financial management of entities being assessed. Managing finances consistently with the applicable legislation is a necessary factor, but not a sufficient one for the effectiveness and efficiency of a given entity's operations. It is thus advisable to extend the control criteria so that its results enable full data to be prepared with regard to the condition of the entire 
public finance sector, which could be actively used in decision-making processes by both state and local authorities. Transformation of the public finance control model should be accompanied by an evolution away from the significant dominance of the legality criterion to the broad and generally applied criteria of purpose, economy, and effectiveness.

Finally, there is the problem of the audit - specifically the external audit which the public finance sector lacks, at least in the sense of a compulsory check of the budgetary and financial statements by external auditors. A basic problem appears here, that of who should conduct such an audit, assuming professionalism and objectivity of the assessment. Should it be entities which are part of the public finance sector (the Supreme Audit Office or regional auditing chambers?), or auditors from outside the public sector?

Another crucial issue is the system for seeking out responsibility for breaches in the discipline of public finance. Despite attempts at change, this remains dysfunctional to a great degree, does not guarantee that public finance will function properly and does not protect the state's fiscal interests effectively. Systemic reforms are required aimed at increasing efficiency and tightness, not just at cosmetic adjustments designed to retain the status quo of particular bodies and institutions in spite of the changing socio-economic reality. Above all, the aim is to clearly define the legal character of the aforementioned responsibility. The most sensible, and also the most substantively and procedurally justified, solution seems to be to include elements affecting discipline of public finance within the regime of responsibility for fiscal offences and crimes, if not to form a completely separate financial judiciary to adjudicate on breaches of public financial discipline (Szołno-Koguc, 2015: 1).

\section{Flow Rationality of Public Finance}

Problems connected with the cash flow itself are no less controversial. The reform should aim to specify the conceptual apparatus - revenue and income, expenses and expenditure. The current regulations in the Public Finance Act do not provide a clear picture of the flow of public funds, e.g., when revenue obtained by public sector entities from the business they conduct or other sources counts as income and when as revenue (Public Finance Act of 27 August, Art. 5/2/3-8 and Art. 5/1/5). The main requirements generally refer to reform of the system of public revenue from impositions - the basic foundations of the Polish tax system formed in the early 1990s were subjected in later periods mainly to transformations forced by their adaptation to EU standards, subordinated to interim requirements of fiscal policy and often also to short-term goals in the run-up to elections. This omitted the wide-ranging, multi-level context of the pro-effectiveness and pro-social reforms. 
Reforming the tax system requires coordinated and consolidated actions which undoubtedly last longer than one parliamentary term. It is difficult to find any positive examples in this field - on the contrary, interesting proposals are forgotten along with changing governments and parliaments.

The flow context makes it necessary to evaluate what rationalization of public spending means in practice - is it merely the postulate to save or be efficient, or does it result from a model, adopted and consistently realized, of the state, the tasks and duties of public authorities in the social and economic sphere which are accepted not just by political forces but above all by a majority of democratic society. In my opinion, the second belief should be the dominant one because, as I mentioned at the beginning, a goof public finance system cannot be created without a proper basis in a clear and consistently implemented vision of the state (Kosikowski, 2011). Changes to the system of income and expenditure, revenue and expenses, translate directly into the problems of budget deficit and public debt - the cause, nature, and extent of the phenomenon in the context of meeting convergence conditions, but also the broader perspective of security of public finance.

\section{Conclusions}

Further reforms mean further challenges taken up in search of rational public finance, a system of collecting and spending public money which is consistent with scientific principles and relevant to the conclusions drawn from practical experience in this and other countries. In addition, the changing social and economic reality entails changes to the approach, a redefinition of priorities, appropriate adaptation of structures, procedures and above all of the flow. An analysis of previous experience proves that it is fruitless to seek rationality in public finance, as its system will never fulfill its role properly without a clear and plainly defined vision of the state. It is the realization of that vision which is served by operations involving collection and spending of public funds.

\section{References}

Buchanan, J.M.: Finanse publiczne w warunkach demokracji (Public Finance in Democratic Process), Warszawa: PWN, 1997.

Buchanan, J.M., Musgrave, R.A.: Finanse publiczne a wybór publiczny. Dwie odmienne wizje państwa (Public Finance and Public Choice: Two Contrasting Visions of the State), Warszawa: Wydawnictwo Sejmowe, 2005.

Filozofia a nauka. Zarys encyklopedyczny (Philosophy and science. Outline encyclopedic), WrocławWarszawa: Ossolineum, 1987. 
Gajl, N.: Gospodarka budżetowa w świetle prawa porównawczego (Budgetary economy in the light of comparative law), Warszawa: PWN 1993.

Gomułowicz, A.: Zasady podatkowe wczoraj i dziś (Tax principles yesterday and today), PWN: Warszawa 2001.

Kosikowski, C.: Finanse publiczne w świetle Konstytucji RP oraz orzecznictwa Trybunału Konstytucyjnego (na tle porównawczym) (Public finances in the light of the Constitution of the Republic of Poland and Jurisprudence of the Constitutional Tribunal - comparative approach), Warszawa: Wydawnictwo Sejmowe, 2004.

Kosikowski, C.: Naprawa finansów publicznych w Polsce (Repair of public finances in Poland), Bialystok: Temida 2, 2011.

Leśkiewicz, Z.: Racjonalność w ekonomii (Rationality in economics), Szczecin: Uniwersytet Szczeciński, 1994.

Musgrave, R.A., Musgrave, P.B.: Public Finance in Theory and Practice, New York: McGraw-Hill Book Co, 1976.

OECD: The Legal Framework for Budget Systems. An International Comparison, OECD Journal on Budgeting no. 3 (2004).

Owsiak, S.: Finanse publiczne. Teoria i praktyka (Public Finance. Theory and Practice), Warszawa: Wydawnictwo Naukowe PWE, 2005.

Owsiak, S.: Metody budżetowania sfery nieprodukcyjnej (Methods of budgeting the non-production sphere), Kraków: Akademia Ekonomiczna, 1983.

Pomorska, A.: Zasady ogólne finansów publicznych (General principles of public finance), Przegląd Ustawodawstwa Gospodarczego (Review of Economic Legislation) no. 6 (2002).

Pypeć, M.: Cele i kryteria racjonalizacji wydatków publicznych (Goals and criteria for rationalization of public expenditure), in: Pomorska, A., Pypeć, M. (eds.), Racjonalizacja wydatków publicznych w warunkach deficytu budżetowego (Rationalization of public expenditure in the conditions of budget deficit), Radom 2004.

Słownik wyrazów obcych (Dictionnary of foreign words), Warszawa: PWN, 1980.

Smith, V.L.: Racjonalność w ekonomii (Rationality in economics), Warszawa: Wolters Kluwer, 2013.

Szołno-Koguc, J. (ed.): Racjonalność w absorpcji środków unijnych (Rationality in the absorption of EU funds), Lublin: Wydawnictwo Naukowe Wyższej Szkoły Ekonomii i Innowacji w Lublinie, 2009.

Szołno-Koguc, J.: Dyscyplina finansów publicznych- refleksje w świetle dotychczasowych doświadczeń (Discipline of public finances - reflections in the light of previous experience), Biuletyn orzecznictwa o naruszenie dyscypliny finansów publicznych (Bulletin of jurisprudence on violation of public finance discipline), spec. iss. (2015).

Szołno-Koguc, J.: Funkcjonowania funduszy celowych w Polsce w świetle zasad racjonalnego gospodarowania środkami publicznymi (Functioning of earmarked funds in Poland in 
the light of the principles of rational management of public funds), Lublin: Wydawnictwo UMCS, 2007.

Szołno-Koguc, J.: Istota i zakres reorganizacja sektora finansów publicznych w świetle nowej regulacji ustawowej (The essence and scope of the reorganization of the public finance sector in the light of the new statutory regulation), in: Owsiak, S. (ed.), Nowe zarządzanie finansami publicznymi w warunkach kryzysu (New management of public finances in crisis conditions), Warszawa: Polskie Wydawnictwo Ekonomiczne, 2011.

Szołno-Koguc, J.: Od czego zacząć reformę finansów publicznych - struktur, procedur czy strumieni? (Where to start to reform public finances - structures, procedures or streams?, in: Wieteska, S., Wypych, M. (eds.), W poszukiwaniu efektywności finansów publicznych (In search of the efficiency of public finances), Łódź: Wydawnictwo Uniwersytetu Łódzkiego, 2009.

Szołno-Koguc, J.: Zasady gospodarki budżetowej w ujęciu teoretycznym (The principles of budgetary management in the theoretical approach), Annales Universitatis Mariae CurieSkłodowska, sectio H Oeconomia no. 39 (2005).

Wiklin, J. (ed.): Efektywność a sprawiedliwość (Effectiveness and justice), Warszawa: PWN, 1997.

Zdasień, W.: Kontrola „efekt za pieniądze - value for money” na przykładzie dorobku Narodowego Urzędu Kontroli Wielkiej Brytanii (Control of value for money - on the example of the output of the National Audit Office of the United Kingdom), Kontrola Państwowa (State Control) no. 2 (2001).

PL: Act of 27 August 2009, on Public Finance. 


\title{
PROTECTION OF PUBLIC FINANCE INTERESTS IN TERMS OF PUBLIC FINANCES MANAGEMENT
}

\author{
YULIA GOROSH
}

\begin{abstract}
The article considers the issues related to safeguarding public interest in the process of managing public finances. Based on the analysis of such concepts of financial science as "public finances", "public interest", "levels of public interest development", "interests of different groups" and "public finances functions", the Author has made an attempt to identify and classify current issues in the sphere of safeguarding public interest in the process of managing public finances. According to the Author, the given issues vary in character and nature. The reason for that is that there are several factors that give rise to the given issues. In particular, it's the fact that "public finances" have different functions; there is competition and conflict of interests of different groups of persons in the course of identifying "public interest"; there are common issues that exist in the public sector (bureaucracy, corruption, lack of trust in public institutes, lack of legislation stability); problems in defining "public interest", the sources of "public finances" formation and their allocation (reallocation) at the national, regional and local levels; problems in allocating and delegating authorities among the public authority bodies in terms of "public budgets" development (at the national and local levels).
\end{abstract}

\section{Keywords}

Public interest; public authority functions; public finances functions; levels of public interest development; public income and expenditure

\section{JEL Classification: D63, K34, K40}

1 Candidate of Legal Sciences, Doctoral student for Financial Law, Department of Financial Law and Economics, Faculty of Law, Masaryk University, Czech Republic. Contact email: julia.goros@volny.cz. 


\section{Introduction}

To understand the character of the issues existing in the area of safeguarding "public interest" in the process of state management of "public finances", the Author will make an attempt to analyse what "public finances" and "public interest" are; to characterize them, to identify their nature and goals, to describe the levels of their formation and their functions. An attempt will be made to consider the interconnection with the process of state management and to describe the way "public finances" contribute to the fulfilment of the public authority's functions and serve as an instrument of serving "public interest" Based on this analysis the Author will identify the character and nature of current issues, give them a brief description and classify them.

\section{Public Finances Characteristics, Their Nature and Goals}

In financial law there is a differentiation between public and private finances. P. Mrkývka points it out too that finances should be divided into public and private ones. By "public" he means state and local finances, while private finances are the finances of households and firms (Mrkývka, 2009: 45). M. Bakeš differentiates public and private finances based on the parties and defines "public finances" as the totality of monetary relations connected with formation, allocation and use of the monetary aggregate and its components in the bodies and organizations of the public sector (Bakeš, 2006: 741). P. Mrkývka shares his opinion and writes that "as opposed to public finances, by private finances one should mean the relations connected with the formation, allocation and use of the monetary capital in the private sector that is represented mostly by households and firms" (Mrkývka, 2009: 45).

P.M. Godmet's position is congruent with the given Authors too: "as the allocation of the public product is carried out by the subjects, it is the subject that should be used as the criterion for the classification of financial relations. This allows one to divide finances relatively into public and private ones" (Godmet, 1978: 41). N.A. Scheveleva shares the given viewpoint, too. She points out that "public finances express the part of public monetary relations that is connected with the formation of the monetary funds of public territorial entities that are the financial basis of the state and local government". Based on this, "public finances are a system of monetary relations organized by the state and municipal units, in the course of which public monetary funds are formed and disposed of with the aim of providing for the achievement of the goals and fulfilment of the functions of public authority" (Scheveleva, 2014: 10). 
So when characterizing public finances, we always differentiate them from the private ones. And not only by the parties, but also by their nature and goals.

The first distinctive feature of "public finances", as we have already said, is that it is the kind of economic (monetary, financial) relations that are formed between the state (its bodies, institutes of public authority) on the one hand and other private actors (citizens, households, firms, non-commercial organizations, etc.) on the other. The second feature of "public finances" is that they are relations and operations that appear and take place among the subjects mentioned above in the course of formation, allocation, reallocation and use of public funds. "The system of public finances is formed at the state and local levels" (Mrkývka, 2009: 72). "The system of public monetary funds includes state budgets (federal budget, sub-federal entities budgets)", local budgets, as well as state non-budgetary funds (Scheveleva, 2014: 10). The third characteristic feature of "public finances" is that the reason for their appearance and existence is the necessity to form financial resources for the state to be able to provide public benefits, goods and services in the sphere of health, education, social welfare, public transport, national defence, social security, social allowances, transfers etc., as well as to support the existence of relevant bodies and services that are necessary for achieving the given goals. The fourth peculiarity of "public finances" is that by their nature "public finances" are non-reciprocal, non-equivalent and voluntary. Thus, if we try to summarize everything mentioned above, one could give the following characteristic to "public finances", their nature and the goal of their existence.

1. They are financial relations and transactions between the state (its bodies, institutes of public authority) on the one hand and private actors (citizens, households, firms, non-commercial organizations, etc.) on the other.

2. "Public finances" are monetary relations that appear in the course of formation, allocation, reallocation and use of public funds.

3. They are specific financial relations that have three distinctive features: they are non-reciprocal, non-equivalent and compulsory

4. The reason these financial relations are formed and exist is the need to form the funds (GOAL): for the state to provide private actors with public benefits, goods and services in the sphere of health, education, social security, public transport, national defence and population security, social allowances, grants, transfer payments, etc., as well as for covering the costs of administration of relevant bodies and services necessary to carry out the given tasks. 
5. "Public finances" satisfy the people's needs for public benefits, goods and services at the level of and by the state, region or municipal units, and thus realize the public interest.

6. "Public finances" are an instrument of public policy, the subject of which is public authority and its bodies. With the help of public finances the state realizes the following of its functions:

1. Economic - providing for the economic development of the state, growth of GDP and improving the people's welfare.

2. Social function of providing the so called social benefits, goods and services in the sphere of health, education, social security services, public transport, national defence and public safety, allowances, grants and transfer payments, etc.

\section{Public Finances as Means of Implementation of Public Interest}

As it has been noted in the characteristic of "public finances", they serve the satisfaction of public needs by the state, region and municipality in terms of providing social benefits, goods and services and observing "public interest" in this way.

A lot of Authors mention the fact that "public finances" serve as a means of "public interest" implementation. According to well-known French researcher in the field of financial law, P.M. Godmet, if private finances are oriented mainly at making profit, public finances are "means of implementation of the so called common interest" (Godmet, 1978: 42). M.V. Karaseva thinks that "by public financial activity one should mean the activity of the state, its Authorized bodies, municipal units as well as non-governmental actors that have been charged with the responsibility to perform public tasks in the sphere of finance" (Karaseva, 1998: 152). Speaking about "public interest" one should note that as a rule in scientific literature it is pointed out that "public interest" is an interest of social community recognized by the state and secured by law, the satisfaction of which is the condition and guarantee of its existence (Tikhomirov, 1995: 55). According to A.A. Nechay, public finances are public legal relations connected with the satisfaction of all kinds of public interest and appear in the course of formation, management, allocation (reallocation) and use of public funds and means and control over this process (Nechay, 2005: 15-16). A.A. Nechay mentions that "public interest" exists as some aggregated, average social interest in each of the spheres of social life (Nechai, 2005: 62). Professor Y.A. Tikhomirov points out that the concept of "public interest" is generic and includes more concrete interests (Tikhomirov, 1995: 59-65). The Author of the 
given article believes that formation of "public finances", their allocation and use are aimed at the realization of the following kinds of "public interests":

- Social "public interest" is providing social benefits, goods and services in the sphere of healthcare, education, social security services, public transport, national defence and people's safety, social allowances, grants and transfer payment for private actors by the state (i.e. fulfilment of the social function of the state).

- Economic "public interest" is ensuring stable economic development of the state, growth of GDP and improving the people's welfare (i.e. fulfilment of the economic function of the state).

- Administrative "public interest" is providing for the efficient functioning of the system of public administration and the need for financing the expenditure related to public authorities, local self-government bodies and public corporations activity.

\section{Levels of Public Interest Formation and Interests of Different Groups in Use and Reallocation of Public Finances}

Speaking of "public interest" one should keep it in mind that it can be formed at different levels: state, regional and local. Considering the fact that "public interest" is formed with regard to providing social benefits, goods and services, and their provision must be ensured by the public funds (state, regional or local public budgets), the formation of public budgets takes place at different territorial levels. Depending on the level "public interests" are formed at and at what level the provision of public benefits, goods and services must be financed, the state, regional and local budgets are formed.

It is not only the public funds formation that takes place with the help of public budgets, but it's their reallocation, too. As a result of this reallocation it is possible to transfer the income of a territorial unit that formed it to the public budget of the actor that did not take part in its formation. The efficiency of this kind of reallocation depends on a lot of factors, including: the level of economic development of the region, the quantitative and demographic composition of the population, the level of social requests, climate and location.

Another important issue related to "public interest" and "public finances" is the existence of "interests of different groups" and the competition or sometimes a conflict among them. In the course of public interest formation and reallocation of public resources, the interests of different groups clash. Public finances are a sphere where different, often contradictory and differently directed interests - state, 
group, individual - clash. And in the end the possibility of finding the "resultant" of vectors determines the social, economic and political stability in the state, the possibility of efficient functioning of all public and state institutions.

According to the paradigm that is predominant in financial science today and from the perspective of which the mechanism of formation, allocation and use of "public finances" is considered, as well as the mechanism of "public interest" formation, the implementation of which is the goal of "public finances" it is claimed that there are 4 subjects influence the formation and allocation of "public finances": 1) politicians, 2) the electorate (citizens), 3) public organizations based on common interest principle, 4) bureaucracy (Hamerníková, Maaytová, 2010: 30). Each of the groups tends to protect its own interest, which often leads to competition and conflicts.

\section{Functions of Public Finances as Instrument of Public Policy}

As it has already been noted by the Author of the given article, "public finances" are an instrument of public policy, the subject of which is public authority and its bodies. With the help of public finances the state fulfils the following of its functions:

- Economic function is ensuring stable economic development of the state, GDP growth and improving the welfare of its citizens.

- Social function is providing the so called social benefits, goods and services in the area of healthcare, education, social security, national defence and population safety, allowances, grants and transfer payments, etc.

Taking all of this into account, the Author of the article believes that being an instrument of public policy, "public finances" fulfil some of its independent functions, namely:

- The resources allocation function. The given function includes the activity connected with creation, maintenance and financing public goods and services, as well as public institutes. Regarding the public policy it is decided what public goods, services and bodies and to what extent should be financed from the public funds. The criterion for making decisions here is efficiency.

- The reallocation function is connected with the question of public funds allocation. Regarding the target audiences (social groups) it is decided which groups should be the sources and to which they should be transferred by means of public budget preparations. The criterion here should be fair reallocation. 
- The stabilization function is about the use of "public finances" (income and expenditure) as an instrument that influences the positive dynamics of the economic growth, ensuring stable economic development of the state, GDP growth and improving the citizens" welfare. The evaluation criterion here is economic stability.

\section{Issues in Safeguarding Public Interest while Managing Public Finances}

Having analysed the concepts of "public finances", "public interest", "levels of public interest formation", interests of different groups", "functions of public finances" and having established their interconnection, one can suggest that the issues in safeguarding "public interest" while managing "public finances" exist in a few perspectives and, according to the Author, can be classified in the following way.

The first issue is improper fulfilment of the functions of "public finances" (the function of allocation reallocation of resources, stabilization function). This leads to inefficient determination of sources of revenue and expenditure of public budgets; the sources of revenue are reallocated unfairly among the public budgets among the subjects, and neither the stable economic growth, nor the increase of GDP and improvement of citizens' welfare can be ensured. The second issue is the predominance of the interests of one group over another in the process of identifying the "public interest", as well as the formation, reallocation and use of "public finances". The third issue is related to common problems in public administration and public sector (bureaucracy, corruption, lack of trust in public institutes, lack of stability and frequent changes in legislation). The fourth issue is in the area of public authorities and their delegation to the local levels. Local public authority is always more efficient in solving local problems, identifying the scope of "public interests" and forming financial sources for their satisfaction. The question here is how to deal with the problem: to choose the way of decentralization or, on the contrary, centralization in the sphere of "identifying" public interest" and forming and using "public finances". There is a constant scientific discussion on the subject.

To our mind, when dealing with this issue, as well as working out the approach to the solution of the given problems, one should keep in mind one very important thing: all rights come with an equal number or responsibilities for the result and efficiency of the decisions that one makes. K. Engliš put it very clearly: power (i.e. authorities that it has) must be directly determined by the correspondent degree of responsibility. Nobody can be charged with more authority than an entity is ready to take on and be responsible for" (Vencovcký, 1993: 63). 


\section{Conclusions}

Having analysed such concepts as "public finances", "public interest", "levels of public interest development", "interests of different groups "that exist in financial science and having described their nature and goals, as well as their interconnection and the connection with the process of public administration, the Author came to the following conclusion.

The issues in safeguarding "public interest" in the course of managing "public finances" exist in several dimensions and may be classified in the following way. The first issue is about improper fulfilment of the functions of "public finances" (the function of resources allocation and reallocation and the stabilization function). The second issue is about the predominance of interests of one group over another in the course of identifying "public interest", as well as forming, allocating and using "public finances". The third issue is related to common problems that exist in the sphere of public administration and public sector (bureaucracy, corruption, lack of trust in the institutes, lack of stability and frequent changes in legislation). The fourth one is in the field of public authority and their delegation to the local levels and has to do with the necessity to deal with the question of decentralization or, on the contrary, centralization in determining the "public interest" and forming and using "public finances".

\section{References}

Bakeš, M. et al.: Finanční právo (Financial Law), Praha: C.H. Beck, 2006.

Godme, P.M.: Finansovoye pravo (Financial Law), Moscow: C.H. Beck, 1978.

Hamerníková, B., Maaytová, A. et al: Veřejný finance (Public Finance), Praha: Wolters Kluwer, 2010.

Karaseva, M.V.: Pravove regulyuvannya derzhavnikh dokhodiv ta vidatkiv (Some Legal Problems of Government Revenue and Expenditure in the Russian Federation), Kiev: Akad. pravovikh nauk Ukraini, 1998.

Mrkývka, P. et al.: Finanční a daňově právo (Financial and Tax law), Plzeň: Aleš Čeněk, s.r.o., 2009.

Nechay, A.A.: Pravovi problemy rehulyuvannya publichnykh vydatkiv u derzhavi (Legal Issues in the Regulation of Public Expenditure), doctoral dissertation, Kiev: 2005.

Nechay, A.A.: Publichie fondy kak kategoria sovremennogo finansovogo prava (Public Funds as a Category of Modern Financial Law), Zhurnal Rossiyskogo Prava (Journal of Russian Law) no. 11 (2004).

Sheveleva, N.A. et al: Finansovoye pravo (Financial Law), Saint Petersburg: Piter, 2014.

Tikhomirov, Y.A.: Publichnoye pravo (Public Law), Moscow: BEK, 1995.

Vencovský, F.: Karek Engliš (Karel Englis), Brno: Nadace Universitas Masarykiana v Brně, 1993. 


\title{
SOCIAL INTEREST IN FINANCIAL REGULATION AND THE CONSTITUTIONAL PRINCIPLES
}

\author{
AKSANA SHUPITSKAYA ${ }^{1}$
}

\begin{abstract}
This article deals with financial regulation is a major activity of the state, whose goal is the definition of order in the important sphere of social activity - the sphere of accumulation and distribution of state funds. This activity is carried out in the interests of society and of each individual member. The main aim of the contribution is to confirm that the financial regulation is kind of the state action based on the Basic law of the state - its Constitution. The Author concluded that the objectives of these activities, its directions, forms and methods are based on the constitutional principles, establishing the scope of this activity in order to achieve a balance between public and private interests. The main method used by the Author is the analytical method.
\end{abstract}

\section{Keywords}

Financial regulation; Constitution; constitutional principle; public interest; private interest

JEL Classification: D63, K00, K10

\section{Introduction}

Financial regulation is a kind of state-legal activity aimed at public relations related to the state's finances. No state can realize its internal and external functions, ensure the implementation of social and economic programs without having sufficient funds for this, without having the financial resources. The purpose of this work is to

1 Docent, Associate Professor of International Law Department, Educational Institution Janka Kupala State University of Grodno, Belarus. The Author specializes in constitutional law. She is a member of Center for the Research on the Public Finances and Tax Law in the Countries of Central and Eastern Europe. Contact email: oshupitskaya@mail.ru. 
analyze the financial activities of the state in terms of the constitutional principles of democracy, sociality, humanism, etc. The hypothesis investigated the Author, - the constitutional principles define the directions, forms, methods, borders of activity of legislative bodies, the law-enforcement activity of the state institutions in the sphere of financial regulation, act as criteria for the resolution of legal conflicts, coordinate public, and private interest. The analysis method was used as the main research method. Public and private interest, including in the field of financial regulation was studied in the works of Y.A. Tikhomirov (1995); G. Vorobey (2012). Constitutional principles are the subject of interest of such researchers as A.A. Liverovskiy (2015, 2017).

\section{Financial Regulations and Social Interests}

Financial regulation is the activity carried out by objective necessary. This need, according to G.A. Vorobey (2012: 5), is the need to distribute and redistribute national income, to meet the needs of individual citizens, society, and the state. Regulating and guiding the cash flows, forming monetary funds subsequently spent on the needs of society, the government can stimulate the activity of certain areas of production or reduce it. The state authorities play the decisive role in the direction and implementation of the state financial activities. They approve budgets and performance reports, delineating income and expenditures between different budgets, establish and cancel taxes. Financial activity of the state is mostly management activities at its core.

State bodies, carrying out financial activities through, including its legal regulation, implement certain interests. Interests express the social claims of the most socially active strata of society. The fixing in the law of socially significant interests is relevant to the objective interests of society, is crucial in achieving social peace in the state. It is obvious that the protection of the interests which are not satisfying objective interests of the whole society leads to the violation of their balance and threatens to the public order. Here the most important social task is the harmonization of different interests, compromise, ensuring social cohesion and partnerships. This challenge decides by the public authorities on behalf of the people.

The law initially reflected the interests of society as a totality of its members (all or a dominant portion thereof) and the interests of each individual (or certain members). Social interest is a kind of average interest. The dialectic of the relationship of social and private interest is as follows: the social interest is formed by eliminating private interest from the totality of the interests, but private interest could not be 
Social Interest in Financial Regulation and the Constitutional Principles

implemented without social interest. The social interest is necessary for a balanced sustainable development of the state and society.

In scientific literature, it is often asserted that the public and private interests create the basis of public administration. Public interest considered the interest of the public. Private interest considered the interest of individuals or corporations. One of the important issues in this regard is the question about the coincidence of the social and the public interest. Public interests, as well as the social, defined as a kind of averaging of personal and group interests. It is the interests, without which it is impossible to ensure the integrity, stability, normal development of the state and society as a whole. As can be seen from these factors, public interests and social interests are one and the same. However, public interests have the distinctive feature - its formal character. They are the interests that are recognized by the state, have its support and protection. Consequently, the public interest is, as correctly claimed by Y.A. Tihomirov (1995: 55) recognized by the state and law secured interests of the social community, the satisfaction of which is a condition and guarantee of its existence and development.

The role of the state in implementation of social (public) interest is extremely important. Social interest is the interest of multi-level social groups. It is the interest of people united in political parties. It is the interest of people united in trade unions. It is the interest of territorial communities of people - people living in the regions, cities, small towns. The state, as is known, represents the society. Thus, social (public) interest becomes the public interest. These interests are realized in different spheres of life: economic, political, ideological, and social. So, for the normal functioning and development of the economy, the state protects all forms of ownership, ensures the development of production, organizing external relations. In order to ensure public order, the state protects its territory and sovereignty from external attack, suppresses the resistance of the opposing social forces, is taking steps to find a national and general agreement. The government supports education, science, culture, expands the state ideology in the ideological sphere. Through public branches of law - constitutional, administrative, criminal, financial, etc. the state regulates activities in areas governed the specified branches of law, makes it certain regulations, controls and protects it.

Government regulation is specific. In the sphere of implementation of public interest the state uses mainly the imperative method of legal regulation, i.e. a method of power and subordination. If necessary, the state establishes certain prohibitions. The state has the right of coercion, allowing him to effectively influence social relations. Thus, the state is a powerful mechanism of realization of interests. But the question arises: "Is it always the state supports and protects social in their essence interests?" After all, the state is also its bodies, officials and decision makers on behalf of the 
society, on behalf of the people. The experience of many countries knows many examples, when under the guise of the public, social interest private interests of corporations and social groups, bureaucratic interests, personal interests of public servants who abuse the right were implemented. The obvious conclusion is that the state in order to ensure the interests of each, without prejudice to the freedom of any of its members, should be organized in such a way so to limit, if not eliminate completely, this kind of manifestation. Legislative and enforcement bodies perform the problem of determining the social interest and distinction between them and private interests in the sphere of financial regulation. The state Parliament as the supreme representative body of the country passes laws, determines bases of legal regulation in the financial sector of the country as a whole. Local authorities by issuing normative acts regulate these issues at the regional level. In Belarus, for example, among the most important legislative acts adopted by the National Assembly of the Republic of Belarus (the Belarusian Parliament) are the Tax code of the Republic of Belarus (General part), the Tax code of the Republic of Belarus (Special part), the Budget code of the Republic of Belarus, the Banking code of the Republic of Belarus, the Investment code of the Republic of Belarus, the annual Act On the State Budget, etc. The President of the Republic of Belarus as the Head of the State has the special place in system of bodies of the Belarusian state involved in financial regulation. Belarusian President signs the laws related to financial legislation, issue decrees and orders on the issues of taxation, foreign currency transactions and other matters, carries out preliminary control of the main financial plan of the state of the draft national budget, establishes the fundamentals of financial control in the country. Local Councils - local authorities - confirm the local budget, establish local taxes and fees, determine the manner of disposal of municipal property. Executive-regulatory authorities of the state decide the issues arising in the process of implementation of the law, the use of the state coercion. The Government of the Republic of Belarus - the Council of Ministers - ensures the execution of the Republican budget income, makes decisions on taxation. A significant part of the authority of the Ministry of Finance of the Republic of Belarus, Ministry for Taxes and Levies of the Republic of Belarus, the State Control Committee of the Republic of Belarus, the National Bank of the Republic of Belarus, local executive and administrative bodies is also linked to the financial sector.

Violations of the balance of public and private interests are possible at the stage of legislative activity, and in particular, at the stage of enforcement. The court could and should to restore to the specified balance. The constitutional justice body can do it by considering the conflicts between normative legal acts. The general court can do it by solving the different categories of legal disputes. The Constitutional Court of the Republic of Belarus exercises control over the conformity of laws, decrees 
Social Interest in Financial Regulation and the Constitutional Principles

and edicts of the President of the Republic of Belarus, international contractual and other commitments of the Republic of Belarus, other normative legal acts to the Constitution of the Republic of Belarus and international legal acts ratified by the Republic of Belarus. The system of courts of general jurisdiction, including district, regional (Minsk City), economic courts of areas (Economic Court of Minsk), the Supreme Court of the Republic of Belarus shall administer justice on criminal and administrative cases, civil, family, labor, economic, and other disputes.

The solution to such global challenges as achieving conformity between the social and the public interest appears to be possible only in the conditions of realization of the most important principles of the law - the constitutional principles. The constitutional principles are the elements of the law that have a natural origin. The fundamental constitutional principles are initial ideas, accepted by people and/or anchored in the text of normative legal acts. They are the components of database regulation of social relations. The fundamental constitutional principles create a system of interconnected influence on the constitutional development of the society. They operate in a specific social space and time, handling social relations through the formation of democratic institutions that ensure the interaction of man, society and the state, the individual and social groups. As a legal matter, the constitutional principles are the universal, universally valid, imperative. The main task of the constitutional principles is to determine the direction of constitutional regulation of social relations in each historical and legal moment.

\section{Constitutional Principles and Social Interest}

The system of fundamental constitutional principles defines the basis of the content of any of the Constitution (the constitutional model) (Liverovskiy, 2017: 187). Concretization of the constitutional principles, their existence as a law is a conscious decision of the people through the adoption of the Constitution as the Fundamental Law of the state. Thus, the legal form of social development, the state constitutional path is determined. From the point of view of A.A. Liverovskiy (2015: 7-9), the constitutional model is constructed in such a way that the components of its fundamental constitutional principles implementing the supreme constitutional values. The constitutional principles not only define the legal the state of society but also to some extent determine its constitutional development by mediating the different values within a "pyramid" of social values, "headed" by the higher one. The Constitution of the Republic of Belarus and the Constitution of the Russian Federation considered the Man as the highest value. Man is the Supreme value and goal of the state and society according to the Art. 2 of each Constitution (Constitution of the Republic of Belarus of 24 November 1996; Constitution of 
the Russian Federation of 12 December 1993). Constitutional principles define the principles of the social structure of the society and implement its values. It is logical to assume that there are social values that can be universal for any community, belonging to the population of the state and living on its part, autonomous in some sense to it. Such values, at least according to scientists, are the highest constitutional values, such as "human dignity".

The constitutional principles, as the law in general, provide interaction of human being, society, and the state. The regulation of social space on the basis of modern constitutional models is carried out in a man-centered paradigm. So, the meaning and content of activities of public authorities are to protect the rights and freedoms of the individual, that is, in the realization of the highest constitutional values of the Constitution. The constitutional principles operate within the boundaries of a particular social space and social time. Because their meaningful and long-term use leads to a sustainable sense of justice of people, substantial change of the constitutional model leads to serious social upheaval. At the same time, the very set of constitutional principles is a developing system which characterized by integrity and sustainability.

The constitutional principles perform several important functions in relation to the legal regulation, including the financial sphere of social relations. Functions of constitutional principles are the main directions of their influence on social relations that reflect their subject characteristics. Directions of the impact of the principles of law on social relations persist for centuries. But, according to N.V. Silchenko (2004: 40 ), "change the contents of the social relations regulated by law changing ways, forms, and means by which law influences on social processes". Functions of the constitutional principles can be divided into social and actually legal.

The implementation of the social function by the constitutional principles follows from the fact that the law is a social phenomenon that has arisen in society and provides a significant impact. This effect is in relation to the state and against the institutions of society, and in relation to the individual. The constitutional principles play an important role in the organization and functioning of the state, because they control the system of state bodies, their relations, and fix their order formation and action. Such principles of the Constitution as democracy and separation of powers are obviously of this feature in. Such basic ideas of the Fundamental Law as humanism or democracy clearly show another function of the constitutional principles in relation to the state - the function to be the instrument of communication with society, its citizens, and their groups.

Social functions of the principles of the Constitution are also the directions of their effects on the individual. Thanks to the constitutional principles the citizens learn 
about the nature of law, existing in the national legal system in the specific historical stage of its existence, the content of its components. This is especially true in the case of such constitutional principles as equality or controllability, for example. By means of constitutional principles, individuals get information about recognized in this society social values that allow them to build their behavior according to them.

The fundamental constitutional ideas aimed at strengthening the existing social relations. They have a stabilizing effect on social connections that are within the scope of their regulation. They are designed to ensure the development of social relations which are in constant motion, presenting a dynamic part in the bunch of "law - society". The constitutional principles also protect social relations in the case of the threat to them. Named functions of the constitutional principles can be viewed as legal. And they should be analyzed in more details.

The system of the constitutional principles that govern financial regulation and, therefore, set the balance between public and private interests in this area includes such fundamental ideas as humanism, democracy, sociality, the separation of powers, equality, controllability, etc. The recognition, observance, and protection of the rights and freedoms of the individual are the essence of the principle of humanism - the most important basic idea underlying the organization and functioning of the modern state. This principle, at first glance, seems moral. However, defining legislative and law enforcement bodies of the state, sometimes fixed on the level of legal norms and sometimes inferred from their contents, it is an essential principle of organization, functioning, limitation, the kind of scale of the state and its bodies. The idea of humanism is also the measure of the state institutions activities. This principle should underlie the legal expertise of the normative legal acts that regulate social relations in the financial sector, preliminary examination of normative acts carried out by the body of constitutional justice if any in the state. For example, the preliminary normative control exercised by the Constitutional Court of the Republic of Belarus in the Belarusian state. In the analysis of activities of law enforcement bodies, their decisions in the field of financial regulation, the assessment of their activities, the resolution of disputes arising in the field of social relations an observance of the principle of recognition and protection of the rights and freedoms of man must be rigorous.

One more important principle governing the financial activities of the state is the principle of democracy. The idea of democracy enshrined, for example, in the Art. 3 of the Constitution of the Republic of Belarus. According to it the people is the only source of state power and bearer of sovereignty in Belarus. The people exercising their power in defined forms. The principle of democracy means that the people are the subject of public authority, acting as the totality of the whole population. The object of the people's power is all social relations of public interest across the 
country. The power of the people has primacy in relation to all other forms of power. The people exercise the fullness of power belonging to him in two forms: directly and indirectly. Direct democracy is the referendum and the elections. Mediated expression of the will or interests of individuals is expression it through a specially created state bodies or bodies of public associations. Democracy is exercised through both of these forms in the finance sphere. The people directly elect the state bodies (higher and local) which have an authority in the field of publication of the law regulating the financial activity of the state. The government, ministries, executive committees are the specialized bodies that regulate financial activities on behalf of the state in the interests of all people. The question arises, can there be a contradiction between the people and the state authorities formed by them or on their behalf? Obviously, yes. And in this connection special importance has the resolution of this potential conflict through the established ways but in the interests of the person.

Another important constitutional principle which defines the legal regulation in the financial sector is the principle of sociality. The social state is manifested in caring for the person, the support of the social strata that are unable to provide for themselves - children, the elderly, the disabled and mothers with children. The sociality of states also is the latter's pursuit of uniform and equitable distribution of vital goods. The given path resolving and mitigating social contradictions in society. It creates equal opportunities in the provision of material well-being and satisfaction of spiritual needs for all members of society. In the regulation of social relations connected with financial resources of the state, sociality as the constitutional principle manifesting in the establishment of differentiated tax rates, the incentives to certain categories of persons and (or) income received by them, etc. The balance between public and private interests in the implementation of social tasks of the state, on the one hand, promotes economic development, increase production and incomes. On the other hand, it allows preventing the critical gap between the wealthy and the poor or unsecured members of society.

The separation of powers as a constitutional principle is a specialization of state bodies in the activities. As correctly noted by A.A. Bezuglov and L.L. Belomestnyh (2004: 162), based the separation of powers, state bodies vested with a specific competence. They are autonomous and independent in exercising their powers and have the potential to mutually constrain each other. However none of the branches of power may assume the functions of the other branches of power, but to act in isolation they may not too. The existence of legislative, executive and judiciary branches of power - the so-called horizontal dimension of the principle of separation of powers - is clearly described in modern Constitutions - Fundamental Laws of states. The vertical aspect of the separation of powers is no less important. It means 
that the United States power demarcates the subjects of conducting and power between state authorities of federation and state bodies in terms of federations, as well as between central state bodies and local authorities and administration as in federal states or in unitary states. What about the financial regulation of social relations, the separation of the powers between the central and local authorities in terms of setting taxes and fees, their collection and distribution, as well as in the execution of various types of the budget (national and local, for example) is using.

Equality is the universal phenomenon, the idea, the proclamation of which is associated with the period of bourgeois revolutions, the adoption of the first legal acts regulating the basis of the legal status of the individual, including Habeas Corpus Act, the French Declaration of the Rights of Man and Citizen, the Constitution of the United States of America, etc. The basic meaning of this principle is that men are born and remain free and equal in their rights. This applies to all areas of social relations. Equality means that each subject of the state is provided by the equal legal opportunities with other members that the law imposes equal responsibilities, and realization of the rights and duties provided to him on an equal footing. Equal duties are no less important than equal rights. The establishment of equal rights and obligations in the financial sector, equal protection of financial entities, equal responsibility in the case of the offense in the specified area, etc. is the manifestation of the principle of equality in the sphere of financial regulation aimed to balance social and private interest.

The principle of controllability is the idea of great importance in the field of economic and monetary relations of the state. The control is the verification of the results of the social activities in accordance with aims and norms of organizations, communities, states, and universal values. The control is realizing towards the activity of individuals, their professional and spatial community organizations and the state. In the financial sector the legal acts issued by the authorities, their implementation, the realization of legal norms that establish the legal liability in case of committing financial offenses are controlled. Financial control covers all social relations arising in the sphere of financial activities of the state, ensuring the legality and appropriateness of financial policies. The control is intended to prevent the mismanagement and extravagance, to establish the facts of theft of inventory and fraud in this area.

\section{Conclusions}

The manifestation of public and private interest in the process of financial regulation of social relations is inevitable. It is sometimes very difficult to separate the public and private interest because the boundary between them is movable. It is defined 
by the legislator on the concrete historical stage of the legal system development. And the task of the legislator is to balance public and private interest by means of legal regulation. The contradictions could be between the various private and public interests. In some cases, it is the contradictions between legal and illegal interests. In others, contradictions between the legal, but misunderstanding interests of one of the subjects. The legal method (way) has the special importance for both types of contradictions resolution. But the procedure of the consultation and coordination of interests are also very effective.

The coordination of public and private interests in the sphere of financial regulation is carried out through the implementation of the constitutional principles of humanism, democracy, sociality, separation of powers, equality, controllability, etc. These principles determine the directions, forms, methods, the boundaries of the activity of legislative authorities in this area, enforcement of state institutions, act as criteria to resolve legal conflicts.

\section{References}

Bezuglov, A., Belomestnyh, L.: Конституционное право России (Constitutional law of Russia), Moscow: Publishing House AAFP, 2004.

Liverovskiy, А.А.: Право Конституции (Law of the Constitution), in: Методология современного конституционализма: конституционализация позитивного права, конституционная аксиология пропорциональности: материалы XIV Международной научнопрактической конференции по конституционному праву (Methodology of modern constitutionalism: the constitutionalization of positive rights, constitutional axiology of proportionality: proceedings of the XIV International scientific-practical conference on constitutional law), St. Petersburg: Saint-Petersburg state University of Economics, 2017.

Liverovskiy, А.А.: Правопонимание в конституционной юстиции (Understanding of law in the constitutional justice), Конституционное и муниципальное право (The Constitutional and municipal law) no. 6 (2015).

Silchenko, M. et al.: Общая теория права (General theory of law), Grodno: GRGU, 2004.

Tihomirov, Y.: Публичное право (Public law), Moskow: C.H. Beck,1995.

Vorobey, G.: Финансовое право Республики Беларусь: учебный курс (Financial law of the Republic of Belarus: study guide), Minsk: Amalfeya, 2012.

BY: Constitution of the Republic of Belarus of 24 November 1996.

RU: Constitution of the Russian Federation of 12 December 1993. 


\title{
THE POSSIBILITIES AND THE PRACTICE TO PROTECT THE PUBLIC AND THE STATE'S FISCAL INTEREST BY THE CONSTITUTIONAL TRIBUNAL
}

\author{
PIOTR WOLTANOWSKI ${ }^{1}$ RÓŻA KOSIŃSKA ${ }^{2}$
}

\begin{abstract}
According to the Authors opinion in this paper's, sometimes undertaken practice of the judgments regarding the tax law relationship conducted by the Constitutional Tribunal to specify the public interest in opposition to the entity rights and by bringing the need to respect the State Treasury and to achieve the planned revenue for the budget, cannot be approved. State's fiscal interest justified by the CT case is contrary to the public interest: retroactivity, the legislation ambiguity and lack of the respect to the established right. At the same time, there is underlying the need to provide for the tax legislator certain freedom while creating tax policy. The Tribunal should strive to balance the protection of the individual and social interest as well as to protect the interests of the single participants in the economic life. The CT should continue issue interpretative judgments - it is a valuable tool in the efforts to ensure an appropriate level to protect the individual and public interest, but it should accuse the current practice of issuing application judgments.
\end{abstract}

\section{Keywords}

State's Treasure Interest; fiscal interest; State's interest; budget interest; taxpayers' rights

\section{JEL Classification: K10, K34, H0O}

1 Board Member and General Secretary of Information and Organization Centre for the Research on the Public Finances and Tax Law in the Countries of Central and Eastern Europe, Department of Public Finances and Financial Law, Faculty of Law, University of Bialystok. He is the author of over 50 publications in the field of tax administration, human rights, health service finance and social security. Contact email: piotrwoltanowski@ gmail.com.

2 Member of the Audit Committee of Information and Organization Centre for the Research on the Public Finances and Tax Law in the Countries of Central and Eastern Europe, Secretary of Drohiczyn Scientific Society. An experienced practitioner of economics, a long-standing employee of the tax apparatus, an external and internal risk analyst, author of many publications in the field of tax administration. Contact email: rozmark@wp.pl. 


\section{Introduction}

The need to protect the public interest is the essential value emphasized by the Constitutional Tribunal in the tribute paid case law. The analysis of the objective scope in the polish constitutional court's case law practice, cause some anxiety regarding the inconsistency of the used terminology: the Tribunal seems to identify the constitutional value and the needs to achieve the planned budgetary revenue all together with the State's Treasure interest, fiscal interest, the State's interest, budget interest, as well as with the public interest. As a consequence, The Polish Constitutional Court seems to use the interchangeable terminology with the similar and interlocking meaning but with the different significance for the public interest as:

- State's Treasury interest (Constitutional Tribunal: W.12/92);

- State's fiscal interest (Constitutional Tribunal: K.4/03; Constitutional Tribunal: P.90/08 ; Constitutional Tribunal: K.21/14);

- Keeping the public finance balance interest (Constitutional Tribunal: K.21/14);

- State's interest (Constitutional Tribunal: W.3/94; Constitutional Tribunal: K.22/96; Constitutional Tribunal: K.23/98; Constitutional Tribunal: K.11/98; Constitutional Tribunal: P.9/15);

- Budget interest (Constitutional Tribunal: K.16/07);

- General interest (Constitutional Tribunal: W.3/94);

- Social interest (Constitutional Tribunal: P.9/15; Constitutional Tribunal: U.5/86; Constitutional Tribunal: W.1/89; Constitutional Tribunal: W.3/93; Constitutional Tribunal: W.8/93);

- National interest (Constitutional Tribunal: K.22/96; Constitutional Tribunal: U.24/97; Constitutional Tribunal: K.11/98).

The Tribunal, in his case law, respects the need to protect the local government authority interest (Constitutional Tribunal: W.12/92) as well as the municipality interest (Constitutional Tribunal: K.27/95). In terms of the public interest, and above all the fiscal interest, the Constitutional Tribunal mentioned also about the fiscal justice and the general obligation of the taxes liability. In this way, together with the observed chaos, within the used terminology, we are facing the worrying phenomena provided by the polish ombudsman, where "the general legal rules recognition in terms of the collective nature, which so far cannot be apportioned between the similar set of certain values - the dangerous phenomenon, which is leading to underline the recognition of the nature of the individual goods" (Ombudsman of Citizens' Rights: II.501.4.2017.MH). 
This paper refers to the Tribunal law case study, which actually equates to the fiscal (as the budget interest within the lax law relationship) and public interest. Such simplification of the complicated dependency between the two values are worrying - there for more, the CT withstand the unit of values regarding the fiscal interest (called "the public interest") with the values related to the taxpayers interest, the groups of taxpayers (e. g. consumers, disabled persons or most often entrepreneurs) or even legitimate the interest of citizens (Constitutional Tribunal: P.9/15). Only several situations can be listed as the limited exemptions, where the CT clearly distinguish (or even oppose) public and fiscal interest (Constitutional Tribunal: SK.35/14; Constitutional Tribunal: P.41/10).

It seems, that the Tribunal could more often implicate the situations in the case law, where the interest of the taxpayers coincide (e.g. by establishing the law of the sufficient quality) with the public interest (not necessarily with the state's fiscal interest). The study development may consider to the equation of the public interest with the practice of the democratic state based on the rule of law (as described in the case law) than maximizing the budget financial needs. The relevant approach to the scope of the public interest could give the appropriate range for the key constitutional values, e.g. correct tax legislation, which would enhance the protection of the taxpayer interest. There would not be anything new, especially, if we look at the ECHR case law practice, which combines different aspects of the rule of law and the implementation of the public interest.

\section{Limits Public and Fiscal Interest Protection in Case Law of Constitutional Tribunal}

Particularly, there is the apparent importance of the fiscal interest, if we consider the principles relevance and obvious, which could be in some way "faced" in the CT case law. We are writing about the fundamental and proper taxes rules, which often are violated by the taxation legislator (Woltanowski, 2012: 530).

The public interest in the Tribunal judgments regarding the tax law relationship relates first of all to the need to ensure the budget revenues at an appropriate level (Constitutional Tribunal: SK.23/03). For this reason "Constitutional Tribunal accept permissible possibility for the legislative reduce the rights of the individuals public property due to the public interest and (...) the barriers of the state's capability to execute, which are common goods" (the article 1 of the Constitution) and due to (...) the state's ability to assume it fundamental obligations" (Constitutional Tribunal: K.2/04). 
The scope, where these values can limit the rights and freedoms is determined by the specific nature of the individual rights and the entity freedom, and above all, by the principle of proportionality. In the Tribunal opinion "the principle of the proportionality is the constituent component of the rule of law. The rule of law is based on the assumption of the rationality of the legislator, and a prerequisite for the assumption is compliance with proportionality in the law-making process.

The rational legislator provide the right justice, hence, in principle, it should also be seen as the base of the principle of proportionality" (Constitutional Tribunal: K.9/95). Against this background, it should be recalled, that in the Tribunal opinion "the harsher standards and the examination should be applied to the law regulations and the personal and political freedom, rather than to the economic or social rights" (Constitutional Tribunal: U.3/96). In the case law of the Constitutional Tribunal regarding the tax law, the issue of the protection limits the right of the taxpayers are closely related to the legislator compliance with the principle of proportionality, which is expressed in the Art. 31/3 of the Constitution of the Republic of Poland.

Polish Constitutional Court underlined, that the rank of the public interest contains enumerated objectives, which are prescribed in the article 31 paragraph 3. In fact, they are the tasks for the public authority to be able to limit legal constitutional rights and freedom within the analyzed context. In this regard, by providing the appropriate financial funds to the state's budgetary for implementing these tasks is one of the necessary conditions to pursue the public interest. The scope of policy jurisdiction, formed by the Constitutional Tribunal and initiated by the decision given on 26 May 1995 (Constitutional Tribunal: SK.11/94), where previously occurred propositions have been generalized in the case law of the Tribunal, are unified and consistent.

The Tribunal recognises the values of the public interest, which often are in a conflict with the "group interests" (Constitutional Tribunal: K.22/96) and "the interests of the individual" (Constitutional Tribunal: K.11/98) and having guarantee nature as proper legislation, justice, equality, property protection, a closed catalog of the law sources and the statutory definition of the tax construction components (Woltanowski, 2005: 60).

This is a very narrow approach, which does not take into account the interests of a significant group of people, who are interested in a wider redistribution, rather than the protection of the taxpayers' rights. Additionally, the term of the public interest, also in the field of the tax issues, does not completely equal to the term of the state interest, or even more, with the "the state's fiscal interest", where is often identified with (Constitutional Tribunal: K.22/96). It seems, that such terminological inconsistency should not take place - especially regarding the 
The Possibilities and the Practice to Protect the Public and the State's Fiscal Interest...

presented in the CT case law, where are opposing the interests of the commune (or territorial self-government authorities) - with the state's interest (Constitutional Tribunal: W.12/92).

It is also worth to raise, that despite emphases in this context (Constitutional Tribunal: SK.23/01) the content of the Art. 1 of the Constitution, whereby the Republic of Poland is the common good of all citizens, even in the state formal legitimacy, but also with the contrary needs of the community. Perceiving the classification of "the state interest" as sui generis the sum of the individual entities seems to be also the serious simplification - especially when we will take into the account the contradictions proceed within them (Woltanowski, 2005: 60). There is arising anxiousness regarding the reduction of the material scope meaning to the need to ensure the state budget revenues at the planned level (Woltanowski, 2012: 531).

The public interest in the CT case law regarding the taxes can be interpreted as the ratio legis by establishing the obligation of the levy (Constitutional Tribunal: P.6/02; Constitutional Tribunal: K.2/03) or as the fiscal interest of the regulatory relationships (Constitutional Tribunal: K.2/94; Constitutional Tribunal: K.9/92; Constitutional Tribunal: P.4/98; Constitutional Tribunal: K.4/03; Constitutional Tribunal: K.8/03).

\section{Fiscal Interest and Non Retroactivity of Tax Law in terms to Need to Protect Public Interest}

The need to protect the budgetary revenues on the planned level forms usually justification to withdraw from the fundamental rights execution and the taxpayers' rights as well as the state's democratic order protection by the Tribunal - thereby the public interest - the principles of the proper legislation, by including the principles of the non-retroactivity of the tax law.

The Polish Constitutional Court declares, that the retro action is reasonable, when the law regulation seeks to remove the effects of the activities, which aims to be nefarious or seeks to evade the law (Constitutional Tribunal: U.10/89; Constitutional Tribunal: K.3/91; Constitutional Tribunal: K.8/94; Constitutional Tribunal: K.13/94). However, in practice, such approach is justified in the situations, where the legislator rectifies his own previous the legislative mistakes, which can affect on the effective law circumvention. That approach can be hardly acceptable, especially, when it based on the tax nature, where the need of strengthening the law is essential. It should be mentioned, that this solution's offer is the convenient path to correct the legislative mistakes without any Constitutional Tribunal objection. 
Unfortunately, it seems to be particularly tempting nowadays, by representing the comfortable (although deceptive) alternative to the laborious process of the proper creation of the tax law.

\section{Fiscal Interest and Need to Maintain relevant Vacation Legis in terms to Protect Public Interest}

The obligation to keep the reasonable long vacatio legis provides the equitable implementation (similar to the principle of non-retroactivity) of the public interest. Regarding this, it is possible to:

- introduce the amendments of the rules to the recipients (taxpayers) which may come into the force;

- protect the taxpayers' interest in the ongoing process;

- prevent the legislative authority abuse towards citizens.

According to the extensive case law of the Tribunal and by examining the accuracy of the length of the period of vacatio legis, takes into the consideration, inter alia:

- the nature and substance of the new regulations (Constitutional Tribunal: K.1/94);

- the social importance of the new regulations (Constitutional Tribunal: K.1/94);

- regulations wideness, which may come into the force (Constitutional Tribunal: K.1/94);

- the need to provide for the entrepreneurial taxpayer's particular assurances of legal security (Constitutional Tribunal: K.9/92; Constitutional Tribunal: K.8/93).

Regarding the proper evaluation of vacatio legis, the Tribunal in the case law uses the term "public interest" in relation to the legislator activities, which aim is defying the frauds and the taxation malfeasance (Constitutional Tribunal: K.2/94) and even can validate the back down from the established period of vacatio legis (Constitutional Tribunal: K.9/94). In this case, the public interest somehow can be reduced - as in the previously mentioned case (Constitutional Tribunal: K.2/94), where arises the need to ensure the achieving State's budgetary incomes.

Particularly, we can be worried about, when we will remind, that in the Tribunal opinion, generally, if the taxation issues saved 14 days adjustment period, violation of the Art. 2 of the Constitution can succeed barely - only in the conspicuous cases (Constitutional Tribunal: K.55/02). It seems, that we are dealing with the situation, 
in which the public interest is to understand extremely narrowly and reduced to the current fiscal interest only. The Tribunal seems to allow for the legislator too big freedom in the imperious interference of the taxpayer's property area (Constitutional Tribunal: K.57/13). Obviously, it is possible to imagine exceptional situations, as war or large-scale natural disaster, in connection, where the omission of the adjustment period will be indicated indeed and compatible with the public interest. However, the current amendments brought by the incompetent legislator to the previously adopted legal norms do not deserve such justification. According to the Authors' opinion of this article, they arise as the result of irregularities in the earlier legislative process, and not appear in the expression of the legislator attention (or the Polish Constitutional Court) to the public interest.

\section{Practice to Amend the Changes into Legal Acts in the period of their Vacatio Legis in terms to Protect Public Interest}

Changes introduced in this mode reduce the authority of the legislator body, destroy the taxpayers' security regarding the sense of legal certainty and, above all, make it impossible to adapt to the content of the new regulations (Woltanowski, 2012: 537). The act adopted by the parliament in the prescribed mode, signed by the President and announced in the "Journal of Laws", created among the potential recipients of the law the conviction and at the same time the expectation, that the adopted legislation in its original form will come into the force within the specified by that act period (Constitutional Tribunal: K.12/03).

Unfortunately, the Constitutional Tribunal accepts the revision of the legal act in the period of coming into the force in the two cases only by:

1. revising the mistakes, internal inconsistency or solutions, which leads to the incompatibility of the law system after the adoption of the normative act,

2. preventing the negative effects (especially fiscal consequences) of the adopted regulations coming into force of the adopted, but not applicable yet (Constitutional Tribunal: K.12/03).

In the Authors' opinion, such practice cannot be justified. In both presented cases above, should not be accepted the reduction of the fundamental rights of the public interest ( and the protection of the individual interest) in terms of the legal certainty. The relevant shares of budgets are possible to collect without destroying the foundation of the legal state. 


\section{Protection of Established Rights in terms of Tax Law Relationship Regulations and Public Interest}

It seems that emphasized the relative freedom of the legislator in terms of the tax law by the Tribunal in the case law (Constitutional Tribunal: K.1/95), rationally limits the scope of the public interest protection in favor for the common interest. The Constitutional Tribunal emphasizes the power of the legislator authority regarding the lawmaking in accordance with the assumed political and economic objectives (Constitutional Tribunal: K.7/93) and together implement the tax policy based on the principle of the social solidarity of the tax policy, in terms of the public interest. In the Constitutional Tribunal opinion, as far, the changes of the construction of the individual taxes, including the maintain or withdraw of the tax exemptions by the legislator promotes presumptive relative regulatory freedom (Constitutional Tribunal: K.6/02).

However, it should be strongly emphasized, that the Tribunal should rather endeavor the principle of protection of the established rights nor with the public or (mostly direct) fiscal interest, but with the principle of the prevalence of taxation, under the Art. 84 of the Constitution (Woltanowski, 2012: 541).

\section{Protection of State's Fiscal Interest and Practice to Issue so-called Interpretative and Application Judgments by Constitutional Tribunal}

The violation of the constitutional requirements about the clarification and the proper communications of the legal text, which are unclear and inaccurate in terms of formulating the rule, and affects the recipients' fragility regarding their rights and responsibilities at the same time create the legal trap for the citizen (Constitutional Tribunal: K.13/93; Constitutional Tribunal: K.1/94). Breaking that rule leads to use the extended interpretation by the fiscal authorities (Kosińska, Ruśkowski, Woltanowski, 2016: 533) and their activities can occur for example, through:

- the lack of ability for the conclusive statement regarding the structural components of the taxes;

- the multiple interpretations and the rules use, due to the lack of legislator precision in this terms;

- the extended scope of using the tax law relationship rules among the entities range in an inappropriate manner due to the earlier purpose of the legislator (Constitutional Tribunal: K.33/02; Constitutional Tribunal: K.44/07; Constitutional Tribunal: K.28/02; Constitutional Tribunal: 
The Possibilities and the Practice to Protect the Public and the State's Fiscal Interest...

K.45/02; Constitutional Tribunal: K.31/10; Constitutional Tribunal: K.33/05; Constitutional Tribunal: K.4/06; Constitutional Tribunal: P.28/07; Constitutional Tribunal: K.32/03; Constitutional Tribunal: K.4/09; Constitutional Tribunal: K.1/05; Constitutional Tribunal: SK.51/05; Constitutional Tribunal: K.21/05; Constitutional Tribunal: SK.96/06; Constitutional Tribunal: SK.17/07; Constitutional Tribunal: SK.64/08; Constitutional Tribunal: K.1/10).

Straightforward elimination of the nonprecious and unclear regulations for the overall recipients from the existing law by the Tribunal, can be tough in judgment practice, due to the negative consequence for the judgment regarding the budgetary revenues or for the whole system of the rules of the tax law. Protecting the fiscal interest - however, in the Authors opinion, the public interest also, the CT issues the interpretative judgments, which (optionally):

- recognise the provision to be incompatible in a specific - subjective, objective or temporal scope of its implementation;

- recognise the provision as an incompatible under the condition of its proper understanding (Woltanowski, 2012: 533).

The Polish Constitutional Court, by publishing that kind of judgments, expose himself for the allegation regarding the existing general law interpretation (that could be the attack of the judiciary independence through the binding the judiciary by the courts' given interpretation) or through the activity of the lawmaking. However, for the opponents of this scope of the CT activity, can point the presumption of constitutionality and the hierarchically lower acts legality, as the purposefulness of law enforcement by the Constitutional Tribunal, and the principle of legal certainty and formulation of the content under Art. 190 of the Constitution.

Published the interpretative judgments are certainly compatible with the public interest through:

- the strengthening the legal certainty and by the clarifying the non-restrictive tax law regulations;

- the reducing the vulnerability of the appearing gaps', which arises as the result of the removal the unconstitutional regulations from the legal circulation;

- the possibility to influence the doctrines of law in force additionally;

- the respectively deliberated balance between the protection of the taxpayer's rights and the state's fiscal interest.

There is no possible to agree with the practice of given application judgments. The CT within the framework decides regarding the scope of the influence of 
the unconstitutional provision on the social relations, i.e. based on the activities performed in the past. Application judgments are particularly often issued in the area of tax law - for example the CT concluded, that the tax or payment paid due to the noncompliant rules of the constitutional law is non-refundable (Constitutional Tribunal: P.7/00; Constitutional Tribunal: P.6/02). It seems, that issuing such judgments beyond the scope of constitutional competence of the Constitutional Tribunal cannot be reconciled with the base function of the Constitutional Tribunal, which is just monitoring the legislation. However, the Tribunal conclude, that it is not only entitled to adjudicate on non-conformity of the normative acts with the Constitution, but also has the authority to determine the temporal framework of such inconsistency, especially the time limits of the retrospective scope of the judgments which determine incompatibility with the Constitution described in the specific provision (legal norm). The argument, provided under the Art. 190/3 of the Constitution, gives the possibility to postpone the date of binding the force for the normative act. The CT derives the conclusion from that provision, that it is able to determine the more extended scope for the retrospective coverage as well as the effects on its given judgments (Constitutional Tribunal: K.24/03). It seems, that such arguments is not justified due to the lack of clear connection between the competence truly given to the Tribunal and the usurped authority.

\section{Conclusions}

The Constitutional Tribunal, by examining, the subject of the compatibility with the constitutional applicable measures to protect the state's fiscal interest uses three main criterion:

- the criterion of the purpose limitation;

- the criterion of the proportionality;

- the criterion of the usefulness (Constitutional Tribunal: SK.33/03; Constitutional Tribunal: SK.23/01; Ombudsman of Citizens' Rights: II.501.4.2017.MH).

The first listed - the criterion of the purpose limitation refers to the rank of probability to implement the assumed effects by the legislator on the monitoring regulation The used tools to protect the public interest are inspecting in regards to their applicable necessity (the criterion of the usefulness). There is also examined issue of the proportionality of regulation's effectiveness through their imposed liabilities.

The specific "axiological measured" need to protect the fiscal and individual interest handles the central role in the case law of the Constitutional Tribunal regarding the 
tax law. However, in several judgments regarding that range, the $\mathrm{CT}$ recognizes also the scope, where is the need to ensure the budget revenues on the appropriate level and the need to protect the taxpayer's rights, which are not contrary, but are identical. As an example, there can be the need to maintain the budget balance, which considers as the constitutional value by the Tribunal. That value, emphasized many times in the case law, maintain the state's and the local self - governments authorities ability to act and solve multiple public needs (Constitutional Tribunal: K.27/98; Constitutional Tribunal: K.13/01; Constitutional Tribunal: K.6/02). The big part of the taxpayers appears also directly (or maybe first of all) as the beneficiary of the public funds by receiving from the state's budget salaries, retirements, and other supplied benefits. The need to protect that individuals interests influence the direction of understanding the proper meaning (in some way by the Tribunal too) of the public interest.

There will be difficult not to agree with the Commissioner for the Human Rights conclusions, who in his application to the Tribunal ask to examine a number of proposed solutions in the law of the National Revenue Administration, in which is described, that "it is impossible to maintain the trusted and loyal relationship [essential from the point of view of the public interest], if the state forms its competences in seriously interfering way with the freedom and citizens' rights, without indicating the limits of the benefiting from these competences, or setting the limits beyond the principle of proportionality" (Ombudsman of Citizens' Rights: II.501.4.2017.MH). However, the public interest requires the effective and the fully implemented law - as the fundamental aspect of the state's presence - that is why the fight against his violations (unless the used tools do not reconcile to the violate the basic principles of the democratic state of the law) pursues the public interest.

Furthermore, fiscal frauds together with the loans extortion, dishonest business management, "money laundering" strike not only to the budget financial security but also to the subject interest, which performs the honest and legitimate economic activity. Performing the tax-free economic activity by the same subjects in a same scope of the operations under the free market competitions can affect on the elimination those subject from the economic turnover, whom reliably fulfill their tax obligations. The CT underline, that, "if in polish economic reality exist "the shadow zone", when the legislator has the right and even the responsibility to adopt the regulations, which eliminate it", (Constitutional Tribunal: SK.11/94) and also "recognize the presence of the substantial public interest, where established regulations are using for the purpose to protect not only the state interest but also those economic subjects, who wish to carry out their activity in the honest and legal way" (Constitutional Tribunal: SK.11/94). 


\section{References}

Kosińska, R., Ruśkowski, E., Woltanowski, P.: Effectiveness of tax services during the reformation period - selected issues (Efektywność służb podatkowych w okresie ich reformowania wybrane zagadnienia), Finanse, Rynki Finansowe, Ubezpieczenia (Finances, Financial Markets, Insurances) no. 6 (2016), DOI: 10.18276/frfu.2016.6.84/2-02.

Woltanowski, P.: Category of public interest in Constitutional Court jurisdiction in tax cases, in: Štrkolec, M.: Current questions of the efficiency of public finance, financial law and tax law in the countries of Central and Eastern Europe, Košice: Pavol Jozef Šafárik University in Košice, 2005.

Woltanowski, P.: Zasady prawidłowej legislacji podatkowej, a ochrona interesu Skarbu Państwa w orzecznictwie Trybunału Konstytucyjnego (The principle of proper tax legislation and protection of the interest of the State Treasury in the jurisprudence of the Constitutional Court), in: Etel, L., Tyniewicki, M. (eds.): Księga jubileuszowa profesora Eugeniusza Ruśkowskiego (Anniversary book of Professor Eugeniusz Ruśkowski), Bialystok: Temida 2, 2012.

PL: Constitutional Tribunal: P.9/15.

PL: Constitutional Tribunal: K.21/14.

PL: Constitutional Tribunal: K.57/13.

PL: Constitutional Tribunal: K.31/10.

PL: Constitutional Tribunal: K.1/10.

PL: Constitutional Tribunal: K.4/09.

PL: Constitutional Tribunal: SK.64/08.

PL: Constitutional Tribunal: P.90/08.

PL: Constitutional Tribunal: SK.17/07.

PL: Constitutional Tribunal: K.16/07.

PL: Constitutional Tribunal: P.28/07.

PL: Constitutional Tribunal: K.44/07.

PL: Constitutional Tribunal: K.4/06.

PL: Constitutional Tribunal: SK.96/06.

PL: Constitutional Tribunal: K.1/05.

PL: Constitutional Tribunal: K.21/05.

PL: Constitutional Tribunal: K.33/05.

PL: Constitutional Tribunal: SK.51/05. 
PL: Constitutional Tribunal: K.2/03.

PL: Constitutional Tribunal: K.12/03.

PL: Constitutional Tribunal: K.32/03.

PL: Constitutional Tribunal: K.8/03.

PL: Constitutional Tribunal: K.4/03.

PL: Constitutional Tribunal: SK.23/03.

PL: Constitutional Tribunal: K.45/02.

PL: Constitutional Tribunal: K.33/02.

PL: Constitutional Tribunal: K.6/02.

PL: Constitutional Tribunal: K.28/02.

PL: Constitutional Tribunal: P.6/02.

PL: Constitutional Tribunal: SK.23/01.

PL: Constitutional Tribunal: K.13/01.

PL: Constitutional Tribunal: P.7/00.

PL: Constitutional Tribunal: K.11/98.

PL: Constitutional Tribunal: K.23/98.

PL: Constitutional Tribunal: K.27/98.

PL: Constitutional Tribunal: P.4/98.

PL: Constitutional Tribunal: U.24/97.

PL: Constitutional Tribunal: K.22/96.

PL: Constitutional Tribunal: K.27/95.

PL: Constitutional Tribunal: K.13/94.

PL: Constitutional Tribunal: K.2/94.

PL: Constitutional Tribunal: K.8/94.

PL: Constitutional Tribunal: W.3/94.

PL: Constitutional Tribunal: W.3/93.

PL: Constitutional Tribunal: W.8/93.

PL: Constitutional Tribunal: K.8/93. 
PL: Constitutional Tribunal: W.12/92.

PL: Constitutional Tribunal: K.9/92.

PL: Constitutional Tribunal: K.3/91.

PL: Constitutional Tribunal: W.1/89.

PL: Constitutional Tribunal: U.10/89.

PL: Constitutional Tribunal: U.5/86.

PL: Ombudsman of Citizens' Rights: II.501.4.2017.MH, 
CHAPTER 2

\section{PROTECTION OF PUBLIC INTEREST IN FINANCIAL LAW}

SECTION 2.1

PUBLIC FINANCIAL INTEREST AND EUROPEAN UNION 



\title{
PROTECTION OF THE EUROPEAN UNION'S PUBLIC (FINANCIAL) INTEREST IN NORMATIVE BUDGETARY PRINCIPLES
}

\author{
MARCIN TYNIEWICKI
}

\begin{abstract}
The problems concerning the protection of the EU financial interest are generally discussed in the context of fighting corruption or preventing and eliminating fraud (financial irregularities). In many cases, the actions taken have ex-post character since they concern situations of inappropriate distribution (allocation) of public funds. In this article, the Author approached these problematics a bit differently because he tried to prove that already on the stage of planning (constructing) EU budget as well as during its implementation there are instruments such as normative budgetary principles which may serve to protect its financial interest ex-ante. Moreover, the primary sources of this protection should be also found in the public choice theory, functioning in the economics. Therefore, the aim of this article is to prove the following hypotheses: the basis for protection of the EU financial interest is to be found in the functioning public choice theory as well as in - being its consequence - normative budgetary principles, whose content includes duty to properly govern, and especially plan, public funds accumulated in the EU budget. Conclusions resulting from the analysis of the indicated problematics have been determined on the basis of non-reactive (non-empirical) research methods, i.e. examination of the reference literature and binding EU regulations.
\end{abstract}

\section{Keywords}

Public choice; EU budget; budget discipline; resource scarcity; financial interests

\section{JEL Classification: E62, H41, H61}

1 Doctor of Financial Law, Department of Public Finance and Financial Law, Faculty of Law, University of Bialystok, Poland. The Author specializes in local government finance, EU public finance, and public debt management. He is a member of the Regional Chamber of Account in Bialystok and the Center for Information and Research Organization in Public Finance and Tax Law of Central and Eastern Europe. Contact email: tyniewicki@uwb.edu.pl. 


\section{Introduction}

The problems concerning the protection of EU financial interest are generally discussed in the context of fighting corruption or preventing and eliminating fraud (White, 1998: 2-3; Szarek-Mason, 2010: 73; European Commission, 2016: 8-11). In many cases, the actions taken have ex-post character, since they concern situations of inappropriate distribution (allocation) of public funds. It needs to be emphasized that the duty to implement the protection of the EU financial interest has been generally determined in Art. 325 of the Treaty on the Functioning of the EU².

In this article, the Author approached these problematics a bit differently because he tried to prove that already on the stage of planning (constructing) EU budget as well as during its implementation there are instruments such as normative budgetary principles which may serve to protect financial interest ex-ante. Moreover, the primary sources of this protection should be also found in the public choice theory, functioning in the economics.

Therefore, the aim of this article is to prove the following hypotheses: the basis for protection of the EU financial interest should be found in the public choice theory functioning in the economics as well as in - being its consequence - normative budgetary principles whose content includes duty to properly govern, and especially plan, public funds accumulated in the EU budget. Referring to such stated hypotheses, the Author tried to answer the following research questions, which are essential to implement the aim of this paper:

- in what way and in what scope will the public choice theory constitute the source protecting the EU financial interest?

- in what way will the budgetary principles included in the content of legal norms be able to protect the EU financial interest?

Conclusions resulting from the analysis of the indicated problematics have been established on the basis of non-reactive (non-empirical) research methods, i.e. examination of the reference literature as well as binding EU legal regulations.

It should be generally stated that budgetary principles functioning in the EU law, i.e. rules regarding designing and functioning of the Union budget has not yet been analyzed in the aspect of financial interest protection. In the financial literature, if the problems of principles are discussed, they have descriptive character and the Authors focus mainly on the legal regulations concerning these principles as well as indicate how they are implemented (Strasser, 1992: 47-70; European Commission, 
Protection of the European Union's Public (Financial) Interest...

2014: 147-178; Lenaerts, Van Nuffel, 2011: 571-572). Often also their practical dimension is discussed.

Not without a reason, the Author used the term "normative budgetary principles" in the title of this article. It results from the fact that in the EU law these principles, on the one hand, may be separated as a matter of interpretation of the TFEU provisions and on the other hand they were enumerated in Art. 3 of the Regulation of the European Parliament and the Council (EC, Euratom) no. 966/2012 on the financial rules applicable to the general budget of the Union and repealing Council Regulation (EC, Euratom) no. 1605/2002 ${ }^{3}$, however, their list is not closed. The Treaty provisions give basis to distinguish other principles by interpretation. However bearing in mind both legal acts, the following basic budgetary principles may be indicated: unity and budgetary accuracy, annuality, financial continuity, financial autonomy, anteriority, budgetary discipline, equilibrium, unit of account, universality, specification, sound financial management, and transparency (Kosikowski, 2008: 121; Tyniewicki, 2012: 210). Due to limited publication framework the Author will not analyse all of them, but will focus only on these which in his opinion create significant norms to implement the protection of the EU financial interest, i.e. the principle of annuality and connected with it principles of anteriority and financial continuity, unity, budgetary accuracy as well as sound financial management. However, it needs to be emphasized that all enumerated principles are significant for the analyzed problematics and it even may be stated that they constitute a kind of a system protecting financial interest at the stage of budget planning, implementing and supervising.

It is also important that these principles in the process of the EU budget management, including administering its financial funds, are binding not only for the EU institutions and bodies, in particular, the European Commission which is responsible for implementing the EU budget on the basis of Art. 53/1 FR. But this process also involves the Member States, which due to the means obtained from the EU budget participate in its implementation, what results from the method of budget implementation defined as the shared management method (Art. 58/1/a FR). As a result, a large part of the funds is allocated by the Member States. With regard to the financial statement for 2016, they are responsible for implementation of more than $86 \%$ of all expenditure of the EU budget (European Commission, 2016: 37).

Budgetary principles which are to facilitate proper spending of the EU budgetary appropriations, and which are a kind of legal protection of the Union financial interest, are not autonomous instruments. Their establishment was one of the indirect consequences of the public choice theory functioning in the economics. The 
theory itself should be recognized as the primary source protecting the EU financial interest, whereas budgetary principles take the form of legal norms which should realize this protection in the practical dimension. This hypothesis was formulated at the very beginning and from proving it the Author will start further considerations.

\section{Public Choice Theory as the Primary Source Protecting the EU Financial Interest}

In the process of public funds management, there is almost always a question: how to spend them properly (optimally) taking into consideration public tasks implemented and in particular on the basis of what principles it should be done. From the axiological point of view, the source of this problem seems obvious, both in the context of public and non-public finance. It results from existing in the economics two contradictory phenomena: human limitless demands and resource scarcity which are to satisfy these demands. As a result, the theory of scarcity appears (Eklund, Hebert, 2014: 31; Murherjee, 2005: 11).

In the area of public finance, it has even stronger influence than in the private sector. The additional factor limiting public resources is their accumulation (seizure) on the basis of income which private people have at their disposal. However, the phenomenon of scarcity does not limit the process of public sector expansion, what is manifested in the willingness of public authorities to enlarge allocations range and redistribution of public funds as well as to guarantee the participation in the division of these funds to particular social groups. On the one hand, these tendencies are expressed by the law of increasing public spending, also called Wagner's law, although the causes of such situation are of diverse character: sociological, historical, political as well as economic and social (Buchanan, Musgrave, 2001: 64; Gaudemet, Molinier, 2000: 78-81). On the other hand, in the process of law-making, implementing particular financial policy, the state creates expenditure norms which are the basis for the so-called mandatory spending (Austin, 2017: 5-6), and thus are "imposed" by the introduced regulations.

Both phenomena - increasing public spending and creating mandatory spending are focused on allocations of public funds which, regarding these phenomena, faces two substantial problems, namely:

1. who do the decision-makers (public authority) represent in reality and in whose interest do they fulfill their functions?,

2. what criteria are the decision-makers (public authority) guided by when managing public funds - allocating public and social goods? (Owsiak, 1998: 71). 
Protection of the European Union's Public (Financial) Interest...

The above mentioned problems are the subject of interest of liberal public goods theory as well as public choice theory (Buchanan, 1987: 175-177; Kiefer, 1997: 15-16; Musgrave, Musgrave, 1989: 87-109; Lee, 2013; Buchanan, Musgrave, 1999; Stiglitz, 2000: 230-248), as well as of a more narrow issue - rationalizing public spending. Basically, public choice theory concerns problems of goods allocation and income redistribution selection. In other words, its content includes the issues of type, amount and quality of public goods as well as the method of paying for them. Citizens are to decide about it by means of democratic elections, thereby limiting arbitrariness and freedom of decision-making of public authorities. Such manner of expressing own election preferences matches known in the literature agency problem, which is a model of public sector functioning (Weingast, Moran, 1984: 147-192; Moe, 1984: 739777). In this model, a Principal is the society/citizens and an Agent - politicians.

Even though the public choice theory concerns problems of goods allocation and income redistribution, it should not be forgotten that these processes must be conducted according to legal regulations. Politicians who obtained a social mandate to exercise public authority, i.e. their political program was accepted by the society (voters), may implement this program within a legal framework. Only at the very end, by the implementation of this law, there is a real allocation of goods and income redistribution. Hence, the public choice theory indirectly influences establishing expenditure norms and this process is presented in the Graph below.

\section{Graph 1 Impact of Public Choice Theory on Establishing Expenditure Norms and Public Goods Allocation}

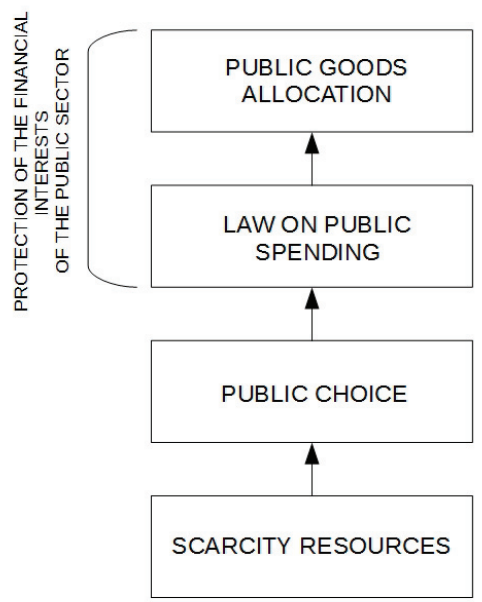

Source: Own study. 
It needs to be emphasized that even the most socially generous political programs included in the content of the established legal regulations meet limitations resulting from the mentioned resources scarcity, whose consequences are in the possibility to manufacture goods and impose the fiscal burden on the income generated from it. Ignoring this whole mechanism manifested in too expanded social programs or populistic promises together with their implementation will sooner or later cause excessive debt of the state and/or cause the economic crisis. Having this in mind, in legal systems of a lot of countries, not only those characterized by free market economy, appear regulations regarding the public spending of limiting, savings and disciplining character. How effective they are and to what extent they are enforced is a disputable issue. Also in not fully free market economic systems, with the different scope of the state interference in the market mechanism, such regulations exist, what has been noted by the Author. In this case, the sense of their existence may be questioned, but from the formal point of view, they are introduced to keep up appearances of free market mechanisms and proper functioning of the public finance system.

To summarize, the public choice theory also has its reflection in the legal norms regulating the principles of public spending. A part of these norms concerns through proper directives on planning, savings, efficiency, purposefulness or broadly understood rationalization of spending - the protection of public finance interest of a given public organization: state, international organization, etc. This theory impacts decision which are to care for these interests. Besides it should be added that both in the sphere of law-making as well as in the real actions of managing public finance, including financial decisions, the key role should play moral norms and citizenship education (For more see: Salachna, Tyniewicki, 2016: 11-20; Salachna, Tyniewicki, 2017: 81-83).

\section{Implementation of the EU Budgetary Principles in the Context of Proper Public Funds Management and Protection of the EU Financial Interest}

\subsection{Principle of Annuality as a Norm Determining Time Frame for Spending Budgetary Appropriations}

The principles of EU budget annuality is complex, also in the context of protecting the Union financial interest. In the general dimension, it defines the length of the financial year for which the budget is adopted and which begins on 1 January and ends on 31 December (Art. 313 TFEU). In the economic and management dimension it means that planning and managing budgetary appropriations take place during this period. On the other hand, in the legal dimension, it determines the episodic 
Protection of the European Union's Public (Financial) Interest...

character of the budgetary act (act including the EU budget), which after each financial year loses its Authorizing power. With regard to the EU financial economy it means limiting the possibilities to make revenue and expenditure operations because funds in the budget are "approved" for one financial year (Art. 310/2 TFEU, Art. 9 FR). This "approval" in the financial terminology means the budget authorization, i.e. giving it legal force. This fact together with the episodic character of the budget act, in reality, means temporal - limited to one year - possibility to manage funds accumulated in the EU budget. The issue of authorization is quite complex and will be discussed in 3.3. of this article.

Taking into consideration only analyzed principle of annuality, the end of financial year causes on the one hand "automatic" loss of the power to Authorize the budget act, and on the other hand - the phenomenon of expenditure expiry, what is stipulated in Art. 13/1 FR: "Appropriations which have not been used by the end of the financial year for which they were entered shall be canceled". So by virtue of law, there is a prohibition to incur expenditure after the financial year is ended. Actions against this prohibition will infringe financial discipline and will be harmful to the EU financial interest. However, in Art. 13/2-4 FR there are exceptions from the non-expiry principle consisting in the possibility to transfer expenditure.

When confronting the results of the principle of annuality and the complexity and plurality of tasks anticipated in the budget, the principle should be considered quite restrictive. The period to implement these tasks, taking into consideration the global character of the EU aims, often exceeds one financial year. Strictly obeying this rule would make it impossible to achieve these tasks effectively. An instrument which mitigates the contradictions between long-term tasks and the principle of annuality is the institution of differentiated appropriations, which includes commitment appropriations and payment appropriations. According to Art. 10/2 FR commitment appropriations cover the total cost of commitment entered into during the financial year. This category determines projected costs which are to be covered from the budget as a result of the commitments entered into the financial year. Due to their different maturity periods, it is not tantamount to the number of their real payments. It will also include the annual cost of the long-term tasks. Whereas the real amounts of budget expenditure will be reflected in payment appropriations (Art. 10/3 FR) which will include payments of legal commitments entered into the financial year or preceding financial years.

The principle of annuality is fully applied in the context of the EU multi-annual financial frameworks, i.e. financial perspectives currently adopted for seven 
years ${ }^{4}$. They belong to medium-term instruments managing EU funds (European Commission, 2008: 182). They include EU priorities which will be implemented in the indicated period with the concurrent determination of financial ceilings for their financing.

The principle of annuality, having regard to the process of multiannual financial planning in the EU, does not make an exception and is rather a supplement. On the one hand, successive annual EU budgets in terms of amounts must be in accordance with the ceilings for commitments resulting from the seven-year financial frameworks (Art. 312/3TFEU, Art. 51 FR), but on the other hand, the frameworks alone do not Authorise expenditure. Such authorization takes place as a result of adopting the budget act by the European Parliament and the Council, what has been already discussed. Therefore, it may be stated that in the EU there is a coexistence model of multiannual and annual financial planning and not their mutual exclusion (Ruśkowski, 2014: 39). Moreover, the European Commission itself believes that the sole fact of "entering" annual budgets into the multiannual frameworks should not be seen as a conflict with the principle of annuality (European Commission, 2014: 159).

Principles of anteriority and financial continuity, connected with the principle of annuality, are also significant to the protection of the EU financial interest. They constitute a protection measure for the possibility to conduct economy on the basis of the EU annual budget. In the financial doctrine through the anteriority, principle is formulated the directive according to which the budget should be adopted before the beginning of the period for which it was designated so that it could enter into force with the first day of the new financial year. Due to the episodic character of the budget and the loss of its Authorizing power with the end of the year, the EU should have possibilities to manage funds for the following year based on a new budgetary plan. From this perspective, it is a guarantee to maintain budgetary discipline. On this basis, it may be stated that the anteriority principle ensures stability and financial continuity of the Union.

In the EU law, the principle of anteriority results from a few provisions, e.g. Art. 313 and Art. 314 TFEU. The latter article regulates the procedure of adopting the general budget, which includes strict deadlines for particular stages so that it could be adopted prior to the beginning of the financial year for which it is to be binding. On the other hand, Art. 315 TFEU includes principles regarding transitional management of the financial economy (also expenditure) in the case no final budget is adopted at the beginning of a new financial year.

4 Pursuant to Art. 312/1/2 TFEU minimal period for which multi-annual frameworks should be adopted is 5 years. 
Protection of the European Union's Public (Financial) Interest...

\subsection{Budgetary Rules as Instruments Determining EU Budget Expenditure Principles}

Key principles for maintaining budgetary discipline, and in a broader sense - for protecting the EU financial interest, are also the principles of unity and budgetary accuracy. Their general frameworks result from Art. 310 TFEU, which stipulates that all revenue and expenditure of the Union should be entered in the budget for each financial year. The content of these principles is developed in the provisions of the Financial Regulation - Art. 7 and 8, respectively. In the doctrine of public finances, the principles of unity and budgetary accuracy belong to the broadly understood principle of budget comprehensiveness (completeness).

Generally, both analyzed principles are focused on the formal role of the budget act in the processes of managing appropriations accumulated in the budget. At the same time, they impact the manner in which this management should be done (i.e. according to the EU budget principle of universality ${ }^{5}$ ) and they define the legal character of the budget act, including its Authorizing power.

Pursuant to Art. 7/1 FR the principle of unity specifies whose and what revenue and expenditure are included in the EU general budget, i.e.:

1) revenue and expenditure of the Union, including administrative expenditure concerning Common Foreign and Security Policy ${ }^{6}$; in the case of this policy also operational expenditure should be included if they are covered by the budget. They may be financed directly by the Member States. If the Council decides so, then the EU budget participation is excluded",

2) revenue and expenditure of the European Atomic Energy Community.

Additionally, regarding Art. 7/2 FR, guarantees for borrowing-and-lending operations, including the European Stability Mechanism and Balance of Payment Facility operations should be entered into the EU budget.

The principle of unity does not have an absolute character. There are many cases in which the appropriations are excluded from the annual budget of the Union (European Commission, 2014: 149), in particular:

1) appropriations for borrowing-and-lending operations, but as it was indicated above the guarantees for these operations are included in the budget,

2) appropriations at the disposal of the European Development Fund,

\footnotetext{
5 Regarding the science of public finances the principle of EU budget unity is, in fact, a principle of formal unity and the principle of universality - is a principle of substantive unity.

6 Cf Art 41/1 TFEU.

7 Cf Art 41/2 TFEU.
} 
3) appropriations at the disposal of the European Investment Bank.

It needs to be emphasized that the EU budget does not include European Central Bank (ECB), but it is not an exception from the principle of unity. It is a matter of separate monetary policy independently conducted by the Central Bank and fiscal policy - mainly based on the budget, as well as having independence from the Union institutions, central, regional and local governments of the Member States according to Art. 123 TFEU. Besides in Art. 2/b of the Financial Regulation itself there is a clear indication that ECB is not a Union institution to which this regulation applies.

The second principle - budgetary accuracy is focused on the role of the EU budget, and basically of the budget act, as the main basis in the process of managing budget appropriations. This act, what has already been mentioned, constitutes the only form of Authorizing budgetary resources, what de facto means giving them legal force. As a consequence no revenue and expenditure can be implemented if they are not entered in the proper part of the budget - the so-called line in the budget (Art. 8/1 FR). It is also forbidden to commit or Authorize expenditure in the excess of the Authorized appropriations (Art. 8/2 FR).

The obligation to cover in the content of the budget the biggest number of titles on the basis of which the EU accumulates appropriations also influences the adopted method of their distribution, which was determined by the principle of universality mentioned above, also called the gross budget principle (Strasser, 1992: 48-49). This rule is mainly anchored in Art. 310/1 TFEU and its clarification is in Art. $20 \mathrm{FR}$. Its essence is to appropriate all accumulated revenue to cover all planned expenditure. So the possibility to "reserve" or connect particular revenue titles with specific expenditure is excluded. Such a way of conducting financial economy is based on the no-funding principle, known in the literature, which is to ensure the possibility to finance all and not only selected aims (tasks) of the Union, what may also be evaluated through protecting its financial interest. This rule has no absolute character because Art. 21 FR provides many exceptions.

The above mentioned Authorizing character of the budget act (the EU budget) is of fundamental significance in managing public funds, and in the broader aspect, it is essential to maintain financial discipline and protect the EU financial interest. Repeatedly in particular provisions of the Financial Regulation there is the notion of "authorization" of appropriations by the budget (Art. 2/c, 8/1-2, 9, 11) or "enter" funds into the budget (Art. 2/c, 8/1-3, 11/5). Moreover, even in the catalog of the basic notions used for the Regulation, it was defined as an: "instrument which, for each financial year, forecasts and Authorizes all revenue and expenditure considered necessary for the Union". 
Protection of the European Union's Public (Financial) Interest...

Coming back to the sole authorization of the budget, it should be stated that it is a multi-faceted issue. From the formal point of view, it means adopting the EU budget during a special legislative procedure by the Parliament and the Council pursuant to Art. 314 TFEU. However, from the tangible point of view, it means legalizing or giving other legal force to the whole content of the budget, which includes mainly revenue and expenditure. In relation to the revenue aspect, authorization means the possibility to collect revenue because as provides Art. 8/1 no revenue shall be collected unless booked to a line in the budget. To be more precise, the budget act itself does not constitute the legal basis to collect funds. It is done on the basis of other act - the Council Decision no. 2014/335/EU on the system of own resources of the EU (OJ 2014/L168/105) as well as implementing acts issued on its basis. This decision has basic significance in this process. Provisions of Art. 8/1 FR emphasize only the obligation to enter (record) collected revenue into the proper line in the budget.

On the other, taking into consideration the processes of making the expenditure, the budget authorization significantly influences maintaining financial discipline. The direct effect of the final adoption of the EU budget in the legislative procedure for Authorizing officers is on the one hand authorization (law) to manage appropriations, and on the other hand - prohibition to exceed planned expenditure. They set absolute ceilings. This particular - disciplinary character of budgetary expenditure authorization is often emphasized in the provisions of the Financial Regulation. As an example the following regulations may be indicated:

- no expenditure shall be effected unless booked to a line in the budget (Art. $8 / 1)$

- no expenditure may be committed or Authorized in the excess of the Authorized appropriations (Art. 8/2);

- an appropriation may be entered into the budget only if it is considered necessary (Art. 8/3);

- appropriations not used by the end of the financial year shall be canceled (Art. 13/1);

- the limit of the appropriations provided for in the draft budget cannot be exceeded in the case if the budget has not been adopted at the beginning of the financial year (Art. 16/2);

- the budget must be amended in the case of making the legal act with financial implications (Art. 52);

- the Commission shall implement the budget within the limits of appropriations Authorized (Art. 53/1). 
However, it should be indicated that the EU budget (the budget act) itself does not give the possibility to distribute funds. In the Union law, there is a dual legal basis rule arising from Art. 54/1 FR. Formal entering of funds into the budget is insufficient. There must be a separate legal act - basic act (e.g. regulation, directive, decision) which regulates tangible rules of spending these funds. As a result, both law-making forms - basic and budget act are necessary legalizing instruments, i.e. Authorizing to commit budget expenditure.

The Authorisation to implement budget expenditure by Authorizing officers, resulting from budget authorization, does not entitle to fully use expenditure limits. In other words, exhausting limits of the entered appropriations is not an obligation or authorization to spend "by force". A reference point in the process of expenditure management is the implementation of a provided task. Its financing should be based on the principle of sound financial management. It is generally described in Art. 310/5 TFEU and then specified in Art. 30-33 FR. Its basis are three particular rules which may be regarded as a kind of criteria for proper expenditure management, so, on the one hand, to prevent wasting and maintain discipline and on the other hand to ensure effective implementation of the established tasks.

With regard to Art. 30/1 FR appropriations should be used in compliance with the principles of economy, efficiency, and effectiveness. The economy is defined as making the resources available in due time, appropriate quality and quantity and at the best price. Efficiency, which should be identified with efficacy, means striving to achieve the best relationship between resources employed and results achieved. And effectiveness is the implementation of set objectives and intended results.

The principle of sound financial management applies also to the issue of ex-ante and ex-post evaluation of the tasks implementation (Art. 30/4), to the obligation to analyze financial consequences of all legislative initiatives submitted by the European Commission, the High Representative of the Union for Foreign Affairs and Security Policy or the Member States, which influence the Union budget (Art. $28 \mathrm{FR}$ ) as well as to ensure effective and efficient internal control of the budget implementation (Art. $32 \mathrm{FR}$ ). It also needs to be emphasized that the evaluation of financial consequences should be prepared with respect to limiting financial fraud and irregularities.

General evaluation of the above principles should suggest a conclusion that they implement a general norm expressed in Art. 310 TFEU whose aim is to obey financial discipline in the EU. Their task is also to counteract situations in which budget funds management would take place outside the budget (the so-called debudgetization) and not on the basis of the budget act. Concentrating the majority of appropriations in the budget and making expenditure based on it favors better 
Protection of the European Union's Public (Financial) Interest...

control, openness, and transparency of the EU finance as well as should lead to more effective tasks implementation. In a wider context, these principles implement the demand to protect EU financial interest, and what is important here, already on the stage of planning and gathering revenue due.

\section{Conclusions}

Taking into consideration the above analysis, a general conclusion should be formulated that protection of the EU financial interest is implemented not only by preventing and fighting financial irregularities, including corruption but also by proper designing (planning) of the EU budget which constitutes the basis for managing public funds. Instruments used in both these fields - fighting and counteracting fraud as well as financial planning form a kind of a comprehensive system of the EU financial interest protection.

The need to guarantee the protection of the financial interest of every public organization, including the EU, results from the theory of scarcity appearing in the economics. Proper and desirable resources management, also in the public sphere, is a natural process. In the public sector, the phenomenon of scarcity has the even greater impact than in the private sector. Therefore, when the citizens choose their representatives (authorities) in reality they decide what goods and in what amount should be financed from public funds (public choice theory).

Specific decisions of the citizens supporting particular political programs translate into the implemented financial (economic) policy conducted by authorities. Key instruments of this policy effectiveness are legal norms and public budgets, for whose contents are responsible politicians directly elected. Despite received social mandate, they do not have complete freedom in creating the content of the law, also regarding public expenditure, which then will be the basis for making financial decisions. In spite of sometimes generous social programs which gained social support, politicians should consider (financial) interest of the public organization which they manage regarding the scarcity phenomenon. In this context, the problem of scarcity, as well as public choice theory, indirectly translate into the way of managing public funds accumulated in budgets.

Essential legal norms regulating public budget, and especially concerning its construction and the manner of financial forecasting, constitute budgetary principles. In the EU law, they are significant, also in the legal dimension. It is reflected in the fact that main content was regulated in the Treaty law. In the financial aspect, the budgetary principles implement directives of proper (desirable) EU budget management, and thus such administration of the accumulated resources 
as to protect its financial interest starting from the planning stage. Additionally, it may be emphasized that in this last aspect also multiannual financial frameworks play a significant role.

Therefore, the issue of protecting the EU financial interest should not be related to the actions connected with counteracting and fighting irregularities or corruption but also to proper design (planning) of the Union budget and managing on its basic financial resources, which are to serve budgetary principles. A different issue worth analyzing in a separate elaboration - is how effectively these principles are implemented.

\section{References}

Austin, A.D.: Present Trends and the Evolution of Mandatory Spending, Congressional Research Service Report, 2017. www.everycrsreport.com.

Buchanan, J.M., Musgrave, R.A.: Public Finance and Public Choice, Two Contrasting Visions of the State, Cambridge: Massachusetts Institute of Technology, 2001.

Buchanan, J.M.: Public finance in the democratic process: Fiscal institutions and individual choice, Chapell Hill: University of North Carolina Press, 1987.

Eklund, R.B., Hebert, R.F.: A History of Economic Theory and Method, Long Grove, IL: Waveland Press, 2014.

European Commission: EU Budget 2016. Financial report, Luxembourg: Publications Office of the European Union, 2017. www.ec.europa.eu.

European Commission: Report from the Commission to the European Parliament and the Council. Protection of the European Union's financial interests. Fight against fraud 2016 Annual Report, Brussels: European Union, 2016. www.ec.europa.eu.

European Commission: European Union Public Finance, Luxembourg: Publication Office of the European Union, 2008.

European Commission: European Union Public Finance, Luxembourg: Publication Office of the European Union, 2014.

Etel, L., Tyniewicki, M. (eds.): Finanse publiczne i prawo finansowe. Realia i perspektywy zmian (Public finance and financial law. Realities and perspectives of changes), Bialystok: Temida 2, 2012.

Gaudemet, P.M., Molinier, J.: Finanse publiczne (Public finance), Warszawa: PWE, 2000.

Kiefer, D.: Macroeconomic policy and public choice, Berlin: Springer, 1999.

Kosikowski, C.: Financial Law of the European Union, Bialystok: Temida 2, 2008.

Lenaerts, K., Van Nuffel, P.: European Union Law, London: Sweet \& Maxwell, 2011.

Lee, D.R.: Public Choice, Past, and Present. The Legacy of James M. Buchanan and Gordon Tullock, New York: Springer New York, 2013.

Mukherjee, S.: Modern economic theory, New Delhi: New Age International, 2005. 
Protection of the European Union's Public (Financial) Interest...

Moe, T.M.: The New Economics of Organization, American Journal of Political Science no. 28 (1984).

Musgrave, R.A., Musgrave, P.B.: Public Finance in Theory and Practice, India: McGrawHill Education, 1989.

Owsiak, S.: Finanse publiczne. Teoria i praktyka (Public finance. Theory and practice), Warszawa: PWN, 1998.

Report from the Commission to the European Parliament and the Council. Protection of the European Union's financial interests. Fight against fraud 2016 Annual Report, Brussels: European Union, 2016. www.ec.europa.eu.

Ruśkowski, E. (eds.): Roczność i wieloletniość w finansach publicznych (Annuality and mutliannuality in public finance), Warszawa: Lex a Wolters Kluwer business, 2014.

Salachna, J.M., Tyniewicki, M.: Communication and the financial decisions made by public authorities, Prawo Budżetowe Państwa i Samorządu (Budget Law of the State and Local Governments) no. 4(5) (2017).

Salachna, J.M., Tyniewicki, M.: Moralność jako element podejmowania decyzji finansowych w sektorze publicznym (Morality as a factor in financial decisions making within the public sector), Prawo Budżetowe Państwa i Samorządu (Budget Law of the State and Local Governments) no. 3(4) (2016).

Strasser, D.: The Finances of Europe, Luxembourg: Office for Official Publications of the European Communities, 1992.

Szarek-Mason, P.: The European Union's Fights Against Corruption. The Evolving Policy Towards the Member States and Candidate Countries, New York: Cambridge University Press, 2010.

Stiglitz, J.E.: Economics of the public sector, New York: Norton, 2000.

Weingast, B.R., Moran, M.: The Congressional-Bureaucratic System: A Principal-Agent Perspective, Public Choice no. 44 (1984).

White, S.: Protection of the Financial Interests of the European Communities: The Fight against Fraud and Corruption, Hague: Kluwer Law International, 1998.

EU: Treaty on the Functioning of the European Union: no. 2012/C 326/01.

EU: Regulation of the European Parliament and the Council (EC, Euratom): no. 966/2012 on the financial rules applicable to the general budget of the Union and repealing Council Regulation (EC, Euratom) no. 1605/2002.

EU: Council Decision: no. 2014/335/EU on the system of own resources of the EU (OJ 2014/ L168/105). 



\title{
THE IMPACT OF THE TRADITIONAL OWN RESOURCES ON THE BUDGET OF THE EUROPEAN UNION
}

\author{
ANNA REIWER-KALISZEWSKA ${ }^{1}$
}

\begin{abstract}
Traditional own resources are a part of a broader category of European Union revenues - the own resources. The own resources category consists of three types of resources: traditional own resources, which mainly consist of customs duties on imports from outside the European Union and sugar levies, own resources based on value-added tax (VAT) and own resources based on GNI - gross national income (each Member State transfers a standard percentage of its GNI to the EU), which serves as the balancing resource. Currently, the types of own resources and the methods for calculating them have been set by Council in a decision of 26 May 2014 on the system of own resources of the European Union. Changes were introduced to the system of the own resources for the period 2014-2020. The decision has entered into force on 1 October 2016, however, the rules apply retroactively as of 1 January 2014. The aim of this article is to analyze the issue of traditional own resources (a part of a broader category of resources - the own resources) and its impact on the budget of the European Union.
\end{abstract}

\section{Keywords}

Law; customs; trade defense instruments; anti-dumping; anti-subsidy

\section{JEL Classification: F13, F19, G18}

\section{Introduction}

The issues concerning the budget of the European Union have been placed in the Treaty on the Functioning of the European Union. According to art. 311 of TFUE

1 Doctor, Department of Financial Law, Faculty of Law, University of Business and Administration in Gdynia, Poland. The author specializes in tax and customs law, especially in the issues concerned with the trade defense instruments. She is the author and co-author of numerous books and articles published in prestigious journals. Contact email: areiwer@yahoo.co.uk. 
the European Union shall provide itself with the means necessary to attain its objectives and carry through its policies. Without prejudice to other revenue, the budget shall be financed wholly from own resources.

The Council, acting in accordance with a special legislative procedure, shall unanimously and after consulting the European Parliament adopt a decision laying down the provisions relating to the system of own resources of the Union. In this context, it may establish new categories of own resources or abolish an existing category. That decision shall not enter into force until it is approved by the Member States in accordance with their respective constitutional requirements. The Council, acting by means of regulations in accordance with a special legislative procedure, shall lay down implementing measures for the Union' own resources system. The Council shall act after obtaining the consent of the European Parliament. Currently, the types of own resources and the methods for calculating them have been set by Council in a decision of 26 May 2014 on the system of own resources of the European Union.

The aim of this article is to analyze the issue of traditional own resources (a part of a broader category of resources - the own resources) and to confirm or disprove the main hypothesis, that although they have a huge impact on the budget of the European Union the long-term trend in traditional resources is downwards. This article aims to present the evolution of traditional own resources in the European Union and the assessment of their development. Method used are the analysis and the synthesis.

\section{Own Resources System}

The own resources category consists of three types of resources: traditional own resources, which mainly consist of customs duties on imports from outside the European Union and sugar levies, own resources based on value-added tax (VAT) and own resources based on GNI - gross national income (each Member State transfers a standard percentage of its GNI to the EU), which serves as the balancing resource. The Union's own resources are collected by the Member States in accordance with the national provisions imposed by law, regulation or administrative action. These provisions should be adapted to meet the requirements of Union rules.

Between 1958 and 1970 the European Union, similarly to other international organizations, was exclusively financed by member-states contributions (Van der Hoek, 2005: 268). The system of the own resources was introduced on 21 April 1970. The system initially contained 3 different revenue sources. The first own resource - levies on agricultural and sugar trade was introduced in 1971. Customs 
The Impact of the Traditional Own Resources on the Budget of the European Union

duties on trade with third countries were added between 1971 and 1975. The own resource based on value added tax was added in 1979. Due to growing budget expenditures, it was gaining an increasing share of the contribution structure (this led to an increase in the rate of VAT payments). In the 80's, traditional own resources began to decline, and that was why the own resources based on GNP (gross national product) were introduced.

In the beginning, the own resources based on GNI (gross national income) were designed to cover the balance of total expenditure not covered by the other own resources. However later in the following years, the share of VAT payments began to decline gradually, and at the same time, the contribution from gross national product increased. In 2002, the GNP-based measure was converted to GNI payments. The current funding system provides a smooth, stable financing of the EU budget, as any deficiencies are supplemented by GNI.

\section{Figure 1 EU Budget Revenues from 1970 till 30 November 2016 in EUR million}

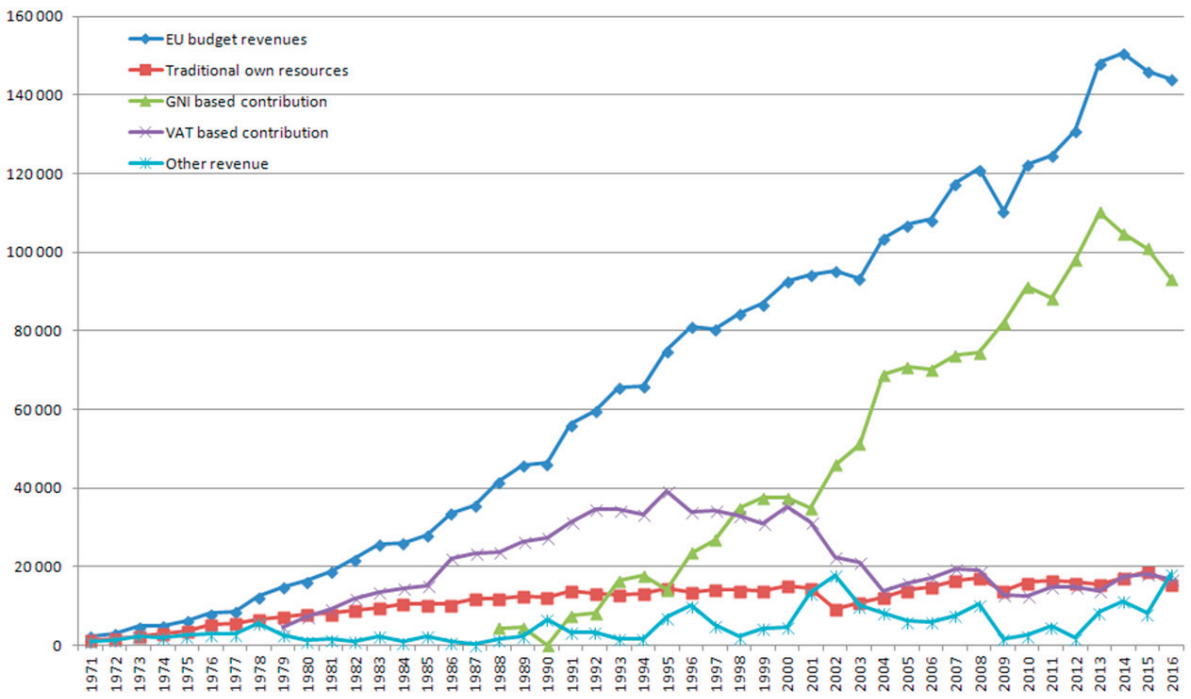

Source: Annual accounts of the European Union for years 1971 to 2015, excl. revenues from exchange transactions, i.e. financial income and other. Data for the year 2016 includes figures for the period ending 30 November 2016. www.eu.europa.eu/budget/figures/index_en.cfm, accessed 6 June 2017.

Nowadays most revenues come from GNI based contributions (Figure 2). Member States contribute according to their Gross National Income. However, this basis is straightforward as there are some adjustments to the payments as a result of negotiation. In order to correct excessive contribution by certain countries, 
correction mechanisms have been designed. First of all, The United Kingdom is reimbursed by $66 \%$ of the difference between its contribution and the amount it receives back from the EU budget. Additionally, over the current period (20142020) Denmark, the Netherlands and Sweden have secured reductions to their GNI based contribution.

The second significant source of revenue of the European Union is VAT-based contributions. VAT based contributions are based on a harmonized measure of consumer spending and thus have little to do with actual VAT payments. This is because different countries have different rates, and over time they have not been harmonized. As indicated above the share of VAT based contributions has been declining and now estimates for about 13\% of the EU budget revenue (Figure 2).

Traditional own resources consist of levies, premiums, additional or compensatory amounts, additional amounts or factors, Common Customs Tariff duties and other duties established or to be established by the institutions of the Union in respect of trade with third countries, customs duties on products under the expired Treaty establishing the European Coal and Steel Community, as well as contributions and other duties provided for within the framework of the common organization of the markets in sugar. Traditional own resources make up about 13\% of the EU budget.

There are also revenues other than own resources which include tax and other deductions from European Union staff remunerations, contributions from non-EU countries to certain programs (e.g. in research), interests on late payments and fines and other diverse items. If there is a surplus at the end of the year, the difference in the form of reduced contributions the following year is returned to the Member States.

Figure 2 EU Budget Revenue in EUR Million from 2009 till 2016

\begin{tabular}{|l|c|c|c|c|c|c|c|c||}
\hline $\begin{array}{l}\text { Own resources and } \\
\text { contributions revenue } \\
\text { (note 3.1 to annual } \\
\text { accounts) }\end{array}$ & 2009 & 2010 & 2011 & 2012 & 2013 & 2014 & 2015 & 2016 \\
\hline GNI based contribution & 81978 & 91178 & 88442 & 98061 & 110194 & 104688 & 100967 & 93367 \\
\hline VAT based contribution & 12795 & 12517 & 14763 & 14871 & 14019 & 17462 & 18087 & 16936 \\
\hline Traditional own resources & 14002 & 16065 & 16528 & 16087 & 15467 & 17137 & 18730 & 15703 \\
\hline $\begin{array}{l}\text { Other revenue (excl. } \\
\text { corrections) }\end{array}$ & 1762 & 2568 & 4944 & 1900 & 8579 & 11338 & 8243 & 18187 \\
\hline Total revenue & 110537 & 122328 & 124677 & 130919 & 148259 & 150625 & 146027 & 144193 \\
\hline
\end{tabular}

Source: Annual accounts of the European Union for years 2009 to 2015, excl. revenues from exchange transactions, i.e. financial income and other. Data for the year 2016 includes figures for the period ending 30 November 2016. www.eu.europa.eu/budget/figures/index_en.cfm, accessed 6 June 2017. 
The Impact of the Traditional Own Resources on the Budget of the European Union

The data presented in Table 2 show that the general budget for 2009-2011 showed an upward trend, while in 2015 and 2016 there was a slight decrease. Regardless of the period under review, the most budgeted resources in the structure of budget resources are the budget for GNI based contribution. VAT based contribution and traditional own resources tend to be stable in each year, however the fourth source of the budget revenue - other revenues differ each year, because of the content of this group, especially interests on late payments, fines and a surplus at the end of the year can be different each year.

In 2014 a High-Level Group on Own Resources has been established. Its aim is to examine how to make the system of financing the budget of the European system more transparent, fair, simple and democratically accountable. Its final report and recommendations were published on 17 January 2017 and was handed over to the presidents of the European Parliament, the Council, and the Commission. The Commission should now assess whether the reform of the own resources system is needed and appropriate.

\section{Traditional Own Resources}

The European Union is a customs union, which mean that there are common provisions on tariffs on trade within the customs area of the EU. There are no tariffs on trade within the European Union. The goods and services that arrive at the European customs area face a common external tariff irrespective of where they arrive at the European Union ${ }^{2}$. Other levies, for example, anti-dumping and countervailing duties are also collected together with ordinary customs duties (Reiwer-Kaliszewska, 2017: 421-434). During the years 1970-2008 duties on agricultural products were grouped separately, however, since 2008, they are identified with customs duties.

Traditional own resources are collected at the point that goods enter the European Union by the Member States. This revenue should then be transferred to the European Commission, even if they have not been actually collected by national customs authorities (Limbach, 2015). Due to the collection of the duties by the national customs authorities, the services at the central level remain minimal and regard mainly controls and oversight.

The Member States have the right to keep the collection costs $(20 \%$ of the collected amounts). This percentage was $10 \%$ during the years $1970-2000$, in 2001 it was increased to $25 \%$ and stayed at this level till 2014 .

2 The agricultural duties have been replaced by the customs duties in July 1995, however, some of them apply in the sugar market arrangement (van der Hoek, 2005: 269). 
Figure 3 Duties as Percentage of Total EU Revenues

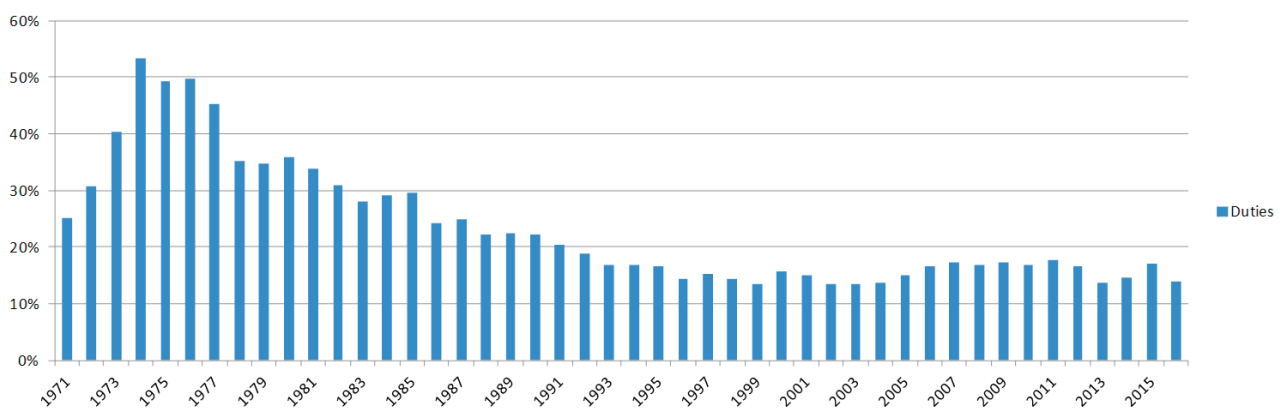

Source: Own calculation based on Annual accounts of the European Union for years 1971 to 2015, excl. revenues from exchange transactions, i.e. financial income and other. Data for the year 2016 includes figures for the period ending 30 November 2016. www.eu.europa.eu/budget/figures/index_ en.cfm, accessed 6 June 2017.

The impact of the traditional own resources has changed over the years. At the beginning of the customs union, they were the main resource of the EU budget. Between 1971 and 1975 it nearly doubled. Revenue from traditional own resources increased for about 10 years, until the end of the 1970s. From 1979 their impact decreased mainly due to introducing the VAT resource and GNI. Nowadays traditional own resources make up about $13 \%$ of the EU budget. The long-term trend in traditional own resources is downwards, due largely to the trade policy of the European Union and WTO trade liberalization.

Figure 4 Traditional Own Resources Contribution Per Capita by Country in 2015

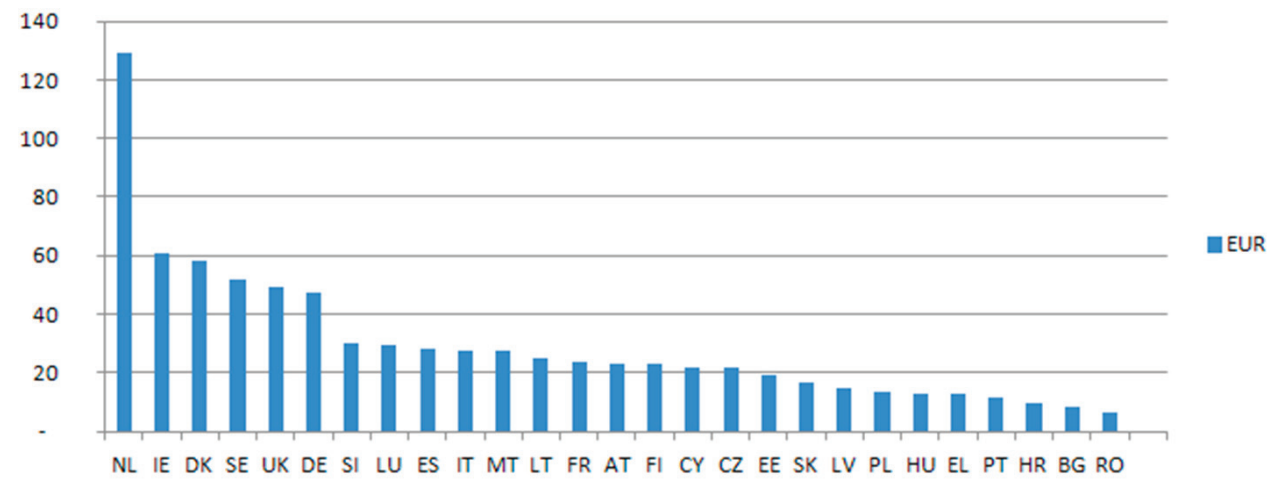

Source: Own calculation based on Annual accounts of the European Union for the year 2015, excl. revenues from exchange transactions, i.e. financial income and other. www.eu.europa.eu/budget/ figures/index_en.cfm, accessed 6 June 2017. 
The Impact of the Traditional Own Resources on the Budget of the European Union

Figure 5 Traditional Own Resources Contribution as Percentage of GNI by Country in 2015

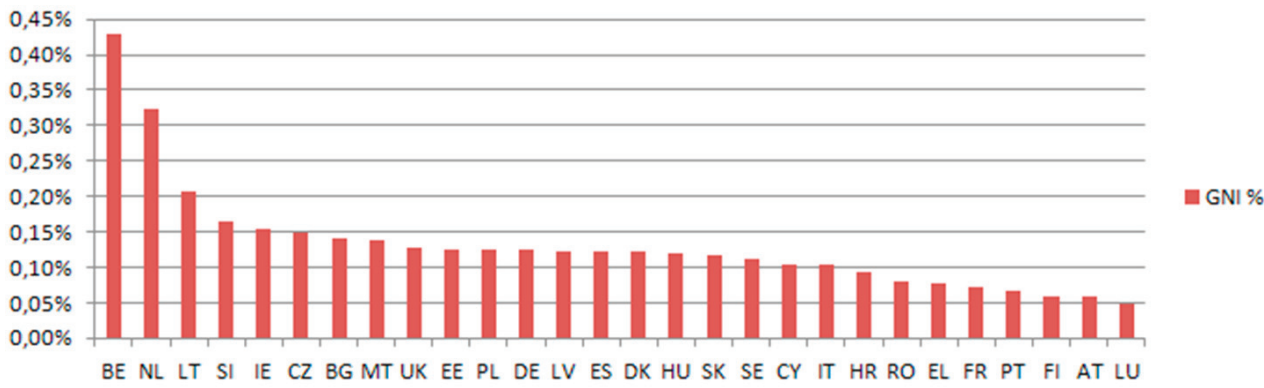

Source: Own calculation based on Annual accounts of the European Union for the year 2015, excl. revenues from exchange transactions, i.e. financial income and other. www.eu.europa.eu/budget/ figures/index_en.cfm, accessed 6 June 2017.

Figures 4 and 5 show traditional own resources per capita and as a percentage of GNI per country in 2015. What is not surprising countries with large ports, especially The Netherlands and Belgium, collect the largest amounts of duties. The landlocked countries, with few borders to non-EU countries, like Austria and Luxemburg collect relatively little in customs duties. The data presented in Table 5 show that there is little difference between richer and poorer countries regarding the amount they contribute as a share of their national income.

On 26 May 2014, the Council adopted a decision on the system of own resources of the European Union in the result of which changes were introduced to the system of the own resources for the period 2014-2020. The change concerning the traditional own resources is significant. Due to it, the proportion of traditional own resources retained by member states has been reduced from $25 \%$ to $20 \%$. In practice, the cost of collecting the duties has lately been far below this level. HM Revenue \& Customs estimated, that the average cost of collection of the taxes in the UK dropped from 0.66 pence per pound in 2010-2011 to 0.58 p for every pound collected in 2014-2015 (Annual Report and Accounts 2014-2015).

The reduction of the rate of the collection costs will obviously increase the amount of revenue that the European Union receives from traditional own resources and in result reduce the size of GNI-based contributions. The decision has entered into force on 1 October 2016, however, the rules apply retroactively as of 1 January 2014. This means, that the member states have to transfer to the European Union the extra $5 \%$ of the traditional own resources that have been retained as costs of collection. Their GNI based contributions will thus be lowered (Browne, Johnson, Philips, 2014: 11). With great probability, the net contribution of Belgium and The 
Netherlands, the countries collecting largest amounts of duties ${ }^{3}$, will increase, however, the other member states' overall contributions will stay unaffected. The reductions in the GNI-based payments to the EU will offset the increase in the proportion of tariffs paid over to the European Union Budget.

The High-Level Group on Own Resources in its Final Report and Recommendations published on 17 January 2017 has assessed the traditional own resources as a simple and transparent revenue (Future financing of the EU, Final report, and recommendations of the High-Level Group on Own Resources, 2016: 40). Due to the Final Report the current system of the traditional own resources is efficient, the national customs authorities agree to the rules and over years the system has not raised any major concerns in its implementation. The rules of the traditional own resources constitute the mostly undisputed baseline of the revenue of the European Union and seem satisfactory to all Member States.

\section{Conclusions}

The system of traditional own resources has undergone many changes over the years. In the beginning, in the seventies, it was the main EU budget revenue, however, with time the income concerned with traditional own resources were falling. The longterm trend in traditional resources is downwards, largely due to the trade policy of the European Union and the WTO trade liberalization. Traditional own resources now estimate about $13 \%$ of the EU budget remaining a non-negligible source of revenue. Thus the main hypothesis of this contribution that although the traditional own resources have a huge impact on the budget of the European Union the longterm trend is downwards has been confirmed.

In result of the recent change in traditional own resources, the proportion of traditional own resources retained by member states as collection costs has been reduced from $25 \%$ to $20 \%$. The aim of the changes was to increase the EU budget's revenue from traditional own resources, at the expense of funds retained by individual states. Although this solution is not beneficial for countries that have so far levied the largest duties as their remuneration drops, this would reduce the GNI share in the budget of the European Union.

The current system of the traditional own resources is simple, transparent and efficient and its rules seem satisfactory to all Member States. Over the years it has been the most undisputed revenue of the budget of the European Union.

The collection costs have often been considered as a "hidden" rebate that aim to reduce the contribution of the Netherlands to financing the budget of the European Union. 


\section{References}

Browne, J., Johnson, P., Philips, D.: The budget of the European Union: a guide, London: Institute for Fiscal Studies, 2014.

Limbach, K.: Uniformity of Customs Administration in the European Union, London: Bloomsbury, 2015.

Reiwer-Kaliszewska, A.: The Issue of Modernization of the XXI Century, in: Radvan, M., Gliniecka, J., Sowiński, T., Mrkyvka, P. (eds.): The Financial Law Towards Challenges of the XXI Century, Brno: Masaryk University, 2017.

Van der Hoek, M.P.: Handbook of Public Administration and Policy in the European Union, London: Routledge, 2005.

Annual accounts of the European Union for years 1971 to 2016. www.eu.europa.eu.

Future financing of the EU, Final report, and recommendations of the High-Level Group on Own Resources, 2016. www.ec.europa.eu.

HM Revenue \& Customs in its Annual Report and Accounts 2014-2015. www.gov.uk.

Multiannual Financial Framework - European Commission. www. ec.europa.eu. 



\title{
SELECTED ISSUES ON THE PROTECTION OF THE EUROPEAN UNION'S FINANCIAL INTERESTS
}

\author{
ADAM P. CHOCIEJ ${ }^{1}$
}

\begin{abstract}
This study deals with selected issues regarding the protection of the financial interests of the European Union. The protection of the EU financial interest is the responsibility of both Polish and EU institutions. There is no doubt that the coordination of activities of national and EU institutions can contribute to increasing the effectiveness of the protection of EU financial interests. The study presents Polish and EU institutions. The Author focuses predominantly on the actions taken by the Commission, in particular, its specialized body - the European Anti-Fraud Office (OLAF). The activity of law-making, coordination of activities undertaken by member states and activities undertaken jointly by the Commission and the Member States are indicated. The effects of the actions taken have been presented based on available reports. It presents Polish and EU institutions' involvement in combating fraud to the detriment of the Union. Actions taken by the EU institutions and OLAF have been broadly explored, given their particular role. On the basis of the available reports, the Author has responded to the question whether the institutions' current system of protecting the financial interest of the Union is sufficient and whether the actions taken by the institutions set up to counter fraud to the detriment of the Union's financial interests are effective and efficient.
\end{abstract}

Keywords

Financial interest; OLAF; Commission; European Union; financial law JEL Classification: K34, E62, H41

1 Master of Law, graduate from the Faculty of Law at the University of Bialystok. A Court Mediator in Warsaw and Bialystok. Contact email: adam.chociej@consolator.com.pl. 


\section{Introduction}

Protecting the European Union's financial interests is an important goal of the actions taken by bodies and institutions at the level of the EU and national institutions. At the outset, however, it should be noted that the financial interests of the European Union are not always the financial interests of individual Member States. It should also be borne in mind that the notion of the European Union's financial interest is not tantamount to the concept of the European Union interest.

The EU's interest is undoubtedly a broader concept than the notion of the Union's financial interest ${ }^{2}$. The financial interest of the Union cannot be considered as a sum of the financial interests of individual Member States, in view of the fact that at the national level the financial interest of a State is not the sum of the interests of its citizens (Woltanowski, Kosińska, 2014). There may be a situation where the financial interests of Poland will not fully coincide with the financial interest of the European Union. In this context, it is very important that the Member States, at the stage of setting the financial framework for particular financial perspectives, can express their expectations, and in the course of the negotiations, reach a compromise which will make the assumptions about the Union budget to be coincident with the interests of individual Member States.

According to Art. 317 of the Treaty on the Functioning of the European Union, the European Union budget shall be implemented by the Commission in cooperation with the Member States. Article 325 imposes on both - the Union and the Member States - the obligation to fight fraud and any other illegal activity affecting the financial interests of the Union; wherein the Member States combating fraud affecting the Union's financial interests, shall take the same measures they undertake to combat fraud violating their own financial interests.

It should be stressed here that the bodies of the Member States account for around $80 \%$ of the expenditure of the whole European Union (Commission: COM(2016) 472). The functioning of the supervisory system in each Member State should be an effective element of an effective anti-fraud counteraction. At the same time, it is equally appropriate to coordinate the actions of the institutions responsible for counteracting and combating abuse against the EU, both on EU and national level, which is equally important in the effective fight against fraud. In recent years, the European Commission has taken a number of measures to ensure the most effective

2 It can be acknowledged that it is in the interest of the Union to, above all, implement the objectives of the Union. In the original wording of the Treaty on European Union of 7 February 1992, Art. B, the stated Union's objectives are: promoting balanced economic progress, implementing the common foreign and security policy, developing close cooperation in the field of justice and home affairs. The Lisbon Treaty has changed the original wording of the article, and currently, in Art. 3/1 of the Treaty, it is stated that the purpose of the Union is to promote peace, its values and the prosperity of its people. 
protection of the EU financial interest, which will be analyzed in the further part of this paper. Before presenting the activities of the European Commission, it seems important to at least briefly present EU and Polish institutions responsible for the protection of the financial interests of the European Union.

\section{Institutional System for the Protection of the Financial Interests of the European Union}

The most important European institutions participating in the audit of the implementation of the European Union budget and, as a consequence, counteracting the actions adversely affecting the financial interests of the European Union are European Commission, European Court of Auditors (ECA) as well as European Anti-Fraud Office (OLAF). OLAF is in this context a particular institution. As a part of the European Commission, it has total independence in the exercising of its investigative function.

In Poland the institution responsible for protecting the financial interests of the European Union is primarily the Ministry of Finance. Control of the correct use of EU funds and, as a result, the detection of irregularities detrimental to the financial interests of both the European Union and Poland, is carried out by several institutions at various stages. The Supreme Audit Chamber plays the most important role and is subordinated to the Ministry of Finance National Tax Administration (pl. Krajowa Administracja Skarbowa) ${ }^{3}$ (Act of 16 November 2016). Important role plays also controls carried out by the managing authorities (Regulation (EU) no. 1303/2013). In cases of violation of public finance discipline Arbitration Committees also play an important role ${ }^{4}$.

3 Prior to 1 March 2017, i.e. before the Act of 16 November 2016 of the National Tax Administration Act came into force, in the Polish legal system, the Tax Inspectorate (pl. Urząd Kontroli Skarbowej), the Tax Offices (Urzędy Skarbowe) and the Customs Offices (pl. Urzędy Celne) were primarily responsible for the detection of irregularities and actions against the financial interests of the EU. On the date of entry into force the Act of the National Tax Administration, their competence were taken over by the bodies of the National Tax Administration.

4 The bodies adjudicating at first instance on cases of violation of public finance discipline are the following: 1) Joint Arbitration Committee (Wspólna Komisja Orzekająca); 2) Arbitration Committee attached to Head of the Prime Ministers' Office (Komisja Orzekająca przy Szefie Kancelarii Prezesa Rady Ministrów); 3) Interministerial Adjudicating Committee attached to the Minister in charge of Public Finances (Międzyresortowa Komisja Orzekająca przy Ministrze właściwym do Spraw Finansów Publicznych); 4) Interministerial Adjudicating Committee attached to the Minister in charge of Public Administration (Międzyresortowa Komisja Orzekająca przy Ministrze właściwym do Spraw Administracji Publicznej); 5) Interministerial Adjudicating Committee attached to the Minister of Justice (Międzyresortowa Komisja Orzekająca przy Ministrze Sprawiedliwości); 6) Regional Adjudicating Committees attached to the Regional Accounting Chambers (Regionalne Komisje Orzekające przy Regionalnych Izbach Obrachunkowych); The Court adjudicating in cases of breach of discipline in public finance of the second instance is the Chief of the Judicial Commission in Cases of Violation of the Public Finance Discipline. 
The European Commission prepares the annual accounts of the European Communities. It also carries out internal audits as well as controls the implementation of budgets in the Member States. The European Commission requires the Member States to have efficient management and control systems for spending funds from the Union. The Commission may carry out checks in the Member States, including random checks of operations financed by EU funds as well as checks on the management and control systems in the Member States.

The main task of the European Court of Auditors is to monitor the implementation of the European Union budget, i.e. the regularity and legality of all Union expenditure and financial management. ECA auditors conduct audits both in European institutions and in Member States (also in countries receiving EU assistance). The ECA draws up its annual activity reports (Treaty on the Functioning of the European Union - consolidated version, Art. 287/4).

The task of the European Anti-Fraud Office (OLAF) is to detect fraud, misappropriation of subsidies and tax evasion, as well as fighting against corruption and any illegal activities that interfere with the interests of the Union. Although OLAF is functioning within the structure of the European Commission, it is necessary, in context of the specific nature of its activities, to isolate OLAF's investigations and actions taken to protect the financial interests of the European Union.

It is worth stressing out that Poland was still in the process of negotiating before joining the European Union, and has committed to implementing the EU acquis in the field of counteracting fraud against the EU financial interests. On 1 July 2003 the Government Plenipotentiary for Combating Financial Irregularities against Poland and EU (pl. Petnomocnik Rzadu Do Spraw Zwalczania Nieprawidtowosci Finansowych na Szkode Rzeczypospolitej Polskiej lub Unii Europejskiej) was appointed by the Council of Ministers to the Harmony of the Republic of Poland or the European Union (Regulation of the Council of Ministers of 1 July 2003).

The tasks of the Government Plenipotentiary for Combating Financial Irregularities against Poland and EU include, in particular, the initiation, coordination, and implementation of activities aimed at securing the financial interests of the Republic of Poland and the European Union. The Plenipotentiary in particular coordinates activities of governmental authorities in this regard and ensures the proper flow of information between them. He is also responsible for reporting to the European Commission on irregularities in the use of EU funds and, collects, verifies and analyzes the documents and information necessary for their preparation. The plenipotentiary may also initiate and carry out work on the preparation of legal acts in the field of the protection of the Union's financial interests. 
Selected Issues on the Protection of the European Union's Financial Interests

Government Plenipotentiary for Combating Fraud against Poland and EU is the Head of Interdepartmental Team for Combating Fraud against Poland and EU the auxiliary body of the Council of Ministers. The team plans, coordinates and monitors activities related to the EU financial interests by the governmental administration bodies, develop proposals for effective exchange of information between administration bodies in order to improve prevention actions and combating breaches of the EU financial interests.

Both the Plenipotentiary and the Interdepartmental Team provide technical and office assistance to the Public Finance Department at the Ministry of Finance.

The Public Finance Department, in addition to the Government Plenipotentiary and the Interministerial Group, also carries out auditing and controls tasks for EU funds and non-reimbursed funds from other sources, as well as plays an important role in combating fraud against the financial interests of the EU - The Anti-Fraud Coordination Service (AFCOS), in cooperation with the European Anti-Fraud Office (OLAF) (Regulation (EC, Euratom) no. 883/2013).

\section{European Commission}

The European Commission to prevent fraud at EU level undertakes a series of actions at various levels (Commission: $\operatorname{COM}(2015)$ 386; Commission: $\operatorname{COM}(2016)$ 472). Most actions directly or indirectly contribute to closer cooperation between the Member States and better coordination of actions aimed at counteracting and preventing fraud to the detriment of the financial interests of the European Union. The most important actions of the Commission in this area include:

- Initiative for change in the legal system of the European Union,

- Fighting corruption in the European Union,

- Combating fraud related to the revenue of the European Union.

\subsection{Initiatives for Changes in the Legal System of the European Union}

The most important initiatives of the European Commission include working on improving and harmonizing the prosecution of crimes against the financial interests of the European Union on the basis of criminal law. As early as 2014, at the initiative of the European Commission, two proposals were made by the European Parliament and the Council to improve the effectiveness of criminal law with regard to the protection of EU financial interests (Commission: $\mathrm{COM}(2015) 386$ ): 
- the proposal of a directive on the protection of EU financial interests enabling the fight against fraud through criminal law;

- the draft regulation on the establishment of the European Public Prosecutor's Office.

Between 2015 and 2016, the proposed legal arrangements were agreed with the Member States. On 25 April 2017, the Council of Europe adopted a directive on the protection of EU financial interests (European Council Press Release of 25 April 2017 no. 209/17), previously agreed with EU governments. The adopted project predicted custodial sentences for serious frauds to the detriment of the EU budget, including VAT. This directive has yet to be approved by the Member States and the European Parliament.

The European Prosecutor's Office was stipulated in the treaties already in 2009 but has not been established to date. On 9 February 2017, the Council of Europe ran unanimously for the proposed regulation establishing the European Public Prosecutor's Office (European Council Press Release of 7 February 2017, no. 48/17). Due to the lack of unanimity in the Council, 16 Member States ${ }^{5}$ announced their intention to step up their cooperation in order to establish a European Public Prosecutor's Office (European Council Press Release of 3 April 2017, no. 184/17), so that the negotiations on the final version of the Regulation could be resumed in the Council. On 5 October 2017, the European Parliament approved the creation of a European Public Prosecutor's Office on the basis of enhanced cooperation ${ }^{6}$.

\subsection{Combating Corruption in the European Union}

In the European Commission report from 3 February, 2014 on combating corruption in the EU (Commission: COM (2014) 38) The Commission focused on corruption in the public procurement. This was the first report prepared by the Commission to which it was obliged, based on the EU anti-corruption mechanism introduced in 2011, based on Art. 83 of the Treaty on the Functioning of the European Union. The report contained the description of trends and developments in corruption and methods to counter corruption in the Member States. The report of the Commission has been criticized by the European Court of Auditors (www.eca.europa.eu), as based on the results of Member States' perceptions of corruption and not on analyzes and findings. This study was also criticised for excluding the institutions and bodies of the European Union from the analysis. Justified seemed the European

5 Belgium, Bulgaria, Croatia, Cyprus, Finland, France, Greece, Spain, Lithuania, Luxembourg, Germany, Portugal, Czech Republic, Romania, Slovakia, and Slovenia.

6 Poland, Denmark, the Netherlands, Ireland, Malta, Sweden, the United Kingdom and Hungary didn't join the European Prosecutor's Office. 
Selected Issues on the Protection of the European Union's Financial Interests

Court of Auditors critique of this document - of not including reporting to the EU institutions, and postulating the extension of the next report by the details available from OLAF European Commission.

Among the Commission's initiatives, the Hercules III program operation in years 2014-2020, should also be mentioned (Regulation (EU) no. 250/2014). This program aims to promote anti-fraud measures against the interests of the Union in the Member States. It is a continuation of the Hercules II program, which ran from 2007 to 2013. The program includes training and conferences to exchange experiences between the Member States and to strengthen cooperation in the fight against fraud. Within the project, technical resources for anti-fraud institutions to the detriment of EU financial interests are purchased.

\subsection{Combating Fraud Related to Revenue and Expenditure of the European Union}

The actions of the European Commission aimed at protecting the Union's financial interests in the field of EU income include, in particular, measures to improve the flow of information between the Member States and mutual assistance in matters relating to customs operations, agricultural law and VAT fraud.

At the initiative of the Commission on 9 September 2015, was adopted the Regulation of the European Parliament and of the Council (Regulation (EU) no. 2015/1525). This regulation anticipates the creation of a centralized database on containers and goods imported, exported and transited through the European Union (Regulation (EU) no. 2015/1525, Art. 1/1). The introduced regulation should make the analysis of the data considerably easier and therefore more effective for both the national customs authorities and OLAF.

At the initiative of the Commission, the Anti-Fraud Information System (AFIS) has been adopted. The term is defined as an application system that enables the timely and secure exchange of information about fraud, as well as the storage and analysis of such data. By 2015, the system had more than 8,000 registered users acting on behalf of over 1700 institutions in the Member States, Commission departments and other EU bodies (Report $\operatorname{COM}(2016)$ 472: 11). This centralized system of information helps to prevent fraud against the financial interests of the Union, both the customs authorities of the Member States and to OLAF entities, it also enables joint customs operations.

The joint customs operations undertaken by the Commission are coordinated by OLAF and will be analyzed in the OLAF part of this paper. In the Commission's annual report to the European Parliament - Fight against fraud for the year 2015 
- the Commission set up the Member States' experience of VAT fraud, pointing out that there is a common impediment to the investigation of transaction chains in the presence of third-country operators (Commission: COM(2016) 472: 13). To assist the national authorities, the Commission, together with the Member States, is exploring the possibility of improving the functioning of Eurofisc so that VAT fraud schemes are detected faster than before (Commission: COM(2016) 472: 13). Commission initiatives to eliminate fraud while spending EU funds are primarily legislative initiatives designed to monitor the spending of these funds in the Member States and to report any irregularities.

In 2015, the Commission adopted 4 Delegated Regulations and 4 Implementing Regulations on rules for reporting financial irregularities using EU funds for 20142020 (Commission: (EU) 2015/1970; Commission: (EU) 2015/1971; Commission: (EU) 2015/1972; Commission (EU) 2015/1973; Commission: (EU) 2015/1974; Commission: (EU) 2015/1975; Commission: (EU) 2015/1976, Commission: (EU) 2015/1977). Thanks to the introduced reporting system, many abnormalities in the use of EU funds are being detected on the level of verification of payment applications by the National Managing authorities of the EU programs.

\section{European Anti-Fraud Office (OLAF)}

The European Anti-Fraud Office (OLAF) was established on 28 April 1999 (Commission: (1999/352/EC, ECSC, Euratom)). OLAF is the only EU body Authorized to investigate fraud and abuse of EU funds. During the initial period of operation, OLAF primarily provided assistance in conducting investigations to the authorities of the Member States as well as, to a lesser extent, conducting independent investigations. In 2006 for the first time, the number of OLAF investigations was equal to the number of investigations in which it provided assistance.

The tasks of OLAF were defined in Art. 2 of the Commission Decision from 28 April 1999 establishing the European Anti-Fraud Office (current wording of art 2 was implemented on the basis of Commission Decision (2013/478/EU) and Commission Decision (EU) 2015/2418). According to Art. 2 OLAF's tasks include in particular external and internal investigations to protect the financial interests of the Union.

External investigations are aimed at combating corruption, fraud and other illegal activities detrimental to the financial interests of the Union, as well as the activities of economic operators run in breach of EU law. 
Selected Issues on the Protection of the European Union's Financial Interests

OLAF's internal investigations occur within the Union's bodies and are aimed at combating fraud, corruption as well as violations by officials and employees of EU bodies. Internal investigations, if infringements are found, may be effective in initiating criminal or disciplinary action against EU officials.

OLAF may investigate violations of the Union financial interest in respect of all Union expenditures (in particular under the Structural Funds, agricultural policy, rural development), Union revenues (mainly customs duties and VAT revenues), and suspicion of irregularities in the work of the staff and officials of the European Union.

According to Art. 2, The Office's tasks outside the scope of investigations should also include:

- Assisting the Commission in dealing with the Member States to counter and fight against fraud.

- Developing concepts and strategies to combat fraud. This goal is achieved in particular through participation in a variety of international initiatives, actions undertaken by institutions and associations to fight fraud and corruption, the promotion of exchange of experience and best practices.

- Preparing legislative and executive initiatives for combating fraud and corruption.

- Preparing all operational activities of the Commission, in particular by developing appropriate infrastructure, collecting and analyzing information, providing technical support to national authorities, and supporting national authorities in the education and training of staff.

OLAF's investigation procedure is regulated by Regulation of the European Parliament and of The Council of 11 September 2013 concerning investigations conducted by the European Anti-Fraud Office (OLAF) (Regulation (EU, Euratom) no. 883/2013). Regulation in Art. 2/1 defines a concept Financial interests of the Union "as it shall include revenues, expenditures, and assets covered by the budget of the European Union and those covered by the budgets of the institutions, bodies, offices and agencies and the budgets managed and monitored by them".

The Regulation, as well as the Commission Decision from 28 April 1999 (Commission: (1999/352/EC, ECSC, Euratom)), divides OLAF's investigations into external and internal ones. The Regulation regulates the procedures for initiating investigations, the investigation procedure and it Authorizes OLAF to exchange information between the competent authorities of the Member States. It also Authorizes OLAF to cooperate with Eurojust and Europol (Art. 13). 
The regulation also monitors the internal organization of the Office. OLAF is headed by a Director-General appointed by the Commission for a seven-year term (Art. 17/1). OLAF's investigative tasks are monitored by the Supervisory Committee, consisting of five independent members elected for a five-year term?

According to the OLAF activity report for 2016, OLAF employees considered 1157 cases reported to the office as abusive. On the basis of these notifications, 219 inquiries were opened in 2016 (Olaf Report, 2016: 12). At the same time, the Office also issued 346 recommendations to the Member States to recover funds totaling $€ 631.1$ million. It should be noted here that the issue of OLAF's recommendation is not consistent with the recovery of funds by a Member State. OLAF reports for 2015 and 2016 did not include information on what actually had been recovered on the basis of the recommendations issued, which seems to be an important element in the assessment of OLAF's activities.

Expenditure on OLAF's operation in 2016 amounted to over $€ 58$ million, of which $€ 40.5$ million was spent on staff salaries. This is a slight increase compared to 2015 , with personnel expenditure of $€ 39$ million ( $€ 57.7$ million in total) (OLAF Report, 2015: 37).

OLAF's investigations which ended in 2016 covered all areas related to EU expenses. For example, out of 344 investigations completed in 2016, 69 were related to Structural Funds, 52 to external assistance and 48 to staff and Union officials (OLAF Report, 2016: 14). Those investigations were related to, among others: public procurement, EU spending on research and development and personnel employed in EU institutions.

A very important element of OLAF's activity is coordination and cooperation with the Member States in joint customs operations (JCOs). The joint customs operations are coordinated actions performed by the customs authorities of individual states to combat the illicit trade of goods. OLAF provides intelligence, technical and financial support for JAFs, and enables the secure exchange of information (eg. using the AFIS platform) (Report COM(2016) 472 from the Commission to the European Parliament: 12).

In 2015, OLAF conducted seven joint customs operations (JCO) (Ibid):

- JCO JETSTREAM - joint operation coordinated by the French Customs Service. The aim to detect illegal trade in the Atlantic Ocean. The action resulted in the seizure of over several tons of hashish transported by sea. working in high-level positions in judicial or investigative bodies. Members of the Committee are appointed by common accord of the European Parliament, the Council and the Commission. 
- JCO JUPITER - The aim of this operation was to combat illicit transport and trade in sensitive goods in the Mediterranean. The operation was coordinated by the Spanish Customs Service.

- JCO FRANKSTEAD - operation organized and run by the customs authorities of Germany and the United Kingdom aimed at combating drug trafficking.

- JCO SASHA - operation organized and coordinated by the French customs authorities. The aim of this action was to combat smuggling and the trade of chemical drug precursors. Most of the EU member states participated in the operation, which was supported by the services of EUROPOL. As a result of the activities, approximately $185 \mathrm{~kg}$ of illegal substances were seized.

- JCO BALTICA - directed and coordinated by OLAF and the Polish customs authorities. Six European countries (Estonia, Latvia, Lithuania, Poland, Finland, and Sweden) and EUROPOL participated in this operation. Its aim was to fight the smuggling of cigarettes from the Russian Federation and Belarus to the European Union. As a result of the activities carried out, around 13 million illegally transported cigarettes were seized by Customs services.

- JCO HANSA - operation organized by the UK Customs Service and Europol to combat the illegal movement of excise goods, particularly cigarettes. OLAF participated in this operation and provided a secure information exchange system.

- JCO ROMOLUK II - operation organized by OLAF and the Romanian customs authorities. Moldovan and Ukrainian customs services were involved in the operation as well, and its aim was to inspect consignments sent to the European Union by road and rail. The operation resulted in the seizure of over 3.8 million cigarettes and about 100 liters of alcohol.

Data on the effects of Joint Customs Operations (JCO) included in the Commission's Annual Report and the OLAF Annual Report for 2015 is very laconic. It is difficult to assess whether the joint operations carried out with the enormous involvement of customs services from many countries brought real and measurable results, and above all, what effect it had on the financial resources involved.

In 2016, OLAF co-organized or supported 12 joint customs operations, 4 of which were organized in cooperation with the Member States and financed by OLAF (The Olaf Report 2016: 24):

- JCO MAGNUM - operation coordinated by the customs authorities of Estonia. Its purpose was to fight the smuggling of tobacco products by land 
from Russia, Belarus, and Ukraine. This operation resulted in the seizure of about 11 million cigarettes.

- JCO WAREHOUSE III - operation coordinated by the customs services of Finland to combat the smuggling of excise goods, in particular, mineral oils and fuels, as well as avoidance of tax obligations. The operation involved 26 Member States and Europol and it resulted in the acquisition of several thousand liters of diesel.

- JCO ORION - the operation was coordinated by the Greek Customs Services, and was aimed at fighting non-EU goods entering the European market with the omission of customs duties and VAT. This operation was managed by the OLAF Permanent Operational Coordination Unit, involving 23 Member States and Europol. It helped to identify cases of underestimation of the objects which were a subject to customs declaration.

- JCO Wafers - operation coordinated by the customs services of the Kingdom of the Netherlands. Its purpose was to counter the import of counterfeit semiconductors and other counterfeit products into the EU from China and Hong Kong. It was conducted in cooperation with Europol and the industry representatives and led to the acquisition of several hundred thousand counterfeit semiconductors and other non-original products.

Reports on both - joint customs operations conducted in 2015, as well as OLAF operations, lack information on the value of detected irregularities or the value of detected irregularities in relation to the expenditure incurred for detecting them.

In the data published in the OLAF report, however, there is information about the number of cigarettes seized in connection with the anti-trafficking operations. About 68 million cigarettes were disposed of in 2013, 132 million in 2014, 17 million in 2015 and 201 million in 2011.

Attention is drawn to the fact that after the very effective year 2014, the number of smuggled cigarettes fell nearly tenfold within the next two years. It would be appropriate for the Commission and OLAF to respond to the question of why such significant reductions in the detection of smuggled cigarettes occurred, despite the considerable involvement of the customs services of various countries and the coordination of OLAF activities 8 . Another question, to which is difficult to find the answer in the documents and reports of both the Commission and OLAF, is the question about the commensurability of the financial resources and human resources involved and the financial effects achieved. cigarettes was noticed, while more non-branded cigarettes were smuggled. This is not the answer to the question of reducing the detection of cigarette smuggling. 


\section{Conclusions}

When analyzing both - the European Commission and OLAF's annual reports, it can be said that numerous actions are undertaken to protect the EU financial interest. Existing legislation at the EU level not only obliges the Commission, OLAF, and the Member States to protect the financial interests but also establishes tools to protect them. It seems that the problem of protecting the Union's interest is not in the field of tools. Both the Commission and OLAF have tools to protect them and the problem seems to lie elsewhere.

Firstly, the coordination of activities undertaken by the member states is becoming ever more important. Fraudulent acts of the Union are more often of international nature. Without proper coordination of actions in different countries, the fight against fraud can be very difficult and ineffective. This aspect seems to be particularly important when taking into account the joint customs operations, but also in the fight against the increasing gap in VAT payments.

Secondly, as it is often highlighted in the Commission reports, Member States report delays in the detection of financial irregularities. The Commission documents often contain information that the reporting system is very heterogeneous, making it difficult to monitor both Member States' actions and their effectiveness (European Parliament resolution of 11 March 2015).

Thirdly, the effectiveness of Member States' enforcement of the recommendations issued by OLAF and the Commission appears to be a big issue ${ }^{9}$ (European Parliament Resolution of 11 March 2015: 22). OLAF reports contain information on the amount and value of recommendations made during the course of the proceedings, but they lack information on its effectiveness. It seems necessary to harmonize the information provided by the Member States in order to assess the effectiveness of Member States actions.

In the context of the actions taken by the Commission and in particular by OLAF, it seems reasonable to question the effectiveness of EU expenditure on OLAF's functioning. Without questioning the legitimacy of OLAF's operation, it is possible to raise the question of the amount of expenditure incurred for OLAF's staff, which in 2016 amounted to more than $€ 40$ million (while OLAF's technical infrastructure and IT networks were over $€ 10$ million) obtained by the Union through its functioning. It is difficult to assess the rationality of spending on OLAF's functioning without having full information about the actual size of the financial benefits resulting from its functioning. This data could help to assess the relevance

9 For example, in the agriculture and rural development area, an amount of $€ 197$ million was recovered, while at the end of $2013 € 1318$ million were recovered. 
of the EU initiative on the establishment of the European Public Prosecutor's Office. Analyzing the benefits resulting from its possible appointment should also evaluate this initiative from the perspective of its operating costs.

\section{References}

Woltanowski, P., Kosińska, R.: Granice ochrony praw podatnika w świetle orzecznictwa Trybunału Konstytucyjnego (Limits of protection of the taxpayer's right in the light of the case law of The Constitutional Court), in: Wójcicka, E. (ed.): Ochrona praw i wolność jednostki wobec władczej ingerencji administracji publicznej - stan obecny i wyzwania (Protection of rights and individual's freedom against imperious interference of public administration - current status and challenges), Częstochowa: Akademia im. Jana Długosza, 2014.

EU: Treaty on the Functioning of the EU no. OJ 2016/C 202.

EU: Commission Decision no. 1999/352/EC, establishing the European Anti-fraud Office.

EU: Commission Decision no. 2013/478/EU, amending Decision 1999/352/EC, ECSC, Euratom establishing the European Anti-fraud Office.

EU: Commission Decision no. 2015/2418, European Anti-fraud Office.

EU: Council Regulation (Euratom) no. 1074/1999, concerning investigations conducted by the European Anti-Fraud Office.

EU: Regulation no. 1073/1999 of the European Parliament and of the Council, concerning investigations conducted by the European Anti-Fraud Office.

EU: Commission Delegated Regulation no. 2015/1970, supplementing Regulation no. 1303/2013 of the European Parliament and of the Council with specific provisions on the reporting of irregularities concerning the European Regional Development Fund, the European Social Fund, the Cohesion Fund, and The European Maritime and Fisheries Fund.

EU: Commission Delegated Regulation no. 2015/1971, supplementing Regulation no. 1306/2013 of the European Parliament and of the Council with specific provisions on the reporting of irregularities concerning the European Agricultural Guarantee Fund and the European Agricultural Fund for Rural Development and repealing Commission Regulation no. $1848 / 2006$.

EU: Commission Delegated Regulation no. 2015/1972, supplementing Regulation no. 223/2014 of the European Parliament and of the Council with specific provisions on the reporting of irregularities concerning the Fund for European Aid to the Most Deprived.

EU: Commission Delegated Regulation no. 2015/1973, supplementing Regulation no. 514/2014 of the European Parliament and of the Council with specific provisions on the reporting of irregularities concerning the Asylum, Migration and Integration Fund and the instrument for financial support for police cooperation preventing and combating crime, and crisis management.

EU: Commission Implementing Regulation no. 2015/1974, setting out the frequency and the format of the reporting of irregularities concerning the European Regional Development Fund, the 
European Social Fund, the Cohesion Fund and the European Maritime and Fisheries Fund, under Regulation no. 1303/2013 of the European Parliament and of the Council.

EU: Commission Implementing Regulation no. 2015/1975, setting out the frequency and the format of the reporting of irregularities concerning the European Agricultural Guarantee Fund and the European Agricultural Fund for Rural Development, under Regulation no. 1306/2013 of the European Parliament and of the Council.

EU: Commission Implementing Regulation no. 2015/1976, setting out the frequency and the format of the reporting of irregularities concerning the Fund for European Aid to the Most Deprived, under Regulation no. 223/2014 of the European Parliament and of the Council.

EU: Commission Implementing Regulation no. 2015/1977, setting out the frequency and the format of the reporting of irregularities concerning the Asylum, Migration and Integration Fund and the instrument for financial support for police cooperation, preventing and combating crime, and crisis management, under Regulation no. 514/2014 of the European Parliament and of the Council.

EU: Council Regulation no. 1083/2006, laying down general provisions on the European Regional Development Fund, the European Social Fund, and the Cohesion Fund and repealing Regulation no. 1260/1999.

EU: Regulation no. 883/2013 of the European Parliament and of the Council of 11 September 2013 concerning investigations conducted by the European Anti-Fraud Office (OLAF) and repealing Regulation no. 1073/1999 of the European Parliament and of the Council and Council Regulation no. 1074/1999.

EU: Regulation no. 1303/2013 of the European Parliament and of the Council, laying down common provisions on the European Regional Development Fund, the European Social Fund, the Cohesion Fund, the European Agricultural Fund for Rural Development and the European Maritime and Fisheries Fund and laying down general provisions on the European Regional Development Fund, the European Social Fund, the Cohesion Fund and the European Maritime and Fisheries Fund and repealing Council Regulation no. 1083/2006.

EU: Regulation no. 250/2014 of the European Parliament and of the Council, establishing a program to promote activities in the field of the protection of the financial interests of the European Union (Hercule III program) and repealing Decision no. 804/2004/EC.

EU: Regulation no. 2015/1525 of the European Parliament and of the Council, amending Council Regulation no. 515/97 on mutual assistance between the administrative authorities of the Member States and cooperation between the Member States and the Commission to ensure the correct application of the law on customs and agricultural matters.

EU: European Parliament Resolution no. 2014/2155 (INI), on the 2013 Annual Report on the protection of the European Union's financial interests - Fight against fraud.

PL: Act of 16 November 2016, on National Tax Administration, as amended.

PL: Regulation of the Council of Ministers of 1 July 2003, on the Government Plenipotentiary for the Combating of Financial Irregularities for the Harmonization of the Republic of Poland or the European Union. 
PL: Regulation no. 58 of the President of the Council of Ministers of 19 August 2010 on the Interdepartmental Team for Combating Financial Irregularities for the Harmonization of the Republic of Poland or the European Union. www.bip.kprm.gov.pl.

PL: Ordinance of the Minister of Development and Finance of 3 March 2017, on the establishment of organizational regulations of the Ministry of Finance.

EU: Report COM(2014) no. 38 from The Commission to The Council and the European Parliament EU Anti-Corruption Report.

EU: Report $\operatorname{COM}(2015)$ no. 386 from the Commission to the European Parliament and the Council Protecting the European Union's Financial Interests - Fight against fraud 2014 - Annual Report.

EU: Report COM(2016) no. 472 from the Commission to the European Parliament and the Council Protecting the European Union's Financial Interests - Fight against fraud 2015 - Annual Report.

European Court of Auditors' View on the Commission's Report on Anti-Corruption Measures. www. eca.europa.eu.

European Council Press Release of 07 February 2017 no. 48/17. www.consilium.europa.eu.

European Council Press Release of 03 April 2017 no. 184/17. www.consilium.europa.eu.

European Council Press Release of 25 April 2017 no. 209/17. www.consilium.europa.eu.

OLAF Report 2014. www.ec.europa.eu.

OLAF Report 2015. www.ec.europa.eu.

OLAF Report 2016. www.ec.europa.eu. 


\title{
THE SYSTEM OF EU FINANCIAL INTEREST PROTECTION UNDER THE COMMON AGRICULTURAL POLICY BASED ON THE EXAMPLE OF THE PAYMENTS RELATED TO THE AREA
}

\author{
JOANNA CZAPSKA ${ }^{1}$ PIOTR WOLTANOWSKI ${ }^{2}$
}

\begin{abstract}
The Authors of this article focus on the analysis of the basic elements, which are constituting the system of the European Union financial interest' protection under the Common Agricultural Policy. The article analyzes the scope of the responsibilities of the Member States in this field, the role of the accredited paying agencies and the conditions to protect the EU interest by the European Commission as a part of the spending the funds of the CAP. There was highlighted the specific issues such as the advance payment and non-financing of the expenditure made after the deadline as the manifestations of the protection of the EU financial interest. In the paper was described the practical problems of the operation of the Integrated Management and Control System. The Authors have drawn the attention on the fundamental issues regarding the rules of the granting payments, which are fundamental in the protection of the EU interest, in that respect, there had been evaluated the legal and practical conditions to administer the administrative penalties, by detecting the irregularities and by preventing the fraud.
\end{abstract}

\section{Keywords}

EU financial interest protection; Common Agricultural Policy; control; EAGF; EAFRD

\section{JEL Classification: E62, H60, Q14}

\footnotetext{
1 Member of the Information and Organization Center for the Research on the Public Finances and Tax Law in the Countries of Central and Eastern Europe since 2017. Chief specialist at ARMA (Agency for Restructuring and Modernisation of Agriculture) since 2004. Contact email: joanna.czapska@yandex.com.

Board Member and General Secretary of Information and Organization Center for the Research on the Public Finances and Tax Law in the Countries of Central and Eastern Europe, Department of Public Finances and Financial Law, Faculty of Law, University of Bialystok. He is the author of over 50 publications in the field of tax administration, human rights, health service finance and social security. Contact email: piotrwoltanowski@ gmail.com.
} 


\section{Introduction}

The Common Agricultural Policy is the one of the oldest and most basic among the all Union policies. Work on the assumptions of this policy began in 1957 and finally came into force in 1962. The Common Agricultural policy, due to it range and importance, represents a special kind of the structural Policy and are oriented to implement the short - term, the medium - term and the long-term objectives, which growth fast and respond flexibly to the present situation on the agricultural markets, environment, agricultural producers and consumers. The action taken under the CAP is funded wholly (direct payments) or partly (the payment under the RDP) from the EU budget. The scope and the complexity of the system cause, that it requires special arrangements regarding the rigor of spending the funds, including the prevention of the unduly disbursement of fund, the excessive or inconsistent with the objectives of a program or measure, by preventing the frauds and abuse until obtaining the funds unduly collected. On the other hand, this requires to establish a certain legal and institutional framework for the distribution and reimbursement of these funds. The sectoral regulations, both at the union and the national level, include both expenditure management, the system of the sanctions and the administrative penalties, as well as the regulations regarding the recovery of the amounts unduly paid or excessively paid, the control, the monitoring and the evaluation of individual activities. In the Authors' opinion of this paper, all those regulations form contiguous, coherent and precise system, characterized by a pretty high efficiency. The functioning of this system is best to visualize by the example of the system of the direct subsidies - or, more broadly, the system of subsidies related to the area - in addition, besides the direct subsidies, there should be included the programs co-financed as agri-environmental, ecological or climate payments (Miąsik, Półtorak, Wróbel, 2012: 414).

\section{Impact of Method of Payment related to Area on EU Measures Interest Protection within Subject Scope}

The measures for the CAP implementation has been provided by Art. 40 (common agricultural markets organization) and Art. 41 TFEU (Treaty on European Union and the Treaty on the Functioning of the European Union no. 2012/C 326/01). Article 40(3) TFEU constitutes the basis for the establishment, to perform the common agricultural policy, the one or several funds for the agricultural guidance and guarantee. On 1 January 2007, pursuant to the Regulation 1290/2005, two funds were established: the European Agricultural Guarantee Fund (EAGF) and the European Agricultural Fund for Rural Development (EAFRD). The Regulation 1290 was in force until 31 December 2013, when it was repealed by the provisions 
The System of EU Financial Interest Protection under the Common Agricultural Policy...

of the Regulation 1306/2013, however, both funds were maintained. The direct subsidies are financing from the EAGF. By contrast, the EAFRD funds are intended, as the EU financial contribution of the Union to co-finance the activities under the programs of the rural development (Regulation 1306/2013, Art. 5). Both funds represent the part of the Union general budget, in which is specified the total amount of the expenditure intended to finance the normatively defined objectives of the common agricultural policy. The incomes and the expenditure of the funds are related to the implementation of the common agricultural policy and financed on the common general principles for the whole Union budget.

\section{Principles of Implementation of Budget under CAP and Union Interest Protection - Scope of Responsibilities of Member States}

The implementation of the European Union's budget rests with the Commission, which carries it out on its own responsibility and within the limits of the appropriations. However, the Member States are obligated to cooperate within the budget implementation in such a way, that the grants' appropriations used are used in accordance with the principle of sound financial management, in the transparent and non-discriminatory manner (TFEU, Art. 317). The implementation of the budget under the Common Agricultural Policy takes place within the so-called shared management with the Member States (Regulation (EU, Euratom) no. 966/2012, Art. 58). The Commission delegates the implementation of tasks under the budget to the Member States, which are required to take all necessary measures to protect the Union's financial interests. The scope of the responsibilities of the Member States, in this regard, is quite broad, and it should be assumed, that the provisions of the Financial Regulation contain only an example of an enumeration; the obligation of the Member State to take all necessary steps to protect the financial interests of the Union arises first of all from Article 325 TFEU. Thus, the Member States are required to appoint and supervise the bodies responsible for the Union financial resources management and monitoring it, to introduce an integrated management and control system, to perform duties regarding the clearing accounts and providing the information, subjecting the institutions and beneficiaries by the relevant audits and controls. In addition, the Member States are required to supervise the allocation of the funds, to impose the effective and dissuasive penalties, if they are provided by the sectoral or national legislation or to prevent, detect and correct the irregularities and the fraud, including the funds recovery, which have been unduly collected, including through the legal proceedings (Regulation (EU, Euratom) no. 966/2012, Art. 59; Regulation (EU) no. 1306/2013, Art. 58). In a simplified way, the member state's tasks could be possible to divide into the two main groups: the first, refers to the accountable and organizational part of the funds distribution, the technical 
and the organizational assistance for the whole process, and second, which refers to the material validity of the payment granting, the irregularities detection, the administrative sanctioning and reclaiming the unduly taken payments.

\section{Accreditation of Paying Agency and EU Financial Interest Protection}

The expenditures under the EAGF and the EAFRD can be covered by the Union funding only, if there have been carried out the accreditation for the paying agency (Regulation (EU) no. 1306/2013, Art. 7). This ensures the funds disbursement by the professional subjects, whom are prepared to maintain those tasks both organizationally and substantively, which reduces the risk of irregularities. The accreditation belongs to the Member State: the accredited paying agency should meet at least the requirements provided under the Union regulations, with notification of the possibility to establishing the additional criteria by the Member State. In the Republic of Poland, the role of an accredited paying agency plays the Agency for Restructuring and Modernization of Agriculture, established by the Act of 29 December 1993, regarding the Agency for Restructuring and Modernization of Agriculture establishment, currently ARMA acts under the Act of 9 May 2008. According to the Art. 6/1/1, the ARMA implements, among the others, the tasks related to the direct payments and the rural development defined in the regulations applicable to a given type of the payment. As a typical executive agency, it is the state legal entity, functioning as an element of the public finance (Ruśkowski, Salachna, 2014: 214). At the margins, it is worth to mention, that till 1 September 2017, there was exiting the second paying agency, Agricultural Market Agency, established under the law of 11 March 2004 regarding the Agricultural Market Agency and some other organization of the agricultural markets. On 1 September, the AMA has been decommissioned, and its tasks has been assumed by the ARMA. Meanwhile the part of these tasks has been delegated to the established at the same day the National Centre of the Agriculture Support, but apart from the payments executions and the execution of the undue aid amounts. These amendments were within the respect of the provisions of the Regulation 1306/2013, and partly constitute its execution (e.g. regarding the administrative service costs reduce), but in practice the competence allocation in some cases could cause some controversies. However, it's not applicable to the field of the payments, where the granting is continuing to be within the limits of the competence of the Agency of Restructuring and Modernization of Agriculture. The competent minister of the public finances decides about the granting and withdrawing of the accreditation, as the coordinating unit provides the informing about the granting of the accreditation to the Commission. The accreditation is preceded by an internal 
The System of EU Financial Interest Protection under the Common Agricultural Policy...

audit inspected by an external audit body. In particular, the audit includes these elements of the paying agency's function, for which exist the procedures intended to approve and execute the payments, the security of the information systems as well as their scope, in which existing procedures and systems are able to protect the Union budget, in this, based under the risk analysis measures able to prevent the financial frauds. The information regarding the accreditation is provided to the European Commission. Additionally, besides the constant supervision of the competent minister responsible of the public finances over the paying agency, every three years the certification body carried out the revision of the given accreditation. Currently, the role of the certification body is performed by the Head of the National Revenue Administration, who is performing his tasks in accordance to the Act of 16 November 2016 regarding the National Revenue Administration. Therefore, the authority to accredit, certify and supervise the paying agency rest on the institutions of a Member State. Whereas, that the given accreditation covers, among others, the inspection of the existing payment systems and the procedures, including, in terms, the protecting of the Union budget and risk-based anti-fraud measures, by checking compliance with the accreditation conditions constitute as the Member State's obligations to protect the Union's financial interest. The European Commission can apply to the Member State to withdraw the accreditation, if the paying agency does not meet the accreditation requirements and did not amend the deadline, if the recovery plan is not implemented by the Member State, or, if the paying agency act without accreditation. The Commission authority also include the adoption of delegated and the implementing acts, which are necessary to protect the Union's financial interests. The Commission also has an impact on the audit, including the setting of the guidelines. Within this construction of the audit mechanism of the paying agency, it is not possible to rule out the discrepancies in the positions regarding the accreditation criteria fulfillment. However, the final decision, in this respect, belongs to the Commission, which having due to protect the Union financial interests, can question the settlement of the expenses made by the agency, which doesn't meet the accreditation requirements.

\section{The system of Funds Payment by European Commission under EAGF and Contribution under the EAFRD in the context of the Protection of the EU Financial Interests}

The expenditure under the EAGF completed by the accredited paying agencies shall be borne by the Commission in the form of monthly payments, on the basis of the declaration of the expenditure presented by the Member State. The expenditure included in the declaration should correspond to the expenditure actually incurred by the paying agencies, it should also be done at the specific periods, in accordance, 
with the procedures and following all relevant controls, including the administrative and on-the-spot checks. The Commission, after acceptance of the declaration, shall transfer the appropriate resources reduced by the potential corrections or other deductions to the account carried out by that Member State. These funds are transferred after to the paying agency's account based on the request from the competent minister for the rural development, in accordance, with the submitted need made by the paying agency. The funds allocated for the implementation of the national contribution, in the case of co-financed payments (EAFRD), are transferred by the competent minister for the rural development in the form of the designated subsidy. Whilst, in the case of the EAFRD, the Commission after the decision on the approval of the rural development program, transferred the pre-financing amounts in the form of the annual payments from $1 \%$ to $1.5 \%$ of the total amount of the support, however under the condition, that the Member State will starts using them within 24 months from the date of receiving the first refinancing, under the rigour of the repayment. The remaining part of the resources as the contribution from the Commission shall be transmitted within 45 days after the submission of the relevant declaration by the Member State. The funds recovered by the Member State are deductible and can be re-used under that fund. The financing and accounting of the expenditure under the EAFRD is carried out separately within the each activity. In the case for both Funds, the Member State is obliged to submit both the annual clearance of the expenditure of the paying agency and the declaration of the expenditure for the following year within a specified period. The above mechanism is limited by the numerous Commission's powers concerning the cessation, the suspension, the clearance and the correction of the payments, including also the duty to provide the information by the Member State. The Commission may postpone the monthly payments under the EAGF, if the information provided by the Member State in the statement of the expenditure or the need raises doubts, questions or require the clarification (Commission Delegated Regulation (EU) no. 907/2014, Art. 9). Additionally, the Commission may suspend the payments for the both Funds in the case, if the information was not provide on time regarding the checks carried out on the aid application and the and payment applications (Regulation (EU) no. 1306/2013, Art. 42; Commission Delegated Regulation (EU) no. 907/2014, Art. 10). It should also be noticed, that the postponement, the cessation or the suspension of the payment, relatively the refusal of the financing shall not refer to the results against the beneficiaries: in the case of the late payment of benefits or the refusal of the funding for the beneficiaries, the payments are covered from the Member State's funds, and more precisely the obligation of the payment falls on the accredited paying agency. The system of the funds withdrawing and the clearing the accounts has been structured in such a way to secure the European Union financial interest in the best way. The system is supplemented by the Commission powers related to the possibility of carrying out the controls and the issuing of the delegated and the 
The System of EU Financial Interest Protection under the Common Agricultural Policy...

implementing acts. However, this system demonstrate certain flexibility, because the Member States have the possibility to supplement the provided before information and documents, the application adjustment, abundantly including the submission of explanations and the corrective procedure (Regulation (EU) no. 1306/2013, Art. 52). The Commission has also the right to moderate the amount of the correction, which depends on the gravity of the irregularity - here the assessment criterion is the significance of the risk of losses for the Union budget. This allows each situation to treat separately and considerably by enhancing the efficiency of the entire system.

\section{Advance Payment and EU Financial Interest Protection under CAP}

Particular payment installments are further reduced due to the payments made before or after the payment deadline (Regulation (EU) no. 1306/2013, Art. 75) which are not the subject to be financed, under the provision to pay the advance payment through the direct payments and the RDP. In 2017, the Republic of Poland benefited from this right, and from 16 October $70 \%$ of the advance payments were paid to the farmers. The advance payments are paid following the administrative inspection and in the case of those applications, where was not detected the mistakes. However, in practice, the advance payment would be possible to treat as a certain exemption from the system's integrity in terms of the Union's financial interest protection. Although the advances payment should occur only after the administrative inspection of the application and when no irregularities were detected, however, due to the period of the advance, the probability of the undue or the excessive payment is slightly higher than in respect to the period of the major payment. In the case of the advance payments, therefore, the difficult situation in the agriculture and the necessity of the rapid improvement of the financial situation of the farmers was prevailing the factor over the protection of the Union's financial interest.

\section{Integrated Administration and Control System and EU Interest Protection under CAP}

The payments related to the area are granted to beneficiaries after the appropriate administrative inspection including, inter alia, cross-checks and the on-thespot inspections. The Member States are obliged to carry out the administrative inspection of each application, although the on-the-spot inspection is not required in all cases. Both, the administrative inspections as well as the payment calculations are carried out under the support of the communication and 
information system so-called the Integrated Management and Control System. The system is a computerized database, where is recorded the data obtained from the applications for assistance and the payment applications with regard to each beneficiary of the support, in addition, the database allows to acquaint with the detailed data from the previous ten years. In addition, the system identifies each agricultural parcel, the registration and the identification of the payment entitlements allow to carry out the administrative inspection, by including the cross-checks inspection comparing to other applications, as well as with other areas and the other assistance programs. The system allows to verify each application, grant the payments, impose the administrative penalties or reduce, and in addition, count the payments. It is fully justified to burden the Member States with the obligation to construct and implement such system: on the one hand, the system enforces the equal treatment of beneficiaries, in particular, as to the application of the granting payments, reductions, the administrative penalties and the deadlines, the partial automation, and, hence, also the acceleration and the reduction of the administrative payments costs, which is particularly important for the direct payments and for the agri-environment payments, due to the widespread participation of the producers into these programs. On the other hand, the system increases the level of the Union's financial interest protection by facilitating the detection and the prevention of the irregularities as well as the double financing. The registration of beneficiaries, the applications, and the agricultural parcel, prevents the duplication of the applications, by applying for the payments to the same parcel by various beneficiaries, which are not compliant with the conditions of the individual programs or there is the infringement of the requirements as regards to the good agricultural culture. The system also facilitates the detection of the fraud, including, in particular, the cases of the circumvention of the law to obtain the payment. The system also enables the precise monitoring of the level of spending of funds during their payment to beneficiaries.

The disadvantage of the integrated management and the control system is its size and complexity. The system is a subject of the evaluation and ongoing updates, related to these responsibilities, as well as the maintenance of the system rests on the Member State. The European Commission attaches the great importance to the effective functioning of the systems of the separate Member States, what manifests, inter alia, among others liabilities of the Member States require to provide the annual evaluation reports of these systems. It should be noticed, that the negligence of the Member State regarding the functioning of the system, can affect by the imposing of the severe financial corrections up to the partial exclusion from the funding. 
The System of EU Financial Interest Protection under the Common Agricultural Policy...

\section{Rules for Granting Payments and EU Interest Protection under CAP}

The European Union's financial interests protection in the field of the Common Agricultural Policy does not focus only on the institutional aspects of spending funds: equally important are the regulations concerning the rules for their granting provided by the Union regulations and, in the case of the EAFRD, the national as well. The structure of the participation in the individual programs aims to minimize the risk of the irregularities as well as the improper use of the funds, including the reductions and the administrative penalties. The entire is completed by an effective system of the recovery the unduly or the excessively collected payments. The rules for the granting of the payments under the direct support systems was directly concluded in the provisions of the Regulation no. 1307/2013, moreover in the national regulations, in the Act regarding the payments under the direct support system hereinafter referred to as the Act of the OB and the regulations issued on that basis. In the case of the direct payments, the act based on it regulations are clarified only by the Union's provisions.

The direct payment is the base payment, which includes the widest possible circle of the group of the recipients within the whole Union. The rules and the schedules for the granting of these payments are harmonized, which facilitates management and the equal treatment of beneficiaries. In respect of the rate, the Republic of Poland demanded in the negotiating process align them with the other member states. However, this process was introduced gradually. The rate of the direct payments for the 1 ha after the reform of the Common Agricultural Policy in 2014, has been lowered and now the amounts are 461.55 PLN.

The detailed discussion regarding the rules of the granting of each of these payments exceeds the scope of this study, however, it is worth, in terms of the Union's financial interest protection to draw the attention of these aspects such as the introduction of the financial discipline, the limiting of the upper amount of the payments by introducing the concept of the relatively understanding of the active farmer.

The financial discipline maintenance involves the introducing of the reduction coefficient of the payment, in the situation, where, according to the forecasts for a given year, the payment limits will be exceeded. The reduction coefficient is defined as a percentage and applies to the payments by exceeding the total amount of 2,000 EUR. The obtained provision in this way constitutes to be secure, in a case, when the limit of the funds was exceeded for a given budget year. If this limit was not used, the funds are returned to the beneficiaries (the final recipients) which were collected from them - wholly or partially. This is a very interesting mechanism, 
which aims to maintain the balance of the Union's budget in regards to the direct payments. It should be emphasized, that the reduction concerns only the highest amounts of the payments, which is compatible with the objectives of the direct payments, to whom shall include the increase of the income of the agricultural farms, however, it cannot exceed a certain framework. The public funds obtained under this program constitute the aid, however, they should not constitute a source of the excessive profit for the farmers.

In a similar way should be evaluated the reduction of the amount of the direct payments, which is above the total amount of 150 thousand EUR for one beneficiary. However, here the Commission has left the way to adjust the amount of the aid, in the case, if there will be applying for it the particularly large collective entity; it cannot be excluded the occurrence for the payment by the organizations associating the farmers indeed.

In 2014 was introduced the concept of the active farmer. According to Regulation 1306/2013, Art. 9, the direct payments cannot be granted to the farmers, whose agricultural lands consists mainly of the persisting naturally lands, which are suitable for the grazing or cultivation activities, and whose farmers do not carry out the minimum activities defined by the Member States on those areas. The financing has also excluded the entities, which operate the airports, the water pipes, the permanent sporty and the recreational areas, as well as provide the rail transport or real estate services. This solution has a flexible character - on the one hand, it prevents the granting of the payment contrary to their purpose, as well as incompatible with the objectives of the Common Agricultural Policy for the entities, who do not provide the agricultural activity. On the other hand, it is enabled for such entities to obtain the payments, when they will be able to prove, that agricultural activity is the main source of their income, as well the main object of the activity. It should be noticed, that as the part of the review of the CAP, which took place in 2016, and the changes planned for this reason, it was decided not only to maintain the concept of the active farmer, but also to extend the concept of the farmers towards being the subject of the social insurance and the subject, who pays the taxes.

\section{Possibility to Impose Administrative and EU Interest Protection under CAP}

Preventing the irregularities is also encouraged by the possibility to impose the administrative penalties and deductions on farmers if the beneficiary does not meet the eligibility criteria, the liabilities or other obligations related to the granting aid 
The System of EU Financial Interest Protection under the Common Agricultural Policy...

or support. The administrative penalties are imposed, if they have been provided in the Union sectoral law, or in the case of the funds payable through the EAFRD, also national, independently of the refusal to grant or to impose the obligation to return the unduly paid aid.

The administrative penalties may take the form of reduction of the amount of aid or the support of the payment in relation to the support application or the payment application, where have been detected the non-compliance or in regard with the subsequent applications; disbursement of the amount of aid based on its size or period, which non-compliance refers to, exclusion from the right to participate in a given aid scheme or in support measure. The penalties should be proportional and calculated by taking into account the scope, the durability, the severity and the repeatability. The penalties should be also effective and dissuasive particularly, and the aim of their implementation, first of all, is to encourage beneficiaries to comply with the principles of the adopted programs and the liabilities. The construction of the provisions governing the granting of the payments fits into the system of the EU's financial interests protection, mainly, by reducing the possibility of the irregularities perpetrated by the beneficiaries or relative their prevention through the launched system of the administrative penalties.

\section{Detection of Irregularities and Recovery Undue or Unduly Taken Granting EU's Financial Interest Protection}

The irregularities detection and the fraud preventing is one of the most basic ways to protect the European Union financial interests. It is combined with the issue of the funds recovering, which was paid unduly or in the excessive amounts.

The general principles regarding the detection and the elimination of the irregularities and the recovery of the amounts unduly and excessively collected have been laid down in the Regulation 2988/95. According to the Art. 1/2 of that regulation, irregularity means any infringement of provision of the Community law arising out of an act or omission from the economic subject, that caused or could cause damage to the general budget of the Communities or the budgets, that are managed by the Communities or by the reducing or losing the revenue, which comes from own resources and collected directly on behalf with the Communities, or as an result with the unjustified expenditure. The regulation lays down the general rules of the financial interest protection, and, therefore, applies to the Communities, in case of the payments related to the area, the cited definition should be referred to the Union budget. 
Therefore, the irregularity is related to the act or negligence of the payment's beneficiary, which caused damage to the Union budget, either, by reducing or losing the revenue or by the unjustifiable expense, which should be related to the funds received unduly or in excessive amounts. It is debatable, whether the mere possibility of the harm is sufficient for the existence of an irregularity, and therefore, the situation, where this effect has not occurred. Under the principle of the Art. 2/1, point $g$ of the regulation $1306 / 2013$, this definition applies to the payments paid from the EAGF and to the assistance co-financed by the EAFRD.

The mechanism of recovering the unduly or the excessively collected payments is one of the most important elements of the European Union's financial protection system. The basis for its operation are the EU regulations, however, at the national level are using properly the existing procedures, which not only eliminates the costs associated with the implementation of a completely new system, but also due to the use of existing tools is characterized by high efficiency, which should be assessed positively due to their multiplicity and the high level of complexity of the aid programs.

As a general rule, the irregularity entails the need to return of the unlawfully obtained benefit with the relevant interest. In addition, the payments cannot be granted to beneficiaries, who artificially created the conditions to receive the payment. The risk related to the impossibility of the recovering the amount of unduly collected payments is half-burdening the Union and the Member State. The similar is in the situation when the amounts of support were wrongly recovered. The settlement of expenses does not relieve the Member State from the obligation to continue the proceedings to recover the undue payments. The Member State shall ask beneficiary for a refund of the amount to prevent any irregularity or negligence within the 18 months after the approval or receipt by the paying agency of an audit report or similar document stating that the irregularity has taken place.

In the Republic of Poland, the ARMA is the authority as the accredited paying agency, which is responsible to determine and recover the unduly collected payments. The determination of the amount of the unduly or the excessively collected payments takes place by a decision of the competent ARMA authority when the administrative procedure occurred. The proceedings have the independent character, the separation from the procedure of granting the payment; it is assumed, that, in order, to determine the amount of the unduly collected payments, it is not necessary to eliminate the legal decision of granting the payment from the turnover.

The receivables due to improperly or excessively collected funds are applied under the provisions of Sec. III of the Act of 29 August 1997 the Tax Ordinance, The enforcement proceedings in the administration is applied to the enforcement of 
The System of EU Financial Interest Protection under the Common Agricultural Policy...

these claims, which are applying the administrative enforcement proceeding. The tax authority is the competent authority to issue the decision on the determination of the unduly paid or the overpaid payments. The execution of that liabilities is using the proceedings in the administration to enforce these claims.

The provisions, relating to the recovery of the amounts the unduly or the overpaid payments cross the group of the entities, against which the amount of the claim may be fixed. Here may be applied the provisions of the Tax Ordinance Act. However, the very interesting solution is provided under the Art. 29/1a of the Act on the ARMA, according to which, the possibility to determine the amount of the unduly or the excessively collected payments also refers to the entities, which are not the parties of the proceedings for the granting payments or the financial aid, who have drawn the public funds the unduly or the excessively. This provision applies to the situation, that is often in practice when the funds have been transferred to the bank account of a farmer, who has died or was wound up and then has been taken from the account by the third parties, those are not the successors or the legal successors. By extending the group of the entities to these persons, it makes possible to recover an improperly obtained benefit also from the persons, who acquired the funds from the bank account, however, they were neither able to be parties of the procedure for granting the payment and, in consequence, in another situation, the recovery of the acquired funds through administrative proceedings would not be possible. It should be noticed, that this provision does not seem to apply to the bank, that collected such funds, because its role is limited to maintain a party's account, which, of course, does not completely exclude the probable compensative responsibility of the bank, if, for example, the account was disbursed by an unAuthorized person.

For the specific mechanisms regarding the recovery of the unduly or the excessively collected payments, should also be included the possibility of the amounts deduction, which were determined by the decision from an indisputable and due claim or receivables, due to payments from the pursued by the Agency payments under the individual the European Union funds and the national public funds intended for the co-financing the expenses undertaken from these funds.

The deductions are made by a declaration submitted to the debtor in written form, it has the retroactive effect from the moment when it became possible. Similarly, the costs, which have been arisen from the recovery of claims and the receivables, can be also deducted. This solution, significantly facilitates the recovery of the funds, which were collected the unduly or the excessively without the need to conduct the separate enforcement order proceedings, although, it seems, that in practice, certain doubts may arise regarding the area of the payments, by setting the time to determine the entitlements, for example, in the case, when the court-administrative proceedings are taking the place in this issue. 


\section{Conclusions}

The presented, in brief, the payment mechanisms related to the area under the Common Agricultural Policy illustrate how wide is the range of the activities necessary to protect in a proper way the European Union financial interests in this field. The scope and the complexity of this policy forces to use the appropriate measures to protect it. The cohesive, tight system, which would allow the proper protection of the European Union interests, would not, however, be possible without close cooperation between the Member States, both, as on the institutional and the legislative level.

At the same time, this system is not perfect - it is characterized by the high dynamics, it is the subject of the constant modifications, aiming to provide the best possible protection. The current ongoing reform of the payment system arises from the review of the payment system under the EAGF and the EAFRD, which occurred in 2016, by aiming to simplify the payment distribution system, will have an impact on the functioning of the presented mechanisms. Similarly, there should be evaluated the shape of the discussion regarding the CAP after 2020.

\section{References}

Miąsik, D., Półtorak, N., Wróbel, A.: Traktat o funkcjonowaniu Unii Europejskiej (Treaty on the Functioning of the European Union), Warszawa: Wolters Kluwer, 2012.

Ruśkowski, E., Salachna, J. (eds.): Finanse publiczne. Komentarz praktyczny (Public Finances. Practical comment), Gdańsk: ODDK, 2014.

EU: Treaty on the Functioning of the European Union: no. 2012/C 326/01.

EU: Commission Delegated Regulation (EU): no. 907/2014 supplementing Regulation (EU) no. 1306/2013 of the European Parliament and of the Council with regard to paying agencies and other bodies, financial management, clearance of accounts, securities, and use of euro.

EU: Council Regulation (EC): no. 1290/2005 on the financing of the common agricultural policy.

EU: Council Regulation (EC, Euratom): no. 2988/95 on the protection of the European Communities financial interests.

EU: Regulation (EU): no. 1305/2013 of the European Parliament and of the Council of 17 December 2013 on support for rural development by the European Agricultural Fund for Rural Development (EAFRD) and repealing Council Regulation (EC).

EU: Regulation (EU): no. 1306/2013 of the European Parliament and of the Council of 17 December 2013 on the financing, management, and monitoring of the common agricultural policy and repealing Council Regulations (EEC). 
The System of EU Financial Interest Protection under the Common Agricultural Policy...

EU: Regulation (EU, Euratom) no. 966/2012 of the European Parliament and of the Council of 25 October 2012 on the financial rules applicable to the general budget of the Union and repealing Council Regulation (EC, Euratom) no. 1605/2002.

PL: Act of 16 November 2016 on National Revenue Administration, as amended.

PL: Act of 5 February 2015, on payments under the direct support system, as amended.

PL: Act of 9 May 2008, on the Agency for Restructuring and Modernization of Agriculture, as amended.

PL: Act of 11 March 2004 on the Agricultural Market Agency and some other organization of the agricultural markets, item, as amended.

PL: Tax Ordinance Act of 27 August 1997, as amended.

PL: Act of 29 December 1993 on the Agency for Restructuring and Modernization of Agriculture, as amended. 



\title{
INITIATIVES IN THE AREA OF THE FINANCING OF THE EU BUDGET IN THE CONTEXT OF ENVIRONMENTAL PROTECTION ${ }^{1}$
}

\author{
ADRIÁN POPOVIČ
}

\begin{abstract}
In the article the Author discusses the structure of the EU budget initially, focuses on its revenue component and expenditure component and examines its status de lege lata. Subsequently, after this description, he describes the principles applied to the intended reform of the EU budget. Following the reform principles, the Author points out the recent initiatives of the environmental new own resource of the EU budget, whose primary objective is to comply with one of the most important EU policies, which is the environmental protection in accordance with the High-Level Group on Own Resources study from December 2016. In the end, the Author submits an evaluation of environmental own resources in the light of the presented reform principles of the financing of the EU budget.
\end{abstract}

\section{Keywords}

EU; own resource; environment; protection; initiatives

\section{JEL Classification: H61, H69, O44}

\section{Introduction}

The EU budget is one of the most problematic and one of the most complicated areas of European Law, Financial Law, and Tax Law. Of course, with regard to financing,

1 This article represents a partial output of the grant project VEGA no. 1/0846/17 "Implementation of the initiatives of the EU institutions in the field of direct taxes and indirect taxes and their budgetary law implications" and no. APVV-16-0160 "Tax evasion and tax avoidance (motivation factors, formation, and elimination)".

2 Internal Ph.D. Student, Department of Financial Law, Tax Law and economy, Faculty of Law, Pavol Jozef Šafárik University in Košice, Slovak Republic. The Author specializes in tax law and budgetary law. He is the author of more than 10 articles published in the Slovak Republic, Czech Republic and Poland. Contact email: adrian.popovic@student.upjs.sk. 
each Member State of the EU would want to contribute as little as possible to the EU budget and obtain as much as possible. However, the current system of the EU own resources has many shortcomings and, in addition to its complexity, this system suffers from the fact that many of its sources can be identified as the EU own resources only with difficulties and the funding of the EU should be achieved, under the Treaty on the Functioning of the European Union, by its own resources.

Many experts call for initiatives to reform the current way of financing the EU budget, simultaneously suggesting the different ways of its possible future financing. However, it is well known that the discussion about the reform of the EU budget is a "long distance run" and will not end with a simple consensus. It should be noted, that the opposite cannot be expected since this discussion leads to reducing the fiscal sovereignty of each Member State.

In accordance with the High Level Group on Own Resources study from December 2016, the effectiveness of the EU general budget depends on the ability (and the perception of this ability by the public) to solve the EU priorities and to help resolve the problems that European citizens face in their lives, whether economic, security, geopolitical, social or cultural problems.

This effort is not helped by the current funding system, which has gradually become a system of national contributions when the EU budget is perceived as a zero-sum game between "net contributors" and "net recipients". In addition, such a system could create an unsustainable ratio between payments and commitments, which needs to be monitored closely.

The reformed system of own resources could contribute to the achievement of EU policy goals and also to the task of adequately financing the EU budget and simplifying budget adoption. Many documents produced by the EU institutions state that EU citizens deserve a budget that addresses these problems directly when action is needed at EU level. Soon there will begin preparations for the next Multiannual Financial Framework. They will act in unique circumstances which could help overcome the traditional barriers to which the reform encountered on the revenue side. The future MFF will provide scope for a review of how the EU budget can support the Member States and European citizens more effectively, and it is very important to maximize this opportunity. This should be reflected on the revenue side and on the amount and composition of expenditure, in order to meet the EU budget targets and requirements for this budget (Monti et al.: 2016: 10).

In order to understand initiatives for reforming the EU's own resources in all contexts, it will be necessary to describe initially the structure of the EU budget, conditional upon the current legal status in which we bring to the reader the revenue part and the expenditure part of this budget. We would like to point out that while 
it will be a conceivable idea of a contribution of this article to bring the possible own resources of the EU budget as the revenue side of the budget in the context of environmental protection, we cannot forget on the description of the EU budget expenditures. These parts lead us to fulfill an overview of the budget and the "spirit" of the EU budget.

In the first part of the article, our scientific research will be ruled by several methods. However, it will be characterized in particular by the use of a systematic method and a descriptive method which will be used in analyzing the structure of the EU budget. These methods cannot be applied separately and we will be able to carry out scientific work that is not dogmatically aimed at a certain part of the problem.

One of the ideological goals of the paper is expressed in its second part, which discusses the planned reform of the EU budget. Specifically, in this section, we will focus on proposing possible new EU own resource to support EU environmental policy, which should be subjected to the principles of the budget reforming itself and which have long been under review not only by the EU institutions but also by the academic community and experts of European Law, Financial Law and Tax Law.

In addition to the abstraction method, which is inherent to the second part of this article, it will also be necessary to make extensive use of methods of analysis and synthesis. One of the logical methods characterizing this part of the work will be the method of induction as a process from special to general. We will use this in particular when assessing the nature of each possible new own resource of the EU budget. One of the most important methods we will use at the end of the paper will undoubtedly be a comparative method. ${ }^{3}$

The main ideological goal of the paper will be presented in the Conclusion, where we will evaluate the environmental own resources in the light of the presented reform principles of the financing of the EU budget.

\section{Revenues and Expenditures of EU Budget - de lege lata}

\subsection{Revenues of EU Budget}

The EU budget should be financed by own resources and other revenue ${ }^{4}$ in accordance with Art. 311 of the Treaty no. 2012/C 326/01 on the Functioning of the

3 In this sense, we will use both macro-comparison and international comparison, also bilateral and multilateral comparisons (Knapp, 2003: 88).

4 Other revenues are, for example, charges for the administrative operation of the institutions, fees relating to the functioning of the European Economic Area, fines, default interests, staff taxes of the EU institutions, an 
European Union (TFEU). As we mentioned above, own resources are assigned once and for all to the EU to finance its budget, which automatically becomes income of this budget without the need for any additional decision by the national authorities. The EU's total revenues must be in line with overall spending, moving within the agreed legal limits. Between 2014 and 2020, the EU can, under the new rules, acquire own funds for payments up to $1.23 \%$ of the sum of all Member States' GNIs. The total commitment appropriations shall not exceed $1.29 \%$ of EU GNI.

In order to highlight the latest proposals for reforming the financing of the EU budget, it seems justified to present the types of own resources of this budget for the period 2014-2020 (Leen, 2011: 205). The rules for the current seven-year budgetary cycle stipulate the following types of own resources:

- Traditional own resources (ie, in particular, customs duties and sugar levies) (Bujňáková, 2009: 69-73; Prievozníková, 2008: 148). Customs duties and agricultural levies result from the use of EU customs legislation and the common agricultural policy for imports from third countries. Sugar levies are imposed on sugar producers and used to cover EU spending in this sector. The advantage of traditional own resources is that they do not affect the Member States' budgetary balances and do not burden the Member States in which they are levied because they retain a part of the funds collected to cover the collection costs (König, Lacina, 2004; König et al.: 2009).

- Own resource based on the value-added tax (VAT). This form of funding was introduced due to the lack of EU budget revenue to date. Each Member State's harmonized VAT assessment bases are charged at a flat rate of $0.3 \%$ and the VAT taxable amount is limited to $50 \%$ of their Gross National Income (GNI) for the Member States. However, this is not a real tax-based own income, but only a method of calculating the Member State's contribution (Begg et al.: 2009: 7; Leen, 2013: 6-8). The harmonized VAT base shall be calculated in accordance with the provisions of Council Directive 2006/112 / EC on the common system of value added tax (Štrkolec, 2013: 398-409).

- Own resource based on gross national income (GNI). These resources are obtained by using a rate determined each year in the framework of the budgetary procedure on a basis representing the total quantity of GNI in market prices (Beličková et al.: 2010: 173). It is also possible to describe them in such a way that the standard percentage of GNI of each Member

income from lending and borrowing, and in particular a surplus from the previous budget. In general, however, if there were no budget surpluses, this group of revenue would be almost negligible. For instance Regulation (EEC, Euratom, ECSC) no. 260/68 of the Council laying down the conditions and procedure for applying the tax for the benefit of the European Communities, or Council Regulation (EU) 2016/300 determining the emoluments of EU high-level public office holders. 
Initiatives in the Area of the Financing of the EU Budget in the Context...

State is selected for expenditure not covered by other own resources in order

to achieve a balance between EU revenues and expenditures.

It cannot be omitted that selected Member States have claimed various corrections aimed at reducing their own share in the financing of the EU budget. Reliefs and other forms of corrections for the Member States have become one of the most contentious aspects of the current EU budget financing system. One way of looking at modifying the financing of the EU budget is that these corrections are generally the result of a failure in the budgetary process, including the EU budget spending component. This means that if there is a need to introduce a certain correction for the benefit of a Member State, it is generally better to make such a correction on the revenue side, not to distort the EU budget expenditures (Begg et al.: 2009: 13). This is one of the main reasons why those Member States and EU institutions have long been calling for a reform of the way in which EU revenue is collected.

\subsection{Expenditures of EU Budget}

Even though we do not intend to spend too much interest on the expenditures of the EU budget, we cannot omit this component in order to understand the structure of the EU budget.

Commitments as a part of the EU budget expenditures are divided into five headings through the seven-year financial framework ${ }^{5}$ for $2014-2020^{6}$, namely:

1) Smart and inclusive growth:

a) Competitiveness for growth and jobs.

b) Economic, social and territorial cohesion.

2) Sustainable growth: natural resources (including market-related expenditure and direct payments).

3) Security and citizenship.

4) Global Europe.

5) Administrative expenditure (for all EU institutions).

6) Special instruments.

Besides that, payment appropriations are budgeted for each year, the budget reserve is determined for exceptional cases, and at the end, a maximum own resources ceiling is set, up to $1.23 \%$ of the total GNI of all Member States. Each

5 The multiannual financial framework (MFF) defines the annual general budgets of the European Union. It defines how many funds total and how many different areas of action the EU could use each year if it adopts legally binding obligations for a period of at least 5 years. The most recent MFF normally covered 7 years.

6 Council Regulation (EU, EURATOM) no. 1311/2013 laying down the multiannual financial framework for the years 2014-2020. 
year, therefore, the estimated budget is determined, and data from the multiannual financial framework could be appropriately altered while preserving the envisaged process. $^{7}$

\section{Reform of EU Own Resources in the Context of Supporting EU Policy on Environmental Protection}

One of the most important features of state sovereignty is the right to impose taxes and fees on citizens. This does not only belong to every EU Member State but also to every sovereign state. However, this is contrary to the status of the EU as an integration group, as it is neither a federation nor a confederation, nor any other form of classical state organization. Therefore, it is necessary to approach this issue very carefully and it is necessary to not ignore the findings not only of the theory of law but also of the findings and research of the recognized Authors of the tax-legal science (Babčák, 2015).

The idea of changing the funding of the current EU own resources system is nothing new. Discussions on this issue have been ongoing for many years not only at national level but also at the transnational level (Monti, 2016: 2-3; De Feo, 2016: 63). The issue of reforming the EU's own resources is closely linked to the considerable need for reforming the EU budget, pointing in particular to corrections and derogations for those Member States in connection with the complexity of the current system (Laffan, 2016: 8). There is a need to establish an original financial instrument to ensure a fair and efficient financing of the EU budget in accordance with EU common policies (Kicová, 2011: 114-121).

The Amsterdam Treaty stipulated that "without prejudice to other revenue, the budget shall be financed wholly from own resources". The current system of funding, however, according to many experts, is contrary to this article. The third and fourth sources (VAT and GNI resource) of the EU budget are often considered as mandatory contributions by the Member States ${ }^{9}$, many of whom are not considered to be genuine EU own resources. In addition, the amount of these revenues and their structure are not decided by the autonomous EU institutions, but each one decision on own resources has to be approved by the national parliaments of the EU Member States. Finally, they ultimately have control over the fiscal policy of the EU

7 The Council, together with the European Parliament, adopts the annual EU budget under the special legislative procedure and on the basis of a Commission proposal, together with the European Parliament, may amend the annual budget and recommend to the European Parliament whether shall give a discharge to the Commission in respect of the implementation of the budget.

$8 \quad$ Article 311 (e.g. Art. 269 TEC) of the TFEU.

9 It is important to note that this third and fourth source of funding is required by the Member States under the threat of sanctions. 
Initiatives in the Area of the Financing of the EU Budget in the Context...

in relation to the financing of the EU budget. Although the current funding model is in fact functioning, a number of scientific authorities, as well as working groups directly Authorized by EU institutions, are exploring the possibilities of reforming the EU's own resources.

The reform of own resources should be guided by the different principles that should be followed in order to achieve the desired purpose in view of the nature of the new envisaged EU own resources. This is specifically about these principles (Monti, 2016: 9-16):

1) European added value - the EU budget needs to focus on areas bringing the highest "European added value", or on European public goods for which action at EU level is not only relevant, but indispensable, or where national financing possibilities are insufficient for achieving our European goals.

2) Subsidiarity - changes to the composition of EU own resources should respect the powers of the national authorities to decide on them; on the expenditure side, any reform should include a subsidiarity test to determine the level at which spending should be best undertaken: sub-national, national or European.

3) Budget neutrality - the size of the budget is firstly determined by the own resources ceiling and secondly by the MFF, i.e. on the expenditure side. The structure of EU financing does not, as such, have an impact on the volume of the EU budget.

4) Overall fiscal burden - new own resources do not aim to increase the fiscal burden for the EU taxpayer. On the contrary, a reduction in national contributions, combined with EU spending that is better geared towards policies with the higher added value such as security of external borders or defense, is also aimed at better European governance and can create savings for Member State budgets.

5) Improvement of the synergies - greater attention should be given to synergies between the EU budget and national funding for areas with a high European added value or where national financing possibilities are insufficient for achieving a European public good.

6) Unity of the budget - the unity of the EU budget should be explained and preserved, and "satellite" budgets should be limited to strictly justified cases and subject to proper parliamentary scrutiny.

7) Transparency of the EU budget - the EU budget and its financing should be more transparent and readable for citizens, so that the benefits of the EU, and not only its costs, are made visible. This would improve the overall accountability of the EU budget. 
8) Own resources should support EU policies - own resources should also be designed to support EU policies in key areas of EU competence: strengthening the Single Market, environmental protection and climate action, energy union, and reducing the fiscal heterogeneity in the Single Market.

At present, after many years of research and analysis in this area, and following these studies, there is a whole range of proposals of new own resources of the EU budget funding that could reform the current funding system. The reform itself should follow the above-mentioned principles. In accordance with the High-Level Group on Own Resources study from December 2016, there are proposed own resources of EU budget funding:

1. CO2 levy / Carbon pricing.

2. The inclusion of the EU Emission Trading Scheme proceeds.

3. Motor fuel levy (taxes on fossil fuels /excise duties).

4. Electricity tax-based own resource.

5. CCCTB, EU corporate income tax.

6. FTT - Financial Transaction Tax.

7. An alternative option to FTT: a bank levy or financial activities' tax (FAT).

8. A reformed own resource based on VAT.

9. Seigniorage.

Within the paper, we consider it important to point out, in particular, potential new own resources in the context of environmental protection (Sábo, 2013: 93-101). This is, mainly, the first four proposals for the new own resources of the EU budget, namely CO2 levy / Carbon pricing, inclusion of the EU Emission Trading Scheme proceeds, motor fuel levy (taxes on fossil fuels/excise duties) and electricity taxbased own resource. The key and direct impact of these possible new EU own resources could be the achievement not only increased environmental protection but also to maximize compliance with the aforementioned reform principles.

\subsection{CO2 Levy / Carbon Pricing}

Carbon pricing can take various forms, either in the form of taxation or in the form of market instruments. Carbon pricing can generally be seen as a tax on fossil fuels. $\mathrm{CO} 2$ levy should be imposed on all sources of greenhouse gas emissions and should have a significant impact on the costs and costs of the process in which they arise. Therefore, there is a presumption that it will stimulate the behavior of the consumer or the manufacturer in such a way as to favor another production process or other 
Initiatives in the Area of the Financing of the EU Budget in the Context...

type of consumption where fewer emissions could occur (Pearce, 1991: 938-940). Such behavior represents a significant advance in the fight against climate change, which is largely in line with EU policy (Luptáčik, Luptáčik, 2016: 2-3).

Although there are energy taxes in all Member States, and to a certain extent also harmonized at EU level, carbon taxes (or $\mathrm{CO} 2$ taxes) are less common. According to this harmonization, reference may be made to Council Directive 2003/96/EC restructuring the Community framework for the taxation of energy products and electricity, the main purpose of which is to avoid distortion of competition in the energy sector within the internal market (Eijndthoven, 2011: 284). This Directive establishes common rules for the Member States, namely what they should tax and when and what exemptions are permitted. Minimum tax rates, based in particular on the amount of energy consumed, are set for products used in the heating, electricity and motor fuels sectors. However, outside these minimum rates, Member States are free to set their own national rates (Štieberová, 2016: 73-79).

Several EU Member States have already introduced specific carbon and CO2 taxes ${ }^{10}$, but most environmentally-related taxes (in relation to greenhouse gas emissions) are imposed as part of the taxation of energy products and motor vehicles and they are not taxed directly on $\mathrm{CO} 2$ emissions.

In the latest proposal from the year 2011 to reform Directive 2003/96/EC, the European Commission planned to introduce a single minimum $\mathrm{CO} 2$ tax rate (exactly $€ 20$ per ton of CO2) for all sectors not covered by the EU ETS. ${ }^{11}$ After three years of negotiating and amending the text, the European Commission has assessed that the original text has changed so much that it no longer recognizes the main points of the original proposal. Therefore, this proposal was officially withdrawn on 7 March 2015.

An alternative could be the indirect carbon tax on consumption (product taxation, not taxation of a production), the amount of which would be determined by how much $\mathrm{CO} 2$ would be produced during the production of certain products, regardless of whether the whole or part of the production process takes place in within or outside the EU. Such a carbon tax was analyzed in detail in a study commissioned by the European Economic and Social Committee, which was positively evaluated as a prospective study. One of the main advantages of this tax is that includes the consumption of not only imported but also locally produced products. The $\mathrm{CO} 2$ content would be measured using $\mathrm{I} / \mathrm{O}$ models taking into account the entire

10 Currently, Denmark, Ireland, Finland, Sweden, France and Slovenia have a carbon tax in place. However, national rates are fixed at very different levels and do not reflect the carbon price under the EU Emissions Trading System (ETS) (Monti et al.: 2016: 41).

11 This would in particular affect households, transport, smaller businesses and agriculture that are not covered by the EU ETS. 
production chain. Research has even concluded that for the year 2011 and the tax rate of $€ 40$ per ton of $\mathrm{CO} 2$ emissions, it would be possible to generate revenue of $1 \%$ of the EU GDP. It cannot be forgotten that, from the point of view of the EU's industrial competitiveness, this approach is a challenge and it is questionable whether the most affected sectors of industry will not be involved in diminishing the adoption of such a kind of EU own resource (Monti et al.: 2016: 41).

\subsection{Inclusion of the EU Emission Trading Scheme Proceeds}

The European Emissions Trading Scheme (EU ETS) has been introduced in several successive steps as a key tool for combating climate change and as a means of reducing industrial greenhouse gas emissions (Medarova-Bergstrom et al.: 2012: 4-6). This system currently covers about $45 \%$ of the total amount of greenhouse gas emissions produced in the $28 \mathrm{EU}$ Member States. Emission quotas are allocated to a specific Member State and subsequently auctioned. The market stability reserve was only recently created as a result of the surplus of market certificates. This surplus occurred after the outbreak of the economic crisis, which itself reduced production and associated production of emissions more than expected (Coria, Jaraité, 2015: 2-3; Monti et al.: 2016: 43-44).

The main purpose of the entire ETS is to reduce emissions to a predefined level. This system was not set up to achieve a steady profit or a certain share of the trading intended to the EU budget as its own resource. This option was first examined in the 2010 budget review, but the European Commission's subsequent proposals in 2011 did not recommend to continue with these activities, in particular for the following two reasons:

1. The economic impact of the ETS varies significantly from one Member State to the other due to the fact that the national economic structures and energy mixes are different.

2. 50\% of auction revenues are already earmarked to be used for climaterelated actions.

\subsection{Motor Fuel Levy (Taxes on Fossil Fuels ${ }^{12} /$ Excise Duties $^{13}$ )}

Taxation of motor fuels is at present an important source of national income in each EU Member State and is at the same time the most relevant source of tax revenue in the transport sector. The level of taxation is decided by the national governments themselves, but still within the limits (such as reduced rates of taxation and tax 
Initiatives in the Area of the Financing of the EU Budget in the Context...

exemptions) laid down in Council Directive 2003/96/EC. The revenue obtained then leads either to the national budgets of the Member States or, in some cases, the revenues lead to the entities below the national level.

From the point of view of own resources, two scenarios could be envisaged:

1. A full transfer of the revenue collected by from the Member States from the motor fuel tax to the EU level.

2. A partial share or percentage of the motor fuel tax collected by the Member States.

In the first case, there would be a major systemic change and there would be a very visible shift from the current EU budget financing system, which would be visible both at EU level and national level. Such a reform would most likely enhance harmonization and ultimately neutralize competition between the Member States through the level of taxation (Morris, Munnings, 2014: 1-4). Centralizing such a tax at European level would also be in line with Arts. 192 and 194 of the TFEU, which provide a legal framework for fiscal measures in relation to future environmental and energy policy. These provisions, which have already been introduced by the Treaty of Lisbon, are not yet used. It is also important that such own resource could cover the financing of a substantial part of the EU budget, but would also be in accordance with the European public interest (environmental protection). It is also important to point out that funding through this own resource would be in line with the European Energy Union initiative, which aims to gradually decarbonize the transport sector.

In the second case, to the EU budget would be given a certain proportion of the tax deducted from the fixed amount or percentage of the collected motor fuel taxes as a new own resource. This scenario would probably be more acceptable to the EU Member States, although harmonization, neutralization of fiscal effects between the Member States or promoting a common and stable fiscal environment policy would not be achieved so well as in the first case (Keen et al.: 2013: 2-20).

\subsection{Electricity Tax-Based Own Resource}

Electricity taxation already exists in all EU Member States. In most cases, the level of taxation is decided by national governments and parliaments, and the taxes obtained are part of national public revenues. EU legislation sets minimum levels of taxation and mandatory exemptions (such as tax exemptions).

There are different types of taxes on electricity that can be implemented:

1. Taxes on electricity production (e.g. Environmental/pollution taxes). 
2. Taxes on the transport of electricity (e.g. tax or levy on the use of public space).

3. Taxes on the sales of electricity (e.g. consumption taxes, environmental taxes).

The first two types of taxation are collected from electricity companies. The third type of electricity tax is paid by the consumer of electricity (whether household or company).

In this regard, it should be noted that consumers spend on average $6.4 \%$ of total electricity consumption. According to the Energy Union initiative, the European Commission has put forward important proposals to revamp the European electricity market. The expected result would be an improvement of the security of the distribution network, more integrated and transparent markets, greater market supply for the electricity consumer and making profits more efficient. Such a fundamental transformation of the electricity market should bring tangible benefits to households and companies.

How, however, we can substantiate such a tax at European level? The justification for the introduction of such a tax could in principle be justified by the fact that the integration of the internal market would lead to economic savings, the benefits of the manufacturing sector and, last but not least, to the benefit of consumers. Moreover, the current efforts to create a common international interconnected electricity grid only contribute to argumentation in favor of such a tax.

It is important to mention that such own resource has the great potential to finance a large part of the EU budget. The EU could also link the potential of this own resource with European environmental policy and energy saving policy. However, it is necessary to draw attention to the fact that any proposal to introduce an own resource based on electricity tax should take account of the fact that electricity production is generally covered by the ETS.

In conclusion, we can summarize why this tax could appear as an appropriate own resource to finance the EU budget. A number of analyzes favor the taxation of electricity before taxes on production and transport, especially for the following reasons:

a) Such a method is simpler, less expensive and more transparent to consumers through an electricity bill. All consumers pay their electricity bill with the counted tax. This would simply allow the European electricity tax to be passed on to the electricity bill, thereby increasing transparency and awareness on the question how the EU budget is financed. 
Initiatives in the Area of the Financing of the EU Budget in the Context...

b) The control of the usage and payment is already being done by the electricity companies, making this tax less prone to tax evasion.

c) Analyzes show that there is a ratio between electricity consumption and income level. Rich regions tend to consume more electricity than poorer regions. Taxation of consumers could, therefore, be re-distributive. Proportionality is lost, however, when there is compared specific households. The change in electricity prices may have a greater impact on poor households than on richer households (Kosonen, 2012: 10-16). This deficiency could be eliminated by compensatory mechanisms at national or European level (e.g. subsidies), respectively the conditions for exemption from the tax could be laid down in the legislation (or conditions for the application of the reduced rate of tax) (Monti et al.: 2016: 47).

\section{Conclusions}

Proposed own sources of the EU budget funding can also be referred to as environmental own resources, which means that their implementation could be expected in the short term to achieve a sustainable improvement in the quality of the environment. This is fully in accordance with EU policy in this area.

Compared to the current EU budget financing, a sufficient return could also be expected. Therefore, the proposed environmental own resources of EU budget funding are considered important to be subject to evaluation in the context of the reform principles.

1) European added value - the nature of the possible adaptation of these environmental own resources implies that their implementation would be most appropriate at the transnational level in order to ensure uniform application of harmonized legislation in all EU Member States, either in the form of regulations or directives. Top-level coordination of Member States could provide not only a very effective financing of the EU budget but could also serve as a means of preventing the speculative behavior of EU Member States' national lawmaking in this area. For environmental own resources, European added value appears to be sufficiently high.

2) Subsidiarity - the application of this reform principle is closely linked to the principle of European added value, yet it has a different application. In each Member State, there are likely to be significant differences in the set of financial obligations that they would have against the EU budget. This applies in particular to geographic variations, population density, industrial level and the extent of environmental pollutants, whether at the level of the production 
process or in the case of final consumers. An essential requirement for the successful implementation of environmental own resources will, therefore, be the precise determination of the scope of rights and obligations at the transnational and national levels. The subsequent development of the level of pollution, which is actually the justification for the introduction of these own resources, will need to be closely monitored and adapted to any further reforms (Babčák, Madliak, 2016: 53-59; Červená, 2005: 140-163).

3) Budget neutrality - this reform principle should be fulfilled in relation to environmental own resources. Regarding the volume of funds raised from this budget, even the assumed level of the yield from environmental own resources would allow dispensing with the disputed, currently applied own resources (for example, the VAT-based own resource). Abovementioned would also eliminate the shortcomings that the own resource based on VAT and the GNI-based own resource give rise, in terms of conceptual meaning, to own resources as we understand them in EU budget law.

4) Overall fiscal burden - by the effective implementation and rigorous interpretation of the binding text of EU legal acts could be successfully harmonize the legislation on the financing of the EU budget by its own resources, which will ultimately lead to more effective cooperation between Member States and a reduction in the cost of individual Member States' budgets. Nor should the overall tax burden on taxpayers be increased, but only if the conditions for the effective implementation of such EU budget financing are met. It is important to remember that by the introduction of new own resources should be simultaneously abandoned current funding. This approach can also be expected to be met with the principle of overall fiscal burden.

5) Improvement of the synergies - European added value in the area of environmental own resources is demonstrably high and coordinates with the direction of EU policy on improving the quality of the environment. In terms of efficiency, the achievement of European public interests could be ensured by harmonizing legislation in the EU Member States through regulations or directives adopted at EU level.

6) Unity of the budget - respecting the application of this principle could be achieved by rigorously following the other principles of the reform and by precise wording and by defining the set of rights and obligations that Member States will have in relation to the EU budget and the set of rights and obligations that national authorities will have at their disposal in order to the efficient financing of the EU budget.

7) Transparency of the EU budget - the regulation of reformed own resources and the definition of the rights and obligations of national authorities in the 
Initiatives in the Area of the Financing of the EU Budget in the Context...

financing of the EU budget should meet the requirement of simplicity and clarity that EU citizens, even without legal and economic education, should understand the contribution and purpose of financing the EU budget through environmental own resources. This requirement will be a major challenge in the future for all interested parties.

8) Own resources should support EU policies - as the nature of the environmental own resources as such essentially fulfills this requirement, the application of this reform principle should not pose a more serious problem, but this does not apply to the current system of financing the EU budget through a VAT-based own resource and a GDP-based own resource.

\section{References}

Babčák, V.: Europeizácia slovenského daňového práva (skutočnost' a vízia) (Europeanization of Slovak Tax Law (Reality and Vision)), Ius et Administratio no. 1 (2015).

Babčák, V.: Úvahy o daňových oprávneniach Európskej únie (Reflections on the European Union's tax entitlements), in: Dobrobičová, G., Sagan, S.: Implementacja prawa unijnego do systemów prawa krajowego w Polsce i na Słowacji po dziesięciu latach członkostwa w Unii Europejskiej (Implementation of EU law into national law systems in Poland and Slovakia after ten years of membership in the European Union), Rzeszów: Wydawnictwo Uniwersytetu Rzeszowskiego, 2015.

Babčák, V., Madliak, J.: Sankcie a princíp “Znečistovatel” platî” vo vybraných štátoch EÚ (Sanctions and the "polluter pays" principle in selected EU countries), Karlovarská Právní Revue no. 2 (2016).

Begg, I. et al.: Financing of the European Union Budget. Study for European Commission, Directorate General for Budget. Final report, 2009.

Beličková, K. et al.: Rozpočtová teória, politika a prax (Budgetary Theory, Policy and Practice), Bratislava: Iura Edition, 2010.

Bonk, F.: Vlastné dane Európskej únie - nevyhnutnost' úniovej integrácie? (The European Union's own taxes - the necessity of EU integration?), Právní Rozprawy 2015: mezinárodní vědecká konference oblasti práva a právních věd (Legal Discourse 2015: International Scientific Conference on Law and Legal Sciences), Hradec Králové: Magnanimitas, 2015.

Bujňáková, M.: Colné právo ako podsystém finančného práva (Customs law as a subsystem of financial law), Praha: Nakladatelství Leges, 2009.

Cattoir, P.: Options for an EU financing reform, Brussels: Notre Europe, 2009.

Červená, K.: Etika podnikania a priaznivé životné prostredie (Business ethics and a favorable environment), Historické, politicko-právne a filozofické aspekty práva a právnej kultúry (Historical, political, legal and philosophical aspects of law and legal culture), Košice: UPJŠ v Košiciach, 2005. 
Chaloupka, F.: How Effective are Taxes in Reducing Tobacco Consumption?, Valuing the Cost of Smoking, in: Jeanrenaud, C., Soguel, N.C.: Assessment Methods, Risk Perception and Policy Options, New York: Springer, 1999.

Coria, J., Jaraité, J.: Carbon Pricing: Transaction Costs of Emissions Trading vs. Carbon Taxes, CERE Working Paper no. 609 (2015).

De Feo, A.: EU Own Resources: Momentum for a Reform?, EU Own Resources: Momentum for a Reform? Florence: European Union Institute, 2016.

Eijndthoven, J.: Energy Taxation at European Level: What does it do for the Environment and Sustainability?, EC Tax Review no. 6 (2011).

Knapp, V.: Vědecká propedeutika pri právniky (Scientific propedeutics for lawyers), Praha: Eurolex Bohemia, 2003.

König, P., Lacina, L.: Rozpočet a politiky Evropské unie (The budget and policies of the EU), Praha: C.H. Beck, 2004.

High Level Group on Own Resources, First Assessment Report, 2014.

Keen, M. et al.: Planes, ships and taxes: Charging for international aviation and maritime emissions, Economic Policy, 2013.

Kicová, A.: Tax policy of the European Union and its influence on national legislation, in: Pawłowska, A., Grabowska, S.: Zasada pomocniczości wymiar europejski, narodowy, regionalny i lokalny (Subsidiarity principle - the European, national, regional and local dimension), Rzeszów: Wydawnictwo Uniwersytetu Rzeszowskiego, 2011.

Kosonen, K.: Regressivity of environmental taxation: myth or reality?, Taxation Papers: Working Papers no. 32 (2012).

Krenek, A., Schratzenstaller, M.: Sustainability-oriented EU Taxes: The Example of a European Carbon-based Flight Ticket Tax, FairTax - Working Paper Series no. 1 (2016).

Laffan, B.: Own Resources: The Need for a Reform, in: EU Own Resources: Momentum for a Reform?, Florence: European Union Institute, 2016.

Leen, A.: The Return of the Value Added Tax: A New Own Resource to Finance the Budget of the European Union, ATINER's Conference Paper Series no. 496 (2013).

Leen, A.: What an EU Tax Means (From Collective to Individual Net Positions), EC Tax Review no. 4 (2011).

Luptáčik, M., Luptáčik, P.: Analysis and quantification of a new fiscally neutral European tax Executive summary, European Economic and Social Committee, 2016.

Medarova-Bergstrom, K. et al.: Criteria for maximising the European added value of EU budget: the case of climate change, Brussels: Institute for European Environmental Policy, 2012.

Monti, M.: Summary Statement of Mario Monti's Keynote Introduction, in: EU Own Resources: Momentum for a Reform?, Florence: European Union Institute, 2016. 
Initiatives in the Area of the Financing of the EU Budget in the Context...

Monti, M. et al.: Future Financing of the EU - Final report and recommendations of the High Level Group on Own Resources, 2016.

Morris, D., Munnings, C.: Progressing to a Fair Carbon Tax - Policy Design Options and Impacts to Households, Issue Brief, 2014.

Pearce, D.: The Role of Carbon Taxes in Adjusting to Global Warming, The Economic Journal no. 407 (1991).

Prievozníková, K. Colné právo (Customs law), Žilina: Knižné centrum, 2008.

Sábo, J.: Pojem environmentálnej dane v kontexte daňovej politiky Slovenskej republiky (The concept of environmental tax in the context of the tax policy of the Slovak Republic), in: Ura, E., Stelmasiak, J., Pieprzny, S. (eds.): Assessment of Legal Model of Environmental Protection in Poland and Slovakia, Košice: Equilibria, 2013.

Štieberová, I.: Aktuálne výzvy vedy o daňovom práve v oblasti daňovej morálky (Current Challenges of Tax Law Science in the Area of Tax Morality), Zborník príspevkov zo spoločného zasadnutia katedier finančného práva Právnických fakúlt univerzít Slovenskej a Českej republiky (Proceedings of the Joint Meeting of the Financial Law Departments of the Faculty of Law of the Universities of the Slovak Republic and the Czech Republic), Bratislava: UK v Bratislave, 2016.

Štrkolec, M.: Intrakomunitárne a "extrakomunitárne" obchody a daň z pridanej hodnoty (IntraCommunity and "extra-community" trades and value added tax), in: Právo, obchod, ekonomika (Law, business, economics), Košice: UPJŠ v Košiciach, 2013.

EU: Treaty on the Functioning of the European Union: no. 2012/C 326/01.

EU: Regulation (EEC, Euratom, ECSC) no. 260/68, laying down the conditions and procedure for applying the tax for the benefit of the European Communities.

EU: Council Regulation (EU) no. 2016/300, determining the emoluments of EU high-level public office holders.

EU: Council Regulation (EU, EURATOM), no. 1311/2013 laying down the multiannual financial framework for the years 2014-2020. 



\title{
THE ROLE OF THE FINANCIAL ENGINEERING INSTRUMENTS IN THE ALLOCATION OF EU FUNDS - THE RESULTS OF THE RESEARCH BASED ON THE EXAMPLE OF THE KUYAVIAN-POMERANIAN VOIVODSHIP
}

\author{
MACIEJ TOKARSKI', PAWEŁ KUFEL ${ }^{2}$
}

\begin{abstract}
The aim of the paper is to present the role of the financial engineering instruments and their implementation in the 2014-2020 financial perspective based on the example of kuyavian-pomeranian voivodeship. The analysis has been based on the reference books on the subject as well as on the results of own research based on the survey questionnaire carried out among the enterprises in the kuyavianpomeranian voivodeship titled: The perspectives of the utilization of the EU funds in the form of the returnable instruments by the enterprises in the kuyavianpomeranian voivodeship for the 2014-2020 financial perspective. The advantages of the financial engineering instruments speak in favor of the amplification of their share in financing within the European Union Funds. However, it shall not mean giving up on subsidies which are indispensable for the financing of various projects. The decision whether to apply the returnable or subsidized financing of the specific undertakings shall be preceded by a detailed analysis, which enables to identify the financial gap in the given sector requiring support.
\end{abstract}

\section{Keywords}

Financial gap; returnable instruments; financial engineering instruments

JEL Classification: G23, H60, P48

1 Doctor, Assistant professor at Institute of Finance, Faculty of Finance and Management, WSB University in
Toruń, Poland. Contact email: maciej.tokarski@wsb.torun.pl.
Doctor, Assistant professor at Institute of Management, Faculty of Finance and Management, WSB University
in Toruń, Poland. Contact email: pawel.kufel@wsb.torun.pl. 


\section{Introduction}

The multi-annual financial plan of the European Union for 2014-2020 provides for the possibility of financing the objectives of the cohesion policy, not only through non-returnable subsidies but also through the use of returnable financing mechanisms. Particular importance is given to non-subsidy instruments, such as credits, loans, and sureties ${ }^{3}$.

In the perspective 2007-2013 in Poland, the financing of projects was possible from the structural funds through subsidies (non-returnable system) and, for the first time, the returnable instruments, also called the financial engineering instruments ${ }^{4}$, were used.

The aim of the article is to present the specificity of returnable financing on the example of financial engineering instruments functioning in Poland in 2007-2013 and their implementation in the financial perspective 2014-2020 on the example of the Kuyavian-Pomeranian Voivodship.

The analysis was based on the literature and the results of own research - using a questionnaire survey conducted among enterprises of the Kuyavian-Pomeranian voivodship - "The prospects for using the European funds in the form of returnable aid by the companies in the Kuyavian-Pomeranian voivodship in the financial perspective 2014-2020".

\section{Concept and Mechanism of European Funds. European Funds for Poland in the Financing Perspective 2004-2020}

One of the objectives of the EU is to strive to equalize the level of development of individual states. The accomplishment of this objective takes place under the EU structural policy. It includes a series of measures aimed at stimulating the longterm socio-economic changes of individual regions and the Member States of the European Union. These measures are to reduce the disparities between regions and remove the delays in the development of the poorest areas. The literature

3 According to estimates by the Ministry of Infrastructure and Development - at present the Ministry of Development - (in the perspective 2014-2020 in Poland, 10\% of the funds allocated from the general EU budget to the cohesion policy will be spent on the returnable aid (for comparison, it was less than $2 \%$ in the ended perspective 2007-2013), and most of the subsidies will be returnable (Bobrowska, 2013: 2; CzykierWierzba, 2013).

$4 \quad$ The concept of financial engineering refers in this case to returnable financing mechanisms created on the basis of combined resources from EU funds and the private capital. The European Commission includes credits, loans, sureties and capital interest offered to beneficiaries under these mechanisms as financial instruments of the financial engineering. In this case, the concept of financial engineering should not be identified with the use of advanced financial science tools, such as derivatives and other alternative instruments. 
The Role of the Financial Engineering Instruments in the Allocation of EU Funds...

distinguishes a regional policy that seeks to increase the economic and social cohesion within the European Union and a cohesion policy aimed at reducing the disparities within the European Union. In practice, however, these concepts are used interchangeably ${ }^{5}$, as their common ultimate objective is the harmonious development of the entire EU.

The structural funds, under which financial resources are distributed between individual regions, include the instruments for implementing the EU structural policy (Regulation no. 1303/2013, Council Regulation no. 1083/2006, Regulation no. 1081/2006, Regulation no. 1080/2006, Regulation of the Minister of Regional Development of 26 October 2011 on the financial aid from the financial engineering instruments under the Regional Operational Programmes).

There are two basic types of funds:

- the European Regional Development Fund (ERDF) - used to finance the so-called "hard projects" within all objectives of the structural policy; it is aimed at reducing the disparities in relation to wealthier regions and reducing the backwardness of the poorest regions, and

- the European Social Fund (ESF) - mainly financing the projects aimed at improving the quality and availability of jobs and reducing unemployment.

The EU structural policy also includes the Cohesion Fund (CF; which is not a structural fund) supporting two areas: environment and transport ${ }^{6}$. However, contrary to the ESF and the ERDF, it is distributed between countries rather than regions. In addition to the structural policy, the EU conducts the Common Agricultural and Fisheries Policy, under which the funds under theEuropean Agricultural Fund for Rural Development (EAFRD) and the European Maritime and Fisheries Fund (EMFF) can be obtained (Regulation no. 1083/2006 laying). Since 2014, the above-mentioned funds have been operating under the common name: the European Structural and Investment Funds (ESIF). This change aims at improving the coordination and harmonization of the implementation of these funds and facilitating their use by the recipients.

The EU budget is set in the seven-year financial perspective. Since its accession to the EU, i.e. 1 May 2004, Poland has participated in the implementation of three

5 One concept was used in the study to define the EU policy - the structural policy - not to introduce terminological chaos.

6 In the perspective 2014-2020, from the amount of EUR 351.8 billion (at current prices) allocated to financing the cohesion policy: EUR 288.4 billion will constitute the structural funds and EUR 63.4 billion will constitute the Cohesion Fund. The main beneficiary of the funds for financing the cohesion policy is Poland, to which EUR 77.6 billion were allocated for this purpose, i.e. $22 \%$ of the total funds allocated to the cohesion policy. It is worth noting that despite the relative reduction in the funds for the cohesion policy, in the current financial framework, compared to 2007-2013, more funds were allocated to Poland (Czykier-Wierzba, 2016: 10-11). 
such budgets 7 . The period and individual amounts that it has already received are as follows (Uryga, Jagielski, Bienias, 2007: 7-8; Tokarski, Tokarski, 2015: 87-105):

- 2004-2006 - Poland received financing at the total amount of PLN 60.5 billion under the National Development Plan. These were mainly preaccession funds under the SAPARD, ISPA and PHARE programmes;

- 2007-2013 - EUR 85.6 billion was allocated for the implementation of the National Cohesion Policy programme to be used by $2015^{8}$;

- 2014-2020 - on 23 May 2014, the Partnership Agreement was approved, under which EUR 82.5 billion were allocated to Poland?.

The EU budget for the financial perspective 2014-2020 is based on 5 main objectives set out in the EU Europe 2020 strategy (Europa 2020; Świstak, 2014: 19-20):

- employment $-75 \%$ of people aged $20-64$ should have a job;

- research and development - at least 3\% of the EU's GDP should be spent on this objective;

- climate changes and sustainable use of energy - reducing greenhouse gas emissions, increasing the share of energy from renewable resources, increasing energy efficiency;

- education - increasing the number of people aged 30-34 with higher education, reducing the number of early school leavers;

- fighting poverty and social exclusion - limiting the number of people at risk of poverty by at least 20 million.

In 2014-2020, 6 programmes financed under the ERDF, the ESF, the CF, the EAFRD, the EMFF, and the ETC programmes will be implemented in Poland at national

Poland is the biggest beneficiary of EU funds. However, the amount of support for Poland per capita is not the highest compared to other Member States (it is higher, among others, in the Czech Republic, Slovakia, Lithuania, Latvia, Estonia, and Hungary).

8 In the financial perspective 2007-2013, the $n+3$ rule was introduced for the first three years of the implementation of operational programmes. This meant that the funds allocated to Poland for 2007 (year $n$ ) could be spent by $2010(n+3)$, resources for 2009 - by 2012, and the funds for 2010 - by 2013 . The $n+2$ rule applied in the following years (i.e. 2011-2013), which means that the final spending period of the funds ended in 2015 (hence the majority of tenders for subsidies from the new perspective 2014-2020 was announced in 2016).

9 The main document in the programming process is the Partnership Agreement, which, like the National Strategic Reference Framework (NSRF) in the previous financing period, defines how the resources of the funds, subject to joint programming, will be spent to achieve the objectives of the Europe 2020 strategy. Unlike the NSRF, the Partnership Agreement also covers agricultural funds and programmes managed by the Commission. 
The Role of the Financial Engineering Instruments in the Allocation of EU Funds...

leve ${ }^{10}$. At regional level, as in the years 2007-2013, 16 ROPs will be implemented ${ }^{11}$. The adopted programme structure is based on positive experience from the programming period 2007-2013 and it is optimally aligned with the objectives of the Partnership Agreement. It also takes into account the integrated thematic and territorial approach as well as the mechanisms of multi-level development policy management functioning in line with the Polish legal order ${ }^{12}$.

\section{Financing Systems Under Which EU Support is Made Available}

In 2007-2013, beneficiaries of the EU aid could take advantage of two forms of support: the non-returnable and returnable financing.

The first form was based on a subsidy mechanism and strongly dominated in the perspective 2007-2013. In general, the submitted applications were assessed in two ways: either in a continuous mode or a tender mode. The continuous mode meant that the applications were accepted and assessed on an ongoing basis - the "first come, first served" principle was predominant. The tender mode is one where, once in a while, the call for applications was announced, and the applicants submitted their applications presenting their undertakings, which were subject to formal and substantive assessment, and the financing was received by beneficiaries whose applications were assessed highest under the available funds allocated for a given tender (Tokarski, Konieczka, 2012: 582; Bera, Tokarski, 2012: 17-20) ${ }^{13}$. In practice, there was a considerable predominance of demand for European funds over their supply. The level of allocation of funds for the implementation of measures under the programmes addressed to enterprises was too small in relation to the needs, which was reflected at least by the number of submitted applications (often the allocation of funds under a given measure was exceeded several or more than a dozen times). Hence the subsidies were available only to a small number of companies.

10 In 2014-2020, the funds under the cohesion policy will be invested in Poland through 6 national operational programmes (OP Infrastructure and Environment EUR 27,513.9 billion, OP Intelligent Development EUR 8,614.1 billion, OP Knowledge Education Development EUR 4,419.3 billion, Eastern Poland EUR 2,117.2 billion, PO Digital Poland EUR 2,255.6 billion, OP Technical Assistance EUR 0.7 billion and regional programmes of voivodeships - ROPs), including one supraregional programme for Eastern Poland voivodeships (Lublin, Podkarpackie, Podlaskie, Świętokrzyskie, and Warmian-Masurian). The Partnership Agreement is the point of reference for them. The national programmes will be managed by the minister competent for regional development.

11 In the current perspective 2014-2020, the financing of operational programmes implemented in the Member States will not take place through one fund, as was the case in 2007-2013, but by pooling the financial resources from the ERDF, the ESF, and the CF.

12 The article does not provide the detailed descriptions of individual programmes of the perspective 20142020 , which can be found on the website of the Ministry of Infrastructure and Development. www.mir.gov.pl/ fundusze/fundusze_europejskie_2014_2020/strony/start.aspx.

13 In practice, there is a significant predominance of demand for European funds over their supply. The level of allocation of the funds for the implementation of measures under the programmes addressed to enterprises is too small in relation to the needs, which is reflected at least by the number of submitted applications (often the allocation of resources under a given measure is exceeded several or more than a dozen times). 
The second form of support is regarded as returnable mechanisms and refers to products defined as financial engineering instruments that are offered by financial intermediaries (banks, loan, and surety funds). The main purpose of these instruments is to increase access to capital. Their characteristic feature is the renewability for subsequent applicants (Pełka, 2012: 224-225). The received funds are repaid by the beneficiary and then re-offered by the intermediary to other entities. Unlike the subsidy support system, the end beneficiary cannot count on the non-returnable aid, but instead, it receives access to the returnable source of financing on preferential terms. The main differences between the two forms of support related to such issues as the returnability of the funds, the type of entity applying for the support, the impact on the conditions of competition, the economic efficiency of the use of a given source of financing. As regards the issue of returnability of funds, the idea is that in the case of new instruments the obtained funds are not allocated forever just to one beneficiary, as in the subsidy system, but they can be used by several entities as a returnable loan provided by a financial intermediary to the beneficiary on terms more favourable than market terms. Thus, in the case of financial engineering instruments, a greater number of end beneficiaries may take advantage of the aid than in the subsidy system (Nicolaides, 2013). The total value of the funds allocated to the financing of the projects is in such a situation higher than in the subsidy system. This allows for a considerable prolongation of the circulation of the funds in the economy, as opposed to the subsidy mechanism in which the granted support cannot be used again by another entity (Szczepański, 2011: 8). The returnability of funds provides for the occurrence of a rollover effect, that is the multiple uses of the same capitals to multiply the value of enterprises. According to EU estimates, the financial instruments worth EUR 2-10 will be created on the basis of each Euro (Instytut Badań nad Gospodarką Rynkową, 2010: 4). It is expected that the resulting multiplier effect will bring far greater benefits to micro, small, and medium-sized enterprises than the subsidy system, by guaranteeing the continuity and stability of the support system. In the entrepreneurs' opinion, the most important feature of returnable instruments is their greater reach than subsidies and improved credit terms (Nicolaides, 2013; Program Rozwoju przedsiębiorstw do 2020 roku, 2014). An element distinguishing the subsidy mechanism from the returnable one is the type of entity that applies for the EU aid. In the case of non-returnable mechanism, entrepreneurs and local governments submit applications if they wish to receive support in the form of EU funds. In contrast to the non-returnable subsidy system, in the case of returnable mechanisms, the financial intermediaries, i.e. banks, business development agencies as well as loan and surety funds, rather than entrepreneurs, apply for the EU funds, who then distribute the funds to SMEs in the form of a loan (including, but not limited to, a micro-credit), sureties or resureties, and the (equitytype) capital entrance (Jaworski, Tokarski, 2014: 103; Dobija, 2014: 80). 
The Role of the Financial Engineering Instruments in the Allocation of EU Funds...

The non-returnable subsidy mechanism can cause disruptions in the competitive conditions. Entities that received a subsidy can eliminate the companies that have not received such support from the market. When using the financial engineering instruments, such a situation does not take place, since the financial resources obtained will have to be repaid on market-like conditions. Compared to the subsidies, the characteristic of the returnable financing is the ability to enforce the economic efficiency of undertakings in which the financial funds are involved. An investor using the loan is forced to ensure such profitability of the implemented investment to enable the repayment of the debt incurred. Too easy access to the subsidies can lead to a situation that the entities are mainly limited to activities aimed at meeting the criteria on which the receipt of support depends, at the expense of the economic efficiency of the financed project. This means the risk of displacing the effective investments by less attractive investments financed by way of subsidies. The returnable instruments also allow financing the investments with a higher level of risk. Therefore, the non-subsidy system will fulfill its role if, on the one hand, it will contribute to raising the efficiency of the absorption of the EU support and, on the other hand, it will allow minimizing the risk of destroying the market (Pełka, 2012: 225-226). Thus, the returnable nature of non-subsidy instruments provides for a higher efficiency of spending of funds compared to the subsidy system. The project implemented by an entrepreneur must be profitable and cost-effective enough to guarantee the repayment of funds obtained.

An important issue related to returnable instruments is the occurrence of the leverage effect associated with the ability to combine public and private financing. This involves the ability to involve private funds in the economic development with the support of public financing with appropriate risk sharing. This process is conducive to building relationships between the parties and greater involvement of private funds in accomplishing the objectives of the cohesion policy.

In conclusion, the inclusion of returnable instruments in the distribution system of EU funds is primarily related to the increased efficiency of the funds used, given the revolving nature of these instruments, which, in the conditions of the fiscal crisis in the European Union countries, is an undeniable asset of this type of funds. It is also important to limit the phenomenon of the so-called capital gap by increasing the availability of micro, small, and medium-sized enterprises for financing, especially start-ups and innovative enterprises without adequate credit collateral. 
Maciej Tokarski, Paweł Kufel

\section{Financial Engineering Instruments in Poland - Past Experience and Objectives For 2014-2020}

The returnable support instruments introduced or planned to be implemented in Poland can be divided into three groups, of which the following are distinguished (Instytut Badań nad Gospodarką Rynkową, 2010: 70):

- loan instruments (global loan for loan funds, global loan for banks);

- surety instruments (resurety for surety funds, portfolio surety for banks);

- capital instruments (capital support of technology transfer funds, capital support of mezzanine funds).

Table 1 The returnable instruments used in Poland in the financial perspective 2007-2013

\begin{tabular}{|c|c|c|c|c|}
\hline Program & Instrument & Objective & Implementing body & $\begin{array}{c}\text { Beneficiaries of } \\
\text { support }\end{array}$ \\
\hline $\begin{array}{l}\text { Regional } \\
\text { Operational } \\
\text { Progras } \\
\end{array}$ & loans, sureties & $\begin{array}{c}\text { increasing the } \\
\text { competitiveness of } \\
\text { enterprises }\end{array}$ & Marshal Offices & $\begin{array}{l}\text { micro, small, and } \\
\text { medium-sized } \\
\text { enterprises }\end{array}$ \\
\hline \multicolumn{5}{|c|}{$\begin{array}{l}\text { JEREMIE } \\
\text { Instrument: Ioans, sureties, resureties, capital instruments } \\
\text { Objective: supporting small and medium-sized enterprises } \\
\text { Implementing body: Bank Gospodarstwa Krajowego (for the Masovian, Lower Silesian, Pomeranian, Greater } \\
\text { Poland, West Pomeranian and Łódź voivodships) and the Kuyavian-Pomeranian Loan Fund (for the Kuyavian- } \\
\text { Pomeranian Voivodship) } \\
\text { Beneficiaries of support: sector of micro, small, and medium-sized enterprises } \\
\text { JESSICA } \\
\text { Instrument: loans, sureties, resureties, capital instruments } \\
\text { Objective: supporting the development of urban areas through the implementation of projects enabling their } \\
\text { sustainable development during urban regeneration and development in the economic and social dimensions } \\
\text { Implementing body: UDFs, that is Urban Development Funds. The following three banks played their role: Bank } \\
\text { Gospodarstwa Krajowego, Bank Ochrony Środowiska and Bank Zachodni WBK. The initiative in Poland was } \\
\text { implemented in } 5 \text { voivodeships: Greater Poland, West Pomeranian, Pomeranian, Silesian and Masovian }\end{array}$} \\
\hline \begin{tabular}{|c|} 
PO IG - Sub- \\
measure 3.4 \\
Venture Capital \\
\end{tabular} & $\begin{array}{l}\text { venture capital } \\
\text { funds }\end{array}$ & $\begin{array}{l}\text { supporting } \\
\text { innovative } \\
\text { enterprises } \\
\end{array}$ & National Capital Funds & $\begin{array}{c}\text { new micro and small } \\
\text { enterprises }\end{array}$ \\
\hline $\begin{array}{c}\text { OP IE - Sub- } \\
\text { measure } 3.1 \text { Seed } \\
\text { Capital } \\
\end{array}$ & $\begin{array}{l}\text { seed capital } \\
\text { funds }\end{array}$ & $\begin{array}{l}\text { development of } \\
\text { new innovative } \\
\text { enterprises }\end{array}$ & National Capital Funds & $\begin{array}{l}\text { new micro and small } \\
\text { enterprises }\end{array}$ \\
\hline $\begin{array}{l}\text { OP IE - Sub- } \\
\text { measure } 4.3 \\
\text { Technological } \\
\text { credit }\end{array}$ & $\begin{array}{l}\text { Technological } \\
\text { credit }\end{array}$ & $\begin{array}{c}\text { supporting the } \\
\text { investments in the } \\
\text { implementation of } \\
\text { new technologies } \\
\text { through granting a } \\
\text { technological credit }\end{array}$ & $\begin{array}{l}\text { Bank Gospodarstwa } \\
\text { Krajowego Department } \\
\text { of European Programs }\end{array}$ & $\begin{array}{l}\text { micro, small, and } \\
\text { medium-sized } \\
\text { enterprises }\end{array}$ \\
\hline $\begin{array}{l}\text { NFEP\&WM/ } \\
\text { VFEP\&WM }\end{array}$ & $\begin{array}{l}\text { loans, credit } \\
\text { lines }\end{array}$ & $\begin{array}{c}\text { environmental } \\
\text { protection and water } \\
\text { management } \\
\end{array}$ & $\begin{array}{c}\text { National Fund for } \\
\text { Environmental Protection } \\
\text { and Water Management }\end{array}$ & $\begin{array}{l}\text { local government } \\
\text { units and enterprises }\end{array}$ \\
\hline
\end{tabular}

Source: Own study. 
The Role of the Financial Engineering Instruments in the Allocation of EU Funds...

Up to now, loan and guarantee products have been used as part of the financial engineering instruments. It should be emphasized that there is also room for the development of other products, including capital ones, which have not been used in Poland yet. However, the first step is to intensify and maximize the support in the form of existing instruments.

In the budgetary perspective 2007-2013, the voivodeships spent PLN 3.52 billion from the EU funds on returnable support instruments. This is very little - less than $1.5 \%$ of all EU money allocated to Poland for 2007-2013. This should change in the current financial perspective 2014-2020 - according to estimates by the Ministry of Infrastructure and Development (at present the Ministry of Development), 10\% of the funds allocated from the general EU budget for the cohesion policy in Poland will be spent on returnable aid, and most of the subsidies will be of returnable nature (Bobrowska, 2013: 2; Czykier-Wierzba, 2013).

From the experience of the financial perspective 2007-2013 in Poland, attention should be paid to the relatively late mobilization of these instruments, with a simultaneous significant increase in interest in them only when subsidy funds are depleted. The limitations of the effective use of the proposed solutions also include the lack of experience with the financial engineering instruments and the lack of methodology for assessing the effectiveness of absorption of European Union funds when used. There is still little awareness and understanding among beneficiaries of EU funds in terms of new returnable instruments.

In the case of financial engineering instruments, up to now in the period 20072013, the returnable aid could only be used by voivodeships in two areas (when supporting small and medium enterprises under the Jeremie Initiative and urban regeneration projects under the Jessica Initiative). In 2014-2020, it will be possible in all the so-called areas of intervention and throughout the programme.

\section{Financial Engineering Instruments in Allocation of European Union Funds - Results of Research Based on the Example of Kuyavian-Pomeranian Voivodship}

In the perspective 2007-2013, the dominant form of obtaining EU funds by entrepreneurs in the voivodship were non-returnable subsidies. Although to a lesser extent, the returnable instruments were also used under two models:

- the first one divided the funds under the ROP into the individual loan and surety funds. Loans or loan sureties were granted from them; 
- the second model is the so-called JEREMIE Initiative. It included a "fund of funds". It was the Kuyavian-Pomeranian Loan Fund, which was entrusted with almost PLN 40 million. It announced a tender procedure for the selection of intermediaries in which various loan, surety or bank institutions took part. They passed these funds on - mostly to entrepreneurs from the SMEs sector. The Kuyavian-Pomeranian Loan Fund (KPLF) disposed of this money in eight tenders, entering into 15 agreements with the intermediaries. It expected from them own contribution, which brought another PLN 12 million for preferential loans for the companies. JEREMIE started with a capital of less than PLN 40 million and, in the end, 579 companies from the Kuyavian-Pomeranian voivodeship received a total amount of about PLN 100 million (www.torun.wyborcza.pl, 2017; Tokarski, Tokarski' 2013: 951110).

In the current perspective 2014-2020, in the Regional Operational Programme the voivodeship has at its disposal EUR 2.23 billion, of which EUR 211 million, that is nearly 10 percent of the budget, was allocated to the returnable instruments. In the first stage, the Marshal Office will transfer them to "funds of the funds' managers", that is public institutions specialized in money management - these are Bank Gospodarstwa Krajowego, the Kuyavian-Pomeranian Development Fund, and the European Investment Bank. The EIB's domain as the "fund of the funds" manager" in the Kuyavian-Pomeranian voivodeship is to be the green economy, that is renewable energy sources and increasing the energy efficiency. Here, the end beneficiaries of money will be not only companies interested in eco-friendly energy solutions but also, for example, communities and cooperatives that need funds for thermal modernization of facilities. In addition, entrepreneurs, government administration, and local government units, as well as non-governmental organizations, will be able to take advantage of loans for financing the construction or modernization of installations for the production, processing, and storage of electricity from renewable energy sources.

In the second stage, they will select intermediaries whose role will be to distribute support directly to companies, in some cases also to other legal entities. The entrepreneurs should receive the financial resources under the returnable instruments in 2018 .

Below are the results of the research carried out among the voivodeship enterprises regarding the possibility of using the returnable funds in the form of financial engineering instruments. The aim of the research was to identify the awareness (knowledge) and needs of companies from the Kuyavian-Pomeranian Voivodeship as regards the functioning and possibilities of using the returnable funds in the form of financial engineering instruments. 
The Role of the Financial Engineering Instruments in the Allocation of EU Funds...

The research was conducted by means of a direct survey among 140 enterprises in the Kuyavian-Pomeranian Voivodeship. $55 \%$ of micro-enterprises, $27 \%$ of small-sized enterprises, $12 \%$ of medium-sized enterprises and $6 \%$ of large-sized enterprises were surveyed. The enterprises of natural persons $(59 \%)$ and in the form of limited liability companies $(25 \%)$ were predominant. Enterprises in the form of a limited liability company (civil partnership, registered partnership, limited partnership and joint stock company) accounted for $11 \%$ of the surveyed companies, while the remaining forms of ownership accounted for $5 \%$ of the sample. The scope of business activity of the surveyed companies is shown in Chart 1 .

\section{Chart 1 Scope of Business Activity}

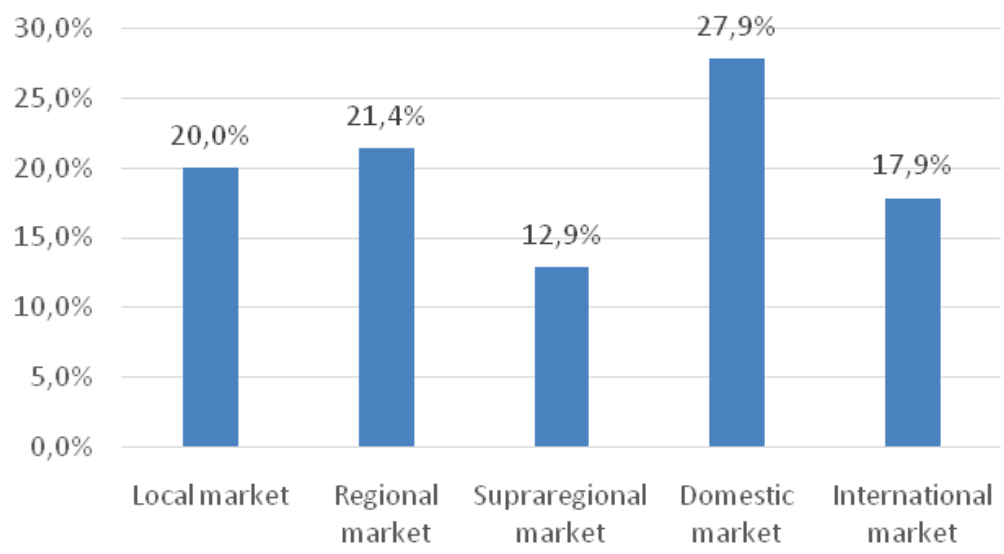

Source: Own study based on the results of the research.

The majority of the surveyed companies were enterprises with only Polish capital (90\%), while the remaining $10 \%$ were companies with foreign or mixed capital. The business activity profile of surveyed companies was as follows: services (59\%), trade (14\%), industry (14\%), services and trade $(6 \%)$, services and industry $(3 \%)$, trade and industry (3\%) as well as services, industry and trade (1\%).

By analyzing the willingness to take advantage of the non-subsidy support among the surveyed enterprises, it can be stated that $71.4 \%$ of surveyed companies have heard about the loan and surety funds. However, there is a significant $57.1 \%$ of enterprises) animosity towards this kind of support. The distribution of the type of non-subsidy support is shown in Chart 3. The main reason for this situation is the lack of interest in support under the Operational Programs of the KuyavianPomeranian voivodeship declared by $67.1 \%$ of enterprises. 
Chart 2 Distribution of Number of Enterprises Willing to Take Advantage of Non-subsidy Support and Expected Forms of Support

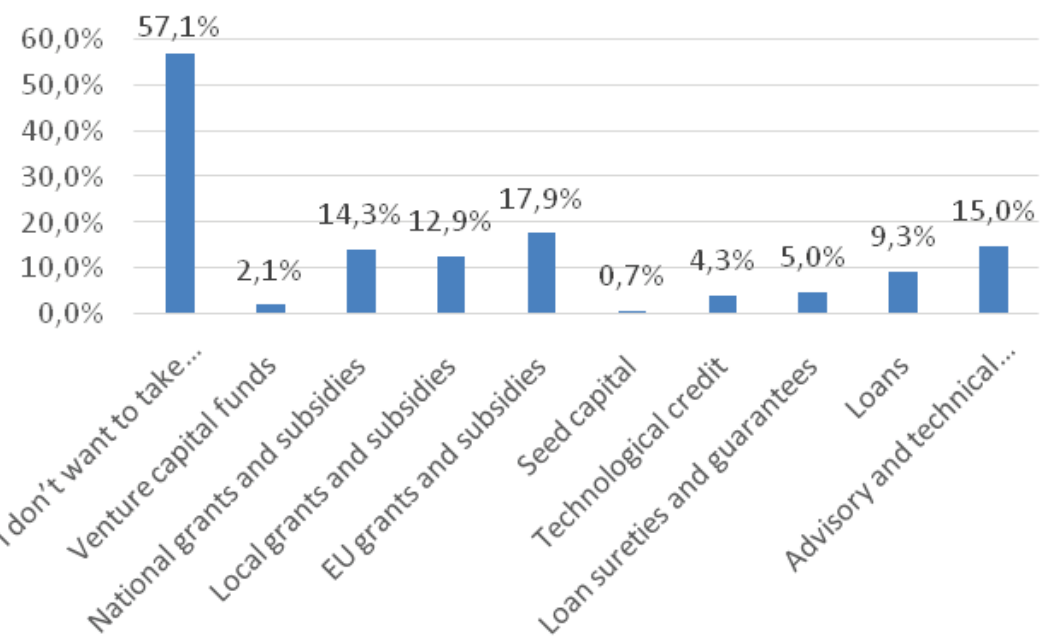

- Local grants and subsidies (e.g. co-financing employment, participation in the costs of trade missions)

- EU grants and subsidies (e.g. co-financing employment, participation in the costs of trade mission)

Source: Own calculations based on the results of the research.

Most entrepreneurs do not recognize and do not want to take advantage of the preferential returnable instruments offered under the programs co-financed from EU funds. The expectation of subsidies as a principal support for business is still predominant, which is due to the fact that, up to now, the non-returnable subsidies were the predominant form in the Kuyavian-Pomeranian Voivodeship in terms of obtaining EU funds by entrepreneurs.

The binary logit model was assessed to determine the factors influencing the willingness to take advantage of the non-subsidy forms of support. The enterprise's declaration on its willingness to take advantage of the support is subject to modeling. Variables that would explain the willingness to take advantage of non-subsidy supports include the size of the enterprise, the legal form, the scope of business activity, the number of employees, the share of foreign capital and the sector. Due to the fact that these variables are of a qualitative nature, dichotomous zero-to-one variables describing the individual states for the described factors were applied. The results of the estimated model are shown in Table 2. 
The Role of the Financial Engineering Instruments in the Allocation of EU Funds...

Table 2 The Estimated Binary Logit Model for the Willingness to Take Advantage of the Non-subsidy Support

Logit estimation, used observations 1-140 $(n=135)$

\begin{tabular}{|l|c|c|c|c|}
\hline & coefficient & Std. error & p-value & End effect* $^{*}$ \\
\hline Drodzaj_2 & 0.83862 & 0.62568 & 0.1801 & 0.20641 \\
\hline Drodzaj_3 & 1.71058 & 1.12305 & 0.1277 & 0.38917 \\
\hline Drodzaj_4 & 0.414102 & 1.4004 & 0.7675 & 0.10302 \\
\hline Dforma_praw_2 & 0.291979 & 0.55406 & 0.5982 & 0.07230 \\
\hline Dforma_praw_3 & -0.347087 & 0.72134 & 0.6304 & -0.08343 \\
\hline Dforma_praw_4 & -1.92191 & 1.34489 & 0.1530 & -0.35051 \\
\hline Dzasieg_1 & 0.602364 & 0.54150 & 0.2660 & 0.14930 \\
\hline Dzasieg_2 & 0.768485 & 0.54261 & 0.1567 & 0.18972 \\
\hline Dzasieg_3 & 0.771709 & 0.62578 & 0.2175 & 0.19052 \\
\hline Dzasieg_5 & 0.666446 & 0.65431 & 0.3084 & 0.16504 \\
\hline Dzatrud_1 & -0.218747 & 0.71019 & 0.7581 & -0.05312 \\
\hline Dzatrud_3 & -0.403567 & 0.56532 & 0.4753 & -0.09707 \\
\hline Dzatrud_4 & -0.123289 & 0.64704 & 0.8489 & -0.03016 \\
\hline Dzatrud_5 & -0.434048 & 0.85379 & 0.6112 & -0.10351 \\
\hline Dzatrud_6 & -1.3775 & 0.97014 & 0.1556 & -0.29041 \\
\hline Dzatrud_7 & -1.65364 & 1.41084 & 0.2412 & -0.32078 \\
\hline Dzatrud_8 & -1.47417 & 1.61319 & 0.3608 & -0.29519 \\
\hline Dbranza_1 & 0.150662 & 0.64791 & 0.8161 & 0.03726 \\
\hline Dbranza_2 & -1.03043 & 0.44062 & 0.0194 & $-0.25102^{* *}$ \\
\hline Dkapital_zagr_1 & -0.210557 & 1.15628 & 0.8555 & -0.05107 \\
\hline Dkapital_zagr_3 & -0.566962 & 1.20065 & 0.6368 & -0.13194 \\
\hline
\end{tabular}

Source: Own calculations based on the results of the research.

The quality of the estimated model is satisfactory - the model correctly predicted $66.7 \%$ of responses. By analyzing the significance of the assessment of structural parameters, only the sector of conducted business activity had a significant impact (at the significance level of 5\%). All other explanatory variables used were found to be statistically insignificant. That means that such factors as the size of the enterprise, the legal form, the scope of business activity, the number of employees, and the share of foreign capital are not decisive in deciding on the willingness to take advantage of the support. The probability that an enterprise providing service is not willing to take advantage of the support is $22 \%$ compared to an enterprise whose business activity is the trade. For other variables (apart from the absence of statistical significance), the following statements can be made: 
- there is a greater likelihood of willingness to take advantage of the support for a small, medium and large-sized enterprise than for a micro-enterprise;

- the number of employees in the enterprise gives a lower probability of taking advantage of the support than if only one person is employed;

- the occurrence of foreign capital in the enterprise resulted in the lower probability of taking advantage of the non-subsidy support than in the case of an enterprise only with Polish capital (it should be emphasized, however, that the variability was very low for this variable - enterprises with only Polish capital were predominant in the survey).

Of the companies that declare their willingness to take advantage of the nonsubsidy support, the main objective of allocating the obtained funds would be the purchase of machinery and equipment (50.9\%) and means of transport $(35.1 \%)$, as well as construction, expansion and modernization of buildings (29.8\%) and the implementation of new technologies (28.1\%). The distribution of responses as regards what the funds would be spent on is shown in Chart 3.

\section{Chart 3 Distribution of Allocation of Financing (it was possible to select more than one answer)}

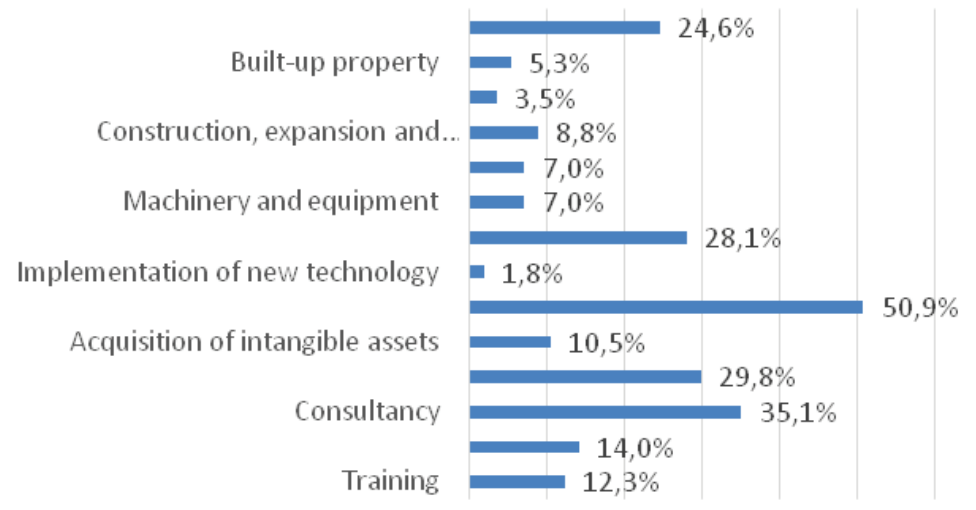

$0,0 \% 10,0 \% 20,0 \% 30,0 \% 40,0 \% 50,0 \% 60,0 \%$

Source: Own calculations based on the results of the research.

\section{Conclusions}

The reasonable use of European funds is one of the tools that can significantly improve the economic situation, especially at local level, and accelerate the 
The Role of the Financial Engineering Instruments in the Allocation of EU Funds...

economic growth. The full use of EU funds allocated to Poland for 2014-2020 creates an opportunity, as shown by experience from the previous multi-annual financial framework, to accelerate the economic growth, increase the competitiveness of the economy and, consequently, limit the distance in the level of economic and social development separating Poland from "old" EU countries. The financial engineering instruments provide an opportunity to increase the access of micro, small, and medium-sized enterprises and local governments to capitals needed to finance their development. This is also an opportunity to reduce the capital gap in the European Union countries.

The most important reason why the European Commission is changing the manner of granting support for the financial engineering instruments of returnable nature is the willingness to increase the efficiency of the use of EU development funds. There are many arguments supporting such a solution. Firstly, the pool of money in EU funds can be multiplied by the fact that these will be returnable funds. Secondly, under such a system, there is a greater chance that the EU support will actually contribute to the economic development and will be allocated to projects that are economically most feasible and guarantee that the granted funds will be multiplied. The subsidy is of a one-off nature, and the returnable instruments can be a system solution.

The inclusion of returnable instruments in the distribution system of European funds is primarily related to the increased efficiency of the funds used, given the revolving nature of these instruments, which is an undeniable asset of this type of resources. It is also important to limit the phenomenon of the so-called capital gap ${ }^{14}$ by increasing the availability of micro, small, and medium-sized enterprises for financing, especially start-ups and innovative enterprises without adequate credit collateral. As demonstrated by experience from 2007-2013, they are more efficient than traditional subsidies. As opposed to the subsidies, they enable multiple uses of financial resources and provide the better quality of the implemented projects, since the credits incurred for the investments must be repaid. This ensures access to the financing for a broader group of entities. The ultimate effect of using the returnable instruments should be increasing the efficiency of the absorption of European Union funds.

The advantages of the financial engineering instruments support the increase in share in financing under the EU funds. This cannot, however, mean a complete abandonment of subsidies that are necessary to finance many types of projects.

14 The gap is connected with the problem of the lack of capital supply, with the existing demand from enterprises that have interesting investment projects. The capital gap problem mainly concerns enterprises in the early stages of development and innovation entities. This is the financial market failure due to information asymmetry between an enterprise and the provider of external capital, resulting in the lack of possibility to obtain funds despite the feasibility of the project to which they are to be allocated. 
A decision to cover certain undertakings with the returnable rather than subsidy financing should be preceded by an analysis that will allow identifying the financial gap in a given sector (Pełka, 2012: 238). Importantly, the use of returnable instruments should in no case be considered as a competition for the subsidy support instruments offered under the Regional Operational Programs. Their role, besides providing additional forms of financing, is to increase the capacity to absorb the funds for small and medium-sized enterprises under the regional programs. The implementation of projects co-financed from the funds under ROPs requires the beneficiary to each time provide own contribution, which is one of the biggest challenges faced by SMEs planning the implementation of investments co-financed from the European funds. And this is where financial engineering instruments that offer relatively easy and inexpensive external financing allowing to create the appropriate financial engineering of undertakings implemented by micro, small, and medium-sized enterprises come to the aid (Gawrychowski, 2017).

Reducing the size of the financial gap in Poland using the returnable instruments should take into account the experience and identified constraints that existed already during the implementation of the above instruments. Otherwise, the potential of returnable instruments for increasing the capital availability for small and mediumsized enterprises will remain unused, and the allocated financial resources will also be unused. The use of returnable instruments is to allow access to external capital for development investments, which can be used multiple times, and the access to it will not be limited by the eligibility of the next financial perspective.

Based on past experience, it is worth to design future returnable instruments to ensure, on the one hand, the high involvement of financial intermediaries and, on the other hand, high interest from the end beneficiaries. To this end, the preparation of central and regional institutions, including, in particular, loan and surety funds as well as cooperative banks, through which funds will be sent to investors, will be of crucial importance for the efficient spending of the funds.

\section{References}

Bera, A., Tokarski, M.: Zaawansowane usługi wsparcia dla mikro, małych i średnich przedsiębiorstw w ramach regionalnych programów operacyjnych na przykładzie województw zachodniopomorskiego i kujawsko-pomorskiego - jak zwiększyć szansę na otrzymanie dotacji? (Advanced support services for micro, small and medium enterprises within the framework of regional operational programs on the example of the Zachodniopomorskie and Kujawsko-Pomorskie voivodships - how to increase the chance of receiving grants?), Zeszyty Naukowe Uniwersytetu Szczecińskiego (Scientific Papers of the University of Szczecin) no. 81 (2012). 
The Role of the Financial Engineering Instruments in the Allocation of EU Funds...

Bobrowska, M.: Fundusze Europejskie w formie pomocy zwrotnej (European funds in the form of repayable aid), Fundusze Europejskie w Polsce (European Funds in Poland) no. 31 (2013).

Czykier-Wierzba, D.: Inicjatywa Jeremie w polityce spójności Unii Europejskiej na lata 2007-2013 i jej funkcjonowanie w Polsce (Jeremie's initiative in cohesion policy of the European Union for 2007-2013 and its functioning in Poland), Journal of Management and Finance no. 2 (2013).

Czykier-Wierzba, D.: Wpływ strategii "Europa 2020” na politykę spójności w Unii Europejskiej w wieloletnich ramach finansowych na lata 2014-2020 i wnioski dla Polski (Impact of the Europe 2020 strategy on cohesion policy in the European Union in the Multiannual Financial Framework 2014-2020 and conclusions for Poland), Journal of Management and Finance no. 14 (2016).

Dobija, E.: Geneza i istota funkcjonowania zwrotnych instrumentów finansowania małych i średnich przedsiębiorstw w Polsce ze środków unijnych: przypadek Jeremie (The origin and essence of the functioning of repayable instruments of financing small and medium enterprises in Poland from EU funds: case of Jeremie), Studia i Prace Kolegium Zarządzania i Finansów SGH w Warszawie (Studies and Works of the Collegium of Management and Finance of the Warsaw School of Economics) no. 139 (2014).

Gawrychowski, M.: Pożyczka zamiast dotacji czyli rozmnażanie euro (Loans instead of subsidies the multiplication of the euro), 2017. www.m.obserwatorfinansowy.pl.

Jaworski, J., Tokarski, M.: Inicjatywa JEREMIE jako forma wsparcia rozwoju mikro, małych i średnich przedsiębiorstw na przykładzie województwa pomorskiego i kujawskopomorskiego (The JEREMIE initiative as a form of support for the development of micro, small and medium enterprises on the example of the Pomeranian and Kujawsko-Pomorskie voivodships), Zeszyty Naukowe Uniwersytetu Szczecińskiego (Zeszyty Naukowe Uniwersytetu Szczecińskiego) no. 111 (2014).

Nicolaides, P.: Financial Engineering Instruments and their Assessment Under EU State Aid Rules. College of Europe, Department of European Economic Studies, Bruges European Economic Policy Briefings no. 26 (2013).

Pełka, W.: Rola instrumentów inżynierii finansowej w alokacji funduszy Unii Europejskiej (The role of financial engineering instruments in the allocation of European Union funds), Studia Biura Analiz Sejmowych (Studies of the Sejm Analysis) no. 31 (2012).

Szczepański, M.: Pozadotacyjne instrumenty finansowe w polityce spójności UE po 2013 r. - wymiar wspólnotowy i krajowy (Adopted financial instruments in EU cohesion policy after 2013 international and national dimension), Warszawa: Ministerstwo Rozwoju Regionalnego, 2011 .

Świstak, M.: Fundusze unijne na lata 2014-2020: programowanie na poziomie unijnym i krajowym (EU funds for 2014-2020: programming at EU and national level), Unia Europejska.pl no. 224 (2014).

Tokarski, A., Tokarski, M.: Barriers and Benefits of Financing projects with European Funds by micro, small, and medium-sized enterprises (MSMEs) in Poland, Journal of Management and Financial Sciences no. 21 (2015). 
Tokarski, M., Konieczka, T.: Działalność inwestycyjna wsparta dotacjami unijnymi a pozycja finansowa przedsiębiorstwa (Investment activity supported by EU grants and financial position of the company), in: Sojaka, S. (eds.): Rachunkowość. Dylematy praktyki gospodarczej (Accounting. Dilemmas of economic practice), Toruń: Wydawnictwo Naukowe Uniwersytetu Mikołaja Kopernika, 2012.

Tokarski, M., Tokarski, A.: Zwiększenie dostępności źródeł finansowania dla sektora mikro, małych i średnich przedsiębiorstw województwa kujawsko-pomorskiego w latach 2007-2013 poprzez fundusz powierniczy JEREMIE (Increasing the availability of financing sources for micro, small and medium enterprises of the Kujawsko-Pomorskie voivodship in the years 2007-2013 through the trust fund JEREMIE), Roczniki Naukowe Wyższej Szkoły Bankowej w Toruniu (Annals School of Banking in Toruń) no. 12 (2013).

Uryga, J., Jagielski, W., Bienias, I.: Środki unijne - klasyfikacja, funkcjonowanie, ewidencja i rozliczanie (EU funds - classification, functioning, accounting and settlement), Gdańsk: Ośrodek Doradztwa i Doskonalenia Kadr Sp. z o.o., 2007.

EU: Council Regulation (EC) no. 1083/2006 laying down general provisions on the European Regional Development Fund, the European Social Fund and the Cohesion Fund, and repealing Regulation (EC) no. 1260/1999.

EU: Regulation (EC) no. 1081/2006 of the European Parliament and of the Council on the European Social Fund and repealing Regulation (EC) no. 1784/1999.

EU: Commission Regulation (EC) no. 1828/2006 laying down detailed rules for the implementation of Council Regulation (EC) no. 1083/2006 laying down general provisions on the European Regional Development Fund, the European Social Fund and the Cohesion Fund as well as Regulation (EC) no. 1080/2006 of the European Parliament and of the Council on the European Regional Development Fund.

EU: Regulation (EU) no. 1303/2013 of the European Parliament and of the Council of 17 December 2013 laying down common provisions on the European Regional Development Fund, the European Social Fund, the Cohesion Fund, the European Agricultural Fund for Rural Development and the European Maritime and Fisheries Fund, as well as laying down general provisions on the European Regional Development Fund, the European Social Fund, the Cohesion Fund and the European Maritime and Fisheries Fund, and repealing Council Regulation (EC) no. 1083/2006.

PL: Regulation of the Minister of Regional Development of 26 October 2011 on the financial aid from the financial engineering instruments under the Regional Operational Programmes. 
SECTION 2.2

PUBLIC INTEREST IN BUDGETARY LAW 



\title{
PUBLIC INTEREST IN BUDGET LEGAL RELATIONS - UKRAINIAN EUROPEAN ASPECT
}

\author{
OKSANA MUZYKA-STEFANCHUK ${ }^{1}$, NATALIYA GUBERSKA ${ }^{2}$
}

\begin{abstract}
The research is devoted to the problems of public interest in budget legal relations. Proved that the public interest is a thing that unites all members in civil society between themselves, state and public power authorities, between Ukraine and EU. The problems of delimitation of the terms "interest", "legitimate interest", "interest protected by the law", "private interests" and "public interests" are analyzed. It is argued that the prevalence of imperative methods of legal influence in the budget law of Ukraine and EU does not assume any possibility for a party under control to impact on taking decisions by the managerial party. Stages in the development of public interest in budget legal relations are investigated. The Author's definition of the concept of public interest in the budget law (legal relations) is offered. It is proved that in the budget legal relations the people who are the source of power do not realize public interest. It is concluded that the public interest of public power authorities in budget legal relations is the main reason if not all but most legally significant actions in the sphere of the budget at national and local levels.
\end{abstract}

\section{Keywords}

Budget; budget law; budget legal relations; public interest; private interest JEL Classification: D63, K00, K15

\footnotetext{
1 Doctor of Law, professor, Taras Shevchenko National University of Kyiv. Contact email: oa.stefanchuk@ gmail.com.

2 Doctor of Law, assistant professor Taras Shevchenko National University of Kyiv. Contact email: gubernat@ bigmir.net.
} 


\section{Introduction}

The purpose of the article is to study the problems of public interest in budget legal relations, as well as inter-budgetary relations, which is one way to ensure the combination of interests of all subjects of these relations. In addition, it is necessary to clearly define the budgetary interests of public authorities. Having clearly defined interests, one can clearly outline the limits of budgetary authority. Such boundaries are important for differentiation of budgetary and tax relations, which differ, in particular, on subjects. And where there are such subjects as individuals, there are private interests of a material and financial nature. In this regard, the issue of defining public interest in budgetary relations does not waste its relevance.

While preparing this material, we used the work of scientists and practitioners from different countries, such as L. Voronova (2007); Jr. R.D. Lee, R.W. Johnson, Ph.G. Joyce (2013: 656); A.C. Hyde (2001: 480); H. Šimović (2005: 245-262); V. Chernadchuk (2009); A. Nechai (2000); O.A. Muzyka (2004); S. Zapolskij (1992); A. Kovalchuk (2005; 2009); A. Wildavsky (1992); P. Anessi, M. Sicilia (2015: 819840).

\section{Interest and its Types in Law and Legislation}

Interest is a thing that unites all members in civil society between themselves, state and public power authorities, between Ukraine and EU. Let's mention that sometimes it is rather difficult clearly to distinguish some or other approach, Author's vision of category "interest"; in some cases, the approach of scientist may even be changed. This means rather a certain convention than the generalization of such division. Hereby, there is no uniqueness in understanding the category "interest" both in national and European law administration and enforcement practice.

Let's mention that the regulatory legal acts refer to "legitimate interests", "legally protected interests". In the opinion of Yu.S. Zavialov (1968: 157-158), the abovementioned concepts are identical, instead, some Authors are inclined to differentiate (Sabikenov, 1986: 45) them. O.I. Chepys (2009: 552) distinguishes the categories "legitimate interests" and "legally protected interests" as objects of legal protection. Within this aspect, there are two objects of legal protection - subjective regulatory rights and legally protected interests. Hereby, it is necessary to take into consideration the fact that the protection of public interest shall be carried out not for the protection of the state itself as a final goal but for the most efficient realization of rights at private persons (Dankov, 2005). 
The Contract about EU (Lisbon agreement of 2007) mentions the concepts "common interest", "mutual interest", "fundamental interest", "strategic interest". All these kinds of interests are united by one - "public interest".

The text of Constitution of Ukraine contains the concept "interest" (its kinds) within its widest meaning for many times: Art. 18 (national interests), Arts. 32, 34, Arts. 36, 39 (interests of national security), Art. 35 (interests of public order protection), Art. 36 (political, economic, social, cultural interests), Art. 41 (interests of society), Art. 44 (economic and social interests), Art. 54 (moral and material interests), Arts. 79 and 104 (interests of all compatriots), Art. 89 (public interest), Art. 121 (interests of citizen, state), Art. 127 (professional interests of judges), Art. 140 (joint interests of territorial communities in villages, settlements and cities). Pointing to availability of such interests, the Constitution of Ukraine emphasizes the necessity in their provision (Art. 18), satisfaction (Art. 36) or protection (Arts. 44, 127). Hereby, the content of interests is not broadly defined. Only the Act of 19 June 2013, on National Security of Ukraine,

(1) contains the definition of term "national interests" - as vital material, intellectual and spiritual values of Ukrainian people as a carrier of sovereignty and the single source of power in Ukraine, determinative needs of society and state, which realization guarantees the state sovereignty of Ukraine and its progressive development (Art. 1). In this occasion, we should also remind on the decision by the Constitutional Court of Ukraine, dd. 1 December 2004, in the case about official interpretation of certain provisions in P. 1 Art. 4 of Civil Procedural Code of Ukraine (a case about legally protected interest) (7), where 3.1 mentions that the etymological content of word "interest" includes: a) attention to someone, something, commitment in someone, something; curiosity, admiration; b) importance; significance; c) a thing that interests someone most of all, that makes sense of someone's thoughts and concerns; d) aspiration, needs; e) a thing that is beneficial to someone, something, conforms to someone's aspiration, needs; profit, benefit, gain. In common sociological meaning the category "interest" is understood as an objectively existing and subjectively realized social need, motive, incentive, causal agent, incitement to action; in psychology - as an attitude of personality to a subject, as to something valuable for it, such one that attracts. In legal acts the term "interest", taking into consideration both its etymological and general sociological, psychological meaning, is used within a wide and narrow meaning as an independent object of legal relations, which realization is satisfied or blocked by regulatory methods.

In Sec. 3.5 of decision mentions that interest may be legally protected, law protected, legal and illegal, i.e. such one that is not protected either by legislation, or by law, shall not be satisfied or provided by them as such interest is directed 
to infringe upon rights and freedoms of other natural persons and legal entities, restricts the interests of society, state or "all compatriots", protected by Constitution and laws of Ukraine or does not conform to the Constitution or laws of Ukraine, generally recognized principles of law. The lawmaker makes the emphasis on "legal protection" or legality in some or other interest not always taking into consideration the fact that the interests, mentioned in legal provisions, do not contradict to the Constitution of Ukraine or arise from its content.

Thus, actually distinguishing the terms "interest", "legitimate interest", "legally protected interest", the Constitutional Court of Ukraine does not point to the substantiation of formal difference between corresponding categories. That's why there is the task to find this difference and to point to the expediency or inexpediency in the application of these terms in existing civil legislation of Ukraine (Chepys, 2009: 551). In our opinion, the public interest of public power authorities in budget legal relations is always legitimate and at the same time legally protected the interest.

The category of interest in the public law allows defining the subject of legal regulation - social relations that are formed on occasion of realization of social interests as a single whole, i.e. social relations with the participation of state (Mikhailov, 2002: 66), as well as public power authorities.

\section{Signs of Publicity in Financial Legal Relations}

As A.A. Nechai (2004: 29) reasonably writes, the criterion for differentiation of public and private part in law, is the interest: the state interests, legal status of its authorities, official, as well as regulation of relations that are distinguished with vividly expressed social character is of prevalent importance for public law; the interests of certain persons are the main ones for private law Let's mention that the national doctrinal developments of issues from public and private interest do not suit in full for European law as Ukraine has its own division into the sectors and subsectors of law; such division cannot be copied to the law in other EU countries, thus, it is not worth speaking about similar division of right into public and private in Ukraine and EU. As it concerns the public interest, so, it still has the same manifestation in budget relations both in Ukraine and other EU countries.

In opinion of A.A. Nechai (2004: 17-18), the legal features of "publicity" in social phenomena may include 1) ownership in object under research: state ownership or community ownership, 2) purpose for use of object under research: whether it is used within the interests of the whole humankind, the whole state, the whole nation, the whole community or the whole union of people, established not due to class 
principle. As O.A. Lukashev mentions, the features of publicity "may undoubtedly apply to characteristics of financial relations, which publicity is shown through assignment of ownership at administrative territorial formations for monetary funds that are accumulated in centralized funds and purpose of their use - provision with fulfillment of functions and tasks of state and territorial communities. The principles for analysis of public finances are characterized by such original provisions in the most general form" (Lukashev, 2009: 404).

In opinion of E.D. Sokolova (2008: 15), "the principle for combination of public and private interests in the sphere of finances is shown in the fact that the state, establishing the rules of common game" in civil turnover, anticipates the conditions for participation of all business entities regardless of pattern of ownership in establishment of centralized state funds of monetary assets. In its turn, it stipulates the necessity in the performance of state financial control for financial activity of business entities regardless of their pattern of ownership.

During development of jurisprudence, most of the scientists-lawyers in the sphere of financial law have not doubted and do not doubt the fact that financial law is the public sector of law and regulates the public relations. Analyzing the concept of public law, the theoreticians make the conclusion that this is the subsystem of law that reflects the state, interstate and public interests. As a result from the appearance of new objects that requires the public legal regulation (self-government, parties, public unions, etc.). For financial law, this means the enlargement of its subject, inclusion of relations that appear on occasion of mobilization, distribution, and use of monetary funds into it, for example, local self-government (Nechai, 2000: 56). The changes in relations of ownership in post-Soviet countries have stipulated the changes in the subject of financial law - in particular, the financial activity of local self-government was included into it (at present moment we will not fix on the issue about inclusion of financial activity at local self-government into the subject of financial law as it has already found its solution in the science of financial law (Muzyka, 2004). Hereby, the publicity of financial legal relations has not been doubted.

However, some recent publications on issues of financial law to a certain degree call in question the whole concept of financial law as public one. So, unlike the statements about public character of financial legal relations, being provided, there are the thoughts that require the special consideration. For example, A.T. Kovalchuk writes: "the determinative peculiarity of financial law under market conditions is not the hard opposition or boundary differentiation of "public" and "private" but their organic combination and interlacement in those financial aspects, where the principle of legal equality, coordination and agreement prevails and which are generated by market reality at the corresponding levels of financial economic 
system" (Kovalchuk, 2009: 13). "The narrow idea about financial law is incorrect, i.e. its restriction only by limits of public law" (Kovalchuk, 2005: 103). Such opinion seems to be doubtful. If we state that the financial law regulates not only public but private relations, so, in fact it cancels the need in existence of the main criteria for division of rules at law system due to sectors, namely due to subject and method of legal regulation. The rules of financial law regulate the relations of power property character. Figuratively speaking, they are the relations of power character, which related to money (funds). However, this "money" has its own peculiarities that differ it from that money, which are the objects of civil legal relations. Money in financial law always relates to public interest. In civil law there is private interest, even the state may have its own private interest (for example, in relations of interstate loans, an issue of state lottery), although hereby private interest to some extent relates to public interest. The rules of (Civil Code of Ukraine (Civil Code, no. 435-IV, no. 435-IV) in particular testify to this fact. According to Art. 81 in this act, legal entities, depending on procedure for their establishment, are divided into legal entities of private law and legal entities of public law. The latter ones are established by directive act from the President of Ukraine, state authority, authority of ARC or local self-government. According to P. 2 Art. 2 in (Civil Code, no. 435IV, no. 435-IV) the participants in civil relations are State Ukraine, ARC, territorial communities, foreign states and other entities of public law. In our opinion, any from abovementioned entities of public law, while entering the civil legal relations, for example, again the relations of "loan character" (concluding credit, loan agreements and acquiring a status of creditor or debtor), realize all the same public interest as loaned funds in $99 \%$ of cases will be used to satisfy the public needs of the state, region, population. Besides, in either case the realization of private interest stipulates the appearance of financial legal relations, in particular, budget relations in the sphere of public debt.

The thought, set forth by A.T. Kovalchuk, may also be acceptable for the financial law of EU countries as the budget and tax law that are considered within economic relations are never distinguished into legal formation there. L.N. Dreval (2008: 113) states that it is incorrect to consider as if private onset is unknown to public financial activity. The realities of life point out to the fact that the state anyhow exceeds the limits of its financial activity. As the confirmation, they provide the opinion of another scientist - D.A. Lisitsyn (2004: 12), who writes that the state does not create any money (here we speak not about emission - Author), it can receive it through transfer of money from non-state into state ownership (as well as - into municipal one - Author) through collection of taxes, other compulsory payments, etc., and, vice versa, it may transfer this money to other entities, including non-state ones. That is we speak about the constant and absolute relation of the private and public law in budget law and budgetary activity, that the one depends on the other or is the 
prerequisite for the origin of the other. But not about interference or acquisition of private relations by a public sphere or vice versa.

The statement by S.V. Zapolskyi (2008: 22-23) that the state carries out its financial activity both as a subject of public power and a carrier of private property interest seems to be rather appropriate in this plane. As "it would be incorrect to consider that the private onset is unknown to financial activity of the state", the scientist also thinks that it is admissible to call the realization of private law interests by the state also as the financial activity. Similarly, we can speak about private property interests at local self-government in budget legal relations but in no case, one can state that the budget legal relations under such circumstance acquire the feature of the private law.

Private interest in public power will always take place as public power is realized by people, who have private interests. In this connection, the constant task of state and society shall be the maximum neutralization of private interests, not Authorized by legislation, in public power as it distorts the purposes and tasks of the state as the general organization of the whole people (Polianskyi, 2002: 52).

The prevalence of imperative methods of legal influence in the budget law of Ukraine and EU does not assume any possibility for a party under control to impact on taking decisions by the managerial party. The development of the country under new economic and state political conditions stipulates the extension in use of the optional method of legal influence on budget relations. The "penetration" of the optional method into the public sphere, namely: budget law - testifies to the possibility for a lawmaker to a certain extent to combine private and public interests (Polianskyi, 2002: 111). Further Yu.A. Krokhina (2014) mentions that the optionality in relation to public financial sphere shall be considered as granting the entities of budget law with the known alternative possibility for the choice of variants for behavior within the limits of budget legislation. In our opinion, the identification of optional method for legal regulation with Authorized budget legal rules, which all the same are imperative, takes place at such vision of optionality. We believe that it is more reasonable to speak about legal influence on entities and participants in budget relations and about legal regulation of budget relations. One should not identify "influence" and "regulation". Influence is a derivative of regulation, although it relates mainly to the inner state regulation. When we speak about the law in EU, so, we can state about the availability of purely influence on inner law and not about regulation of inner relations in the sphere of the budget.

Sometimes we can also notice a certain non-agreement in examples that demonstrate the combination and conflicts of interests. So, Yu.L. Smirnikova (2002: 134) mentions the agreement of certain rules in the budgetary provision for the next 
budget year still until the adoption of acts about the budget as an example for a way to overcome with the conflict of private and public interest in budget relations. At once there appear the questions: where is here private interest? Who has it? Even if we compare the interests of public power authorities - entities of budget legal relations and budget establishment - so, it is a very disputable question about the availability of public interest at the first ones, and only private interest at later ones.

As R.Ye. Artiukhin (2002: 116) writes, the principle for equality of parties in relations of budget establishments with authorities that provide with the fulfillment of budget enjoys more and more popularization that makes the duties of the parties more symmetrical. So, earlier the duties mainly for budget establishments were fixed in budget legislation and executive power authorities were granted with the rights, so, now, budget establishments are legislatively granted with additional laws, to which the duties of executive power authorities correspond. Such categorical statement about almost full "lack of rights" at budget establishments causes the objection. If the rights are fixed at the sub-legislative layer, so, this does not mean that someone does not have the rights, legislatively fixed (of course if we are based on a wide understanding of concept "legislation" itself). The existence of budget establishments on their own already anticipates the rights to receive the funds from the corresponding budget at them. The availability of acknowledged public interest transforms the economic relations into financial ones and incites the state to regulate the part of money flow by imperative method (Chernadchuk, 2008: 142).

In opinion of M. Perepylytsia (2009: 116), public interest in financial law "logically means the objective needs of society, acknowledged by state and provided by law, in organizational and purposeful mobilization (establishment), distribution and use of general (public) financial resources, which may be expressed in different subject form (funds, other material values), as well as performance of control for these processes, which satisfaction may serve as a guaranty for its existence and development".

If we use the category "private interest" in financial law, so, we can be sure that a carrier of such interest would never voluntarily want to acquire the status of subordinate entity: no powerful authorities can be applied to it. How will the financial activity of state and local self-government be realized in this case? In which financial legal relations will a state power authority have the power authorities, and in which will not? We would like to receive the answers to these questions from followers for the existence of so-called "complex" sectors of law.

Providing that the "expanding conception concept" of financial law, which was suggested by A.T. Kovalchuk (2005: 103), is adopted, the method of financial law also requires the revision. As it is known, the imperative method is used for 
regulation of public relations, in financial law - this is the method of power (statepower) instructions, for private relations - optional method. Thus, the imperative optional method of the legal regulation shall be applied in the "expanded" (publicprivate) financial law that in fact due to the legal nature of relations, which are the subject of the independent sphere of law, is not admissible. Therefore, the "expanding concept" of financial law, suggested above, could hardly be accepted as such one that would assist to further development of legal regulation of relations in the sphere of public finances. The financial and budget law concerns the sphere of public relations. If private interest appears at entities of those legal relations, so, this automatically transforms them into entities of other property relations, for example, civil legal ones. We should not remember that the participation in some relations does not assume the possibility for parallel (simultaneous) participation of the same entities in other relations.

The issue of interest is very important for financial and budget law. L.K. Voronova (2007: 34) emphasizes that namely in financial legal relations "the state and local self-government show the public financial interest, satisfying the financial needs of the state, certain territorial formations and at the same time all citizens, interested in the constant function of state authorities and local self-government". E.S. Dmytrenko (2006: 86) on this occasion mentions that the characteristic features of financial law as a sphere of public law is the regulation of relations between state authorities, local self-government, legal entities and natural persons, who are oriented to satisfy the public financial interests using the instructions, issued by state power and which have the categorical and compulsory character .

In the opinion of V.V. Khokhuliak (2004: 5), the category "public interest" in the national science of financial law that is a component of its conceptual categorical construct is applied mainly as a methodological instrument at characteristics and research of certain financial legal institutes. This is the basic, fundamental common scientific concept, as well as one from through categories in the science of financial law. "As one from key cores in definitive identification of financial law as a public sphere of law, this category is used at definition and characteristics of subject, system and principles of financial law, at establishment of sectoral belonging of financial legal institutes, detection of the main landmarks and tendencies in transformation and further development of financial legal system. The content of public interest is certain needs of its subject and its expression is in used ways and means to satisfy these needs" (Khokhuliak, 2004: 9).

In the opinion of V.D. Chernadchuk (2008: 196), we can distinguish the following successive stages in the development of public interest in budget legal relations: 
- objective existence of need in budget funds (budget expenses) as a prerequisite for public interest (availability of objective public needs);

- realization of public interest in satisfaction of needs as a prerequisite for the budget activity of subjects (establishment of public needs);

- fixation (recording in budget legal act) of public interest by rules of budget law (definition of public needs) (here it should be mentioned that the Author, being cited, somehow narrowed the limits of fixation as social (public) needs are defined by the rules of the Main Law and other laws or arise from them);

- budget activity and its result as a realized (provided with budget funds) public interest (budget provision of public needs).

There is the inextricable connection between public interest in budget legal relations and objects of those relations. The object of interest in budget legal relations are the weals that satisfy the acknowledged public needs, and the object of legal relations are the funds, defined by act about the budget, on which occasion there is the legal relationship between entities of budget legal relations as to enrollment, distribution and use of budget funds. An entity of budget legal relations is stipulated by public interest, i.e. acknowledged public needs, which are not an entity of budget legal relations, as are an entity of other relations (Chernadchuk, 2008: 196-197).

\section{Concept of Public Interest in Budgetary Law and Budget Legal Relations}

Public interest in budget law (legal relations) - this is an objectively existing phenomenon, which does not depend on the will of public power authorities and general compulsory regulatory legal acts, approved by them. Such acts only mediate the existence of public interest but their absence does not exclude the further existence of public interest.

The idea is that "another major distinction between private and public budgeting is the motivation behind budget decisions. The private sector is characterized by the profit motive, whereas government undertakes many things that are financially unprofitable. In the private sector, profit serves as a ready standard for evaluating previous decisions. Successful decisions are those that produce profits (as measured in dollars). Some companies, of course, focus on short-term profits, and others may take a longer-term view, but in the end, failure to achieve a profit or at least break even means the company goes out of business" (Lee, Johnson, Joyce, 2013: 3). So, the issue of public budgeting related to the drafting, review, approval, and execution of the budget is regulated at the legislative level. All decisions are public in nature. The law protects the objective budget interests and only within the limits, which 
are acknowledged to be socially significant. According to the rules of Budget Code of Ukraine, the socially significant interested, which are protected by law, are such ones that correspond to existing legislation. Here we mean precisely Art. 116 in Budget Code of Ukraine "Infringements of budget legislation". Thus, the budget interests of public power authorities may be the ones, related to 1) inclusion of authentic data into budget requests; 2) non-infringement of periods, established for submission of budget request; 3) definition of authentic volumes for budget funds at planning of budget indices; 4) planning only those receipts and expenses of budgets, which are anticipated by Budget Code of Ukraine or law about State Budget of Ukraine; 5) non-infringement of established procedure or periods for submission of draft law about State Budget of Ukraine (draft decision about local budget) for consideration of Verkhovna Rada of Ukraine (Verkhovna Rada of ARC, local council); 6) non-infringement of established procedure or periods for consideration of draft law and adoption of law about State Budget of Ukraine (decision about local budget); 7) taking decision about local budget exclusively according to requirements of Budget Code of Ukraine or law about State Budget of Ukraine (including as to composition of budget in the part of inter-budget transfers, incomes and expenses of local budgets, which are taken into consideration at definition of volume for interbudget transfers); 8) non-infringement of requirements in Budget Code of Ukraine about approval of state budget (local budget) with deficiency or proficit; 9) noninclusion of receipts from sources, if they are referred to such ones by Budget Code of Ukraine or law about State Budget of Ukraine, into composition of special fund at budget; 10) non-enrollment of budget incomes to any accounts, except single treasury account (except the assets that are received by establishments of Ukraine, which function abroad), as well as their accumulation in accounts of authorities that control the collection of budget receipts; 11) non-enrollment of budget incomes to budget, other than defined by Budget Code of Ukraine or law about State Budget of Ukraine, including as a result from division of taxes and duties (compulsory payments) and other incomes between budgets with infringement of determined sizes; 12) making the state (local) loans, rendering the state (local) guarantees according to requirements of Budget Code of Ukraine; 13) not taking the decisions that cause to excess of limit volumes for state (local) debt or limit volumes to render the state (local) guarantees; 14) non-placement of temporary free budget funds with infringement of requirements in Budget Code of Ukraine; 15) prohibition for establishment of extra-budget funds, opening the extra-budget accounts to place the budget funds; 16) non-infringement of procedure or periods for submission, consideration and approval of estimates and other documents that are used during fulfillment of budget, as well as approval of indices in estimates, which are confirmed by calculations and economical substantiations; 17) observance of procedure or periods for submission and approval of passports for budget programs (in case if the special-purpose program is used in budget process); 18) observance of periods, 
established for proof of documents about volumes of budget appropriations to managers of budget funds at low level or recipients of budget funds; 19) observance of procedure and periods to open (to close) accounts at authorities of Treasury of Ukraine; 20) acceptance of obligations with corresponding budget appropriations and according to authorities, established by Budget Code of Ukraine or law about State Budget of Ukraine; 21) observance of procedure for registration and accounting of budget obligations; 22) non-infringement of requirements in Budget Code of Ukraine while making the previous payment for goods, works and services to account of budget funds, as well as observance of procedure and periods to make such payment; 23) not making the payments to account of budget funds without registration of budget obligations; 24) special use of budget funds; 25) observance of requirements in Budget Code of Ukraine while making the expenses of state budget (local budget) in case of untimely adoption of law about State Budget of Ukraine (untimely taking decision about local budget); 26) not rendering the credits from budget or return of credits to budget according to requirements in Budget Code of Ukraine; 27) making the loans in any form by budget establishments or granting the credits from budget by budget establishments to legal entities or natural persons according to Budget Code of Ukraine; 28) not making the expenses, crediting the local budget, which shall be carried out from another budget; 29) noninfringement of requirements in Budget Code of Ukraine as to allocation of assets from reserve fund of budget; 30) non-infringement of requirements, established to application of budget classification; 31) inclusion of authentic data into reports about fulfillment of state budget (local budget), annual report about fulfillment of law about State Budget of Ukraine (decision about local budget), as well as observance of procedure and periods for submission of such reports; 32) observance of requirements, established to run accounting and to compose reporting about fulfillment of budgets; 33) observance of procedure and periods, established for submission of financial and budget reporting or budget establishments, as well as submission of such reporting in full; 34) provision with conformity of data, provided in financial and budget reporting of budget establishments, accounting data; 35) inclusion of authentic data into reports about performance of passports for budget programs (in case if the special-purpose program is used in budget process), as well as observance of procedure and periods for submission of such reports; 36) issue of regulatory legal acts that do not reduce the receipts to budget or increase its expenditure part in contrary to the law; 37) making expenses to keep a budget establishment; 38) observance of procedure for disclosure and availability of information about budget, etc.

One of the ways to provide with the combination of interests at all entities of these relations is the construction of the hierarchy of those interests at the legal regulation of inter-budget relations. Taking this fact into consideration, the main criteria to 
establish the limits for the satisfaction of interests at state Ukraine that really have the higher place in the hierarchy of interest are budget interests of its administrative territorial units and local self-government, which shall not be restricted.

The realization of public interest in budget legal relations has certain restrictions. We mean the restriction of its realization through the expression of will. According to Art. 69 in Constitution of Ukraine the people's expression of will is carried out through elections, referendum and other forms of direct democracy. Thus, it is not allowed to perform the referendums about draft laws on issues about taxes, budget, and amnesty (Art. 74 in Constitution of Ukraine). The possibility for realization of public interest in budget legal relations through elections seems to be doubtful. There are only "other forms of direct democracy", which traditionally include different meetings, forums, public discussions, demonstrations, addresses of citizens, rarely - not peaceful forms (starvation in protest against something, strikes, picketing, rebellions, etc.). It is rather problematic to refer these forms to the forms for the realization of public interest in budget legal relations. There is the question: how is the public interest realized in relations, which are considered? In our belief, the people (despite the fact that according to Art. 5 in Constitution of Ukraine it is a carrier of sovereignty and the single source of power in the state) is not able really to realize the public interest in budget legal relations, thus, its realization relies namely on public power authorities.

It is believed that public budgeting is also about assigning responsibility for accomplishing the results intended by the executive and legislative actors that ultimately set the budget. Budgets are generally executed by individuals in large bureaucracies (Lee, Johnson, Joyce, 2013: 2). But such a statement is somewhat erroneous or too narrow, given that individuals as such are not subjects of budget legal relations. When we call individuals among subjects, they mean officials - budget funds managers, heads of budget institutions, acting on behalf of the institution and solely in the public interest. In general, budget execution is a function of executive power, not individuals.

\section{Conclusions}

The public interest of public power authorities in budget legal relations is the main reason if not all but most legally significant actions in the sphere of the budget at national and local levels.

In our opinion, the public interest of public power authorities in budget legal relations establishes the connection of these authorities with natural persons and legal entities of different legal forms, hereby such connection is mediated by budget 
(as a legal category, i.e. the act about budget that grants certain authorities to receive the incomes and to make the expenses by corresponding bodies and establishments; as an economical category as it is the fund of assets that are practically spent, in particular, to keep concrete establishments, to pay out salaries, pensions) and defines the subject of budget law, which are the relations, related to budget activity.

\section{References}

Anessi, P., Sicilia, M.: Biased budgeting in the public sector: Evidence from Italian local governments, Local Government Studies no. 4 (2015).

Artiukhin, R.Ye.: Частно-правовые элементы в бюджетном праве. Интерес в публичном и частном праве: материалы науч. конф. (Private legal elements in budget law. Interest in public and private law: materials by scientific conference), Moscow: 2002.

Chepys, O.I.: Законний інтерес як категорія цивільного права (Legal interest as a category of civil law), Форум права (Forum of law) no. 1 (2009).

Chernadchuk, V.D.: Стан та перспективи розвитку бюджетних правовідносин в Україні (Conditions and perspectives for development of budget legal relations in Ukraine), Sumy: University book, 2008.

Dankov, A.А.: Баланс частного и публичного интересов и его значение в правоприменительной деятельности. Проблемы местного самоуправления (Balance of private and public interests and its meaning in law enforcement. Problems of local self-government), 2005. www.samoupravlenie.ru.

Dmytrenko, E.S.: Фінансове право України. Загальна частина: навч. посіб (Financial law of Ukraine. General part: study guide), Kyiv: Alerta. KNT, 2006.

Dreval, L.N.: Субъекты российского финансового права (Subjects of Russian financial law), Moscow: Jurisprudence, 2008.

Hyde, A.C.: Government budgeting: theory, process, and politics, Belmont, California: Wadsworth Publishing, 2001.

Khokhuliak, V.V.: Публічний інтерес як категорія науки фінансового права (Public interest as a category of science of financial law), Наук. вісн. Чернів. ун-ту: зб. наук. пр. Сер. «Правознавство» (Scientific herald of Chernivtsi university: a collection of scientific works. Series "Legal Science") no. 4 (2004).

Kovalchuk, A.T.: Фінансове право України в ринкових умовах: проблеми формування, розвитку, застосування. Автореф. дис. докт. юрид. наук. (Financial law of Ukraine under market conditions: problems of formation, development, application. Author's abstract by Doctor of Law), Kyiv: Taras Shevchenko National University of Kyiv, 2009.

Kovalchuk, A.T.: Фінансове право: усталений термін з невизначеним предметом (Financial law: stable term with indefinite subject), Право України (Law of Ukraine) no. 8 (2005).

Krokhina, Yu.А.: Финансовое право России (Financial Law of Russia), Moscow: Norma, 2014. 
Public Interest in Budget Legal Relations - Ukrainian European Aspect

Lee, Jr.R.D., Johnson, R.W., Joyce, P.G.: Public Budgeting Systems, Burlington: MA: Jones \& Bartlett Learning, 2013.

Lisitsyn, D.A.: Финансовая деятельность государства: содержание, методы осуществления. Автореф. дис. канд. юрид. наук (Financial activity of the state: content, methods of implementation. Author's abstract by Candidate of Law), Cheliabinsk: South Ural State University, 2004.

Lukashev, O.А.: Класифікація публічних фондів коштів в контексті побудови системи фінансового прав (Classification of public monetary funds in the context of building the system of financial law), Форум права (Forum of law) no. 3 (2009).

Mikhailov, S.V.: Категория интереса в российском гражданском праве (Category of interest in Russian civil law), Moscow: Statut, 2002.

Muzyka, O.А.: Доходи місцевих бюджетів за українським законодавством (Incomes of local budgets under Ukrainian legislation), Kyiv: Atika, 2004.

Nechai, А.А.: Фінансова діяльність держави та фінансове право в сучасний період: їх поняття (Financial activity of state and financial law during present period: their concepts), Право України (Law of Ukraine) no. 1 (2000).

Nechai, A.А.: Проблеми правового регулювання публічних фінансів та публічних видатків (Problems on legal regulation of public finances and public expenses), Chernivtsi: Ruta, 2004.

Perepylytsia, М.: Публічний інтерес як мета діяльності суб’єктів фінансового права (Public interest as a purpose for activity of financial law entities), Вісн. Акад. прав. наук України (Bulletin of Academy of Legal Sciences of Ukraine) no. 2 (2009).

Polianskyi, V.V.: Публичные и частные интересы в конституционном праве: проблемы и гармонизация. Интерес в публичном и частном праве: материалы науч. конф (Public and private interests in the constitutional law: problems and harmonization. Interest in public and private law: materials by scientific conference), Moscow, 2002.

Rubin, I.S.: The Politics of Public Budgeting: Getting and Spending: Borrowing and Balancing, Washington: CQ Press, 2013.

Sabikenov, S.N.: Право и социальные интересы (Law and social interests), Alma-Ata: Znaniie, 1986.

Šimović, H.: The European Union budget, Financial Theory, and Practice, no. 3 (2005).

Smirnikova, Yu.L.: Соотношение частных и публичных интересов в финансовой деятельности. Интерес в публичном и частном праве: материалы науч. конф. (Correlation of private and public interests in financial activity. Interest in public and private law: materials by scientific conference), Moscow, 2002.

Sokolova, E.D.: Теоретические аспекты правового регулирования финансовой деятельности государства и муниципальных образований: дис. докт. юрид. наук (Theoretical aspects for legal regulation of financial activity of state and municipal formations: dissertation by Doctor of Law), Moscow: Moscow State Academy of Law, 2008. 
Oksana Muzyka-Stefanchuk, Nataliya Guberska

Wildavsky, A., Caiden, N., Kettl, D.F., The New Politics of the Budgetary Process, London: Pearson, 2003.

Voronova, L.K.: Фінансове право України (Financial law of Ukraine), Kyiv: Precedent: My book, 2007.

Wildavsky, A.B.: The politics of the budgetary process, New York: Harper Collins, 1992.

Zapolskyi, S.V.: Дискуссионные вопросы теории финансового права (Debating points in theory of financial law), Moscow: RAP: Exmo, 2008.

Zavialov, Yu.S.: Проблема интереса в марксистской теории социалистического права: дис. канд. юрид. наук (Problem of interest in Marx theory of socialistic law: dissertation by Candidate of Law), Moscow: Lomonosov Moscow State University, 1968.

UA: Constitution of 28 June 1996, as amended.

UA: Civil Code, no. 435-IV, as amended.

UA: Civil Procedure Code of Ukraine, no. 1618-IV, as amended.

UA: Act of 19 June 2013, on National Security of Ukraine, as amended.

UA: Constitutional Court of Ukraine: no. 18-рп/2004. 


\title{
TEN YEARS OF PERFORMANCE BUDGET IMPLEMENTATION IN POLAND - SUCCESSES, FAILURES, FUTURE
}

\author{
MARTA POSTUEA
}

\begin{abstract}
The article presents public governance instruments used to fulfill respective functions of the state. At the same time, attention is drawn to the fact that what matters is not only the instruments but also governance methods in which the same are used, which is why an attempt is made in the article to make reference mainly to the issues related to performance budgeting. However, guidelines on how to improve this tool should not overshadow the main conclusion, namely that citizens can be confident about the quality of tools used in Poland. Consequently, efforts should be made to further improve them, but they should be adapted to the realities of a given country as there is nothing more erroneous than to apply models that, admittedly, work out worldwide but can be in no way incorporated into Polish social systems and into Polish traditions, habits and culture. Furthermore, solutions developed for the purposes of one country may prove not only effective locally, but also usable elsewhere. A good example would be the Polish recipe for maintaining GDP growth rate during the crisis, which Europe can learn from.
\end{abstract}

\section{Keywords}

Performance budget; efficiency; governance; transparency

\section{JEL Classification: H30, H40, H50}

1 Habilitated doctor, associate professor at the University of Warsaw, Faculty of Department, Director of the
Centre for Entrepreneurship, professor at Kozminski University (Poland). The author specializes in government
finance, EU public finance and public debt management. Contact email: mpostula@wz.uw.edu.pl. 


\section{Introduction}

Poland is one of the CEE countries which, for the last 28 years, have been undergoing a quite systematic process of transitioning from centrally-controlled economy to free-market economy. As part of the institutional changes taking place, the economic structure has also been changing, and the social and economic policy has been faced with newer and newer challenges. The recent crisis of 2007-2008 showed that the tools chosen in Poland to stimulate and stabilize the social and economic growth are bringing the expected outcomes. Poland was one of the few EU countries, and of the few countries in general, to record an economic growth of ca. 3\% GDP in the period of 2009-2010. The condition of public finance in the period analyzed was improving quite systematically and the government quite smoothly (and with no negative effect for public finance deficit and for public debt) was implementing consolidation packages which, as proven over time, helped lay the solid foundation for the Polish economy.

Considering the evolution of indicators reflecting the fiscal policy, it is important to establish whether and in what way these were promoted not only by relevant decisions but also by methods of public finance management supporting the decision-making process. Consequently, one of the main goals of the article is to evaluate one of the institutional solutions applied in Poland to ensure efficient, smooth management of public funds that is performance budgeting. Several years into the implementation of this solution, it is worth reflecting on it and drawing conclusions from the measures adopted by the Polish government.

The article presents a comparative analysis of performance budget definitions, and the new trends emerging in the contemporary discourse on public governance methods. The analysis was applied to publications on this topic as part of the purposive sampling of literature. The fundamental differences and similarities between the traditional and performance-based public finance management are discussed. A thought experiment method is also used as part of the iterative process of the analytical method and logical construct. To that end, stress conditions are identified as defined in the performance-based budget development - both in the context of threats and opportunities, by constructing relevant logical sequences between the gaps and possibilities to use correlations presented therein, as part of corrections of the logical process.

\section{Management by Objectives as a Tool Used in Public Sector}

For decades now, experts and economists have been analyzing and debating on the public spending efficiency, especially the efficiency of the distribution role of 
the government. These debates have been conducted both internationally and in Poland. Eminent researchers develop various methods to demonstrate the efficiency of public transfer sector or lack thereof, due to bad governance method or bad choice of instruments used by the public finance sector. In Poland, the discussion on the quality of public transfers, especially of the public spending, has been on for at least several decades now, pointing out, each time, to the ever-topical need to improve the efficiency of public spending both from the state budget and from other entities comprising the public sector. The eternal question that proposes itself is how to measure this efficiency and how to set the yardstick for such efficiency? Should this yardstick be the scale of expenditure transferred to the economy, as this way we can, indirectly, increase consumption and make it grow faster, or directly, stimulate the growth in the desirable direction, which thus reduces the range of poverty or the scale of social exclusion, among others? Or maybe the efficiency of public spending should be measured out in public goods provided, their quality or even by the citizens' satisfaction level?

With dilemmas presented this way, one cannot talk solely about the quality of public goods as the only priority. After all, they are funded from taxes, the amount of which undoubtedly impacts the economic growth, which was discussed more broadly in the first part of the article. What are the tools for measuring this efficiency then? If we take a close look at international solutions, obviously the practice of efficiency measurement is a widely-established phenomenon, and one that is intensely developed as methodological progress is achieved and knowledge in that domain grows. For example, in 2015 (OECD, 2011: 140), OECD formulated the so-called quality-of-life index, which refers to several major elements indicating the role of government, and the indicators of importance for this issue. Such perspective on the issue corresponds to the fundamental dilemma of "what is the government's purpose"?

There is a widely accepted paradigm that the government acts for and for the benefit of citizens, in order to, among other things, balance social differences, eliminate poverty, satisfy the basic needs of the citizens who live on its territory (and of those living abroad), as well as to ensure the sense of security (optimizing the satisfaction level). In this context, when defining the efficiency of public spending, we first and foremost refer to the standards of living of our citizens both in economic terms and in terms of satisfying the basic social needs and ensuring security (Barro, 1996: 29). Considering the top-down solutions such as the indicator suggested by OECD or other commonly applied quality-of-life indicators, and bearing in mind that these are very synthetic, highly generalised aggregates, a question presents itself of how to reach the due level of accuracy of analysis, when moving from the category of spending, which is defined in respective classification items, and how to refer to 
those aggregates? In this context, a number of instruments are available to evaluate the quality of respective spending items in the mid- and long-term, including performance budget (EC, 2002: 45), which, in the past several decades, has been the object of many publications, numerous studies and expert evaluations, as well as many discussions, monographs and polemics.

At the same time, a question arises, to which OECD is trying to find an answer, by conducting in 2016 another analytical and comparative study: is the performancebased budget and its other equivalents in respective countries of the world still being developed or not. In this context, it is worth looking at Polish experiences to check whether this tool is applied in Poland. Without getting too much into details, though respective stages related to performance budget may be considered successful, one can say that central-level performance budget has been developing dynamically in Poland since 2006 when the Polish government decided to implement it (Postuła, 2012: 68). An assumption was made that Poland's accession to the European Union was a good time to change the instruments of efficient management and to join the trend of modern management of EU funds which - in line with the standards set out by the European Commission - are accounted for in an innovative manner referred to as performance-based. This means that specific spending items have a clearly defined use for which they can be spent, the purposes they are meant to achieve, the milestones (work schedule - often a multiannual one), with the achievement of both impact and output indicators (and thus the achievement of objectives) contributing to the possibility of spending and accounting for the money.

Though the performance-based budget is a tool used by many countries worldwide, it is actually difficult to find a clear definition of what it is, both in the scientific nomenclature and in international studies (Robinson, 2013: 14). However, we can assume that the term "performance budget/planning" means, simply put, an institution consisting in planning the state budget expenditures by referring them to relevant tasks and sub-tasks, objectives and metrics (Jong, 2016: 4). It is a cuttingedge method of managing public funds by objectives that are adequately concretized and prioritized to achieve specific results, i.e. to complete tasks measured by a defined system of metrics.

State expenditure planning with the use of performance budget helps obtain answers to the following questions:

1. What tasks are executed by respective holders of budget parts in the state budget?

2. What expenditure does the state earmark to respective tasks?

3. What objectives are to be achieved by earmarking expenditure for specific tasks? 
4. What effects (results) are to be achieved by the accomplishment of the intended objectives?

5. To what degree have the intended objectives been achieved thanks to the expenditure undertaken?

Answers to these questions are hard to obtain using the traditional state expenditure planning.

Performance budget is an institution that has been applied and proved effective in the practice of many countries (among which the United States and New Zealand), including European Union member states (e.g. the United Kingdom, The Netherlands, France, Germany, Slovakia). Poland is clearly drawing on those solutions and experiences (e.g. France) (Postuła, 2011: 68). Some CEE countries, as of today, declare to have a performance budget in place, while it only means they have a defined catalog of budget classification, including a division of tasks, but it's hard to say they literally have a full-scale performance budget (Ruśkowski, 2011: $84)$.

Performance budget also has other advantages, namely:

- It is based on multiannual performance planning and ensures integration of multiannual financial plans with the state's formal strategies, thus drawing on financial planning methods in place in the European Community (e.g. New Financial Perspective 2007-2013, multiannual financial framework, annual budget of the European Communities), and it enables implementing the Lisbon Strategy and updating the Convergence Programme;

- It enables consolidating the public expenditure incurred both from the state budget and from other sources (e.g. EU funds, national special purpose funds);

- It enables planning public expenditure relating to the implementation of inter-ministry performance programs;

- It makes it easier to maintain a low budget deficit, which represents one of the requirements for meeting convergence criteria;

- It increases and broadens the transparency of public finance, in particular, it ensures full disclosure of the intended and actual use of public funds in the form of budget expenditure and expenditure financed from state specialpurpose funds and from EU funds;

- It increases the transparency of the public spending recognized in the budget law;

- It enforces budgetary control over what is important for the efficiency of public spending; 
- It enforces strict public finance discipline as regards the implementation of the budget law and the implementation of public finance entities' financial plans;

- It supports the process of good governance of public funds, which represents the fundamental principle of finance in the European Union.

\section{Solutions Used in Polish Work on Performance Budget}

In Poland, the first attempts at introducing performance budget were taken by local government entities (among others Kraków, Lublin, Szczecin, and Poznań in the 1990s). Meanwhile, at the central level, the process of introducing performance budget was initiated in 2006 at the Chancellery of the Prime Minister, where the first methodology of performance budget was developed, and the model of performance budget was prepared for some budget parts (i.e. for part 28 - Science and part 38 - Higher education). The areas and entities covered as well as the performance budget methodology were systematically broadened and improved as part of the implementation process, which has been coordinated by the Ministry of Finance since 2008.

It has been assumed that the objective of phase I of the work would be to implement a budget referred to as presentation or performance budget (according to the threelevel OECD classification, it is level one). In this model, the expenditure structure is presented based on performance, usually as a supporting document for legally binding acts, which helps increase the transparency of public spending and improve the quality of the debate on the state-wide spending policy. At the same time, efficiency information can be used, as an aid, in managing public finance as the information and management functions complement each other. Meanwhile, at further implementation stages, efficiency information is expected to be developed towards the so-called performance-informed budgeting, which enables direct support for allocation decisions taken as part of the budget process and mid-term planning (Marcel, 2012: 34).

Assumptions as to objectives and as to major stages of performance budget implementation are reflected in the adopted legislative solutions, introduced with the Act of 27 August 2009, on Public Finance, and Act of 27 August 2009 - Implementing measures to Act on Public Finance, and then specified in greater detail in the implementing measures (Postuła, 2009: 84). The Law on Public Finance defines the concept of the so-called "performance-based" presentation while specifying the place, role, scope (in terms of areas and entities) of performance budget in the public finance system. Meanwhile, relevant regulations 
of the Minister of Finance define the methodology of performance-based budget planning, performance-based budgetary reporting and the principles of performance-based budget implementation recording (Stankiewicz, 2010: 45). It should be emphasized that the provisions of the Law on Public Finance, which regulate respective elements of performance budget system, became effective gradually, as per time schedule provided for in the implementing measures. The last ones to take effect, as of 1 January 2013, were the legal provisions relating to the assessment of public spending efficiency and effectiveness, which regulate the overall control of the Minister of Finance as regards efficiency and effectiveness of performance budget implementation as well as supervision and control of holders of respective budget parts over efficient and effective implementation of performance plans based on objective achievement metrics (Owsiak, 2011: 68). Hence, the first budget year which saw a full application of performance budget mechanisms planning (including consolidated ones), recording, reporting as well as control and supervision mechanisms - was 2013.

The adopted work schedule for performance budget implementation process enabled a gradual improvement of the solutions adopted, taking account of suggestions and recommendations formulated both by budget holders directly engaged in the process and by the Supreme Audit Office (O'Keefe, Simunic, Stein, 1994: 67). Particularly significant recommendations were also formulated in final reports from two far-reaching reviews conducted by OECD experts (Performance Budgeting in Poland. An OECD Review of 2011 and Public Governance Review (OECD, 2011: 26). Poland. Implementing strategic-state capability of 2013), where high appreciation was expressed for what had been achieved so far in the area of performance budgeting. The actions undertaken were oriented to increase transparency, cohesion, quality, usability, and comparability of data on public spending efficiency and effectiveness, as acquired through performance budget.

When joining the European Union in 2004, Poland was aware that transfers received from that community would bring great benefit to the Polish economy. In addition, they also contributed a new model of public spending, the so-called management of European funds by objectives (Orłowski, 2010: 124). Therefore, this spurred reflection on whether to apply similar principles of spending to all expenditures of the public sector in Poland and marked the beginning of official work on implementing performance budgeting in the government administration.

The principal factors that were necessary for Poland when taking the decision to implement performance budgeting included:

- Support from Parliament and government for the performance budget implementation process; 
- Building a team with the strong determination to carry out the necessary reforms;

- Financial resources necessary to prepare public administration employees and decision-makers for the implementation and use of performance budgeting.

If public funds are spent, they should be earmarked for specific tasks which need to be completed, and concrete results of the completion of those tasks are anticipated (Cohen, 2008: 88). If the expected results are not met, then it must be examined why this happened and conclusions must be drawn for the future - this is the proper spending management. Such an assumption was most correct. One fundamental error was committed, however. The term "performance budget", as is well known, corresponds, first and foremost, only to a selected strictly "financial" aspect of public sector functioning. Indeed, the budget is associated exclusively with financial funds and refers neither to the efficiency of operations, nor to the results achieved, and it is directly handled by financial services.

Such positioning of work on performance planning can be seen as the source of trouble with understanding the appropriate function of the reform being undertaken. If we compare the public finance sector to the private sector, in the private sector the preparation of strategic documents, their evaluation and drawing conclusions from this process are the responsibility of specially appointed business units, directly reporting to a Management Board Member. Financial departments take part in such a process, but without the leading role as to the shape of the whole document. To a great extent, such rule should be reflected in the public sector. However, a decision was made to delegate the process of management by objectives in the public sector directly to budgetary units rather than strategic ones. This was one of the greatest ailments in the first years of performance budget implementation in Poland.

The accounts of those taking part in the first Polish experiences, where performance budget was first applied at the local level (it was in the city of Kraków) show that the assumptions were similar already from the beginning (Marczewski, 2012: 21). Those responsible for performance budget implementation at the government administration level did not opt to change the name, despite this concern. This, unfortunately, caused a shift in the emphasis of this budgeting method towards a budget that is associated solely with a breakdown of money intended to perform tasks. This imperfection, initiated in the beginning, was repeated when the process of budget implementation in the government administration sector started, when the responsibility for the functioning of this tool was placed, first and foremost, on budgetary units, which, obviously, went beyond the specifics of their work. Of course, throughout the period of performance budget implementation in Poland, which involved a great number of seminars and expert opinions, there were attempts to convince competent units at ministries, central offices and agencies, 
that performance budget is a tool formulated to enable them to use it in the decision-making process rather than only for the financial and accounting purposes (Mielcarz, 2012: 60). Undoubtedly, this had also its advantages as, in many cases, those coordinating and taking an active part in budget negotiations, and those managing those units had a chance to get a deeper understanding of the essence of the matter for which funding was provided, while, previously, the amounts of that funding had been planned primarily based on historical trends and data. Better efforts were made to understand the use of funds for which demand was reported, if, in parallel, a consideration was given to the objectives and metrics of respective budget tasks. However, ultimately this could not replace the expertise input of line units competent for the control, supervision, and evaluation of respective public tasks, as well as for strategic planning in those areas (Franek, 2010: 6). Admittedly, this way of involving competent units, for example, those at ministries, came later at a mass scale, but ultimately it has come to be quite a widespread, unquestionable, thorough, systematic and reliable practice of the holders of all budget parts.

First and foremost, efforts were made to increase the degree of integration of performance budget with the development policy, and the degree of integration of internal management systems and instruments with the performance budget. To combine responsibility for public finance management (as resulting from the Public Finance Law) with responsibility for initiating, formulating, as well as implementing and coordinating Council of Ministers policy (as defined in the Law on Government Administration Divisions), while maintaining the constitutional or statutory independence of respective supreme public authorities and audit, judiciary and security institutions, was the aim of detailed changes regarding the principles of laying down the performance structure (that of budgetary tasks, subtasks and measures), defining objectives or identifying the measures of their completion. Work on fine-tuning the system for measuring the degree of completion of objectives defined as part of performance budget (system of metrics) was another major element in this respect. In order to improve the quality of the measurement system, starting from the planning process for 2013, a procedure was introduced whereby the Minister of Finance would assess, ex-ante, the completion and compliance of metrics for a given budgetary year with standards and methodological guidelines.

Secondly, with an aim to satisfy information and analytics needs related to the assessment of public spending efficiency and effectiveness in the context of the possibility of using efficiency information in support of allocation decisions, efforts were also made to connect both classification perspectives of budget planning (performance-based and traditional one) - by integrating financials at the level of "budgetary task - division and chapter of budget classification", and to ensure stricter correlation between planning results and expenditures, and thus the budget 
holders' accountability - for example by introducing a principle that at the stage of preparing materials for the Multiannual State Financial Plan, objectives and metrics for budgetary tasks and subtasks are defined, and the values of metrics are adapted to full compliance with the level of budgetary allocation of funds in accordance with the budget law for a given year.

Thirdly, work was also undertaken to ensure the necessary assistance, and integration of IT processes supporting performance-based budgetary reporting and planning at the Trezor platform. Ultimately, these processes should enable the integration of all budgetary processes into one IT system.

A fourth area involved training activities, which were strictly entwined with the adopted further stages of the implementation process. Initially, they focused on the aspects relating to performance budget concept and methodology. However, as time went by, the increasingly greater emphasis was placed on the development of knowledge, skills, and attitudes which make it possible to use data from the presentational model of performance budget to manage units and assess the public spending efficiency and effectiveness and to monitor and evaluate public tasks.

Table 1 features the main stages of work on performance budget implementation in Poland, as presented by the Ministry of Finance.

\section{Table 1 Information on Main Stages of Work on Performance Budget Implementation in Poland}

\begin{tabular}{|c|c|c|}
\hline Period & Legal solutions & Expected result (products) \\
\hline $2006-2007^{*}$ & $\begin{array}{l}\text { 2006: the following duties introduced in the Public } \\
\text { Finance Law: } \\
\text { Budget holders' duty to provide a performance- } \\
\text { based presentation of expenditure in the explanatory } \\
\text { memorandum for the budget bill } \\
\text { Council of Minister's duty to present task performance } \\
\text { information to the lower house of Polish Parliament } \\
\text { (Sejm) as part of the reports on the implementation of } \\
\text { the state budget }\end{array}$ & $\begin{array}{l}\text { Explanatory memorandum for the } 2007 \text { budget bill } \\
\text { - performance budget model for } 2 \text { budget parts, i.e. } \\
\text { part } 28 \text { - Science and part } 38 \text { - Higher Education } \\
\text { Explanatory memorandum for the } 2008 \text { budget bill } \\
\text { - expenditure of } 67 \text { budget holders, recognized } \\
\text { in } 82 \text { budget parts, broken down into tasks and } \\
\text { subtasks }\end{array}$ \\
\hline 2008-2010 & $\begin{array}{l}\text { 2009: new Public Finance Law adopted: } \\
\text { Performance-based presentation defined } \\
\text { A duty introduced to present a performance-based } \\
\text { consolidated expenditure plan (inclusive of state } \\
\text { budgetary units, state special-purpose funds, executive } \\
\text { agencies, state legal persons and public finance } \\
\text { institutions (pl. instytucje gospodarki budżetowej) in the } \\
\text { explanatory memorandum for the budget bill } \\
\text { A duty introduced to provide a performance-based } \\
\text { presentation of the information on expenditure } \\
\text { implementation, in reports on the implementation of the } \\
\text { state budget } \\
\text { A duty introduced to provide a performance-based } \\
\text { presentation of multiannual programs in the budget law } \\
\text { Delegations for the Minister of Finance to define } \\
\text { by regulations: the performance-based planning } \\
\text { methodology, performance-based budgetary } \\
\text { reporting, and principles performance-based budget } \\
\text { implementation recording. }\end{array}$ & $\begin{array}{l}\text { Performance-based explanatory memoranda } \\
\text { for the budget law - for respective years (from } \\
\text { the explanatory memorandum for } 2013 \text { onwards, } \\
\text { these have been prepared as a consolidated } \\
\text { presentation) } \\
\text { Performance-based information on the } \\
\text { implementation of expenditure in respective years. } \\
\text { Performance-based budgetary planning } \\
\text { methodology set out annually in a regulation of the } \\
\text { MoF on detailed method, procedure, and deadlines } \\
\text { for developing materials for the budget bill. }\end{array}$ \\
\hline
\end{tabular}




\begin{tabular}{|c|c|c|}
\hline Since 2010 & $\begin{array}{l}\text { 2012: entry into force of the duties as regards } \\
\text { performance-based budget reporting and performance- } \\
\text { based budget implementation recording } \\
\text { 2013: entry into force of legislation as regards: } \\
\text { Overall MoF's control over the efficiency and } \\
\text { effectiveness of performance-based budget } \\
\text { implementation } \\
\text { Supervision and control by holders of respective } \\
\text { budget parts as regards efficiency and effectiveness of } \\
\text { the implementation of performance-based plans based } \\
\text { on objective completion metrics } \\
\text { Methodological efforts focused on, among other things: } \\
\text { Linking performance-based budgetary planning with } \\
\text { strategic planning and with the Law on Government } \\
\text { Administration Divisions (objectives set by competent } \\
\text { ministers at the task level) } \\
\text { fine-tuning the performance-based expenditure } \\
\text { classification - by linking it with the Law on } \\
\text { Government Administration Divisions and the } \\
\text { traditional budget classification (at the level "task- } \\
\text { division/chapter") } \\
\text { fine-tuning the metrics system (among others, thanks to } \\
\text { the procedure of their prior vetting by MoF, introduced } \\
\text { from planning for } 2013 \text { onwards) } \\
\text { linking performance-budget system with budget } \\
\text { holders' other management systems }\end{array}$ & $\begin{array}{l}\text { Performance-based explanatory memoranda } \\
\text { for budget bills - for respective years (from the } \\
\text { explanatory memorandum for } 2013 \text { onwards, } \\
\text { these have been prepared also as a consolidated } \\
\text { presentation) } \\
\text { Performance-based information on the } \\
\text { implementation of expenditure in respective years. } \\
\text { Performance-based summary semi-annual reports } \\
\text { on the implementation of expenditure from the } \\
\text { state budget and EU budget and financial plans of } \\
\text { state special-purpose funds, executive agencies, } \\
\text { state legal persons and public finance institutions. } \\
\text { Performance-based budgetary planning } \\
\text { methodology set out annually in a regulation of the } \\
\text { MoF on detailed method, procedure, and deadlines } \\
\text { for developing materials for the budget bill. }\end{array}$ \\
\hline
\end{tabular}

* In 2008, the responsibility for the process of performance budget implementation was taken over by the Ministry of Finance.

Source: Own elaboration based on data provided by the Ministry of Finance.

Taking account of the complex and multi-aspect nature of performance budgeting introduction as part of which it was necessary to work out and then implement legal, systemic and technical solutions regarding planning, accounting, reporting as well as supervision and control over efficiency and effectiveness with the involvement of budget holders of all levels, external experts, and the necessary resources, it was decided that this process would be divided into several phases over many years, using the financial support from EU funds. To that end, two system projects were pursued, co-funded by the European Social Fund, as part of Operational Programme Human Capital, Priority 5 Good Governance, Measure 5.1 Enhancing the capacity of the government administration, Sub-measure 5.1.2 Implementing performancebased finance management system. Apart from the above-mentioned systemic measures, the projects also provided for training, information and promotional measures to support the institutional, analytical and competitive capacity of budget holders, and for preparing the employees in question adequately for fulfilling the new tasks. Indeed, ensuring that the employees involved in the process have the skills, motivation, and awareness of the significance of the changes being introduced is one of the key success factors. 


\section{Successes and Failures of Implementation Efforts}

What was the first success of the Polish work on performance budget, or the first product of the budget implementation process? These were elements already included in the explanatory memorandum for the 2008 budget bill; namely, the document contained information on performance budget for two budget parts, i.e. 28. Science and 38. Higher education. This was no random choice since, as mentioned before, immense knowledge was undoubtedly needed to carry out the whole process; knowledge and experts assisting budget holders at given ministries in preparing the explanatory memorandum for the budget law from a performancebased perspective.

In 2006, attempts were made to implement performance-based budget not only at the Ministry of Science and Higher Education. Such an attempt was made also at the Ministry of Agriculture and Rural Development, and at the Ministry of Health, but it failed, at least when it comes to the 2007 budget law. However, this was not time wasted as appropriate conclusions were drawn from the experiences of those two ministries, including the identified risks that arose and materialized in this case at those ministries. These conclusions served to prepare, the next year, that is in 2007, a performance-based explanatory memorandum for the budgetary legislation for 2008, for as many as sixty-seven budget holders, and these expenditures were recognized in eighty-two parts. Tasks and subtasks were identified as part of this spending envelope. This undoubtedly required huge amount of work, including work on building the awareness of performance budget advantages, as well as discussions and arguments that the implementation of that tool would bring indisputable benefits to each budget holder.

As often mentioned in international reports, it is of great importance to reach the adequate decision-making level to support this process. For Poland, such position was the Secretary of State at the Chancellery of the Prime Minister, who was directly responsible for the performance budget implementation process and performed all operations involved in the process. Once performance budget implementation was moved to the Ministry of Finance, the National Coordinator for Performance Budget was the equivalent of that position. At the time the first results were obtained, as reflected in the explanatory memorandum for the budget law for 2008, several other elements were also noticed and it was understood that time is needed to implement the provisions in the Public Finance Law to fully implement this tool (Jong, Hardt, 2012: 16). Consequently, as part of the ongoing work on a brand new Public Finance Law, a few new regulations were implemented and proposed to fully describe performance budget in terms of its structure, scope, responsibility, evaluation. This was one of the best ideas on how to sanction the whole process, and to convince 
those still in doubt that the performance budget implementation process would not end with a pilot project, or with the presentational aspect, but it would have further consequences in the coming years, and thus one should prepare for it in a proper and systemic manner.

Another success in performance budget implementation is having included, as one of the appendices to the budget law itself, a performance-based breakdown of multiannual programs. In 2010, a performance-based breakdown of multiannual programs was compiled for the first time, which was presented in the 2011 budget law. Indeed, in accordance with Art. 102 of the Law of 27 August 2009 - Implementing measures for the Public Finance Law, investment projects that are recognized in the breakdown of multiannual investment projects enclosed as appendix to the 2010 budget law, and whose completion date is set after 31 December 2010, became multiannual programs as of 1 January 2011.

Another thing that can be called a major success is having developed and implemented an application program making it easier to prepare performancebased materials for the budget law. Initially, this program was called BUZA. It was commissioned by the Minister of Finance and contained the currently applicable principles of performance budget preparation. It was also adapted to the fact that budget holders came from three different levels. As time went by and as performance-budgeting developed in Poland, an attempt was made to make the application program compatible with the IT system whose operation is still a work in progress. As part of that work, a program extension was developed for the Trezor IT system used for state budget management. This way, the Minister of Finance aims to ensure, in future, the integrality of both budgetary systems.

However, performance budget in Poland has not been all success - a few failures that happened can also be indicated. Probably one of the biggest ones was to include the performance budget in the explanatory memorandum to the budget bill. Even though performance budget elements are contained in the law itself, performancebased state expenditures are still presented in the explanatory memorandum for the bill.

Another thing that can be indicated as a failure is a lack of the link and of the full integration of the traditional budget with the performance budget. Though many regulations have already introduced performance budget to the daily practice of the holders of budget parts, full awareness and integration of those budgets have not yet been achieved. Nevertheless, looking back, it can be concluded that an IT system that takes account of both budgetary systems would solve many problems faced by budget holders. 


\section{Performance Budget Implementation in Poland - Sources of Funding for Project}

Performance budget preparation and implementation required large financial outlays, as evidenced by many international experiences. Out of concern for the condition of public finance in Poland, co-funding from EU funds for this task was envisaged. The costs of the reform relating to performance budget implementation were estimated in 2006 by the Chancellery of the Prime Minister at the time Operational Programmes were being prepared and negotiated with the European Commission. Operational Programmes were approved by the decision of the European Commission. An action plan for the years 2007-2008 was prepared for parts of Sub-measure 5.1.2 "Implementing performance-based finance management system" to be implemented as part of Measure 5.1 "Enhancing the capacity of the government administration" of the Operational Program Human Capital, Priority 5 of OP HC, approved on 5 December 2007 by the OP HC Managing authority, acting pursuant to a recommendation from the OP HC Monitoring Committee included in the resolution no. 4 of the Monitoring Committee of 21 November 2007.

When embarking on measures related to performance budget implementation in 2008, it was planned that all of first- and second-level budget holders and $5 \%$ of those at the third level would receive support in their work on preparing a performance-based budget. Work was completed on laying down the terms of cooperation between the Intermediate Body (Chancellery of the Prime Minister) and the Beneficiary (Ministry of Finance) on implementing system projects as part of Measure 5.1 "Enhancing the capacity of the government administration" of the Operational Programs Human Capital - a memorandum of understanding was signed between General Directors of both institutions.

The Action Plan envisaged that projects worth, in total, ca. PLN 234,137,000 would be implemented in the years 2008-2015, including "Support for performance budget preparation and implementation at the central level" (worth, in total, ca. PLN 70,488,000); "Staffing and technical support for main budget holders in the process of performance budget implementation" (worth ca. PLN 83,258,000) and "Performance budget implementation by all budget holders" (worth ca. PLN $80,391,000)$.

As part of the first project, "Support for performance budget preparation and implementation at the central level", measures funded in 2008 included remuneration for professional and support staff at the Ministry of Finance salaries and performance allowances, 40.5 people in total; 19 work stations were equipped for the purposes of work on performance budget and implementation of EU projects; training was held for MoF staff; an international conference promoting 
performance budget was organized; expert opinions and analyses were prepared, for example, on the applicable legal regulations in force, to identify the regulations that need to be amended in order to implement multiannual performance planning; on international experiences with the implementation and development of annual and mid-term planning and multiannual performance planning; on monitoring and evaluation of budget implementation as regards priority tasks ("efficiency audit"), on design assumptions for the IT System to support an efficient public finance management using the tools created by performance budget.

As part of "Staffing and technical support for main budget holders in the process of performance budget implementation in the years 2009-2015", staffing support was provided, further workstations were equipped and many training courses for main budget holders were held.

As part of the third project, "Performance budget implementation by all budget holders", 2008 saw activities such as methodology training on performance budgeting, multiannual and strategic planning for employees of selected secondand third-level budget holders; further expert opinions were prepared: as regards the definition of priority tasks, implementation of an indicator-based system for monitoring and evaluation of top-priority public tasks.

\section{Conclusions}

The future of performance budget in Poland remains an open-ended issue, while the present debates and discussions, as well as actions and decisions, often call into question even the fundamental foundations of the work to date, in the search of new, more optimum solutions. It's worth emphasizing that many major issues related to performance budgeting are also regularly called into question in OECD countries. There is a constant quest for the best methodological solutions to maximize usability and increase the functionality of this tool in public finance systems of respective nation states. OECD is conducting comparative research (survey) consisting of running questionnaires to analyze the practical application of this tool worldwide. Research and analytical activities in this respect are also being performed by the European Commission, as evidenced by the last conference dedicated to the performance budgeting method (among others, for the purposes of European Commission's budget planning) held in the first half of 2016.

Since 2016, the current Polish government has been announcing a budget system reform, starting from the budget planning process for 2018. However, the discussion of this reform mostly focuses on spending reviews, giving less and less attention to performance budget. When structuring the 2017 budget, performance budget 
still remains a presentation instrument, sometimes discussed at the Parliament (mostly at the sessions of Sejm committees), and some other times at the Council of Ministers level.

There was one more method that could have undoubtedly streamlined the performance budget implementation in Poland. It could have happened at the time the first results, i.e. the ability to define objectives, were being implemented and accomplished. What should have been done back then is the instruments already functioning in Poland, used by the administration of various levels to increase or assess the public spending efficiency, should have been reviewed. Indeed, few people realize that such tools were functioning, let alone on what principles this was done. For example, not many citizens know that the state subsidizes inter-voivodship train transport, in some voivodships, with amounts in the order of PLN $580 \mathrm{M}$ a year, and even fewer people are aware that the carrier who receives that money must meet specific punctuality and safety indicators as well as many others. If it fails to, it is liable to a penalty. Therefore, it's a typical mechanism of management by results or management by objectives - meaning that we pay for a service, but if a service is of a lesser quality, the service provider pays a penalty. This is a classical element that is in place in the private sector. However, it turns out that it is also in place in the Polish public sector, and this is but one of many examples. Consequently, the element that was overlooked when implementing performance budgeting in Poland was to identify such solutions that already function, and integrate them with performance budget, or at least, indicate to the administration that such mechanisms exist and work very well. This would have been, undoubtedly, a good spur for full implementation of an integrated and compatible system for the efficiency assessment (public spending evaluation). Indeed, if we have performance tools enabling management by objectives, in some areas, then, undoubtedly, they could be also implemented in further spheres of state functioning.

Another aspect of such an approach would be to intensify practices vying for the limited public funds based on the operating results achieved. A textbook example of that would be the United Kingdom introducing, in early 1980s, a model of selective scientific research funding, the role of this system being not only to allocate resources, but also to impact the efficiency as a means of communication (for signaling needs and expectations) between the providers of funds, higher education institutions and those being educated (Owsiak, 2008: 66).

The implementation of the above solutions could, obviously, involve developing a set of standards for public services (and development of benchmarks for their provision) that could be negotiated and mutually worked out during public debates (including public consultations on the budget), evaluating the level at which those standards are met, and, consequently, strengthening the function of social choice 
towards optimization of goods provided by the state (which are, in many countries, presented in the so called citizens charts - a set of guidelines on civic society's expectations on how the administration should deliver public tasks).

In consequence, the implementation streamlines the management process, thus increasing the efficiency of resource allocation. Considering that, on the local level, there exists more direct communication with the community of a local administrative division, the message sent by the latter to its citizens (voters) on the efficiency of its operations, is more clear. If it doesn't efficiently manage its funds, political opponents will be quick to notice it - in the coming elections. Consequently, in those administrative divisions, much more often than at the central level, management is by objectives and by result planning, even though it's not expressly referred to as performance budget. Therefore, it would probably suffice to create some legal instruments to sanction it both at central and local level. It is necessary, then, to introduce responsibility for the results achieved, and for the objectives achieved, and a method to ensure relevant mid- and long-term accountability. It is also important to make the bonus and reward system dependent on the results achieved, while not fully relying on its functioning, considering the objectively inevitable risks that can materialize (e.g. risk of results being manipulated, external circumstances of the activities undertaken etc.).

This is also corroborated by OECD research. One of the basic problems faced by the public sector is to attract highly skilled individuals with leadership skills to accept the challenge of managing an immense scale of public funds, and of implementing public tasks. Public sector managers cannot be given a simple objective that is measured by a profitability ratio. For public sector managers, profit means having achieved a higher citizen's satisfaction level and having improved quality of life and sense of security indicators, depending on the sphere in which we operate. Consequently, these objectives are still a challenge. Of course, the question remains of how to evaluate, on the performance basis, the efficiency of respective expenditures, or the efficiency of investment projects, which shall be discussed in detail further in the paper.

\section{References}

Barro, R.: Determinants of Economic Growth: A Cross-Country Empirical Study, National Bureau of Economic Research, NBER Working Paper no. 5698 (1996).

Central Expenditure Evaluation Unit, Department of Public Expenditure and Reform. www. publicspendingcode.per.gov.ie.

Cohen, J.R.: The Corporate Governance Mosaic and Financial Reporting Quality, Journal of Accounting Literature no.1 (2008). 
De Jong, M.: Performance-Based Budgeting: Lessons from Academic Research and Practices in the Public Sector, 2016. www.ec.europa.eu.

DG ECFIN, Thematic Review on the Quality of Public Expenditure. Preparing and Implementing Spending Reviews, Brussel, 2014.

Evaluating EU Activities. A Practical Guide for the Commission Services, Directorate-General for the Budget, European Communities, Brussels: European Commission, 2004.

Franek, S.: Reguły fiskalne w przemianach instytucjonalnych finansów publicznych (Fiscal rules in the institutional changes of public finances), Zeszyty Naukowe Uniwersytetu Szczecińskiego (Scientific Papers of the University of Szczecin) no. 3 (2010).

Kołodko, G.: Nowy pragmatyzm, czyli ekonomia i polityka dla przyszłości (A new pragmatism, i.e. economy and politics for the future), in: Pach, J., Kowalska, K., Szyja, P. (eds.): Ekonomia umiaru. Realna perspektywa? Nowy paraygmat Grzegorza W. Kołodko (Economics of moderation. The real perspective? A new paradigm of Grzegorz W. Kolodko), Warszawa: PWN, 2016.

Marcel, M.: Budgeting for Fiscal Space and Government Performance Beyond the Great Recession, Paris: OECD, 2012.

Marczewski, K.: Budżet zadaniowy a cele polityki gospodarczej w Polsce (Performance budget and economic policy goals in Poland), in: Albiński, P. (ed.), Budżetowanie zadaniowe w kontekście sanacji finansów publicznych w krajach Unii Europejskiej (Performance budget in the context of public finance restructuring in the European Union countries), Warszawa: Szkoła Główna Handlowa, 2012.

Mielcarz, A.: Modernizacja budżetowania zadaniowego (GPRAMA) jako działania podejmowane przez administrację prezydenta B. Obamy w celu racjonalizacji finansów publicznych w Stanach Zjednoczonych (Modernization of performance budget (GPRAMA) as activities undertaken by the administration of President B. Obama in order to rationalize public finances in the United States), in: Woźniak, B., Postuła, M. (eds.): Budżet zadaniowy metodą racjonalizacji wydatków (Performance budget based on the rationalization method), Warszawa: CeDeWu, 2012.

Moździerz, A.: Strengthening the Post-crisis Fiscal Rules - the Case of Spain, Slovakia, and Sweden, Equilibrium, Quarterly Journal of Economics and Economic Policy no. 2 (2015)

O'Keefe, T.B., Simunic, D., Stein, M.: The Production of Audit Services: Evidence from a Major Public Accounting Firm, Journal of Accounting Research no. 2 (1994).

Orłowski, W.: Ewaluacja - instrument refleksyjnego zarządzania państwem (Evaluation - the instrument of reflective state management), in: Szałaj, A. (ed.): Ewaluacja w strategicznym zarządzaniu publicznym (Evaluation in strategic public management), Warszawa: PARP, 2010.

Owsiak, S.: (ed.), Nowe zarządzanie finansami publicznymi w warunkach kryzysu (New public finance management in crisis conditions), Warszawa: PWE, 2011.

Postuła, M.: Rola ewaluacji w budżetowaniu zadaniowym (The role of evaluation in performance budget), in: Haber, A. Szałaj, M. (ed.): Ewaluacja wobec wyzwań stojących przed sektorem 
finansów publicznych (Evaluation of the challenges facing the public finance sector), Warszawa: PARP, 2009.

Postuła, M.: Budżet zadaniowy w Polsce - osiągnięcia i wyzwania na przyszłość (Performance budget in Poland - achievements and challenges for the future), in: Ruśkowski, E. (ed.): Instrumenty nowego zarządzania finansami publicznymi w wybranych krajach Unii Europejskiej (Instruments of new public finance management in selected European Union countries), Bialystok: Temida 2, 2011.

Postuła, M.: Racjonalizacja wydatków publicznych a podstawowe funkcje państwa (Rationalization of public expenditure and basic state functions), Warszawa: Wydawnictwo SGGW, 2012.

Public finance in EMU 2002, European Commission, Directorate-General for Economic and Financial Affairs, European Economy no. 3 (2002).

Public Service Reform Plan 2014-2016, 2016. www.reformplan.per.gov.ie.

Robinson, M.: Spending Reviews, Paris: OECD, 2013.

Ruśkowski, E. (ed.), Instrumenty nowego zarządzania finansami publicznymi w wybranych krajach Unii Europejskiej (Instruments of new public finance management in selected European Union countries), Bialystok: Temida 2, 2011.

Shick, S.: Budgeting for Fiscal Space, 2014. www.oecd.org.

Spending Review, HM Treasury, 2010. www.gov.uk.

Spending Review: Objectives, Design \& Processes, World Bank Seminar, Warszawa: Ministerstwo Finansów, 2014.

Stankiewicz, J.: Problemy racjonalizacji wydatków publicznych i wieloletniego planowania finansowego w aspekcie budżetu zadaniowego i wieloletnich planów finansowych w Polsce (Problems of rationalization of public expenditure and long-term financial planning in the aspect of perfomance budget and long-term financial plans in Poland), in: Ruśkowski, E. (ed.): System prawa finansowego (System of financial law), Warszawa: Wolters Kluwer, 2010.

Woźniak, B., Postuła, M.: Budżet zadaniowy metodą racjonalizacji wydatków, CeDeWu, Warszawa, 2012.

European Fund for Strategic Investments in 2016, 2016. www.eib.org.

PL: Act of 27 August, on Public Finance, as amended.

PL: Act of 27 August 2009 - Implementing measures to the Act on Public Finance. 



\title{
PERFORMANCE BUDGETING AND MEDIUM-TERM FINANCIAL PLANING IN THE RUSSIAN FEDERATION
}

\author{
ALEKSEI G. PAUL ${ }^{1}$
}

\begin{abstract}
Last decades budget expenditure planning in the Russian Federation transferred from line-item budgeting to performance budgeting. The basis of multiannual financial planning was laid in the Russian Federation by the Concept of budget process reforming in the Russian Federation in 2004-2006 approved by the Government of the Russian Federation Budget Code provides budgeting for next fiscal year and a two-year planned period. However, the process of transition was hard. Russian authorities had to use the international experience of budget planning. So the aim of the paper to discover some approaches to performance budgeting with help of comparative legal studies.
\end{abstract}

\section{Keywords}

Performance budgeting; medium-term financial planning; budget expenditure; objective program

\section{JEL Classification: D63, H69, K39}

\section{Introduction}

Last decades budget expenditure planning in the Russian Federation transferred from line-item budgeting to performance budgeting. Budget Code provides budgeting for next fiscal year and a two-year planned period. However, the process

1 Associate Professor of Financial Law Department, Faculty of Law, Voronezh State University, Voronezh, the Russian Federation. The Author specializes in budget law and tax law. The author of 3 books and the coauthor of 7 textbooks. He presented his scientific research in 17 reviewed articles in prestigious journals and in more than 70 another journals and conference proceedings. He is a member of the Information and Organization Centre for the Research on the Public Finances and Tax Law in the Countries of Central and Eastern Europe. Contact email: pag@law.vsu.ru. 
of transition was hard. Russian authorities had to use the international experience of budget planning. So the aim of the paper to discover some approaches to performance budgeting with help of comparative legal studies.

\section{Performance Budgeting in Medium-Term Financial Planning}

The basis of multiannual financial planning was laid in the Russian Federation by the Concept of budget process reforming in the Russian Federation in 2004-2006 approved by the Government of the Russian Federation (Act no. 249/2004). Earlier in the post-Soviet period, budget planning had other approaches. By the beginning of the reform, Russian budget law provided for neither multiannual budget planning nor estimation of budget expenditure results. There were the next problems:

a) the mid-term financial plans were developed for annual budget cycle only; budget expenditures were planned just for next year. The budget legislation did not define sums and structure of budget appropriations allocated to budget administrators,

b) the budget expenditures were calculated by adjusting (indexing) of recent year expenditures. Budget Code of the Russian Federation did not prescribe mechanisms of budget resource redistribution. We did not have clear criteria and procedures for selection of funded directions in accordance with the priorities of state policy,

c) there was no clear formulation of budget expenditure objectives as well as criteria for estimating of budget administrator results.

The main purpose of the conception was the introduction of conditions for the most efficient management of the state (municipal) funds in accordance with the priorities of state policy. The essence of the reform was to shift the budget process from "management of budgetary resources (expenditures)" to "management of results"; to enhance responsibility and to expand the independence of budget administrators in the framework of medium-term objectives.

Russian authorities offered the following directions of the reform:

a) to reform the budget classification of the Russian Federation and the fiscal accounting in accordance with international financial reporting standards,

b) to divide budget into existing obligations and accepting (new) obligations,

c) to improve medium-term financial planning,

d) to introduce performance budgeting,

e) to streamline procedures for drafting and adopting of law on budget. 
The core of the new organization of the budget process should be the concept of "performance budgeting in the medium-term financial planning" widely used in the world. In other words, the main purpose was to increase the horizon of financial planning and to introduce program-objective methods of budget planning.

Some guidelines of the reform were based on the international experience of budget reforms. According to the Russian financial authorities, a number of budgetary and legal institutions were affected by international standards adopted by the International Monetary Fund, the World Bank and the Organization for Economic Co-operation and Development (Artukhin, 2012). In relation to the introduction of multi-annual financial planning and performance budgeting, the Concept stated that one of the main elements of budget reforms undertaken in the last decade in most developed countries was the transition to medium-term budget planning. A budget cycle begins with a review of previously approved in the previous budget cycle main parameters of the medium-term financial plan, with analysis of changes in external factors and conditions, with substantiation of changes in the main budget indicators of the planned year as well as updating the budgetary projections for the next years of the forecasting period.

The Authors of the reform proposed introducing of mentioned approach into the Russian practice of budget planning. The budget for the next fiscal year should become a part of the mid-term (three years) plan that was annually updated. On the one hand, this system ensures the continuity of the state policy and predictability of budget allocations; on the other hand, it allows making transparent annual adjustments in accordance with the policy objectives and the conditions of their achievements.

\section{Stages of Reforms}

The purposes of the reform were implemented in stages. Firstly, Russian authorities started the transition to the multiannual budget. The Federal budget for 2006 became the first budget formed within the three-year financial plan. It was the basis for the drafting of fiscal policy for the next three-year budget.

The budget legislation provided for the transition to drawing up a three-year budget in 2007 when the Parliament of the Russian Federation amended the Budget Code. The amendments to the Budget Code of the Russian Federation provided for the annual drafting and adopting of the federal budget for 3 years (the next financial year and two-year planned period). That rules should ensure continuity and predictability of fiscal policy, contribute to the sustainability of the budget system of the Russian Federation, improve the reliability of budget expenditures, and make 
the state contracts for 3 years or for the whole period of implementation of the longterm objective programs (investment projects).

The basis of budget planning consisted of the method of "sliding three-year budgeting". In such conditions, earlier adopted budget expenditures for second and third years of the three-year period become the basis of the next year budget. Actually, the Russian budget legislation reflected provisions adopted in Art. 9 of the Council of the European Union Directive 2011/85/EU of 8 November 2011 on requirements for budgetary frameworks of the Member States that prescribes providing for the adoption of a fiscal planning horizon of at least 3 years.

Adopting projections for second and third years of the planned period did not mean a ban on their adjustment in the next budget cycle. However, these changes should not worsen the position of the main budget administrators and recipients of budgetary transfers. These provisions of Russian budget legislation meet Art. 9/2b of the Directive 2011/85/EU prescribed that medium-term budgetary frameworks shall include procedures for establishing of projections of each major expenditure and revenue item of the general government for the budget year and beyond, based on unchanged policies.

Thus, the "sliding three-year budgeting" ensures, on the one hand, the stability and predictability of the budgetary projections and, on the other hand, the possibility of their amending in case of changes, restructuring expenditures, the implementation of new priorities of the budget policy. In order to increase budget sustainability, the Budget Code introduced "conditionally adopted expenditures" (5\% of the total expenditures) that not distributed among main budget administrators and articles of budget classification for the planned period (second and third year of the three-year period). These rules allowed to create a reserve in case of an unexpected decline of incomes or to use the "conditionally adopted expenditures" for making new obligations in the next budget cycle.

Mentioned budget rules about "sliding three-year budgeting" were indispensable just for the federal budget. Regional and local authorities of the Russian Federation have the choice between adopting of their budgets for 3 years or for the next financial year (with the drafting of the mid-term financial plan).

\section{Implementation of Reforms}

Implementation of the performance budgeting was more problematic. Earlier Russian budget legislation provided for line-item budgeting. Financial authorities drafted budgets by indexing of previous year budget expenditures. There were 
no estimations of budget expenditure effects. Because of the reform, the main instruments of budget planning should be federal objective programs and departmental objective programs.

The federal objective programs had an inter-sectoral nature. They should be adopted by the Government of the Russian Federation and include a large investment, scientific-technical and (or) structural projects requiring a long period of realization. The departmental objective programs are intra-sectoral. They are adopted by special executive authorities. The Budget Code of the Russian Federation provided for these types of programs. They were used in the budget planning. However, currently, the federal objective program was renamed into the state program of the Russian Federation.

Nowadays the state programs should, in particular, contain the objections and priorities of the state policy; the list and characteristics of the main activities to achieve the state program objections with timelines for their implementation and expected results; the main measures of the legal regulation aimed at achieving the objections and (or) the expected results of the state program; the information about the objection indicators of the state program broken down by years of its implementation, information about financial provision of the state program funded by the federal budget (details by the main budget administrators, by federal objection programs and by the years of the state program implementation).

By present time, the Government of the Russian Federation has adopted the Procedure for development, implementation and estimation of effectiveness for state programs of the Russian Federation (Act no. 588/2010), the list of state programs of the Russian Federation (Act no. 1950-R/2010). The Ministry of Economic Development has approved the Methodological recommendations for the development and implementation of state programs of the Russian Federation (Act no. 582/2016). Now we have 42 state programs of the Russian Federation.

The law on the federal budget for 2014 and for planning period of 2015 and 2016 became the first budget approved in the context of state programs. It contained an exhibit that breaks down expenditures by state programs. Nowadays performance budgeting is implemented at the regional level with the methodical support of the Ministry of Finance. Despite the gradual implementation of multi-annual financial planning and performance budgeting in Russian budget law, the reforms are continuing.

The President of the Russian Federation drew attention to the fact that the planning of socio-economic development and budget planning still remain insufficiently coordinated. The tasks of socio-economic policy and the results of their implementation are still considered separately from the budget policy. There is no 
clear system for estimating of budget expenditure effectiveness. The state programs did not become means for the formulation and implementation of state policy in long term. Many programs demand to increase budgetary financing without identifying financial sources. Some programs have been adopted in several variants that differ both on planned results and on amounts of funding. The task of transition to longterm budget planning is not solved. The Government of the Russian Federation has not approved long-term budget strategy that should determine the cost framework of the state programs in connection with the forecast of the main budget parameters (Act no. 13/07/2013, on budget policy in 2014-2016).

The Program of the Government of the Russian Federation on increase of budgetary expenditures efficiency for the period until 2012 (Act no. 1101-R/2010, on Program of the Government of the Russian Federation on increase of budgetary expenditures efficiency for the period until 2012) drew attention to the fact that strategic planning remained to be poorly linked with budget planning. In this regard, one of the main tasks was to draft mechanisms aimed at ensuring better integration of strategic and budget planning as well as at monitoring of achieved stated objectives. Actually, in the Program, Russian authorities took into account the provisions of documents adopted by international organizations. For example, according to the Art. 2/1/2 of the Code of good practices on fiscal transparency (Act of the International Monetary Fund, 2007) the annual budget should be realistic and should be prepared and presented within a comprehensive medium-term macroeconomic and fiscal policy framework. Fiscal targets and any fiscal rules should be clearly stated and explained. In fact, these tasks were prescribed by the mentioned Program.

Last year the Government of the Russian Federation adopted the Program for an increase of public (state and municipal) finances management efficiency for the period until 2018 (Act no. 2593-R/2013). The Program shows some unsolved problems in budget planning, including:

- the absence of regulated procedures for drafting, studying and using of socio-economic development forecasts in the budgetary process and in the drafting of state strategic planning documents;

- despite the program structure of the federal budget for the year 2014 and for the planning period 2015 and 2016, the Government of the Russian Federation did not take into account achievement of state program objectives in the planning of budget appropriations;

- the issues of state program efficiency are not essential in the drafting of the federal budget:

- the absence of an integral system of strategic planning and weak linkage between the strategic and budget planning; 
- the uncertain relations and lack of coordination between various objective program means;

- the incompleteness of formation and limited practice of state (municipal) programs as the main instrument to achieve the objectives of the public (municipal) policy as well as the basis for budget planning.

The Program suggests the following solutions:

- to define all directions of the state (municipal) policy only in the framework of state (municipal) programs. At the same time, strategic planning documents should define the main directions of the policy as well as requirements for the state (municipal) programs;

- to draft the Budgetary strategy of the Russian Federation for the period until 2030 that should determine budget expenditures for the state programs on the basis of main budget parameter forecast. The President of the Russian Federation prescribes to the Government of the Russian Federation to complete the development of the budgetary strategy of the Russian Federation for the period up to 2030 in a short time as well as to amend the long-term forecast of socio-economic development if it is necessary (Act no. 13/07/2013, on budget policy in 2014-2016). This suggestion meets the requirements of Art. 9/3 of the Directive 2011/85/EU that demands so that projections adopted within medium-term budgetary frameworks shall be based on realistic macroeconomic and budgetary forecasts.

Russian scientists express the same opinion. They say that the problems related to the performance budgeting due to the objectives of budget expenditures are formulated outside the budget process in the course of budget administrator activity. In addition, detailed plans of economic and socio-economic development (national economic plans) (three years, five years, and others) are not published.

The mechanism of drawing up such plans in the Russian Federation was lost with the dissolution of USSR and the State Planning Committee of the USSR (Komyagin, 2011). By now, the Ministry of Economic development of the Russian Federation has adopted the Forecast of long-term socio-economic development of the Russian Federation for the period until 2030. Based on this document in accordance with the requirements of the Budget Code of the Russian Federation the Ministry of Economic development drafts a forecast of socio-economic development of the Russian Federation for the next financial year and two-year planning period. In its turn, this forecast is the economic basis for drafting a budget for the next financial year and two-year planning period. In addition, the Government of the Russian Federation has adopted the Concept of long-term socio-economic development of the Russian Federation for the period until 2020 (Act no. 1662-R/2008). 


\section{Conclusions}

The last decade the Russian Federation made serious steps in the transition to medium-term financial planning on the basis of performance budgeting. The federal budget is adopted for the next financial year and two-year planning period with breaking down by state programs. At the same time, there are problems related to the correlation between mid-term financial planning and socio-economic planning, to the estimation of program implementation. These problems should be solved by continuing reforms in the field of the financial sector.

\section{References}

Artukhin, R.: Вопросы развития бюджетного права (Issues of budget law development), Pеформы и право (Reforms and law) no. 3 (2012).

Komyagin, D.: Бюджетное право России (The Budget Law of the Russian Federation), Moscow: The Institution of public law research, 2011.

EU: Directive no. 2011/85/EU, on requirements for budgetary frameworks of the Member States.

RU: Act no. 1101-R/2010, on Program of the Government of the Russian Federation on increase of budgetary expenditures efficiency for the period until 2012.

RU: Act no. 13/07/2013, on budget policy in 2014-2016.

RU: Act no. 1662-R/2008, on Concept of long-term socio-economic development of the Russian Federation for the period until 2020, as amended.

RU: Act no. 1950-R/2010, on List of state programs of the Russian Federation.

RU: Act no. 249/2004, the Concept of budget process reforming in the Russian Federation in 20042006, as amended.

RU: Act no. 2593-R/2013, on Program for the increase of public (state and municipal) finances management efficiency for the period until 2018.

RU: Act no. 582/2016, on methodological recommendations for the development and implementation of state programs of the Russian Federation.

RU: Act no. 588/2010, on Procedure for development, implementation and estimation of effectiveness for state programs of the Russian Federation.

RU: Act of the International Monetary Fund, 2007, on Code of good practices on fiscal transparency. 


\title{
PUBLIC INTERESTS PROVISION IN THE ACTIVITIES OF CONTROL AND ACCOUNTS BODIES OF THE SUBJECTS OF THE RUSSIAN FEDERATION
}

\author{
ELENA KIREEVA ${ }^{1}$
}

\begin{abstract}
This contribution deals with the analysis of the activity of control and accounts bodies (CAB) in the subjects of the Russian Federation. Based on the results of monitoring the data published at the official websites of the $\mathrm{CAB}$ and using the method of comparative legal analysis, the Author makes an attempt at assessing the activity of $\mathrm{CAB}$ in terms of openness, studies the issues in the legal regulation of their activity, reviews available feedback mechanisms and the forms of protection and representation of interests of civil society in the course of financial control implementation. We conclude that currently the created information resources ensure publicity in the work of $\mathrm{CAB}$ of the subjects of the Russian Federation by providing information on the composition, structure, performance (publication of reports, statistical and analytical materials), contact information including schedules for citizens however there is a number of problems and shortcomings in terms of ensuring the interaction of citizens and control and accounts bodies, among which one can point out that some websites do not provide the possibility of submitting on-line appeals, as well as obtaining information on the results of the examination of the latter.
\end{abstract}

\section{Keywords}

Public interests; control and accounts bodies; subjects of the Russian Federation

\section{JEL Classification: K34, K40, M40}

1 Doctor of Legal Sciences, Dean of the Faculty of Personnel Management and Civil Service of the Institute of Public Administration and Civil Service of the Russian Presidential Academy of National Economy and Public Administration, Russian Federation. She is a member of the Advisory Board of the Higher Attestation Commission under the Ministry of Education and Science of the Russian Federation. She is the author of 3 books and more than 45 reviewed articles in prestigious journals. Contact email: elena_kireeva02@mail.ru. 


\section{Introduction}

In this article the Author presents the results of monitoring the official websites of control and accounts bodies of the subjects of the Russian Federation concerning control exercising by civil society institutions over the activities of the $\mathrm{CAB}$ (Control and Accounts Bodies) of the subjects of the Russian Federation, and also the feedback mechanisms use.

On the basis of the methods of systematic, comparative legal analysis and monitoring, the study of normative regulation of activities of control and accounts bodies of constituent entities of the Russian Federation is made; the conclusions about the openness of CAB activities of the RF subjects and forms of protection and representation of interests of civil society in the implementation of financial control are formulated.

\section{Analysis of Constitutional Norms}

The principle of the primacy of the good of the people formulated by Cicero and proclaimed in Roman law - Salus populi suprema lex esto - has undergone a significant transformation and has received various incarnations both in the legislative systems and the real power mechanisms of modern states. And if at the initial stages of statehood it was implemented in the activities of parliaments designed to represent the will and interests of the people, later with the development of democratic institutions, it became a universal principle of the activity of public authorities and found its normative consolidation in the constitutions of modern states.

Thus, the Constitution of the Russian Federation (adopted by popular vote on 12 December 1993) proclaims: "A person, his rights, and freedoms are the highest value. Recognition, observance, and protection of human and citizen's rights and freedoms is the duty of the state" (Constitution of the Russian Federation, Art. 2). In the Constitution of Lithuania, it's stipulated that "institutions of power serve people" (Constitution of Lithuania, Art. 5). The Constitution of the Republic of Poland of 2 April 1997 declares that this state "shall be the common good of all its citizens" (Constitution of the Republic of Poland, Art. 1) and that it is "a democratic state ruled by law and implementing the principles of social justice" (Constitution of the Republic of Poland, Art. 2).

Unlike Eastern European states, Russia has a federal structure and two levels of public authority - the federal and the constituent entities of the Russian Federation, for which general principles for the organization of a system of public authorities 
Public Interests Provision in the Activities of Control and Accounts Bodies...

and local self-government have been established in clause "n" Art. 72 of the Constitution of the Russian Federation.

Being applied to the control and accounts bodies of the subjects of the Russian Federation, which are the object of close scrutiny by representatives of the science of financial and budgetary law, the principles for their organization and activities are set forth in Act on the general principles of organization and operation of control and accounting bodies of the subjects of the Russian Federation and municipal entities (Act 6-FZ/2011, Art. 903). Among them, there's the rule of law, objectivity, effectiveness, independence, and transparency. And although the principle of ensuring and protecting the interests of society in this federal law is not directly stipulated, the legislator has fixed a number of mechanisms ensuring its implementation. In the next section, the examples are presented.

\section{Principle of Transparency in Activity of Control Bodies}

Let us begin with securing the principle of transparency in the activities of control and accounting bodies of the constituent entities of the Russian Federation (Hereinafter referred to as $\mathrm{CAB}$ of the subjects of the Russian Federation) which involves two components:

1) informing the public about the main activities and results of the control and accounting body,

2) exercising control by civil society institutions over the activities of the $\mathrm{CAB}$ (Control and Accounts Body) of the subject of the Russian Federation, the use of feedback mechanisms from the facility to the subject of management.

First, the public is informed of the results of its activities in the following ways:

- by providing the final (annual) and current reports of the state and municipal financial control authorities to the bodies that formed them and other authorities;

- by publishing the reports on the results of inspections, as well as information on taking measures to eliminate the identified violations (except for information containing confidential information, access to which is limited by the current legislation) in mass media;

- by legislative consolidation of the procedure for publicizing the results of control.

In the legislation of the constituent entities of the Russian Federation, guarantees are provided for the implementation of the principle of transparency. Thus, in Art. 22 of the Krasnodar Krai Law on the Control and Accounts Chamber of the Krasnodar 
Territory it is established that the Control and Accounts Chamber annually in the first quarter of the year following the reporting year submits a report on its activities to the Legislative Assembly of the Krasnodar Krai. The report of the Control and Accounts Chamber is published in the media or published on the official site of the Control and Accounts Chamber on the Internet only after it has been considered by the legislative assembly of the territory.

The Control and Accounts Chamber, in order to provide access to information about its activities, places on its official website the Internet and publishes in its official publications or other mass media information about the monitoring and expert-analytical activities carried out, the violations detected during their conduct, submitted applications and prescriptions, as well as decisions and measures taken on them.

Publication of information on the activities of the Control and Accounts Chamber in the mass media and posting on the Internet is carried out in accordance with the legislation of the Russian Federation, the legislation of the Krasnodar Territory and the regulations of the Control and Accounts Chamber.

Similar provisions are contained in (Act On the Control and Accounts Chamber of Moscow Region, Part 3.1-6 of Art. 23). This article also establishes that the Control and Accounts Chamber publishes an Information Compendium of the Control and Accounts Chamber of Moscow Region, which is its official information publication. The information collection of the Control and Accounts Chamber of the Moscow Region is issued quarterly in an electronic form and posted on the official website of the Control and Accounts Chamber on the Internet.

The annual report on the activities of the Control and Accounts Chamber is subject to official publication by the Control and Accounts Chamber in the newspaper "Daily News. Moscow Region" and the Information Collection of the Control and Accounting Chamber of the Moscow Region (Antroptseva et al.: 2016).

Second, exercising control by civil society institutions over the activities of the $\mathrm{CAB}$ (Control and Accounts Body) of the subject of the Russian Federation, the use of feedback mechanisms.

One should note that there is a well-organized system of feedback and interaction with citizens. Thus, on official sites of control and accounting bodies the schedule of work of the body, contact information is available, as well as an opportunity to send an appeal for consideration on-line (for example see: official site of the Control and Accounts Chamber of the Bryansk Region. www.kspbo.ru/ksp-bo). 
Public Interests Provision in the Activities of Control and Accounts Bodies...

The presence of these options indicates the involvement of the control and accounting body in the process of introducing information technologies, as well as its development towards more transparent and open interaction with citizens and other authorities.

CABs of the subjects of the federation post information on the results of consideration of applications of citizens on their official websites. For example, in 2016, the Control and Accounts Chamber of the Khabarovsk Territory received 16 appeals from citizens and representatives of organizations. The considered appeals dealt with issues of violation of budget legislation, provision of high-quality medical assistance, misuse of funds of the regional budget, verification of accounts receivable of consumers of water and wastewater services. The citizens appealed to the Control and Accounts Chamber with complaints about the actions of officials.

At the request, containing an appeal to conduct an audit to assess the legality of granting financial benefits and preferences to officials of local government, clarifications and materials were sent to the Khabarovsk Krai Prosecutor's Office to take measures of prosecutorial response. On the basis of one appeal in 2016, the Control and Accounts Chamber of the Khabarovsk Territory conducted a control measure for the legality, effectiveness (efficiency and economy) of using the funds of the regional budget allocated for the construction of the "Social and cultural center in the village of Data of the Vanino district". The report on the results of the control measure was sent to the regional prosecutor's office and the Ministry of Construction of the Khabarovsk Territory. The review of applications of citizens who entered the Control and Accounts Chamber of the Khabarovsk Territory in 2016 was published at the official website of the given CAB (Control and Accounts Chamber of the Khabarovsk Territory).

The website of the Control and Accounts Chamber of the Republic of Crimea shows only general statistics for 2015 and 2016. So, in 2016 the Control and Accounts Chamber of the Republic of Crimea received 30 appeals, one of which is collective.

Next, an analysis is made of the appeals received during the reporting period, from which it follows that the largest number of letters contain requests for verification activities in relation to state budgetary institutions, state unitary enterprises, as well as information on irrational, inefficient use of budget funds by officials of enterprises, institutions and organizations. However, the results of consideration of the received applications on the site are not given (Accounts Chamber of the Republic of Crimea). It should be noted that not all CAB sites of RF subjects contain information on the number of applications received and the results of their consideration, either the section i-reception or "citizens' appeals". The analysis of 
Elena Kireeva

information on citizens' appeals presented on the official websites of CAB subjects of the Russian Federation is presented in the form of a comparative table $1^{2}$.

Table 1 Citizens' Appeals in the Russian Federation

\begin{tabular}{|c|c|c|c|c|}
\hline & $\begin{array}{l}\text { Name of the CAB of the } \\
\text { subject of the RF }\end{array}$ & Official website & Number of appeals in 2015 & $\begin{array}{l}\text { Number of appeals } \\
\text { in } 2016\end{array}$ \\
\hline 1 & $\begin{array}{c}\text { Control and Accounts } \\
\text { Chamber of the Republic } \\
\text { of Adygea }\end{array}$ & www.kspra.ru & $\begin{array}{l}\text { The page "Information on citizens' } \\
\text { appeals" is not active }\end{array}$ & \\
\hline 2 & $\begin{array}{c}\text { Control and Accounting } \\
\text { Chamber of the Altai } \\
\text { Republic }\end{array}$ & www.ksp04.ru & $\begin{array}{l}\text { Information on citizens' appeals is not } \\
\text { available }\end{array}$ & \\
\hline 3 & $\begin{array}{c}\text { Control and Accounting } \\
\text { Chamber of the Republic of } \\
\text { Bashkortostan }\end{array}$ & www.ksp02.ru & 206,39 of which are collective & $\begin{array}{l}\text { 237, } 31 \text { of which are } \\
\text { collective }\end{array}$ \\
\hline 4 & $\begin{array}{c}\text { Control and Accounting } \\
\text { Chamber of the Republic of } \\
\text { Buryatia }\end{array}$ & www.sp03.ru & $\begin{array}{l}\text { The page "Information on citizens' } \\
\text { appeals" is not active }\end{array}$ & \\
\hline 5 & $\begin{array}{c}\text { Control and Accounting } \\
\text { Chamber of the Republic of } \\
\text { Dagestan }\end{array}$ & www.spdag.ru & $\begin{array}{l}\text { Electronic application form is } \\
\text { provided. The page "Appeals } \\
\text { statistics" is not active }\end{array}$ & $\begin{array}{l}\text { control measures } \\
\text { were taken in } 16 \\
\quad \text { for } 24\end{array}$ \\
\hline 6 & $\begin{array}{l}\text { Control and Accounts } \\
\text { Chamber of the Republic of } \\
\text { Ingushetia }\end{array}$ & www.kspri.ru & & 5 job applications \\
\hline 7 & $\begin{array}{c}\text { Control and Accounts } \\
\text { Chamber of the Kabardino- } \\
\text { Balkarian Republic }\end{array}$ & www.kspkbr.ru & $\begin{array}{l}\text { Information on } 2 \text { appeals } \\
\text { consideration results }\end{array}$ & \\
\hline 8 & $\begin{array}{l}\text { Control Chamber of the } \\
\text { Republic of Kalmykia }\end{array}$ & www.ksprk08.ru & $\begin{array}{l}\text { Electronic application form is } \\
\text { provided. Statistics are not available }\end{array}$ & \\
\hline 9 & $\begin{array}{l}\text { Control and Accounting } \\
\text { Chamber of the Republic } \\
\text { of Karelia }\end{array}$ & www.ksp.karelia.ru & & 8 of these 1 electronic \\
\hline 10 & $\begin{array}{c}\text { Control and Accounting } \\
\text { Chamber of the Republic of } \\
\text { Tatarstan } \\
\end{array}$ & www.sprt.ru & $\begin{array}{c}\text { Electronic application form is provided } \\
\text { in the section "Electronic reception". } \\
\text { Statistics is not available }\end{array}$ & \\
\hline 11 & $\begin{array}{c}\text { Control and Accounting } \\
\text { Chamber of the Republic of } \\
\text { Sakha (Yakutia) }\end{array}$ & $\begin{array}{l}\text { www.schetnaja-palata. } \\
\text { sakha.gov.ru }\end{array}$ & $\begin{array}{l}\text { Electronic application form is provided } \\
\text { in the section "Electronic reception". } \\
\text { Statistics are not available }\end{array}$ & \\
\hline 12 & $\begin{array}{l}\text { Control and Accounting } \\
\text { Chamber of the } \\
\text { Transbaikalian Territory }\end{array}$ & www.kspzab.ru & 2 appeals & 16 appeals \\
\hline 13 & $\begin{array}{l}\text { Control and Accounting } \\
\text { Chamber of Krasnodar } \\
\text { Region }\end{array}$ & www.kspkuban.ru & The latest data is for 2012.53 appeals & \\
\hline 14 & $\begin{array}{l}\text { Control and Accounting } \\
\text { Chamber of the } \\
\text { Krasnoyarsk Territory }\end{array}$ & www.spkrk.ru & $\begin{array}{l}\text { Electronic application form is provided } \\
\text { in the section "Electronic reception". } \\
\text { Statistics are not available }\end{array}$ & \\
\hline 15 & $\begin{array}{c}\text { Control and Accounting } \\
\text { Chamber of the Stavropol } \\
\text { Territory }\end{array}$ & www.kspstav.ru & 23 appeals & 12 appeals \\
\hline 16 & $\begin{array}{c}\text { Control and Accounting } \\
\text { Chamber of the Belgorod } \\
\text { Region }\end{array}$ & www.belksp.ru & The section of appeals is missing & \\
\hline 17 & $\begin{array}{c}\text { Control and Accounting } \\
\text { Chamber of Bryansk } \\
\text { Region }\end{array}$ & www.kspbo.ru & 10 appeals & $\begin{array}{l}17 \text { of these } 1 \\
\text { electronic }\end{array}$ \\
\hline
\end{tabular}

2 Out of 85 subjects of the Russian Federation 30 subjects of the Russian Federation or $25.5 \%$ have been selected, and all types of subjects are represented: the republics of the Russian Federation, the region, the cities of federal significance, the autonomous region and the autonomous district. 
Public Interests Provision in the Activities of Control and Accounts Bodies...

\begin{tabular}{|c|c|c|c|c|}
\hline 18 & $\begin{array}{l}\text { Control and Accounting } \\
\text { Chamber of the Voronezh } \\
\text { Region }\end{array}$ & www.ksp-vrn.ru & & $\begin{array}{l}16 \text { of these } 10-\text { from } \\
\text { citizens, } 6-\text { from } \\
\text { organizations }\end{array}$ \\
\hline 19 & $\begin{array}{c}\text { Control and Accounting } \\
\text { Chamber of the Irkutsk } \\
\text { Region }\end{array}$ & www.irksp.ru & & $\begin{array}{l}137 \text { assignments and } \\
\text { appeals from citizens } \\
\text { and organizations, } \\
\text { of these } 15 \text { from } \\
\text { individuals }\end{array}$ \\
\hline 20 & $\begin{array}{c}\text { Control and Accounting } \\
\text { Chamber of the Kaliningrad } \\
\text { Region } \\
\end{array}$ & www.ksp39.ru & $\begin{array}{l}\text { Electronic application form is provided } \\
\text { in the section Public reception. } \\
\text { Statistics are not available }\end{array}$ & \\
\hline 21 & $\begin{array}{l}\text { Control and Accounts } \\
\text { Chamber of the Nizhny } \\
\text { Novgorod Region }\end{array}$ & www.ksp.r52.ru & 25 appeals, of these 10 from citizens & \\
\hline 22 & $\begin{array}{l}\text { Control and Accounts } \\
\text { Chamber of the Rostov } \\
\text { Region }\end{array}$ & www.ksp61.ru & $\begin{array}{l}\text { Online application form on corruption } \\
\text { crimes. Reception schedule of citizens }\end{array}$ & \\
\hline 23 & $\begin{array}{c}\text { Control and Accounts } \\
\text { Chamber of Tomsk Oblast }\end{array}$ & www.audit.tomsk.ru & 10 appeals, of these 1 collective & 7 appeals \\
\hline 24 & $\begin{array}{c}\text { Control and Accounting } \\
\text { Chamber of the Yaroslavl } \\
\text { Region }\end{array}$ & $\begin{array}{l}\text { www.kspalata76. } \\
\text { yarregion.ru }\end{array}$ & 19 appeals, of these 16 from citizens & 12 appeals \\
\hline 25 & $\begin{array}{l}\text { Control and Accounting } \\
\text { Chamber of Moscow }\end{array}$ & www.ksp.mos.ru & 3575 appeals and inquiries & $\begin{array}{c}3483 \text { of these } 277 \\
\text { from citizens, } 521 \\
\text { appeals from entities }\end{array}$ \\
\hline 26 & $\begin{array}{l}\text { Control and Accounts } \\
\text { Chamber of St. Petersburg }\end{array}$ & www.ksp.org.ru & $\begin{array}{l}\text { Electronic application form is provided } \\
\text { in the section Electronic reception. } \\
\text { Statistics is not available }\end{array}$ & \\
\hline 27 & $\begin{array}{l}\text { Control and accounting } \\
\text { chamber of Sevastopol }\end{array}$ & www.ksp-sev.ru & $\begin{array}{l}\text { Electronic application form is provided } \\
\text { in the section "Appeals from citizens". } \\
\text { Statistics are not available }\end{array}$ & \\
\hline 28 & $\begin{array}{l}\text { Control and Accounts } \\
\text { Chamber of the Jewish } \\
\text { Autonomous Region }\end{array}$ & www.eao.ru & $\begin{array}{c}\text { Information on the results of work with } \\
\text { citizens' appeals in the Government of } \\
\text { the Jewish Autonomous Region and } \\
\text { local bodies is provided }\end{array}$ & \\
\hline 29 & $\begin{array}{l}\text { Control and Accounting } \\
\text { Chamber of the Nenets } \\
\text { Autonomous District }\end{array}$ & www.cпнао.pф & No appeals & \\
\hline 30 & $\begin{array}{l}\text { Control and Accounting } \\
\text { Chamber of the Yamalo- } \\
\text { Nenetsk Autonomous } \\
\text { District }\end{array}$ & www.spyanao.ru & $\begin{array}{l}\text { Section on work with appeals from } \\
\text { citizens is missing }\end{array}$ & \\
\hline
\end{tabular}

Source: Own elaboration.

\section{Conclusions}

Based on the information given above one can draw the conclusions, as follows.

First, currently, the created information resources ensure publicity in the work of $\mathrm{CAB}$ of the subjects of the Russian Federation by providing information on the composition, structure, performance (publication of reports, statistical and analytical materials), contact information including schedules for citizens.

Second, the opportunity to receive feedback on existing violations of budget legislation through posting information on the procedure for filing and reviewing applications, the availability of the on-line reception section, or the placement of 
electronic circulation forms on the $\mathrm{CAB}$ websites of the constituent entities of the Russian Federation was created.

Third, on average 10-15 appeals from citizens and legal entities (with the exception of Moscow) are received annually by the $\mathrm{CAB}$ of the subject, of which about 40$60 \%$ (in different subjects the figures vary) refer to the facts of violation of budget legislation, and accordingly, cause carrying out control measures.

Fourth, the subjects of the Russian Federation keep records of incoming appeals in different ways, including requests or orders from state and local government bodies or taking into account only appeals of citizens and legal entities, therefore statistical indicators vary greatly.

Fifth, the appeals directed to the control and accounts bodies of the constituent entities of the Russian Federation can be classified into several groups. First, the subjective composition: individual and collective; physical, legal persons, public authorities and local self-government; second, the form ones: written, oral (filed during the reception of citizens), online appeals; third, content ones: violations of the current legislation, facts of ineffective use, or evaluation of the effectiveness and effectiveness of spending budget funds, explaining the current legislation, public service and employment issues.

Sixth, there is a number of problems and shortcomings in terms of ensuring the interaction of citizens and control and accounts bodies, among which one can point out that some websites do not provide the possibility of submitting on-line appeals, as well as obtaining information on the results of the examination of the latter (Republic of Buryatia, Belgorod Region, and others, at the time of writing this article the official site of the CAB of Chukotka Autonomous Okrug did not work at all). The information provided on the official websites is outdated or is not updated (Krasnodar Territory), or not related to CAB activities (Jewish Autonomous Region has posted a report on the work with the appeals of the Government of this entity, the $\mathrm{CAB}$ of Ingushetia takes into account applications for employment). There are no unified requirements for the structure and content of $\mathrm{CAB}$ websites of entities and for keeping statistical reports on incoming and considered appeals.

\section{References}

Antroptseva, I.O., Kireeva, E.Yu. et al.: Комментарий к Федеральному закону от 7 февраля 2011 г. № 6-Ф3 Об общих принципах организации и деятельности контрольносчетных органов субъектов Российской Федерации и муниципальных образований (постатейный) (Commentary to Federal Law no. 6-FZ of 7 February 2011 on General Principles of Organization and Operation of Control and Accounting Bodies of Subjects of the Russian Federation and Municipal Formations (itemized), 2016. www.consultant.ru. 
Public Interests Provision in the Activities of Control and Accounts Bodies...

Информационный бюллетень Законодательного Собрания Краснодарского края (Information Bulletin of the Legislative Assembly of Krasnodar region) no. 4 (2011).

LT: Constitution of the Republic of Lithuania of 25 October 1992.

RU: Constitution of the Russian Federation of 12 December 1993.

RU: Act 6-FZ/2011, on the general principles of organization and operation of control and accounting bodies of the subjects of the Russian Federation and municipal entities, as amended.

RU: Krasnodar Krai Law no. 2321-KZ/2011, on the Control and Accounts Chamber of the Krasnodar Territory, as amended.

RU: Act no. 135/2010-OZ, on the Control and Accounts Chamber of Moscow Region, as amended.

PL: Constitution of the Republic of Poland of 2 April 1997, as amended. 



\title{
REVENUES AND EXPENDITURES OF PUBLIC BUDGETS IN THE CZECH REPUBLIC RELATED TO GAMBLING ${ }^{1}$
}

\author{
RADIM BOHÁC̆
}

\begin{abstract}
This contribution deals with revenues and expenditures of public budgets related to gambling in the Czech Republic. The main aim of this article is to evaluate revenues and expenditures of public budgets related to gambling and to confirm the hypothesis that these revenues are higher than these expenditures. In the paper are used methods of description, synthesis, and analysis. Revenues of public budgets from gambling are many times higher than the direct government expenditures associated with gambling. The hypothesis that these revenues are higher than these expenditures was confirmed. It is possible to reduce government revenues from gambling tax and, on the contrary, increase gambling-related expenditures.
\end{abstract}

\section{Keywords}

Gambling; revenues; expenditures; public budgets

JEL Classification: E62, H71, L83

\section{Introduction}

A new legal regulation of operating gambling has been effective in the Czech Republic since 1 January 2017. This regulation consists of three laws, i.e. the Act

1 This paper has been elaborated within the programme "PROGRES Q02 - Publicization of Law in the European and International Context" which is realized in 2018 at the Faculty of Law of the Charles University.

2 Associate Professor of Financial Law and Financial Science, Department of Financial Law and Financial Science, Faculty of Law, Charles University, Czech Republic. The Author specializes in tax law and budgetary law. He is the author or co-author of 3 books and more than 20 reviewed articles in prestigious journals. He is a member of Information and Organization Centre for the Research on the Public Finances and Tax Law in the Countries of Central and Eastern Europe. Orcid.org/0000-0003-4496-4699. Contact email: bohac@prf.cuni.cz. 
on Gambling (Act no. 186/2016, on Gambling). This regulation replaced former ineffective Act on Lotteries and Other Similar Games enacted in 1990.

The enactment of this regulation has important effects upon public budgets, i.e. revenues (esp. revenue from gambling tax) and expenditures (esp. expenditures for preventing the emergence of pathological gambling and tax administration costs).

The main aim of this article is to evaluate revenues and expenditures of public budgets related to gambling and to confirm the hypothesis that these revenues are higher than these expenditures. In the paper are used methods of description, synthesis, and analysis.

New gambling legislation has been adopted recently. Therefore, relevant literature is not yet available. No commentary of the Gambling Act has yet been made. However, there are already some commentaries of the Gambling Tax Act (Boháč, Krasulová, 2017 or Pelc, 2016). There are also some guides for municipalities related to gambling (Vacek, 2014). In 2006, the book Gambling Law was published, which generally deals with this legal sector, but of course, does not take into account the new legal regulation of gambling (Kramáŕ, Hušák, 2006).

The first part of this contribution defines the hazard and describes the gambling market in the Czech Republic. The second part of the contribution focuses on the gambling reform that took place in the Czech Republic in 2016 and 2017. The third part is focused on gambling reform in the Czech Republic. The main parts of the paper are the fourth and fifth part which relate to revenues and expenditures of public budgets associated with gambling.

\section{Gambling and Gambling Market}

With regard to the topic of the article, it is necessary first to mention basic information about the gambling and gambling market in the Czech Republic. Gambling or hazard is generally understood as a very risky behavior, the outcome of which is a matter of chance.

The basics of legal regulation of gambling are contained in private law, in the Civil Code. This Code regulates bet, game and lot as types of aleatory contracts. By bet, at least one party undertakes to make a win against the other if the incorrect claim of the party is unknown to the parties, or if the other party's allegation of the event is correct. The game and the lot are not explicitly defined; the provisions on betting apply accordingly. 
The basic rule applicable to bets, games and lots is the rule of non-enforceability of winnings by courts. However, this rule does not apply to bets, games and lots operated by the State or subject to official permission.

In the area of public law gambling is a strictly regulated area. The reason is that gambling has a number of negative social consequences. These negative social consequences are summarized, for example, in the annual report on gambling in the Czech Republic in 2016 (Mravčík, 2017). It can be mentioned pathological dependence, indebtedness of gamblers and their families, personal bankruptcy, playing of recipients of social benefits and committing crimes.

As already mentioned in 2016, new gambling legislation was adopted. The Gambling Act regulates eight types of gambling that can be operated on the basis of licensing or notification. Specifically, it is the lottery, odds bet, totalizator game, bingo, technical game, live game, raffle and small size tournament.

The most damaging for society is the technical game. Technical game means a game operated through a technical device directly handled by the bettor. Technical games include, without limitation, reel slot machines, electromechanical roulette, and electromechanical dice. Live odds betting (in running betting) are also very dangerous. Odds bet means a game in which a win is subject to guessing a betting event (particular a sports result or a public attention event). Live odds betting are an odds bet type where the bets are accepted while the betting event unfolds (Act no. 186/2016, on Gambling).

Players lost in gambling in the Czech Republic in the year 2016 total CZK 39.3 billion, which represents the aggregate gross income of gambling operators. The sum of bets and other deposits was CZK 196.4 billion and the sum of wins paid to players was CZK 157.1 billion. It is also possible to mention the share of individual games in the gambling market in 2016 according to the bets and other deposits assigned to individual games. Technical games have the biggest share of these bets and other deposits, the second one is odds bet (Mravčík, 2017).

It follows that the most serious gambling (technical games) have the largest share in the gambling market.

\section{Gambling Reform in the Czech Republic}

The gambling reform in the Czech Republic had two phases. The first phase took place on $1^{\text {st }}$ January 2016 . The essence of this phase was only the increase of rates of levy from lotteries and other similar games. Until 2016, the rate of levy from lotteries and other similar games for slot machines and other technical devices was 
adjusted to a proportional part $(20 \%$ of the amount by which the total of the bet amounts exceeds the total of the prizes won) and a fixed part (CZK 55 per day for each slot machine and devices, approx. CZK 20,000 per year). The levy rate for other lotteries and other similar games was $20 \%$ of the amount by which the total of the bet amounts exceeds the total of the prizes won.

From 2016, the rate of levy from lotteries and other similar games for slot machines and other technical devices was increased (proportional part to $28 \%$ and fixed the part to CZK 80). The rate of levy from lotteries and other similar games for other lotteries and other similar games was increased to $23 \%$. However, the increase of the rate of levy from lotteries and other similar games was not accompanied by any other measures that would counteract the negative consequences of gambling. This brought the second phase of the reform from $1^{\text {st }}$ January 2017. As already mentioned, the second phase of the reform was completed by enacting a new legal regulation of operating gambling. This regulation consists of three laws, i.e. the Act on Gambling (Act no. 186/2016), the Gambling Tax Act (no. 187/2016).

The aim of this regulation is particularly protecting gambling participants, preventing and eradicating socially pathological phenomena connected to with operating these games, effective collecting tax revenues, opening the Czech gambling market to operators from the European Union countries and regulation of operating online gambling.

The Act on Gambling (Act no. 186/2016) regulates games of chance and their types, conditions governing their operation, measures for responsible gambling and, the jurisdiction of administrative authorities over the gambling operation. It is a complex and modern legal act. Measures for responsible gambling are mandatory player registration, operator's obligation to offer a self-limiting measure to the player, etc. Technical games and live games can be operated only in a gambling room or casino (previously these games could be operated in other places, such as in pubs or petrol pumps). The gambling tax has replaced the lottery and other similar games levy. Gambling tax rates remained basically the same as rates of the lottery and other similar games levy.

\section{Gambling Revenues of Public Budgets}

The gambling revenues of public budgets in the Czech Republic can be divided into two main groups. The first group are revenues from operators; the second group is revenues from players. The revenues of public budgets from players are very small. The reason is that most of the players' wins are exempt from individual income tax. Winnings of players are exempt of individual income tax, if they are from gambling 
which is licensed under the Gambling Act in the Czech Republic, from gambling which must be notified under this Act or from gambling which runs under the laws of similar gambling laws in the States of European Union or the States forming the European Economic Area. It follows that only wins from operators from third countries and from illegal operators are taxed.

Revenues of public budgets from operators can be divided into three groups. The first group are revenues of corporate income tax, the second group are revenues of administrative charges and the third group are revenues of gambling tax.

Gambling operators according to the Gambling Act may be only the Czech Republic represented by its organizational units or corporation. The corporation must fulfill a lot of conditions, e. g. a registered office in the Czech Republic; in another EU Member State; or in a state that is a party to the Agreement on the European Economic Area, a transparent and unobjectionable origin of its resources etc. (Act no. 186/2016, on Gambling, Sec. 6). Corporations and organizational units of the state are subjects (taxpayers) of corporate income tax in the Czech Republic. The gambling incomes are objects of this tax. If these corporations or units are operating gambling they must pay this tax. The tax base is determined as the difference between gambling revenues and gambling expenditures and the tax rate is $19 \%$ of the tax base.

The amount of the tax base of gambling operators can only be estimated. In 2013, according to the automated tax information system, gambling operators reported a corporation tax of CZK 653 million (Explanatory report to Gambling Tax Act). The difference between bets and wins was in 2013 CZK 29.3 billion and in 2016 CZK 39.3 billion, so the revenue should be higher. But, on the other hand, the gambling tax is an expense and its rates have been increased, so the revenue should be lower. It can be deduced that the corporate income tax revenue from gambling operators is about CZK 600-800 million per year.

Revenues from administrative charges paid by gambling operators are very small, rather symbolic. An administrative charge of CZK 5,000 is set for acceptance of the application for a basic license to operate gambling and of CZK 3,000 for acceptance of the application for a change of this license. These administrative charges are revenues of the state budget. An administrative charge of CZK 4,000 is set for acceptance of the application for gambling premises location license and of CZK 2,500 for acceptance of the application for a change of this license. These administrative charges are revenues of municipality budgets.

The highest revenue flows into public budgets from gambling tax, until 2017 from a levy on lotteries and other similar games. Until the increasing of levy on lotteries and other similar games rates from 2016 the total annual revenue of this levy was 
CZK 8,15 billion in 2013, CZK 7,98 billion in 2014 and CZK 8,08 billion in 2015. About $75 \%$ of this revenue was from technical games (CZK 6,08 billion in 2013, CZK 6,26 billion in 2014 and CZK 6,13 billion in 2015) and the remainder of other games (CZK 2,07 billion in 2013, CZK 1,72 billion in 2014 and CZK 1,94 billion in 2015). It is clear that the highest revenue came from technical games.

As noted above, from 2016 there has been an increase of lottery and other similar games rates. The total annual revenue of this levy was in 2016 CZK 10,49 billion. It means, that this increase brought more than 2,4 billion CZK per year for public budgets (state budget and municipality budgets). However, the revenue from technical games and other games remained approximately the same. The revenue from technical games was CZK 8,04 billion and the revenue from other games was CZK 2,45 billion.

Similar revenue as in 2016 should also be achieved in 2017. In 2018, however, a decline may be expected, as regulatory measures of the Gaming Act should be fully reflected. In particular, a reduction in the number of technical devices to operate a technical game can be expected. This should mean a decrease in the tax revenue from technical games. On the other hand, this loss of revenue from technical games can be partly compensated by an increase in revenue from other games, especially internet games.

Now I will deal with dividing the revenue of gambling text, (resp. levy on lotteries and other similar games) between individual public budgets. Municipal budgets received CZK 5.5 billion in 2013, 2014 and 2015 and CZK 6.1 billion in 2016 and state budget received CZK 2.6 billion in 2013, 2014 and 2015 and CZK 4.4 billion in 2016. The largest portion of revenue flowing to municipal budgets is shared between municipalities that have gambling rooms and casinos in their territory.

\section{Expenditures of Public Budgets associated with Gambling}

Expenditures associated with gambling are spent from the state budget and from municipalities and regions budgets.

Expenditures from municipalities and regions budgets are not quantified and it is very difficult to estimate them. There are 14 regions and more than 6200 municipalities in the Czech Republic and each region or municipality can spend some expenditures related to gambling. Expenditure on eliminating the negative phenomena associated with gambling will be spent by those municipalities which have gambling rooms or casinos in their territory and which are recipients of gambling tax revenue. 
There are special programs focusing on prevention against negative phenomena associated with gambling at the state budget level. These are programs of Government Council for Drug Policy Coordination. Expenditure on drug policy does not usually distinguish between different areas of drug policy such as alcohol, tobacco, illicit drugs and gambling (Mravčík et al.: 2017). But programs of Government Council for Drug Policy Coordination do so. Government Council for Drug Policy Coordination provides grants for prevention and treatment of problem gambling. The Council from its budget in the year 2016 supported 50 projects associated with gambling at total amount CZK 24.5 million. But to 2013 activities against consequences of gambling were not supported. In 2013-2015, Council submitted projects in the field of prevention and treatment of problem gambling of CZK 3-5 mil. per year (Mravčík et al.: 2017).

As can be seen, the direct spending on negative phenomena associated with gambling is not very large. However, it must be stressed once again that this is not all expenditures, but only those that can be quantified. Actual expenditures are higher. However, it can be estimated that there will be a maximum of hundreds of millions of Czech crowns.

Regarding gambling-related expenditures, it must be mentioned social costs for gambling. There are several studies that try to quantify these costs. But their results are quite different. The Psychiatric Centre in Prague study estimates these costs in 2012 at CZK 14.2-16.1 billion per year. However, about $75 \%$ of this amount is represented by intangible costs, especially emotional detriment and the suffering of players and their relatives (Winkler et al.: 2014).

The Centre for Economic and Market Analysis carried out a revision of the Psychiatric Centre in Prague study and arrived at its own estimate of social costs for the year 2012 at the level of CZK 5.3-5.7 billion (Schwarz et al.: 2015). Unlike the first study, this study does not include intangible costs.

\section{Conclusions}

The main aim of this article was to evaluate revenues and expenditures of public budgets related to gambling and to confirm the hypothesis that these revenues are higher than these expenditures.

I described gambling and gambling market in the Czech Republic first. The technical games have the largest share in the gambling market.

Then I focused on gambling reform in the Czech Republic. It is necessary, from a government's point of view, to seek a level of regulation that is optimal in terms 
of revenues and expenditures of public budgets, on the one hand, and which will lead to the protection of players and the fight against socially harmful phenomena associated with gambling on the other hand. Excessive regulation can lead to a decline in government revenue and a rise in the illegal operation of gambling. Conversely, little regulation can have same consequences. Finding a balance between these goals is therefore very difficult and there is a question whether the Czech legislator has succeeded in this to confirm the hypothesis that these revenues are higher than these expenditures.

In terms of public budgets revenues from gambling, the highest revenue flows into public budgets from gambling tax. The total annual revenue of lottery and other similar games levy was in 2016 CZK 10,49 billion. Similar revenue as in 2016 should also be achieved in 2017 from gambling tax.

In terms of public budgets expenditures associated with gambling expenditures from municipalities and regions budgets are not quantified and it is very difficult to estimate them. Expenditures of the state budget on drug policy do not usually distinguish between different areas of drug policy such as alcohol, tobacco, illicit drugs, and gambling. The exemption concerns the programs of Government Council for Drug Policy Coordination. The Council from its budget in the year 2016 supported 50 projects associated with gambling at total amount CZK 24.5 million.

It is obvious that public revenues from gambling are many times higher than the government expenditures associated with gambling. The hypothesis that these revenues are higher than these expenditures was confirmed. I think it is possible to reduce government revenues from gambling tax and, on the contrary, increase gambling-related expenditures.

\section{References}

Boháč, R., Krasulová, H.: Zákon o dani z hazardních her: komentář (Gambling Tax Act: commentary), Praha: Wolters Kluwer, 2017.

Důvodová zpráva k zákonu o dani z hazardních her (Explanatory report to Gambling Tax Act), Praha: Poslanecká sněmovna Parlamentu (Chamber of Deputies of Parliament), 2016. www.psp.cz.

Kramář, K., Hušák, A.: Herní právo (Gambling Law), Pilsner: Čeněk, 2006.

Mravčík, V. et al.: Výroční zpráva o hazardním hraní v České republice v roce 2016 (Annual Report on Gambling in the Czech Republic in 2016), Praha: Úřad vlády České Republiky, 2017.

Pelc, V.: Daň z hazardních her s komentářem (Gambling Tax Act: Comments), Olomouc: Anag, 2016. 
Schwarz, J. et al.: Regulace hazardu v ČR - východiska, podoba a dopady změn v legislativě (Regulation of Gambling in the Czech Republic - the Basis, the Form and Impact of Changes in Legislation), Praha: CETA, 2015.

Vacek, J.: Identifikace a řešení rizik spojených s hraním hazardních her: příručka pro obce a jejich zastupitele (Identifying and addressing the risks associated with gambling: a guide for municipalities and their representatives), Prague: Úřad vlády České Republiky, 2014.

Winkler, P. et al.: Problémové hráčství: Společenské náklady na hazardní hraní v České republice (Problem Gambling: The Social Costs of Gambling in the Czech Republic), Praha: Psychiatrické centrum Praha, 2014.

CZ: Act no. 186/2016, on Gambling, as amended.

CZ: Act no. 187/2016, on Gambling Tax, as amended.

CZ: Act no. 188/2016, which amends certain laws in connection with the adoption of the Gambling Act and the Gambling Tax Act. 



\title{
SOURCES OF FINANCING PUBLIC GOODS IN POLISH AGRICULTURE
}

\author{
BARBARA ROSZKOWSKA-MĄDRA ${ }^{1}$, ELŻBIETA ZALESKO
}

\begin{abstract}
The purpose of this paper is to indicate the scope of public intervention measures (Rural Development Program Funds) contributing to the fulfillment of the agricultural sector, which is an important sector of the Polish economy, not only for production but also for non-productive functions in the form of public goods and services, increasingly perceived and appreciated by the public. This constitutes a strong foundation for their support and is considered as a form of remuneration for farmers to generate positive externalities (public goods) provided to the society for which creation, the market does not reward the agricultural producers. The analyzes carried out show that, under the Common Agricultural Policy, rural development policy offers a number of measures to support the agricultural economy, agricultural practices and other investments thus contributing to the generation of public goods in agriculture. These measures support the development of rural areas and encourage the creation of public goods, both of an environmental and social nature.
\end{abstract}

\section{Keywords}

Agriculture; public goods; public spending; European model of agriculture; Common Agricultural Policy

\section{JEL Classification: H41, H72, P32}

1 Doctor habilitated in Economics, the professor at the University of Bialystok, Faculty of Economics and Management, Poland. The Author specializes in the issues of balanced and multifunctional development of agriculture and rural areas, as well as the influence of the state and community policies on rural development and agriculture. The Author of nearly 80 publications on the national and international scale. Contact e-mail: broszkowska@poczta.onet.pl.

2 Doctor of Economics, University of Bialystok, Poland, Faculty of Economics and Informatics in Vilnius (Lithuania). The Author of publications on macroeconomic issues (foreign trade, foreign investments, and competitiveness of the economy) and agri-food market. Contact email: ezalesko@gmail.com. 


\section{Introduction}

The sectors of the modern economy reached by public spending made in the public interest include agriculture. It is developing in rural areas comprising $80 \%$ of the European territory and as much as $93 \%$ of the Polish territory. Activities conducted as a part of agricultural activity result in the generation of private and public goods. Provision of private goods is regulated by the market, unlike public goods, in case of which the market mechanism fails, being unable to develop markets which would enable ensuring payments for the provision of such goods. Lack of compensation for provision of public goods by agriculture may result in a decline in satisfaction of needs of the entire society which wishes to live and enjoy a beautiful landscape with a high degree of biodiversity; it may also lead to degradation of certain resources the maintenance of which in agriculture is economically substantiated (Czyżewski, Kułyk, 2011: 16-25). Therefore, it is very important to support creation thereof through public intervention in the form of appropriate activities capable of ensuring a sufficient level of generation of public goods to match the social needs. This will enable implementation of the idea of sustainable agriculture and rural areas, serving as a base for the modern European agriculture model (EAM), consisting, above all, in: (Roszkowska-Mądra, 2010: 35): dissemination of the idea of sustained development, ascribing essential importance to multi-functionality enabling agriculture to enter the path of sustained development; departure from the market-type agricultural policy in favors of support to multifunctional rural development detached from ongoing production; financing of positive external effects of agriculture; transition from sector-type agricultural policy to integrated agricultural and rural development policy; an increase in appreciation of the role of human capital, social capital and institutions in agricultural and rural development, in line with the concept of endogenous development.

The goal of the present study is to indicate the scope of the applied public intervention measures (the measures of the rural development program) in Poland and assorted countries of the European Union, contributing to performance by the agricultural sector of not only production functions but also of non-production ones in the form of public goods and services, increasingly noticed and appreciated by societies.

\section{Agriculture as Source of Public Goods}

Public goods are a category of market failure; they are goods desired by the society, unable to be provided by the market mechanism. Under the traditional approach, the term "public good" refers to goods which are generally available and nobody 
is excluded from the benefits resulting from use thereof (lack of exclusion from consumption) (Czyżewski, Kułyk, 2011: 16-25). Due to these characteristics, it is difficult to receive payment for the provision of these goods, causing, in turn, that there are no incentives to provide them (Małażewska, 2015: 132-147). P. Samuelson was the first to write on public goods in 1954, and his article is regarded as the foundation of the modern theory of public goods (Samuelson, 1954: 387-389).

The development of interest in public goods in agriculture has been largely caused by the concept of sustained development, being a peculiar antidote to the emergence of numerous restrictions and hazards for further development of agricultural, connected with farming according to the industrial formula accompanied with the predominant focus on the implementation of the production function. Today, the accepted model is developed in line with the concept of sustained development, and multi-functionality of agriculture plays a special role in its nature. It is regarded as the most important guarantee of implementation of the concept of sustained agricultural and rural development. Its role with regard to economy, environment, and society, as well as the preservation of the rural heritage and ensuring of fair income for farmers, is special. The notion of multi-functionality in relation to the agricultural sector means performance by agriculture of not just the production functions but the non-production ones in the form of public goods and services, increasingly noticed and appreciated by modern societies, both domestically and internationally, providing a strong base substantiating support thereof (Wilkin, 2008: 9-20; Marsden, Sonnino, 2009: 422-431; Renting, Rossini, Groot, Van der Ploeg, Laurent, Perraud, Stobbelaar, Van Ittersum, 2009: 112-123).

The provision of public goods by agriculture is treated as one of agriculture's functions (Liziński, 2012: 146-163). Goods provided by agriculture are of special nature, as their availability depends on both natural conditions and human activity. They often have the character of external effects of agricultural production processes. Therefore, activities undertaken by farmers and the applied practices with regard to manufacturing techniques may result in a contribution to an increase in availability of public goods or limit their value in case of overexploitation (Małażewska, Gajos, 2016: 158-163). The demand for these goods results from the expectations of the entire society which wishes to enjoy such things as beautiful landscapes with a high degree of biodiversity (Cooper, Hart, Baldock, 2009: 14-29).

The main public goods provided by agriculture include (Europejska Sieć na rzecz Rozwoju Obszarów Wiejskich, 2010; Cooper, Hart, Baldock, 2009: 14-29):

- biological diversity of agricultural areas;

- water quality and availability;

- soil functionality; 
- air quality;

- climate stability;

- resistance to floods and fires;

- agricultural landscapes;

- the vitality of rural areas;

- welfare and health of farm animals;

- food safety;

- alternative modes of supply.

The Thematic Working Group "Public Goods" (European Network for Rural Development, 2009) has distinguished two basic types of public goods generated by agriculture, namely, environmental and social ones. The environmental goods include agricultural landscape, biodiversity of agricultural land, water quality and availability, soil functionality, climate stability, air quality, resistance to floods and fires. The social goods include vitality of rural areas, food safety, and security, as well as welfare and health of animals (Małażewska, 2016: 138). A different approach to the classification of public goods in agriculture has been presented in the Study for the European Parliament, dividing public goods into five groups: environmental (including biodiversity of agricultural land, water quality and availability, soil functionality, air quality), agricultural landscapes, cultural values, vitality of rural areas, welfare of farm animals, and food safety and security (Dyrekcja Generalna do Spraw Polityki Wewnętrznej, 2011).

The scale of occurrence of goods may be local or global. The extent of usage thereof by the society (availability) may be very diverse as well. The extent of public availability of goods is determined by the maximum number of people able to consume the given good. Due to the very wide diversity of public goods generated in agriculture, both in terms of their scale of occurrence and their availability, the Authors of the report for the Institute for European Environmental Policy and Duer have identified degrees of their public availability, as presented in Table 1. Private goods are characterized by the fact they exclude non-owners from consumption. Public goods, on the other hand, have varying degrees of availability - average or high (common).

Biological diversity of agricultural areas is regarded as the most important public good depending on agriculture; its existence and stability is an effect of the applied agricultural practices generating diverse external effects (positive or negative). External effects, both positive and negative, occur when a part of costs or benefits of actions of one person is transferred to others without an appropriate compensation (Duer, 2010: 87). Generation of public goods in agriculture is connected with 
bearing of certain costs for which farmers are not compensated by the market. Therefore, it is necessary to implement appropriate programme activities as incentives for farmers to generate them, although not all farmer activities connected with provision of an appropriate level of public goods require support using financial resources in a public intervention. According to the "polluter pays" principle, farmers receive no compensation for actions they are obliged to perform within the framework of the legal requirements in force or other binding standards - they are supposed to bear the related costs themselves. However, observation of the legal requirements in force is a prerequisite for receiving of various payments resulting from the common agricultural policy. e.g. observance of essential principles and standards protecting the environment and landscape of rural areas, contained in the principle of cross-compliance, conditions collection of direct payments and subsidies due to farming in less-favored areas (LFAs). However, observance of these principles only secures generation of public goods in agriculture to a basic extent. It is only voluntary declaration by a farmer to provide and maintain public goods available to the entire society, going beyond the fulfillment of the cross-compliance principle, Authorizes the given farmer to receive an additional bonus in the name of the "provider gets" principle. Therefore, on the part of the state, this requires application of appropriate financial incentives for farmers to generate public goods the creation of which would otherwise have no sense to them from the economic viewpoint. Rewarding of farmers for provision of public goods should take place on the level on which such goods are made available to the society. For instance, protection of biodiversity (genetic, species, ecosystems), water protection, ensuring of food security, prevention of climate changes are all public goods of global nature, with high availability to the society, therefore they should be rewarded according to a uniform system for all countries.

\section{Public Intervention Supporting Creation of Public Goods in Agriculture}

Under the Common Agricultural Policy, the rural development policy provides a range of measures supporting agricultural economy, agricultural practices and other investments, thus fostering generation of public goods in agriculture. These measures support rural development and encourage generation of public goods, both of environmental and social nature. Wilkin divides public goods provided by agriculture as follows (Wilkin, 2010: 17-24):

- environmental (biodiversity, agricultural landscape, soil preservation, appropriate water conditions);

- economic (food security, food safety, energetic safety); 
- socio-cultural (economic and social vitality of rural areas, enrichment of national culture, formation of local, regional and cultural identity).

Measures allocated for rural development, applied as incentives for generation of public goods, may be divided into the three main categories (Baldock, Hart, Schelle):

- area payments encouraging the application of farming practices beneficial to soils, water quality, species habitats, and landscape preservation;

- capital investments which may serve introduction of new, environmentally sustained techniques and technologies to farms, support to the creation of new activities of non-agricultural nature, both in and outside farms, as well as other activities in rural areas, such as preservation and promotion of cultural heritage, traditional social landscape and traditional way of life;

- investment in consulting and training for farmland managers as well as the building of potential of people in rural communities.

Table 1 Measures Applied under Rural Development Programme and Public Goods

\begin{tabular}{|c|c|c|}
\hline \multirow{3}{*}{ Kind of aid } & \multicolumn{2}{|c|}{ Public goods } \\
\hline & Environmental & Social \\
\hline & \multicolumn{2}{|c|}{ Measures applied in order to generate public goods } \\
\hline $\begin{array}{l}\text { Area payments due to } \\
\text { land management }\end{array}$ & $\begin{array}{l}\text { - agri-environmental; } \\
\text { - related to natural handicaps; } \\
\text { - related to the Natura } 2000 \text { network }\end{array}$ & $\begin{array}{l}\text { - agri-environmental; } \\
\text { - related to natural } \\
\text { - handicaps }\end{array}$ \\
\hline $\begin{array}{l}\text { Capital investments in } \\
\text { material infrastructure }\end{array}$ & $\begin{array}{l}\text { - non-production investments; } \\
\text { - modernization of farms; } \\
\text { - development of infrastructure; } \\
\text { - semi-subsistence farms; } \\
\text { - preservation and improvement of } \\
\text { the condition of rural heritage; } \\
\text { - the increase of the added value of } \\
\text { - agricultural products; } \\
\text { - diversification. }\end{array}$ & $\begin{array}{l}\text { - development of infrastructure; } \\
\text { - semi-subsistence farms; } \\
\text { - diversification of economic } \\
\text { activities; } \\
\text { - encouragement of tourism- } \\
\text { related activity; } \\
\text { - essential services for the } \\
\text { economy of the rural population; } \\
\text { - village renewal; } \\
\text { - leader approach. }\end{array}$ \\
\hline $\begin{array}{l}\text { Consulting, training, } \\
\text { and building of potential } \\
\text { serving reinforcement of } \\
\text { the human capital }\end{array}$ & - related to consulting and training. & $\begin{array}{l}\text { - training and transfer of } \\
\text { information; } \\
\text { - Leader approach. }\end{array}$ \\
\hline
\end{tabular}

Source: Own elaboration based on Baldock, Hart, Scheele, 2010.

Many agriculture-supporting resources also foster the simultaneous creation of goods of environmental, socio-cultural and economic nature. Member states of 
the European Union can freely select and allocate the resources as well as choose the kind of availability thereof in accordance with their specific nature and needs. Figure 1 shows the diversity of spending of resources by assorted member states of the European Union (depending on the needs and their specific nature) on individual axes in order to axis 1 (economic) - support the competitiveness of the agricultural and forest sector; axis 2 (environmental) - support sustained management of agricultural and forestry land resources; axis 3 (social) - economic diversification of rural areas and improvement of the quality of life in rural areas; axis 4 (Leader) - building of social capital.

\section{Figure 1 Allocation of financial resources to individual axes in the Rural Development Program for 2007-2013 (\%) in assorted European Union countries}

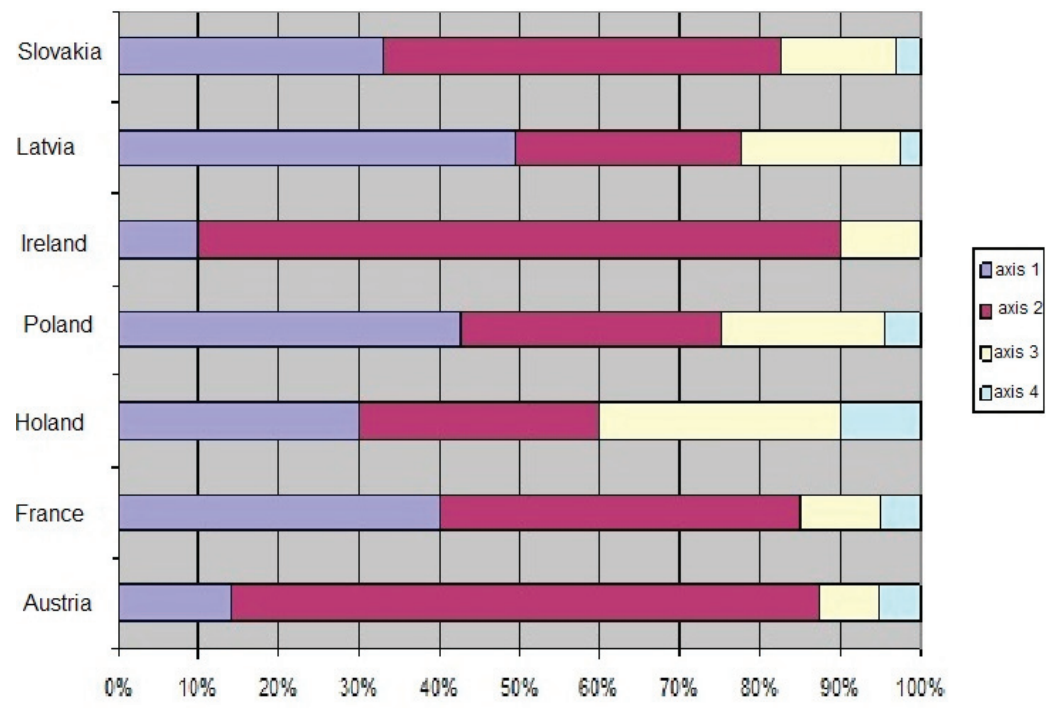

Source: Developed on the basis of RDP 2007-2013 of Assorted EU Countries.

In assorted countries, as illustrated in Figure 1, the structure of spending on individual axes of the RDP are diversified depending on the national specificity. Resources spent under Axis 3 comprise between 7.3\% in the RDP structure in Austria and 30\% in the Netherlands; those under Axis 2 comprise between $30 \%$ in the Netherlands and $80 \%$ in Ireland. The contribution of the EU in the financing of individual axes is diverse and co-financed from national, public and private sources. 
Figure 2 Structure of Expenditures in the EU Member States under Rural Areas Programme in 2007-2013

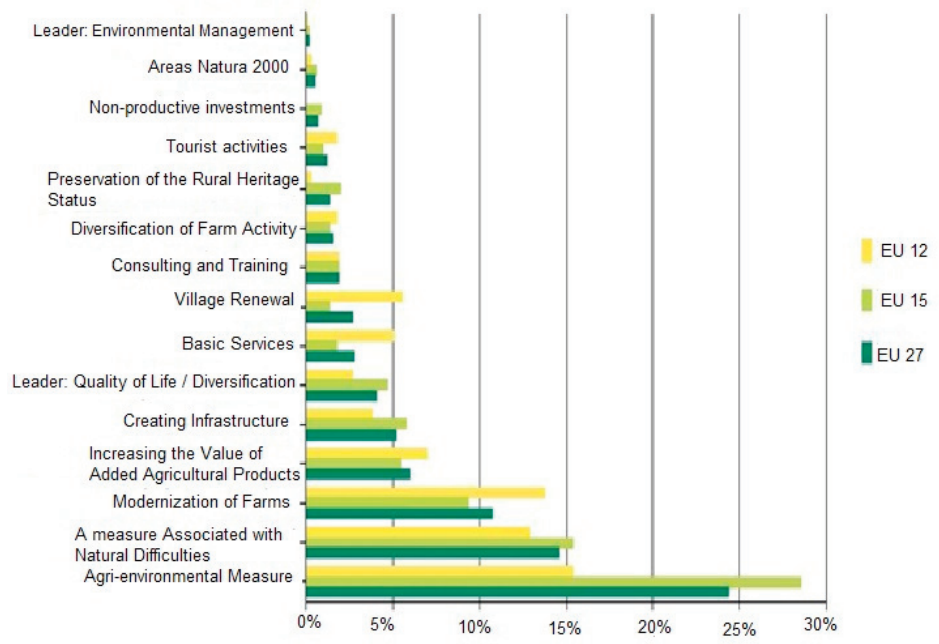

Source: Baldock, D., Hart, K., Scheele, M., 2010.

Analyzing the structure of expenditures under the rural development programmes for 2007-2013 in groups of countries (depending on the date of their accession to the EU), as presented in Figure 2, one can observe that almost a half of the budget for rural development is allocated for 3 resources: an agri-environmental measure, a measure connected with support to areas with farming handicaps, and a measure connected with modernization of farms. All these measures support activities favorable to the generation of public goods (environmental, socio-cultural and economic $\mathrm{c}^{3}$ ) in agriculture, although measures with a more direct focus on the provision of environmental public goods are usually included in Axis 2, whereas those with a more direct focus on the provision of social public goods are found within Axis 3. Therefore, interest on the programmed budget allocated to individual Axes of the RDP provides wide indications concerning the priority is given to individual objectives in different member states.

The European Union policy implemented after 2013 is still associated with the implementation of the so-called European agricultural model the main attributes of which include multi-functionality and sustainability. For Poland, the total amount of resources allocated for activities implemented under the Common Agricultural Policy between 2014 and 2020 is EUR 32.09 billion, including 23.49 billion designated for direct payments. The applied system of direct subsidies is 
favorable to the generation of public goods and connected with the observation of the requirements resulting from the implemented policy by subsidy beneficiaries. This applies, among other things, to greening payment depending on the fulfillment of requirements concerning diversification of crops, maintenance of permanent farmland, as well as the allocation of a part of the area for ecological purposes. 30\% of resources earmarked for direct subsidies were allocated for this purpose (System płatności bezpośrednich w latach 2015-2020, 2015).

The key activities in favor of the provision of environmental public goods include restoration and protection as well as enhancement of biological diversity and agriculture of high conservation value; improvement of water management (including fertilization and use of pesticides); prevention of soil erosion (BiernatJarka, 2016: 144-154). Generation of environmental public goods is also helped by the maintenance of use of farmland located in less-favorable areas, as well as the preservation of landscape advantages and biodiversity in these areas, and, consequently, of their socio-economic vitality. The natural environment is positively impacted by the use of sustainable farming methods, as well as activities in favor of protection of soils with high natural qualities. Ensuring of social public goods is possible through implementation of activities in the area of modernization and structural transformation of agriculture, which consequently enables ensuring of food security.

\section{Conclusions}

Activities implemented under the Common Agricultural Policy provide a wide range of instruments supporting generation of safe and high-quality food, protection of biodiversity and landscape, preservation of production capacities (especially of soils) for the purposes of future production, preservation of attractiveness and vitality of rural areas, production of goods which would be competitive on the global market, making an appropriate contribution to solution of the problem of food security, and halting of degradation of natural environment on a global scale (Zegar, 2010: 11-25).

Therefore, the Common Agricultural Policy should continue to strive to provide a wide array of instruments of rural development policy, efficiently supporting the generation of public goods in agriculture, such goods being expected by the modern European society. 


\section{References}

Adamowicz, M.: Wielofunkcyjne rolnictwo w rozwoju obszarów wiejskich (Multifunctional agriculture in rural development), in: Kłodziński, M., Dzun, W. (eds.): Rolnictwo a rozwój obszarów wiejskich (Agriculture and rural development), Warszawa: IRWiR PAN, 2005.

Baldock, D., Hart, K., Scheele, M.: Dobra publiczne i interwencja publiczna w rolnictwie (Public goods and public intervention in agriculture), Bruxelles: European Network for Rural Develpment, 2010.

Biernat-Jarka, A.: Dobra publiczne w rolnictwie w nowej perspektywie finansowej Unii Europejskiej (Public goods in agriculture in the new financial perspective of the European Union), Zagadnienia Ekonomiki Rolnej (Problems of Agricultural Economics) no. 1 (2016).

European Network for Rural Development: Conceptual Framework on Public Goods Provided Through Agriculture in the EU. Working Document of the Technical Working Group "Public Goods", 2009.

Cooper, T., Hart, K., Baldock, D.: Provision of Public Goods through Agriculture in the European Union. Rapport Prepared for DG Agriculture and Rural Development, London: Institute for European Environmental Policy, 2009.

Czudec, A.: Ekonomiczne uwarunkowania rozwoju wielofunkcyjnego rolnictwa (Economic conditions for the development of multifunctional agriculture), Rzeszów: Wydawnictwo Uniwersytetu Rzeszowskiego, 2009.

Czyżewski, A., Kułyk, P.: Dobra publiczne w koncepcji wielofunkcyjnego rozwoju rolnictwa; ujęcie teoretyczne i praktyczne, Problemy rolnictwa światowego (Public goods in the concept of multifunctional agricultural development; theoretical and practical approach, Problems of world agriculture), Zeszyty Naukowe SGGW w Warszawie (Scientific Works of SGGW in Warsaw) no. 2 (2011).

Czyżewski, B., Matuszczak, A.: Rola rent gruntowych w zrównoważonym rozwoju rolnictwa (The role of land rents in the sustainable development of agriculture) ACTA Scientiarum Polonorum, Oeconomia no. 3 (2010).

Daniel, F.J., Perraud D.: The Multifunctionality of Agriculture and Contractual Policies. A Comparative Analysis of France and the Netherlands, Journal of Environmental Management no. 90 (2009).

Duer, I.: Dobra publiczne użytkowane i dostarczane przez rolnictwo-wspierane w ramach programu rozwoju obszarów wiejskich (Public goods used and supplied by agriculture - supported under the rural development program), Studia i Raporty (Studies and Raports) no. 21 (2010).

Europejska Sieć na rzecz Rozwoju Obszarów Wiejskich: Dobra publiczne i publiczny system interwencji, Raport analityczny przekazany do członków TGR 3 (Public goods and public intervention system, Analytical report passed to TGR members 3), 2010.

Liziński, T.: Problemy wyceny dóbr i usług środowiskowych na obszarach wiejskich (Problems of valuation of environmental goods and services in rural areas), Zeszyty Naukowe Uniwersytetu Szczecińskiego. Ekonomiczne Problemy Usług (Scientific Works of University of Szczecin. Economic Problems of Servicies) no. 89 (2012). 
Małażewska, S., Gajos, E.: Hierarchia dóbr publicznych w rolnictwie (Hierarchy of public goods in agriculture), Roczniki Naukowe SERiA (Scientific Yearbook of SERiA) no. 5 (2016).

Małażewska, S.: Środowiskowe dobra publiczne w rolnictwie i na obszarach wiejskich (Environmental public goods in agriculture and in rural areas), Ekonomia i Środowisko (Economy and Environment) no. 1 (2015).

Malinowski, P.: Wielofunkcyjne rolnictwo jako kierunek rozwoju polskiej wsi (Multifunctional agriculture as a direction of the development of the Polish village), in: Adamowicz, M. (ed.): Zarządzanie wiedzą w Agrobiznesie w warunkach polskiego członkostwa w Unii Europejskiej (Knowledge management in Agribusiness in the conditions of Polish membership in the European Union), Prace Naukowe SGGW (Scientific Works of SGGW) no. 35 (2005).

Marsden, T., Sonnino, R.: Rural Development and the Regional State: Denying Multifunctional Agriculture in the UK, Journal of Rural Studies no. 24 (2009).

Multifunctionality: Towards an Analytical Framework. Paris: OECD, 2001.

Ramniceanu, I., Ackrill, R.: EU Rural Development Policy in the New Member States: Promoting Multifunctionality?, Journal of Rural Studies no. 23 (2007).

Renting, H., Rossini, W.A.H., Groot, J.C.J., Van der Ploeg, J.D., Laurent, C., Perraud, D., Stobbelaar, D.J., Van Ittersum, M.K.: Exploring Multifunctional Agriculture. A review of Conceptual Approaches and Prospects for an Integrative Transitional Framework, Journal of Environmental Management no. 90 (2009).

Roszkowska-Mądra, B.: Obszary wiejskie o niekorzystnych warunkach gospodarowania w aspekcie ich zrównoważonego rozwoju (Rural areas with unfavorable farming conditions in the aspect of their sustainable development, Bialystok: Wydawnictwo Uniwersytetu w Białymstoku, 2010 .

Samuelson, P.A.: The Pure Theory of Public Expenditure, The Review of Economics and Statistics no. 4 (1954).

System płatności bezpośrednich w latach 2015-2020 (Direct payments system in 2015-2020), Warszawa: MRiRW, 2015.

Wilkin, J.: Rolnictwo a społeczeństwo - ewolucja funkcji i relacji (griculture and society - the evolution of functions and relations), in: Uwarunkowania i kierunki przemian społecznogospodarczych na obszarach wiejskich (Conditions and directions of socio-economic changes in rural areas), Warszawa: IRWiR PAN, 2005.

Wilkin, J., Wielofunkcyjność rolnictwa i obszarów wiejskich (Ultifunctionality of agriculture and rural areas), in: Kłodziński, M. (ed.): Wyzwania przed obszarami wiejskimi i rolnictwem $\mathrm{w}$ perspektywie lat 2014-2020 (Hallenges in front of rural areas and agriculture in the perspective of 2014-2020), Warszawa: IRWiR PAN, 2008.

Wilkin, J.: Wielofunkcyjność rolnictwa - nowe ujęcie roli rolnictwa w gospodarce i społeczeństwie (Nactional agriculture - a new approach to the role of agriculture in the economy and society), in: Wilkin, J. (ed.): Wielofunkcyjność rolnictwa. Kierunki badań, podstawy metodologiczne i implementacje praktyczne (Multifunctionality of agriculture. Research 
directions, methodological foundations and practical implementations), Warszawa: IRWiR PAN, 2010.

Wilson, G.A.: From "Weak" to "Strong" Multifunctionality: Conceptualising Farm-level Multifunctional Transitional Pathways, Journal of Rural Studies no. 24 (2008).

Zegar, J.S.: Ekonomia wobec kwestii agrarnej (Ecomy in the face of the agrarian issue), Ekonomista (Economist) no. 6 (2010).

Zegar, J.S.: Polityka Rolna po 2013 roku (Agricultural Policy after 2013), Wieś i Rolnictwo (Village and Agriculture) no. 3 (2010).

Dyrekcja Generalna do Spraw Polityki Wewnętrznej. Jakie narzędzia europejskiej polityki rolnej sprzyjałyby dostarczaniu dóbr publicznych? (What Tools for the European Agricultural Policy to Encourage the Provision of Public Goods?) Studium 2011. www.europarl.europa.eu. 
SECTION 2.3

PROTECTION OF PUBLIC INTEREST IN SPECIFIC ISSUES OF FINANCIAL LAW 



\title{
MUNICIPALITIES AND THE SOLUTION OF EXPENDITURE IN THE PUBLIC INTEREST AND INDEBTEDNESS ${ }^{1}$
}

\author{
HANA MARKOVÁ2
}

\begin{abstract}
Municipalities as basic territorial self-governing units and regions as higher territorial self-governing units are considered to be the territorial self-governing units in the Czech Republic. They are public corporations which may have their own assets and manage according to their own budget. They are a part of the public sector and therefore they cannot be excluded from the budget management rules, including debt issues. An important fact is that they also receive funds collected from the central government, but their management is not burdened with the financing of mandatory expenditures to the extent it is with the state. Introducing the fiscal rules related to indebtedness is for ensuring budgetary discipline, to reduce the long-term deficit management financed from foreign resources and to strengthen co-responsibility for the development of public finances. The public interest and the level of indebtedness have an important role in deciding on the granting of state subsidies, which can take different forms.
\end{abstract}

\section{Keywords}

Municipality; budget; debt brake; subsidies

JEL Classification: H60, H63, H72

1 This paper has been elaborated within the programme "PROGRES Q02 - Publicization of Law in the European and International Context" which is realized in 2018 at the Faculty of Law of the Charles University.

2 Professor of Financial Law and Financial Science, Department of Financial Law and Financial Science, Faculty of Law, Charles University, Czech Republic. The Author specializes in tax law and insurance law. She is the author or co-author of more than 10 books and 70 reviewed articles. She is a member of Information and Organization Centre for the Research on the Public Finances and Tax Law in the Countries of Central and Eastern Europe. Orcid.org/0000-0002-0204-4571. Contact email: markova@prf.cuni.cz. 


\section{Introduction}

Municipalities as basic territorial self-governing units and regions as higher territorial self-governing units are considered to be the territorial self-governing units in the Czech Republic. According to the Constitution of the Czech Republic (Art. 101/3), they are public corporations which may have their own assets and manage according to their own budget. Municipalities and regions, therefore, have their own (separate) budgets that are not part of the State budget. They act under their own name, acquire assets and separately manage according to their own budget. The aim of the article is to analyze selected municipal expenditures in the public interest, in relation to the issue of indebtedness. In particular, the analytical and synthetic method will be used.

\section{Legal Status of Municipalities and their Budgets in the Czech Republic}

The constitutional concept of territorial self-governing units in the Czech Republic is based on the fact that municipalities and regions are public corporations, legal persons governed by the public law other than the State, separated even in the field of property rights. According to an explicit amendment of the law, the State is not responsible for the management and obligations of the municipality or the region, unless such an obligation is taken over by the State. The rules for the establishment of obligations of territorial self-governing units from loans, credits, and other titles, are governed by general rules of private law, but there are restrictions against the rules of private law:

- except for the exceptions allowed by law, it is the prohibition of the liability of territorial self-governing units for third-party obligations, under penalty of invalidity of a legal act which would infringe such a prohibition;

- general obligation to dispose with their assets effectively and efficiently, the obligation to take care of and control the management with the assets of the territorial self-governing units.

This means, for example, that the risk of incurring debts due to issued municipal bonds is limited by the legal requirement of the Ministry of Finance's prior approval to issue municipal bonds.

The budgets of municipalities and regions shall be approved by their authorities, namely the Municipal Council and the Regional Council. The budget of the territorial self-governing unit is compiled balanced, surplus or deficit. A deficit budget may be approved only if the deficit can be covered by funds from past years 
or by secured returnable sources, which according to the law means a contractually secured loan, credit, returnable financial assistance or income from the sale of municipal bonds. It is therefore in the public interest to make the expenditure of municipalities and regions do not exceed certain amounts - do not lead to debt and at the same time cover the need for the territory development.

However, in the case of the mismanagement or lack of responsibility, they can get into a situation where their right will be fundamentally limited by high liabilities and insolvency, that they will not be able to resolve their income and assets in the next few years. The consequence is that the territorial self-governing unit is not able to properly exercise self-government (the right of the territorial self-governing unit citizens is guaranteed by the Constitution). It is also essential for these reasons that certain rules of budgetary responsibility should apply to municipalities and regions.

\section{Rules of Budget Management - Debt Brake}

Municipalities and regions are part of the public sector ${ }^{3}$ and therefore cannot be excluded from the rules of budget management and debt issues. Equally important is the fact that they receive funds collected by the central government for their actions and that their management is not burdened with the financing of mandatory expenditures to the extent as it is in case of the State. The legislation stipulates three sets of obligations for the municipalities and regions (hereinafter territorial selfgoverning units, the TSU):

- approval of a balanced or surplus budget in the event of launching a debt brake (i.e. when the public-sector debt exceeds 55\% of GDP);

- the gradual reduction of the old debts of TSU, in the case, that the current debt exceeds $60 \%$ of the average income for the past 4 years (fiscal rule);

- the publication of data relating to the budget and management.

Rule of the debt brake, which is contained in the Act on Budgetary Responsibility, stipulates that if the debt of public institutions sectors amounts to at least $55 \%$ of nominal GDP, the TSU must approve their budget for the following year as balanced or in surplus. However, this restriction is not absolute and there are exceptions out of it. The budget can be established as deficit if the shortfall can be paid:

1. through money saved from previous years,

3 The public sector institutions is composed of approx. 17,500 entities. They are organizational units of the State, municipalities, state contributory organizations, voluntary associations of municipalities, public research institutions, regions, health insurance companies, legal persons established for the purpose of satisfying needs of public interest, the founder of which is a public institution: financed by a public institution or governed by a public institution (ability to enforce managers' appointment/dismissal), contributory organizations established by the TSU, regional councils, state funds. 
2. through returnable financial assistance;

3. through credit, a loan or the income from the sale of municipal bonds, if these funds are to be used for the pre-financing of projects supported by the EU budget.

Income forms - to put it simply - the sum of all consolidated cash performances received in the budget during the calendar year, and the debt of the TSU consists of unpaid liabilities from issued bonds, borrowings, loans and returnable financial assistance; execution of fulfillment from guarantees, issued promissory notes.

A fiscal rule is introduced by law in order to ensure a budgetary discipline in case of the TSU, to reduce long-term deficit management that is financed from foreign sources and to strengthen co-responsibility for the development of public finances that states following:

a) the amount of the debt should not exceed $60 \%$ of the total income of TSU and if this limit is exceeded,

b) the TSU has an obligation to gradually repay the previous debt at least of 5\% from the difference between the amount of the debt and $60 \%$ of the average income. $^{4}$

The objective of the given fiscal rule is to ensure budgetary discipline in case of the TSU, to reduce the long-term deficit management that is financed from foreign resources and to strengthen co-responsibility for the development of public finances. If the TSU will not repay its debts at least within the limits mentioned, a part of the tax revenues (shared taxes) that will be kept in the special account and will be released for repayment of the previous obligations of the TSU, will be detained. The established fiscal rule leaves considerable leeway to the territorial self-governing units in their management and defines the only debt capacity that is generally considered to be "safe". At the same time, the predictability of public sector indebtedness development is increased through it. ${ }^{5}$

\section{Subsidies - their Structure and Role in Safeguarding the Public Interest}

Subsidies form a significant income of regions and municipalities - either from the State budget or State funds or, in the case of municipalities, the subsidies are from

\footnotetext{
The value of the rule is calculated as the total income calculated as the average for the previous 4 years. At present, roughly 500 municipalities exceed the level of the fiscal rule, while most of them have debts up to their one annual budget. In more than $84 \%$ of the concerned municipalities, the minimum amount of the debt repayment forms less than $5 \%$ of their total income. Almost $80 \%$ of the municipalities for which the minimum amount of the debt repayment exceeds $10 \%$, it is able to finance the income shortfall through balances in their accounts (Matej, 2017).
} 
the budget of regions. One of the criteria used by the providers of subsidies from the State budget and from State funds towards the municipalities is, whether the provision of those resources is in the public interest and therefore, their indebtedness is also investigated. This criterion, however, does not mean the automatic loss of the municipalities' possibility to obtain State subsidy, is the only one of the conditions for deciding on the granting of State subsidies to the municipality, which should be taken into account by providers of subsidies. For this criterion, however, a subjective assessment will not be avoided and the individual departments do not take the given indicator into the consideration in the same way and with the same degree of seriousness. In deciding whether to grant a subsidy, the potential increase in indebtedness due to ensuring the co-financing of the municipality and the region in participating in EU funded programs should also be taken into consideration. However, the subsidies can also be found on the expenditure side of budgets of municipalities, which provide them to different entities, and therefore their nature and impact on the public in a given location should be respected.

The municipality acts as a public authority in the subsidy's provision. The municipality concludes a subsidy grant contract with the recipient of the subsidy, but can unilaterally interfere with the rights and obligations, may cut or totally revoke the subsidy (by administrative decision), impose levies for violating budgetary discipline. The municipality thus has more control over the handling of money.

The provision of subsidies is implemented through public service contracts in the Czech Republic. Although it is designated as the contract, it is not a typical contract according to the Civil Code, but it is based on rights and obligations in the field of public law. By concluding a contract, the subsidy recipient is entitled to receive the subsidy (only after the conclusion of the contract, there is no legal claim to subsidy before the conclusion) and the obligation to use the subsidy for the specified purpose, submit the bill and subject to control and, where appropriate, sanctions. On the one hand, the municipalities are also obliged to pay the subsidy and, on the other hand, the right to control the recipient and, where appropriate, to impose sanctions and levies. The provision of subsidies must be approved by a separate resolution of the authority of the municipality - it is not possible to approve the subsidy only as part of the dealt budget. Any appeal or other legal remedies are admissible against the decision on the failure to provide subsidies, however, it is generally possible to oppose it in court. However, the Court does not have the power to determine how the municipality will handle its assets, so the review of this decision will be very limited.

Criteria for objective and fair distribution system of budget funds of the municipalities should, therefore, respect certain requirements (Peková, 2004: 299): 
- it should be easily identifiable at a given time in each municipality;

- it should be objectively pronounced in easily measurable units;

- it should not be sensitive to the influence of local politics;

- it should not be too dependent on cyclical changes;

- it should take objective changes in time into account;

- it should be fixed at a certain time so that municipalities can plan their level in the medium-term budget forecast;

- it should not be too detailed so that a set of criteria was too extensive and thus difficult to control. Their use should be associated with the lowest administrative costs.

In the Act on Budgetary Rules which concern municipalities and regions as providers, there are two types of subsidies that municipalities can provide - the program subsidy and the individual subsidy.

Program subsidy is paid on the basis of the program - a sort of public communication that the municipality is interested in promoting a specific area, there is a public interest, and applicants can turn to the municipality with their applications. The program, announced by the municipality, must include the elements listed in the law, which means that not everything that was or is marked as the program, is the title which can be marked as the program under the Act on Budgetary Rules of Territorial Budgets.

In addition to the program subsidies, there are individual subsidies, which will be provided by the municipality on the basis of individual applications - the subsidies cannot be provided to unilaterally or only on the initiative of the municipality. Someone must always submit an application which must comply with the formalities - if the application does not contain these elements, it cannot be complied with, but nothing precludes the municipality from requesting the applicant to the supplement, of course.

The subsidies provided to the budget of the municipality or region may be of a demanding or non-demanding nature. The State, using demanding subsidies, tries to ensure that goods and services, which, in particular, municipalities provide on the basis of their delegated powers and to guarantee a certain standard level of certain public services. The path of these subsidies thus allows the State to check the economy and the public interest or purpose for the spending of funds on the part of the recipients. Demanding subsidies from the National budget must be provided to the municipalities by law. Thus, unlike non-demanding subsidies, they are stable and permanent income to the municipality budget. In terms of funding should be allocated to municipalities all the costs associated with the exercise of devolved 
government. Services that a municipality provides delegated scope, however, they are also often performed for the residents of other municipalities. The problem is that municipalities are not adequately compensated for the exercise of delegated powers, and so the municipality loses some of their revenues that could be used for their development. The size of the State contribution to the budget of the municipalities should be based on the objective costs of the activity concerned.

Another problem circuit in the area of the demanding subsidies constitutes subsidies on the devices, for which is the founder the municipality, but whose services are provided to the mainstream territory (subsidies to the social care institutions, retirement homes, selected medical facilities). The subsidy object here is one place, and here it is shown that the provided subsidy does not cover the total costs of municipalities for these facilities. The municipality through a provided subsidy must provide part of the funds from its own resources. In the case that in such facilities, the residents of other municipalities are located, there is not much addressing the question of the settlement between municipalities.

The subsidies for social benefits (transfer of the funds for social benefits) are associated with the devolved government powers to municipalities in relation to the payment of social benefits. These subsidies fully cover municipality payments for social benefits. The non-demanding subsidies (www.denik.obce.cz) are the second part of the subsidies that municipalities can receive from the State, but about which they must bid for the authorities of the State. Obtaining these resources depends on a number of circumstances - the volume of the resources of the State, the number of own resources of the municipality, the amount of the requirements, a debt of municipalities, regional policy of the State, but also likely non-transparent allocation, lobbying, corruption, etc.

\section{Conclusions}

It can be summarized that subsidies are the State-supported activities of the municipalities, which are mostly of an investment character, meeting the public interest. They are provided through State-announced programs. The reason for the existence of the non-demanding subsidies should not be only the compensation to the low level of tax revenue of some municipal budgets and their uneven distribution between the individual size categories of municipalities. The State should ensure that there is greater transparency and also control of their use. Public control would not apply to providers of subsidies only, but also on the recipient. In fact, the application gives very hard verifiable data and the subsidy proceedings are sometimes opaque. 
The area of legislating the provision of subsidies is undergoing dynamic development and it can be expected that in the nearest future additional rules will be adopted, which will complement the existing Act on Budgetary Rules.

\section{References}

Kopecký, M., Suchánek R.: The budgeting process and issues of indebtedness in the Czech Republic, The Lawyer Quarterly no. 2 (2014).

Marková, H.: Dotace, municipality a zneužití práva (Subsidies, municipalities and abuse of rights), in: Mrkývka, P., Pařízková I., Valdhans, J. (eds.): Zneužití práva a svévole při veřejné finanční činnosti (Abuse of law and arbitrariness in public financial activity), Brno: Masarykova Univerzita, 2015.

Matej, M.: Pravidla rozpočtové odpovědnosti v podmínkách obcí a krajů (Rules of Budget Responsibility in the Context of Municipalities and Regions), Obec a finance (Municipality and Finance) no. 1 (2017).

Peková, J.: Hospodaření a finance územní samosprávy (The Management and Finances of the Territorial Self-Government), Praha: Management Press, 2004.

Role dotací v územních rozpočtech (The role of subsidies in local budgets), 2012. www.denik.obce.cz.

CZ: Act no. 250/2000 on Budgetary Rules of Territorial Budgets, as amended.

CZ: Act no. 23/2017 on Budgetary Responsibility Rules. 


\title{
MODEL OF PUBLIC ACCOUNTABILITY FOR PUBLIC DEBT REDUCTION IN PUBLIC INTEREST
}

\author{
URSZULA K. ZAWADZKA-PĄK
}

\begin{abstract}
In the financial context of public interest, the attention should be paid to the public debt, especially in the intergenerational perspective of justice. Thus, the aim of the paper is to present the theoretical, multidimensional model of accountability for public debt that will serve in public interest. The research question is what is the nature of conditions necessary to the effective limitation of public debt. According to the research hypothesis, these conditions are of varied nature, they are not limited to the legal dimension of legal responsibility but they have the basis in the public accountability. To achieve the scientific aim of the research and to search for the evidence to support the study's hypothesis the literature review was made, consisting in the analysis of the existing literature presenting the theoretical and empirical results of the previous research. We conclude that to effectively reduce public debt, the multidimensional model of public debt should be developed, consisting of four components i.e.: the legal responsibility, the democratic accountability, the moral accountability, the financial accountability. Having the knowledge on the particular components of the proposed model it would be possible in future research to analyze the components of the politicians' motivation to issue the regulations in accordance with universally binding moral rules serving the public interest and not their own interests (the legal motivation).
\end{abstract}

\section{Keywords}

Public interest; legal regulation; public values; democratic values

\section{JEL Classification: A13, H30, H63}

1 Doctor of Law, Department of Public Finances and Financial Law, Faculty of Law, University of Bialystok, Poland. The author specializes in financial law and public financial management, including participatory budgeting, public values, fiscal rules and performance management. She is the author or co-author of 7 books and more than 75 papers or books chapters. Member of Centre for the Research on the Public Finances and Tax Law in the Countries of Central and Eastern Europe, International Political Science Association and European Economic Association. More information can be found on her website: uzawadzka.org. Contact email: u.zawadzka@uwb.edu.pl. 


\section{Introduction}

Public interest-based theories are imprecise because the subject of these theories is an ideal rather than a discrete construct (Fesler, 1990). The concept of public interest is sometimes identified with public values, however, the most important distinction between these two concepts is that "public interest" is an ideal, whereas "public values" have specific, identifiable content. In particular context, the public interest refers to the outcomes best serving the long-run survival and wellbeing of a social collective construed as a "public" (Bozeman, 2007: 12). In consequence, in the financial context of public interest, the attention should be paid on the public debt, especially if we take into consideration the intergenerational perspective. In such a case it takes the form of the sustainability that requires the protection of wealth across generations (Norton, 2017: 355). J. Rawl, one of the most influential moral and political philosopher in the liberal tradition, presenting his theory of the intergenerational justice claims that "persons in different generations have duties and obligations to one another just as contemporaries do" (Rawl, 1999: 258).

The level of public debt is one of the crucial, even if not the only one, determinants of the public finance sustainability, understood as the capacity to incur future financial burdens arising from the current debt (Fiscal Sustainability Report 2012: VII). Even if current generations of citizens (and voters) may be pleased by the public debt accumulation used to finance public services, the excessive indebtedness may be dangerous for future generations. In extreme cases the excessive level of public debt decides about the undisturbed existence of states; significant public debt was one of the reasons for the bankruptcy of Argentina, the problems thereof are being compared with the current situation of Greece. Even if there is no doubt that the reduction of the public debt level is in public interest, the public authorities of some countries are effective in that and the other not. The Figure 1 presents the data on the public debt in relation to GDP in the selected European countries in 2005, i.e. before the financial crisis, in 2010, just after its end (even if the delimitation of precise time frame uniformly for all the countries is difficult), and currently (the latest data come from 2015). 
Figure 1 Public Debt in Selected European Countries (as the percentage of GDP)

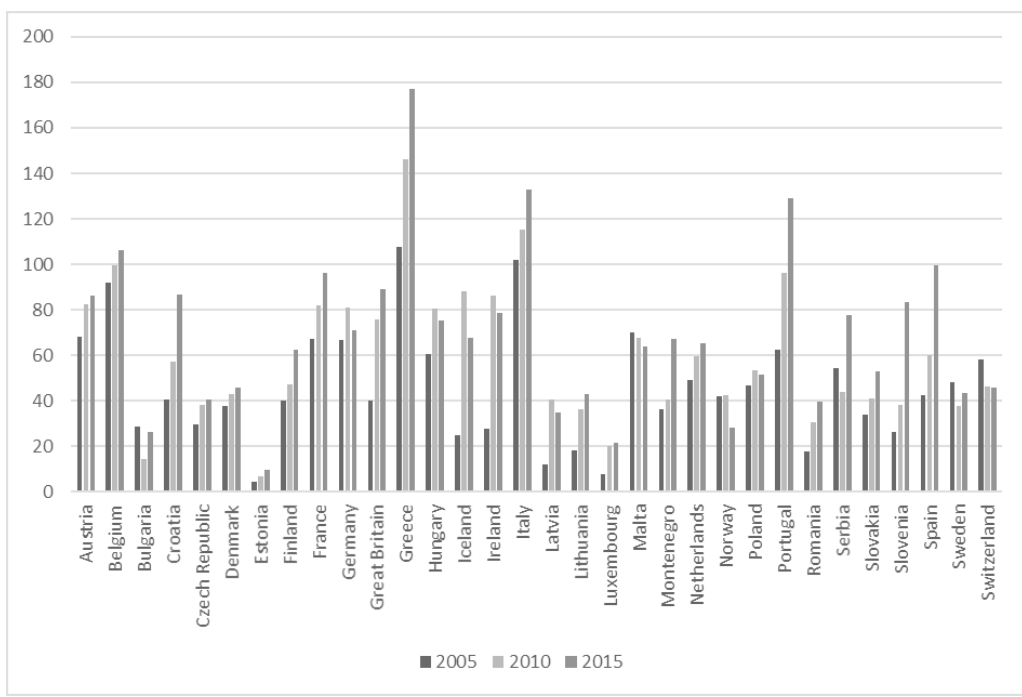

Source: Own elaboration on the basis of data of International Monetary Funds.

The study is composed of six sections, Having presented the overview of the public debt problem (section 1) and the adopted methodology (section 2) we present the literature review analyzing causes and the possible solutions to the public debt accumulation (section 3). That will enable to propose the conceptual framework of the multidimensional model of accountability for public debt (section 5). Our conclusion provides some general implications for law-making.

\section{Methodology}

Despite the efforts to broaden interdisciplinary scholarship, the traditional disciplines that comprise the "law-and" universe are mostly insular (Eisenberg, 2011; Bornstein, 2016: 119). This study proposes the theoretical framework for interdisciplinary research to make the better law, the law informed by reality, i.e. evidence-based law (Rachlinski, 2011: 910). In more details, the aim of the paper is to present the theoretical, multidimensional model of accountability for public debt that will serve in public interest. The research question is what is the nature of conditions necessary to the effective limitation of public debt. According to the research hypothesis, these conditions are of varied nature, they are not limited to the legal dimension of legal responsibility but they should have the basis in the public accountability. To achieve the scientific aim of the research and to search for evidence to support the study's hypothesis the literature review was made (Fink, 
2014: 6), thus the unobtrusive method (Babbie, 2007) consisting in particular in the analysis of the existing literature presenting the theoretical and empirical results of the previous research was applied.

The considerations presented in this chapter constitute the pure (conceptual) research, developing new concepts and reinterpreting the existing ones (Kothari, 2004: 4-5), i.e. the preliminary theory of the multidimensional accountability for public debt reduction. As it results from the Figure 2, within the pure legal research, there are two types of research styles, i.e. the traditional legal theory research and the interdisciplinary fundamental research. In the study, we go beyond the limits of traditional legal research theory and we use the interdisciplinary fundamental research. However, to test empirically the proposed model and to draw the detailed conclusions for the evidence-based law, effective in the public debt reduction (conclusions de lege lata and de lege ferenda) the future interdisciplinary research will be needed, this time using the quantitative and qualitative methods.

Figure 2 Legal Research Styles

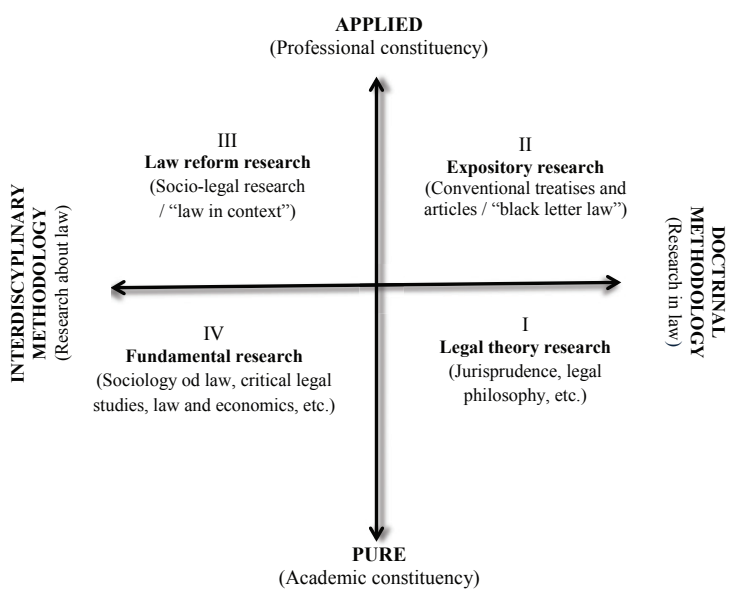

Source: H.W. Arthurs (1983) as cited by A. Knight, L. Ruddock (2008: 29).

\section{Public Debt - Causes and Solutions}

\subsection{Legal Regulations as Cause and Solution to Public Debt Accumulation}

One of the main reason of the public debt is the existence of the public deficits in the consecutive years that, in turn, results from the excessive public expenditure 
that are not covered sufficiently by the annual public revenues. The significant part of public expenditure is legally determined (Dębowska-Romanowska, 2010: 130). Hence, the literature proposes to reduce their share in the structure of the budget and opt more for the flexible expenditure as well as to limit the amount of expenditure from the budget of total funds (Dębowska-Romanowska, 2007: 292). To solve these problems already Buchanan and Wagner (1977) proposed the use of constitutional fiscal rules. Nowadays actually the public authorities try to reduce public debt by these rules, even if rarely having the constitutional rank (ZawadzkaPąk, 2018: 213-228) Fiscal rules typically are defined as the numerical or procedural restrictions on the preparation, approval, and implementation of public budgets (Corbacho, Ter-Minssian, 2013: 38). These rules cover summary fiscal indicators, such as the government budget deficit, borrowing, debt, or major components thereof - expressed as a numerical ceiling or target, in proportion to the gross domestic product, GDP or being procedural limitations (Kopits, Symansky, 1998: 15; Corbacho, Ter-Minassian, 2013: 40). As it results from the research conducted by the International Monetary Fund, the majority of countries in the world has introduced some kind of fiscal rules (Fiscal Rules Dataset 1985-2015, IMF 2016), however as it results from the Figure 1. in some countries the fiscal rules are effective and in other not. However, there are numerous analysis showing that these formal constraints on fiscal policy, even at the constitutional level, do not prevent the excessive debt (Ayuso-i-Casals, et al.: 2009) or encourage politicians to go around these regulations (Hagen, 1991).

\subsection{Democracy as Cause and Solution to Public Debt Accumulation}

The link between democracy and public debt has begun to be recognized in the seventeenth century (Macdonald, 2003). Buchanan and Wagner (1977) has also noted that democracies find it difficult to maintain financial discipline. However, the reduction of public debt and deficit technically is not difficult. The lack of political will in this regard is linked to the essence of a democratic system. The policy-makers are chosen by citizens, so aspiring to take or maintain power they make expensive promises and then they pass the laws allowing them to be reelected, what often is harmful to the public debt level, reflecting the politicians' long-term consequences of budgetary decisions. R. Hannesson (2015: 13) argues that democracy is better at distributing wealth widely than in generating it in the first place and is wondering if it carries within itself the seeds of its own destruction. This is supported by the fiscal illusion theory, espoused by J.M. Buchanan and R.E. Wagner (1977). According to this theory, the politicians, as vote maximizers, tend to propose new government programs to attract new voters as much as possible, which makes public sector bigger. They are motivated to "fool" citizens 
so that they may attract individuals' votes without being blamed for the increase in government spending. By designing and manipulating the fiscal system, politicians try to make the public underestimate the costs of public sector goods and services. The greater the extent of these "illusion-inducing" characteristics of a fiscal system, the greater the size of the government. In this sense, the democratic political system where the citizens' representatives in parliament are chosen in the election, seems to be the cause of the public debt accumulation. The above is strictly related to the political business cycles theory that implies that governments, in order to be reelected try harder to please voters immediately before election day (Breton, 1974). As R. Hannesson (2015) argues "elites are voted into power, or kept in power, by a mostly uninformed electorate that votes for them in the expectation that they will govern well, which mostly means high and rising standards of living. When the elites fail to deliver, they are voted out (...) But raising taxes is not popular (...) The temptation to finance an expanding government sector by increasing debt is therefore strong" (Hannesson, 2015).

On the other hand, the democracy may be seen as a solution to the excessive public debt accumulation. The relations between public debt and the level of democracy are widely analysed in the literature, even if not ambiguous (Feld, Kirchgässner, 2001; Holland, 2016; Stallings, Kaufman, 1988; Frieden, 1985: 300; Cheru, 1989), in some papers being restricted to precious legal analysis but not supported by quantitative proofs (Schragger, 2012), in other works being limited to singlecase analysis (Lindholm, 1946); (Chossudovsky, Ladouceur, 1994: 1506-1507). Also, contributions based on the statistical methods give ambiguous results, thus still require more attention. For instance, G. Anderson (1988) using a simple model supports the thesis that the external public debt levels will be higher in the dictatorship. Next, E.M. Balkan and K.V. Greene (1990: 211) denying the Anderson's contribution and using larger, but still limited, sample of countries and the statistical analysis found little empirical support for the thesis that democracy or autocracy influence foreign debt (Balkan, Greene, 1990). On the other hand T. Oatley (2010: 195) provides the statistical pieces of evidence that the autocratic governments accumulated substantially larger foreign debt relative to their national income than democratic governments. Moreover, the studies have shown that the direct democracy (financial referendum) contributes to a reduction of public debt in Switzerland (Feld, Kirchgässner, 2001). It has also been also proven that the financial referendum in Switzerland contributes to reduction of public debt by limiting by the citizens the growth of social spending, as citizens deciding on public money (in fact on taxes that they pay) are much more economical in that regard than the political elites (Kriesi, Trechsel 2008: 164). In contrast to these Swiss experiences, the pieces of evidence from German municipalities suggest that that direct democracy causes an expansion of local government expenditure (Asatryan, 2016). 
Model of Public Accountability for Public Debt Reduction in Public Interest

3.3 Public Values as Cause and Solution to Public Debt Accumulation

Nowadays, even not without difficulty, the need to combine the legal norms and the moral ones, known since Greek times, is seen again. It was noticed that law deprived of moral attitudes is not able to properly direct citizens to the common good (Dudkiewicz, 2001: 186). Regardless of the dispute about the mutual relations between law and ethics (i.e. the science of morality), both these concepts lay at the heart of the idea of a democratic society (Fulek, 2009: 79. The essence of a democratic legal state seems to be, among others, that such a state should be "moral" and pass moral norms only in a universal "human" sense of this word (Zimmermann, 2013: 81). Legal norms should have their axiological justification, they should be embedded in values (Ziembiński, 1980: 137).

The Rawl's (1999) theory of the intergenerational justice, mentioned in the introduction as the basis of the public debt reduction in the public interests concept is based implicate on at least one of the public values, i.e. justice. On the other hand, the literature provides pieces of evidence that the violation of public values leads to the higher public debt. For instance, C. Liu, T.T. Moldogaziev, J. L. Mikesell (2017: 681) suggest that the levels of public debt issued by state and local governments appear to be higher as corruption levels increase. In consequence, it seems that to resolve the problem there is a need to determine the catalog of public values significant for public debt reduction, and next to find the means to shape appropriately these values by legal norms, as proposed by L. Petrażycki (1959: 200-213).

\subsection{Economic Doctrines as Causes and Solutions to Public Debt Accumulation}

Undoubtedly, the economic concept of the state realized by the policy-makers influences the public debt. For instance, after the First World War, increasing public expenditures and, consequently, public debt, were favored by the demands of state intervention (doctrine of interventionism). The influence of the realization of the welfare state concept was enhanced by the great economic crisis in 19291933 (Przybyciński, 2016: 30). Thus to reduce the public debt level being the consequence of the last financial crisis that in Europe took place in 2007-2008, the realization of the liberalism concept and the fiscal austerity measures are considered to be essential. However, others argue that fiscal austerity is selfdefeating, given its contractionary effect on output, and that reinvigorating growth through fiscal stimulus is more important (IMF, 2012: 101). Still, others suggest that the current problem of public debt could be resolved, as after World War II by the financial repression consisting in the channeling to the public sector funds that in a deregulated market environment would go elsewhere (Reinhart, Kirkegaard, 
Sbrancia, 2011). It seems thus interesting to know what is the most optimal concept of the public expenditures, especially in the relation to public revenues.

\subsection{Recapitulation of Cause and Effect Dimensions of Public Debt}

Figure 3 recapitulates the casual dimensions of public debt. This allows as to propose the multidimensional model of the accountability for public debt presented in the next section.

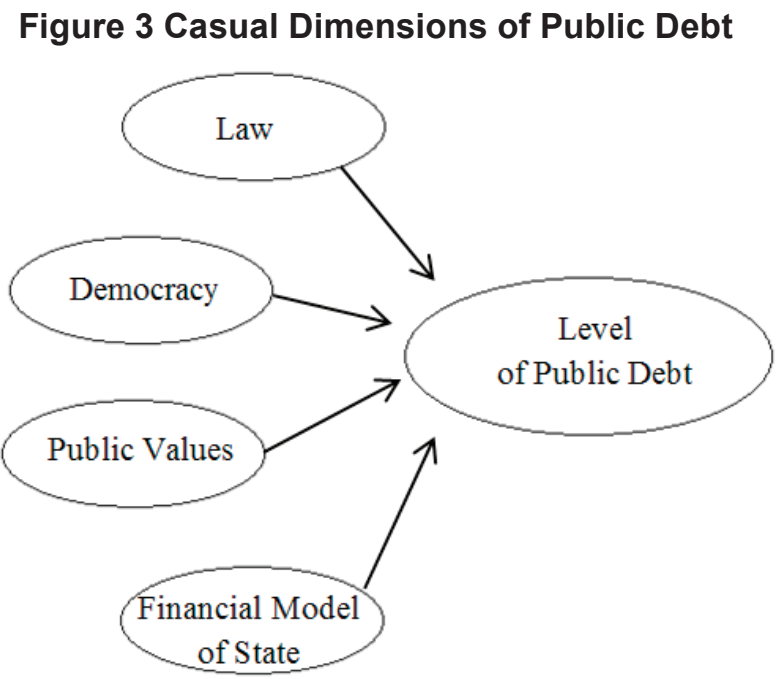

Source: Own elaboration.

\section{Responsibility and Accountability for Public Debt}

\subsection{Traditional Model of Responsibility for Public Debt and Multidimensional Model of Accountability for Public Debt}

Before presentation of the traditional model of responsibility and the multidimensional model of accountability for public debt reduction, let's explain the difference between the terms "responsibility" and "accountability". V.E. Barry (1979) has defined the term "responsibility", as referring to "a sphere of duty or obligation assigned to a person by the nature of that person's position, function, or work" Thus, the responsibility "could be viewed as a bundle of obligations associated with a job or function (...). In many cases, simply discharging this primary obligation (the function associated with the role) may be sufficient unto itself; however, responsibility can also include moral obligations that are in addition 
and usually related to the functional obligations of the role. Thus, responsibility assumes that the actor becomes also a moral agent possessed of a certain level of moral maturity and an ability to reason. (...). If responsibility is defined as a bundle of obligations, functional and moral, associated with a role, then accountability might be defined as blaming or crediting someone for an action - normally an action associated with a recognized responsibility" (www.freedomtocare.org) However as T. Bivins noted "a problem arises, however, in that while responsibility and accountability are often conflated, and admittedly importantly linked, they are not identical by definition or moral implication. The simplest formula is that a person can be held accountable if (1) the person is functionally and/or morally responsible for an action, (2) some harm occurred due to that action, and (3) the responsible person had no legitimate excuse for the action. Ideally, the assumption would then be to hold a person who is responsible for an action also accountable for the results of that action. That, however, may not always be the case. This position assumes that the responsible person is relatively autonomous, or free to make decisions associated with his or her job without outside pressure or influence" (Bivins, 2006: 20-21). In the literature two main usages of "accountability" can be observed. In the dominant usage of accountability is as a social, administrative, or political mechanism, conceptualized as an institutional relation or arrangement in which an agent can be held to account by another agent or institution. In the second usage, accountability is seen as a virtue, as a desirable quality of states, governments organizations, firms, or officials (Bovens, Schillemans, Goodin, 2015: $7-10)$.

As mentioned in section 3.2, the traditional model of responsibility for the public debt, illustrated in Figure 4, comprises only one dimension, i.e. the legal responsibility realized mainly via the fiscal rules.

Figure 4 Traditional Model of Legal Responsibility for Public Debt

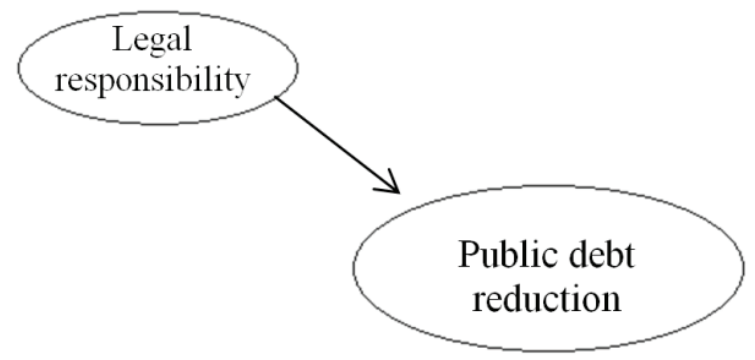

Source: Own elaboration. 


\subsection{Multidimensional Model of Accountability for Public Debt}

The fiscal rules aiming at the public debt reduction generally become ineffective if they are based only on the legal provisions as they may not be severe enough (e.g. if they only project but not oblige to respect the public finance variables, i.e. the level of public deficit, expenditure or debt), not stable enough (e.g. if they are in form of the legal act that can be modified or replaced by the simple parliamentary majority when becomes too severe), or not enough binding (e.g. if they have the form of the coalition agreement). That leads us to the conclusion that to limit the public debt much more effectively, the content of legal provisions on fiscal rules should be built the appropriate dimensions of the public accountability. Thus, we propose the multidimensional model of public debt reduction combining the elements of the responsibility and the accountability (as illustrated on Figure 5).

Figure 5 Multidimensional Model of Accountability for Public Debt

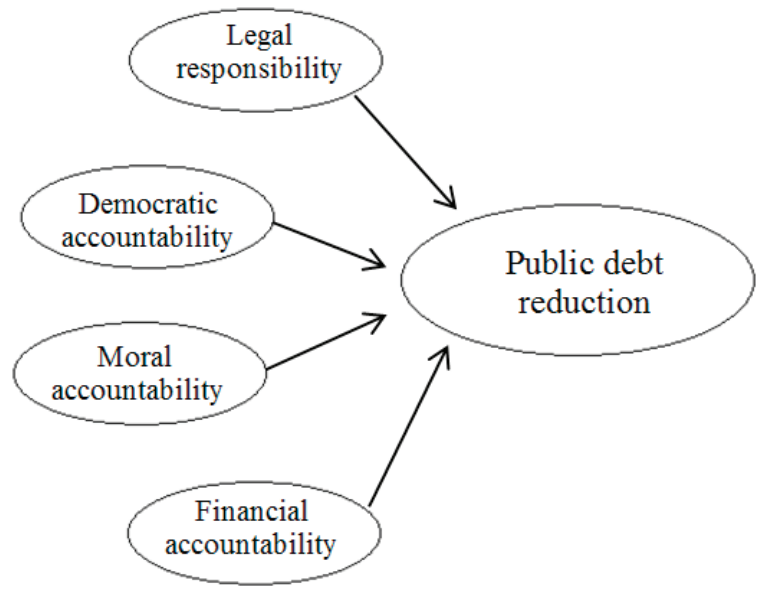

Source: Own elaboration.

Thus, the proposed model consists of four components i.e.:

- the legal responsibility resulting from broadly understood national and international legal norms regulating the fiscal rules and legal instruments supporting their effectiveness (e.g. fiscal councils);

- the democratic accountability resulting from a properly shaped democratic system, including the elements of electoral, liberal, deliberative, participatory, and egalitarian democracy;

- the moral accountability resulting from moral norms and values internalized by citizens and their representatives, i.e. the policy makers (the politicians). The moral accountability requires a change in the human paradigm (both, the 
politicians and the citizens), though not entirely rational, but often motivated by selfish motives (lat. homo-economic), in favour of a man (politician and citizen) guided by moral values (lat. homo ethicus) (Ossowska, 1971: 196; Misztal, 2017). The adoption of the homo ethicus attitude requires a broadly understood attitude of patriotism attribute an intrinsic moral value to the defense of the homeland (Clift, Woll, 2013). Financial patriotism is a derivative of many values and implies an accountable attitude for the public debt of both citizens and politicians, and submission goals important for a country over the personal will base on the solidarity with its own nation and community, social and intergenerational bonds;

- the financial accountability for shaping the appropriate level of public income, expenditure, and balance (in the relation to GDP). Financial dimension of the proposed model has the twofold characteristic, i.e. of the responsibility and the accountability. The first one appears when legal regulations (fiscal rules) oblige public authorities to respect legal limits of public debt, public deficit, public expenditures, or much less frequently, to maintain the minimal level of the public revenues. As this aspect of the financial dimension results from legal provisions, it takes part of the already mentioned dimension of the legal responsibility. On the other hand, the financial accountability of the proposed model consists in the political decisions of the legislators to take the appropriate decisions on fiscal policy.

\section{Conclusions}

All the four components of the model for accountability for the public debt can be operationalized by the variables, the values thereof are determined in the comparative datasets prepared by the international organizations or the research institutes. Testing the proposed model via the interdisciplinary research methods, in particular, quantitative one, on the sample of the groups of appropriately selected countries should lead for developing the theory of accountability for the public debt. The theory would be used to evidence-based law and in consequence be crucial for the effectiveness of the law, in our case the creation and the application of legal provisions ensuring the sustainability of public finances. In consequence, the formulation of postulates de lega lata to improve the application of binding legal norms, and de lege ferenda proposals describing the (innovative hopefully) legal solutions shaping the accountable attitudes of the government and the citizens for the state of public debt.

Nowadays the main instruments of public debt reduction are covered by the legal dimension. However, the fiscal rules inscribed in the legal framework of many 
countries turn out to be ineffective. It seems that in the era of the informational globalization the reason of the ineffectiveness of fiscal rules does not result from the intellectual disabilities of the legislator (the politicians) or lack of the professional support but rather from the lack of motivation to limit themselves in further expenditure planning. Having the knowledge on the particular components of the proposed model it would be possible to analyze the components of the politicians' motivation to issue the regulations in accordance with universally binding moral rules serving the public interest and not their own interests, as we define as "the legal motivation". This concept refers to the commonly accepted in public management, public administration, organizational behavior or the economy term "public service motivation" (Koehler, Rainey: 2008) that however seems not to be analyzed from the legal point of view, whereas it seems to be crucial for the public interest concept.

\section{References}

Anderson, G.M.: Public finance in autocratic process: An empirical note, Public Choice no. 1 (1988).

Arthurs, H.W.: Law and Learning: Report to the Social Sciences and Humanities Research Council of Canada by the Consultative Group on Research and Education in Law, Ottawa: Social Sciences and Humanities Research Council of Canada, 1983.

Asatryan, Z.: The indirect effects of direct democracy: local government size and non-budgetary voter initiatives in Germany, International Tax and Public Finance no. 3 (2016), DOI:10.1007/ s10797-015-9380-1.

Ayuso-i-Casals, J., Deroose, S., Flores, E., Moulin, L. (eds.): Policy Instruments for Sound Fiscal Policies Fiscal Rules and Institutions, London: Palgrave Macmillan, 2009.

Babbie, E.: The Practice of Social Research, Wadsworth: Thomson Learning, 2007.

Barry, V.E.: Moral Issues in Business, Belmont: Wadsworth, 1979.

Balkan, E.M., Greene, K.V.: On Democracy and Debt, Public Choice no. 3 (1990).

Bivins, T.: Responsibility and Accountability, in: Fitzpatrick, K., Bronstein, C., Ethics in Public Relations: Responsible Advocacy, London: Sage, 2006.

Bornstein, B.H.: Law and Social Science: How Interdisciplinary Is Interdisciplinary Enough?, in: Willis-Esqueda, C., Bornstein, B.H. (eds.): The Witness Stand and Lawrence S. Wrightsman, Jr., Cham: Springer, 2016.

Bovens, M., Schillemans, T., Goodin, R.: Public Accountability, in: Bovens, M., Goodin, R.E., Schillemans, T. (eds.), The Oxford Handbook of Public Accountability, Oxford: Oxford University Press, 2015.

Bozeman, B.: Public Interest. Counterbalancing Economic individualism, Washington: Georgetown University Press, 2007. 
Model of Public Accountability for Public Debt Reduction in Public Interest

Breton, A.: The economic theory of representative government, London: Palgrave Macmillan, 1974.

Buchanan, J.M., Wagner, R.E.: Democracy in Deficit: The Political Legacy of Lord Keynes, Carmel: Liberty Fund, 1977.

Cheru, F.: The Silent Revolution In Africa: Debt, Development, And Democracy, Vancouver: Anvil Press, 1989.

Chossudovsky, M., Ladouceur, M.: Debt and Democracy in Brazil, Economic and Political Weekly no. 25 (1994).

Chynoweth, P.: Legal Research, in: Knight, A., Ruddock, L. (eds.), Advanced Research Methods in the Built Environment, Chichester: Wiley-Blackwell, 2008.

Clift, B., Woll, C. (eds.): Economic Patriotism in Open Economies, Abingdon: Routledge, 2013.

Corbacho, A., Ter-Minassian, T.: Public Financial Management Requirements for Effective Implementation of Fiscal Rules, in: Allen, R., Hemming R., Potter, B.H. (eds.): The International Handbook of Public Financial Management, London: Palgrave Macmillan, 2013.

Dębowska-Romanowska, T.: Charakter prawny i klasyfikacja tzw. wydatków sztywnych a granice swobody politycznej władz państwa (Legal character and classification of the legally determined expenditure and the limits of political freedom of state authorities), in: Głuchowski, J., Pomorska A., Szołno-Koguc, J. (eds.), Uwarunkowania i bariery w procesie naprawy finansów publicznych (Conditions and barriers in the process of public finances reform), Lublin: KUL, 2007.

Dębowska-Romanowska, T.: Wydatki publiczne, ich formy prawne oraz zasady realizacji w sektorze finansów publicznych (Public expenditures, their legal forms and rules of implementation in public finance sector), in: Ruśkowski, E. (ed.), System prawa finansowego, t. 2. Prawo finansowe sektora finansów publicznych (Financial law system, vol. 2. Financial law of the public finance sector), Warszawa: Oficyna a Wolters Kluwer business, 2010.

Dutkiewicz, P.: Etyka a prawo (Ethics and law), in: Etyka, Kraków: Uniwersytet Jagielloński, 2001.

Eisenberg, T.E.: The origins, nature, and promise of empirical legal studies and a response to concerns, University of Illinois Law Review no. 5. (2011).

Feld, L.P., Kirchgassner, G.: Does Direct Democracy Reduce Public Debt? Evidence from Swiss Municipalities, Public Choice no. 3 (2001).

Fesler, J.: The state and its study: The whole and the parts, in: Lynn, N., Wildavsky, A. (eds.), Public administration: The state of the discipline, Chatham: Chatham House, 1990.

Fink, A.: Conducting Research Literature Review. From the Internet to Paper, Los Angeles, London, New Delhi, Singapore, Washington: Sage, 2014.

Frieden, J.A: Debt, Development, and Democracy. Modern Political Economy and Latin America, 1965-1985, Princeton: Princeton University Press, 1985. 
Fulek, J.: Rola prawa i etyki w kształtowaniu modelu gospodarczego (Role of law and ethics in shaping the economic model), in: Gasparski, W., Jabłońska-Bonca, J. (eds.), Biznes, prawo, etyka (Business, law, ethics), Warszawa: Akademia Leona Koźmińskiego, 2009.

Hannesson, R.: Debt, Democracy and Welfare State: Are Modern Democracies Living on Borrowed Time and Money?, London: Palgrave Macmillan, 2015.

Holland, D.: Democracies in Crisis: How Do Levels of Democracy Affect Economic Outcomes in Crises of the Developing World?, Users Working Paper, no. 2 (2016).

IMF: Coping with High Debt and Sluggish Growth, World Economic Outlook, 2012.

Kopits, G., Symansky, S.: Fiscal Policy Rules, IMF Occasional Paper no. 162 (1998).

Kothari, C.R.: Research Methodology. Methods \& Techniques, New Delhi: New Age International Limited, 2004.

Kriesi, H., Trechsel, A.H.: The politics of Switzerland: continuity and change, Cambridge, New York: Cambridge University Press, 2008.

Lindholm, R.W.: Debt and Democracy in Germany, The American Journal of Economics and Sociology no. 1 (1946).

Liu, C., Moldogaziev, T.T., Mikesell, J.L.: Corruption and State and Local Government Debt Expansion, Public Administration Review no. 5 (2017), DOI: 10.1111/puar.12711.

Macdonald, J.: A Free Nation Deep in Debt. The Financial Roots of Democracy, New York: Farrar Straus and Giroux, 2003.

Misztal, W.: Homo Ethicus, Homo Moralis. Marii Ossowskiej koncepcja socjologii moralności (Homo Ethicus, Homo Moralis. Concept of the sociology of morality of Maria Ossowska), Warszawa: Scholar, 2017.

Norton, B.G.: Sustainability as the Multigenerational Public Interest, in: Gardiner, S.M., Thompson, A. (eds.), The Oxford Handbook of Environmental Ethics, Oxford: Oxford University Press, 2017.

Oatley, T.: Political institutions and foreign debt in the developing world, International Studies Quarterly no. 1 (2010), DOI: 10.1111/j.1468-2478.2009.00582.x.

Ossowska, M.: Social determinants of moral ideas. Philadelphia: University of Pennsylvania Press, 1971.

Petrażycki, L.: Teorie państwa i prawa w związku z teorią moralności (Theories of state and law related to the theory of morality), Warszawa: PWN, 1959.

Przybyciński, T.: Etyczne i ekonomiczne aspekty państwa dobrobytu (Ethical and economic aspects of the welfare state), Annales. Etyka w życiu gospodarczym (Annalies. Ethics in economic life) no. 3 (2016), DOI:10.18778/1899-2226.19.3.03.

Rachlinski, J.J.: Evidence-based law, Cornell Law Review no. 4 (2011).

Rawl, J.: A Theory of Justice, Harward: Harward University Press, 1999. 
Reinhart, C., Kirkegaard, J., Sbrancia, B.:, Financial Repression Redux, IMF Finance and Development (2011).

Stallings, B., Kaufman, R.: (eds.), Debt And Democracy In Latin America, Boulder: Westview Pres, 1988.

Von Hagen, J.: A note on the empirical effectiveness of formal fiscal restraints, Journal of Public Economics no. 44 (1991).

Ziembiński, Z., Problemy podstawowe prawoznawstwa (Basic problems of jurisprudence), Warszawa: PWN, 1980.

Zimmermann, J.: Aksjomaty prawa administracyjnego (Axioms of administrative law), Warszawa: Wolters Kluwer, 2013.

Zawadzka-Pąk, U.K., Prawnofinansowe instrumenty ograniczania deficytu i długu sektora general government $\mathrm{w}$ państwach europejskich (Financial law instruments for reducing the general government deficit and debt in European countries), in: Lotko, E., Zawadzka-Pąk, U.K.: Prawnofinansowe instrumenty ograniczania deficytu i długu publicznego w Polsce na tle doświadczeń europejskich (Financial law instruments for reducing the general government deficit and debt in Poland in the light of the European experiences), Bialystok: Temida 2, 2018 .

Hunt, G., Accountability. www.freedomtocare.org. 



\title{
SUB-NATIONAL CONSTRAINTS OF FISCAL POLICY-REVIEW OF THE EXPERIENCES OF SELECTED COUNTRIES
}

\author{
KATARZYNA WÓJTOWICZ
}

\begin{abstract}
This contribution deals with the problem of budgetary constraints imposed on local government units. The main aim is to provide descriptive characterization, classification, and evaluation of the advantages and disadvantages of subnational constraints of fiscal policy currently applied in selected countries. The experience of the European Union member states has been taken into account, as well as that of some OECD countries (Norway, Switzerland, USA, Australia and Canada) and countries cooperating with this organization (Brazil, Argentina). The article uses the method of critical analysis of the reports and statements issued by the European Commission and OECD, as well as that of legal acts and academic literature pertaining to the issues raised.
\end{abstract}

\section{Keywords}

Fiscal policy; financial safety; sub-central government units; constraints

JEL Classification: E62, G28, H74

\section{Introduction}

The problem of budgetary constraints imposed on local government units (LGUs), especially the limits of their access to loan funds, is one of the most poignant issues

Assistant professor at the Department of Public Finance at the Faculty of Economics of the Maria CurieSkłodowska University in Lublin. She specializes in the issues of local government finances, with a special focus on the fiscal stability of local government units (LGUs) and local public debt, as well as the local government tax system and municipal services financing. She is the author and co-author of many academic publications in this field (including books, chapters in monographs and scientific articles in Polish and English). She is a member of Organization Centre for the Research on the Public Finances and Tax Law in the Countries of Central and Eastern Europe. Contact email: kwojtowi@hektor.umcs.lublin.pl. 
for determining optimal fiscal relations between the central government and the local government sector. Local government units as one of the most important suppliers of public and merit goods, as well as the main public investor, are usually struggling with the insufficiency of their own budget revenues, which justifies their reaching for external funds. However, the specific functions of self-government public finances - especially when compared to central government public finances (Tiebout, 1956; Oates, 1998) - make it necessary for the use of debt instruments by local governments to be appropriately cautious and reasonable.

The publication of academic papers by the experts from the Fiscal Affairs Department of the International Monetary Fund (Ter-Minassian, 1997), which took place in the second half of the 1990s, as well as the reports prepared under the auspices of the Council of Europe, by the Steering Committee on Local and Regional Authorities (SCLRA 2000), were of fundamental importance for the development of economic research on institutional and legal subnational borrowing regulations. An important role was also played by comparative studies initiated by Dafflon (2002) on the limitations of access of local government units to capital markets. A vital trend is also constituted by the empirical research on the effectiveness of applying various types of a LGU budget constraints carried out in individual countries with the use of more or less complex econometric models. The results of these studies are not unambiguous and do not prove a clear relationship between budget constraints and the condition of local government finances (Braun 2006; Dufrénot et al.: 2010), while others indicate that this kind of a positive correlation indeed occurs (Poterba 1995; Martell 2008). An important part of the research is also constituted by crosssectional empirical studies, in which, based on the experience of properly selected groups of countries, an effort is made to delineate the most crucial determinants of the effectiveness of the budgetary constraints of LGUs, emphasising, among others, the importance of such elements as: the scope of horizontal fiscal imbalance (Rodden, Wibbels, 2002), the degree of local fiscal autonomy, bail-out expectations of LGUs, or transparency of budgetary process (Plekhanov, Singh 2007). The above publications were an incentive to address the issues of local government budget constraints also in Polish reference literature on the subject (Swianiewicz, 2004; Jastrzębska, 2006; Bitner, 2013; Wójtowicz, 2013).

Systems of subnational budget constraints have recently undergone quite significant transformations in many countries. At least two circumstances influenced this state of affairs. The first is a dynamic increase in public debt after the recent global financial crisis. For example, in the OECD countries, the ratio of the local government debt to GDP increased on average from ca. 53\% in 2007 to over $86 \%$ in 2015 (OECD 2017). The main debt generator is still the central government, but basing the local finance system of most countries on grants from the central 
government causes a "pushing" of government debt onto LGU budgets. The second circumstance observed in many countries is constituted by recentralisation tendencies, i.e. the striving to restore the dominant role of central government in the implementation of public tasks previously delegated to self-government. Both of the above trends have caused the necessity to once again pose a question as to the role of central governments in countries with a decentralized fiscal framework - and of the instruments, they could use to safeguard macroeconomic stability and the sustainability of public finances.

The aim of this study is to provide descriptive characterization, classification, and evaluation of the advantages and disadvantages of the currently applied ${ }^{2}$ budgetary constraints to which local government units operating in selected countries are subjected. Comparison of country experiences draws out core design issues concerning sub-national budgetary constraint mechanisms and demonstrates how the design of key elements of such regulations varies across countries. However, the paper does not prescribe how such mechanisms should be transferred to different institutional settings.

Above all, the experience of the European Union member states has been taken into account, as well as that of some OECD countries (Norway, Switzerland, USA, Australia and Canada) and countries cooperating with this organization (Brazil, Argentina). The article uses the method of critical analysis of the reports and statements issued by the European Commission and OECD, as well as that of legal acts and academic literature pertaining to the issues raised.

\section{Why Place Constraints on Sub-National Budgets?}

The concept of "budget constraints", as imposed on LGUs, should be understood as different types of institutional solutions, as well as legal regulations that define the scope, form or method of subnational borrowing. In particular, they limit the level of local public debt, the number of funds that can be allocated to servicing the debt, the purposes for which loan funds can be obtained, as well as the rules of issuing debt instruments abroad or issuing debt denominated in foreign currencies.

The following are usually indicated as the main arguments justifying the application of budgetary constraints at the level of local government units:

1. the insufficient effectiveness of economic instruments regulating the amount of the local government debt, 
2. the strong impact of the fiscal health of local government units on the fiscal sustainability, as well as on the macroeconomic stability of the state,

3. the existence of the so-called soft budget constraints and the phenomenon of the so-called moral hazard.

As regards the first premise, it should be noted that the increase in the demand for debt capital is usually accompanied by an increase in its cost, which limits the further increase of debtor's obligations. In the case of debt issued by local government units, the above-described market mechanism turns out to be unreliable; the reference literature on the subject indicates the following as the main reasons for this state of affairs (Dafflon, 2002):

- the assumption of a lack of bankruptcy capacity on the part of the LGUs as a consequence of their insolvency adopted by the capital providers;

- the limited information available to lenders;

- the high likelihood of a self-government unit failing to enter into bankruptcy activities to improve the financial situation until it is completely excluded from the market.

Another justification for imposing budget restrictions on LGUs is that the effects of local government debt burden the entire country, affecting both the sustainability of public finances and the general socio-economic situation alike. The degree of this impact is determined by both the scope and quality of fiscal decentralization, as well as by the level of economic development of a given country.

Finally, we ought to mention the existence of the so-called soft budgetary constraints, which should be understood as explicit or covert claims of local and regional authorities directed to state institutions in the application for financial assistance and support to cover the permanent budget deficits generated by the local government units in question (Kornai, 1986).

This attitude in relation to individual local government units is sometimes referred to as a moral hazard. The existence of soft budget constraints transfers the consequences of a potential insolvency of a local government unit onto the state budget, by replacing their own financial resources with state grants. In the long term, soft budget constraints may encourage local governments to be more aggressive in their debt policy. In extreme cases, the self-government which counts on bail-out may deliberately generate an excessive debt and take excessive risk in fiscal policy without taking care about such issues as the appropriate reduction of excessive expenses. 


\section{Classification of Local Budget Constraints}

In the subject literature, as well as in the budgetary practice of contemporary states, a certain classification has been established with reference to budgetary constraint systems imposed on local government units. Its basis is also constituted by the criterion of the budgeting process phase in which a specific limit is applied, as well as the criterion of the scope of fiscal autonomy of self-government authorities in defining their own budgetary goals and the legal status of these restrictions.

Depending on the phase of application of budget constraints, the following are distinguished: 1) ex-ante limits and 2) ex-post regulations (Martinez-Vasquez, Vulovic, 2016). The first of them is applied before the adoption of local government budgets, i.e. at the stage of their planning and preparation (Liu, Waibel, 2006).

Within this group of constraints, based on the criteria of fiscal autonomy of local authorities and on the legal status of these restrictions, it is possible to further distinguish the following models (Ter-Minassian, 1997; Eyraud, Sirera, 2015), (cf. Figure 1), i.e.:

- direct administrative control,

- fiscal rules,

- cooperation,

- market discipline.

The ex-post restrictions, in turn, consist of a set of predetermined mechanisms for the allocation of the default risk. They guarantee that in the case of a LGU insolvency, both the borrowers and the lenders would share the burden. Properly designed ex-post restrictions enforce the hard budget constraints (MartinezVasquez, Vulovic, 2016). 


\section{LIMITATIONS}
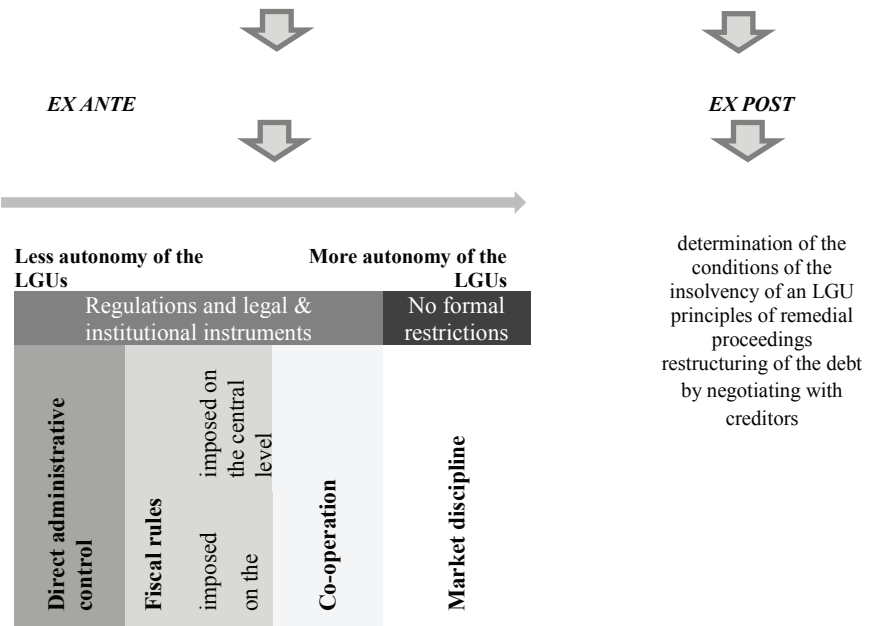

Source: Own elaboration based on Eyraud, Sirera, 2015.

Ex-post control mechanisms consist of three main elements, that is identification of the state of insolvency of a LGU, determination of a remedial principle that must be undertaken to restore fiscal sustainability and establishing the rules for restructuring the resulting debt by way of negotiating with the creditors (Figure 1). At the same time, two main practical approaches to this type of budget constraint can be distinguished, i.e. the use of judicial or administrative resolutions. In the first case, the insolvency of LGUs is announced over the course of court proceedings, while in the second case, the definition of the circumstances (prerequisites) that determine the implementation of the recovery program and the rules for its employment remain the domain of a higher level of public administration (i.e. most oftentimes that of the central government).

\section{Comparative Analysis of Ex Ante Subnational Budget Constraints}

In the ex-ante constraint group, the first category is constituted by legal and institutional solutions, among which the smallest range of a LGU fiscal autonomy is typical of the model of direct administrative control. In this model, the central government exerts a direct influence on the scope of the liabilities incurred by local government units by setting periodic debt limits as well as by establishing 
the specific debt conditions (e.g. the maturity or foreign debt participation). At the same time, it is possible to centralize all loan operations in the public finance sector and to grant local governments a certain limit of loans or credits taken for specific purposes. The main disadvantage of this approach, however, is the lack of any independence of local authorities in determining the level of debt, which seems to contradict the idea of fiscal decentralization and lead to the replacement of investment planning at the local level with central planning (Bitner, 2013). Secondly, this system favors the "moral hazard", forcing the central authorities to bail out LGUs in case of their insolvency - not only in a formal way but also in terms of the actual implementation of these rescue procedures.

The advantages of this approach include, first of all, the possibility for the government to maintain a strict impact on the macroeconomic stability and fiscal sustainability. This system also aids increasing the creditworthiness of local government units, especially towards foreign lenders, which may reduce the costs of incurring liabilities on financial markets (cf. Table 1).

In practice, this solution can be found in i.a. Denmark, Mexico, Great Britain, Canada, and India. It manifests itself in the existence of strict limits on the size of loans and borrowings incurred by local authorities, as well as in the specification of the purposes for which these debts may be allocated, such as, for example, investment expenditures. This requires obtaining the prior approval of the provincial authorities to incur liabilities by local self-government (Denmark, Canada, Great Britain), or to receive guarantees from the central government (India). Sometimes the scope of potential creditors, with whom local governments may get indebted, is limited only to domestic entities (Great Britain, Mexico).

The fiscal rules model requires the establishment of limits or restrictions that are governed by law, which affect the final shape of the fiscal policy. Most often they take the form of quantitative restrictions on the selected budgetary index (referring to such aspects as the level of budget deficit, the public debt, the size of the liabilities, the number of expenditures or the public revenues) which have a relatively stable nature (Symansky, Kopits, 1998). The main advantage of this approach is its transparency and the quite high efficiency from the point of view of ensuring long-term fiscal sustainability as well as intergenerational equity. The shortcomings of this system are associated with the existence of many factors that may weaken the effectiveness of the rules. In the case of local government units, these flaws include the tendency to raise loan funds using various forms of extrabudgetary economy, as well as tendencies to hide local government debt through the use of financial instruments not included in public financial liabilities. Constituting a further problem is also the volatility and arbitrariness of classification of budget 
expenditures as current liabilities or property expenditure (Wójtowicz, 2011; Bitner, 2013).

It is also worth paying attention to the pro-cyclical impact of some fiscal rules, which, in turn, is associated with the existence of trade-offs between their effectiveness in stabilizing public debt and in mitigating the negative effects of the cyclical market mechanism. The proper functioning of the fiscal rules system requires the creation of an appropriate mechanism to ensure compliance with such rules; such a system should encompass the following: the universality of sanctions, the speed, and reliability of their implementation and reliable reporting based on reliable and complete statistical data.

\section{Table 1 Characteristics of Advantages and Disadvantages of Different Models of Subnational Budget Constraints, as well as Description of Their Scope}

\begin{tabular}{|c|c|c|c|}
\hline Specification & Advantages & Disadvantages & $\begin{array}{c}\text { Implementing } \\
\text { states } \\
\text { (examples) }\end{array}$ \\
\hline $\begin{array}{l}\text { Direct } \\
\text { administrative } \\
\text { control }\end{array}$ & $\begin{array}{l}\text { maintaining the government's } \\
\text { direct influence on the overall } \\
\text { macroeconomic and fiscal policy of } \\
\text { the state } \\
\text { the possibility of reducing the costs } \\
\text { of the debts incurred (especially } \\
\text { in foreign markets) owing to the } \\
\text { presumption of state guarantees }\end{array}$ & $\begin{array}{l}\text { restricting the independence of local } \\
\text { self-government units with regards to } \\
\text { the level and directions of debt } \\
\text { "temptation of abuse" (moral hazard) } \\
\text { connected with the expectation of } \\
\text { financial support to be obtained } \\
\text { from the state budget in the event of } \\
\text { possible financial difficulties }\end{array}$ & $\begin{array}{l}\text { Denmark, } \\
\text { Mexico, } \\
\text { United } \\
\text { Kingdom, } \\
\text { Canada, India }\end{array}$ \\
\hline Fiscal rules & $\begin{array}{l}\text { transparency and simplicity } \\
\text { relatively high effectiveness in } \\
\text { achieving the assumed goals } \\
\text { adoption of these rules is a positive } \\
\text { market signal that may affect the } \\
\text { decline in debt servicing costs }\end{array}$ & $\begin{array}{l}\text { the possibility to circumvent rules } \\
\text { the pro-cyclical impact of some rules } \\
\text { the need to implement a system } \\
\text { that guarantees compliance with } \\
\text { the rules } \\
\text { the risk of mechanical budget cuts in } \\
\text { order to fulfill the rules (e.g. the risk } \\
\text { of lowering investment expenditures) } \\
\text { stiffening of budgetary policy }\end{array}$ & $\begin{array}{l}\text { many states } \\
\text { of the USA, } \\
\text { Norway, } \\
\text { Switzerland, } \\
\text { most of the } \\
\text { EU member } \\
\text { states }\end{array}$ \\
\hline Co-Operation & $\begin{array}{l}\text { promoting dialogue and information } \\
\text { exchange between participants in } \\
\text { the agreements } \\
\text { increasing the awareness of the self- } \\
\text { government authorities as regards } \\
\text { the macroeconomic and fiscal } \\
\text { impact of their budgetary resolutions }\end{array}$ & $\begin{array}{l}\text { requires close supervision by } \\
\text { the central authorities over the } \\
\text { implementation of agreements } \\
\text { requires a synchronized operation of } \\
\text { all parties to the agreement }\end{array}$ & $\begin{array}{l}\text { Austria, Spain, } \\
\text { Belgium, } \\
\text { Australia }\end{array}$ \\
\hline $\begin{array}{l}\text { Market } \\
\text { Discipline }\end{array}$ & $\begin{array}{l}\text { the flexible shaping of debt servicing } \\
\text { costs by the market } \\
\text { effectiveness under the condition } \\
\text { of significant development of } \\
\text { financial markets and a full access to } \\
\text { information }\end{array}$ & $\begin{array}{l}\text { the possibility to completely exclude } \\
\text { the debtor from the market } \\
\text { the inefficiency under the condition } \\
\text { of the so-called soft budget } \\
\text { constraints }\end{array}$ & $\begin{array}{l}\text { Canada, USA, } \\
\text { some Latin } \\
\text { American } \\
\text { countries }\end{array}$ \\
\hline
\end{tabular}

Source: Own elaboration based on 2013; Eyraud, Sirera, 2015; Martinez-Vazques, Vulovic, 2016. 

A LGU' budgetary restrictions in the form of fiscal rules are applied in many US states, in Norway, in Switzerland, as well as in most European Union countries (see Table 2); with the exception of the limits apply only to LGUs (on local and/or regional level), there are also rules relating to the general governments sector and, as a consequence, also to local government budgets.

\section{Table 2 Number of Fiscal Rules that Cover Local Government Sector in EU Countries in 2016, According to their Scope of Application}

\begin{tabular}{|l|c|c|c|c|}
\hline \multirow{2}{*}{ Rule type } & \multicolumn{4}{|c|}{ Rules covering the following with their scope: } \\
\cline { 2 - 5 } & $\begin{array}{c}\text { the general } \\
\text { governments } \\
\text { sector }\end{array}$ & $\begin{array}{c}\text { only the } \\
\text { local } \\
\text { governments }\end{array}$ & $\begin{array}{c}\text { only the I } \\
\text { regional } \\
\text { governments }\end{array}$ & $\begin{array}{c}\text { regional and local } \\
\text { governments }\end{array}$ \\
\hline Revenues & 1 & - & - & - \\
\hline Public debt & 13 & 10 & 2 & 0 \\
\hline Budget balance & 30 & 15 & 3 & 2 \\
\hline Expenditure & 13 & 2 & 1 & 0 \\
\hline In total & 57 & 27 & 6 & 2 \\
\hline
\end{tabular}

Source: Own elaboration based on the European Commission, 2017.

Among the rules implemented only at the local (and/or regional) level, the most important are the rules of budget balance and the rules of public debt (see Table 3).

\section{Table 3 Main Types of Fiscal Rules Applied Only at Local (and/or Regional) Level by Individual EU Member States in 2016}

\begin{tabular}{||l|c|c||}
\hline Rule Type & $\begin{array}{c}\text { no. of rules implemented } \\
\text { in 2015 }\end{array}$ & Country \\
\hline $\begin{array}{l}\text { Rules of the budget } \\
\text { balance }\end{array}$ & 20 & $\begin{array}{c}\text { Belgium, Bulgaria, Cyprus, Germany, Finland, } \\
\text { France, Ireland, Italy, Lithuania, Luxembourg, } \\
\text { the Netherlands, Poland, Portugal, Romania, } \\
\text { Sweden, and Slovakia }\end{array}$ \\
\hline Public debt rules & 12 & $\begin{array}{c}\text { Bulgaria, the Czech Republic, Estonia, Spain, } \\
\text { Latvia, Poland, Portugal, Romania, Slovakia }\end{array}$ \\
\hline Expenditure rules & 3 & Bulgaria, France, Italy \\
\hline Revenues rules & - & \\
\hline Total & 35 & \\
\hline
\end{tabular}

Source: Own elaboration based on European Commission, 2017.

They adopt at least a few varieties (Wójtowicz, 2013). One of them is the requirement to balance the total revenues of LGUs with their expenditure in a given fiscal period used i.a. in Belgium, Cyprus, Germany, Finland, and Sweden. Another fairly common variation of the budget balance rule in local government units is the so-called golden rule, according to which current expenditure should be equal to current revenues, whereas incurring public debt is only possible to cover capital 
expenditures (investments). This is the most popular constraint used in Germany (at regional level), in France (where, however, a current deficit is allowed at the stage of budget implementation, provided that it does not exceed 5\% of current revenue), in Italy, in Luxembourg, and under the name of the operational balance rule also in Portugal, Slovakia, Romania, Lithuania and in Poland. A different type of budget balance rule is the budget deficit limit in the form of a so-called budget anchor (Ireland), for instance. In the case of LGU budgets, however, the structural balance constraints - which are otherwise quite common at the level of the central government sector - are very rarely applied. Serving as an example here may be a rule introduced in 2014 in the Netherlands, which applies to all levels of subnational government (regions, provinces and local units), and in the event of exceeding the limits it establishes, appropriate corrective mechanisms have been provided.

The second most popular category of fiscal rules in local government units in EU countries is constituted by the rules of public debt. In 2016, 12 such rules were in force at the local and regional level and they were applied mainly in Central and Eastern Europe, as well as in Spain and Portugal. The most frequently encountered limitation is the debt limit expressed in relation to the level of budget revenues in the current or previous fiscal period. For example, in Estonia, this threshold amounts to $60 \%$ of total income, in Slovakia to $60 \%$ of the current revenues, while in Spain, after exceeding the limit of $75 \%$ of the current revenue, incurring further debt by local governments requires the consent of the central level authorities. Finally, there are rules referring to the ability to debt service capacity, which is most often determined in relation to the annual budget revenues $(15 \%$ in Bulgaria, $25 \%$ in Slovakia and $30 \%$ in Romania) or calculated on the basis of individual debt ratios calculated separately for each LGU (Poland). In the Czech Republic and in Latvia, the debt limit is determined by the central level authorities based on certain indices calculated for the whole local government sector. An interesting solution exists in Portugal, where the debt of a specific local government unit cannot exceed $150 \%$ of the average of the last three current budget revenues. In local government units of EU countries, there are no income rules and it is rare to use expenditure rules. The exception to this principle is the expenditure restriction applied at the regional level in Italy, which aims to stop the increase in public expenditure on health, as well as the new expenditure rules introduced in Bulgaria in 2014 and France in 2015 which determine the maximum allowable increase in local government expenditure.

Another model of LGU budget constraints - a co-operative one - consists in defining the limits of indebtedness in the local government sub-sector by way of negotiations between representatives of the central level authorities and lower levels of public authority (Bitner, 2013). This system assumes an active participation of local government units in determining the terms of such an agreement, taking 
into account the assumed macroeconomic and fiscal objectives. This solution is implemented in some countries of the European Union and in Australia. It is notable that this system is mainly used by countries with a federal system, in which the central government - most often than not - has no power to directly limit the debt of state-level authorities (Ter-Minassian, 1997). For example, in Austria in 1999, a consultation mechanism was introduced, the immediate objective of which was to limit the share of the fiscal deficit in GDP below the 3\% GDP criterion specified in the EU regulations (Martinez-Vazques, Vulovic, 2016). A similar agreement is also in force in Spain. On the other hand, in Belgium debt incurrence by the federal authorities is subject to the supervision of a special independent fiscal institution, which consists of representatives at all levels of public authority, as well as the central bank. Fiscal policy and decisions on incurring financial liabilities are coordinated in a similar fashion in some states in Australia. The cooperative approach combines the advantages of the previously implemented systems (Table 1). In particular, it is about promoting dialogue and information exchange between participants in the agreements, as well as about increasing their awareness of the macroeconomic consequences of certain budget decisions. On the other hand, this system requires that central authorities be able to effectively oversee and enforce the implementation of negotiated agreements.

The market discipline model assumes a lack of any formal limits on local government debt (Bitner, 2013). In this approach, the limits of LGU debt are shaped as a result of adjustment of the supply and demand side in the financial market. The market reacts to an increase in the borrower's debt by increasing the interest rate, which in turn affects the debt servicing costs. Above a certain threshold level of interest rates, lenders are no longer willing to provide debt capital due to the significant risk of the debtor's insolvency, and therefore it is even possible to foreclose them completely from the market. In this approach, the borrower's behavior is aimed at increasing creditworthiness and ensuring the long-term solvency of local government units in the absence of fundamental changes in the fiscal policy pursued. The reference literature, however, points to certain aspects conditioning the effectiveness of this system. First of all, financial markets should be free and open (in particular, in terms of an open access to local markets on the part of LGUs, which in most countries is subject to greater or smaller restrictions). Another issue is that of ensuring that the information on the factors determining the creditworthiness of borrowers is immediately available to lenders. In practice, this requirement poses a number of difficulties for methodical and accounting reasons related to the definition and classification of individual debt obligations, as well as due to the fairly common practice of hiding debt. Finally, it is worth noting that the market discipline system is ineffective in the context of the existence of soft budgetary constraints and in view of the moral hazard phenomenon. The market discipline system operates on 
the municipal capital market in the US, as well as in Canada, and in some Latin American countries, such as Argentina, Colombia, Brazil, and Peru (MartinezVazques, Vulovic, 2016). In the case of the USA and Canada, however, credit rating agencies play an important role in assessing the actual credit risk. It is worth noting that despite the significant degree of development of financial markets in both these countries, relying on the market discipline criterion did not protect them from the emergence of temporary debt crises in the local government sector in the mid-1990s. In turn, in Brazil and Argentina, some solutions were implemented in the 1980s to enhance the market discipline model, which, nonetheless, led to an explosion of the public debt in the local government sector and even to bankruptcies of some local government units (Martinez-Vazques, Vulovic, 2016).

\section{Conclusions}

A comparative analysis of subnational budgetary constraint mechanisms in selected countries points to the fact that their current shape was a more or less successful attempt to find the right balance between the benefits of accelerated development as a result of using debt financing and the risks arising from the use of specific debt instruments, as well as from the uncertainty about the size of future budget revenues and expenses.

At the same time, none of the analyzed four main models of LGU budget constraints turned out to be an optimal solution, and each of them, despite their advantages, also showed some drawbacks. For this reason, a selection of specific solutions is conditioned by the specificity of the functioning of the subnational governments in a given country, with special attention paid to the degree of fiscal autonomy of local authorities, the scope of public tasks assigned to them, and their constitutional positioning.

Among the analyzed models of fiscal constraints, the widest range of occurrences was typical of the fiscal rules model applied in the majority of EU countries, as well as in the USA, Norway, and Switzerland. Among the binding rules, the most poignant importance was held by the regulations which assumed balancing of local government budgets (whether comprehensive balancing or one conducted only in operational terms), which is described in the subject literature as an effective way to restore subnational fiscal sustainability.

However, what is noticeable in the countries surveyed is a gradual retreat from the model based only on market discipline and the lack of formal limits on indebtedness. Constituting the main reason for this state of affairs are the direct consequences of 
the last global financial crisis, which undermined the ability of the financial markets to effectively fulfill their regulatory function.

Another identifiable tendency is the inclination to combine solutions characteristic of various debt reduction models in the local government sector, in particular regarding the typical administrative and legal regulations with reference to the so-called good practices and standards governing mechanisms that promote cooperation and agreement between the central level authorities and local government units.

\section{References}

Bitner, M.: Reguły fiskalne ograniczające zaciąganie długu przez jednostki samorządu terytorialnego w wybranych krajach OECD - analiza prawno-porównawcza (Fiscal Rules restricting Borrowing by Territorial Self-government Units in Selected OECD Countries - Legal and Comparative Analysis), Samorząd Terytorialny (Territorial Government) no. 1-2 (2013).

Braun, M.: The Political Economy of Debt in Argentina, or Why History Repeats Itself. Paper presented at the World Bank Conference on Sovereign Debt and Development: Market Access Countries, Washington D.C., October 12-13, 2006.

Dafflon, B. (ed.): Local Public Finance In Europe. Balancing the Budget and Controlling Debt, Northampton: Edward Elgar Publishing Limited, 2002.

Dufrénot, G., Frouté, P., Schalck, C.: The French Regions' Borrowing Behaviours. How heterogeneous are they? Banque de France Document de Travail no. 289 (2010).

European Commission: Public finances in EMU - 2012, European Economy, Directorate-General for Economic and Financial Affairs no. 4 (2012).

European Commission: Fiscal Rules Database. New methodology. Directorate General Economic and Financial Affairs, 2017.

Eyraud, L., Sirera, R.G.: Constraints on subnational fiscal policy, in: Cottarelli, C., Guerguil, M. (eds.): Designing an European Fiscal Union. Lessons from the experience of fiscal federations, New York: Routledge Taylor\&Francis Group, IMF, 2015.

Jastrzębska, M.: Ograniczenia w zaciąganiu długu przez jednostki samorządu terytorialnego w Polsce na tle rozwiązań w państwach członkowskich Unii Europejskiej (Limitations of local government borrowing in Poland against the background of solutions of other the European Union Member States, Finanse Komunalne (Municipal Finances) no. 6 (2006).

Kornai, J.: The Soft Budget Constraint, Kyklos no. 1 (1986).

Liu, L., Waibel, M.: Subnational Borrowing Notes for Middle-Income Countries, The World Bank, 2006.

Martell, C.R.: Fiscal institutions of Brazilian municipal borrowing, Public Administration and Development, no. 1 (2008). 
Martinez-Vazques, J., Vulovic, V.: How well subnational borrowing regulations work?, Andrew Young School of Policy Studies Research Paper Series no. 7 (2016).

Oates, W.E.: The Economics of Fiscal Federalism and Local Finance, Cheltenham UK: Edward Elgar Publishing Limited, 1998.

OECD: Government at Glance, Public finance, and economics, 2017.

Plekhanov, A., Singh, R.: How should subnational government borrowing be regulated? Some crosscountry evidence, IMF Staff Papers no. 3 (2007).

Poterba, J.M.: Balanced budget rules and fiscal policy: Evidence from the states, National Tax Journal no. 48 (1995).

Rodden, J., Wibbels, E.: Beyond the fiction of federalism: Macroeconomic management in multitiered systems, World Politics no. 4 (2002).

SCLRA: Effects on the financial autonomy of local and regional authorities resulting from the limits set at European level on national public debt, Study Series: Local and Regional authorities in Europe no. 71 (2000).

Swianiewicz, P.: The Theory of Local Borrowing and the West-European Experience, in: Swianiewicz, P. (ed.): Local Government Borrowing: Risks and Rewards, Hungary: DFID and Open Society Institute, 2004.

Symansky, S., Kopits, G.: Fiscal policy rules, International Monetary Fund, IMF Occasional Paper no. 162 (1998).

Ter-Minassian, T. (ed.): Fiscal Federalism in Theory and Practice, Washington, D.C.: International Monetary Fund, 1997.

Tiebout, Ch.M.: A pure theory of local expenditures, Journal of Political Economy no. 5 (1956).

Wójtowicz, K.: Samorządowe reguły fiskalne jako sposób przywracania stabilności finansów publicznych - doświadczenia państw UE, Finanse i nieruchomości w rozwoju lokalnym i regionalnym (Sub-central Fiscal Rules as a Way to Restore Sub-national Fiscal Sustainability of the European Union states), Prace Naukowe Uniwersytetu Ekonomicznego we Wrocławiu (Scientific works of the University of Economics in Wroclaw) no. 280 (2013). 


\title{
BUDGET DEFICIT AND PUBLIC DEBT IN THE BALTIC STATES IN 2010-2015
}

\author{
STANISEAW PILŻYS', ROBERT ALIUKONIS ${ }^{2}$
}

\begin{abstract}
The economic crisis of 2009 sparked a sharp increase in deficits and public debt among most EU countries. While states with different capacities and fiscal policies intervened to alleviate the effects of the crisis, results varied. This article focuses on macroeconomic developments, including public deficit and debt in the Baltic States: namely, Lithuania, Latvia, and Estonia. The main purpose of this analysis is to examine the level of deficit and public debt between 2010 and 2015. We also seek to examine the relationship between deficit and public debt levels and GDP growth rate. We rely on statistical and comparative analyses. We compare domestic deficit and debt figures to the average among EU member states. Our statistical analysis reveals no high correlation between the growth of GDP and reduction of the budget deficit in the three countries. This largely depends on the public finance policy pursued by the government.
\end{abstract}

\section{Keywords}

Public debt; budget deficit, public deficit

JEL Classification: H69, E62, 057

\section{Introduction}

The economic crisis of 2009 sparked a sharp increase in deficits and public debt among most EU countries. While states with different capacities and fiscal policies

1 Research-and-teaching assistant at the Department of Economics, Faculty of Economics and Informatics in Vilnius, University of Bialystok, Lithuania-Poland. The Author specializes in macroeconomics, energy economics, and energy finance. He is the author of 11 reviewed articles in economic journals and books. Contact email: s.pilzys@uwb.edu.pl.

2 Research-and-teaching assistant at the Department of Economics, Faculty of Economics and Informatics in Vilnius, University of Bialystok, Lithuania-Poland. The Author specializes in marketing. He is the author of 5 reviewed articles in economic journals and books. Contact email: r.aliukonis@uwb.edu.pl. 
intervened to alleviate the effects of the crisis, results varied. This article focuses on macroeconomic developments, including public deficit and debt, between 2010 and 2015 in the Baltic States: namely, Lithuania, Latvia, and Estonia.

The Baltic states only recently became a part of Western European politics, joining the European Union and the North Atlantic Pact. Since 2004, many Baltic states have met convergence criteria and introduced the Euro: Estonia in 2011, Latvia in 2014, and Lithuania in 2015. It's important to note that deficit and public debt are one of the most critical components of the convergence criteria, which makes our study particularly interesting. The main purpose of this analysis is to examine the level of deficit and public debt between 2010 and 2015. We also seek to examine the relationship between deficit and public debt levels and GDP growth rate. We rely on statistical and comparative analyses. We compare domestic deficit and debt figures to the average among EU member states. The data for this analysis was sourced from Eurostat and the financial institutions of surveyed countries, including finance ministries, treasuries, central banks, and state statistical offices. In addition, we also considered International Monetary Fund reports throughout our analysis.

\section{Theoretical Issues of Budget Deficit}

The state budget is critical in the public finance system. It accumulates the largest share of public sector finances, making the state government the main body of the political, social and economic system (Owsiak, 1999: 91).

As the theory of public finance evolved, the definition of the state budget changed. Today, a budget is defined as "a set of accounts showing for every calendar year any permanent receipts and burden on the state" (Gaudemet, 1990: 178). This definition implies that the budget can be understood as a numerical description of the state's economic and financial system, meaning that it can be shaped and controlled. The economy may be in a state of equilibrium, deficit, or surplus.

The state budget is a statement of revenue and expenditure for various public purposes. The state's revenue is generally sourced primarily from direct taxes on corporate profits and individual citizens' incomes, as well as from indirect taxes paid on purchased goods. The main state expenditures go to national defense, education, culture, health care, social security payments, and interest paid on internal and external debt (Nasiłowski, 1998: 211).

The state budget, as both a monetary and a legal fund, can be considered as a normative economic act and the legal basis for government activity. Three basic budgetary functions are worth noting: 
1. the allocation function, which involves collecting income and making expenditures by changing the structure of the produced social product,

2. the redistribution function, which occurs when the state budget divides taxes between citizens and the state,

3. and the stabilization function, which occurs when the budget alleviates the negative effects of economic fluctuations to ensure sustainable and stable economic growth.

The state budget requires special rules, one of which is the principle of balancing: that is, balancing the budget in such a way as to not generate a deficit. A state with a balanced budget is one in which a state's total expenditures perfectly match its income (Kańduła, 2006: 91). "In the literature of the subject, it is often also assumed that budget imbalance occurs only in the case of a deficit. The budget in which there is a surplus of expenditure is considered balanced" (Owsiak, 2005: 295). The European Union's budget is created by balancing expenditures with income. Thus, surplus and budget deficits are not possible given the EU's budget planning and implementation.

Budget surpluses are rare; in most countries, there are instead budget deficits. The cause of the deficit may be due to excessive budget expenditures or low income. For today's international economics, unpredictable fluctuations in economic conditions are a constant risk. Hence, states tend to overestimate budget revenue in anticipation of high expenditures (Nasiłowski, 1998: 212-213).

There is no clear answer in the literature on the extent to which budget deficits are acceptable or beneficial to state economies. Views of economists are often contradictory. In their joint work in Economics, Paul Samuelson and Wilhelm Nordhaus quote the "father of economics" Adam Smith, who argues that "the only good budget is a balanced budget". On the other hand, $20^{\text {th }}$ century economist Warren Smith argues that "the only correct rule is that the budget should never be balanced" (Samuelson, 1995: 263).

Prior to the 1930s, there was an assumption that balanced budgets created only positive benefits. However, this was challenged by J.M. Keynes (2003), who argued that disparities between investment and consumer demand and the supply of goods in the developed market economy meant that balanced budgets may lead to prolonged recessions.

The 1992 Maastricht Treaty defined the economic indicators and principles that must be satisfied to join the Economic and Monetary Union. The requirements were later called Maastricht criteria or convergence criteria. In addition to the central 
bank's independence, countries are obliged to meet the following four criteria: price stability, fiscal stability, exchange rate, and interest rate terms.

According to the Treaty, the condition of a potential member state's public finances is of critical importance. The Member State must not be covered by the excessive deficit procedure (EDP), which occurs when general government indicators are exceeded. These indicators amount to $3 \%$ of GDP as compared to deficits and $60 \%$ of GDP in public debt. In practice, the assessment takes into account a sate's trajectory towards these values rather than individual values at a single point in time. There is also the added challenge of reforming the budget to meet standards. Decisions on fiscal policy have not been precisely defined and therefore can be undertaken by states independently.

\section{Theoretical Issues of Public Debt}

Public debt is not a new phenomenon. There are in fact numerous studies on the impact of public debt on the economy and state policy. In the literature, public debt is defined as the "financial commitment of public authorities (state and local government) to loans". Some economists broaden the definition of public debt by including "hidden debt" that involves the state's debt to citizens in the form of future retirement payments, social benefits, and the maintenance of the health care system (Siwińska-Gorzelak, 2015: 14).

The financial obligations of the state include primarily borrowing money, issuing loans, and accepting deposits and state-issued securities. Public debt can be divided using the following four criteria:

1. source of funding, such as internal (domestic) and external (foreign),

2. the type of state unit that draws the debt (central government, local government or social security funds),

3. the principles of gross or net debt records and

4. the debt's longevity.

For the purpose of this article, the debt will be considered primarily with regard to structure, debtors, debt servicing costs, and the debt ratio to deficit and GDP growth.

Public debt is directly linked to the budget deficit. Public debt can adversely affect economic growth and international competitiveness, so its reduction often becomes the main goal of government financial policy. On the other hand, public debt can also be regarded as a policy instrument of a given state's government. Public debt is 
a "capital mass in respect of which the state obtains a temporary right of ownership, including the right of redistribution" (Waśniewski, 2014: 45). This is a very complex and multi-faceted macroeconomic issue. For example, when referring to internal public debt, citizens who are sovereigns of the state are both creditors and debtors when guaranteed repayment of the debt by the state.

The literature on negative consequences of public debt growth includes the displacement of private investment, foreign dependence through external debt, tax efficiency losses, slow economic growth, and limits on the implementation of large government programs (Zagóra-Jonszta, 2015: 157).

The main causes of public debt include:

1. state borrowing in subsequent periods of the budget deficit,

2. increase in public expenditures as a result of wars, natural disasters, or major economic crises,

3. implementation of state policy that involves increasing public expenditures in order to stimulate prosperity,

4. the debt trap or

5. achieving policy goals through increased redistribution of citizens' incomes without limiting another state spending (Daniłowska, 2008: 111-112).

We assess the level of public debt by comparing public debt to GDP, where a debtto-GDP ratio of $50 \%$ is considered critical. In addition, we consider the ratio of debt to exports (critical value $275 \%$ ), debt-service-costs-to export-ratios (critical value $30 \%$ ) and interest-to-export ratios (critical value 20\%). A country is considered to be seriously indebted when three of the four indicators exceed critical values. The state is considered to be moderately indebted when three of the four indicators exceed $60 \%$ of the critical values (Daniłowska, 2008: 112-113).

\section{Public Deficit in the Baltic States}

Between 2010 and 2015, the public deficit in the Baltic states varied drastically. Chart 1 shows that Estonia fell against other Baltic countries as well as the EU average. The highest deficit was Lithuania in 2011, after which it experienced consistent improvement. To better understand how the deficit changed throughout the Baltic States, it is worth considering each state individually. 


\section{Chart 1 Comparison of Public Deficit in Estonia, Lithuania, Latvia and EU} Average of $28, \%$ of GDP

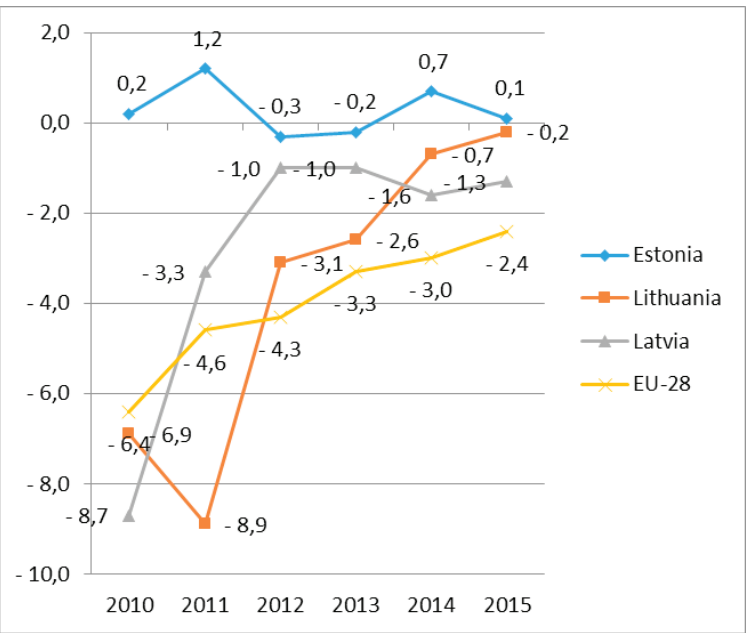

Source: Own elaboration based on Eurostat 2017 statistics.

The primary characteristic of Estonia's economy is a fairly stable budget. Since 2001 the budget has remained fairly balanced, and since with surplus increasing due to GDP growth. The crisis in Estonia came to light so early because as compared to the other Baltic States, accumulated budget surpluses from previous years had softened its situation. Estonian budget deficits occurred in 2008 and 2009. From 2010 to 2011, Estonia regained its prior balance of income surpluses over expenditures. Economic growth in 2010 was $2.3 \%$ of GDP, due in large part to increased exports. Labor productivity grew faster than real Estonian wages since companies became competitive on world markets (Parts, 2013). At the end of the year, increased consumption and investment had positive dynamics, which in subsequent years replaced the drop in exports. Despite the crisis, Estonia joined the Eurozone in 2011. Since then, maintaining the budgetary discipline has been a priority of the Estonian government. Its open economy, liberal economic policies, favorable climate for entrepreneurship, and tax and banking system have kept budget deficit low. Between 2010 and 2015 Estonia's maximum budget deficit was $-0.3 \%$ in 2012 ; this did not exceed the convergence criteria. Estonia's economy's return on the path of growth after the financial crisis was due to creating conditions conducive to business growth. As a result, Estonia experienced a surplus of $0.7 \%$ in GDP in 2014 and a surplus of $1.4 \%$ by 2015 . 
Budget Deficit and Public Debt in the Baltic States in 2010-2015

Table 1 Estonian Budget Deficit and GDP Growth

\begin{tabular}{|l|c|c|c|c|c|c|}
\hline \multicolumn{1}{|c|}{ Indicators } & 2010 & 2011 & 2012 & 2013 & 2014 & 2015 \\
\hline $\begin{array}{l}\text { Public sector revenue (\% of } \\
\text { GDP) }\end{array}$ & 40,7 & 38,6 & 39,0 & 38,4 & 39,1 & 40,5 \\
\hline $\begin{array}{l}\text { Public sector expenditure (\% of } \\
\text { GDP) }\end{array}$ & 40,5 & 37,4 & 39,3 & 38,5 & 38,5 & 40,4 \\
\hline GDP (increase in\%) & 2,3 & 7,6 & 4,3 & 1,4 & 2,8 & 1,4 \\
\hline Budget deficit (\% of GDP) & 0,2 & 1,2 & $-0,3$ & $-0,2$ & 0,7 & 0,1 \\
\hline EU-28 Budget deficit (\% of GDP) & $-6,4$ & $-4,6$ & $-4,3$ & $-3,3$ & $-3,0$ & $-2,4$ \\
\hline
\end{tabular}

Source: Own elaboration based on Eurostat 2017 statistics.

Latvia has been in the euro area since January 2014. Between 2012 and 2013, Latvia's budget deficit was -1\% of GDP: much lower than it had been between 2010 and 2011. Before the 2008 financial crisis, the Latvian budget was nearly balanced. Indeed, in the years between 2002 and 2007, the deficit did not exceed 2.3\%. However, after the financial crisis, Latvia's deficit reached $-8.7 \%$ of GDP in 2010. However, the Latvian economy improved its GDP growth by $6.4 \%$ in 2011, and fiscal policy changes have increased the inflow of investment. During the crisis, Latvia experienced the worst collapse of all of the countries in the region, losing $25 \%$ of its GDP between 2008 and 2010. There were drastic structural changes in the public sector, as well as a $26 \%$ reduction in the average wage in the public sector. With international and financial support, however, it introduced an adjustment program, which allowed it to pay its obligations to the International Monetary Fund long before the deadline. As a result, the European Commission reports that economic growth accelerated to $4 \%$ in 2012 . Good economic condition and stable fiscal policy kept Latvia's budget deficit below $2 \%$ by the end of our study's temporal period.

Table 2 Latvian Budget Deficit and GDP Growth

\begin{tabular}{|l|c|c|c|c|c|c|}
\hline \multicolumn{1}{|c|}{ Indicators } & 2010 & 2011 & 2012 & 2013 & 2014 & 2015 \\
\hline Public sector revenue (\% of GDP & 36,3 & 35,7 & 36,3 & 35,9 & 35,9 & 35,8 \\
\hline $\begin{array}{l}\text { Public sector expenditure (\% of } \\
\text { GDP) }\end{array}$ & 45,0 & 39,0 & 37,3 & 36,9 & 37,5 & 37,0 \\
\hline GDP (increase in\%) & $-3,8$ & 6,4 & 4,0 & 2,6 & 2,1 & 2,7 \\
\hline Budget deficit (\% of GDP) & $-8,7$ & $-3,3$ & $-1,0$ & $-1,0$ & $-1,6$ & $-1,3$ \\
\hline EU-28 Budget deficit (\% of GDP) & $-6,4$ & $-4,6$ & $-4,3$ & $-3,3$ & $-3,0$ & $-2,4$ \\
\hline
\end{tabular}

Source: Own elaboration based on Eurostat 2017 statistics.

Lithuania joined the Eurozone only in January 2015, when it was obliged to fulfill all of the convergence criteria, including keeping the budget deficit below $3 \%$ of GDP. In 2013 Lithuania's public finance deficit was at $-2.2 \%$ of GDP. Lithuania's maximum budget deficit in our temporal period occurred in 2011 when it had a deficit of $-8.9 \%$ of GDP. This was the highest deficit of all the Baltic States considered in our analysis. After the crisis in Lithuania, there were major changes 
to fiscal policy, including tax increases and resignation from tax relief. However, budget revenue was still low. It was only in 2012 that public sector expenditure fell and the budget deficit began to decrease, thanks in part to budget cuts related to social expenses like pensions and benefits. Exports helped boost Lithuania's economy in 2010, generating 31.5\% of GDP. Lithuania's responsible public finance policy decreased the budget deficit to $-0.2 \%$ by 2015 .

Table 3 Lithuanian Budget Deficit and GDP Growth

\begin{tabular}{|l|c|c|c|c|c|c|}
\hline \multicolumn{1}{|c|}{ Indicators } & 2010 & 2011 & 2012 & 2013 & 2014 & 2015 \\
\hline Public sector revenue (\% of GDP & 35,4 & 33,5 & 33,0 & 33,0 & 34,1 & 34,9 \\
\hline $\begin{array}{l}\text { Public sector expenditure (\% of } \\
\text { GDP) }\end{array}$ & 42,3 & 42,5 & 36,1 & 35,6 & 34,8 & 35,1 \\
\hline GDP (increase in\%) & 1,6 & 6,0 & 3,8 & 3,5 & 3,5 & 1,8 \\
\hline Budget deficit (\% of GDP) & $-6,9$ & $-8,9$ & $-3,1$ & $-2,6$ & $-0,7$ & $-0,2$ \\
\hline EU-28 Budget deficit (\% of GDP) & $-6,4$ & $-4,6$ & $-4,3$ & $-3,3$ & $-3,0$ & $-2,4$ \\
\hline
\end{tabular}

Source: Own elaboration based on Eurostat 2017 statistics.

\section{Public Debt in the Baltic States}

Chart 2 shows the results of analyzing the ratio of public debt to GDP. Between 2010 and 2015, none of the Baltic countries exceeded the Maastricht criteria. By 2015, Lithuania was the worst case, where public debt was 42,7\% of GDP. Except for 2013, the debt-to-GDP ratio increased steadily in Lithuania over our study's temporal period. Except for 2012, the trend in Latvia was different. Estonia was the most stable of the Baltic States, where the ratio of debt to GDP slightly worsened in 2011 but fell from $10.7 \%$ to $10.1 \%$ by 2015 .

\section{Chart 2 Comparison of Public Debt Levels of Estonia, Lithuania, Latvia and Average 28 members of the EU,\% GDP}

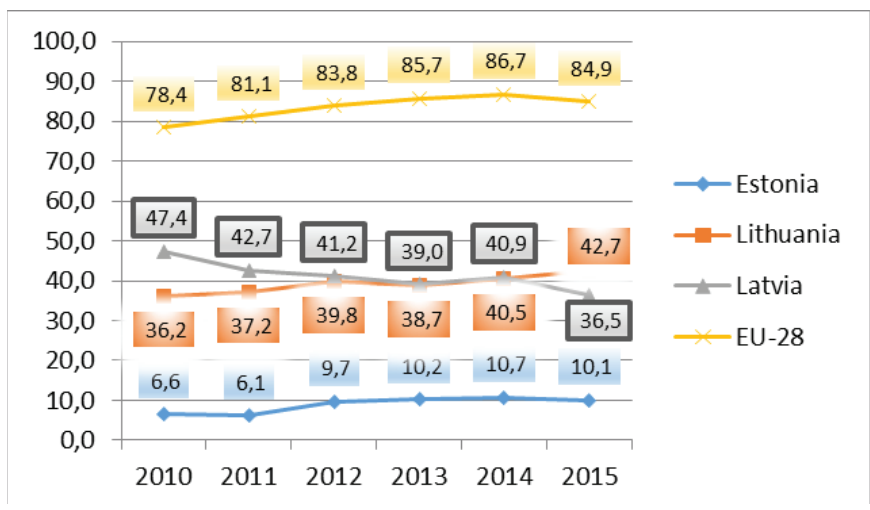

Source: Own elaboration based on Eurostat 2017. 
Comparing the Baltic states public debt with EU averages clearly demonstrates that the Baltic countries were in better financial conditions. Estonia, in particular, is an exemplary example. The main cause of high public debt in Latvia and Lithuania can undoubtedly be the occurrence of a high budget deficit. This could be avoided by decreasing budget expenditures. However, this would likely dissatisfy some electoral groups that are critical for determining government policy.

The Baltic states are similar in that public debt is taken on primarily by the central government. In the period under review, Lithuania's government took on approximately 1.5 times more debt, while Estonia's government took on almost four times more debt. It's worth noting that the debt structure in Lithuania differs from Latvia and Estonia in that it is created primarily by social security funds, which are practically absent in Estonia and Latvia. During the crisis in Lithuania, unemployment increased, and the influence of the Lithuanian State Social Insurance Fund decreased considerably. At that time, the Lithuanian parliament decided to increase pensions and Maternity and Tacit Maternity benefits as a means of handling the crisis.

\section{Table 4 Public Debt in the Baltic States According to Criterion of State Unit Incurring Debt, EUR million}

\begin{tabular}{|c|c|c|c|c|c|c|c|c|c||}
\hline & \multicolumn{3}{|c|}{ Central government } & \multicolumn{3}{c|}{ Local government } & \multicolumn{3}{c||}{ Social security funds } \\
\cline { 2 - 11 } & Estonia & Latvia & Lithuania & Estonia & Latvia & Lithuania & Estonia & Latvia & Lithuania \\
\hline 2010 & no data & no data & 9427.7 & no data & no data & 442.8 & no data & no data & 1647.5 \\
\hline 2011 & 533.0 & no data & 10641.0 & 541.3 & no data & 573.9 & 0.1 & no data & 2204.0 \\
\hline 2012 & 1937.4 & no data & 12260.0 & 566.6 & no data & 638.7 & 0.0 & no data & 2817.1 \\
\hline 2013 & 2082.3 & 8648.6 & 12540.4 & 678.5 & 1362.5 & 695.8 & 0.0 & 0.0 & 3200.5 \\
\hline 2014 & 2247.7 & 9534.6 & 13761.4 & 754.3 & 1426.0 & 754.7 & 0.0 & 0.0 & 3576.4 \\
\hline 2015 & 2221.6 & 8888.5 & 14894.7 & 728.3 & 1454.3 & 722.8 & 0.0 & 0.0 & 3762.3 \\
\hline
\end{tabular}

Source: Own elaboration based on Eurostat 2017.

The figures in Table 4 also show that in Latvia, local authorities incurred significantly more debt than Lithuania and Estonia respectively.

A large part of the state's budget includes not only the size of the public debt but also the costs of servicing it. Chart 3 shows the dynamics of changes in public debt 
servicing costs between 2010 and 2015 in the Baltic states. The highest interest was paid by Lithuania; the smallest, by Estonia. In Lithuania, costs increased steadily until 2012, after which they gradually declined.

\section{Chart 3 Baltic States' Interest for Public Debt, EUR million}

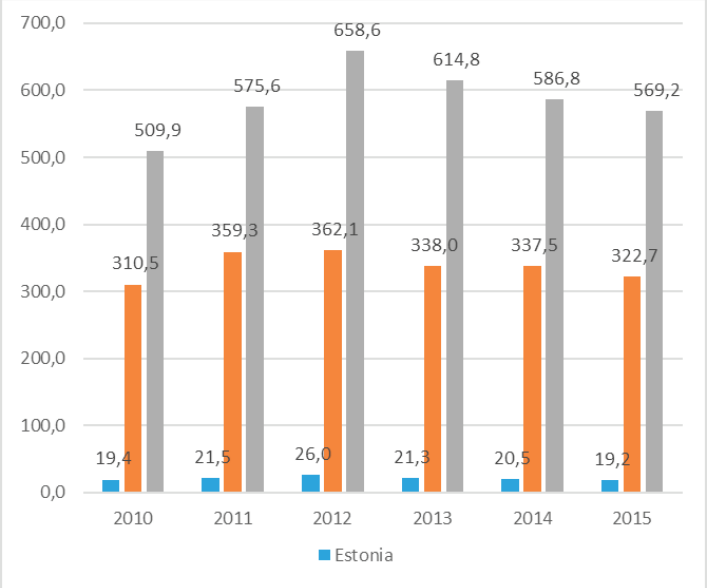

Source: Own elaboration based on Eurostat 2017.

In 2014, Lithuania categorically resigned from borrowing from the International Monetary Fund, claiming it cared more about its prestige and independence. This had a strong influence on foreign direct investment. This refusal may have also been linked to restrictive IMF conditions that require a consistent reduction in de facto government spending, a budget deficit, and political actions such as changes to the tax system.

While the interest rate on a loan from the IMF was about 3\% per year, Lithuania paid anywhere from $5 \%$ to $9 \%$ of interest on loans from commercial banks. This occurred at the same time that Latvia received an attractive loan from the IMF. Lastly, Estonia had the lowest debt servicing costs in the reviewed period.

\section{Deficit, Public Debt, and GDP in the Baltic States}

It is difficult to uniquely determine the correlation between deficit, public debt, and GDP growth in the Baltic countries. It is clear that 2011 was the year of the biggest growth in GDP in all Baltic states, after which there is the tendency towards decline. However, this did not always result in an increase in deficit or public debt. It is worth remembering that high GDP growth in 2011 was in part a result of exceptionally unfavorable conditions in the previous year. 
As shown in Chart 4, there is no direct correlation between GDP growth and deficit and public debt in Estonia. In 2012, public debt increased by 1.5 times in Estonia, while this year saw a decline in GDP growth of over 3\% as compared to the previous year when the budget had a surplus.

Chart 4 Budget Deficit, Public Debt and GDP in Estonia in 2010-2015

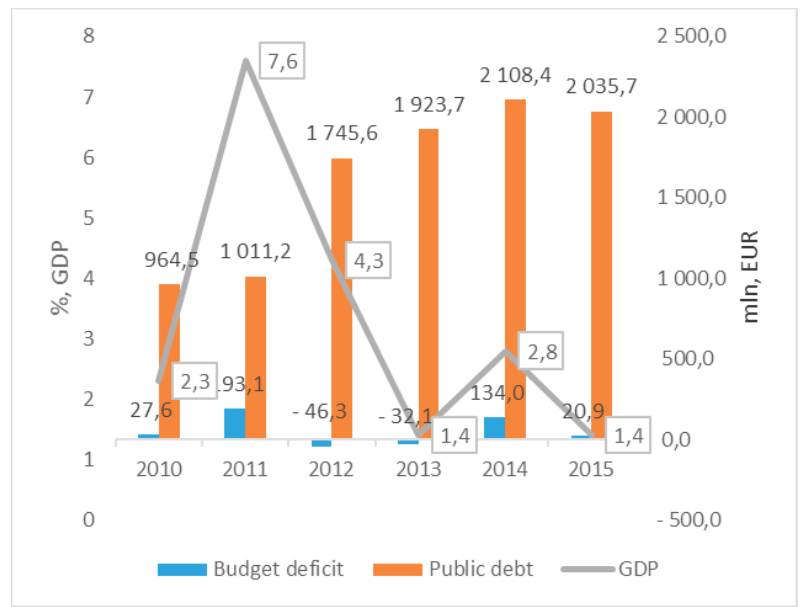

Source: Own elaboration based on Eurostat 2017.

The period between 2010 and 2015 is characterized by relative stability in Estonian politics, where successive governments formed the pro-market Reform Party and its partners.

According to forecasts of the International Monetary Fund, Estonia's public debt will continue to fall consistently in the coming years. According to IMF experts, effective Estonian fiscal policy after the crisis could even contribute to a fall in public debt below 8\% of GDP between 2020 and 2021 (IMF Report, 2016: 26).

As a result of favorable fiscal policies, Latvia has achieved relatively stable economic growth and has managed to stop the growth of its public debt and has reduced the budget deficit. 
Stanisław Pilżys, Robert Aliukonis

\section{Chart 5 Budget Deficit, Public Debt and GDP in Latvia in 2010-2015}

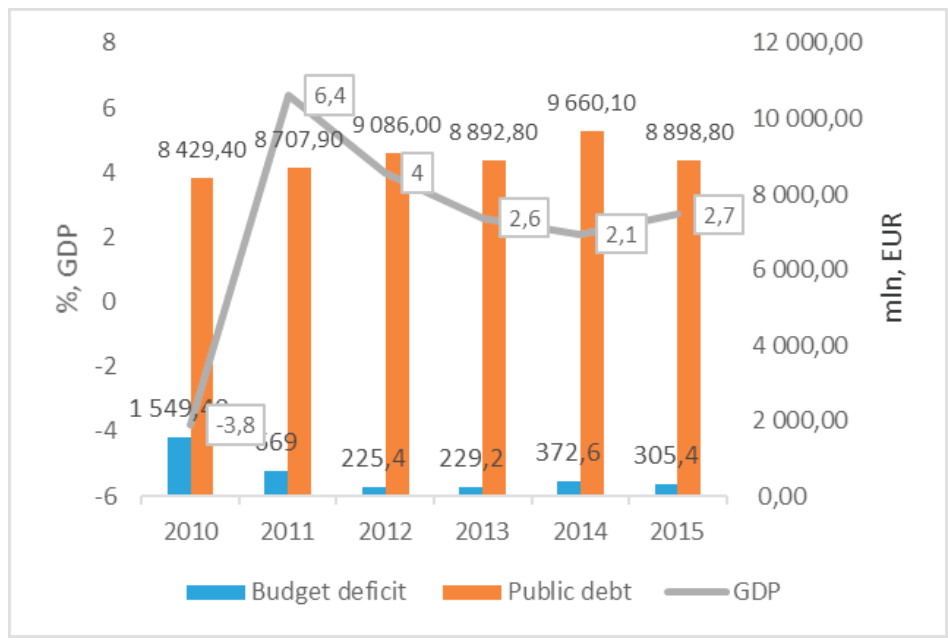

Source: Own elaboration based on Eurostat 2017.

Chart 5 shows that Latvian public debt between 2010 and 2015 was fairly stable, with the deficit falling most significantly between 2010 and 2013 before leveling out.

Chart 6 Budget Deficit, Public Debt and GDP in Lithuania in 2010-2015

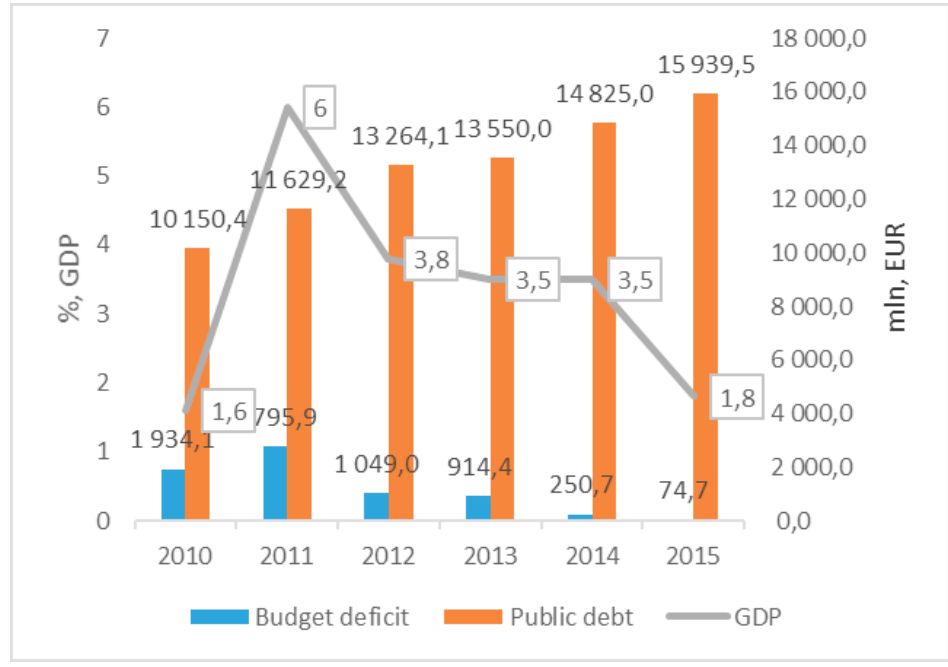

Source: Own elaboration based on Eurostat 2017.

On the other hand, Chart 6 shows that despite a gradual reduction of the budget deficit, Lithuania failed to successfully halt the growth of its public debt. Since 
2011, GDP growth has also declined steadily, which has exacerbated public debt, at least to some extent.

According to Eurostat forecasts, populations in the Baltic states aging less quickly than Slovakia and other southern EU countries. Demographic changes, however, will be one of the factors that will be detrimental to state spending; this will in turn translate to deficit and public debt. In the long-term, public debt may grow as the number of people paying taxes will decrease and expenditures on pensions, social security, and healthcare increase.

\section{Conclusions}

Disaggregating the Baltic States from other Soviet countries is critical for future analyses. Countries such as Poland, Slovakia, the Czech Republic and Hungary were more independent and financially viable as compared to 1991. The Baltic states, on the other hand, were able to build their institutions from the outset without public baggage, but the lack of experience in building a new financial infrastructure proposed a serious risk to their economies. The Baltic countries have chosen an economic model similar to Scandinavian countries. At present, even the Baltic banking system is dominated by Nordic banks. In this paper, we attempted to analyze the state of public finances in the Baltic states after the crisis in 2010 and 2015. Economists often blame the deterioration of public finance on economic recession.

Estonia, which meets the convergence criteria, had the most favorable results with the lowest budget deficit within the EU. It is the only country that generated budget surpluses, and it had the most balanced budget. Despite doubling its public debt during the period considered, its debt was the smallest of all Baltic states when considering debt ratio to GDP. This is because Estonia prioritized its economic policy of balancing budgets, which, in turn, translated to avoiding large state debt.

Latvia exceeded the budget deficit outlined by the convergence criteria between 2010 and 2011. In 2010, the deficit reached $-8.7 \%$ of GDP and was higher than the EU average, which was $-6.4 \%$. Over the years, the situation has improved significantly, and the deficit has since not exceeded $-2 \%$ of GDP. Latvian public debt remained stable in the period under review. It is worth noting that in Latvia, a significant portion of the public debt was generated by local authorities.

Between 2010 and 2012, Lithuania did not meet the convergence criteria: the deficit was above 3\% of GDP and exceeded the EU average. Changes in the public finance sector stabilized the situation, with reduction of the budget deficit between 2012 to 
2015 that amounted to $-0.2 \%$ of GDP by 2015 . Lithuanian public debt grew the most of the Baltic States, due in part to relatively expensive loans. From 2010 to 2015, the debt increased by more than 1.5 times its amount, with the debt from social security funds rising more than 2 times its previous amount. Even so, Lithuania still met the convergence criteria for public debt.

Our statistical analysis reveals no high correlation between the growth of GDP and reduction of the budget deficit in the three countries. This largely depends on the public finance policy pursued by the government. When comparing the public debt of the Baltic States with the countries of the old EU, we must remember that the Baltic countries did not inherit debt after the Soviet period. Their debt, while relatively recent, grew at a rapid pace. At the moment, the Baltic countries are not in debt to the same degree as other countries of the old EU. But the debt, especially in Lithuania, is constantly growing, and a sound economic policy is needed to maintain a stable situation. In particular, Latvia's policy implementation after the recent global financial crisis must be considered in future recommendations. Appropriate fiscal policy, deficit reduction, and public debt are important in order to avoid an income trap that could cause considerable stagnation among the Baltic States.

\section{References}

Ciborowski, R.: Międzynarodowy transfer technologii a innowacyjność krajów Europy ŚrodkowoWschodniej (International Technology Transfer and Innovation of the Central and Eastern European Countries), Bialystok: PTE, 2016.

Daniłowska, A.: Dług publiczny - jego struktura, przyczyny, rozmiary i skutki (Public debt - its structure, causes, dimensions and effects), Zeszyty Naukowe Szkoły Głównej Gospodarstwa Wiejskiego w Warszawie. Ekonomika i Organizacja Gospodarki Żywnościowej (Scientific Papers of the Warsaw University of Life Sciences and Economics in Warsaw. Economics and Organization of Agri-Food Sector) no. 9 (2008).

Gaudemet, P. M.: Finanse publiczne (Public Finance), Warszawa: PWN, 1990.

Gruszewska, E., Rozwój i czynniki rozwoju gospodarczego (Development and factors of economic development), in: Meredyk, K. (ed.): General economics, Bialystok: Wydawnictwo Uniwersytetu w Białymstoku, 2007.

Parts, J.: Estonia and the European Debt Crisis, Cato Journal no. 2 (2013).

Kańduła, S., Kijek, I., Wybrane zagadnienia finansów publicznych (Selected issues of public finances), Poznań: Wydawnictwo Akademii Ekonomicznej w Poznaniu, 2006.

Keynes, J.M.: Ogólna teoria zatrudnienia, procentu i pieniądza (The General Theory of Employment, Interest and Money), Warszawa: Wydawnictwo Naukowe PWN, 2003. 
Nasiłowski, M.: System rynkowy podstawy mikro- i makro ekonomii (Market system of the basics of micro- and macroeconomics), Warszawa: Key Text, 1998.

Owsiak, S.: Finanse publiczne. Teoria i praktyka (Public finance. Theory and practice), Warszawa: PWN, 1999.

Owsiak, S.: Finanse publiczne. Teoria i praktyka (Public finance. Theory and practice), Warszawa: PWN, 2005.

Samuelson, P.A., Nordhaus, W.D.: Ekonomia (Economics), Warszawa: PWN, 1995.

Siwińska-Gorzelak, J.: Dług publiczny a wzrost gospodarczy (Public debt and economic growth), Warszawa: Scholar, 2015.

Waśniewski, K.: Czy dług publiczny musi rosnąć? (Does public debt have to grow?), Warszawa: Scholar, 2014.

Zagóra-Jonszta, U.: Dług publiczny w nowych krajach Unii Europejskiej (Public Debt in New Countries of the European Union), in: Grynia, A. (ed.): Wybrane aspekty rozwoju i konkurencyjności nowych krajów członkowskich Unii Europejskiej (Selected Aspects of Development and Competitiveness of the New Member States of the European Union), Wilno: BMK Leidykla, 2015.

IMF Report, Republic of Estonia: Article IV Consultation-Press Release, 2016. www.imf.org. 



\title{
OPTIMIZATION OF PENSION COMPANIES IN THE CZECH REPUBLIC
}

\author{
EVA TOMÁS̆KOVÁ
}

\begin{abstract}
This paper presents pension system in the Czech Republic, analysis public income, and expenditure connected with pension system and existing supplementary pension funds. It shows the return of pension funds and profit of pension companies and new rules connected with activities and profit of pension companies. The main goal of this paper is to know if public expenditure spent on pension insurance in pension funds of pension companies are optimally expended. Description, analysis, and synthesis are the scientific methods used for processing the paper.
\end{abstract}

\section{Keywords}

Pension system; pension companies; pension funds; optimization; public expenditures

\section{JEL Classification: H55, H75, G22}

\section{Introduction}

The Czech Republic ranks to the developed countries with the lengthening of life and number pensions. The future predictions show that this situation will probably not change. This positive situation is connected with negative impacts on public finance. It is obvious that current public incomes assigned for pensions system will not be enough and state pensions will be very low. Even now, it is possible to see the discrepancy between public incomes and public expenditures. From this reason, some of the people try to insure for pensions and they choose many ways.

1 Doctor, Department of Financial Law and Economics, Faculty of Law, Masaryk University, Czech Republic. The Author specializes in Public Finance and Market Orientation. Contact email: eva.tomaskova@law.muni.cz. 
They invest finance to properties (e. g. realities, precious metals, pieces of jewelry, the object of art) or they have a lot of children (they take care of their parents) or they choose one of the companies offered voluntary supplementary personal pension (named "third" pillar). Every one of these possibilities is characterized by advantages and disadvantages. In addition to these advantages and disadvantages, there are a lot of unnamed risks, future for many people is unbeknown, and they want to solve that.

The main goal of this paper is to know if public expenditure spent on pension insurance in pension funds of pension companies are optimally expended. Description, analysis, and synthesis are the scientific methods used for processing the paper.

\section{Pension System in the Czech Republic}

Pension system in the Czech Republic is divided into two parts. First, mandatory basic pension insurance is funded on a running basis and it is covering employees and the self-employed. The system is characterized as universal and provides for all economically active individuals. The rules of the system are the same for all insured persons and all of industries except power sector, which are e. g. policemen, customs officers, firefighters or soldiers. This first pillar is in the competence of the Ministry of Labor and Social Affairs. The main substantive law regulation, which aims at the entitlement to a pension from the basic pension insurance, methods of determination of pension benefits and conditions of payment, is the Act no. 155/1995 Coll., on pension insurance. This regulation came into effect on 1 January 1996. The contribution rate for the first pillar is $28 \%$. Both, employers and employees contribute to this system (employers pay $21.5 \%$ of payroll, employees $6.5 \%$ of earnings. The self-employed pay the full height of contribution rate. The relation of earnings and pensions has a strong redistributive character. According to Pension Funds Online, the base on which pensions are assessed is 100\% up to CZK 8400 . $30 \%$ between CZK 8 400-20 500, and 10\% above this sum. Table 1 shows the main information about the first pillar in numbers.

Table 1 Summary About First Pillar

\begin{tabular}{|l|c|c|c|}
\hline \multicolumn{1}{|c|}{ Index } & $\mathbf{3 0 . 0 9 . 2 0 1 5}$ & $\mathbf{3 0 . 0 9 . 2 0 1 6}$ & $\mathbf{3 0 . 0 9 . 2 0 1 7}$ \\
\hline Number of old-age pensioners & 2370725 & 2389270 & 2396784 \\
\hline Average of pension (in CZK) & 11334 & 11441 & 11828 \\
\hline Number of taxpayers for one old-age pensioner & 2,14 & 2,15 & 2,19 \\
\hline Total incomes from insurance & 260,88 & 276,38 & 299,23 \\
\hline
\end{tabular}


Optimization of Pension Companies in the Czech Republic

\begin{tabular}{|l|c|c|c|}
\hline Total outcomes to pensions & 282,91 & 291,33 & 303,34 \\
\hline Deficit between incomes and outcomes & $-22,03$ & $-14,94$ & $-4,11$ \\
\hline
\end{tabular}

Source: Own processing according to Czech Social Security Administration.

It is possible to see, that all indexes are increasing during the watched period except deficit of pension system. The reason for decreasing of the deficit between incomes and outcomes is that the economics is increasing; taxpayers pay for pension insurance more than at the time of economic crisis. Alarming is that today's, we need 2.19 taxpayers for paying pension for one old-age pensioner and this trend does not change. This situation is unsustainable. Unfortunately, it is not political motivation for change.

Second, there is a voluntary complementary additional pension insurance with state contributions marked as the third pillar of the pension system. The third pillar also includes products offered by commercial insurance companies - particularly life insurance. The pension companies are joint stock companies and they have to lead the business under the provisions of the Commercial Code. The third pillar is in the competence of Ministry of Finance. All pension companies have to be licensed by the Ministry of Finance, in agreement with the Ministry of Labour and Social Affairs and the Securities Commission. This system is based on products offered by commercial insurance funds. It is possible to choose pension fund and height of contributions. Pensions granted from this third pillar create only negligible part of incomes of the retired.

The state contributes to pension insurance in the third pillar. The state contribution is depending on the level of employees' contributions. For member contributions between CZK 300-399, the state adds CZK 90 plus $20 \%$ of the member contribution above CZK 300. If the pension plan member contributes between CZK 400-499, the state adds CZK 110 plus $20 \%$ of the member contribution above CZK 400 . The allowance gradually increases with the highest allowance (CZK 230) for members contributing more than CZK 1000. Employers can contribute to your employees.

Pension funds are not Authorized to offer more than one pension plan. It is possible to switch pension funds for participants; there are no switching fees. The minimum age for receiving of payments from pension funds is 60 , provided a minimum number of contributory years, which is regulated by each pension fund. If the participants want to receive the money from the pension fund earlier, the state matching contributions have to be repaid and there is additional taxation. Participants can choose if they money in the form of regular installments or as a lump sum, more details are on Pension Funds Online. 
The number of pension insurance in the third pillar is decreasing during the last three years. The highest number of pension insurance was in 2012 (5 134 862), the reason was in a number of new pension insurance, which was increasing about $146.8 \%$ in comparison 2011, see Table 2.

Table 2 Development of Pension Insurance in the Czech Republic

\begin{tabular}{|c|c|c|c|c|c|c|}
\hline & & 2011 & 2012 & 2013 & 2014 & 2015 \\
\hline \multirow{2}{*}{$\begin{array}{l}\text { Pension } \\
\text { insurance }\end{array}$} & Number & 4565741 & 5134862 & 4963344 & 4803134 & 4643016 \\
\hline & $\begin{array}{c}\text { Increase } \\
\text { (\%) }\end{array}$ & 0.8 & 12.5 & -3.3 & -3.2 & -3.3 \\
\hline \multirow{2}{*}{$\begin{array}{l}\text { New pension } \\
\text { insurance }\end{array}$} & Number & 457033 & 1128020 & 77771 & 145841 & 156062 \\
\hline & $\begin{array}{c}\text { Increase } \\
\text { (\%) }\end{array}$ & -7.8 & 146.8 & -93.1 & 87.5 & 7 \\
\hline \multirow{2}{*}{$\begin{array}{l}\text { Pension } \\
\text { insurance with } \\
\text { employers' } \\
\text { contributions }\end{array}$} & Number & 1271934 & 1317563 & 1352461 & 1354485 & 1362283 \\
\hline & $\begin{array}{c}\text { Increase } \\
\text { (\%) }\end{array}$ & -1 & 3.6 & 2.6 & 0.1 & 0.6 \\
\hline \multirow{2}{*}{$\begin{array}{l}\text { State } \\
\text { contributions } \\
\text { to pension } \\
\text { insurance }\end{array}$} & $\begin{array}{l}\text { Volume } \\
\text { (mld CZK) }\end{array}$ & 5.602 & 5.913 & 6.861 & 6.847 & 6.803 \\
\hline & $\begin{array}{c}\text { Increase } \\
\text { (\%) }\end{array}$ & 1.7 & 5.6 & 16 & -0.2 & -0.7 \\
\hline \multirow{2}{*}{$\begin{array}{l}\text { Total members' } \\
\text { contributions }\end{array}$} & $\begin{array}{c}\text { Volume } \\
\text { (mld CZK) }\end{array}$ & 23.426 & 25.493 & 33.306 & 32.897 & 32.667 \\
\hline & $\begin{array}{l}\text { Increase } \\
\text { (\%) }\end{array}$ & 0.9 & 8.8 & 30.6 & -1.2 & -0.7 \\
\hline \multirow{2}{*}{$\begin{array}{l}\text { State contribution } \\
\text { (average per } \\
\text { month) }\end{array}$} & $\begin{array}{l}\text { Volume } \\
\text { (CZK) }\end{array}$ & 105 & 108 & 117 & 120 & 124 \\
\hline & $\begin{array}{c}\text { Increase } \\
\text { (\%) }\end{array}$ & 0.4 & 2.5 & 8.4 & 2.8 & 3 \\
\hline \multirow{2}{*}{$\begin{array}{l}\text { Members' } \\
\text { contribution } \\
\text { (average per } \\
\text { month) }\end{array}$} & $\begin{array}{l}\text { Volume } \\
\text { (CZK) }\end{array}$ & 442 & 465 & 570 & 579 & 598 \\
\hline & $\begin{array}{c}\text { Increase } \\
\text { (\%) }\end{array}$ & 0.5 & 5.3 & 22.6 & 1.7 & 3.1 \\
\hline
\end{tabular}

Source: Own processing according to Basic indexes of development of pension insurance. Ministry of Finance of the Czech Republic.

Table 2 shows that state contributions to pension insurance are decreasing in the last three years in CZK 6,8 milliard in 2015. The same situation was at a total volume of members' contributions, the highest was in 2013. State contribution per month as well members' contribution per month is increasing during the watched period. State contributions to pension insurance reached more than 6,8 milliard in 2015. State contribution per month reaches $20,7 \%$ of members' contribution per month. 
It is possible to see, that the state contributions to members of the third pillar to the third pillar with a lot of money.

According to Association of Pension Companies in the Czech Republic, current average members' contribution per month was 614 CZK at the end of September 2017. A number of participants in the third pillar are $4,47 \mathrm{mil}$. and the total volume of contributions in the third pillar is 405,5 milliards CZK.

Pension insurance system in the Czech Republic absents the second pillar. The second pillar is usual in the EU member states. The second pillar was possible to use between 2013 and 2016. The main reason for scrapping the second pillar was lack of interest of persons. Only 83000 persons signed up. The main steps for scrapping the second pillar was realized in 2016. Incomes to this pillar were flowed from two sources, from gross wages, and from the first pillar. Participants have to send $2 \%$ from gross wages and employers have to send $3 \%$ of the $28 \%$ first pillar social contribution. Increasing of payment from gross wages was unpopular. The monies in the second pillar were transferred to the first pillar. Members of the second pillar had the choice of receiving their money into private bank accounts or reinvest the money into existing third pillar companies.

\section{Commercial Companies Offered Pension Insurance}

Pension insurance offers pension companies according to the Act no. 42/1994 Coll., on State-Contributory Supplementary Pension Insurance. Pension companies have the possibility of gathering and controlling the money of participants in the pension fund or more pension funds according to Act no. 427/2011 Coll., on Supplementary Pension Savings.

According to Ministry of Finance, total 49 commercial insurance companies offered their services on the market in the Czech Republic during 1995 and 2017. Today, eight commercial insurance companies can offer commercial pension insurance in the Czech Republic. The rest of commercial insurance companies were fused, are in bankruptcy or liquidation or are marked as defunct companies. Table 3 shows the biggest companies according to the number of clients. It involves only clients, which make a contract in the period November 2013 - September 2017. Total number of participants during this period is 711 thousand.

Table 3 Pension Companies according to Number of Clients

\begin{tabular}{|c|c|}
\hline Pension company & Number of clients \\
\hline Česká spořitelna - penzijní společnost & 223627 \\
\hline
\end{tabular}


Eva Tomášková

\begin{tabular}{|c|c|}
\hline Penzijní společnost České pojištovny & 163830 \\
\hline ČSOB penzijní společnost & 110586 \\
\hline KB penzijní společnost & 110064 \\
\hline Allianz penzijní společnost & 35861 \\
\hline
\end{tabular}

Source: Tůma, O. Doplňkové penzijní spořeni. Jak si letos vede nové penzijko.

Number 1 in pension companies is Česká spořitelna - penzijní společnost with 223 627 participants. It is $31 \%$ of the total number of participants. Penzijní společnost České pojišstovny places on the second position with $23 \%$. ČSOB penzijní společnost and KB penzijní společnost are both more than 15\%. The market rate of the rest pension companies (according to a number of clients in the presented period) is small.

Pension companies offer different types of pension funds. Conservative types of pension funds buy especially bonds, dynamic or increasing types of pension funds buy more stock. Profit and risk of the first type of pension funds are low, profit and risk of the second type of pension fund are higher. Preference of pension funds can be known according to the size of assets of pension companies. Table 4 shows the biggest 5 pension funds.

Table 4 Biggest Pension Funds according to Assets

\begin{tabular}{|c|c|}
\hline Pension company & Assets (milliards CZK) \\
\hline Česká spořitelna: Conservative fund & 6,063 \\
\hline Česká pojištovna: Saving fund & 5,058 \\
\hline Česká spořitelna: Balanced fund & 2,603 \\
\hline ČSOB: Conservative fund & 2,285 \\
\hline KB: Conservative fund & 2,029 \\
\hline
\end{tabular}

Source: Tůma, O. Doplňkové penzijni spoření. Jak si letos vede nové penzijko.

Table 4 shows that conservative funds and saving fund reach the most size of assets. It is paradox because people want to have enough money in old age, but they prefer conservative funds with the low level of returns. The only small portion of participants prefers dynamic funds with high returns.

The high size of assets involves pension funds of Česká spořitelna. Conservative fund and balanced fund place on the first and third position. It is obvious that pension company Česká spořitelna is the most dynamic in comparison with the other pension companies. Pension company Česká spořitelna has the most part of new clients and two of its pension funds have the high size of assets. One of the pension funds of Česká pojišt'ovna places on the second position. It is the same position as at previous table evaluating the number of clients. Conservative fund of $\breve{C} S O B$ is on 
the fourth position. The total range of ČSOB (according to a number of clients and size of assets) is the third position. The fourth position belongs to pension companies Komerční banka.

Current pension companies offered pension insurance in the Czech Republic with the funds are shown in Table 5. This Table shows the performance of pension fund in 2016 and performance from the beginning of pension fund.

\section{Table 5 Performance of Pension Companies}

\begin{tabular}{|c|c|c|c|c|c|c|c|}
\hline $\begin{array}{l}\text { Pension } \\
\text { company }\end{array}$ & Pension fund & $\begin{array}{l}2016 \\
(\%)\end{array}$ & $\begin{array}{l}\text { Total }^{*} \\
(\%)\end{array}$ & $\begin{array}{l}\text { Pension } \\
\text { company }\end{array}$ & Pension fund & $\begin{array}{l}2016 \\
(\%)\end{array}$ & $\begin{array}{l}\text { Total }^{*} \\
(\%)\end{array}$ \\
\hline \multirow{3}{*}{$\begin{array}{l}\text { Allianz } \\
\text { penzijní } \\
\text { společnost }\end{array}$} & $\begin{array}{l}\text { Conservative } \\
\text { fund }\end{array}$ & -0.04 & 3.98 & \multirow{3}{*}{$\begin{array}{l}\text { Česká } \\
\text { spořitelna } \\
\text { penzijní } \\
\text { společnost }\end{array}$} & $\begin{array}{l}\text { Conservative } \\
\text { fund }\end{array}$ & -0.05 & 2.25 \\
\hline & Balanced fund & 2.21 & 9.5 & & Balanced fund & 5.17 & 9.69 \\
\hline & Dynamic fund & 1.51 & 11.5 & & Dynamic fund & 7.42 & 14 \\
\hline \multirow{3}{*}{$\begin{array}{l}\text { AXA penzijní } \\
\text { společnost }\end{array}$} & $\begin{array}{l}\text { Conservative } \\
\text { fund }\end{array}$ & 0.02 & 3.8 & \multirow{4}{*}{$\begin{array}{l}\text { KB Penzijní } \\
\text { společnost }\end{array}$} & $\begin{array}{l}\text { Conservative } \\
\text { fund }\end{array}$ & -0.15 & 1.91 \\
\hline & Obligation fund & 0.43 & 4.38 & & Saving fund & 0.45 & 0.81 \\
\hline & Balanced fund & 4.48 & 12.3 & & Balanced fund & -0.84 & 5.4 \\
\hline \multirow{3}{*}{$\begin{array}{l}\text { Conseq } \\
\text { penzijní } \\
\text { společnost }\end{array}$} & $\begin{array}{l}\text { Conservative } \\
\text { fund }\end{array}$ & 0.09 & 2.7 & & Dynamic fund & 0.87 & 10.8 \\
\hline & Obligation fund & 1.94 & 11.1 & \multirow{3}{*}{$\begin{array}{l}\text { NN Penzijní } \\
\text { společnost }\end{array}$} & $\begin{array}{l}\text { Conservative } \\
\text { fund }\end{array}$ & 0.21 & 1.02 \\
\hline & Joint-stock fund & 10.81 & 49.2 & & Balanced fund & 2.44 & 1.93 \\
\hline \multirow{5}{*}{$\begin{array}{l}\text { ČsOB } \\
\text { Penzijní } \\
\text { společnost }\end{array}$} & $\begin{array}{l}\text { Conservative } \\
\text { fund }\end{array}$ & 0 & 5.05 & & Inreasing fund & 9.35 & -3.3 \\
\hline & Guaranteed fund & -0.47 & 3.17 & \multirow{4}{*}{$\begin{array}{l}\text { Penzijní } \\
\text { společnost } \\
\text { České } \\
\text { pojištovny }\end{array}$} & $\begin{array}{l}\text { Conservative } \\
\text { fund }\end{array}$ & -0.1 & 4.2 \\
\hline & Balanced fund & 3.11 & 11.6 & & Saving fund & 0.8 & 7.5 \\
\hline & \multirow{2}{*}{ Dynamic fund } & \multirow{2}{*}{5.36} & \multirow{2}{*}{17.9} & & Balanced fund & 3.5 & 10.4 \\
\hline & & & & & Dynamic fund & 6.4 & 11.8 \\
\hline
\end{tabular}

* Total performance since the beginning of the pension fund

Source: Tůma, O., Velké srovnání výsledků fondů doplňkového penzijního spoření za rok 2016. 
These pension funds showed the most performance in 2016: Joint-stock fund of Conseq penzijní společnost (10.81\%), Increasing fund of NN penzijní společnost (9.35\%) and Dynamic fund of Česká spořitelna penzijní společnost (7.42\%). The situation in 2017 showed only small changes, pension fund on the first position moved to the second position and the pension fund on the second position moved to the first position. According to the results in September 2017, the first position belongs to Increasing fund of NN penzijní společnost. It shows performance at $12.5 \%$. The second position belongs to Joint-stock fund of Conseq penzijní společnost with $9.5 \%$. Dynamic fund of Česká spořitelna penzijní společnosti is again on the third position with $9.05 \%$. Detailed information is available in Tůma, O. Doplňkové penzijní spoření. Jak si letos vede nové penzijko.

These pension funds showed the highest total performance (since the beginning of pension fund): Joint-stock fund of Conseq penzijní společnost (49.16\%), Dynamic fund of ČSOB Penzijní společnost (17.92\%) and Dynamic fund of Česká spořitelna penzijní společnost (13.95\%). The situation did not change in 2017. According to the result in September 2017, Join-stock fund of Conseq penzijní společnost reached the first position with $62.29 \%$. Dynamic fund of ČSOB Penzijní společnost had performance on $25.11 \%$. Dynamic fund of Česká spořitelna penzijní společnost increased total performance on $21.81 \%$.

Opposite, pension funds with the low level of performance in 2016 were: Balanced fund of KB penzijní společnost with loss $0.84 \%$, Guaranteed fund of ČSOB penzijní společnost with loss $0.47 \%$ and Conservative fund of KB penzijní společnost with loss 0.15 . There are next three pension funds with losses. It means that $22 \%$ of pension funds showed the loss in 2016. Only $74 \%$ of pension funds showed returns because Conservative fund of ČSOB penzijní společnost showed 0 . The situation was not improved in 2017. The worst performance showed guaranteed fund of ČSOB penzijní společnost with loss 1.01\%, Conservative fund of Allianz penzijní společnost with loss $0.99 \%$ and Balanced fund of Allianz penzijní společnost and Conservative fund of NN penzijní společnost, both with loss $0.8 \%$. Unfortunately, $55.5 \%$ of pension funds showed losses in 2017 (till 30 September). The main reason is that returns of government bonds are very low $(0.25 \%$ at 10 -Year bonds in September 2017). The highest interests of 10 -Year bonds were $0.62 \%$ in 2016 , see Slapnička.

Interests of conservative types of pension funds should be higher than the inflation. Inflation was $0.7 \%$ in 2016 and $2.5 \%$ in 2017 in the Czech Republic.

These pension funds showed the lowest performance (since the beginning of pension fund) in 2016: Increasing fund of NN penzijní společnost with loss 3.26, Saving fund of KB penzijní společnost with profit 0,81 and Conservative fund of 
KB penzijní společnost with profit 1.91. In 2017, pension funds with the lowest level of performance are the same as pension funds in 2016. Saving fund of KB penzijní společnost with profit $0.23 \%$ placed in the first position. Conservative fund of KB penzijní společnost with profit $1.21 \%$ was in the second position. Conservative fund of NN penzijní společnost with profit $1.42 \%$ ranged on the third position. Detailed information is available in Tůma, O. Doplňkové penzijní spoření. Jak si letos vede nové penzijko.

One reason for the low profit is that interest rates were very low, however, there is still question if the pension funds could not have better profit. Profit of pension funds influences profit of pension companies. On the first view, all pension companies reached the profit in 2016. Allianz penzijní společnost had the highest profit - more than 744 thousand CZK. The second position ranked Penzijní společnost České pojišt'ovny. These two companies reached about $64 \%$ of total profits of this industry, see Table 6.

Table 6 Profit After Taxes at Pension Companies

\begin{tabular}{|l|c|c|c|}
\hline \multicolumn{1}{|c|}{ Profit after taxes (in thousand CZK) } & $\mathbf{2 0 1 6}$ & $\mathbf{2 0 1 5}$ & $\mathbf{2 0 1 4}$ \\
\hline Allianz penzijní společnost & 744988 & 809447 & 1041879 \\
\hline AXA penzijní společnost & 113293 & -29081 & -97258 \\
\hline Conseq penzijní společnost & 12646 & -2339 & -3239 \\
\hline ČSOB penzijní společnost & 143406 & 82202 & 34199 \\
\hline Česká spořitelna penzijní společnost & 139802 & 52393 & 44805 \\
\hline KB penzijní společnost & 234400 & 175569 & 134974 \\
\hline NN penzijní společnost & 86794 & 121277 & 81744 \\
\hline Penzijní společnost České pojištovny & 651898 & 355903 & 367183 \\
\hline
\end{tabular}

Source: Annual reports of pension companies.

The highest profit on the market reached Allianz penzijní společnost. It is interesting, that Allianz did not rank among pension companies with high number of clients and their pension funds reach the lowest profit, but it is on the second position in total profit. Penzijní společnost České pojištovny places on the first position. It can be marked as balanced company. It has high number of clients, high size of assets and financial results of its pension funds are not so bad. In comparison with the profit in previous year, the worse profit was showed by Allianz penzijní společnost and NN penzijní společnost. Profit of the other pension companies is increased.

How is it possible that in many cases, pension funds reach loss or low level of profit and the total profit of pension companies is increasing? Since 2016, the fee for administration money in pension funds for closed contracts before 2013 has 
been increased in $0,8 \%$ (in 2015 was the fee for administration $0,6 \%$ ). The reward from the profit of pension funds for contracts before 2013 has been decreased from $15 \%$ to $10 \%$ since 2016 see $\S 60$ Act no. 427/2001 Coll. about on Supplementary Pension Savings. Generally, this situation is better for pension companies because the interest rate is still low. According to the Association of pension companies in the Czech Republic, increasing fee for administration brings more than 650 million. CZK to all pension companies for a one year. Lower rewards from the profit of pension funds create about 277 million. CZK for all pension companies for a one year. According to Hovorka, the results is increasing returns about 375 million. CZK in a year. The situation is changed for the closed contract in 2013 and after. The fee for administration increased from $0.8 \%$ to $1 \%$ except for conservative funds. Rewards from a profit of pension funds increased from $10 \%$ to $15 \%$.

Pension companies promised that this change will be better for their clients as well because pension companies will buy "more expensive" investments with the high rate of return. Change of the rules is shown at changing the portfolio of investments in pension funds in 2016 (Slapnička, 2017):

- Increasing of term deposits and current accounts (from 17.61\% to $23.48 \%$ ).

- Decreasing of investments to bonds OECD and MFI (from $15.21 \%$ to $13.33 \%)$.

- Increasing of investments to bonds the other countries (from $12.27 \%$ to $16.55 \%)$.

- Increasing stock (from $8.77 \%$ to $12.16 \%$ ).

- Increasing investments to unit trust (from $1.22 \%$ to $1.76 \%$ ).

According to the results in 2016 and 2017 (preliminary results), this change in returns of pension funds was not shown.

Owners of these eight pension companies are mostly foreign companies. Profits of the pension companies are often transferred to their parent companies. For example, profits of all pension funds offered by KB Penzijní společnost were very low in 2016. However, the company KB Penzijní společnost reached the high level of profit (234,4 mil. CZK) in 2016. The similar situation was at Allianz penzijní společnost. This company reached total profit 744,988 million CZK in 2016.

Both named pension companies are subsidiary companies of foreign parent companies. This activity leads to redistribution of incomes between poor and rich people. Pension funds are buying government bonds of the Czech Republic, see Table 7. 
Optimization of Pension Companies in the Czech Republic

Table 7 Government bonds according to the holder (on 30 November 2017)

\begin{tabular}{|c|c|c|c|}
\hline & Holder & CZK & in\% \\
\hline 11000 & Non-financial companies & 13790710030 & 0.86 \\
\hline 12000 & Financial companies & 732271590000 & 45.76 \\
\hline 12200 & $\begin{array}{l}\text { An institution receiving deposits except for the } \\
\text { central bank }\end{array}$ & 341882080000 & 21.37 \\
\hline 12203 & $\begin{array}{l}\text { A foreign institution receiving deposits except for the } \\
\text { central bank }\end{array}$ & 311514820000 & 19.47 \\
\hline 12800 & Insurance companies & 122675320000 & 7.67 \\
\hline 12803 & Foreign insurance companies & 121797510000 & 7.61 \\
\hline 12900 & Pension funds & 228190490000 & 14.26 \\
\hline 12903 & Foreign pension funds & 228151240000 & 14.26 \\
\hline 13000 & Agency of government & 34228787180 & 2.14 \\
\hline 14000 & Households & 29582079479 & 1.85 \\
\hline 15000 & Non-profit institutions & 1478182340 & 0.09 \\
\hline \multirow[t]{3}{*}{20000} & Non-residents & 586376784847 & 36.65 \\
\hline & Total government bonds & 1600116483876 & 100 \\
\hline & Holder & CZK & in $\%$ \\
\hline 11000 & Non-financial companies & 13790710030 & 0.86 \\
\hline 12000 & Financial companies & 732271590000 & 45.76 \\
\hline 12200 & Institution receiving deposits except the central bank & 341882080000 & 21.37 \\
\hline 12203 & $\begin{array}{c}\text { Foreign institution receiving deposits except the } \\
\text { central bank }\end{array}$ & 311514820000 & 19.47 \\
\hline 12800 & Insurance companies & 122675320000 & 7.67 \\
\hline 12803 & Foreign insurance companies & 121797510000 & 7.61 \\
\hline 12900 & Pension funds & 228190490000 & 14.26 \\
\hline 12903 & Foreign pension funds & 228151240000 & 14.26 \\
\hline 13000 & Agency of government & 34228787180 & 2.14 \\
\hline 14000 & Households & 29582079479 & 1.85 \\
\hline 15000 & Non-profit institutions & 1478182340 & 0.09 \\
\hline \multirow[t]{2}{*}{20000} & Non-residents & 586376784847 & 36.65 \\
\hline & Total government bonds & 1600116483876 & 100 \\
\hline
\end{tabular}

Source: Bonds according to the holder. Ministry of Finance.

Table 7 shows that financial companies (especially foreign banks and foreign pension companies) are the main holders of bonds. The second group creates nonresidents. These subjects gain profits from holding the bonds. By contrast, every 
citizen has to pay interests connected with bonds through increasing state incomes (that means taxes).

\section{Conclusions}

State prefer only pension insurance at the pension companies. The other possibilities of insurance for old-age are not supported with state contributions. The number of pension companies shows that the number is enough for creating of competition and enough for the stability of every company on the market. Pension companies gain money by the participants of pension insurance and money, which the state send to participants of pension insurance for increasing of your motivation to save. Pension companies can increase their profit through the money from the state. State contributions per pension are still increasing and create more than 6,8 milliard CZK per a year. According to the analysis of pension companies, the most part of these is owned by foreign owners and returns are transferred to the foreign countries. Pension companies invest especially in the bonds that contribute to redistribution incomes in the society. The pension companies have these advantages in comparison with companies doing different business:

- Pension companies can buy some bonds or stock, which are offered, only in big volume. Foreign capital increases the profit of own capital. That is the principle of the financial arm.

- More money allows negotiating better conditions of contracts or investments for pension companies.

- Pension companies receive money by participants of pension insurance and state regularly once per month. Pension companies do not often have embarrassments with gaining the payments in comparison with the companies doing different business.

- Participants in pension insurance close the contract for a long period. Table 2 shows that the number of pension insurance is still high, it is possible to deduce that contracts are not often canceled.

- The state determines the level of state contributions for pension insurance and level of the fee for administration money in pension funds. Increasing of administration fee and decreasing rewards for returns of pension funds can be the reason for low motivation for increasing of profit of pension funds.

All these comments show that pension companies should have a high level of financial stability and profitability. The most participants choose the conservative type of pension funds. Returns of this pension funds are low for this reason. It 
is a question if the monies will be enough for paying pensions in the future and balanced with current expenditures.

\section{References}

Hovorka, J.: Spoření na důchod podraží. Vyděláte na tom, slibují ale penzijní společnosti (Saving for pension will be more expensive. Pension companies promise that we will earn on that), 2017. www.zpravy.aktualne.cz.

Slapnička, M.: Státní dluhopisy prodělávají, penzijní společnosti se jich zbavují (Government bonds lose, pension companies sell them), 2017. www.nasepenize.cz.

Tůma, O.: Doplňkové penzijní spoření. Jak si letos vede nové penzijko (Supplementary pension companies. How does new pension insurance work this year), 2017. www.penize.cz.

Tůma, O.: Velké srovnání výsledků fondů doplňkového penzijního spoření za rok 2016 (Big comparison of supplementary pension funds in 2016), 2017. www.penize.cz.

Association of Pension Companies in the Czech Republic, 2017. www.apfcr.cz.

Annual Report of Allianz penzijní společnost 2016, 2017. www.allianz.cz.

Annual Report of Axa penzijní společnost 2016, 2017. www.axa.cz.

Annual Report of Conseq penzijní společnost 2016, 2017. www.conseq.cz.

Annual Report of ČSOB penzijní společnost 2016, 2016. www.csob-penze.cz.

Annual Report of Česká spořitelna penzijní společnost 2016, 2017. www.csps.cz.

Annual Report of KB Penzijní společnost 2016, 2017. www.kbps.cz.

Annual Report of NN Penzijní společnost 2016, 2017. www.nn.cz.

Annual Report of Penzijní společnost České pojištovny 2016, 2017. www.pfcp.cz.

Basic indexes of development of pension insurance, Ministry of Finance of the Czech Republic, 2017. www.mfcr.cz.

Bonds according to the holder, Ministry of Finance, 2017. www.mfer.cz.

Czech Social Security Administration, 2017. www.cssz.cz.

Pension Funds Online, 2017. www.pensionfundsonline.co.uk.

CZ: Act no. 42/1994 Coll., on State-Contributory Supplementary Pension Insurance.

CZ: Act no. 155/1995 Coll., on pension insurance.

CZ: Act no. 427/2011 Coll., on Supplementary Pension Savings. 



\title{
OPTIMIZATION OF PUBLIC INCOME AND EXPENDITURE IN THE SOCIAL INTEREST AND THE DEVELOPMENT OF LOCAL COMPANIES IN FRENCH LAW
}

\author{
MICHAE MARIAŃSKII
}

\begin{abstract}
This contribution deals with the issue of the optimization of public income and expenditure in the social interest. As the process mentioned above can be done not only on the central but also on the local level, the paper is going to analyze how the legal forms that can be created by local government units in France can realize the social interests of the given community. The main aim of the contribution is to confirm or disprove the hypothesis that the concept of public and social interest, also at the local level, needs to be ensured by a specially created legal forms. These legal forms are very often acting on the market on the basis of the specific rules that are sometimes excluding the free market economy in the given areas. The description of such legal forms, that are very often inspired by the construction of the joint-stock company or limited liability company, can be useful not only for Polish legislator but also for the other East and Centre European Union Countries in the process of the development of their public and local finances regulations. The comparative perspective of the paper may also show the differences in the concept of the social and public interest that are in the French and Polish legal system.
\end{abstract}

\section{Keywords}

Public finance; French law; local government units; local companies

\section{JEL Classification: D63, E72, E79}

1 Doctor of legal sciences, Department of Financial Law, the lecturer at Faculty of Law and Administration UWM in Olsztyn, Poland. Graduated at Faculté de droit - Université d'Auvergne (Clermont-Ferrand (France), The Author specializes in the law of the financial market, international private law and comparative law with a specialization in French law. He is the author of more than 40 reviewed articles in different journals and books. He is a member of Association Henri Capitant des Amis de la Culture Juridique Française and an attorney at law being a member of Regional Bar Associations in Olsztyn. Contact email: michal.marianski@ uwm.edu.pl. 


\section{Introduction}

Public interest (fr. intérêt public), in French law, is more often referred to as social interest (intérêt social) and is very often used as justification for numerous administrative and financial legal regulations. In addition, the public interest is also visible in the case law of the Supreme Administrative Court (fr. Conseil d'Etat) and the Supreme Constitutional Court (fr. Conseil constitutionnel) and it is used often enough to justify partial disregard for certain economic freedoms or public rights in a given area.

Social interest is also one of the reasons for introducing legislation locally in order to make it more possible for local governments in France - known there as territorial units - to optimize public income and expenditure. It should be highlighted that social interest is an extremely general concept which is explained and interpreted at every occasion, not only in terms of the principles followed by a locality but mostly in terms of the circumstances of a specific case. In European law, social interest is considered to be a general clause, thus it is essentially defined and explained through the case law and legal studies (Broch, 2014: 179). Therefore, this concept may not only vary in definition when it comes to an individual branch of law, but also become a certain variant of itself in a particular field of research, e.g. public finance law, depending on the laws or regulations where it is used and on the situation to which it should be applied (Cornu, 2005: 496).

Both in Polish law and in French law, public (social) interest is one of the most important general clauses construed as imprecise terms whose purpose is to ensure flexibility in applying legal regulations. That interest should apply to the entire society or at least to a part of it - a unit, for instance. Thus, further in this paper, the application of the concept of social interest is analyzed in order to introduce certain changes locally when it comes to the status of companies through which French municipalities and communes may perform public tasks. It is worth emphasizing that the concept of social interest is somehow double-sided since it is applied not only to delineate the boundaries of permissible interference of the state in social and economic affairs as well as in civil rights liberties but also to determine the limits of the conduct of organizations in dealings with the state.

That concept discussed very often in Polish law and French law, is defined in the case law. Thus, for instance, one may find in the legislation of the French Conseil d'Etat the extension of the scope of the social interest clause from public entities to private entities (Conseil d'Etat Court: CE Ass. 5.05.1976) and the confirmation that it is possible to restrict or disregard certain freedoms and liberties, including those related to the freedom of establishment, if only it is in the said social interest (Conseil d'Etat Court: CE Ass. 28.05.1971). According to the Polish legislation, 
Optimization of Public Income and Expenditure in the Social Interest...

the public interest is a general clause which should be adequately interpreted on a case-by-case basis. Requirements of the public interest have to be defined in a specific case and have to be individualized based on the actual and legal status of the case (Supreme Administrative Court no.: II FSK 71/13). In addition, as noted by the Polish Administrative Court, in order for the tax authority to identify whether an action is in the public interest, it has to consider it from two standpoints: a general standpoint and an individual standpoint. The authority is supposed to establish what is more advantageous from the perspective of public interest, also taking into account other directives and interpretation clauses common to the entire society (Supreme Administrative Court no.: II FSK 4126/14).

\section{Evolution of Structure of Local Units in France}

In order to present how the structure of territorial units in France has evolved, it is worth emphasizing that, in contrast to the distinctive and uniform definition of local government in Polish law, there are three different (though identical in terms of meaning) definitions in French law. Specifically, those definitions refer to the concept of local communities (fr. collectivités locales), to the concept of administration division (fr. administration teritoriale), and to the most frequently applied concept of decentralized administration (fr. administration décentralisée). Territorial units in France today were established and organized under the Act of 2 March 1982 on Freedoms and Liberties of Municipalities, Communes, Departments, and Regions. That Act identified three key territorial units in France as municipalities, communes (fr. communes), departments (fr. départements), and regions (fr. régions) (Sitek, 2011: 61). Moreover, in accordance with the Territorial Units Code (fr. Code général des collectivités territoriales), a territorial unit is defined as a decentralized unit with legal personality and specific competencies granted by the state authorities, acting under the administrative authority by issuing decisions reflecting the approval of actions undertaken by bodies functioning within such a unit (Monjal, 2013: 449).

In addition, it is also worth highlighting that in 2015 the competences of already existing so-called special collectivities (fr. collectivité à statut particulier) ${ }^{2}$, overseas units (fr. collectivité d'outre-mer) ${ }^{3}$, and uninhabited territories (fr. territoires inhabités ${ }^{4}$ were regulated. In France, the most important role, also when it comes to the implementation and application of the concept of social interest as part of budget income and expenditure optimization through local companies, is played by municipalities and communes (fr. communes). Municipalities and communes

\footnotetext{
As e.g. Corsica.

As e.g. Mayotte, French Polynesia, and New Caledonia.

As e.g. southern and Antarctic territories and Crozet Islands.
} 
have a uniform legal status in France, though they are very diverse in terms of area and population. Based on the information retrieved from the French statistical office (INSEE) , as at 31 October 2017 in France, there are 35,414 municipalities and communes (including 129 overseas municipalities and communes). It has to be emphasized that since 2015 the number of French municipalities and communes has been gradually decreasing; this trend follows the reform of French units. For example, in 2016 there were 493 operations of mergers of municipalities and communes reported (fr. opérations de fusion d'intercommunalités) which in the past occurred extremely rarely, a few mergers per year at most. The foregoing results from the very high fragmentation of municipalities and communes in France, since as many as $2 / 3$ of those units have an area smaller than 1500 ha and only $2 \%$ of them have an area of 5500ha (Donier, 2014: 190).

The aforementioned process aimed at reducing the number of individual types of units in France is most visible in the structure of regions. Namely, since 1 January 2016, the number of regions has decreased from 27 to 18 (Orcier, 2015: 143). Such a procedure, expected to improve local financial management, is all the more interesting from the perspective of Polish law, as in Poland it is more often considered to increase the number of voivodships - equivalents of regions in France. Thus, ultimately, from among 18 French regions, only 13 will be continental regions of France and the remaining five of them will be so-called overseas regions (fr. régions d'outre-mer) (Lasserre, 2016: 8).

It is also worth noting that along with the evolution of the structure of territorial units in France, there have also evolved legal means that those territorial units can use to optimize public income and expenditure in the social interest. Namely, for a very long time those means, developed under the regulations generally applicable to public companies, were subject to free or only slightly restricted competition in the market. As a result of changes also introduced in the EU laws, the French lawmakers significantly increased the legal possibilities to establish companies locally in order to implement important public tasks. Therefore, the provisions of the French Commercial Code (fr. Code de commerce) were an impulse for the development of numerous interesting legal means which are non-existent in the laws of Poland or of other Central and Eastern European countries.

\section{Local Companies Operating on Market Conditions}

Originally, French territorial units for a long time were based on two, typical French legal concepts of public undertakings which include public establishments 
Optimization of Public Income and Expenditure in the Social Interest...

(fr. établissement public) and public enterprises (fr. entreprise public). The notion of public service and public interest appeared in French law through the case law of the above-mentioned Supreme Administrative Court - Conseil d'Etat. It is particularly noteworthy that the meaning and extent of the concept of public service was explained by the French judiciary in the Blanco judgement dated 8 February 1873, and in the Pelltier judgement dated 30 July 1873 in which the responsibilities of the public authorities were defined when they do not fulfil their obligations properly the obligations which very often are aimed at acting in the widely understood social interest (Chapuis, 1998: 12).

It was precisely due to the need to perform many tasks in the general social interest discussed here that people very quickly noted there was a need to define new organizational and legal means based on the means and measures already existing in the Commercial Code. Therefore, it was decided to create a special category of local companies whose structure was based on the provisions of the French Commercial Code regarding public companies. It was noted that modifying the structure of a public company may help French territorial units create quasi-public entities which more easily and flexibly could perform public tasks. However, what is important is the fact that such entities would generally be subject to free competition which was supposed to materially affect the quality and transparency of their operations.

An example of a legal means developed to satisfy the needs of local entities, and especially of municipalities, are local companies established as semi-public companies (fr. société d'économie mixte locale). The necessity to satisfy public needs of the local population, but only if it was not possible through a private initiative, is a prerequisite for using that modified form of a public company. Thus, a local company should be brought to life only if its activities ensure not only the optimization of public income and expenditure but also allow for the satisfaction of the overall needs of a locality, regardless of whether its activities risk permanently generating losses. Therefore, in reference to Polish law, the aforementioned legal form of a local and simultaneously public company may be compared to a municipal company in Poland, bearing in mind that it is similar to its French equivalent only to a certain extent (Byjoch, Klimek, 2015: 12).

The first complete law allowing the establishment of local public undertakings under the provisions regarding public companies was introduced in 1983. The core idea of the French lawmakers was to create such legal persons where the majority shareholders could be territorial units. Due to basing their structure on the provisions of the Commercial Code regarding public companies, local companies have capital divided into shares owned by various shareholders whose liability is limited to the number of their contributions. A major constraint is the fact that the number of shareholders of such a company may not be smaller than seven entities, which 
is supposed to encourage the establishment of such legal entities in collaboration among a few municipalities and/or communes (fr. coopération intercommunale). In practice, such companies are formed very frequently not only in collaboration with public law entities, but also in collaboration with one or, very often, more private entities. Because of the foregoing, when comparing such companies to entities provided for in Polish law, one may find many similarities to the institution of a public-private partnership (Michalak, 2014: 12) It is difficult to find such a comparison in the French doctrine since there is a prevailing interpretation that the local companies analysed in this paper are classified as commercial companies whose the key purpose is to perform public utility tasks at a local level (this is originally named in the French doctrine as services publics locaux) (Serrand, 2012: 279).

The field of activity of local companies in France was closely linked with the need to optimize income and expenditure in the context of the broadly understood social interest; that is why from the very beginning it was very frequently connected with the construction industry. However, when it comes to that sector, of considerable importance - apart from the construction of road infrastructure - has always been construction for social purposes. Another crucial field of activity of the companies discussed were various undertakings related to the implementation of public services of industrial or commercial nature (fr. Services publics à caractère industriel ou commercial). What is also noteworthy is the fact that the extent of operations of local companies was considerably affected by the case law of French administrative courts. It is precisely in the legislation for the first time - either through wider interpretation of social interest (Conseil d'Etat Court: CE, 10.10. 1994) or through enabling public intervention in certain new areas of expertise (Conseil d'Etat Court: CE, 23.12.1994) - where the extent of activities of so-called local companies was indirectly and gradually extended. This increase was done in laws and regulations subsequently, so to speak, as a kind of acknowledgment of the already established judicial doctrine. And so, for instance, in 2004 (Act no. 2004806 on public health policy) a decision about local companies approved in the 1990s was formally regulated; according to the decision, a local company may be used to manage or construct local civil airports, hospitals and medical centers, docks or in renovating properties registered by the relevant minister as monuments. In 2004 (Act no. 2004-669 on electronic communications and audiovisual communication services) municipalities and communes were also enabled to implement, through local commercial companies, investments related to developing terrestrial digital television as well as to increase the availability of wireless Internet network in a given territorial unit. 
It should be highlighted that despite its special status, local companies were subject to the standard competition rules and regulations for a very long time. The foregoing is also reflected in the French Commercial Code where the minimum share capital of a local company is EUR 37,000-225,000, depending on its activities ${ }^{6}$. One should bear in mind that the highest minimum share capital is reserved for local companies which operate in the broadly understood construction and infrastructure investment sectors. The fundamental difference between local companies and "classic" commercial companies is the fact that local companies should be formed by particular territorial unit and groups of territorial unit in such a way so that their combined share exceeds half the share capital of the company, the share which controls more than half the votes in its governing bodies. Obviously, the principles of operation of the governing bodies of the company are regulated by reference to the general provisions of the Commercial Code regarding public companies.

Thus, the structure of a local company helps to optimize public income and expenditure through establishing special purpose vehicles whose purpose is to implement certain investments in the social interest of a given territorial unit. In addition, that structure fosters collaboration among territorial units - since a local company has to consist of at least seven shareholders - as it allows a few neighboring municipalities and/or communes which all want to implement a specific investment to form companies to that end. In its basic form, however, a local company has a disadvantage that often enough hinders the performance of tasks in the social interest of a given territorial unit). Namely, in accordance with the EU legislation, public contract award procedure requirements should always apply to such local companies (ECJ: C-26/03). With regard to the foregoing, in French law, there are also legal means allowing public utility tasks to be performed by the territorial unit which is not restricted in terms of either public contract award procedure requirements or free competition.

\section{Local Companies Not Operating on Market Conditions}

In order to ensure the fulfillment of certain local needs that are a part of social interest, without the need to follow the principles of free-market competition and public contract award procedure, the French legislator has developed several legal forms through which local government units may realize the above needs.

The oldest legal forms, also developed by the case-law mentioned in this paper, are related to certain entities governed by public law, taking the form of either a public entity (fr. établissement public) or a public company (fr. entreprise public) 
(Wojtyczek, Machowska, 2003: 101). These entities, in the light of French doctrine, have two essential characteristics (Rivero, Waline, 2006: 38). First of all, they should represent certain protected public interests, and the nature of those interests should not be reduced to individual interests. Very often these interests are related to the needs of a given community, which is separated administratively by the division of the territory into local self-government units. Secondly, the objectives set out for the above-mentioned entities governed by public law should not be profit-oriented, and should not make from the profitability the main reason for their creation (Dupuis, Guedon, 1993: 14).

Public entity (fr. établissement public) is, therefore, a term referring to a legal person governed by public law whose activities are financed by public funds to carry out missions in the broader public interest either at the central level or at the local level (Braibant, Stirn, 2005: 127). The particular example of these public entities are the so-called public companies (fr. entreprise public), which are legal entities of private law, still financed by public funds. Sometimes, in the context of comparative law, a slightly different division can be found, where that enterprises publics, can fully operate on commercial conditions, while établissements publics cannot (Byjoch, Klimek, 2015: 12). It is undisputed, however, that these units have far reached financial autonomy and considerable administrative autonomy. Areas of their actions often involve social services (like hospitals or agencies like Agence française de sécurité sanitaire), education (universities, higher schools), or culture (museums), or other industrial and commercial spheres. In the French doctrine, there are also specific types of institutions described above: public administrative establishments (EPAs) and public industry and trade establishments (EPIC). The main difference between the above-mentioned forms of public entities is that public administrative establishments (EPAs) employ public employees, while EPIC companies generally employ private-law employees on the basis of the Labor Code (Serrand, 2012: 334-335).

The above distinction between public legal entities is often assessed as insufficient (Longchamps, 2001: 49). The gradual interpenetration of public law and private law has forced the French legislator to introduce a new, more flexible form of local company unit in the year 2006 (fr. société publique locale). The company, which was supposed to merge the advantages of public entities with private entities, while excluding it from the principle of free competition, was one again based on the construction of a joint stock company. The above-mentioned solution was supposed to affect not only the way of carrying out tasks related to the social interest of the community, but also facilitate the management and optimization of local finances in this area. It is worth to underline that the new local companies are not, in principle, subject to the rules of free competition in the market, being at the same 
time beneficiaries of the public aid from the State (Brameret, 2013: 31-32). These companies are understood as entities over which local government units have control similar to that exercised against their own internal organizational units, as they perform in principle the overwhelming part of their activity in favor of these local entities.

New local companies are lex specialis in relation to the classic joint stock company described in the French Commercial Code. This is reflected, for example, in the minimum requirement for a number of entities necessary to establish such a company, which has been reduced from seven to just two. Another limitation is that only local government units or the grouping of such entities (originally described as groupements de collectivités) may be entities that have the status of the company's shareholders.

The scope of activity of new local companies was gradually extended by the legislature, very often inspired by the case law of the already mentioned court - Conseil d'Etat. As an example after the last amendment of the law, from 2010 (Act no. 2010-559), new local companies can carry out activities related to all kinds of legal analysis of a given investment, feasibility studies, projects related to local infrastructure, acquisition and sale of real estate properties, construction or renovation works.

To sum up, the evolution of French legislation has led to a large range of legal and organizational forms available to local government units seeking to satisfy important social interests within a given territorial unit. Apart from traditional forms of public law entities, there are also some local companies in which local government units either hold majority control or are holders of the entire share capital. Local companies are an exception to the general rule relating to public limited companies (Art. L.225-1 of the Commercial Code), as they do not have to be established and function like classic private equity companies. The scope of activity of these companies has also been gradually increased by the legislator (Daucé, 2011: 9-10). The general rule, however, is that local government units can only create local companies only to perform their own tasks, without the possibility to create such companies to perform ancillary activities in the form of human resources management or optimization of a unit's budget. Indirectly, through the creation of such local companies, the French municipalities have the opportunity to optimize their income and expenditure in the broadly understood social interest. This phenomenon has been noticed by representatives of French administrative and financial law and may result in the future in various research in this field, which may be extremely valuable for the development of local finances in Poland and other Central and Eastern European countries. 


\section{Conclusions}

The public and social interest described in this paper were used by the French lawmakers to justify the introduction of new legal means for French territorial units to perform their tasks. The development of such legal means, from public law entities through local companies structured similarly to public companies, shows that along with the evolution of the concept of social interest there also evolved legal means to act in it.

The creation of the category of local companies in its original and new forms allowed the French lawmakers to completely transpose the EU regulations and the ECJ legislation regarding the interpretation of public contract award procedure directives and laws into French law. The flexibility of various forms of local public companies and their possibility of transforming from one form into another allowed territorial units to increase the number of instruments for local public income and expenditure optimization. Those instruments make it possible not only to efficiently and legally exclude the provisions of law pertaining to market competition requirements but also to choose the right legal means for a given investment or for a given case of the social interest. It has to be emphasized that the social interest discussed in the framework of French law, only with reference to Polish legislation, not only contributed to the introduction of special legal regulations but also constituted one of the reasons for their further development, allowing for better optimization of public income and expenditure. The analysis of the aforementioned processes and regulations may give rise to reflections on the content of Polish legislation on the subject, but it may also provide an impulse for further, more detailed research.

\section{References}

Brameret, S.: La société publique locale, société d'économie mixte locale à capitaux intégralement publics (The local public company, a local semi-public company with fully public capital), Contrats publics CP (Public Contracts) no. 4 (2013).

Broch, J.: L'utilité publique dans l'ancienne France (The public utility in the old France), Cahiers poitevins d'histoire du droit (Poitevin Cahiers of Law History) no. 5 (2014).

Braibant, G., Stirn, B.: Le droit administratif français (French administrative law), Paris: Dalloz, 2005.

Byjoch, K., Klimek, D.: Spółka komunalna. Aspekty prawne, ekonomiczne i społeczne (Municipal company. Legal, economic and social aspects), Toruń: Adam Marszałek, 2015.

Cornu, G. (ed.): Vocabulaire juridique (Legal vocabulary), Paris: PUF, 2005.

Chapus, R.: Droit administratif général (General administrative law), Paris: Montchrestien, 1998. 
Daucé, S.: Les SPL et les compétences locales à l'issue de la loi de réforme des collectivités territoriales (SPL and local competences after the law introducing the reform of local authorities), Les entreprises publiques locales, Actes territoriaux (Local Public Enterprises, Territorial Acts), 2011.

Donier, V.: Droit des collectivités territoriales (Law of local authorities), Paris: Dalloz, 2014.

Dupuis, G., Guedon, M.: Droit administratif (Administrative law), Paris: Armand Colin, 1993.

Lasserre, B.: Un nouveau nom et avec un trait d'union (A new name and a part of union), Sud Ouest (South West) no. 6 (2016).

Longchamps, F.: Współczesne kierunki w nauce prawa administracyjnego na zachodzie Europy (Modern directions in the study of administrative law in western Europe), Wrocław: Kolonia Limited, 2001.

Michalak, D., Fitas, A.: Partnerstwo publiczno-prywatne w modelu koncesyjnym. Wybrane zagadnienia praktyczne (Public-private partnership in the concession model. Selected practical issues), Warszawa: Wolters Kluwer, 2014.

Monjal, P.-Y.: La communautarisation de l'organisation décentralisée en France (The communitarization of the decentralized organization in France), in: Journées juridiques franco-polonaises (French-Polish legal meetings), Paris: Mare et Martin, 2013.

Orcier, P.: Régions à la découpe (Regions for cutting), Neuilly-sur-Seine: Atlande, 2015.

Rivero, J.: Waline J., Droit administratif (Administrative law), Paris: Dalloz, 2006.

Serrand, P.: Manuel d'institutions administratives francaises (Manual of French administrative institutions), Paris: PUF, 2012.

Wojtyczek, K., Machowska, A. (eds.): Prawo francuskie (French Law), Kraków: Zakamycze, 2003.

FR: Act of 2 March 1982 on Freedoms and Liberties of Municipalities, Communes, Departments, and Regions, as amended.

FR: Act no. 83-597 on local mixed economy companies.

FR: Act no. 2004-806 on public health policy.

FR: Act no. 2004-669 on electronic communications and audiovisual communication services.

FR: Act no. 2010-559 related to the new local companies

ECJ: no. C-26/03.

FR: Conseil d'Etat Court: CE Ass. 5.05.1976.

FR: Conseil d'Etat Court: CE Ass. 28.05.1971.

FR: Conseil d'Etat Court: CE, 10.10. 1994.

FR: Conseil d'Etat Court: CE, 23.12.1994. 
PL: Supreme Administrative Court: II FSK 71/13.

PL: Supreme Administrative Court: II FSK 4126/14.

PL: Supreme Court: III ARN 33/93. 


\title{
CENTRAL BANK DIGITAL CURRENCY - THE LATEST CHALLENGE FOR THE THEORY OF MONETARY LAW
}

\author{
JOHAN SCHWEIGL $L^{I}$
}

\begin{abstract}
In the last few years, several central banks, such as Bank of England, Sveriges Riksbank, Bank of Canada, ECB or Central Bank of Russian Federation, considered issuance of a new type of money - central bank digital currency. The monetary law theory distinguishes between three currently existing types of money, i.e. cash, deposit money, and reserves. Each of these types has a special combination of features that make them unique. The monetary law theory, however, has not carried out complex theoretical analysis of the central bank digital currency. In this paper, the Author focused on the theoretical aspects of the new type of money - the central bank digital currency.
\end{abstract}

\section{Keywords}

Central bank digital currency; deposit money; reserves; central banks; monetary law

\section{JEL Classification: E50, G00, K19}

\section{Introduction}

Central bank digital currency (or CBDC) has been a crucial topic in the discussions and speeches of the central bankers over the few last years. It is rather likely that CBDC will fundamentally alter the existing system of banking, as it will influence the commercial banks "monopoly" of issuance of accounting money with general accessibility and it will give the central banks a new tool for carrying out monetary

1 Research fellow at the Department of Financial Law and Economics, Faculty of Law, Masaryk University, Brno, Czech Republic. Ph.D. degree obtained in 2016 after defending the thesis aimed at bank regulation. Since then, he has mainly focused on the area of monetary law and regulation of banks. He has published numerous papers, articles and a few chapters in books on the two topics. Contact email: 210729@mail.muni.cz. 
policy. Thus, the creation of CBDC will have strong global consequences in both banking sector and the real economy.

CBCS is now not mentioned only by the central bankers, but also by many economists, journalists, and even lawyers. The concept of CBDC is still in the process of being shaped - even the name CBDC is not being used universally. The recent speeches of central bankers show that the plans of creating CBDC are probably not that far from materialization. Some of the basic functions of CBDC were already introduced by the central bankers, but what is still missing is a theoretical classification of this new type of money by the theory of monetary law.

In this paper, I will extend my previous analysis concerning CBDC (Schweigl, 2017). First, I will briefly outline the existing three forms of money recognized by the theory of central banking and by the monetary law theory. I will do so by showing the main features of these three forms of money in their complexity, i.e. by focusing on the unique variation of their features (chapter II). Next, I will consider the probability of materialization of CBDC, i.e. whether and when the central banks could start issuing them (chapter III). Finally, I will outline the core features of CBDC, or to be more precise the combination of the features (chapter IV). The main goal of this paper is thus to contribute to monetary law theory by outlining the core features of CBDC so that the theory could grasp them and use them in further research of CBDC. This goal is to be achieved by use of the method of comparison when CBDC will be compared to the existing three types of money.

\section{Existing Three Types of Money}

The notion of 'money' is rather of a broad extent. Anything that is generally accepted as a mean of payment may be considered as money. However, only money recognized by the state (or supranational entity) is considered as national (or supranational) currency. The general central banking theory recognizes three fundamental types of money: ${ }^{2}$

1. Currency (in the narrow sense, i.e. cash).

2. Deposits on regular bank accounts (sometimes called "deposit money").

3. Reserves, i.e. deposits of credit institutions on reserve accounts at the central bank (sometimes called "reserve money").

To show the uniqueness of each of these types of money, I will outline the core features concerning their:

2 Comp: Mcleay, M., Amar, R., Ryland, T.: Money Creation in the Modern Economy. London: Bank of England. Quarterly Bulletin no. 1 (2014) 
(i) form,

(ii) accessibility,

(iii) issuer,

and (iv) transfer mechanism. ${ }^{3}$

\subsection{Form}

As for the form, it is clear that currency is the only type having a material form the other two types of money are of immaterial form. Currency is either in form of coins or banknotes, whereas deposit money and reserve money are only represented by accounting entries in the respective books (see below). Thus the deposit money and reserve money are considered to be "accounting money" (niem. Buchgeld).

\subsection{Accessibility}

There are no special limits on accessibility to coins and banknotes or to deposit money. In other words, there is no need to obtain a special license in order to hold cash or have a bank account at a commercial bank. Of course, there might be certain general limitations to access of those two types of money, such as limitation in legal capacity of a person, or limits on cash payments, but they are rather of general nature, they do not exclude certain groups of persons from holding these types of money. Reserve money, on the other hand, have very limited accessibility. As it was explained above, reserve money (reserves) is represented by balances at the reserve accounts at the central bank and there are strict limits on those who can open such a reserve account at the central bank. Usually, only credit institutions, such banks and credit unions are allowed (and required) to have a reserve account at the central bank. To summarize, cash and deposit money are generally accessible, whereas reserves are only accessible by credit institutions.

\subsection{Issuer}

When analyzing this criterion, we need to look at the balance sheet (statement of financial position) of such an entity that records the respective types of money as their liability. Each of the three types of money is a liability on the balance sheet of their issuer. Cash and reserves are liabilities on the central bank's balance sheet, whereas deposit money is a liability on a commercial bank's balance sheet. In other words, cash and reserves are issued by the central banks - these two types of money

3 The first three criteria were already analyzed in Schweigl, 2017. The fourth criterion was also analyzed e.g. by Bech and Garatt, 2017. 
are sometimes called central bank money. The economists use the term monetary base for the central bank money. Deposit money is (in majority) ${ }^{4}$ created by the commercial banks. The creation mainly occurs when a commercial banks extends credit or purchase assets. ${ }^{5}$

\subsection{Transfer Mechanism}

There are two basic types of transfer mechanisms - centralized and decentralized. In the centralized mechanisms, the transactions occur in a centralized ledger led by the provider of the respective payment system. The decentralized transactions require no such a centralized ledger, as they take place directly between the payee and payer without any central intermediary, i.e. peer-to-peer (Bech, Garatt, 2017). Transfer of cash is a typical example of the peer-to-peer transaction, whereas transfer of any type of the existing accounting money represents the centralized transaction.

\section{Central Bank Digital Currency - Science Fiction or Reality?}

As I mentioned in the introduction, the CBDC is currently discussed by numerous central bankers. CBDC is no longer just an idea of academics or economic theory. It is a concept that is being researched by research centers of several central banks. The name CBDC - central bank digital currency - is however not final. So far, there is no generally accepted name or title for the concept of central bank digital currency. There have been used, for instance, the names, such as "digital central bank money" (DCBM), "digital base money" (DBM) ${ }^{6}$, "central bank issued digital currency"7 "digital cash" or "central bank digital currency" (CBDC). In this paper, I use the term CBDC.

Below, I will outlines several studies or research programs concerning CBDC. In 2016, the Inter-American Development Bank published a research paper called Digital Central Bank Money and the Unbundling of the Banking Function. The Authors explained the reasons for the popularity of CBDC. In the same year, the Bank of England published a paper researching macroeconomic questions arising from CBDC. Later that year, the Canadian central bank issued a booklet called

$4 \quad$ Central banks can also create deposit money, but they usually do so only in a very limited extent. Creation of deposit money is not a function of the central banks.

5 For more, see for instance: Gottschalk, J.: Introduction to Money Creation. International Monetary Fund, 2014.

6 For instance, compare Speech by Yves Mersch, Member of the Executive Board of the ECB, of 16 January 2017. www.ecb.europa.eu.

7 For instance, compare the study by (Barrdear, Kumhof, 2016). www.bankofengland.co.uk.

8 For instance, compare the Positive money institute. www.positivemoney.org. 
Central Bank Digital Currencies: A Framework for Assessing Why and How. They mainly focused on the consequences of CBDC on the payment systems. In the last two years, there were a number of speeches by research from the Bank of England on CBDC. CBDC is also paid attention by private research centers, such as Positive Money Institute. In 2017, the CBDC started to be paid more attention also by the Swedish central bank, Riksbank, the Central Bank of the Russian Federation, or the Bank of China. The unprecedented interest in the concept of CBDC by the central bankers makes it very likely that $\mathrm{CBDC}$ will become reality in the future.

\section{Core Features of Central Bank Digital Currency}

The four criterions analyzed above with respect to the existing three types of money, will now be applied to CBDC. As for the form, it is clear that CBDC is supposed to be immaterial, i.e. it will not be represented by any coins or banknotes. The accessibility to CBDC should be general. This would be probably the main difference between $\mathrm{CBDC}$ and reserves, which are only available to credit institutions. The issuer of CBDC should be central banks, i.e. CBDC would be a liability on the issuing central bank's statement of financial position. Just by looking at these three features of $\mathrm{CBDC}$, or to be more precise at the unique variation of the features, it can be deduced that CBDC will significantly affect the existing system of banking sector. Immaterial form of money with general access will be - aside from the commercial banks - issued by the central banks. This will also broaden the options central banks will have when conducting monetary policy.

The nature of transfer mechanism is, however, still open. CBDC is still in the process of being shaped and there are different ideas about how CBDC could be transferred. The transfers of CBDC could be either centralized (an issuing central bank would keep an internal payment system in which the transfers would be tracked and recorded) or CBDC could be transferred in a decentralized form, on some type of distributed ledger technology (Skingsley, 2016).

To summarize, CBDC will be of immaterial form, generally accessible liability of an issuing central bank. The general idea is that CBDC will be a form of national currency, i.e. it will be considered as legal tender.

\section{Conclusions}

In this paper, I chose four features of the existing types of money and compared them to $\mathrm{CBDC}$, a new type of money that is currently considered by certain central bankers around the world. I also presented some of the studies and speeches 
published by central bankers or researchers from central banks from several different countries of the world.

The goal of this paper was to contribute to monetary law theory by outlining the core features of $\mathrm{CBDC}$ so that the theory could grasp them and use them in further research of CBDC. CBDC is a think of future. It is no longer only an abstract idea of several academics, but - according to the attention it has been given over the last few years by the central banks - it will soon become reality.

The economic studies mainly focus on the economic effects the creation of CBDC will have. The research for instance the effects it will have on the banking system as the whole or how it could be used when conducting monetary policy. The monetary law theory has been silent so far as for CBDC. The monetary law theory, however, now faces a new challenge - the challenge to bring theoretical classification of the new type of money. I hope that this brief contribution may help to the monetary law theory in grasping the new concept of CBDC.

\section{References}

Bech, M., Garratt, R.: Central bank cryptocurrencies, Quarterly Review no. 9 (2017).

Gottschalk, J.: Introduction to Money Creation. International Monetary Fund, 2014. www.imf.org.

Engert, W., Fung, B.: Central Bank Digital Currency. Motivations and Implications. Bank of Canada, Staff Discussion Papers no. 16 (2017).

Mcleay, M., Amar, R., Ryland, T.: Money Creation in the Modern Economy. London: Bank of England. Quarterly Bulletin no. 1 (2014).

Schweigl, J.: Monetary law and "electronic cash", Daně a finance (Taxes and Finance) no. 3 (2017).

Skingsley, C.: Should the Riksbank issue e-krona? Speech of November 16, 2016. www.riksbank.se. 


\title{
PUBLIC-PRIVATE PARTNERSHIP IN TERMS OF THE CONTRACT FOR THE CONSTRUCTION OF DISTRICT HOSPITAL IN ŻYWIEC AS AN EXAMPLE OF OPTIMIZATION IN THE PUBLIC INTEREST
}

\author{
KRYSTIAN JASZCZYK ${ }^{1}$
}

\begin{abstract}
The implementation, including financing, of public tasks is not an easy venture. In some situations, public entities are not capable of bearing the costs of this type of investment. The inability to finance such needs from public funds is becoming the main reason for public entities to turn attention to the private sector and its funds in order to finance public needs using public-private partnerships. The objective of the article is to evaluate the public-private partnership as an institution for optimization of public spending on the example of a contract for the construction of a District Hospital in Żywiec. The research problem is the answer to the question whether the institution of public-private partnership serves the public interest through the optimization of public spending. According to the research hypothesis, the currently functioning public-private partnership is a legal solution optimizing public expenditure for benefit of the public interest. The article presents the way of functioning and financing of public-private partnership on the example of a contract for the construction of a District Hospital in Żywiec. The subject was chosen because of its relevance. The Polish legislator, while defining public tasks for their implementation and the requirements for their fulfillment, forgets that public entities are not always willing to carry out these tasks themselves and assume the risk which accompanies their implementation.
\end{abstract}

\section{Keywords}

Public-private partnership; public entity; private partner; District Hospital in Żywiec JEL Classification: H51, H41, H60

1 Ph.D. Student at the Department of Public Financial and Financial Law, Faculty of Law, University of Bialystok, Poland. The author specializes in the public-private partnership. He is a member of Information and Organization Center for the Research on the Public Finances and Tax Law in the Countries of Centre of Eastern Europe. Contact email: jaszczykkrystian@wp.pl. 


\section{Introduction}

The public-private partnership (PPP) in Poland is regulated by the Act of 19 December 2008 on public-private partnership. According to Art. 1/1 of PublicPrivate Partnership Act, the objective of the act is to formulate principles of cooperation between public entity and private partner within the PPP. Therefore, the Act will be applied to any cooperation of public and private entities, providing that legal definition of PPP is fulfilled as presented in Art. 1/2 of Public-Private Partnership Act. This is aimed at providing transparency, competitiveness and equal access to all entities involved in such projects (Partnerstwo publiczno-prywatne, 2010: 32).

According to Art. 1/2 of Public-Private Partnership Act, the subject of PPP is joint execution of venture based on division of tasks and risks between public entity and private partner. The aforementioned regulation indicates the subjective scope of PPP, which includes both public entity and the private partner. The legislator emphasizes that the cooperation takes form of a joint venture based on division of tasks. A characteristic feature of PPP is division of risk between public entity and private partner. According to the legislator, PPP is to be a cooperation of two sectors: public sector, whose objective is to execute public tasks, and private sector, aimed at profit.

Due to framework character of Public-Private Partnership Act, no specific division of tasks between the public entity and private partner is enforced. Such legislative measure allows this issue to be resolved by the partners, so that individual tasks may be assigned to each party efficiently and in accordance with subject of the partnership as well as competences and capabilities.

The next element of public-private partnership is division of risk between public entity and private partner. Notably, no legal definition of risk exists, hence linguistic definition should be used. "Risk is probability, possibility that something will not work, presumed effects will not be achieved or circumstances will occur hindering achieving of the goal" (Dyczkowski, 1998: 1521). The legislation also does not specify what kinds of risk exist. Similarly to the division of tasks, the legislator does not enforce any form of risk division, leaving this matter to the involved parties. Importantly, the division of risk is one of the obligatory criteria used for assessment of offers in process of selection of the private partner.

The subsequent step in PPP is the division of tasks. PPP aims at entrusting private partner with some tasks to perform. The legislation does not indicate what tasks are to be entrusted within the public-private partnership. Since public entities are assigned with the realization of public tasks, it is clear that only tasks within this 
Public-Private Partnership in Terms of the Contract for the Construction of District...

scope may be entrusted to the private partners, hence ventures executed within PPP are public tasks.

The subject of PPP is cooperation of public entity and private partner (PublicPrivate Partnership Act, Art. 1/1). As an effect, the concept of the public entity is of great significance for determination of the range of application of Act on publicprivate partnership in terms of subjective scope.

According to Art. 2/1 of Public-Private Partnership Act, public entities include: a) unit of public finance sector as indicated in Act of 27 August 2009 on Public Finance or b) different than specified in letter (a) legal entity created specifically in order to satisfy general needs which do not have industrial of trading character, if entities indicated in letter (a) either finance over $50 \%$ of this entity, possess over a half of shares, maintain oversight of management authority or have right to appoint over half of management or oversight authorities, either individually or jointly, directly or indirectly through other entities; c) associations of entities indicated in letters (a) and (b).

According to Art. 2/2 of Public-Private Partnership Act, the private partner should be interpreted as the entrepreneur or foreign entrepreneur. The mentioned regulation does not include any definition of the entrepreneur, nor does it refer to any other regulation defining the term. The explanatory memorandum also does not contain any such information.

For this purpose, regulations contained in Act of 2 July 2004 on Freedom of Economic Activity should be applied, as they include the definition of entrepreneur. According to Art. 4/1 of Freedom of Economic Activity Act, "The entrepreneur in the meaning of the Act is a natural person, the legal person and unincorporated organizational unit without legal personality, which is given legal capability by a separate act, running the business on their own behalf". Moreover, according to Art. 4/2 of Freedom of Economic Activity Act, also "as an entrepreneur may also be considered a partner of a civil partnership to the degree of their economic activity". Furthermore, according to Art. 2 of Freedom of Economic Activity Act, economic activity is "(...) any gainful activity involving manufacturing, construction, trading, services as well as surveying, exploration, and extraction of mineral resources performed in an organized and constant manner".

Additionally, Freedom of Economic Activity Act also contains the definition of foreign entrepreneur. This is of fundamental significance from the PPP standpoint, since, according to Art. 2/2 of Public-Private Partnership Act, the foreign entrepreneur may also be the private partner. In this case, proper regulation defining this term is the aforementioned Freedom of Economic Activity Act. This is also confirmed by explanatory memorandum to Public-Private Partnership Act, 
according to which "private partner may also be a foreign entrepreneur, as defined by Art. 5/3 of Act of 2 July 2004 on freedom of economic Activity" (Draft no. 1180: 9). According to Art. 5/3 of Freedom of Economic Activity Act, the foreign entrepreneur is a foreign person, i.e. natural person who is not citizen of Poland, legal person with their registered office located abroad or an unincorporated organisational unit without legal personality but with legal capabilities with their registered office located abroad, performing their economic activities beyond Polish borders.

The public-private partnership is open to any fields and forms of services which, according to existing law, should be provided by public entities. This allows for the realization of projects in such fields as education, healthcare, infrastructure, etc.

In Art. 1/2 of Public-Private Partnership Act, legislator indicated that the subject of cooperation within the public-private partnership is the execution of venture, whereas, according to Art. 2/4 of this act, the subject of the venture may be:

1. construction or renovation of building development,

2. provision of services,

3. performing work, particularly equipping asset with device improving its value or utility,

4. another service.

The aforementioned activities should be combined with maintenance or management of the asset used for the realization of public-private venture or connected therewith. Such definition of the venture is a purposeful act on behalf of the legislator, aimed at encompassing all significant fields of cooperation between public entities and private partners as broadly as possible (Draft no. 1180: 10).

Activities of maintenance and management may be connected to the responsibility of undertaking expenditures, both necessary and those increasing utility of the asset, placed on the private partner. Detailed scope of maintenance and management of the asset should be determined by the contract of public-private partnership. Such contract should also determine the precise division of tasks and costs connected to these activities.

The objective of the article is to evaluate the public-private partnership as an institution for optimization of public spending on the example of a contract for the construction of a District Hospital in Żywiec. The research problem is the answer to the question whether the institution of public-private partnership serves the public interest through the optimization of public spending. According to the research hypothesis, the currently functioning public-private partnership is a legal solution optimizing public expenditure for benefit of the public interest. According to the 
Public-Private Partnership in Terms of the Contract for the Construction of District...

research hypothesis, the currently functioning public-private partnership is a legal solution optimizing public expenditure for benefit of the public interest. The article presents the way of functioning and financing of public-private partnership on the example of a contract for the construction of a District Hospital in Żywiec.

\section{Construction of the New Building of District Hospital in Żywiec}

During analysis of the construction of District Hospital in Żywiec, it should be noted that tasks referring to investments in hospitals are the responsibility of powiat (district) authorities in accordance with Art. 4/1 of Act of 5 June 1998 on District Government. Public-private partnership project presented in this paper is the first example in Poland, where Starost's Office can perform public tasks, such as health care and promotion, despite lack of funds for investments. Private partner selected for the presented project - InterHealth Canada Limited - is to design, finance and construct the hospital. Subsequently, for the next 30 years, the company will manage the hospital, including providing of medical services available to all, regardless of their income and status, based on contracts with National Health Fund (Herbst, Jadach-Sepioło, 2012: 6). For this purpose, Starost's Office in Żywiec adopted a resolution on building the new hospital in form of $\mathrm{PPP}^{2}$.

One of the important aspects of this investment is ensuring of transfer of knowledge (know-how) $)^{3}$ on construction of modern medical facilities and their long-term management, particularly in respect of fulfilling the requirements for medical facilities outlined in decree of the Minister of Health of 2 February 2011 on professional and sanitary requirements placed on premises and equipment in healthcare facilities ${ }^{4}$. In terms of adapting facilities to needs of people with disabilities, installation of modern sanitary equipment and designating new utility rooms, the most common problem is lack of sufficient funds for such purposes. In case of District Hospital in Żywiec, premises and technical conditions forced the decision on constructing modern medical complex and revitalization of facilities currently in use after completion of investment ${ }^{5}$. Providing new hospital building opened new possibilities of organization of available space, for instance, construction of landing platform for emergency helicopters as well as the creation

2 By resolutions of District Council in Żywiec no. XXXV/317/09 and no. XLIII/401/2010.

3 Know-how - operational knowledge, referring to people's abilities, means one's ability to perform an action. It is contained in person's mind and associated with experience (Bayer, 2011: 14).

4 Decree of the Minister of Health of 2 February 2011 on professional and sanitary requirements placed on premises and equipment in healthcare facilities.

5 Building of Żywiec hospital was constructed in 1888-1991. Due to their technical condition, the thorough renovation was required. The cost of such renovation would exceed that of constructing the new building. Moreover, some of the hospital buildings are in the register of objects of cultural heritage, which limits possibilities of adapting them for the modern healthcare facility. 
of new wards and development of existing ones, such as geriatrics, surgery (Herbst, Jadach-Sepioło, 2012: 6).

By realizing the investment through the public-private partnership, Starost's Office in Żywiec developed venture model DBOD (design, build, operate, deliver) as a response to needs of the medical facility.

For the private partner, InterHealth Canada Limited was selected, the company established in 1994, specializing in developing, launching and managing of healthcare facilities (www.interhealthcanada.com). As a result of this venture, modern hospital buildings and systems for providing healthcare services will be created, which will be subjected to assessment of key performance indicators (KPI) specified in partnership contract through internal control and external audits. According to concept project ${ }^{6}$, District Hospital in Żywiec will have 8 wards on 4 floors and a total space of over 24 thousand sqm. The hospital complex will include, among others, surgery ward integrated with other wards, the emergency ward with landing platform for helicopters and additional clinics (www.starostwo.zywiec.pl). The hospital will be managed by InterHealth Canada. Sixteen months before the completion of construction, the private partner will assume management of existing District Hospital, which will be transformed into the geriatric center (Herbst, JadachSepioło, 2012: 8).

According to the partnership contract, private partner is to provide equal access to the services for all residents of the district. The operation will be financed by National Health Fund, and thus should be available to all patients covered by health insurance. I order to ensure high quality of provided medical services, cooperation with public entity will be required (Herbst, Jadach-Sepioło, 2012: 8).

According to this report, lack of public consultations during the selection of the location of investment was an obstruction for execution of public-private partnership, which led to opposition from residents of the town and district to decisions made by Starost's Office. The opposition raised arguments on issues with access due to lack of a bridge, necessity of commuting through the large part of town and local topography (Herbst, Jadach-Sepioło, 2012: 8).

\section{Financing in PPP on the Example of Construction of District Hospital in Żywiec}

In the public-private partnership, it is the private partner who is supposed to provide funds for the venture in total or in part or ensure financing by third parties. This

6 Acceptance of concept project completed the first stage of architectural and engineering works, which were started after signing the contract of investment in form of PPP on 15 September 2011. 
includes all expenses, starting with investments (e.g. construction or renovation of the building, adapting infrastructure to fulfill certain functions), later followed by exploitation expenditures, i.e. maintenance and management of the project. Private partner is obligated to finance at least part of the venture, otherwise, the contract will not constitute public-private partnership (Partnerstwo publiczno-prywatne, 2010: 42). Funds for the financing of given venture may belong to private partner or come from credit, loan, subsidy or issuance of shares. In certain cases, the private partner may use bank promissory note. In such cases contract may be signed conditionally with the determination of the date of obtaining said note, signing credit contract, receiving subsidies, issuance of shares, buyback of debts etc. (Gonet, 2009: 54).

In terms of realization of PPP projects, sources of financing may be divided into two groups, namely returnable and non-returnable funds. Non-returnable funds include funds from European Union and supplementary sources of financing, use of which is dependent on the position of potential creditors. Involvement of authorities is frequently expanded to include guarantees required by creditors. Depending on the degree of realization of the project, private capital may take the form of sponsored capital and bank credits, contracts for provision and sale of services and funds obtained through trading in capital market instruments. On the other hand, the aforementioned returnable funds constitute a significant share of financing of infrastructural projects. This category contains bonds, leasing and subordinated debt. However, the important role is that of credits granted by the banks, groups of banks and multilateral financial institutions, e.g. World Bank Group (Brzozowska, 2006: 81-83).

With regard to the issue of financing of the construction of District Hospital in Żywiec, private partner designs and constructs the object, and subsequently manages the hospital, providing medical services and covering all associated costs. Value of this venture is estimated at 220 million PLN. The private partner will be able to retrieve invested funds through contracts with NFZ as well as through potential commercial medical services.

In case of construction of District Hospital in Żywiec, private partner takes three fundamental risks - those of construction, availability, and demand. The demand risk is of the greatest threat to the project due to the existing system of financing medical services. NFZ - the public entity paying for medical services operates on the basis of one-year orders and maximally three-year long contracts. Private partner does not have any guarantees of financing in long-term, whereas PPP contracts are signed for 20-30 years. This issue may fully manifest already at the stage of credit application. 
A report was created by Ministry of Regional Development containing conclusions from the selection of private partner in Żywiec, which indicated several key issues:

- the capability of public entities to provide guarantees and, hence, the necessity of unequivocal regulation of qualification of liabilities resulting from provided guarantees;

- lack of binding commitments from financing institutions pertaining to assurance of project financing;

- difficulties with assessment of partner reliability;

- the capability of covering costs of project monitoring by the private partner (Urbanowski et al.: 2011).

The notes presented above are general in character and are not directly connected to the project of construction of medical facilities. They do, however, present the certain aspect of difficulties in the preparation of public-private partnership ventures, namely way to completion of the venture in terms of financing.

As has been mentioned above, medical services within described PPP project will be financed by NFZ based on the contract signed with District Hospital in Żywiec. However, the risk exists that such contract may not be signed. In such case, Starost's Office will be obligated to undertake actions towards finding new sources of financing and covering costs of offered medical services. Such situation may threaten the public interest and, subsequently, lead to increase in public spending.

In order to secure the public interest of Starost's Office in Żywiec, it may reasonable to appoint the special committee that can analyze reasons of why the contract between medical facility and NFZ was not signed. Such body may be appointed pursuant to Art. 17/1 of District Government Act, according to which the District Council may appoint permanent and temporary committees for specific tasks, determining the subject of their operation and composition. These committees report to the District Council in the entire scope of their operation, present plans, and accounts of their functioning. The purpose of such committee may also be oversight of the process of applying for contracts with NFZ conducted by the healthcare facility. Such solution would contribute to securing the public interest of local authorities in longer perspective of the functioning of described public-private partnership.

Furthermore, the possibility exists of applying Art. 145/1 of Act of 29 January 2004 on public procurement, according to which "In case of significant change of circumstances causing the conclusion of contract to no longer contribute to public interest, which could not have been forecasted when entering into agreement, or if further execution of contract may threaten important interest of national security 
Public-Private Partnership in Terms of the Contract for the Construction of District...

or public security, contracting entity may cancel the contract within 30 days from the time at which these circumstances were identified". Presented Article grants the right of unilateral withdrawal from the contract as a result of particular circumstances only to the contracting entity. This is undoubtedly a deviation from the principle of equality of parties involved in contract existing in civil law and is considered a special right, independent from the right of both parties pursuant to Civil Code (e.g. Arts. 491-493).

A solution to this problem within the scope of existing system of financing medical services may be a system of basic hospital guarantee of healthcare services introduced as legal institution by amendment to Act of 27 April 2008 on Health Care Services Financed by Public Funds, i.e. Act of 23 March 2017 on amending the Act on Health Care Services Financed by Public Funds, which created a "network of hospitals".

\section{Network of Hospitals}

The legislator's premise in the amendment of Act of 27 April 2008 on Health Care Services Financed by Public Funds is to create a "network of hospitals" which is operating since 1 October 2017. Moreover, the amendment to Health Care Services Financed by Public Funds Act changes rules of financing services within hospital treatment and, partially, also within specialist out-patient care.

The aim of the amendment to Health Care Services Financed by Public Funds Act is stabilization of structure and financing of hospitals. Amendment introduces new legal institution - the system of basic hospital guarantee of healthcare services (PSZ) which should be the main form of guaranteeing access to healthcare services within hospital treatment. As part of PSZ, healthcare facilities in given voivodship will be classified into one of 6 levels of service guarantees (Draft no. 1322: 4). Following levels of service guaranteeing were specified (Health Care Services Financed by Public Funds Act, Art. 95/2): hospitals of I, II and III degree, oncologic or pulmonological hospitals, pediatric hospitals, and national hospitals. These levels of guarantee form the network of hospitals. Pursuant to Art. 95m/1 of Health Care Services Financed by Public Funds Act, the healthcare provider is classified within the system for four years, in terms of the healthcare facility as indicated by regulations on healthcare activity conducted in given voivodship. Considering Art. $95 \mathrm{~m} / 2$ of Health Care Services Financed by Public Funds Act, it should be remembered that classification within the guarantee system involves including given healthcare provider in one of the levels of this system as well as indicating profiles of the system, scope, and forms of treatment, within which the guaranteed healthcare services will be provided. 
According to Art. 95n of Health Care Services Financed by Public Funds Act, director of respective voivodship department of NFZ creates and publishes in Public Information Bulletin a list of healthcare providers classified in guarantee system with indication of all of the profiles of the system as well as scopes and additional forms, within which they will provide healthcare services as part of the system. The list for given voivodship is published no later than 27 March with duration of 4 years and comes into effect on 1 July. The only exception is the first list, which was to be published no later than 27 June 2017 and remains in effect from 1 October 2017 to 30 June 2021.

According to the assessment of effects of regulation, ca. 93\% of total budget for hospital treatment will be assigned to finance services within PSZ. Moreover, aside from contracts for healthcare services provided within the guarantee system, the previous mechanism of contracting medical services based on competitive bids or negotiations will be also functioning. This means that hospitals not classified within the guarantee system will also be able to accept patients as part of the contract with the NFZ. Applications for contracts will still be possible through entering announced competition. According to Art. 136c/1 of Health Care Services Financed by Public Funds Act, healthcare services provided based on contract within PSZ are to be financed in form of flat-rate payment from guarantee system. Basing on Art. 136c/2 of Health Care Services Financed by Public Funds Act, the size of this payment is to be determined for reference period specified in the contract, not longer than a calendar year.

The Act on amending the Health Care Services Financed by Public Funds Act came into effect on 4 May 2017, whereas the network of hospitals started its operation on 1 October 2017. Transitional provisions contained in this amendment should also be mentioned here, as they carried significance for existing healthcare providers. Existing contracts for services within PSZ were extended to 30 September 2017. After that day, i.e. starting on 1 October 2017, these services were integrated into PSZ with the provision, that healthcare providers will no longer be required to fulfill requirements specified in their existing offers.

District hospital in Żywiec, as Complex of Healthcare Facilities, was added to list of hospitals published by the Minister of Health. This means the possibility of entering into a contract with NFZ automatically, without the necessity of participating in competition procedure. This kind of financial stability may positively affect the long-term nature of PPP not only in case of construction of District Hospital in Żywiec but also for later activities connected to maintenance and management of the medical facility. 


\section{Conclusions}

The project of construction of District Hospital in Żywiec is first in Poland example of public-private partnership venture in the field of healthcare. The significance of promotion of PPP as the formula for modernization of hospitals and development of new healthcare facilities should be noted. Some public entities are not capable of performing public tasks entrusted to them by the legislator. Lack of financial capabilities of public entities to conduct such expensive projects should encourage them to seek alternative solutions, such as cooperation of private and public sectors in form of PPP.

Due to the contractual system of financing health care in Poland based on one-year or three-year agreements with NFZ, the possibility of modification of contracts for medical services provided by healthcare operators selected within the PPP should be considered, with regard to the long-term involvement of the private partner in the execution of given project.

Furthermore, both in case of District Hospital in Żywiec and in other ventures, particular attention must be drawn to the necessity of public consultations in reference to the realization of supra-local ventures. Lack of consultations in respect of the location of the project may lead to social concerns and discontent despite the need and general acceptance for execution of given venture.

\section{References}

Bayer, K.: Wiedza jako kluczowy zasób w nowej gospodarce (Knowledge as a key resource in the new economy), Studia i Praca (Studies and Work) no. 3 (2011).

Bem, M., Bogdanowicz, P., Piotrkowski, P.: Ustawa o partnerstwie publiczno-prywatnym. Komentarz (Act on public-private partnership. Comment), Warszawa: C.H. Beck, 2014.

Brzozowska, K.: Partnerstwo publiczno-prywatne. Przesłanki, możliwości, bariery (Public-private partnership. Premises, possibilities, barriers), Warszawa: CeDeWu, 2006.

Dyczkowski, A.: Nowy Leksykon PWN (The new PWN Lexicon), Warszawa: PWN, 1998.

Gonet, W.: Komentarz do ustawy o partnerstwie publiczno-prywatnym. Wzory umów i pism (Commentary to the Act on public-private partnership. Patterns of contracts and letters), Warszawa: LexisNexis, 2009.

Herbst, I., Jadach-Sepioło, A.: Raport ze studiów przypadku PPP sporządzony na potrzeby “Analizy potencjału podmiotów publicznych i przedsiębiorstw do realizacji projektów Partnerstwa Publiczno-Prywatnego" dla Polskiej Agencji Rozwoju Przedsiębiorczości (Report on PPP case studies prepared for the needs of "Analysis of the potential of public entities and enterprises for the implementation of Public-Private Partnership projects" for the Polish Agency for Enterprise Development), Warszawa 2012. 
Ocena Skutków Regulacji do Projektu rozporządzenia Ministra Zdrowia zmieniającego rozporządzenie w sprawie ogólnych warunków umów o udzielanie świadczeń opieki zdrowotnej (Evaluation of the Effects of Regulation to the draft Regulation of the Minister of Health amending the Regulation on general conditions of contracts for the provision of healthcare services no. 546.

Partnerstwo publiczno-prywatne. Poradnik (Public-private partnership. Guide), UZP, Warszawa 2010 .

Urbanowski, M. et al.: Raport z poprawności przeprowadzenia procedury wyboru partnera prywatnego dla przedsięwzięcia "Budowa Szpitala Powiatowego w Żywcu" pod kątem wykorzystania dobrych praktyk w projektach hybrydowych oraz projektowania rozwiązań na przyszłą perspektywę budżetową (Report on the correctness of the procedure for selecting a private partner for the project "Construction of a Poviat Hospital in Żywiec" in terms of using good practices in hybrid projects and designing solutions for the future budget perspective), Warszawa 2011.

PL: Act of 27 August 2009, on Public Finance, as amended.

PL: Act of 19 December 2008, on Public-Private Partnership, as amended.

PL: Act of 2 July 2004, on The Freedom of Economic Activity, as amended.

PL: Regulation of the Minister of Health of 2 February 2011 on the requirements that should be met in terms of professional and sanitary premises and facilities of the healthcare facility.

PL: Decree of the Minister of Health of 2 February 2011 on professional and sanitary requirements placed on premises and equipment in healthcare facilities.

PL: District Council in Żywiec: XXXV/317/09.

PL: District Council in Żywiec: XLIII/401/2010.

Draft no. 1180, justification to the draft Act on public-private partnership.

Draft no. 1322, justification to the Act amending the Act on health care services financed from public funds.

website of InterHealth Canada. www.interhealthcanada.com.

website of Starost's Office in Żywiec. www.starostwo.zywiec.pl. 


\title{
THE PHENOMENON OF BANKRUPTCY OF ENTERPRISES IN THE POLISH ECONOMY IN THE YEARS 2008-2015
}

\author{
ANDRZEJ TOKARSKI
}

\begin{abstract}
Bankruptcy and bankruptcy proceedings are an inherent phenomenon in the market economy, whose scope, size, dynamism, and intensity alter with the changes in the closer and further business environment, as well as in the global economy. The aim of this article is to analyze the phenomenon of the bankruptcy of enterprises in Poland in the years 2008-2015. In the paper, the formulated hypothesis suggests that in practice, contrary to the assumptions of insolvency proceedings, the bankruptcy and liquidation aspects dominated the remedial aspects, which were marginalized, and which resulted in the phenomenon of bankruptcy in the Polish economy in 2008-2015 being an unpredictable process and beyond the actual control of those interested the most: i.e. the insolvent entrepreneur and his creditors.

The methods used are descriptive analysis, literature analysis of the subject matter, analysis of legal regulations concerning the functioning of bankruptcy in Poland and analysis of statistics on the bankruptcy of enterprises in Poland in the years 2008-2015.
\end{abstract}

\section{Keywords}

Bankruptcy; the phenomenon of bankruptcy in the Polish economy models; bankruptcy in the Polish economy; dysfunctions of bankruptcy

\section{JEL Classification: C22, G32, G33}

1 Doctor of Economics, Associate Professor at the Faculty of Finance and Management, WSB University in Torun (Poland). The Author's research interests focus on issues related to the assessment of the financial and economic standing of the economic entity in danger of bankruptcy or when the continuity of the entity's economic activity is jeopardized in the free market economy. The author published or co-published over 100 publications in the scope of accountancy, financial analysis, and corporate finance. Contact email: andrzej. tokarski@wsb.torun.pl. 


\section{Introduction}

The bankruptcy of enterprises constitutes a permanent phenomenon of the economic system of every country with the free market economy. In the paper, the formulated hypothesis suggests that in practice, contrary to the assumptions of insolvency proceedings, the bankruptcy and liquidation aspects dominated the remedial aspects, which were marginalized, and which resulted in the phenomenon of bankruptcy in the Polish economy in 2008-2015 being an unpredictable process and beyond the actual control of those interested the most: i.e. the insolvent entrepreneur and his creditors.

The bankruptcy is a fairly complex process of economic, psychological and social nature in its foundation and it produces results affecting various components of the economic life. In particular the results manifest as the loss of the financial means invested in a given enterprise by the shareholders and creditors, the possibility of a significant deterioration of the financial standing or the loss of the financial liquidity of other companies associated with the bankrupt entity (so-called "bankruptcy domino effect"), or as the frequent increase in the unemployment rate in the region if the bankrupt entity was the major employer there. The bankruptcy phenomenon also serves a significant role in the economy as it eliminates business entities which do not operate effectively and they are not capable of functioning properly in the competitive free market. It is of vital importance that the process of elimination of such business entities was conducted in a manner that ensures the containment of the "bankruptcy domino effect" and in a way that allows the investors to recover the invested financial means and re-invest them into the more commercially viable way. Thus, in most of the countries in the world, the bankruptcy law is legislated which regulates the bankruptcy processes of the business entities.

The phenomenon of bankruptcy is an indispensable component of any market economy and it may concern any business entity. Despite the fact that the binding political, economic and legal systems of a given country influence the level and the structure of the bankruptcy, it still is a common and ever-present phenomenon in the state economies. The developing globalization processes, as well as the internationalization of the economic activities, resulted in the increase of the dependencies and affiliations among enterprises, which consequently and frequently causes a chain of bankruptcy in countries economically dependent.

The issues of the bankruptcy of enterprises, due to their significance to the flow of economic processes, constitute a subject of numerous analyses indicating various dimensions of such an immensely complex phenomenon. Deliberations of sensu stricto legal nature referring to logic, interpretation, and evaluation of the past and present legal acts in force which define the criteria and the procedures of the 
The Phenomenon of Bankruptcy of Enterprises in the Polish Economy...

bankruptcy of enterprises comprise a clearly outlined stream of such analyses. The other common stream of analyses combines both legal and economic threads and finally there are analyses of a distinct economic approach. The combination of legal and economic threads is fully understandable as the phenomenon of bankruptcy is defined both in terms of law and economy and the consequences, both in their broad and economic sense, of the bankruptcy of the business entities, basically, result from legal resolutions applied in a given legislation. Deliberations concerning the criteria of the bankruptcy of enterprises as well as the benefits and drawbacks arising from the various methods of conducting the bankruptcy proceedings play an important role in that trend.

An interdisciplinary trend of deliberations focusing on the theoretical and empirical dimensions of the bankruptcy of enterprises has appeared in Polish literature relatively recently (Mączyńska, 2006). It has been introduced and intensively developed by a research unit led by Prof. E. Mączynska from (SGH) Warsaw School of Economics (Babiarz-Mikulska, Czapracka, Morawska, 2012, as well as Mączyńska, 2015). The papers covering the scale, the causes and the socioeconomic consequences of the bankruptcy of enterprises, both in their historical and spatial dimensions, also fall into the category of economic analyses. As far as Poland is concerned, the former of the aforementioned dimensions seems to be particularly interesting. However, the spatial aspect of bankruptcy is also of particular interest as it allows to compare the selected issues and problems related to the bankruptcy of enterprises on a regional and international scale, which in fact may also be combined with the former of the aforementioned aspects of bankruptcy.

The purposefulness of constant monitoring of the phenomenon of bankruptcy in a given economy of both enterprises and, currently to even higher extent, of households (so-called consumer bankruptcy), results from the fact that the efficient course of these processes constitutes an indispensable component of the effectively operating market economy. Thus, that is not coincidental that the statement was coined that capitalism without bankruptcy and insolvency is like Christianity without the notion of hell. Nowadays, that statement may frequently be also applied to countries as well (Adamska, Mączyńska, 2013).

The main aim of the paper is to analyze the phenomenon of the bankruptcy of enterprises in Poland in the years 2008-2015. The following methods were used in the paper: the descriptive analysis, the analysis of the source literature, the analysis of the legal regulations concerning the functioning of the bankruptcy in Poland as well as the analysis of the statistics data on the bankruptcy of enterprises in Poland in the years 2008-2015. 


\section{Overview of Source Literature}

The issues of the bankruptcy of enterprises constitute a significant area of empirical studies, as numerous research papers prove. There have been many empirical and theoretical research studies conducted in the field of bankruptcy and insolvency of the business entities throughout decades as well as in different countries and different branches of economy, which leads to various conclusions. The research on bankruptcy was conducted with consideration of several areas and various approaches (Hart, 2000; Wang, 2006).

According to Wang (2006), the scientific research on the phenomenon of bankruptcy focus on four main areas:

- the changes concerning the corporate governance in the menace of bankruptcy (e.g. White, 1989; Gilson, 1990; Franks and Sussman, 1999, Eckbo et al.: 2003);

- the costs of bankruptcy (e.g. Altman, 1984, Bris, Welch, Zhu, 2006);

- the prices of shares and the long-term results (e.g. Gilson, Kose, Lang, 1990; Hotchkiss, 1995; Gilson, 1997; Altman, Eberhart, Aggarwal, 1999);

- the changes in the legal regulations concerning bankruptcy (e.g. Eberhart, More, Roenfeldt, 1990; Aghion, Routlgde, Gadenne, 2000).

Many of the research studies focused on the forecast of the bankruptcy of the enterprises (e.g. Beaver, 1966, 1968; Altman, 1968; Ohlson, 1980; Campbell, 1996; Beaver et al.: 2005; Bernhardsen, 2005).

Relatively recently there has been in the Polish literature an interdisciplinary trend of deliberations focused on the analysis of the theoretical and empirical characteristics of the bankruptcy of enterprises. It has been introduced and comprehensively developed by a team of researchers led by E. Mączyńska (Mączyńska, 2005; Mączyńska, Kuciński, 2008; Mączyńska, 2008; Mączyńska, 2009; Mączyńska, 2010; Mączyńska, 2013; Mączyńska, Adamska, 2013; Mączyńska, 2014; Mączyńska, 2015, Mączyńska, Morawska, 2015; Babiarz-Mikulska, Czapracka, Morawska, 2012; Morawska, 2011; Morawska, 2013) who is the head of the Institute of the Bankruptcy of Enterprises at Warsaw School of Economics (SGH). The papers focusing on the phenomenon, the causes and the socio-economic consequences of the bankruptcy of enterprises, both in their historical and spatial terms, also fall into the category of the economic mainstream of analyses. 
The Phenomenon of Bankruptcy of Enterprises in the Polish Economy...

\section{Basic Models of the Bankruptcy System in the Economy - Theoretical Approach}

Every country enjoys the freedom of choice concerning their model of the institution of bankruptcy. Three basic models of proceedings with the insolvent debtor were formed in the course of the development of the bankruptcy law (Druga szansa dla przedsiębiorców. Raport z badań, 2011: 52).

- Model A - the liquidation model which is historically the oldest and which states that the enterprise of the insolvent debtor should be liquidated and its assets should be divided among creditors. Such proceedings are called the general execution and they function mainly as means of sorting out the reciprocal relations among the creditors during the distribution of assets. Within that model, we should single out the bankruptcy of criminal nature (i.e. we should eliminate those entrepreneurs who are guilty of causing the insolvency purposefully and they did not file for bankruptcy on time) from the bankruptcy liquidation proceedings conducted properly by the entrepreneurs who in fact failed in the free market economy.

- Model B - the arrangement proceedings model was formed within the bankruptcy law when it turned out that liquidation of the debtor's assets is not always the most favorable to the creditors. The model involves the provision of proper conditions to form an arrangement between the debtor and the creditors in which the latter constrict their claims so that to enable the debtor to carry on with their enterprise. The law enforcement in the model ensures the effectiveness of the arrangement, which was reached by the majority of votes, also towards those creditors who voted against it. In that case, the economic burden of the entrepreneur's re-birth falls on the creditors. However, the foreseeable advantage of the satisfaction of claims within the arrangement over the conceivable liquidation of the assets constitutes the main criteria considered before the arrangement is allowed.

- Model C - the protective model where the law enforcement is used to temporarily suspend the creditors' rights to arrogate claims in order to enable the debtor to reorganize their enterprise. That mechanism is widely popular in the USA, where it is known as "Chapter 11" (the name derives from the $11^{\text {th }}$ Chapter of the United States Bankruptcy Code), but in Poland, some of its functions are with some difficulty implemented in the reorganization proceedings.

The aforementioned models are merely theoretical in their nature and they put in order the highly differentiated legislative approach in various countries towards the issue of insolvency for the purpose of analysis. In practice, there are procedures 
in every jurisdiction that might fall into all three models. The general approach of the law-makers towards the goals which the bankruptcy law shall fulfill makes the difference and it affects the predominance of one of the models over the others in a given legal system so that it is perceived as "more pro-arrangement" or "preliquidation" in its nature.

The way we treat the creditors and the debtors as well as how many rights they both enjoy is the main criterion which mostly differentiates the particular models of the bankruptcy proceedings. From that point of view, we may enumerate: (Morawska, 2013: 22)

- the pro-creditor or debt-friendly model;

- the pro-debtor or equity-friendly model;

- the hybrid model.

In the pro-debtor model, the reorganization takes precedence over the liquidation more often. In those systems, the creditors are allegedly treated worse than the debtor and the people who manage the insolvent business unit are left in charge after the bankruptcy have been declared more often than in the pro-creditor systems. That fact results from the assumption that the managers already know the troubled enterprise inside out and they shall be left in charge. The social issues, i.e. keeping the jobs, also play a significant role in that approach (Prusak, 2011: 120).

In the model favorable to creditors the best possible protection for the creditors is the priority. The managers in charge of the insolvent enterprise are given a sack due to the fact that they are blamed for the financial troubles and the liquidation of the enterprise since the reorganization does not bring any tangible results and the troubled enterprise having once undergone the restructuration often re-enters the path of reorganization or liquidation, which in turns generates additional high costs. The other differences comprise settling the possible decision making on accepting or rejecting the reorganization plan, the creditors' votes over the plan as well as the so-called "automatic stay", which involves for example lack of penalty interest or the suspension of the execution of the court judgment etc. as a result of bankruptcy being declared. In that system, the mutual agreements are commonly ignored as they favor one of the creditors at the expense of others. On the other hand, the system supports the creation of the so-called groups of privileged claims, which in fact infringes the division of the claims that had been established before the bankruptcy was declared.

Nowadays, the hybrid model is the dominant one in the world, however, there are also countries which systems resemble more one or the other of the abovementioned models. For instance, according to R.R. Bliss countries such as Great Britain, Germany, Italy, China, Japan as well as countries within the British 
The Phenomenon of Bankruptcy of Enterprises in the Polish Economy...

Commonwealth apply the pro-creditor models, whereas countries such as Spain, countries of Latin America, the Middle East or African countries apply the prodebtor models. Countries such as the USA, Canada, and France apply the hybrid models (Bliss, 2003: 4-5). However, G. Recasens perceives that division slightly differently as he claims that countries such as Canada, Great Britain, and Sweden apply the pro-creditor model whereas countries such as the USA and France apply the pro-debtor model. The differences might result from the alterations that occur in the legal systems of the particular countries. For instance, Canada introduced the more pro-debtor model in the recent years. As exemplified by the USA and Great Britain it is noticeable that the thesis that the source of the law influences the treatment of the debtor and the creditors is fallible. Although the bankruptcy law in the USA is derived from the bankruptcy law of Great Britain, nowadays different features characterize both systems, i.e. the American model is more pro-debtor and the British one favors the creditors more.

\section{Basic Models of the Bankruptcy System in the Polish Economy in the Years 2003-2015}

The Polish model is significantly restricted in regard to both the criteria of the commencement of the proceedings as well as the duration of the proceedings. The legislator's cautious approach who focuses on the protection of the interests of the creditors rather than safeguarding the improvement of the economic effectiveness of the debtor clearly defines the Polish model. Nonetheless, the applied mechanisms show the potential to be modified in such a way that allows for a wider application of the mechanism in the business practice.

The current Polish model of the Bankruptcy Law and Reorganisation Law combines the solutions typical for the Model A (i.e. liquidation one) with the solutions used in the Model B (i.e. the arrangement one). The recovery proceedings might indicate the use of the Model $\mathrm{C}$ (the protective one) albeit they contain merely the rudimentary regulations of that model and thus should be treated as a subtype of the Model B the arrangement one (Druga szansa dla przedsiębiorców. Raport z badań, 2011: 55).

It is worth mentioning that the Polish legislator gave the pursuance to satisfy the claims of the creditors the priority in the bankruptcy regulations. That rule, which is often referred to as the optimization rule, involves both the bankruptcy and the reorganisation proceedings (Morawska, Czarpacka, 2009: 135) In compliance with the grounds of the Act as of 28 February 2003 - The Bankruptcy and Reorganisation Law states that "it is in the public interest as not to allow to arise (...) the chain of bankruptcy. Therefore, any insolvency of any entrepreneur shall as soon as possible 
lead to the commencement of the bankruptcy proceedings which would enable the fastest possible satisfaction of the creditors from the assets of the insolvent debtor" (Prawo sprzyjające realizacji Polityki II szansy w Polsce. Rekomendacje zmian, 2011:10-11).

The liquidation bankruptcy is declared by the court when there are no grounds to declare the arrangement bankruptcy. Then, the trustee in bankruptcy becomes in charge of the assets of the bankrupt business and he is responsible for the sale of these assets in order to satisfy the creditors' claims from the money he gained (Gurgul, 2010: 65-6).

The arrangement bankruptcy is declared by the court when there is a "chance" to save the enterprise or, to put it precisely, when there is greater likelihood that in the course of the arrangement the creditors will be satisfied to a higher extent than they would be satisfied in the course of the bankruptcy proceedings involving the liquidation of the assets of the debtor. The name is derived from the arrangement that is made or the particular legal transaction which concludes the proceedings. Under the arrangement, the creditors restrict their claims but in exchange, they expect that their claims will be satisfied i.e. the satisfaction of their claims will not be put in question. There are two types of the arrangement bankruptcy (Świboda, 2003: 4142).

- the one combined with the divestment of the management of the whole or part of the assets so that the insolvency administrator is in charge of the enterprise;

- the one not combined with the divestment of the management of the whole or part of the assets so that the judicial supervisor is in charge of the enterprises.

The declaration of the bankruptcy with the possibility to enter into the arrangement requires the following premises to be fulfilled cumulatively: the positive one, when it is assumed that the likelihood of satisfying the creditors in that kind of the proceedings is higher rather than in the proceedings involving the liquidation of the assets if the bankrupt enterprise, and the negative one, which concerns the lack of the unreliable behaviour on the part of the debtor both before filling for the bankruptcy and during the proceedings to secure the claims as well as during the preliminary creditors' assembly. The general advantage of the arrangement model is that it is possible to maintain some of the debtor's assets (enterprise) while satisfying the creditors' claims. Thus, that model is the most favorable to the debtor.

The separate recovery proceeding is another legal solution which in theory enables to avert the danger of insolvency and bankruptcy (Nibieszczańska, 2013: 332). That kind of proceeding is a non-judicial procedure in its nature. Its main goal is to restructure the bankrupt-to-be and to restore the enterprise's capabilities to operate on the market once again. 
That goal should be implemented by enabling the entrepreneur to present his recovery plan and through concluding the agreement between him and the creditors on restructuring his obligations. Only the entrepreneur who pays his liabilities (with the exception of the situation when does not pay them but the amount past due does not exceed $10 \%$ of the balance sheet value of the enterprise) may utilize the recovery proceedings and the cancelation of debt once he foresees the forthcoming insolvency of his enterprise.

So far, the current practice of the application of the regulations of the recovery proceedings, in particular those involving the admissibility of the commencement of the recovery proceedings, shows that the regulation in its current shape is almost "a defunct law" which does not have a wider application (Morawska, Czarpacka, 2013: 228). The binding regulations hinder the implementation of the recovery proceedings in case of an entrepreneur who suffers from financial problems, despite the fact that his general financial standing indicates the high likelihood of preventing his enterprise from declaring the bankruptcy. The implementation of the recovery plan is albeit impossible in case of an insolvent entrepreneur (within the meaning of the law - The Bankruptcy and Reorganisation Law) who "overlooked" the right moment to undertake the restructuring steps and the first symptoms of his insolvency have already appeared. Thus, the recovery proceedings are not much an attractive and effective way to solve problems of the insolvent entrepreneur.

\section{Number (Scale) of Bankruptcies of Enterprises in Poland in Years 200-2015}

The scale of the bankruptcy phenomena and the fact that the efficiency of the bankruptcy proceedings is taken into consideration while assessing the effectiveness of the national economies prove that the significance of the bankruptcy in the modern economy is on the increase. Even though bankruptcy is not a mass phenomenon, it occurs frequently enough so that it cannot be deemed as irrelevant (Mazurek, 2013: 60). The statistics concerning the bankruptcy gives evidence to the significant scale of that phenomenon. In Polish economic literature on the subject, the scale of the bankruptcy is most commonly illustrated with the number of the declared bankruptcies announced by the Polish Commercial Court of Law in a given year (Mazurek, 2013: 204). In Poland, the intricacies of the statistics are correlated with the gaps in the statistical system. The Central Statistical Office does not publish any comprehensive bankruptcy statistics. In that case, the Ministry of Justice and courts may constitute a good but scattered and hard to reach the source of information (Mączyńska, Morawska, 2015: 9). 
Andrzej Tokarski

\begin{tabular}{|c|c|c|c|}
\hline 占 & $\stackrel{9}{6}$ & 후 & 员 \\
\hline స్ & হ & $\stackrel{N}{\cong}$ & 今ે \\
\hline$\stackrel{N}{N}^{\infty}$ & $\frac{\infty}{\Gamma}$ & $\stackrel{\iota}{\circ}$ & $\underset{\infty}{\infty}$ \\
\hline స̃ & $\underset{\Sigma}{\Sigma}$ & $\stackrel{ॄ}{\circ}$ & 闹 \\
\hline స్亏 & ণ్రి & $\stackrel{\text { ஜㅇ }}{\circ}$ & $\stackrel{乛 ָ}{N}$ \\
\hline ํํํ & $\stackrel{\infty}{0}$ & $\hat{F}$ & 員 \\
\hline ঃั่ & $\underset{i}{\tilde{N}}$ & $\stackrel{\circ}{\rightleftharpoons}$ & Бั \\
\hline :̊ & 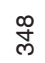 & ஜ & $\bar{q}$ \\
\hline ڤ్ & 令 & R & F \\
\hline : & $\stackrel{\infty}{\stackrel{\infty}{\sigma}}$ & 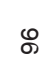 & 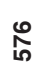 \\
\hline : ڤి & $\widehat{\ddot{0}}$ & 욤 & סू \\
\hline ఫั & 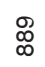 & $\stackrel{N}{N}$ & $\stackrel{\circ}{\risingdotseq}$ \\
\hline ֻั & $\stackrel{\circ}{\stackrel{\circ}{R}}$ & $\bar{\epsilon}$ & 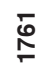 \\
\hline ণั & $\underset{f}{\stackrel{g}{f}}$ & $\frac{d}{\partial}$ & 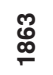 \\
\hline ఫ్ & $\stackrel{\infty}{\stackrel{\infty}{\Gamma}}$ & 寄 & 芯 \\
\hline ঃั่ & ঃ & ్ָలి & $\stackrel{\mathscr{D}}{\underset{N}{\sim}}$ \\
\hline 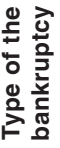 & 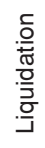 & 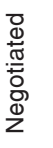 & 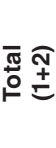 \\
\hline$\stackrel{\circ}{\check{g}}$ & $\dot{r}$ & נi & $\dot{m}$ \\
\hline
\end{tabular}

\begin{tabular}{|c|c|c|c|}
\hline$\stackrel{\circ}{\stackrel{\circ}{n}}$ & $\stackrel{\infty}{\infty}$ & $\dot{\nu}$ & 우 \\
\hline$\stackrel{\Delta}{\stackrel{\Delta}{*}}$ & 冓 & $\underline{m}$ & $\stackrel{0}{\circ}$ \\
\hline$\stackrel{m}{\stackrel{m}{n}}$ & $\bar{\infty}$ & 욷 & 음 \\
\hline స̃ & $\bar{\infty}$ & 우 & 으 \\
\hline$\overline{\tilde{N}}$ & 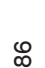 & $\stackrel{\nabla}{\square}$ & $\stackrel{\circ}{\circ}$ \\
\hline ํํํ & $\cong$ & $\stackrel{\infty}{\simeq}$ & 우 \\
\hline ষ্े & $\mathbb{\infty}_{\infty}$ & 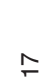 & 으 \\
\hline 怘 & $\stackrel{\infty}{\infty}$ & $\stackrel{\circ}{\llcorner}$ & 으 \\
\hline 今ે & 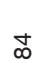 & $\underline{\varphi}$ & 으 \\
\hline : & $\infty_{\infty}^{\infty}$ & 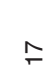 & 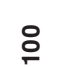 \\
\hline : ڤ్م & $\infty$ & จ & $\stackrel{-}{\circ}$ \\
\hline ఫ్ & g & $\mp$ & 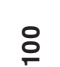 \\
\hline : & $\stackrel{\bullet}{\varrho}$ & $\stackrel{m}{m}$ & $\stackrel{\circ}{\circ}$ \\
\hline ণั่ & $\stackrel{\infty}{\curvearrowright}$ & $\cong$ & $\stackrel{\circ}{\circ}$ \\
\hline ర్ & R & ᄋ & $\stackrel{\circ}{\circ}$ \\
\hline ঃั̀ & $\frac{5}{4}$ & $\stackrel{\leftrightarrow}{\sim}$ & $\stackrel{\circ}{\circ}$ \\
\hline 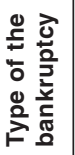 & 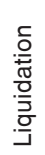 & 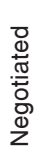 & $\begin{array}{l}\bar{\Xi} \\
\stackrel{0}{0} \underset{+}{*}\end{array}$ \\
\hline$\dot{\circ}$ & $\dot{r}$ & i & $\dot{m}$ \\
\hline
\end{tabular}


The Phenomenon of Bankruptcy of Enterprises in the Polish Economy...

In the years 2000-2015 there were 15.358 cases of the bankruptcy of enterprises in total. In the period in question, we may differentiate three particular sub-periods which varied in terms of their direction and the dynamics of the changes in the bankruptcy of enterprise phenomenon. The first sub-period covers the years 20002002 when the bankruptcy phenomenon was on the particular increase. In the first three years of the analyzed period, there were 4826 bankruptcies declared in total, which accounts for $31.42 \%$ of the bankruptcies for the whole $2000-2013$ period. From 2003 until 2008 the number of the bankruptcies was on the steady decrease, reaching the levels of 1761 (in 2003) and 411 (in 2008), and the pace of the decrease during that period was much faster than in the one associated with the dynamic increase of the phenomenon. The third sub-period saw the reversion to the increase of the bankruptcy number. After the year 2008, there were 5391 bankruptcies in the domestic economy declared (years 2009-2015). However, despite the international crisis, the dynamics of the phenomenon was not so strong in relation to the years 2000-2002. Nonetheless, it marked out a distinct and consistent upward trend.

In order to present the full picture of the shaping of the issue of the bankruptcy of enterprises in Poland J. Wojnar conducted an analysis of the intensity of the phenomenon in relation to the total number of businesses operating in the economy in the years 2004-2013 (Wojnar, 2014: 73). The procedure of the calculation of the indicator of the bankruptcy intensity takes into consideration all businesses that have the capability to declare bankruptcy. Natural persons conducting business activities were also taken into account, which may cause doubts to some extent. However, such a situation took place due to the fact that natural persons conducting business activities are in majority of all ownership structure of the enterprises and as a result, that group of businesses is of crucial significance for the value of the indicator. On the other hand, the bankruptcy of these entities occurs occasionally in the jurisprudence due to the fact that they have relatively small assets at their disposal and thus being unable to satisfy the presumptive liabilities towards creditors from the bankruptcy estate. So, it is justified to make calculations of the indicator with particular consideration given to the above-mentioned group of businesses. What is more, it is crucial from the point of view of the generally applicable law in Poland which clearly stipulates that such entities are fully capable of declaring bankruptcy. However, it must not be forgotten that in case of disregarding of the natural persons conducting business activities while calculating the indicator of the bankruptcy intensity, it would have caused a significant increase in the indicator's value. In view of the availability of the empirical data, the indicator of the bankruptcy intensity has only been analyzed since 2004 . 
Andrzej Tokarski

Table 3 Intensity of Bankruptcy in Poland per 10000 Registered Businesses in years 2004-2013

\begin{tabular}{|l|c|c|c|c|c|c|c|c|c|c|}
\hline Year & $\mathbf{2 0 0 4}$ & $\mathbf{2 0 0 5}$ & $\mathbf{2 0 0 6}$ & $\mathbf{2 0 0 7}$ & $\mathbf{2 0 0 8}$ & $\mathbf{2 0 0 9}$ & $\mathbf{2 0 1 0}$ & $\mathbf{2 0 1 1}$ & $\mathbf{2 0 1 2}$ & $\mathbf{2 0 1 3}$ \\
\hline $\begin{array}{l}\text { Intensity } \\
\text { indicator }\end{array}$ & 3.12 & 2.19 & 1.58 & 1.21 & 1.09 & 1.85 & 1.68 & 1.87 & 2.21 & 2.17 \\
\hline
\end{tabular}

Source: Wojnar, 2014.

When we analyze the values of the indicators in the table, one may come to the conclusion that in 2004 the intensity of the bankruptcy was at its peak i.e. there were 3 cases of bankruptcy proceedings per 10,000 running businesses. It is worth highlighting that the indicator in question underwent positive changes until the year 2008 when the number of the bankruptcy proceedings was at its lowest point. Over the next few years, the values of the indicator were consistently on the increase while in 2013 we noted a slight dip. That confirms the previously suggested downward trend as well as a favorable phenomenon in the analysis of the bankruptcy of Polish enterprises.

It is worth mentioning that within the conducted bankruptcy proceedings liquidation predominates and it involves the sale of the assets of the insolvent entrepreneur and satisfying the claims of the creditors with the money gained on the sale of the bankruptcy estate. The liquidation type of bankruptcy fluctuated between $70-87 \%$ in relation to the total structure of the bankruptcy proceedings for the period in question.

The negotiated type of bankruptcy, which grants the enterprise an opportunity for restructuring, accounted for $11-30 \%$ of all the bankruptcy proceedings. This unfavorable proportion might be changed by the new Act on Restructuring Law in the year 2015 which becomes effective as of 1 January 2016 and which regulates both the way the insolvent debtor, or the one in jeopardy of insolvency, enters a settlement with the creditors and the effects of such a settlement. The Act also regulates the recovery procedures.

Pursuant to Art. 2 of the aforementioned Act, the restructuring can be conducted in the following four proceedings i.e. the proceedings on the approval of the arrangement, the accelerated arrangement proceedings, arrangement proceedings and recovery proceedings. Thus, the main goal of the Act is to restrict the number of declared bankruptcies to the benefit of the increase of the recovery and reformatory procedures in the enterprises (Act on Restructuring Law, 2016: 104). 
The Phenomenon of Bankruptcy of Enterprises in the Polish Economy...

\section{Dysfunctions of the Bankruptcy System in Poland in the Years 2000-2015}

The model of the bankruptcy proceedings which functions in Poland does not fulfill its major goal i.e. the elimination of the unprofitable entrepreneurs. Thus, the model does not perform its preventive function - it does not preclude further insolvencies, which happen in the aftermath of the unpaid liabilities by the debtor (BabiarzMikulska, Czarpacka, Morawska, 2012: 11). The degree to which the creditors are satisfied in the course of the conducted bankruptcy proceeding, including the liquidation of the bankrupt's assets, is minimal. Consequently, the functioning model does not perform its debt recovery function. The cost of the bankruptcy proceedings exceed $40 \%$ of the bankruptcy estate and the average time of the proceedings, counted from the moment the petition for bankruptcy is filed to the moment the bankruptcy is declared, is two years (Masiukiewicz, Morawska, 2012: 45). Therefore, from the point of view of the creditors the bankruptcy proceedings prove ineffective. They freeze the funds and the capital for the period of two years and they do not ensure their quick relocation Furthermore, they do not perform their debt removal function as well.

The restrictive and pro-creditor model of the bankruptcy proceedings does not develop among the entrepreneurs patterns of behaviour, which might be defined as the reliable entrepreneur attitude (the preventive function), because it does not take into consideration the fact that its recipients are economically rational (lat. homo economicus) units which calculate both the risk and time of the proceedings as well as their costs (Morawska, 2013: 58). The repressive system of the bankruptcy law that was in force in the years 2003-2015 along with the stigma of failure results in the fact that entrepreneurs conceal their financial problems so long as it is impossible to solve them. Many entrepreneurs are deficient in the necessary means and experience for the effective solution of the crisis situation. Both proper framework conditions and the flexible regulations as well as well-developed institutional structures are crucial for the utilization of the full potential of the entrepreneurs and making the reorganization of their debt easier. Apart from the normative system the efficient and effective judicature also constitutes another condition which makes the prosecution of any pathology more efficient.

On the basis of the conducted research, E. Mączyńska shows that the Bankruptcy Law and the Reorganisation Law in the Polish economy in the years 2003-2015 (Mączyńska, 2011: 335):

- did not guarantee any transparency or efficiency of the bankruptcy proceedings; 
- did not perform their purging functions i.e. removing the insolvent entities from the market;

- did not prevent to the proper extent the so-called "staged" bankruptcies i.e. the ones which were oriented on bringing benefits to the narrow groups of stakeholders while purposefully infringing the interests of other creditors,

- did not conduce to the proper identification of the "staged" bankruptcies;

- they brought about the dominance of the bankruptcy aspects over the recovery aspects which in practice were marginalized against the principles of the bankruptcy proceedings (Mączyńska, 2009: 276).

\section{Conclusions}

Bankruptcy is one of the most significant phenomena of the free market economy. If it is properly constructed in terms of law and properly implemented by the appropriate institutions that guarantee both the effective protection of the creditors and an efficient allocation of the capital goods. Polish legislators determined that the settlement of any disputable conflict of interests between the debtor and his creditors concerning insolvency issues shall be reached during single judicial proceedings (Tokarski, 2015: 246).

The bankruptcy of the enterprises constitutes an indispensable mechanism of the free market economy in the selection process of the ineffective business entities. In that sense the bankruptcy of enterprises may be deemed positive and necessary, however, it does not mean that bankruptcy does not entail numerous drawbacks as well. Therefore, it is not the phenomenon of bankruptcy that constitutes the core of the problem but the methods of the widely understood institutional background upon which depends the character, the effectiveness and the extent of both positive and negative consequences for any party involved (i.e. stakeholders, participants) in the bankruptcy processes (Tokarski, Matuszak, 2016: 204). Due to the fact that the global economy has been undergoing turbulent changes recently, which has also influenced both the national and regional economies, the significance of the issues of bankruptcy and insolvency shall not be underestimated (Mączyńska, Morawska, 2015: 25-26).

In the free market economy bankruptcy is not a phenomenon of only pathological nature. It serves both as a safeguard of the particular interests of the entities involved in the economic relations and as a provision of security of the economic trade by means of the elimination of the weak and inefficient business entities from the market (Hrycaj, 2006: 1). 
The Phenomenon of Bankruptcy of Enterprises in the Polish Economy...

The Polish law on the bankruptcy of enterprises was highly imperfect in the years 2000-2015. As a result, the liquidation of the enterprises according to the letter of law was basically "the euthanasia of the curable". In many Western European countries, but not only there, the legal regulations were distinctly aimed at the saving of the enterprises which, for various reasons that were frequently beyond their control, fell into financial difficulties and faced the menace of liquidation.

The bankruptcy in the Polish economy in the years 2008-2015 was often an unpredictable process which was beyond any factual control of those closely involved i.e. the insolvent entrepreneur and his creditors. Creditors who also enjoy the right to file for the bankruptcy frequently do not take action for similar reasons. They may become discouraged by the binding regulations of the Polish Bankruptcy Law such as the little control they may exert as well as few opportunities of influence on the whole process (for instance lack of the opportunity to really influence both the choice, the remuneration and the actions of the trustee in bankruptcy).

\section{References}

Altman, E.I.: Financial Ratios, Discriminant Analysis, and Prediction of Corporate Bankruptcy, Journal of Finance no. 3 (1968).

Altman, E.I.: A further empirical investigation of the bankruptcy cost question, Journal of Finance no. 39 (1984).

Altman, E.I. et al.: The Equity Performance of Firms Emerging from Bankruptcy, Journal of Finance no. 54 (1999).

Aghion, P. et al.: The Economics of Bankruptcy Reform, Journal of Law, Economics and Organization no. 8 (1992).

Aghion, P. et al.: Insolvency Reform in the UK: A Revised Proposal, Insolvency Law \& Practice no. 11 (1995).

Babiarz-Mikulska, K. et al.: Ocena efektywności procedur upadłościowych wobec przedsiębiorców. Aspekty prawne, ekonomiczne i organizacyjne (The assessment of the effectiveness of the bankruptcy procedures towards entrepreneurs. Its legal, economic and organisational aspects), Warszawa: Difin, 2012.

Bernhardsen, E.: A Model of Bankruptcy Prediction, Working Paper, Oslo, Norges Bank (2005).

Beaver, W.H.: Financial Ratios as Predictors of Failures in Empirical Research in Accounting, Selected Studies, supplement to the Journal of Accounting Research, Autumn (1966).

Beaver, W.H.: Market prices, financial ratios, and the prediction of failure, Journal of Accounting Research no. 6 (1968).

Beaver, W.H. et al.: Have Financial Statements Become Less Informative? Evidence from the Ability of Financial Ratios to Predict Bankruptcy, Review of Accounting Studies no. 10 (2005). 
Bliss, R.R.: Bankruptcy Law and Large Complex Financial Organization: A Primer Economic Perspectives, Federal Reserve Bank of Chicago no. 10 (2003).

Bris, A. et al.: The Cost of Bankruptcy: Chapter 7 Liquidation Versus Chapter 11Renegotiation, Journal of Finance no. 56 (2006).

Campbell, S.V.: Predicting the bankruptcy decision. Accounting Horizons no. 10 (1996).

Dec, P.: Demografia przedsiębiorstw - analiza ilościowa upadłości w Polsce i na świecie (Demography of enterprises - the quantitative analysis of bankruptcies in Poland and across the world), Ekonomika i Organizacja Przedsiębiorstw (Economics and Organisation of Enterprises) no. 1 (2016).

Druga szansa dla przedsiębiorców. Raport z badań (The Second Chance for the Entrepreneurs. The Research Report), Warszawa: PARP, 2011.

Eberhart, A.C. et al.: Security pricing and deviations from absolute priority rule in bankruptcy proceedings, Journal of Finance no. 45 (1990)

Eckbo, B.E. et al.: Control benefits and CEO discipline in automatic bankruptcy auctions, Journal of Financial Economics no. 69 (2003).

Franks, J. et al.: Financial Innovations and Corporate Insolvency, Mimeo: London Business School, 1999.

Gilson, S.C.: Bankruptcy, Boards, Banks, and Blockholders: Evidence on Changes in Corporate Ownership and Control When Firms Default, Journal of Financial Economics no. 26 (1990).

Gilson, S.C.: Transactions Costs and Capital Structure Choice: Evidence from Financially Distressed Firms, Journal of Finance no. 52 (1997).

Gilson, S.C. et al.: Troubled Debt Restructurings: An Empirical Analysis of Private Reorganization of Firms in Default, Journal of Financial Economics no. 26 (1990).

Gurgul, S.: Prawo upadłościowe i naprawcze - komentarz (The bankruptcy and Recovery Laws commentaries), Wardzawa: C.H. Beck, 2010.

Hart, O.: Different Approaches to Bankruptcy, Harvard Institute of Economic Research, Discussion Paper no. 1903 (2000).

Hrycaj, A.: Syndyk masy upadłości (The bankruptcy trustee), Poznań: Wyższa Szkoła Komunikacji i Zarządzania, 2006.

Masiukiewicz, P. et al.: Koncepcja poprawy efektywności upadłości (The concept of the improvement of the bankruptcy effectiveness), Kwartalnik Nauk o Przedsiębiorstwie (The Enterprise Sciences Quarterly) no. 2 (2012).

Mazurek, S.: Niewypłacalność i jej ustalanie (Insolvency and its assessment), Szczecin, 2013.

Mazurek, S.: Statystyka upadłości (podmiotów biznesowych) (The statistics of bankruptcy of the business entities), Zeszyty Naukowe Uniwersytetu Szczecińskiego, Finanse, Rynki Finansowe, Ubezpieczenia (The Scientific Journals of the University of Szczecin - Finances, Markets and Insurance) no. 5 (2013). 
Mączyńska, E.: Bankructwa przedsiębiorstw a nadzór właścicielski (The bankruptcy of enterprises and the owners' supervsion), in: Mączyńska, E.: Cykle życia i bankructwa przedsiębiorstw (The cycle of life and bankruptcy of the enterprises), Warszawa: SGH, 2011.

Mączyńska, E.: Bankructwa przedsiębiorstw jako niedostosowanie do przyszłości. Analiza w kontekście funkcjonowania sądów gospodarczych (The bankruptcy of the enterprises as the symptom of incompatibility with the future. The analysis in respect to the functioning of the Commercial Courts), in: Finanse 2009 - teoria i praktyka (Finances of 2009 - theory and practice), Szczecin: Uniwersytet Szczeciński, 2009.

Mączyńska, E.: Bankructwa przedsiębiorstw wybrane aspekty ekonomiczne i prawne (The bankruptcy of enterprises and its selected economic and legal aspects), Warszawa: SGH, 2014.

Mączyńska, E. et al.: Bankructwa przedsiębiorstw. Wybrane aspekty instytucjonalne (The bankruptcy of enterprises and its institutional aspects), Warszawa: SGH, 2008.

Mączyńska, E.: Bankructwa, upadłości i procesy naprawcze przedsiębiorstw. Wybrane aspekty regulacyjne (The bankruptcy, insolvency and recovery of enterprises. Selected regulatory aspects), Warszawa: SGH, 2015.

Mączyńska, E. et al.: Cykle życia i bankructwa przedsiębiorstw (The cycle of life and bankruptcy of enterprises), Warszawa: SGH, 2010.

Mączyńska, E. et al.: Efektywność procedur upadłościowych. Bankructwa przedsiębiorstw katharsis i nowa szansa (The Effectiveness of the bankruptcy proceedings. The bankruptcy of the enterprises, catharsis and the new chance), Warszawa: SGH, 2015.

Mączyńska, E. et al.: Ekonomiczne aspekty upadłości przedsiębiorstw w Polsce (The economic aspects of the bankruptcy of the enterprises in Poland), Warszawa: SGH, 2005.

Mączyńska, E. et al.: Meandry upadłości przedsiębiorstw (The intricacies of the bankruptcy of enterprises), Warszawa: SGH, 2009.

Mączyńska, E. et al.: Procesy upadłościowe i naprawcze w Polsce na tle doświadczeń Unii Europejskiej (The bankruptcy and recovery processes in Poland in comparison to the European Union), Warszawa: SGH, 2013.

Mączyńska, E. et al.: Upadłości, bankructwa i naprawa przedsiębiorstw. Wybrane zagadnienia (The insolvency, bankruptcy and recovery of enterprises. Selected issues), Warszawa: SGH, 2013.

Mączyńska, E.: Upadłość przedsiębiorstw (The bankruptcy of the enterprises), Kwartalni Nauk o Przedsiębiorstwie (The Science of Enterprises Quarterly) no. 1 (2006).

Mączyńska, E. et al.: Zagrożenie upadłością (The Menace of Bankruptcy), Warszawa: SGH, 2008.

Morawska, S.: Efektywność oraz skuteczność postępowań upadłościowych na tle praktyki sądowej perspektywa wierzycieli (The effectiveness and efficiency of the bankruptcy proceedings with regard to the court practices - the creditors viewpoint), Biuletyn PTE (PTE Bulletin) no. 1 (2013).

Morawska, S.: Instytucja upadłości a odpowiedzialność menedżerów - badanie polskiej praktyki sądowej na tle rozwiązań w krajach Unii Europejskiej (The bankruptcy and the managerial accountability - the Polish courts practices in comparison to the EU solutions), in: Mączyńska, E.: Procesy upadłościowe i naprawcze w Polsce na tle doświadczeń Unii Europejskiej (The 
bankruptcy and recovery proceedings in Poland in comparison to the European Union), Warszawa: SGH, 2013.

Morawska, S. et al.: Praktyka stosowania prawa upadłościowego a cele regulacji (The application of the bankruptcy law and the aims of its regulation), in: Mączyńska, E.: Meandry upadłości przedsiębiorstw (The intricacies of the bankruptcy of enterprises), Warszawa: SGH, 2009.

Morawska, S.: Przedsiębiorca w obliczu upadłości (An entrepreneur in the face of bankruptcy), Warszawa: SGH, 2013.

Nibieszczańska, W.: Postępowanie naprawcze oraz upadłościowe w ograniczaniu negatywnych skutków kryzysu przedsiębiorstwa (The recovery and bankruptcy proceedings as means of appeasing the negative consequences of the crisis), in: Adamska, A., Mączyńska, E. (eds.): Upadłości, bankructwa i naprawa przedsiębiorstw (Insolvency, bankruptcy and recovery of the enterprises), Warszawa: SGH, 2013.

Ohlson, J.A.: Financial ratios and the probabilistic prediction of bankruptcy, Journal of Accounting Research no. 1 (1980).

Prawo sprzyjające realizacji Polityki II szansy w Polsce. Rekomendacje zmian (The law favorable towards the implementation of the Second Chance Policy in Poland. The recommendation of changes), Warszawa: PARP, 2011.

Prusak, B.: Ekonomiczna analiza upadłości przedsiębiorstw. Ujęcie międzynarodowe (The economic analysis of the bankruptcy of enterprises. The international approach), Warszawa: CeDeWu, 2011.

Routledge, J. et al.: Financial Distress, Reorganization and Corporate Performance, Journal of Accounting and Finance no. 40 (2000).

Święboda, Z.: Prawo upadłościowe i naprawcze. Komentarz (The bankruptcy and recovery laws. Commentaries), Warszawa: Lexis Nexis, 2003.

Tokarski, A.: Kierunki ewolucji systemu upadłościowego w Polsce (The directions of the development of the bankruptcy system in Poland), Przedsiębiorczość a edukacja (The entrepreneurship and education) no. 11 (2015).

Tokarski, A. et al.: Upadłość jako instytucja gospodarki rynkowej (The bankruptcy as a free market economy tool), Przedsiębiorczość a edukacja (The entrepreneurship and education) no. 12 (2016).

Wang, C.: Law and Bankruptcy: An International Comparison of Liquidation and Reorganization, Asian Financial Association / Financial Management Association, Annual Conference Proceedings, New Zealand: Auckland, 2006.

White, M.: The Corporate Bankruptcy Decision, Journal of Economic Perspectives, no. 2 (1989).

Wojnar, J.: Zjawisko upadłości przedsiębiorstw w Polsce - tempo zmian i tendencje (The phenomenon of bankruptcy of enterprises in Poland - the pace of chan ges and tendencies), Przedsiębiorstwo $i$ Finanse (The enterprises and Finances) no. 4 (2014).

PL: Act of 23 February 2003 on, the Bankruptcy and Restructuring Laws.

PL: Act of 15 May 2015, on the Restructuring Law. 
CHAPTER 3

\section{PROTECTION OF PUBLIC INTEREST IN TAX LAW}

SECTION 3.1

PROTECTION OF PUBLIC INTEREST IN GENERAL ISSUES

OF TAX SYSTEM AND FISCAL ADMINISTRATION 



\title{
WEIGHING THE INTEREST OF THE OBLIGED AND THE PUBLIC INTEREST IN THE POLISH TAX LAW
}

\author{
LEONARD ETEL $L^{1}$, MARIUSZ POPŁAWSKI
}

\begin{abstract}
The contribution deals with the introduction into Polish law the principle of weighing the interest of the obligee and the public interest, which will probably be adopted in the new Tax Ordinance Act in Poland in 2019. The considerations in this paper result in a few observations. First, the rule under discussion will be applied both in reference to the provisions of substantive actions taken by tax authorities on the basis of the regulations included in the Tax Ordinance, but also on the basis of other provisions of tax law applied by these tax authorities. Second, the above-mentioned rule will be applicable at the stage of tax law application. It should also be applied in the context of creating tax law. Third, from the essence of this rule results a directive prescribing the interpretation of doubts including the interest of both parties of the tax legal relation. The interpretation of the provisions of tax law through the prism of the rule of weighing interests should be treated as an element of the process of the systemic interpretation. Fourth, the essence of this rule indicates that it should be also taken into consideration in the context of applying the provisions of tax law.
\end{abstract}

\section{Keywords}

Tax law principles; principle of weighing the interests in tax law; interest of the obliged in tax law; interest of taxpayer

\section{JEL Classification: D63, K34, K40}

1 Professor for Tax Law, Department of Tax Law, Faculty of Law, University of Bialystok, Poland. The Author specializes in tax law. He is the author of over 300 books and articles. He is a Chairman of the General Taxation Law Codification Committee in Poland and vice-chairman of the Information and Organization Centre for the Research on the Public Finances and Tax Law in the Countries of Central and Eastern Europe. Contact email: leonard.etel@wp.pl.

2 Professor of the University of Bialystok, Department of Tax Law, Faculty of Law, University of Bialystok. Poland. The author specializes in tax law. He is Vice-Rector for Development and International Cooperation, member of the General Taxation Law Codification Committee in Poland, member of the scientific council of "Public Governance, Administration, and Finances Law Review in the European Union and Central and Eastern Europe". Contact email: mpoplawski@poczta.onet.pl. 


\section{Introduction}

The objective of this paper is an attempt to present a consequence connected with the introduction into Polish law the principle of weighing the interest of the obligee and the public interest, which will probably be adopted in the new Tax Ordinance Act in Poland. Currently, works are conducted aiming at developing a new act including general tax law, which will replace the biding one (Tax Ordinance Act) valid for almost 20 years. They are carried out by the Komisja Kodyfikacyjna Ogólnego Prawa Podatkowego (eng. Codifying Commission of the Universal Tax Law, hereinafter referred to as the Commission). This entity presented the bill of new tax law to the Minister of Finance on 9 October 2017, which completed the 2-year period of work dedicated to the preparation of the bill (Regulation of 21 October 2014). The interest in these issues results from the particular importance of this rule in tax legislation. Directional assumptions of the new Tax Ordinance Act point out that the introduction of a new act is justified, for example, by an increasingly visible need for creating in the Tax Law such mechanisms that would lead to weighing the public interest and the interest of the taxpayer (Kierunkowe założenia, 2015: 6). It is also raised that the issues referring to the matter as delicate as taxes must be solved with respect to taxpayers' rights, but also, which is often forgotten, with considering the interest of the state, or, simplifying, organizations financed by all taxpayers (Kierunkowe założenia, 2015: 132).

The foundation of this paper will be the principle of weighing the interest of the obliged and public interest, hereinafter referred to as the principle/rule of interest weighing, included in Art. 26 of the new Tax Ordinance Bill prepared by the Commission in the version of 6 October 2017 (Projekt ustawy - Ordynacja podatkowa, 2017). In accordance with this regulation, the tax authorities weigh the justified interest of the obliged and public interest (Projekt ustawy - Ordynacja podatkowa, 2017, Art. 26). Problems connected with the application of the mechanism included in the rule in question will be presented in a wider perspective. For this will be accompanied by an attempt to present the current judicial directive of weighing the taxpayer's interest and public interest.

\section{Weighing Interest of Obliged and Public Interest on the Basis of Currently Binding Provisions of Tax Law}

Currently, the rule of weighing the taxpayer's interest and the public interest operates as a directive on judicial decision-making. For it does not result directly from legal regulations but it was formed mainly in judicial decision-making, and also in the doctrine of tax law (Etel, 2017: 363; Kierunkowe założenia, 2015: 137; 
Orłowski, 2009: 184). This rule is currently treated as a typical proceeding rule, operating beside the following rules: legalism, trust, cooperation in the scope resulting from the provisions of law, prohibition of abusing law, proportionality, settlement of affairs, pragmatism, limited application of analogies, and requisition of applying the lifted provisions to assess the occurrences which took place under their rule (Kierunkowe założenia, 2015: 20).

Judicial practice points at the type of regulations, in which the rule in point should be currently applicable. It is raised that the tax authority is obliged to not only establish if there occur premises of the taxpayer's important interest or the public interest, but it is also obliged to weigh the public interest with the individual interest of the party, since it is obliged to do so by Art. 2 of the Constitution of the Republic of Poland (Constitution of 2 April 1997) in any case where a legal norm subordinating the settlement of the affair to the so-called administrative discretion is applicable (Highest Adiministrative Court in Wrocław: I SA/Wr 1458/2001). Thus, in practice, the rule in point is applied foremost in the context of regulations referring to tax reliefs in paying tax obligations (Tax Ordianance of 29 August 1997, Art. 67 and next).

The rule of weighing interests has been expressed in judicial decisions not only directly but also indirectly. It results in the following questions. First, applying the rule of weighing interests, the tax authority should take into consideration various factors concerning the taxpayer, and also the tax creditor. Thus, it is emphasized that in the case of applying the regulations referring to reliefs in tax obligation payments, the authority may adopt different criteria of choice, for example, take into account social and economic circumstances, previous attitude of the taxpayer towards meeting taxation obligations, circumstances of the origins of tax arrears, etc. (Highest Administrative Court: II FSK 2474/2015).

Secondly, the abuse of the rule under discussion will occur if payment reliefs are recklessly applied towards the taxpayer, for this will infringe the public interest understood, for example, as a need for gathering tax incomes. An argument is raised that the tax authority granting a relief in tax obligation payment must bear in mind that the tax obligation is realized and the taxpayer is not hastily exempted from them (Highest Administrative Court in Katowice: I SA/Ka 577/2000).

Thirdly, examining the important interest of the taxpayer, one should not exclusively consider one circumstance, for example, the taxpayer sickness, but also their situation in a broader context. It is also noted that, despite the fact that cancer is undoubtedly a significant event, which should be included in the decision-making process referring to granting or refusal of granting a relief, it is not an automatic basis for canceling tax arrears (Highest Administrative Court: II FSK 1842/2010). 
Fourthly, verifying the possibility of applying for a relief in tax obligation payment, it is important to keep in mind, due to the criterion of public interest, that the consequences of granting reliefs were not borne by the state only. In this context, an argument is raised that while establishing the public interest it is important to take into consideration the budget situation of the state and it is important to eliminate such situations where the result of the relief will be charging the Treasury with the costs of aid (Voivodeship Administrative Court in Warsaw: III SA/Wa 1410/2009).

\section{Rules of Weighing Interest of Obliged and Public Interest as a Rule Referring to Modus Operandi of Tax Authorities and Settling Tax Affairs}

On the grounds of currently binding provisions the rule of weighing interests, as presented above, is a judicial decision-making rule of a typically proceeding nature. After the introduction of a new tax law, this rule will be able to be counted among the rules of operating tax authorities and settling tax affairs (Kierunkowe założenia, 2015: 20, 136). In addition, it will be a general rule of tax law, and not just a proceeding rule, which is demonstrated in the title of chapter 2: "General rules of tax law" in Part I.

The rules of tax authorities' operations and settling tax affairs in the new Tax Ordinance Act will include the following rules: the rule of trust, impartiality and equal treatment, protection of justified expectations, proportionality, purposefulness and effectiveness, pragmatism, objective truth, settling doubts referring to the facts in favor of the obliged, swiftness and plainness of settling affairs, restricted gathering of documents and information, weighing the interest of the obliged and the public interest, active participation of the party, persuasion, arbitral settling of affairs, written form.

The new Tax Ordinance Act will also include three other catalogues of legal rules: program rules (the rule of legality and the prohibition of abusing law by tax authorities (Popławski, 2014a: 27), rules referring to the status of the obliged forming the framework of relations between the obliged and tax authorities (the rule of informing and supporting, cooperation of the obliged with the tax authorities, settling doubts referring to the substance of the provisions of law in favor of the obliged, presumption of honesty of the obliged), rules referring to tax proceedings (the rule of transparency for the parties exclusively, two-tier instance, permanence of the final decisions (Kierunkowe założenia, 2015: 20, 136)). 


\section{Range of Application of New Rule of Weighing Interest of Obliged and Public Interest on Grounds of Tax Law}

As already emphasized, the rule of weighing interests will be on the basis of the new Tax Ordinance Act a universal rule of tax law. Consequently, it will be more extensively applicable than previously. It will be applied in reference to both the provisions of substantive law and procedural law. This rule may be applied on the grounds of actions taken by tax authorities on the basis of the provisions included in the Tax Ordinance Act. It will be applicable for actions performed by tax authorities also on the basis of other provisions of tax law applied by tax authorities. This means that it will be used while applying by tax authorities provisions of tax laws, executive regulations issued on the basis of tax laws, acts of local law issued on the basis of tax laws, as well as the agreements on avoiding double taxation ratified by the Republic of Poland, and other international agreements concerning tax law issues ratified by the Republic of Poland, as well as provisions of the European Union law referring to tax law issues (Projekt ustawy - Ordynacja podatkowa, 2017: Art. 13/11).

In the context of the types of regulations where the rule of weighing interests will be applicable, at the stage of application of tax law, it is important to note the following questions resulting from the justification of the new Tax Ordinance Act. It is underscored that the rule in point will be applied at the stage of application of tax law, in particular in the case of arbitrary decisions, including those on granting reliefs in payment, restoring and prolonging deadlines, abandoning tax collection by the Minister of Finance, in the issue of securing the execution of a tax obligation, making judicial decisions on the liability of third parties (possibility of refraining from holding liable, if it was blatantly unfair), suspending the proceedings on the request of a party, the application of the pain of immediate execution, establishment of the amount of the disciplinary penalty, etc. (Projekt ustawy - Ordynacja podatkowa: justification of Art. 26). It is also underscored that, in fact, in each case these interests in their mutual relation remain important, due to, suffice it to say, that their weighing is required to apply the rule of proportionality, especially in the context of the third of the classic conditions of proportionality of actions resulting in imposing on the obliged obligations or reducing their rights, i.e. the condition of sensu stricto proportionality, assuming weighing the opposed interests and values (Projekt ustawy - Ordynacja podatkowa: justification of Art. 26). The two remaining conditions of the rule of proportionality refers to adequacy and indispensability. It is also emphasized that there are such cases where, because of the form of the legal regulation, there is no room for weighing interests (e.g. in the case of tax measurement), which means, that in such cases, this rule will not be applied, since in the name of the universal rule, a kind of "modification" of the 
content of the tax state of affairs determined in the tax law (Kierunkowe założenia, 2015: 21).

It is important to underscore that weighing these both aforementioned interests should also be taken into account at creating tax law in the scope of, for example, the institution of tax limitation. Not employing this rule in forming tax law could lead to consequences difficult to accept (Popławski, 2014: 63). It would be impossible to recognize as correct a situation where the public interest only is taken into consideration, since at such an assumption, in the institution of limitation could not be any time framework in which tax authorities could claim taxes from the obliged entities. The reverse situation, where only the private interest would be considered at the stage of lawmaking, would also be unacceptable. In this case, we would deal with the situation in which, for example, the institution of limitation would be based on very short time limits (e.g. a few months), within which the tax authorities could claim tax payments from the obliged entities.

\section{Essence of Rule of Weighing Interest of Obliged and Public Interest Introduced to New Tax Ordinance Act}

In accordance with article 26 of the bill of Tax Ordinance, tax authorities weigh the right interest of the obligee and the public interest. A similar rule is articulated in the Art. 7 of the Code of Administrative Procedure, according to which in the course of proceedings the public administration bodies are on guard of the rule of law ex officio or on request of the parties take any actions necessary for thorough explanation of the factual circumstances as well as for settling the affair, bearing in mind the public interest and the proper interest of citizens. A similar rule in reference to arbitrary decisions is also formed in Art. 18/2 of the bill of General Provisions of Administrative Law (Projekt ustawy - Przepisy ogólne prawa administracyjnego; Prawo, 2008: 9-109), underscoring that if the provisions of law indicate that the public administration body employs administrative discretion in settling a case, it should settle it in accordance with the demand of the individual, bearing in mind the need for weighing the reasons of individual, group and public interests disclosed in the case, and the purpose of the legal regulation, as well as the feasibility of the actual implementation of the entitlement, demanded.

In the context of the essence resulting from the rule of weighing interests, the justification of the new Tax Ordinance Bill asserts that the rule of weighing interests results in a directive prescribing interpretation of doubts including the "interests" of both parties of the tax legal relation (Kierunkowe założenia, 2015: 6). Moreover, it is cogently observed that it is not really a novelty since this way 
of law interpretation results from the Act of 2 April 1997, the Constitution of the Republic of Poland (Kierunkowe założenia, 2015: 6). Consequently, the entities interpreting the provisions of tax law should take into consideration, as one of the elements of interpretation, also the need for including the weighing of both aforesaid interests while establishing the meaning of a particular provision of tax law. The interpretation of the provisions of tax law through the prism of the rule of weighing interest, i.e. at including and weighing the booth aforesaid interests should be treated as an element of the process of systemic interpretation. The prescription of interpreting the regulations in accordance with legal rules is one of the most fundamental directives of the systemic interpretation of the law (Morawski, 2014: 130 and next). The literature points out that within the framework of systemic interpretation the issues connected with, among other things, the role of the rules of law are discussed (Nowacki, Tobor, 2007: 199), and also that within the framework of systemic interpretation operates a directive including the structures of an act of law, where the substance of the directive is drawing interpretative argumentation from the structure of the act of law (Brzeziński, 2008: 104).

The rule under discussion will be more broadly applied. The rule should be taken into account also in the context of applying the provisions of tax law. This means that the action of the tax authority performed on the basis of a provision of tax law should be verified through the prism of this rule if the provision grants the tax authority any room for administrative discretion. For the tax authority, applying a provision of law takes particular actions affecting the rights and responsibilities of the taxpayer. However, it should do it taking into consideration the rule in the scope resulting from this regulation.

Taking into account the considerations presented above on the possibility of applying the rule of weighing interests, one may distinguish three categories of the provisions of tax law. The first group includes the provisions of tax law where the rule of weighing interests affects their interpretation and, consequently, the establishment of their meaning. Such a case takes place, for example, in reference to the provision expressing the principle of proportionality. In accordance with Art. 21/1 of the Tax Ordinance Bill, tax authorities will take only such actions imposing responsibilities on the obliged or limiting their rights, which enable to reach the statutory goal, are necessary for its achieving and bring results commensurate with the responsibilities imposed on the obligee or the limitations of their rights. Establishing the meaning of the notion of "actions bringing results commensurate with the responsibilities imposed on the obliged", the authority should weigh the interest of the obligee (the actions taken by the authority should not create additional responsibilities for the obliged of similar or higher degree of intensity than the obligations resulting from the provisions of tax law) as well as the public interest (the actions taken by the tax 
authority should sufficiently serve to perform the responsibilities resulting from the provisions of tax law).

The rule of weighing interests at the stage of interpretation of the regulations should also be taken into consideration in the case of regulating the swiftness of proceedings. In accordance with Art. 24/1 of the Tax Ordinance Bill, tax authorities act on the case insightfully and swiftly, employing possibly simplest means leading to its settlement. The tax authority, assessing what should be understood as the simplest means of action, should weigh both the interest of the taxpayer (the means should interfere in the current affairs and impede the taxpayers operations as little as possible), but also the public interest (the means should not generate very high costs of its application for the tax authority).

The rule of weighing interests also in the context of the interpretation of the regulation will be also applicable in the case of regulations concerning the general clause against avoiding taxation. In accordance with Art. 35/1 of the Tax Ordinance Bill, the action performed foremost in order to gain a tax advantage, contradictory in the particular circumstances with the subject and aim of the tax law, does not result in achieving a tax advantage, if the modus operandi was artificial (tax avoidance). The tax authority, deciding the meaning of the concept of performing a particular action in the circumstances contradictory to the subject and aim of the tax law, should, on the one hand, take into account the private interest (the aim of the tax law may be stimulating certain behaviors of the taxpayer through exception, exemption or a tax relief), but also the public interest (the subject of the tax law is generating the possibly highest incomes from taxes).

The application of the rule of weighing interests also in the context of the interpretation of the regulation refers to, among other things, the regulation being a basis for issuing the general interpretation of tax law. In accordance with Art. 500/1/1 in connection with Art. 505/1 of the Tax Ordinance Bill, the minister competent for public finances interprets the provisions of tax law, ex officio or on request, bearing in mind decisions of courts and the Constitutional Tribunal or the Court of Justice of the European Union. Similarly, the rule will be applicable in the case of issuing tax explanations. For in accordance with Art. 500/1/2 of the Tax Ordinance Bill, the minister competent for public finances seeks to provide consolidated application of tax law by tax authorities, in particular issuing ex officio general information concerning the content of the provisions tax law and explanation of the provisions of tax law referring to the application of these provisions, including decisions of courts as well as the Constitutional Tribunal or the Court of Justice of the European Union. The rule under discussion should be also applied at the stage of applying the regulations referring to individual interpretations, for in accordance with Art. 513/1 of the Tax Ordinance Bill, the director of the National Treasury Information, 
on request of the concerned, issues, in their individual case, the interpretation of the provisions of tax law (individual interpretation).

The competent authorities, issuing the aforementioned interpretations (general or individual) or tax explanations, should obey the rule of weighing interests. The regulations subject to these interpretations and explanations may include unclear wordings, the explanation of which will require the use of the systemic interpretation, and, what follows, including, among other things, the rule of weighing interests.

The law the regulations where the rule under discussion will concern applying certain regulations of tax law are the other group of provisions of the law The rule in point will be taken into account at the application of the provisions of law also in the scope of, for example, the regulation referring to reliefs in tax obligation payments. In accordance with Art. $217 / 1$ of the Tax Ordinance Bill, the tax authority, on request of the obligee, in the cases justified by an important interest of the obligee or the public interest, may grant reliefs in tax payment (reliefs in payment). In this situation, the authority, having verified the facts, should decide on granting or, alternatively, refusing the relief in the tax obligation payment, taking into consideration the private interest of the obligee (the case should concern an important, special and not regular, need of the taxpayer, which should be protected with the relief in payment), but also the public interest (the case should not really threaten the general possibility of generating incomes from taxes).

The application of this rule should also take place in the context of the application and the selection of the method of securing the execution of tax obligations. The tax authority, being able to apply security on the taxpayer's property, judicial mortgage and tax lien (Projekt ustawy - Ordynacja podatkowa, 2017: Art. 628 and next), should bear in mind the interest of the obligee (the means applied should not limit the possibility of conducting their business), yet also public (the security used should be realistic and refer to the components which could be easily cashed in the event of the taxpayer's refusal to pay the tax voluntarily).

The rule under discussion should also be applicable in reference to the pain of immediate execution. In accordance with Art. 433/1 of the new Tax Ordinance Bill, a non-final decision may be granted the pain of immediate execution, if the tax authority has information that executive proceedings against the party are in progress in the scope of other amounts due, or the party does not have property the value of which corresponds with the tax arrears with the default interest, on which it is possible to establish a judicial mortgage or tax lien, which would enjoy the priority of satisfaction, or the party sells the property of considerable value. Consequently, the tax authority taking a decision on providing the non-final decision with the pain of immediate execution should bear in mind the taxpayer's interest (the execution 
of the decision should not result in the application of such executive means that may threaten the taxpayer's fundamental source of income), but also the public interest (the execution of the non-final decision should prevent taxpayers from avoiding tax burdens through swift and efficient "disposal" of their property, for example, in favor of their families and friends).

The third group of regulations will refer to the regulations, in which the rule of weighing interests will be considered neither in their interpretation nor application. This refers to the provisions of the establishment of the meaning of which does not require the extra-language interpretation. Therefore, the rule of weighing interests cannot be applicable. This refers simultaneously to both regulations which do not require the application of this rule at applying these regulations. Such a situation occurs, for example, in the case of the regulation concerning the right to information and support. In accordance with Art. 42/1 of the Tax Ordinance Bill, the concerned is entitled to receive on demand from the tax authorities information on the rights and responsibilities resulting from the provisions of tax law, as well as support in individual, correct and voluntary performance of the responsibilities and exercise of the rights. It is similar in the case of the regulation concerning the use of the means of electronic communication. For in accordance with Art. 46, the condition of a written form defined in the law is regarded as met if the electronic document including the text is signed with the qualified electronic signature or the electronic signature confirmed by the ePUAP trusted profile or in another way determined in separate regulations. The regulations in reference to which we will not deal with the application of the rule of weighing interests will be also regulations concerning the representation and power of attorney, where, according to Art. 57/1 of the Tax Ordinance Bill, a natural person may take actions in the scope of tax law, if they are fully capable of taking legal actions.

\section{Conclusions}

The considerations in this paper result in the following observations. First, the rule of weighing interests of the obliged and the public interest on the ground of the currently binding provisions of tax law functions as a directive in judicial decisions, and its basis is to be found in Art. 2 of the Constitution of the Republic of Poland (Constitution of 2 April 1997). In should be currently applied in every case where it is possible to apply in the case the legal norm which makes the settling of the case dependent on the so-called administrative discretion. In practice, the subjective rule is applied foremost in the context of the provisions referring to reliefs in tax obligation payment. 
Second, after introducing the new Tax Ordinance Bill, this rule will be possible to count among the rules of operation of tax authorities and settling tax affairs. Moreover, it will be a general rule of the legal law and not only procedure principle. The rule of weighing interests will constitute a particularly important principle among other rules of the general tax law included in the new Tax Ordinance. Its crucial importance has been pointed out in the direction assumptions of the new Tax Ordinance, claiming that it should be articulated in the new Tax Ordinance immediately after the rule of legalism (Kierunkowe założenia, 2015: 19 and next).

Third, in the new Tax Ordinance, the rule under discussion will be applied both in reference to the provisions of substantive actions taken by tax authorities on the basis of the regulations included in the Tax Ordinance, but also on the basis of other provisions of tax law applied by these tax authorities.

Fourth, in the new Tax Ordinance, the rule under discussion will be applicable at the stage of tax law application. It should also be applied in the context of creating tax law.

Fifth, from the essence of this rule included in the new Tax Ordinance, results a directive prescribing the interpretation of doubts including the interest of both parties of the tax legal relation. The interpretation of the provisions of tax law through the prism of the rule of weighing interests should be treated as an element of the process of the systemic interpretation.

Sixth, the essence of this rule indicates that it should be also taken into consideration in the context of applying the provisions of tax law. This means that the action of a tax authority carried out on the basis of the provision of tax law, should be verified through the prism of this rule, if this provision provides the tax authority with any room for administrative discretion.

Seventh, taking into account the possibilities of applying the rule of weighing interests in the light of the new Tax Ordinance, we can distinguish three categories of the provisions of tax law, where the first group encompasses the provisions of tax law, in which the rule of weighing interests will affect their interpretation and, consequently, the establishment of their meaning. The second group of provisions of law is constituted by the regulations where the rule under discussion refers to applying particular regulations of tax law. Finally, the third group of provisions of the law will refer to the regulations in which the rule of weighing interests will be taken into consideration neither in their interpretation nor their application. 


\section{References}

Brzeziński, B.: Podstawy wykładni prawa podatkowego (Fundamentals of interpretation of tax law), Gdańsk: ODDK, 2008.

Etel, L. (ed.): Ordynacja podatkowa. Komentarz (Tax Ordinance Act. Comment), Warszawa: Wolters Kluwer, 2017.

Orłowski, J.: Uzasadnienie decyzji w sprawie ulgi w spłacie zobowiązania podatkowego niebędącej pomocą publiczną (Justification of the decision on tax relief not being a state aid), in: Dowgier, R. (ed.): Ordynacja podatkowa. Wokół nowelizacji (Tax Ordinance Act. Around the amendment), Bialystok: Temida 2, 2009.

Popławski, M.: Nadpłata i zwrot podatku. Zagadnienia wspólne dotyczące realizacji uprawnień podatkowych (Overpayment and tax refund. Common issues related to the implementation of tax entitlements), Warszawa: Wolters Kluwer, 2014.

Popławski, M.: Uprawnienia podatkowe. Procedura dochodzenia należności podatkowych od Skarbu Państwa lub jednostek samorządu terytorialnego (Tax entitlements. Procedure of claiming tax receivables from the State Treasury or local self-government units), Warszawa: Wolters Kluwer, 2014a.

Prawo do dobrej administracji (Right to good administration, the Ombudsman's Newsletter Materials), Biuletyn RPO (Bulleting of the Polish Ombudsman) no. 60 (2008).

Morawski, L.: Zasady wykładni prawa (Principles of law interpretation), Toruń: TNOIK 2010.

Nowacki, J., Tobor, Z.: Wstęp do prawoznawstwa (Introduction to jurisprudence), Warszawa: Wolters Kluwer 2007.

PL: Constitution of the Republic of Poland, 2 April 1997, as amended.

PL: Tax Ordinance Act of 29 August 1997, as amended.

PL: Regulation of 21 October 2014, on creation, organization and functioning of Commission Codifying Commission of the Universal Tax Law.

PL: Code of Administrative Procedure of 14 June 1960, as amended.

PL: Highest Administrative Court: I SA/Wr 1458/2001.

PL: Highest Administrative Court: II FSK 2474/2015.

PL: Highest Administrative Court: I SA/Ka 577/2000.

PL: Highest Administrative Court: II FSK 1842/2010.

PL: Voivodeship Administrative Court: III SA/Wa 1410/2009

Projekt ustawy - Przepisy ogólne prawa administracyjnego z 29 grudnia 2010 r. (Bill of General Provisions of Administrative Law of 29 December 2010). www.orka.sejm.gov.pl. 
Projekt ustawy - Ordynacja podatkowa z dnia 6 października 2017 r. (Bill of New Polish Tax Ordinance Bill of 6 October 2017 and Its justification). www.mf.gov.pl.

Kierunkowe założenia nowej ordynacji podatkowej przygotowane przez Komisję Kodyfikacyjną Ogólnego Prawa Podatkowego (Directional Assumptions of the New Tax Ordinance Act prepared by the Codifying Commission of the Universal Tax Law), 2015. www.legislacja.rcl. gov.pl. 



\title{
TAX LAW AND ITS IMPACT ON THE STATE BUDGET ${ }^{1}$
}

\author{
MÁRIA BUJŇÁKOVÁ2
}

\begin{abstract}
The Author presents some reflections regarding the current role of States and international entities and the role and functioning of law as such in the sphere of public finances and, especially, the fight against tax frauds. She emphasizes that a positive effect may be brought only by acting at the global level and that artificial or even irrational persisting on the State sovereignty or isolated attitude of the States regardless of the "common good of many" can cause the opposite to the desired effect. The State has already implemented a series of measures that should partially reduce tax evasion, but it should be noted that as legislators are looking for ways to prevent tax evasion, taxpayers also use all available means to avoid paying the taxes or minimizing their amount. Mutual cooperation among the countries not only within the EU but globally, should help to improve the situation in tax collection in the future.
\end{abstract}

\section{Keywords}

Tax; tax evasion; tax frauds; EU

JEL Classification: H26, H69, K42

1 This paper was written as a partial output of the research project APVV-16-0160 "Tax evasions and tax avoidance (motivation factors, formation and elimination)", as well as the output of the project VEGA 1/0846/17 "Implementation of the initiatives of the EU institutions in the field of direct taxes and indirect taxes and their budgetary law implications".

2 Associate Professor of Financial Law at the Department of Financial Law, Tax Law, and Economics at the UPJŠ Faculty of Law in Košice. She is a recognized authority in the field of tax law and financial law. So far, she has published over 100 publishing outputs of various categories in aggregate. She is involved in the field of financial and tax law, particularly in the field of direct taxation. She is a member of the Information and Organization Centre for the Research on the Public Finances and Tax Law in the Countries of Central and Eastern Europe. Contact email: maria.bujnakova@upjs.cz. 


\section{Introduction}

Every social establishment necessarily requires some regulation that will ensure order, system, but it will also maintain this order and system while guaranteeing the balance of society. The most important way of social regulation is normative regulation, i.e. regulation performed by social normative systems, by which we understand open dynamic and targeted regulatory systems comprised of social standards in the form of instructions, prohibitions, and permissions (Knapp, 1995: $39)$.

There exist several normative systems operating in society. Law occupies a special position among them, whose norms are, as a rule, formally published and their fulfillment is enforceable by the State. The basic division of law into public and private can already be seen in the work of Roman lawyers, although the significance of understanding both public and the private law had been different from their current perception.

Uplianus characterized public law as one that expresses the interests of the State and expresses the interests of the individual (Ulpianus, D I I I 2). Such a muchsimplified statement in today's modern world must be seen in a wider context, but also in the context of ongoing globalization, and in our conditions even in the context of Europeanization of law. In the theory of law, there exists a considerable number of published monographs that present the views and arguments for dividing the law into private and public. ${ }^{3}$

The introduction to this paper is unusual for still another reason. We live in the 21st century and believe that everything that is happening around us has its justification and the world keeps convincing on what is right and what is not right. Perhaps it would be worth considering our returning to old values, traditions, and sometimes even recollections. When studying the background sources for this paper, which is aimed at examining the current issues of tax law and tax evasion prevention, I received a publication from a colleague of mine, Prof. Bröstl "Institutionalism A New Theory of Procedure, Law, and Democracy". This is a translation of the book by Prof. Oto Weinberger, published in 1995. While studying, anyone would be looking for something that would interest, what has not yet been published and what has not yet been quoted and I can it is original. I was particularly interested in the introductory words by Prof. Bröstl, which are his personal assessment of this book. It certainly is a very interesting reading, and I, being a person who prevailingly comes into contact with the positive law, it gave a great opportunity to explore this positive law in a different context (Weinberger, 1995).

3 Various works of law theorists may be worth mentioning: Harvánek, 2008; Boguszak, 2004; Kubů, 2007; Knapp, 1995; Prusák, 2001; Brôstl, 2004. 
My inner uncertainty and moral pursuit have led me to try and make an attempt at making rational analyses as available as possible. I believed and still believe that human reason is a tool of effective and moral action. Nevertheless, I have never thought that only the reason alone could or should condition our desire or what it is supposed to be - meaning, I have never been a cognitivist (Weinberger, 1992).

The science that wants to clarify and determine human existence must, in addition to raw facts, also take into account institutional reality. According to Weinberger, the law is an institutional reality (Weinberger, 1992). The ontology of Weinberger's institutionalism, therefore, relies on the fact that an individual (as well as human society) may determine their behavior on the basis of practical information and factual information. Weinberger rejects pure normativism, which calls for the ideal being of norms without any direct relation to observable processes. However, he also rejects legal realism, for which the applicable law is just observable and predictable behavior of the legally consistent State. The applicable law, in his view, is precisely that co-existence of norms with behavior and with the existing institutions. Legal norms appertain the law - they are a valid law - because they exist in the context of dealing with real and observable processes (Bröstl, 2004). The existing law consists not only of standards of behavior and of empowering norms, but also of legal principles, the teleological background of law, and of institutionalized legal doctrine and methodology. Weinberger takes the view that law and morality separate from each other as two different normative systems, which, however, work together in conditioning the human behavior (Bröstl, 2004).

In the current world, it is necessary to pay special attention to these institutes also because of the existence of phenomena which in law we may rightly call negative, and whose origin is certainly in morality. According to Weinberger, it is necessary to notionally separate law from morality: a) principles of law are part of the positive law, b) the validity of law is conditional on the present creation, not the moral criteria, c) we have to have a possibility of evaluating (valid or proposed) law, but the validity of law is not subject to the moral filter of an individual judge, an official, etc., d) legal life needs a harmony of moral roles of the decision-making bodies - especially in the sphere of discretion - and their connection to the law that functions as a stand-alone system of norms. Law and morality are concepts that specifically resonate in tax law, and often these concepts are perceived in the application practice. Of many considerations, it is worthwhile to recall one oftenstated thesis, "What is moral does not have to be in accordance with law", but this also holds true vice versa, "what is in accordance with the law, does not always have to be moral". 


\section{Impact of Tax Policy}

Taxes and tax policy are part of the State's budgetary policy and also a tool of the State's economic policy. We may state that it is actually a set of measures by which the State modifies the tax system. Tax policy has its objectives, economic, political, and social ones, and, above all, the tax system is used as a means of achieving them. In particular, the tax policy should be stimulating, i.e. it should promote economic development and entrepreneurial activity. When applying the tax policy, however, it is necessary to take into account the specific features of the specific State, therefore it is not possible to fully apply the tax policy of another State to our conditions. Each State has its own specifics, a certain degree of development, social composition, geographical location, and many other features and specifics, which must also be respected in tax policy.

Tax law as an institution that began to emerge in this country after the year 1992, when we start talking about tax law as a separate branch of law, aims to monitor and regulating those social relationships that also have the attributes of the economy, but on the other hand, they must be regulated by law. Taxes represent a social phenomenon that includes economic, legal, social, sociological, moral, and psychological aspects (Babčák, 2012: 24). In particular, it is possible to influence the resources of public budgets, but also economic policies of the State and the economic development.

Law is, in essence, inseparably linked and connected with the society in which it arises and operates. In addition to this conditionality of law, the social context of its existence may also be identified by the conditionality of the development of social relations by a valid and effective set of legal norms implemented in it. The result of this is that society and law are interrelated, which must be respected and taken into account in their close scrutiny. The tax legislation that the State has in place should create the conditions for the application that will also anticipate the emerging situations in the tax system. Tax law in Slovakia has been undergoing a turbulent development since 1992 and has been marked in particular by the adoption of norms that reflect the change in economic and social conditions. Tax norms have often been adopted in a non-systemic manner, requiring frequent amendments, not to mention subordinate norms that have frequently been in conflict with the applicable legislation. Legal norms in the field of tax law have become obtrusive, not to mention their frequent amendments even through other legislation. In this process of transforming the economy, it was not easy to look for acceptable boundaries between public and private finances, between seeking optimal tax justice and economic development. 
A very substantial change in the concept of tax policy in Slovakia took place in the year 2004, as the Slovak Republic had to adapt its legislation also in the field of taxation at its accession to the European Union (Romanova, 2014; Červená, 2008). Finding an optimally suitable and effective compromise in tax policy implementation to present the interests of the public and the needs of the State is very complex and possibly even unrealistic. We need to take into account all the factors that can affect tax legislation itself. The key factors that affect tax legislation can include the tax law system and the tax system. These concepts are not identical, because each of them expresses different internal arrangement and classification. We could characterize the tax law system as a complex of taxation, and in terms of the classification of the legal norms that govern it, we may talk about the material tax law and procedural tax law. The tax system is a component of the tax system, and it is thus the system of all taxes in the country. The tax system may also be characterized as a concept for a particular group of taxes that are levied and collected in a particular state.

The Slovak Republic needs to adapt its tax system on the one hand to both the internal conditions both in the State and in relation to the European Union and to the international aspects to be taken into account. From the point of view of tax law, it is necessary to say that we should enforce such legislative measures that would be of benefit to the State, that would be equitable and simple for citizens, and would at the same time create some space for the competitiveness of the economy even with regard to foreign relations. It is well known that some regularities and limitations have been defined when accessing the EU, particularly with regard to indirect taxes. The field of direct taxation remained the responsibility of national States.

In this paper, I would like to point out some facts that have a significant influence on the tax law itself on its position and the role it plays in economic processes, but also its importance for the national economy and stable development of the economy in Slovakia. Taxation in every market economy is a frequently discussed professional issue, but also one of the most frequently asked questions by the public. In order to achieve the prosperity of any country, the rational economic policy of the State and a pragmatic financial policy are necessary. If the State wants to focus its economic policy on a particular tracked area, it can do so through the targeted policies that form part of it. Tax policy, whose focus and objectives depend on the economic policy applied by the State, plays an irreplaceable role (Beňová, 2005). An integral part of the economic policy is the tax policy which is defined by some Authors as the application of tax principles and measures so that taxes serve to promote the social and political needs of the State (Schultz, 2007: 117). According to Schultz, tax policy is related to the use of taxes and their instruments, which serve to influence macroeconomic and microeconomic processes in the economy (Schultzov, 2007: 
117). It is generally based on the application of economic policy. For example, in the case of a restrictive economic policy, there is an increase in the tax burden and, in the case of an expansionary economic policy, the tax burden is reduced. The aim of the tax policy is to apply tax principles and measures so that taxes serve to promote the economic, social, and political goals of the State (Schultzov, 2011: 11-12).

According to Sivák (2007: 185) most of the public revenue is received by the State through taxes, so the total tax revenue is decisive. If this is to be most effective, it is necessary to keep in mind, when applying the tax policy, the subject matter of the relevant tax, the method of calculating the tax base, as well as other essential elements of taxes.

Economists perceive the role of taxes not just passively, that is to say, as a source of monetary revenue for public budgets, but also actively, as an action on taxpayers and the entire economic system, which is largely contributed by the legislative framework of tax law and tax proceedings. I present these considerations for two main reasons. The first reason is that the issue of taxation and tax legislation is largely addressed in economic theoretical sources, and the second reason is that it is precisely in the Europeanization of the tax system where taxes, in general, should have an increased share in the presentation in the law science. Why is this my consideration? For a simple reason: any good economic justification and analysis, unless they are reflected in legal form, cannot produce desirable results. I am aware of the fact that these are such attributes of law that also include economic features and mutually intertwine, but that should be the reason for their correct understanding, perception, application, and decision making.

Taxes have existed practically from the time of the formation of organized forms of society, and their development is related to the development of the State and the consolidation of the monetary economy. The evolution of taxes is a reflection of the changes that our society has undergone, reflecting the changes in the functioning of the State, economy, trade, and reflecting the understanding of the notions of justice and good (Medved, 2011: 185).

Taxes represent a social phenomenon that includes economic, legal, social, sociological, moral, and psychological aspects (Babčák, 2012: 24). It is in particular through taxes where it is possible to influence public budgets. Taking into account the fact that tax law as a separate branch of law in legal theory is not always appropriate, it will be necessary to raise this issue on a day-to-day basis through all available means of law enforcement. At the same time, the law is a phenomenon that is inherently inseparable from the society in which it arises and operates. In addition to this conditionality of the law, the social context of its existence may also be identified by the conditionality of the development of social relations by a valid 
and effective set of legal norms implemented in it. As a result, the society and the law are interrelated, which must be respected and taken into account in their close scrutiny.

A very daunting place in tax law and tax policy as such is tax evasion. This is a phenomenon in a society whose development is much faster than the legislation in this area. While the economy has been increasingly globalizing for several decades, which is very visible in areas like the digital market, tax systems are lagging far behind, and there exists a suitable hotbed for different taxpayers' practices whose aim and intent is to reduce their own tax burdens. Most of this is visible in indirect taxes, such as value added tax and excise duties, but the income tax is also a painful place in the legislative process. Not to mention that while indirect taxes have a kind of harmonization, even if we could argue about it, direct taxes are, contrary to that, in the direct competence of the Member States of the European Union.

All of the previous proposals for a harmonized corporate tax base have come under the resistance of some European Union Member States. It has to be said that part of EU officials continues to be endeavored to implement it. The European Commission was discussing a transparent and fair tax regime in the EU during this period. Thanks to the widespread revelations of scandalous ways of large corporations avoiding paying their taxes, this is an extremely interesting and up-to-date discussion. All the more so at a time when States are forced to cut back on the basic spending for which there is, reportedly, not enough money. The proposal to harmonize direct taxes has already been in the EU institutions for discussion for four years and has ended with failure. The proposal has come across some Member States' disapproval and has been hibernating since then. I think there is a similar fate today, but for the Commission, the common tax base is an integral part of the plans to combat illegal and unfair tax tactics. Agreements on the automatic exchange of information on bank account holders with countries such as Switzerland, Liechtenstein, Andorra or Monaco, or pressure on tax havens, should go hand in hand with mending the EU. Tax havens are heavily used for aggressive tax planning, as some banking institutions have pointed out (European Newspapers, 2015).

The activity has so far focused on punishing individual cases, which is, in fact, ineffective. The Commission will examine the special regimes and future tax agreements that companies have concluded with countries such as Ireland or Luxembourg. In many of them, there are record-high fines for breaches of competition rules threatening. However, a system solution is needed. The agreement on a common tax base is part of it. It will transparently determine what is taxable in the common European market and where exemptions are possible. It is to ensure that companies pay taxes in the country where they do their business. After all, they should compete with product innovation, not with the capabilities and tactics 
of tax advisors and legal services. However, any tax decision must be unanimously agreed by all of the EU Member States, and here the Commission will experience resistance. For the many EU Member States, this issue is taboo. The speech on "sovereignty in the tax area", however, is difficult to conceive in any other way but fogging and retention of the current state of affairs that suits the States. This is about specific economic interests. Inadequacies in the tax rules of Ireland, the welcoming approach of the Luxembourg authorities, the labyrinth of box office companies on the islands under the British crown rule, or the particularly advantageous taxation of intellectual property in the Netherlands certainly suit certain groups of particular interest. However, this cannot be considered a national interest and advocate in this way a dissenting opinion on an equitable tax regime in the EU.

Very interesting was also the debate in the European Parliament, where Members demand more equitable taxation. The EU Member States must be more open about their national tax decisions, as unfair tax competition distorts competition between businesses and can lead to a tax cut to a minimum. It is generally known that differences in national tax rules lead to fragmentation of the EU single market.

The European Commission has presented a package on fiscal transparency as part of its ambitious programme to combat tax evasion and harmful tax competition in the EU. A key element of this package of fiscal transparency measures is the introduction of an automatic exchange of information on binding tax opinions in the Member States. The objective of the tax transparency package is to ensure that the Member States receive information to protect their tax bases and effectively deal with companies that try to avoid paying a fair share of the tax. The central element of the transparency package presented by the Commission is a legislative proposal to improve Member States' cooperation on cross-border binding tax opinions, which should be the beginning of a new era of transparency. At present, the Member States are exchanging very little information on their binding tax opinions. The issue of a binding tax position as being relevant to another EU country is decided by the Member State. As a result, the Member States often do not know about cross-border binding tax opinions issued in other EU countries that may affect their own tax bases. Some companies abuse the lack of transparency in binding tax positions and artificially reduce their tax obligations. In order to remedy this situation, the Commission proposes to remove this space for free decision-making and interpretation. The Member States will automatically be required to exchange information on their binding tax position. National tax authorities will have to send a short report to all other Member States every three months on all the crossborder binding tax opinions they have issued. The Member States will then be able to ask for more detailed information on a specific tax position. By automatically exchanging the information on binding tax positions, the Member States will be 
able to detect and take appropriate action against certain unfair tax practices of companies. In addition, a sounder tax competition should be encouraged as it would be less likely that tax authorities would offer companies selective tax treatment when they can be controlled by partner tax authorities from other Member States.

In the field of tax transparency, there are increasingly frequent EU-level discussions on the assessment of new requirements for multinational companies. The Commission will examine whether new requirements for transparency, such as the disclosure of certain tax information by multinational companies, can be introduced for companies. The objectives, benefits, and risks of any such initiative need to be carefully considered. The Commission will, therefore, assess the impact of possible additional transparency requirements in order to make an informed decision.

One of the EU instruments is included in the Code of Conduct for business taxation. It should be a tool to ensure a fair tax competition for businesses. It sets out the criteria for determining whether or not the tax regime is harmful and requires the Member States to abolish any harmful tax measures that are contrary to the Code. The Member States regularly meet to assess compliance with the Code. In recent years, however, the effectiveness of the Code for the elimination of harmful tax regimes has fallen, as its criteria do not take into account more sophisticated systems to avoid tax evasion. The Commission, together with the Member States, will, therefore, revise both the Code of Conduct and the Code of Conduct Group mandate in order to make it more effective to ensure fair and transparent tax competition within the EU (European Newspaper, 2015).

The impact of the EU on tackling tax evasion cannot just remain on a declarative level. It will be necessary to monitor the adoption of all the measures that will help reduce tax evasion and detect tax evasion. The Commission and Eurostat, together with the Member States, are trying to find out how reliable estimates of tax evasion can be obtained. There is increasing evidence that tax evasion and tax avoidance are ubiquitous and cause significant revenue losses.

In general, tax evasion may be characterized as the result of the economic behavior of taxpayers, minimizing their tax burden to the State. In part of the textbooks, especially of economic focus, we find that the optimal environment for tax evasion is rather in a non-standard economy than in countries where the economic situation is standard. Especially in the transforming economies, the growth of illegal non-payment of taxes has also affected other factors. These factors may include the introduction of the VAT (Value Added Tax), which was something new to the transforming economies, but which is linked to demanding administrative requirements and processing itself (Červená, 2016). It also undoubtedly includes tax legislation, notably frequent changes in regulations, the introduction of many 
exceptions, but also lack of clarity and complexity of the legislation, lack of qualified staff ensuring tax accounting in accordance with tax rules and extensive customs shortcomings, as customs offices are also tax administrators (Strelcova, 2006: 97). It should be noted, however, that tax evasion and its exact definition are much more complicated than we often encounter. The European Commission, which recently launched a series of investigations into alleged tax agreements by which the Member States should favor large companies, also pays special attention to this issue. The EU Parliament has set up a special committee on tax decisions and tax measures.

What is the obvious difference between tax agreements, tax frauds, and tax evasion in a simplified form? For tax agreements (tax rulings), there is always one specific company or person. It could be said that this is a legal act that provides taxpayers with legal certainty and transparency. Tax fraud may be characterized as a deliberate circumvention of rules in order to avoid paying taxes. What, however, is very important from a legal point of view is that this should be the deliberate action, and proving this fact is very complex and often unachievable (Románová, 2017; Románová, 2015). In addition, there is one more term that is often used, namely tax optimization, which is legal, unlike tax fraud, but can legally be considered illegal, especially in those cases where a taxpayer abuses legal remedies to eliminate tax liability. Thus, if the tax is optimized, it means that the statutory options or gaps in the law are used.

Illegal tax avoidance and the level of circumventing taxation results in tax evasion that damages soundness of public finance. Tax evasion is a characteristic negative phenomenon of the present, just like the shadow economy. Illicit tax evasion is also done by manipulating the accounting data. The most important reasons for tax evasion can be the following: economic factors, legislative factors, socio-political factors, tax-technical factors, psychological factors, social and ethical factors (Slepecký, 2008).

\section{Conclusions}

The term of tax optimization is used more often than legal tax evasion, it is also more acceptable and does not give rise to suspicions of committing a crime in the public. Certainly, it is better to name things that most taxpayers would not want to implement, but they are often forced to do so, and adapt their activity primarily to their own benefit, even on the "edge of the law". Thus, if the tax is optimized, it means that the law is also used with its shortcomings or through "holes" in the law. From the very definition of tax optimization, we can characterize some of the principles that are used through this institute. These options include the use of a non- 
Tax Law and Its Impact on the State Budget

taxable minimum, non-taxable income, and various exemptions, which are defined in the laws, different options for applying costs, costs of different legal forms of doing business, different types of business contractual relationships - between the firms, as well as between companies and individuals.

The State has already implemented a series of measures that should partially reduce tax evasion, but it should be noted that as legislators are looking for ways to prevent tax evasion, taxpayers also use all available means to avoid paying the taxes or minimizing their amount. Mutual cooperation among the countries not only within the EU but globally, should help to improve the situation in tax collection in the future.

\section{References}

Babčák, V:: Slovenské daňové právo (Slovak tax Law), Bratislava: EPOS, 2012.

Beňová, E. et al.: Financie a mena (Finances and Currency), Bratislava: Iura Edition, 2005.

Boguszak, J. et al.: Teorie práva (Theory of Law), Praha: 2004.

Brôstl, A. et al.: Teória práva (Theory of Law), Košice: P.J. Šafárik University in Košice, 2004.

Červená, K.: Business Environment in the Slovak Republic after the Accession of the SR to EU Legal and Economic Aspects, Gospodarka i finanse w warunkach globalizacji (Economy and Finances in the Conditions of Globalisation), Toruń: Wyższa Szkoła Bankowa, 2008.

Červená, K. et al.: DPH - genéza a stav de lege lata na území Slovenska: podkapitola 1.1 (VAT - Development and Current State in the Area of Slovakia: subchapter 1.1), Daň z přidané hodnoty z perspektivy aktuálních legislativních změn (Value Added Tax in the Light of Current Legislative Changes), Olomouc: Iuridicum Olomoucense, 2016.

Harvánek, J. et al.: Teorie práva (Theory of Law), Plzeň: Aleš Čeňek, 2008.

Kubů, L. et al.: Teorie práva (Theory of Law), Praha: Linde, 2007.

Knapp, V.: Teorie práva (Theory of Law), Praha: C.H. Beck, 1995.

Medved', J. et al.: Verejné financie (Public Finance), Bratislava: Sprint, 2011.

Prusák, J.: Teória práva (Theory of Law), Bratislava: Komensky University, 1999.

Románová, A.: Boj proti obchádzaniu zákona pri priamych daniach v SR (Fight Against Circumvention of Law in Direct Taxation), Days of Law 2016, Brno: Masaryk University, 2017.

Románová, A.: The New Anti Abuse Rule in Slovak Tax Law: Strengtening of Legal Certainty? System of Financial law : System of Tax Law, Brno: Masaryk University, 2015. 
Románová, A. et al.: Assessment of the Impact of EU Law on National Procedural Tax Legislation, SGEM Conference on Political Sciences Law, Finance Economics \& Tourism, Sofia: Stef92 Technology, 2014.

Schulzová, A. et al.: Daňovníctvo: daňová teória a politika (Taxation: Tax Theory and Policy), Bratislava: Iura Edition, 2011.

Schultzová, A.: Daňovníctvo (Taxation), Bratislava: Iura Edition, 2007.

Sivák, R. et al.: Verejné financie (Public Finance), Bratislava: Iura Edition, 2007.

Slepecký, J. et al.: Ekonomické dôsledky katastrof (Economic Consequences of Disasters), Žilina: Edis, 2008.

Strelcova, S.: Konvergencia ekonomík Českej a Slovenskej republiky k EÚ (The Convergence of Czech and Slovak Economies to the EU), Krízový manažment (Crisis Management) no. 2 (2006).

Takto komisia bojuje proti vyhýbaniu sa daňovým povinnostiam právnických osôb (Thus the Commission Fights Against Tax Avoidance by Legal Entities), Európske noviny (European Newspapers), 2015. www.europskenoviny.sk.

Ulpianus, D I, I, I, 2.

Weinberger, O.: Inštitucionalizmus. Nová teória konania práva a demokrácie (Institutionalism. New Theory of Law and Democracy), Bratislava: Archa, 1995.

Weinberger, O.: Moral und Vernunft, Beiträge zur Ethik, Gerechtigkeitstheorie und Normenlogik (Morality and Reason, Contributions to Ethics, Justice Theory and Normative Logic), Vienna - Cologne - Weimar, 1992. 


\title{
THE ROLE OF NATIONAL FISCAL SECURITY AND TAX SOVEREIGNTY IN COLLECTION OF TAXES
}

\author{
ALEKSANDER KOSTYUKOV ${ }^{1}$, KIRILL MASLOV ${ }^{2}$
}

\begin{abstract}
This contribution deals with the issues of the collection of taxes in the fiscal security context. The main aim of the contribution is to confirm or disprove the hypothesis that collection of taxes, being the sign of tax sovereignty, is one of the most important methods of provision for national fiscal security. The methodology of the study includes general scientific methods (analysis, synthesis, induction, deduction, comparison, description) as well as particular legal academic methods (interpretation of legal acts, formal-legal method). The Authors analyze scientific approaches to the concept of national security as a generic term to the fiscal security, highlights its elements and contents. The Authors note that the state, public and personal security shouldn't be opposed each other, but they should be considered as elements of a unified system of national security. Full and effective implementation of the rights and legitimate interests of citizens and their communities equally meets the needs of national security as the protection of the interests of the state as a whole. The Authors prove that national security and tax security, in particular, are achievable only in conditions of genuine state sovereignty.
\end{abstract}

\section{Keywords}

Fiscal security; tax sovereignty; the collection of taxes; threats; methods

\section{JEL Classification: K34, M40, H71}

1 Professor for Financial Law, Head of Department of Constitutional and Municipal Law, Faculty of Law, Dostoevsky Omsk State University, Russian Federation. The Author specializes in tax law and local selfgovernment finance. He is the author of more than 10 books and more than 150 reviewed articles in prestigious legal journals. He is a member of Information and Organization Centre for the Research on the Public Finances and Tax Law in the Countries of Central and Eastern Europe. Contact email: omsk.post@ gmail.com.

2 Associate professor for Financial Law, Department of Constitutional and Municipal Law, Faculty of Law, Dostoevsky Omsk State University, Russian Federation. The Author specializes in tax law and tax administration. He is the author of 5 books and more than 40 reviewed articles in Russian legal journals. Contact email: maslov.omsu@gmail.com. 


\section{Introduction}

The main aim of the contribution is to confirm or disprove the hypothesis that collection of taxes, being the sign of tax sovereignty, is one of the most important methods of provision for national fiscal security. The main research question is how the effectiveness of the collection of taxes impacts on the provision for national fiscal security. The answer on this question will be given in the article by using general scientific methods (analysis, synthesis, induction, deduction, comparison, description) as well as particular legal academic methods (interpretation of legal acts, formal-legal method). The issues of national security and it's threats were in the focus of research of M.J. Glennon (2014), F. Alting von Geusau and J. Pelkmans (1982), A.B. Adams (1936), V.M. Redkous (2011), S.V. Kortunov (2007), S.V. Stepashin (1994), V.S. Polikarpov (2001), N.V. Mikhalkin (1993), N.N. Rybalkin (2006), A.V. Siusiukin (2004), V.I. Mayorov (1997). The issues of tax sovereignty were researched by S. Douma (2011), S. Jansen (2011), I.I. Kucherov (2017), A.I. Pogorletskiy (2005), S.V. Ovsyannikov (2001). The problems of national fiscal security and the role of the collection of taxes in ensuring of national fiscal security were not researched by lawyers sufficiently.

Although the issues of national fiscal security and efficiency of collection of taxes are very actual nowadays. The current stage of economic development of many countries is characterized by new challenges and threats, undermining the economic national security of the country, which actualizes the problem of finding solutions aimed at stabilizing the revenue part of the budgets of all levels.

Taxes and other compulsory payments are one of the key sources of budget revenues. The sovereign right of the state is anchored in the collection of taxes (Karaseva, 2001: 99, 107). "A significant proportion of tax sources in the budgets of many countries plays the [key] role in tax revenues for the stable development of the economy and national security" (Zhuravleva, Izmailova 2011: 23-26). According to experts' estimates, the tax system of the Russian Federation is close to the average world standards, while the simplicity of the interaction of taxpayers with tax authorities is quite lower than world standards. In such circumstances, the main reserve of leveling tax threats to national security is the improvement of tax administration and of the collection of taxes as its key component.

\section{Essence of National Security}

There are many similar categories connected to security: these are public security, national security, public security etc. The views of researchers on the interrelation of these categories vary widely: from identification (Redkous, 2011: 
14) to delimitation depending on the subject (the state, the titular nation, society) (Kortunov, 2007: 18). In the Russian Constitution, there are three main varieties of the security highlighted: "state security" (Constitution, Art. 13/5), "safety of citizens" (Constitution, Art. 56/1), "public security" (Constitution, Art. 72/1). The most well-reasoned, and therefore is a preferred one is a position, representing the national security as a generic term, and state security, public security, and personal security - as the species selected depending on the subject whose interests are protected (Yurchenko, Davydov, 2011: 169-173).

National security, in our view, is unacceptable to be understood in the context of protecting the interests of the titular nation, as a minimum, because the adjective "national" is derived from the English "nation", indicating not only and not so much a nation (people) but the state. Based on the National Security Strategy, the latter involves the security of the state, society and the individual in their unity.

That's why the state security, public security, and personal security should be viewed as elements of a single system of national security. "Security of the State, of society and of the individual are in dialectical relationships" (Litvinov, 2012: 67), that is based on the unity and mutual responsibility (Bashuk, 2013: 350-353). This approach involves the community on a fundamental level of the interests and needs of each security actor. That's why in the state-building process it is unacceptable to eliminate the threats to state security by infringing on the vital interests of the individual. "Security of the integrated complex social system as a set of interconnected structural elements is determined by the security of its weakest structural element" (Litvinov, 2012: 67).

That is why the full and effective implementation of the rights and legitimate interests of citizens and companies as taxpayers equally meets the needs of national security as the protection of the interests of the state as a whole.

\section{Essence of Tax Sovereignty}

The national security in general and the fiscal security, in particular, are achievable only if the true state sovereignty exists. It is possible to distinguish economic sovereignty, part of which the fiscal sovereignty is, in the structure of state sovereignty (Ostroukhov, 2009: 20). Categories of tax and fiscal sovereignty, are often used as synonyms in the legal acts and legal literature (Havanova, 2013: 41-51; Solovyova, 2015: 200; Shakhmametiev, 2014: 121). We can hardly agree with such an identification because even etymologically fiscal sovereignty (from the Latin fiscus) refers to the collection of not only fiscal but all of the budget revenues. 
There is no legal definition of tax sovereignty in Russian legal system. Some of its elements are disclosed in decisions of the Constitutional Court of the Russian Federation: there is recognition by the international community of the rights of the state to impose and collect taxes on its territory (Constitutional Court, no. 1572-O-O/2010) by enforcement unilateral actions (Constitutional Court, no. 16$\mathrm{P} / 2016$ ); the right of the state to determine indicators of assessment the financial and economic activity of the taxpayer needed for tax purposes (Constitutional Court, no. 24-P/1998). Being the kind of state sovereignty, tax sovereignty has all its attributes in the field of taxation. The Russian Constitutional Court explained that such attributes include "the supremacy, the independence, and autonomy of state power, the fullness of legislative, executive and judicial authority of the state over its territory and independence in international communication".

In the context of the tax sovereignty, the supremacy refers to the ability of the state power to impose and collect taxes and charges on the entire territory of the country in respect of any groups and individuals, regardless of their will. The independence of the state power in the field of taxation means the ability to define and implement tax policies, without being influenced by foreign governments or certain groups of taxpayers inside the country, including acting in the interests of the entire state population.

The autonomy of the state authorities is also closely connected to independence. This attribute indicates that, contrary to popular opinion (Shakhmametiev, 2014: 121; Krivyh, 2009: 44), the conclusion of international treaties, in which the state assumes the obligations in the field of taxation, does not limit tax sovereignty, but on the contrary, it is one of the ways of its realization. The possibility of denunciation of the treaties, if they cease to meet the interests of the state and will create a threat to its tax security, is not excluded. International cooperation in the area of collection taxes (the exchange of tax information, combating tax crimes, joint activities of tax authorities of various states) significantly contributes to tax security of each state.

In some aspects tax, sovereignty can be limited by the existence of the universally recognized principles and norms of international law, operating in the territory of the country directly, even if they contradict the decisions taken by bodies of the state. According to A.V. Demin, "the maintenance of tax rules is being more and more influenced by the will of the international community, which significantly limits the fiscal sovereignty and law-making discretion of the States" (Demin, 2015: 187).

It is difficult to agree with M. Orlov in his opinion that taxes are the form of limitation of the fiscal sovereignty (Orlov, 2006: 19). Taxes as compulsory payments are the manifestation of the sovereignty of the state. Legal principles of 
taxation limit sovereignty to a reasonable extent. Illustrating this limitation, the Constitutional Court of the Russian Federation noted that, although the legislator is acting within its discretionary powers while in determining the tax liabilities and possessing fiscal sovereignty, tax regulation should have a sufficient degree of certainty. Tax sovereignty can be limited (but only by the national courts) in the case and to the extent when decisions of legislative bodies in the tax area are going to become a threat to national fiscal security. Thus, Art. 2/4 of the General Part of the Tax Code of the Republic of Belarus prohibits the establishment of taxes, dues (duties) and benefits which can threat to national security of Belarus, its territorial integrity, political and economic stability (Pilipenko, 2006: 21-31).

Full power means the ability of the state to exercise legislative power, governance and law enforcement in tax relations throughout the country without the need of anyone to agree on decisions. It is difficult to accept the position that every subject of tax policy (including regions and municipalities) may have sovereignty within the limited powers (Ovchinnikova, 2008: 56).

Scholars of constitutional law mention the unity of state power as an important sign of sovereignty (Kazannik, Kostyukov, 2016: 7). With regard to the field of taxation, the unity means the system integrity of the bodies forming and implementing tax policy (Ministry of Finance of Russia and his subordinate authorities). From the standpoint of maintaining the tax sovereignty the Russian legislator's decision to transfer the right to initiate the criminal prosecution for tax crimes from the specialized system of tax authorities to the investigation bodies should be assessed negatively. On the contrary, from the viewpoint of the unity of state power, the tax authorities should be empowered to operational and investigative activities.

It is unacceptable to reduce the implementation of tax sovereignty only to the imposition and collection of taxes. The external manifestation of tax sovereignty includes:

- the imposing of taxes on the territory of the state (Kucherov, 2009: 191; Orlov, 2006: 19), as well as for the entities, economically related with the state;

- the collection of taxes, including their unilateral recovery (Gaudmet, 1978: 371), as well as the rejection of their collection ("tax amnesty") (Pokachalova, Belova, 2015: 28-31);

- establishing and implementing control and accountability mechanisms in the tax field (Pogorletskiy, 2005: 10);

- the resolution of disputes between the participants of tax relations (Ovsyannikov, 2001: 11-12). 
Thus, essential characteristics and forms of implementation of tax sovereignty are in a systemic relationship. Because it is difficult to agree with the view that, by their nature, tax sovereignty is a set of fragmented principles, entered the practice of states though (Kudryashova, 2005: 35-43).

\section{Key Features of National Fiscal Security}

There are a few scientific approaches to the content of "security" as the general category and to the category of "national security":

- Security as a characteristic of the society as of a complex system in its functioning and development (systematic approach) (Stepashin, 1994: 23; Polikarpov, 2001: 109).

- Security as the level of public relations, ensuring their further sustainable development (sociological approach) (Mikhalkin, 1993: 48).

- Security as a conscious need of the subject, or the value (axiological approach) (Rybalkin, 2006: 52).

- Security as the activity of the subjects to stop threats (dynamic approach) (Timokhin, 1993: 30).

- Security as a condition of protection (Tropin, 2004: 31-35), when there are no danger (Belov, 1994: 88) or threats (static approach) (Rozhdestvenskiy, 1995: 83). In this context, the terms characterizing certain types of national security are classically used in legal research (Mayorov, 1997: 12; Siusiukin, 2004: 8-9) and in legislation.

In the legal sense, taking into account the conventional approaches to the subject of legal regulation, national security should be understood primarily as the level of development of public relations in the state. Etymologically, "security" is "no danger". Because of it, the protection of public relations from the negative impact of threatening their existence should be one of the objectives of national security. The second equal task of national security is the development of public relations according to values established in the society. "The phenomenon of security initially is not associated with the presence of danger, but with the desire of the subject to preserve its existence, the opportunity to continue to develop in accordance with his nature" (Guskov, Reznik, 2013: 18). The preservation of any phenomenon in a dynamically changing world is impossible without continuous improvement of its key elements. Sustainable socio-economic development is identified as one of the goals of national security in the eponymous Strategy approved by the President of the Russian Federation. 
Thus, national security can be defined as a level of development of social relations in the state, in which their protection from internal and external threats is ensured in accordance with national values. In accordance with the above mentioned approach national fiscal security is a level of development of social relations in fiscal sphere when the amount of collecting taxes corresponds to the number of planned tax revenues taking into account the need for full funding of all functions and tasks of the state and municipalities both in the current period and in the future. This level could be achieved only with systematic and continuous work of all participants of public relations.

\section{Threats to Tax Sovereignty and National Fiscal Security}

Taxation in the state can be described as the process aimed at achieving a status of national fiscal security by eliminating its threats and ensure compliance between such process and indicators of the national tax security. The identification of threats and indicators of the national fiscal security allows us to specify the orientation of legal regulation, to prevent the development of negative trends of taxation as a social process by legal methods, as well as to assess the effectiveness of legal means adequately.

The threat is explained in sociological theory as the presence of a certain external objective and subjective factor, which can cause negative and dangerous consequences regardless of the will and behavior of the recipient. The threat is a real possibility of destructive changes caused by external factors in respect of objects, subjects, statuses important and valuable to society and the individual. Keywords in this definition are "the external factors" and "the negative effects". Meanwhile, not only external factors but internal and inherent properties of the object also may become threats to the object of security. Thus, the process of taxation in the state can be influenced destructively by the actions of other states, by the defects of the legal technique of the national tax bills; and by the tax evasion by taxpayers due to their subjective feeling of heaviness of the tax burden.

Thus, the threats to national fiscal security can be defined as the external objective and subjective factors, as well as specific manifestations of the properties of the process of taxation, leading to a lack of tax revenues of the state in comparison with the amount necessary for full funding of all functions and tasks of the state and municipalities both in the current period and in the future. The correspondence between taxes planned and collected while the country's GDP grows and the expenditure obligations of the state and municipalities are executed is the indicator of national tax security. Legal regulation of tax relations should be aimed at eradication the identified threats to the fiscal security and achievement of its 
indicators, by the usage of regulating the impact of legal tools on the process of taxation.

Tax sovereignty of any state is continually subjected to "trial of strength" on the part of other subjects. Threats to tax sovereignty, as well as to tax security, depending on the source of origin can be divided into public (emanating from the authorities of the government and state-like entities) and private (the sources are persons without public-legal status). Threats can be classified into internal and external. Internal threats originate in the territory under the jurisdiction of the state. Among them, there are attempts of the regions to break the unity of the tax system of the country, up to the "tax separatism". Source of occurrence of external threats can be found outside the territory of the State, like actions and decisions of other states or MNEs.

Tax competition may contribute to the improvement of the tax system of competing states. However, in a situation where it is associated with the provision of the benefits of an administrative nature (in particular, concealment of information on the beneficiaries of the business) it is a serious challenge to the sovereignty and security of other countries. The value of tax sovereignty is that its presence allows the state to pursue an independent tax policy to meet their needs of the population living in the territory of the state. Because of it the obstacles in the implementation of tax sovereignty ultimately threaten the national fiscal security.

\section{Ratio of Tax Sovereignty and National Fiscal Security}

Scholars speak about synonymous meanings of the terms "economic sovereignty" and "economic security", and, therefore, their manifestations in the tax field (Boldyrev, 2014: 71-75). We believe that these concepts cannot be synonymous. Providing of peoples' security should be the sole purpose of existence (functioning) of the state and of realization of its sovereignty (Egorov, 2001: 121). The financial activity of the state is carried out "in order to implement the tasks of social and economic development, maintaining national defense and security of the country" (Khimicheva, 2012: 86). Tax, when it is considered from the standpoint of atomic theory (theory of benefits) is a cost made by each person in order to ensure personal and property security by the protection of the state (Montesquieu, 1955: 77). "People agree to pay taxes as a way to reward those who provide services to the people security" (Bastiat, 2006: 232).

Proper collection of taxes is recognized by the Constitutional Court of the Russian Federation as the condition of proper maintenance of functions of public power. According to Art. 55 of the Russian Constitution, the establishment of taxes is a reasonable limitation of private property rights, as it is necessary "in order to protect 
The Role of National Fiscal Security and Tax Sovereignty in Collection of Taxes

the constitutional order, morality, health, rights and lawful interests of others, national defense and state security". "Enforcing tax liabilities is the necessary condition of the financial independence of the state and, consequently, its economic security" (Kucherov, Kikin, 2011: 25). Thus, the tax sovereignty is a key factor in ensuring of the national fiscal security.

\section{Collection of Taxes in the Scope of National Fiscal Security}

Legal ensuring of national fiscal security may be performed by using a range of methods of rulemaking and enforcement nature. Adopting of legal enforcement acts in the sphere of the collection of taxes is a key tool for fiscal authorities in implementing their powers to ensure the national fiscal security, because the effective collection of taxes actually express the force of tax law (Alekseev, 1971: 144). "Tax collection as a form of implementation of the rules of tax law contributes to the development and protection of existing fiscal relations and the formation of new means of creating new legal facts, providing subjective rights and laying the legal obligations on the parties of the tax process, the imposing of tax liability" (Dementiev, 2013: 21).

The above-mentioned tasks of tax collection entirely meet the objectives of ensuring national fiscal security and it allows us to talk about the collection of taxes as a key method of ensuring national fiscal security.

\section{Conclusions}

The interests of the national fiscal security, based on the identified it's sovereign nature, of course, must be taken into account in the tax collection procedures. Ignoring threats of national fiscal security by tax authorities during tax collection reduces the level of security and does not meet the objectives of the implementation of the law in a sovereign state. So the aims of the research were met. It is approved that collection of taxes, being the sign of tax sovereignty, is one of the most important methods of provision for national fiscal security.

\section{References}

Adams, A.B.: National Economic Security, Oklahoma: University of Oklahoma Press, 1936.

Alekseev, S.S.: Социальная ценность права в советском обществе (Social value of law in Soviet society), Moscow: Yurid. lit. Publ., 1971. 
Alting von Geusau, F., Pelkmans, J. (eds.): National Economic Security: Perceptions, Threats, and Policies, Tillburg: John F. Kennedy Institute, 1982.

Bashuk, V.V.: Понимание национальной безопасности в философско-правовом и социокультурном аспектах (Understanding of national security in the philosophical, legal and socio-cultural aspects), Теория и практика общественного развития (Theory and practice of social development) no. 9 (2013).

Bastiat, F: Грабеж по закону (Robbery by law), Chelyabinsk: Socium, 2006.

Belov, P.G.: Системные основы обеспечения национальной безопасности России (Systematic way of ensuring the national security of Russia), Безопасность (Security) no. 6 (1994).

Boldyrev, O.Y.: Вызовы глобализации и проблемы защиты экономического суверенитета государства (The challenges of globalization and problems of protection of the economic sovereignty of the state), Конституционное и муниципальное право (Constitutional and municipal law) no. 5 (2014).

Dementiev, I.V.: Налоговое правоприменение как форма реализации налогового права (Тах enforcement as a form of realization of the tax law), Финансовое право (Finanaial law) no. 6 (2013).

Demin, A.V.: Принцип определенности налогообложения (The principle of certainty in taxation), Moscow: Statut Publ., 2015.

Douma, S.: Optimization of Tax Sovereignty and Free Movement, Amsterdam: IBFD Publications BV, 2011.

Egorov, S.N.: Аксиоматические основы теории права (Axiomatic foundations of the theory of law), Saint-Petersburg: Lexicon Publ., 2001.

Gaudmet, P.М.: Финансовое право (Financial law), Moscow: Yurid. lit. Publ, 1978.

Glennon, M.J.: National Security and Double Government, Oxford: Oxford University Press, 2014.

Guskov, Yu.V., Reznik, E.P.: Безопасность: проблемы постижения сущности (Security: the problem of understanding the nature), Науковедение (Sciencelogy) no. 5 (2013).

Havanova, I.A.: Фискальный (налоговый) суверенитет и его границы в интеграционных образованиях (Fiscal (tax) sovereignty and its borders in integration formations), Журнал российского права (Journal of Russian law) no. 11 (2013).

Jansen, S. (ed.): Fiscal Sovereignty of the Member States in an Internal Market: Past and Future, Amsterdam: Kluwer Law International, 2011.

Karaseva, M.V.: Финансовое правоотношение (Financial relationship), Moscow: Norma Publ., 2001.

Kazannik, A.I., Kostyukov, A.N. (eds.): Конституционное право: Университетский курс (Constitutional law: University course: textbook), vol. 2, Moscow: Prospect Publ., 2016.

Khimicheva, N.I. (ed.): Финансовое право: учебник (Financial law: Textbook), Moscow: Norma Publ., 2012. 
The Role of National Fiscal Security and Tax Sovereignty in Collection of Taxes

Kortunov, S.V.: Концептуальные основы национальной и международной безопасности (Conceptual fundamentals of national and international security), Moscow: HSE Publ., 2007.

Krivyh, I.A.: Источники налогового права Российской Федерации: понятие, проблемы классификации, основные принципы действия (Sources of the tax law of the Russian Federation: concept, classification problems, basic principles of action. Doctor (higher doctorate) Thesis, Ekaterinburg: Ural Federal University, 2009.

Kucherov, I.I.: Теория налогов и сборов (правовые аспекты) (Theory of taxes and duties (legal aspects)), Moscow: Junifor, 2009.

Kucherov, I.I., Kikin, A.I.: Меры налогово-процессуального принуждения (Measures of the tax procedural coercion), Moscow: Jurisprudence, 2011.

Kudryashova, E.V.: Юрисдикция (суверенитет) государств и налоговый иммунитет в области косвенного налогообложения (Jurisdiction (sovereignty) of States and tax the immune system in indirect taxation), Финансовое право (Financial law) no. 10 (2005).

Litvinov, E.P.: Философские основы концепции безопасности (Philosophical foundations of the concept of security), Пространство и время (Space and time) no. 1 (2012).

Mayorov, V.I.: Административно-правовые проблемы управления обеспечением безопасности дорожного движения (Administrative-legal problems of management of safety of traffic. Doctor (higher doctorate) Thesis, Ekaterinburg: Ural Federal University, 1997.

Mikhalkin N.V.: Безопасность Российской Федерации. Вопросы теории и практики (Тhe Security of the Russian Federation. Issues of theory and practice), Moscow: Time Publ., 1993.

Montesquieu, Ch.: The spirit of laws. Selected works, vol. 1, London: Liberty Fund, 1777.

Orlov, M.Yu.: Налог как форма разумного ограничения фискального суверенитета государства (Tax as a form of reasonable limit fiscal sovereignty of the state), Финансовое право (Financial law) no. 2 (2006).

Ostroukhov, B.A.: Международно-правовые проблемы фискального суверенитета государства (International legal and fiscal issues of state sovereignty), Юридический мир (Legal world) no. 3 (2009).

Ovchinnikova, N.O.: Налоговое планирование и налоговый контроль со стороны правоохранительных органов (About tax planning and tax control by law enforcement agencies: a practical guide), Moscow: Dashkov and Co. Publ., 2008.

Ovsyannikov, S.V.: Конституционно-правовые основы налоговых отношений (Constitutional and legal basis of tax relations. Doctor (higher doctorate) Thesis, Saint-Petersburg: SaintPetersburg University, 2001.

Pilipenko, A.А.: Экономико-правовые начала формирования налоговой системы (Economic and legal principles of formation of tax system), Финансовое право (Financial law) no. 10 (2006).

Pogorletskiy, A.I.: Принципы международного налогообложения и международного налогового планирования (Principles of international taxation and international tax planning), Saint-Petersburg: State University Publ., 2005. 
Pokachalova, E.V., Belova, T.A.: «Налоговая амнистия» в системе финансово-правовых понятий и институтов (“Тах Amnesty" in the system of financial and legal concepts and institutions), Налоги (Taxes) no. 2 (2015).

Polikarpov, V.S.: Философия безопасности (Philosophy of security), Saint-Petersburg, Rostov-onDon, Taganrog, 2001.

Redkous, V.M.: Административно-правовое обеспечение национальной безопасности в государствах - участниках Содружества Независимых Государств (Administrativelegal provision of national security in the States - participants of Commonwealth of Independent States). Doctor (higher doctorate) Thesis, Moscow: Moscow State University, 2011.

Rozhdestvenskiy, Yu.V.: Безопасность России и словесность (тезисные суждения) (Security of Russia and the literature (abstracts of judgment)), Безопасность (Security) no. 3 (1995).

Rybalkin, N.N.: Философия безопасности (The philosophy of security), Moscow: MPSI Publ., 2006.

Shakhmametiev, A.А.: Международное налоговое право (International tax law), Moscow: International relations Publ., 2014.

Siusiukin, A.V.: Административно-правовое регулирование экономической безопасности (Administrative-legal regulation of economic security. Doctor (higher doctorate) Thesis, Rostov-on-Don: Southern Federal University, 2004.

Solovyova, N.A. (ed.): 101 термин налогового права: краткое законодательное и доктринальное толкование (101 term of tax law: the legislative and doctrinal interpretation), Moscow: Infotropic Media Publ., 2015.

Stepashin, S.V.: Безопасность человека и общества (политико-правовые вопросы) (The safety of person and society (political and legal issues)), Saint-Petersburg, 1994.

Timokhin, P.P.: К формированию концепции безопасности России (Formation of the concept of Russia’s security), Безопасность (Security) no. 6 (1993).

Tropin, S.A.: Экономическая безопасность России (Economic security of Russia), Законодательство и экономика (Legislation and economics) no. 5 (2004).

Yurchenko, M.V., Davydov, A.V.: Научно-теоретические основания категории «национальная безопасность России» (Scientific-theoretical bases of a category "national security of Russia”), Вестник Бурятского государственного университета (Herald of Buryat State University) no. 6 (2011).

Zhuravleva, O.O., Ismailova, L.Yu.: Проблемы унификации подходов к налоговому администрированию (Problems of unification of approaches to tax administration), Финансовое право (Finanaial law) no. 10 (2011).

RU: Constitutional Court, no. 1572-O-O/2010.

RU: Constitutional Court, no. 16-P/2016.

RU: Constitutional Court, no. 24-P/1998. 


\title{
PREMISES OF GRANTING RELIEFS IN PAYMENT OF TAX LIABILITY
}

\author{
KATARZYNA ŚWIĘCH-KUJAWSKA ${ }^{1}$
}

\begin{abstract}
The paper was devoted to issues related to the premises of granting reliefs in the payment of tax liability. The prime purpose of the study is an in-depth analysis of the conditions of application of the tax preferences in question. The considerations serve to justify the thesis that the main purpose of the application of tax reliefs in the payment of tax liability is to ensure flexibility in the application of tax law. At the same time, the criteria for their application were formulated on the basis of general clauses, which hinders the practical use of this institution. The research used the method of analyzing the legal text and the judicature acquis as well as the tax law doctrine.
\end{abstract}

\section{Keywords}

Tax; tax relief, tax act; tax liability

JEL Classification: E62, K34, K40

\section{Introduction}

The purpose of this paper is to present and analyze the conditions for granting tax reliefs in the payment of tax liability. The structure of the study was adapted to the researched field. The starting point was to present general issues of an introductory nature. Against this backdrop, in-depth discussions were conducted to confirm the basic premise that granting tax reliefs in the payment of tax liability is based on administrative discretion, and the premises of the use of this institution

1 Professor for Financial Law, Chair of Territorial Self-Government Law, Faculty of Law and Administration, University of Szczecin, Poland. Member of Center for Information and Research Organization in Public Finance and Tax Law of Central and Eastern European Countries. Contact email: k.swiech-kujawska@ wpiaus.pl. 
are formulated using general clauses and terms not fully defined, which creates significant doubts in the practical application of these reliefs. For the purpose of conducting research in the indicated scope, the method of analysis of legal acts, the rich case law of administrative courts and the views of doctrine were used. It included study results presented in particular in publications (Redelbach, 1992; Ziembiński, 1989). The state of discussion over the issues of general clauses.

\section{Reliefs in Payment of Tax Liability - Terminological Findings}

The concept of tax reliefs is important for the outlined problem area, and therefore its analysis is indispensable. First and foremost, it should be noted that the legal definition of this term was first introduced into the legal market under the Tax Ordinance Act of 29 August 1997.

According to Art. $3 / 6$ of the aforementioned law, this concept is to be understood as exemptions, deductions, reductions or cuts provided for in the tax law, the application of which results in the reduction of the tax base or the amount of tax, with the exception of the reduction of the tax due by the amount of input tax within the meaning of provisions on goods and services tax, and other deductions forming part of the construction of this tax. In anticipation of further reflection, it should be noted that classifying an exemption as a relief is at least questionable, and one can agree only that its application produces the same or similar effects as those involved in the application of a relief. It is, therefore, possible to appraise the view that tax reliefs within the meaning of the Tax Ordinance Act are tax reliefs sensu largo, which include tax exemptions and tax reliefs sensu stricto (deductions, reductions, cuts) (Nykiel, 1998: 180).

The interpretation of the provision in question should also apply to the scope of the definition contained therein. Its examination leads us to the conclusion that the concept of reliefs defined within it does not cover either the deferment of the tax payment deadline or breaking up the payment into installments (these elements do not result in a reduction of either the tax base or the tax) (Kulicki, 2000: 53). Therefore, the conclusion that the definition of tax reliefs formulated in Art. 3 of the Tax Ordinance Act is applicable only to systemic reliefs, and thus to reliefs which are a structural element of taxation does have ground.

At the same time the legislator entitles Chapter 7a of the Tax Ordinance Act "Reliefs in the payment of tax liability", including in this category: deferment of tax payment deadline or payment of tax in installments, deferment or installment payment of tax arrears together with default interest or interest on unpaid advances on tax, as well as remission in whole or in part of tax arrears, default interest or prolongation fee. 
According to the findings already made, the above reliefs do not fall within the definition of a legal "tax relief". This leads to a direct conclusion that the reliefs referred to in the aforementioned chapter of the Tax Ordinance Act are a separate category from system reliefs.

This allows one to make a general classification of reliefs into so-called system reliefs, within which detailed breakdowns can be performed, and reliefs in the payment of tax liability. The principles and premises of granting them are the subject of in-depth considerations taken in the later sections of this study.

\section{Principles of Granting Reliefs in Payment of Tax Liability}

As noted, tax reliefs constitute a separate category of tax privileges, both in terms of the place of regulation and the rules of application. The direct legal basis for their application is the Tax Ordinance Act, which also defines the rules for granting such preferences. First and foremost, it should be noted that granting tax reliefs in the payment of tax liability is provided through tax proceedings, although the deferral and the redemption themselves are related to the way in which tax liabilities arise and expire. It should be emphasized that the tax procedure is a special type of administrative procedure in which an administrative body is at the same time the body conducting the proceedings and the entity of the material law relation. Its main purpose is therefore to implement the standards of specific tax law. It is stressed that it consists of a whole series of activities of both administration bodies and other participants, aimed at determining the tax liability and its voluntary settlement. This is at the same time in the broad sense a procedure taking into account the specificity of tax law, such as the self-assessment of tax and the calculation of tax by the payer (Mastalski, 2000: 231).

In the context of the above statements, it is indispensable to cite the definition of tax liability as determining the scope of application of the outlined institution. In the light of the Tax Ordinance Act, the tax liability is taxpayer's liability resulting from the tax obligation to pay tax to the State Treasury, voivodship, county or commune in the amount, within the time limit and at the place specified in the tax law. The specifics of this must involve the taxpayer, the amount of the performance (tax), the date and place of payment. Accordingly, the tax liability is most often referred to as the specification of the tax obligation. In such a sense, it should be assumed that this is a secondary concept, "outflowing" from the tax obligation, constitutes its normative consequence, i.e. the arising of tax liability is a consequence of facts, having a legal significance, whose source can only be a tax obligation specified in the law (Olszowy, 1997: 22). Because of this, it is particularly important to correctly define tax obligation; defectiveness of this construction may prejudice the 
impossibility of concretizing into a tax liability. This leads to the conclusion that the fulfillment of the conditions specified in the tax law norm (the existence of the indicated facts) is the basis for establishing a relationship which is a tax obligation. Like any legal relationship, it has a specific content. In this case, it is always the duty of a specific tax-related behavior.

In conclusion, it must be noted that the interpretation of the title of Chapter 7a of the Tax Ordinance Act referred to at the beginning and the provisions contained therein indicates that the reliefs in question refer to tax liability, i.e. granting them is only possible in respect of tax obligations already reclassified as a legal relationship of a tax liability. Apart from that, the essential features of the institution in question need to include their application, in principle, upon request. The principle that the tax authority decides on granting a relief on the basis of the so-administrative discretion is fundamental for the outlined subject area. That is why they are sometimes referred to as discretionary reliefs. Therefore, it is indispensable to refer to the issue of administrative discretion. We are faced with it when a legal norm does not unambiguously define consequences but allows the body to make choices, leaving a considerable degree of freedom in defining them. This amounts to the establishment of a norm's legal effect by an administration body (Mincer, 1976: 63). In other words, it is combined with the granting to an administrative body the capacity to shape a legal position of the addressee of the norm through specific legal acts, in particular, the administrative act (Nowacki, 1986: 40).

It should be emphasized that a discretionary decision is one that the legislature itself clearly recognizes as such (Filipek, 1997: 47-48). In practice, granting a body the authority to use the institution in question is expressed in the words "the body may". It is also significant to define the scope of the freedom of action of a body using specific types of directives. These are guidelines for the body making the decision. Their common feature is that they are para-legal or non-legal rules, and when formulating them, the legislator usually uses undefined phrases or general clauses ${ }^{2}$. It should also be stressed that in any case of the application of administrative discretion the body must take into account the rules of conduct established by the relevant provisions (Ochendowski, 1997: 132), e.g. tax procedure from the Tax Ordinance Act, such as the principle of reasoning, trust. It should also be noted that the judicial review of discretionary decisions is limited and boils down to an assessment whether the deciding authority has investigated the issue in terms of statutory directives as well as whether it collected and considered all the evidence in the case (Voivodship Administrative Court: I SA/Lu 944/12, Voivodship Administrative Court: I SA/Po 315/15). On the other hand, the misapplication of a provision as the legal basis for a decision, where there is a rule of law giving rise to 
a decision, does not constitute such defectiveness which would justify reversing the decision (Supreme Administrative Court: SA/Wr 3095/95).

\section{Premises of Granting Discretionary Reliefs}

Granting one of the reliefs in the payment of tax liability requires, as has already been emphasized, the conduct of tax proceedings, which are not of a particular nature or distinct from other proceedings covered by the regulations of the Tax Ordinance Act. The subject of this procedure is the attribute (Brolik, 2012: 40). Employing the institution of administrative discretion means that the tax authority may but does not have to issue a positive decision, i.e. the application of the relief established within it is a right and not a duty of the tax authorities. The authority, however, is not exempted from the obligation to carry out complete and precise findings of fact and to assess whether the circumstances of the case correspond to the conditions for granting the relief sought. When justifying the discretionary decision, the authority must provide clear and convincing arguments both as regards facts and law. Recognizing that the party is in a situation where it is possible to grant a relief under the procedure indicated in the law, the authority is obliged to explain reasonably why, under administrative discretion, it refuses to grant it or grants it in the amount lower than expected by the party (Supreme Administrative Court: OSK 1334/14). Basically, as already indicated, this procedure is initiated by the taxpayer's request, and for business entities, additional conditions for granting tax preferences have been introduced.

However, for the subject area under discussion, premises of granting one of the reliefs in the payment of tax liability indicated at the outset are of fundamental importance. According to Art. 67a of the Tax Ordinance Act the tax authority may grant a relief in cases justified by an important interest of the taxpayer or of the public interest. As it clearly results from this, the assurance of flexibility in the application of tax law is to be served by the use of undefined phrases and general clauses. It should be noted here that in the provision referred to the clause was placed first and only then a vague phrase was used. Doing so impacts a high degree of flexibility of the text (Borszowski, 2017: 172).

As already mentioned, the premises of granting reliefs in the payment of tax liability are formulated using vague terms and general clauses. Because of their function, general clauses should be the subject of theoretical analysis. First of all, it should be emphasized that they are treated as one of the groups of undefined phrases, which, among others, prejudges the fact that they also fall under means of achieving flexibility of the law. They are, at the same time, a frequently used means by which directives for the authority exercising the law are formulated, 
specifically for the body Authorized to use the decision-making freedom (they affect the scope of this freedom). According to L. Leszczyński, general clauses allow the content of the law to be opened, which is to be understood as transferring part of the responsibility for the content of the law from the bodies that constitute them - to the authorities exercising the law. This is due to the extension of the share of legal practice, which makes decisions on the application of the law, also on the basis of the criteria indicated in these clauses, in determining the content of the law being created (Leszczyński, 2000: 4). The common (and not controversial) feature of views formulated by the science is a statement that general clauses contain a reference to a normative system separate from the law (Wójcik, 1987: 124) (nonlegal system).

It is also generally assumed that these clauses are related to all cases in which the authority exercising law derives its authority to be directed not only by the content of positive law based on written sources (legal texts) or possibly binding precedents on the ground of sufficiently developed doctrine, but also by some evaluations or non-legal directives, whose character is often the subject of ongoing litigation (Ziembiński, 1989: 14).

It should also be noted that in the literature there is no clearly formulated definition of the clauses under discussion. It is, however, desirable to present their representative terms. According to the first definition of general clauses, contained in the Small Encyclopedia of Law of 1959, a general clause is a legal provision that aims to achieve flexibility in the application of law by the use of general concepts subject to the assessment of the authority exercising (Dąbkowski, 1960: 235). T. Zieliński acknowledged the fact that it is not limited to specifying the defined concept but also points out what the function of a provision (phrase) constituting a general clause is (it seeks to achieve flexibility in the application of the law). The metaphorical word "flexibility" is not a juridically precise phrase (Zieliński, 1988: 35). On account of that, the Author proposed that general clauses be defined as non-specific phrases referring to extra-legal rules and assessments that allow the authorities exercising the law to decide on the application of the rules in force and thus to treat each case individually. According to this concept, general clauses include both phrases containing direct references to extra-legal rules (norms), as well as phrases and expressions that have different "denotations" depending on the assessment used by interpreters in specific situations (Zieliński, 1988: 56). Diversification of these assessments allows for individual treatment of each case.

In turn, given the role of general clauses in the legal text, two types of general clauses were distinguished: 
1) Classic general clauses - which consist in giving the authority exercising the law the capacity to exercise individual judgments of a particular situation or certain principles of conduct of axiological justification, not formulated in the law, when deciding on particular cases (Redelbach, 1992: 260). In this case, reference may be made to certain extra-legal standards, extra-legal rules of conduct, i.e. directives of a general nature.

An assumption needs to be made here that an orderly system of values, evaluations, and norms to which reference is possible is valid. It also does not mean that it is not evolutionary, but it is sufficient that it is stable enough to be helpful (constitute the basis) for certain determinations. One of the roles of the legislator, in this case, is to closely monitor the changes taking place, so that, if necessary, appropriate amendments in the legal regulation are made.

On the one hand, this allows the flexibility of the law to be maximized as the body has the power to individualize the decisions being made, but on the other hand, there is a danger of inconsistency in the decisions taken by the authority. In practice, leaving the body with complete freedom of judgment could lead to the absence of any control and to the arbitrariness of the decisions taken too far.

2) Functional general clauses - related to the deliberate introduction of undefined terms into the text of legal acts, the interpretation of which every time is most frequently associated with the evaluative issue of the authority exercising the law (Redelbach, 1992: 260).

At this point in the study, it is appropriate to analyze the general clauses used by the legislator in the aforementioned Art. 67a of the Tax Ordinance Act. The existence of an important interest of the taxpayer or of the public interest is a necessary condition for a favorable consideration of the taxpayer's request while being subject to the assessment of the tax authority. The terms "taxpayer's interest" and "public interest" play a key role. In the first place, it should be noted that legal science deals more with explaining the role of the concept of interest in lawmaking and the application of law rather than defining it (Presnarowicz, 1998: 31).

However, it is pointed out that the term "interest" can be understood as "a state of a certain tension that ceases at the moment of satisfying the interest or the relationship arising between man and something conceived or existing as a result of desiring this thing by man". "Good", serving to satisfy the interest, is usually distinguished from the interest (Lang, 1997: 129-130).

The clustering itself of the word "interest" with the words "public" or "taxpayer's" means that they are completely different categories. When referring to the public interest, what is pointed to is the manner in which it is expressed and what is 
relevant here is the fact that all the findings are of a general nature. Individual interest, however, is identified with the sphere of powers, needs, or values perceived by a particular subject who refers to them or to whom it is referred (Orłowski, 2000: 96).

One can conclude from this that the interest of the taxpayer will involve the desire to preserve the benefits (values) already in hand or the state of waiting for a new good (Presnarowicz, 1998: 30). There is no obstacle than to perceive it as a relation between an objective state and an evaluation of that state from the point of view of the benefits it does or may bring to the individual (Lang, 1997: 139). The legislator also exposes the gradation of "interest", which must be "important" to allow preferential treatment of the person presenting that interest. The term "public interest" is most often associated with the fact of socialization of an individual and is sometimes perceived as a result of individual interests (Zdyb, 1993: 298). It is permissible to talk about it as the interest of the state representing all its citizens. There is often conflict between the private interest and the public interest, and it is, therefore, essential to work out a certain type of compromise. This is all the more difficult when it comes to "the consensus between values symbolizing individual freedoms and values that symbolize certain necessities conditioning public order" (Zdyb, 1993: 302).

It is concluded that the precise distinction between the "important interest of taxpayers" and the "legitimate public interest" is at times impossible in practice, sometimes the same premises can be the basis for referring to one of these "interests" when the latter are equated. In view of the above, it cannot be accepted that tax authorities are required to settle cases taking into account the taxpayer's important interest unless precluded by public interest - by which the tax authority seems to understand the interest of the state budget. The conjugate "or" as used in the Tax Ordinance Act denotes a possibility of exchange which entails that both of these conditions are of equal character (Supreme Administrative Court: I SA/Lu 1770/98; Supreme Administrative Court: II FSK 510/11).

The natural consequence of the use of general clauses in the content of the Tax Ordinance Act as regards granting tax reliefs in the payment of tax liability is to interpret the conditions for the application of these reliefs by the authorities exercising the law. It is characteristic that a certain attempt to systematize the notions is made by the judicature. The case law of administrative courts in this area is extremely rich. Its analysis allows for further findings. First and foremost, it has been signaled that the condition of "the taxpayer's important interest" requires the determination of the financial and material situation of the party and the economic effects that would arise as a result of fulfilling the obligation, since the existence of an important interest of the applicant is not determined by the subjective conviction 
of the party. The term "public interest" is to be understood as a directive for conduct which requires taking account of the respect of the entire society's common values such as: justice, equality, security, citizens' confidence in the authorities, the efficiency of action of the state apparatus, correcting wrong decisions as well as a situation where the payment of tax liability results in the taxpayer's need to seek state aid measures. When examining the case, the authority should also each and every time determines what is more advantageous from the point of view of the public interest (pursuing claims or application of relief) (Voivodship Administrative Court: I SA/Gd 362/17; Voivodship Administrative Court: I SA/Sz 1063/16).

It is therefore justified to state that the evaluative nature of the directives has a significant impact on judicial decisions in which these conditions are specified. In a rather uniform pattern of deciding, it is assumed that the taxpayer's important interest involves a situation where, due to extraordinary, random circumstances, the taxpayer is not in a position to pay tax arrears. It will be the loss of opportunity to earn money, loss of property. On the other hand, the public interest means a situation where the payment of tax arrears will require the taxpayer to seek state aid because he will not be able to meet his material needs (Supreme Administrative Court: SA/Sz 850/98).

Accordingly, the granting of a relief is justified in those cases which have been caused by factors which the taxpayer has no influence on and which are independent of the manner of his conduct (Supreme Administrative Court: III SA 372/99, as well as Supreme Administrative Court: I SA/Kr 983/98, Supreme Administrative Court: I SA/Lu 1485/98). Not only emergency situations, but also a regular economic situation, the amount of income earned and expenditure incurred by the party should be taken into account (Voivodship Administrative Court: I SA/Op 111/17; Supreme Administrative Court: I FSK 31/08; Supreme Administrative Court: II FSK 1134/15).

In this respect, one of the rulings is characteristic where it was specified that even a serious illness of a taxpayer and his wife, which qualifies as taxpayer's important interest, is not sufficient to grant a relief in the form of a remission of tax. It is necessary to analyze the material situation of the party (Voivodship Administrative Court: I SA/Po 1281/16). This implies an assessment of the real material situation of the taxpayer, which affects the existence of a condition for granting a relief, even though not exhaustive of the term "taxpayer's important interest".

In conclusion, the terms "important interest of the taxpayer" and "public interest" are to be referred each and every time to the specific situation of the taxpayer in the course of tax proceedings, reflecting theoretical assumptions underlying the use of the institution of general clauses. 


\section{Conclusions}

The primary, although not the sole, function of taxes is the fiscal function. Regulations of the general part of tax law serve to feed the state budget and the budgets of local government units with tax revenues. In practice, unconditional enforcement of tax liability could, however, lead to a violation of legally protected values. Hence, it was necessary to ensure flexibility in the application of the levy law. Institutions of protection of interests of taxpayers include among others reliefs based on administrative discretion, which leaves the tax authority with a wide margin in decision-making. Even if the statutory conditions are met, the authority may refuse to grant the privilege to the applicant.

The legal basis for the use of reliefs in the payment of tax liability is set out in the Tax Ordinance Act, which suggests that the introduction of legal regulations in an act of a general nature gives the possibility of applying them to all currently applicable taxes. Only the rules for handling them with regard to taxpayers conducting business activity were defined in a more rigorous way. In the legal structure of the institution in question, general clauses and vague phrases have been used whose practical use has given rise to a number of interpretative doubts. Irrespective of this, the adoption of such a solution should be assessed as unequivocally positive. Allowing tax authorities to make decisions with some freedom makes it possible to individualize the tax burden, which is extremely important, especially in intrusive tax law.

\section{References}

Bogucka, I.: Państwo prawne a problem uznania administracyjnego (Rule of law and the problem of administrative discretion), Państwo i Prawo (State and Law) no. 10 (1992).

Borszowski, P.: Określenia nieostre i klauzule generalne w prawie podatkowym (Vague terms and general clauses in tax law), Warszawa: Wolters Kluwer, 2017.

Brolik, J.: Postępowanie podatkowe w przedmiocie ulg w spłacie zobowiązań podatkowych $\mathrm{z}$ art. $67 a \S 1$ ordynacji podatkowej (Tax proceedings in the scope of reliefs in the payment of tax liability pursuant to Article 67a $\$ 1$ of the Tax Ordinance Act), Przegląd Podatkowy (Tax Review) no. 8 (2012).

Dąbkowski, S. (ed.): Mała Encyklopedia Prawa (Small Encyclopaedia of Law), Warszawa: PWN, 1960.

Filipek, J.: W sprawie uznania administracyjnego (On administrative discretion), Przegląd Prawa i Administracji (Law and Administration Review) vol. XXXVIII (1997).

Kulicki, J.: Konstytucyjne podstawy nakładania podatków (Constitutional basis for levying taxes), Prawo Spółek (Company Law) no. 3 (2000). 
Lang, J.: Z rozważań nad pojęciem interesu w prawie administracyjnym (Considerations on taking up interest in administrative law), Przegląd Prawa i Administracji (Law and Administration Review) no. 38 (1997).

Leszczyński, L.: Funkcje klauzul odsyłających a model ich tworzenia w systemie prawa (Functions of referring clauses and the model of their creation in the system of law), Państwo i Prawo (State and Law) no. 7 (2000).

Mastalski, R.: Prawo podatkowe (Tax law), Warszawa: C.H. Beck, 2000.

Mincer, M.: Pojęcie uznania administracyjnego (The concept of administrative discretion), Państwo i Prawo (State and Law) no. 3 (1976).

Nowacki, K.: Kontrola decyzji opartych na uznaniu administracyjnym (Review of decisions based on administrative discretion), Wrocław: Uniwersytet Wrocławski, 1986.

Nykiel, W.: Zwolnienia i ulgi podatkowe a konstrukcja podatku (wybrane zagadnienia) (Tax exemptions and reliefs and the structure of tax (selected issues)), in: Brzeziński, B. et al.: Księga pamiątkowa ku czci Profesora Apoloniusza Kosteckiego. Studia z dziedziny prawa podatkowego (Professor Apoloniusz Kostecki's commemorative book. Studies in the area of tax law), Toruń: TNOiK Dom Organizoatora, 1998.

Ochendowski, E., Prawo administracyjne (Administrative law), Toruń: TNOiK Dom Organizatora, 1997.

Olszowy, W.: Decyzja podatkowa, podejmowanie i kontrola (Tax decision. Taking and review), Warszawa: KiK, 1997.

Orłowski, J.: Przesłanki umorzenia zaległości podatkowych w ordynacji podatkowej (Conditions for writing off tax arrears in the Tax Ordinance Act), Radca Prawny (Legal Adviser) no. 4 (2000).

Presnarowicz, S.: Zwolnienia i ulgi uznaniowe - przesłanki rozstrzygnięć (Discretionary exemptions and reliefs - conditions for decisions), Przegląd Podatkowy (Tax Review) no. 7 (1998).

Redelbach, A. et al: Zarys teorii państwa i prawa (Outline of the theory of state and law), Warszawa: PWN, 1992.

Wójcik, K.: Klauzule generalne jako odesłanie pozasystemowe (General clauses as non-system, referral), Acta Universitatis Lodziensis no. 32 (1987).

Zdyb, M.: Interes jednostki a interes publiczny (społeczny). Konflikt interesów (Individual interest and public (social) interest. Conflict of interests), Zeszyty Naukowe Uniwersytetu Marii Curie-Skłodowskiej w Lublinie (Scientific Papers of the Maria Curie-Skłodowska University in Lublin) no. 31 (1993).

Zieliński, T.: Klauzule generalne w prawie pracy (General clauses in labour law), Warszawa: PWN, 1988.

Ziembiński, Z.: Stan dyskusji nad problematyką klauzul generalnych (The state of discussion over the issues of general clauses), Państwo i Prawo (State and Law) no. 3 (1989).

PL: Tax Ordinance Act of 29 August 1997. 
PL: Supreme Administrative Court: SA/Wr 3095/95.

PL: Supreme Administrative Court: SA/Sz 850/98.

PL: Supreme Administrative Court: I SA/Lu 1485/98.

PL: Supreme Administrative Court: I SA/Kr 983/98.

PL: Supreme Administrative Court: III SA 372/99.

PL: Supreme Administrative Court: I SA/Lu 1770/98.

PL: Supreme Administrative Court: I FSK 31/08.

PL: Supreme Administrative Court: II FSK 510/11.

PL: Supreme Administrative Court: II FSK 1134/15.

PL: Voivodship Administrative Court: I SA/Lu 944/12.

PL: Voivodship Administrative Court: I SA/Po 315/15.

PL: Voivodship Administrative Court: OSK 1334/14.

PL: Voivodship Administrative Court: I SA/Po 1281/16.

PL: Voivodship Administrative Court: I SA/Op 111/17.

PL: Voivodship Administrative Court: I SA/Sz 1063/16.

PL: Voivodship Administrative Court: I SA/Gd 362/17. 


\title{
A POVIAT GOVERNOR AS A PARTY TO THE AGREEMENT TRANSFERRING THE OWNERSHIP OF OBJECTS AND PROPERTY RIGHTS TO THE STATE TREASURY OR A LOCAL GOVERNMENT UNIT IN EXCHANGE FOR TAX ARREARS
}

\author{
MAEGORZATA OFIARSKA ${ }^{l}$
}

\begin{abstract}
The aim of the article is the analysis and evaluation of the legislation applicable within the scope of using a specific manner of expiry of a tax liability, which is transferring of the ownership of an object or property rights by the obligor to the State Treasury or a local government unit and, thus, carrying out of the liability in kind. The main objective of the study has been achieved by proving that, depending on the type of tax arrears, i.e. due to the State Treasury or a poviat, what changes the scope of powers and duties, which are the essence of the functions performed by a poviat governor. As a result of the conclusion of the agreement transferring the ownership of objects and property rights to the State Treasury in exchange for tax arrears, the tax liability expires, yet, it is executed only exceptionally in kind and not in a pecuniary form. The study uses the dogmatic-legal method in order to examine the normative material and the achievements of the doctrine as well as the empirical method necessary for the examination of the court rulings.
\end{abstract}

Keywords

Poviat governor; tax arrears; agreement; State Treasury; local government unit

\section{JEL Classification: H7, K34, K12}

1 Professor of University of Szczecin, Doctor of Law, Head of the Department of Local Government Law, Faculty of Law and Administration, University of Szczecin, Poland. The Author of over 250 publications, including 10 books, 40 articles, 94 studies in joint works and other electronic publications. Specialises in local government law and administrative enforcement proceedings. He is a member of Information and Organization Centre for the Research on the Public Finances and Tax Law in the Countries of Central and Eastern Europe. Contact email: malgorzata.ofiarska@usz.edu.pl. 


\section{Introduction}

The aim of the study is the analysis and evaluation of the legislation applicable within the scope of using a specific manner of expiry of a tax liability, which is transferring of the ownership of objects or property rights by the obligor to the State Treasury or a local government unit (ins short LGU) and, thus, carrying out of the liability in kind. A tax liability is, in fact, carried out in the financial form because one of the most significant features of a tax mentioned under Art. 6 of the Tax Ordinance Act (further TOA) is the financial nature of this regulatory, gratuitous, compulsory and non-returnable performance for the benefit of the State Treasury, a voivodeship, poviat or commune. Taxes belong to the category "finance", which only refers to economic phenomena connected with gathering and division of financial resources. Thus, benefits in kind, personal services, objects and property rights are not taxes. In general, a tax shall not have the in-kind form (Gomułowicz, 2016: 146). Currently, the form of settling tax liabilities in kind has not been completely eliminated. It has remained in a rudimentary form as a specific manner of being exempted from a tax liability. Its use enables the State Treasury or any other Authorized entity to acquire some entities of interest, thus, increasing the national property (Bouvier, 2000: 24).

The financial nature of the tax is not questioned currently. Nevertheless, the obliged entity may sometimes be exempted from the obligation to pay tax through the provision of some benefits in kind (Brzeziński, 2001: 31). In a special situation, the legislator allows a possibility to perform a tax liability by transferring the ownership of objects or property rights (Brzeziński, Olesińska 2014: 31). This, nevertheless, requires the use of proper procedures and the necessary initiative within this scope on the side of the obliged entity (taxpayer). As a part of the applicable procedures, a specific role is ascribed to a poviat governor (pl. starosta), who represents respectively the interest of the State Treasury (if the tax receivable should enter the state budget) or the interest of the poviat (if the receivable for the specific public levy should enter the poviat budget). In the other cases, the interests of the respective LGU are represented by a commune administrator (pl. wójt), a town mayor (pl. burmistrz) or a city mayor (pl. prezydent miasta) (in the case of any receivables due to a commune) or a voivodeship governor (pl. marszałek województwa) (in the case of any receivables due to the voivodeship local government).

The study is to prove that a poviat governor - as a party to an agreement with a taxpayer concerning a transfer of the ownership of objects or property rights in exchange for taxpayer's tax arrears - enters into multilateral relationships with a taxpayer, the head of a tax office as well as the poviat executive body and legislative body. Only a poviat governor appears in a double role, i.e. as a representative of the 
A Poviat Governor as a Party to the Agreement Transferring the Ownership...

interests of the State Treasury or the poviat. A tax liability for the benefit of a poviat shall not be understood in a narrow manner and limited only to a tax. The model of poviat's own revenues adopted in Poland ${ }^{2}$ is not perfect because it does not include any local taxes, but only fees the payments of which constitute the revenues of a poviat pursuant to separate provisions of the act (e.g. waste storage and warehousing fees $^{3}$, mining fees for searching for and recognizing of a hydrocarbon deposit ${ }^{4}$, fees for activities related to maintaining of the poviat geodetic and cartographic resources $^{5}$, fees for issuing of vehicle registration cards ${ }^{6}$ ). The phrase "expiry of a tax liability" used in the content of Art. 66/1 of TOA should refer not only to a tax but also to any other public levies whereto the provisions of this act apply. Pursuant to Art. 2 of TOA, the provisions of this act apply to taxes, fees and nontax dues to the state budget and budgets of LGU, which the tax authorities or any other authorities empowered based on separate provisions, are entitled to establish or determine. The subjective and objective frames of applying the provisions of Tax Ordinance have been determined relatively broadly (Brzezicki, Morawski, 2009: 514), and, thus, the phrase "expiry of a tax liability" should also refer to other public levies.

The analysis and evaluation of the applicable legislation is supposed to lead to verification of the thesis, pursuant to which a rational legislator creates conditions facilitating the performance of a tax liability, even in a specific manner due to the fact of a temporary or definitive loss of the ability to settle the liabilities with the use of any means of payment. The possibility to use a specific manner of a tax liability settlement, which is transferring of the ownership of objects or property rights by the obligor to the State Treasury or LGU, simultaneously protects the obligor's interests because it does not lead to any additional encumbrances related to performance of the liability and, in particular, any enforcement costs or default interest. The study uses the dogmatic-legal method (examination of the normative material and the achievements of the doctrine) as well as the empirical method (examination of the court rulings). It has been established, first of all, that the application of this specific manner of performing a tax liability (performance in kind) is permissible upon an obligor's request and consent of the entity representing the interests of the State Treasury or LGU. Both conditions have to be fulfilled jointly (the obligor's request and the tax obligee's consent). The dual role of a poviat governor within this scope is shaped by the provisions of the local government constitutional law, tax law and local government financial law (also determining the sources of poviats' revenues).

Cf Art. 5 of the Act on revenues of local government units.

Cf Art. 402 of the Environmental Protection Law Act.

Cf Art. 141 of the Geological and Mining Law Act.

Cf Art. 41b of the Geodetic and Cartographic Law Act.

Cf Art. 77 of the Road Traffic Law Act. 
Significant findings have been made based on the achievements of the doctrine, including the doctrine of the local government law and the tax law. So far, there has been no study in the literature on the subject where the legal position and the functions of a poviat governor would be analysed in such detail in the context of applying a specific manner of expiry of tax arrears through a contractual transfer by a taxpayer of the ownership of objects or property rights for the benefit of the State Treasury or a poviat.

\section{Selected Problems Concerning Status of Poviat Governor in Local Government Law Tax Law}

The legal position of a poviat governor is mostly shaped by all the provisions of the Poviat Local Government Act (further PLGA). A poviat governor elected by the legislative body of a poviat is a member of the poviat board (the poviat executive body), being its chairman (Art. 26/2 of PLGA). A poviat governor organizes the work of the poviat board and the poviat office, supervises the current affairs of the poviat and represents the poviat outside, develops an operational plan of flood protection as well as announces and recalls a flood emergency and alarm (Art. 34 of PLGA). It is a public administration authority of the first instance issuing administrative decisions in individual matters within the scope of public administration (Art. 38 of PLGA).

Pursuant to the provisions of Art. 13/1/1 of TOA, a poviat governor is a tax authority of the first instance as regards public charges and non-tax budget dues which are the sources of poviat's own revenues (e.g. fees for issuing of vehicle registration cards). In these cases, a poviat office shall not replace a poviat governor as an authority as it is only an auxiliary apparatus (office), understood as an organized group of people useful for helping an administrative authority to perform its functions. Thus, it shall not enter the competences of a tax authority (Voivodeship Administrative Court: III SA/Wa 2972/05). Pursuant to Art. 14 of TOA, a poviat governor is Authorized to issue individual interpretations of tax law provisions in tax matters of his competence. In such an event, a fee for the application for issuing of an individual interpretation constitutes the revenue of the poviat budget. An applicant may not freely select an authority issuing the interpretation (Viovodeship Administrative Court: I SA/Sz 1212/14).

The most significant thing, from the point of view of the subject matter, is two groups of poviat governor's competences. The first group shall include the poviat governor's competencies related to the representation of the poviat outside, including tasks connected with executing of the poviat's budget by the poviat board 
A Poviat Governor as a Party to the Agreement Transferring the Ownership...

chaired by the poviat governor. The activities related to the collecting of budget revenues are included within the limits of the task involving budget execution. Within the meaning of the constitutional act, representation is understood as the performance of public law activities and not civil law activities. Representation in the proper meaning, i.e. filing of declarations of intent within the scope of the civil law and procedural activities is regulated by special provisions (Dolnicki, 2003: 62). This category of regulations may include the provisions of Art. 66/2/2 of TOA permitting a transfer of the ownership of objects or property rights to a poviat in exchange for tax arrears (fees, non-tax budget dues) constituting poviat's budget revenues. In such an event, the ownership is transferred based on an agreement concluded between a poviat governor and a tax payer.

Except for its own tasks, a poviat also performs tasks within the scope of government administration, the performance of which is connected with the second group of poviat governor's competences. The types and the scope of these tasks are determined by agreements concluded by a poviat with government administrative authorities or provisions of separate acts. In the analyzed case, an important example of the statutory determination of the issues included within the scope of poviat's activities, as a task from the catalog of government administration performed by the poviat are the provisions of Art. 66/2/1 of TOA. Pursuant to this provision, in order to lead to the expiry of tax arrears as regards taxes constituting the state budget revenues, an agreement is concluded on transferring of the ownership of object or property right to the State Treasury. The term "tax" used in this provision should be understood in a manner specified under Art. 3/3 of TOA, i.e. broadly, and, therefore, it should also include advance tax payments (characteristic for income taxes), tax installments (if tax regulations provide for the payment of a tax in installments), fees and non-tax budget dues. This means that any tax arrears, i.e. any overdue amounts of taxes, advance tax payments, tax installments, fees or non-tax budget dues may expire in the manner regulated in Art. 66 of TOA. The agreement with a taxpayer in such a situation is concluded by a poviat governor (performing the task within the scope of government administration) upon consent of the competent head of a tax office.

Literature often points to multidimensionality and complexity of the functions performed by a poviat governor as well as the legal position thereof, in particular in relation to poviat bodies (the council and the board). It is due to the performance of specific tasks within the scope of government administration by a poviat that the position of a poviat governor is specifically conditioned in relation to local and central government structures (Niemczuk, 2011: 75-93; Bielecki, 2010: 9-21). A reflection of this specific position of a poviat governor and the complex relations 
is e.g. the provisions of Art. 66 of TOA permitting the method of expiry of a tax liability in an in-kind manner, i.e. without using any means of payment.

\section{Material Scope of Applying Art. 66 of TOA}

Specification of the material scope of applying Art. 66 of TOA is possible by means of determining the limits of the term "tax arrears". It is necessary to emphasize that, in spite of the inclusion, in the content of Art. 66 of TOA, of a general statement about "a specific case of expiry of a tax liability" in further provisions of the regulation, the legislator refers it only to one form of a tax liability, which is tax arrears. The scope of the term "tax arrears" has been determined in Art. 51 of TOA. The term is to be understood as tax, advance tax payment, and tax installment if these dues have not been paid by the payment deadline. Taking into consideration, previously quoted Art. $3 / 3$ of TOA, tax arrears may also arise due to an overdue fee or non-tax budget due (Olesińska, 2009: 118). Furthermore, tax arrears also include any dues in respect of taxes, advance tax payments and tax installments which have not been paid by the payment deadline by a taxpayer or a payment collector. The essence of tax arrears is, thus, lack of payment of a specific amount due by the payment deadline. The terms "tax liability" and "tax arrears" shall not be considered equal because this may lead to serious interpretation doubts (judgment of the Voivodeship Administrative Court: I SA/Rz 67/14). Tax arrears are a specific form of a tax liability, i.e. a liability for which the payment deadline has lapsed ineffectively.

Tax arrears are of an objective nature and their arising, as well as existence, shall be connected to a failure to pay the whole or a part of a tax (advance tax payment, tax installment, fee, non-tax budget due) by the payment deadline. They only constitute a tax liability that has not been fulfilled as a whole or in part (judgment of the Voivodeship Administrative Court: III SA/Wa 861/10). It has been accurately assessed that tax arrears are not an independent tax liability but arise as a consequence of a failure to fulfill a tax payer's tax liability (Burzyński, 2012: 25). Pursuant to Art. 52 and 52a of TOA, the following shall be treated as tax arrears:

- overpayment or tax return indicated in a tax statement unduly or in an amount higher than the amount due;

- amounts of overpayments or taxes previously returned to a taxpayer and not returned by the taxpayer within 30 days of being delivered a decision specifying a return obligation;

- the remuneration of taxpayers or tax collectors collected unduly or in the amount higher than the amount due. 
A Poviat Governor as a Party to the Agreement Transferring the Ownership...

Due to the fact that default interest is a consequence of the arising of tax arrears, their legal existence is connected with the obligation from which they result (Ciecierski, 2011: 97). Default interest is not an independent benefit separated from tax arrears. It is of accessory nature in relation to tax arrears. It may only arise when tax arrears arise. Expiry of the arrears as a whole or in part result in expiry of the default interest as a whole or in part (Etel, 2017: 507). The special manner of expiry of tax arrears regulated in Art. 66 of TOA refers, thus, not only to the principal amount of tax arrears (e.g. due to a tax unpaid by the payment deadline) but also to the default interest calculated on the overdue amount. Transferring an object or a property right to the State Treasury or LGU based on an agreement, a taxpayer may, in this manner, lead to the expiry of a tax liability in the form of tax arrears and default interest or a respective part of tax arrears and the corresponding part of default interest. Such an assessment of the regulations included in Art. 66 of TOA is Authorized by the provisions of Art. 66/5 of TOA ordering the relevant application of Art. 55/2 of TOA stipulating that in the event when the payment made does not cover the amount of tax arrears together with default interest, the amount will be proportionally credited to tax arrears and default interest in relation to the amount of tax arrears to the amount of default interest on the date of payment.

Pursuant to the findings made, the manner of expiry of a tax liability regulated in Art. 66 of TOA shall not be applied to tax payer's current or future tax liabilities and, thus, to any for which the payment deadline has not elapsed yet. On the other hand, taking into consideration the scope of the term "tax arrears" determined by the provisions of Art. 51-52a of TOA, it may be assumed that a specific manner of expiry of this form of a tax liability determined in Art. 66 of TOA is permissible both with regard to typical tax arrears mentioned in Art. 51 of TOA as well as with regard to other amounts due to the State Treasury or LGU, which a taxpayer (or collector) has received unduly or in the amount higher than the amount due and has not returned within the specified time limit.

A specific manner of expiry of tax arrears regulated in Art. 66 of TOA may be applied to any existing (i.e. not overdue) tax arrears regardless of their amount or the moment of their arising as well as regardless of the legal form of the original liability (tax, tax installment, advance tax payment, fee, non-tax budget due). It is also not important whether, at the moment of application of this manner of settlement of tax arrears, the obligor is subject to arrears on account of one or many tax titles. It is also of no significance whether the obligor's tax arrears are the result of a conducted business activity or the effect of various events related to the personal sphere. 


\section{Agreement on Transferring of Ownership of Objects or Property Rights}

The conclusion of an agreement transferring the ownership of objects or property rights to the State Treasury or LGU in exchange for tax arrears may only occur on the initiative of a taxpayer subject to such arrears. A material expression of this initiative is an application filed by a tax payer with a poviat governor. In the application, a taxpayer shall indicate the types of tax arrears as well as the objects or property rights intended to be transferred in order to lead to the expiry of these arrears. The conclusion of the agreement regulated in Art. 66 of TOA shall not be initiated by any other entity (Siemieniako, 2008: 45) ${ }^{7}$, including but not limited to a tax authority or a poviat governor representing the interests of the State Treasury. A tax authority or a poviat governor may, nevertheless, inform a taxpayer that this specific manner of performance of a tax liability is regulated in the tax law.

Transferring of the ownership of objects or property rights to the State Treasury or LGU in exchange for tax arrears may be effected only based on an agreement concluded between a taxpayer and a poviat governor (in the event when a poviat governor represents the interests of the State Treasury, conclusion of the agreement is only possible after obtaining a consent from the competent head of a tax office). Consent of the head of a tax office is a form of controlling the activities of a poviat governor representing the interests of the State Treasury.

For many years, a scientific discussion has continued as regards the legal status of such an agreement. In the doctrine, there are varied views within this scope. Taking into consideration the fact that, in specific cases, the conclusion of the agreement requires the consent of the competent head of a tax office, it has been concluded that the consent not only constitutes an inherent element of the performed legal activity but is also an activity within the scope of the public law. The legal construction regulated in Art. 66 of TOA is internally complex, yet its basic element remains a civil law agreement, which additionally requires a consent of the competent head of a tax office to become effective (Borszowski, 2003: 16). This means that transferring of the ownership of objects or property rights in exchange for tax arrears occurs under private law, yet this does not change the essence of the regulation included in Art. 66 of TOA, which introduces a specific mechanism of expiry of a tax liability and does not refer to business transactions (Gomulowicz, 2008). Other Authors consider this to be an agreement of an ambiguous nature because some of its features are characteristic both for nominate agreements (sale agreement) as well as innominate agreements (Bielenik, 2000: 57; Ślifirczyk, 1998: 6).

7 A different view permitting the initiative of a different entity than a taxpayer was expressed by A. Huchla (2000: 52). 
A Poviat Governor as a Party to the Agreement Transferring the Ownership...

In court rulings, in accordance with the dominant assessment, the agreement specified in Art. 66 of TOA is of a civil law nature (e.g. Supreme Administrative Court: I FSK 555/13), yet it is not a classic civil law agreement (judgment of the Supreme Administrative Court: I FSK 1635/10). Simultaneously, the courts emphasize that the parties using the contractual form of transferring the ownership of objects or property rights do not perform the equivalent legal act (Supreme Administrative Court: I FSK 501/06). As a result of the conclusion of this agreement, a special (e.g. in-kind) manner of collecting taxes or another public levy is effected. Nonequivalence of the activity of tax liability settlement excludes its inclusion in paid supply of goods (Voivodeship Administrative Court: I SA/ Po 718/13; Voivodeship Administrative Court: III SA/GI 1312/12) and, thus, it shall not be subject to the tax on goods and services. A taxpayer settling the tax in the manner specified in Art. 66 of TOA fulfills the liability under the tax act, not obtaining any equivalent in the form of payment of the selling price, which is the immanent feature of bilateral, mutual civil law acts (Supreme Administrative Court: I FSK 434/10).

Within this scope, the courts take into consideration the arguments included in the resolution of 7 judges (Supreme Administrative Court: I FPS 2/07), referring to the legal definition of a tax formulated in art. 6 of TOA. A tax is not any pecuniary performance that may be obtained "in exchange" for another performance because its basic feature is the unilateralness and the nonequivalence of the tax. A taxpayer settling a tax does not obtain any benefit. Similarly, the state or LGU authorities, consenting to the collection of tax arrears arising as a result of a failure to pay the tax by the payment deadline with the use of the contractual form of transferring the ownership regulated in Art. 66 of TOA do not perform the equivalent legal act. They only perform their competences within the scope of enforcement of public revenues within the state empire sphere even if this occurs with the use of private law instruments, i.e. an agreement concluded between a taxpayer and a poviat governor performing the tasks within the scope of government administration/ cooperating with the head of a tax office (Supreme Administrative Court: I FPS 2/07). Thus, there are no features characteristic for business transactions as regards the transaction performed between a tax payer and a poviat governor representing the interests of the State Treasury or a poviat (Wołowiec, 2012: 25).

Neither does transfer of the ownership of objects or property rights for the benefit of the State Treasury or LGU in exchange for tax arrears on account of taxes result in any revenue on the side of a taxpayer who would be subject to income tax (personal or corporate income tax respectively). The essence of the regulation included in Art. 66 of TOA does not refer to business transactions but only introduces one special mechanism of collecting a tax in the form of tax arrears. Conclusion of such 
an agreement does not generate any revenue on the side of a taxpayer or any other benefit based on a civil law relationship, but results in performance of the liability of a tax nature (judgement of the Supreme Administrative Court: I SA/Po 3066/14; Voivodeship Administrative Court in Gliwice: I SA/GI 552/16).

It has been mentioned above that the activities of a poviat governor concerning the conclusion of the agreement under discussion are controlled by the head of a tax office. The provisions of Art. 66/3b of TOA include a competence norm determining the liability of the head of a tax office to give or refuse consent for transferring of objects or property rights for the benefit of the State Treasury with a view to the expiry of a tax liability on account of taxes constituting the state budget revenues. In the provisions of Art. 66/3a of TOA, the legislator specifies the procedure of transferring the ownership of objects or property rights for the benefit of the State Treasury involving the conclusion of an agreement between a taxpayer and a poviat governor and, subsequently, giving of a consent for its conclusion by the head of a tax office. Such a sequence of activities of a poviat governor is determined by the obligation specified in Art. 66/3a of TOA. A poviat governor shall notify the competent head of a tax office of concluding the agreement, at the same time sending a copy thereof. As a result, the effectiveness of the agreement concluded between a taxpayer and a poviat governor arises subject to the condition precedent and, thus, only upon giving of a consent by the head of a tax office through a decision. A refusal to transfer objects or property rights for the benefit of the State Treasury in exchange for tax liabilities on account of taxes constituting state budget revenues results in the ineffectiveness of the agreement (Supreme Administrative Court: II FW 2/14).

In the event of the contractual transfer of the ownership of objects or property rights to a poviat in exchange for tax arrears on account of public levies constituting state budget revenues, the position of a poviat governor as a party concluding such an agreement is independent, i.e. does not require consent of any other bodies, including a poviat council. In the event of concluding the agreement, a poviat governor issues a decision determining the amount of expiry of tax arrears. The activities involving conclusion of the agreement and issuing of the decision on expiry of tax arrears are included within the limits of the exclusive competences of a poviat governor.

The provisions of Art. 66 of TOA are a special regulation in relation to Art. 12/8/a of PLGA, pursuant to which adoption of resolutions on property issues of a poviat concerning the principles of acquiring real property are exclusively within the competences of a poviat council unless otherwise provided in special acts. The circumstances that a poviat board intends to maintain full control over individual cases of acquiring real property is of no legal significance in a situation where 
A Poviat Governor as a Party to the Agreement Transferring the Ownership...

statutory regulations do not grant any competences to it to express a consent to such a transaction (or adopt a resolution generally specifying the principles of acquisition) each time (Voivodeship Administrative Court: II SA/Łd 1518/03). The principles of acquiring objects or property rights by a poviat from a taxpayers in exchange for tax arrears are specified in Art. 66 of TOA and, thus, the provision, as lex specialis to Art. 12/8/a of PLGA, prevail over the constitutional regulation, which means that effective performance of a legal act by a poviat governor within the scope normalized in Art. 66 of TOA does not require any previous consent of a poviat council. Simultaneously, Art. 66/2/2 of TOA does not create any obligation, as regards a poviat governor, to obtain the consent of a poviat council for acquisition of real property pursuant to the procedure specified in Art. 66 of TOA. Moreover, it must be emphasized that the provisions of Art. 12/8/a of PLGA do not grant any competences to a poviat council within the scope of determining the principles concerning the acquisition of movable property for the benefit of a poviat.

Pursuant to the provisions of Art. 66/3 of TOA, an ordinary written form is determined by the agreement on transferring of objects or property rights by a taxpayer for the benefit of the State Treasury or a LGU in exchange for tax arrears, yet, due to the nature of the act (agreement) transferring the ownership of real property, it should be concluded in a special form, i.e. in the form of a notarial deed, pursuant to Art. 158 read in connection with Art. 73 of the Civil Code (Morawski, 1998: 242).

\section{Moment of Expiry of Tax Liability}

In the event of a contractual transfer of the ownership of objects or property rights by a taxpayer for the benefit of the State Treasury or a LGU in exchange for tax arrears, the expiry date of a tax liability is considered to be the date of transferring the ownership of objects or property rights. Therefore, the conclusion of a preliminary agreement, being an agreement of an organizational (preparatory) nature, does not lead to the expiry of a tax liability. The preliminary agreement shall be distinguished from the definitive agreement, which accomplishes the objective intended by the parties. The accomplishment of the objective is only possible in the event of providing the performance based on the final agreement (Voivodeship Administrative Court: I SA/Po 846/10). Expiry of a tax liability occurs on the date of transferring of the ownership of an object or a property right. Transferring of the ownership of the objects indicated as to their identity occurs on the date of concluding the agreement, the object indicated as to their type - on the date of transferring of their possession, whereas transferring of the right occurs in a manner resulting from its essence (Dauter, 2002: 41). 
A reference from Art. 66/5 of TOA containing an order to apply the provisions of Art. 55/2 of TOA accordingly as well as lack of references to Arts. 72-80 of TOA mean that the value of objects or property rights transferred to the State Treasury or a LGU in exchange for tax arrears on account of taxes constituting the revenue of the state or a LGU budget shall be equal to or higher than the amount of tax arrears (Drela, 2014: 26). The scope of Art. 72 of TOA regulating the essence and the manner of arising of a tax overpayment does not include transferring of the ownership of objects or other property rights resulting in expiry of a tax liability based on Art. 59/1/6 of TOA being, however, only a different manner of expiry of a tax liability than the tax payment. The provisions of Art. 72 of TOA regulate only two instances (from among eleven mentioned in Art. 59/1 of TOA), which provide the basis for verification of the correctness of a tax settlement pursuant to the procedure of determining an overpayment. They correspond to the expiry of a tax liability through payment of a tax or collection thereof by a taxpayer or tax collector (Art. 59/1/1-2 of TOA) (Voivodeship Administrative Court: I SA/Sz 910/10). Thus, it is not possible for a taxpayer to effect a contractual transfer, to the State Treasury or a LGU, of the ownership of objects or property rights of a value higher than the amount of tax arrears and, then, to apply - pursuant to the procedure for tax overpayment - for a return of the overpayment resulting from the conducted operation.

Acknowledgment of the expiry of tax arrears or a respective part thereof (in the event when the value of objects or property rights is lower than the value of tax arrears) is effected in a formal manner, i.e. through issuing a decision by a tax authority of the first instance. The decision may be issued only on the date of transferring the ownership of an object or a property right because the date is considered the expiry date of a tax liability (Lewandowski, Pahl, 2012: 47). The role of a poviat governor within this scope is varied depending on whether a contractual transfer of the ownership of objects or property rights occurred in exchange for tax arrears on account of taxes constituting the revenues of the state budget or the poviat budget. In the first case, the decision acknowledging the expiry of tax arrears is issued by the competent head of a tax office, whereas in the second case, the decision is issued by a poviat governor, who, within the meaning of the provisions of TOA, is a tax authority of the first instance competent in the matters of public levies (taxes, fees, etc.) constituting the sources of poviat's own revenues. Thus, in the first case, there is a certain splitting of the role, since a poviat governor, concluding the agreement under discussion (representing the interests of he State Treasury as a part of performing a public task within the scope of government administration), does not have the competences to formally acknowledge the expiry of tax arrears mentioned in the content of the agreement. Only in the second case, a poviat governor is a party to the agreement transferring the ownership of objects or property right to 
A Poviat Governor as a Party to the Agreement Transferring the Ownership...

a poviat in exchange for tax arrears and, simultaneously, the entity Authorized to issue a decision acknowledging the expiry of such arrears.

\section{Conclusions}

Based on the applicable legislature, achievements of the doctrine and court rulings, all functions of a poviat governor performed in the case of applying a special manner of expiry of tax payer's tax arrears have been identified. A contractual transfer of the ownership of objects or property rights in exchange for tax payer's tax arrears due to the State Treasury or a LGU constitutes a form of a dialogue between the parties of a fiscal-legal relationship and, simultaneously, is included in the category of effective methods of cessation of a tax liability (Nita, 2014: 204-205). A poviat governor plays an important but varied role in this dialogue. In the case of applying this form of expiry of tax arrears on account of taxes providing revenues for the state budget, the dialogue is of a multilateral nature because the conclusion of the agreement requires a consent of the competent head of a tax office issued in the form of a decision. A refusal to give consent also requires the formation of a decision. Thus, a poviat governor maintains a dialogue with a taxpayer (its material expression is the agreement on transferring of the ownership of objects and property rights) as well as the head of a tax office (the material effect is the decision issued by the head of a tax office as regards consent or refusal to conclude the agreement).

The process of obtaining the consent is, thus, a manner of maintaining a dialogue between a poviat governor and the competent head of a tax office. A poviat governor formally represents the interests of the State Treasury, performing tasks within the scope of government administration, but, simultaneously, is a party to the agreement concluded with a taxpayer intending to lead, in this manner, to the expiry of tax arrears on account of taxes constituting the source of revenues of the state budget. As Art. 66 does not provide for any possibility of a taxpayer directly addressing the head of a tax office, a poviat governor also acts as an intermediary between the taxpayer and the head of a tax office requesting for issuing of a decision as regards expressing consent or refusal to give consent to conclusion of the agreement with the taxpayer. An application for issuing of such a consent is, nevertheless, filed after the conclusion of the agreement between the poviat governor and the taxpayer because pursuant to Art. 66/3a of TOA, the poviat governor notifies the competent head of a tax office of concluding the agreement and sends a copy thereof.

The order of poviat governor's activities adopted in TOA means that, first, an agreement is concluded between a taxpayer and a poviat governor and, then, a poviat governor requests the head of a tax office for a consent to conclude it. The decision issued is binding after the conclusion of the agreement subject to 
the condition precedent. For, its substantive effectiveness only has effects after a consent is expressed in the form of a decision. A refusal to transfer the ownership of objects or property rights to the State Treasury in exchange for tax liabilities on account of taxes constituting state budget revenues results in the ineffectiveness of the agreement. The decision of the head of a tax office acknowledging the expiry of tax arrears accomplishes a complex procedure of a special manner of tax payment, i.e. in the in-kind (material) form rather than pecuniary one.

In the case of a contractual transfer of the ownership of objects or property rights in exchange for tax arrears on account of public levies due to a poviat, the dialogue maintained with the participation of a poviat governor is simplified. A poviat governor concludes an agreement with a taxpayer independently. In this case, Art. 66 of TOA is a special regulation in relation to the provisions of Art. 12/8/a of PLGA regulating the exclusive competence of a poviat council to adopt resolutions in property matters concerning e.g. the principles of acquiring real property. A poviat governor is not obliged to obtain the consent of the poviat for the conclusion of an agreement with a taxpayer concerning a transfer of the ownership of objects or property rights to the poviat in exchange for tax arrears on account of public levies due to the poviat. A poviat governor, being simultaneously a tax authority, issues a decision acknowledging the expiry of tax arrears and, thus, accomplishes, in this manner, the procedure of tax payer's payment of the tax due in-kind (in a material form).

A poviat governor is the chairman of a poviat board and, i.e. a collective executive body of the poviat responsible for e.g. execution of the poviat budget (Art. 32/2/4 of PLGA). For proper execution of the poviat budget and, in particular, for maintaining of a budget balance and other framework arrangements determined in the budget resolution of a poviat council, it is necessary to collect revenues for the benefit of the poviat budget in the pecuniary form in order to secure the financial resources necessary for performance of public tasks financed from the budget. Excessive application of the use of in-kind (material) form of settlement of public levies, being an important form of poviat's revenues, could have a negative influence on the current financial balance and financial liquidity of the poviat budget. Within this scope, a poviat governor should permit the application of this form of settlement of public levies for the benefit of the poviat in a reasonable manner. The current practice indicates that contractual transfer of the ownership of objects and property rights in exchange for tax arrears on account of public levies whereto a poviat is entitled is a rare phenomenon and, thus, the danger does not have any real dimension.

To conclude, an agreement of a civil law nature concluded between a poviat governor and a taxpayer with a view to leading to effective expiry of tax arrears on account of public levies due to the State Treasury or the poviat is a precondition for 
A Poviat Governor as a Party to the Agreement Transferring the Ownership...

making of a sovereign administrative decision by the head of a tax office or a poviat governor, i.e. issuing of an administrative deed of a specific content (acknowledging the expiry of tax arrears). It is an obligatory administrative deed because a tax authority (the head of a tax office or a poviat governor) is obliged to act in a specific manner and issue a specific administrative deed (Mucha, 2008: 360-361).

\section{References}

Bielecki, L.: Starosta powiatu. Zarys charakterystyki prawnej (Poviat governor. Outline of legal characteristics), Rozprawy z Zakresu Nauk Prawnych (Dissertations in the Legal Science) no. 1 (2010).

Bielenik, T.: Przejęcie przez gminę mienia podatnika za zaległości podatkowe (Takeover by the municipality of taxpayer's property for tax arrears), Finanse Komunalne (Municipal Finance) no. 3 (2000).

Borszowski, P.: Przeniesienie własności na rzecz Skarbu Państwa (Transfer of ownership to the Treasury), Glosa (Gloss) no. 3 (2003).

Bouvier, M.: Wprowadzenie do prawa podatkowego i teorii podatku (Introduction to tax law and tax theory), Warszawa: KiK, 2000.

Brzezicki, T., Morawski, W.: Zakres przedmiotowy Ordynacji podatkowej w świetle orzecznictwa sądów administracyjnych (The scope of the Tax Ordinance Act in the light of the judicature of administrative courts), Przegląd Orzecznictwa Podatkowego (Review of Tax Jurisdiction) no. 6 (2009).

Brzeziński, B., Olesińska, A.: Podstawowe instytucje ogólnego prawa podatkowego (Basic institutions of general tax law), in: Nykiel, W., Wilk, M.: Zagadnienia ogólne prawa podatkowego (General tax law issues), Łódź: Fundacja Centrum Dokumentacji i Studiów Podatkowych, 2014.

Brzeziński, B.: Wstęp do nauki prawa podatkowego (Introduction to tax law), Toruń: TNOiK, 2001.

Burzyński, J.: Zaległości podatkowe jako potencjalne źródło dochodów w gminach (Tax arrears as a potential source of income in communes), Przegląd Podatków Lokalnych i Finansów Samorządowych (Review of Local Taxes and Local Government) no. 11 (2012).

Ciecierski, M.: Glosa do uchwały NSA z dnia 7 grudnia 2009 r., II FPS 5/09 (Gloss to the resolution of the Supreme Administrative Court of 7 December 2009), Glosa (Gloss) no. 4 (2011).

Dauter, B.: Efektywne sposoby wygasania zobowiązań podatkowych (Effective means of terminating tax liabilities), Doradztwo Podatkowe (Tax Advisory) no. 5 (2002).

Dolnicki, B.: Monokratyczne organy samorządu terytorialnego (Monocratic territorial selfgovernment bodies), Samorząd Terytorialny (Local Self-government) no. 1-2 (2003).

Drela, M.: Przeniesienie praw majątkowych nieruchomości zabezpieczonej hipoteką umowną łączną zwykłą na rzecz Skarbu Państwa na podstawie art. 66 Ordynacji podatkowej (Transfer of property rights secured by a joint contractual mortgage ordinary to the Treasury pursuant to 
art. 66 Tax Ordinance Act), Nowe Zeszyty Samorządowe (New Self-Government Notebooks) no. 2 (2014).

Etel, L.: Komentarz do art. 53 (Comment on art. 53), in: Etel, L. (ed.): Ordynacja podatkowa. Komentarz (Tax Ordinance. Comment), Warszawa: Wolters Kluwer, 2017.

Gomułowicz, A.: Aspekt prawny podatku (Legal aspect of tax), in: Gomułowicz, A., Mączyński, D.: Podatki i prawo podatkowe (Taxes and tax law), Warszawa: Wolters Kluwer, 2016.

Gomułowicz, A.: Glosa do uchwały NSA z dnia 8 października 2007 r., I FPS 2/07 (Gloss to the resolution of the Supreme Administrative Court of 8 October 2007, I FPS 2/07), Orzecznictwo Sądów Polskich (Jurisprudence of Polish courts) no. 5 (2008).

Huchla, A.: Regulowanie zobowiązań podatkowych w szczególny sposób (Regulating tax liabilities in a special way), Nowe Zeszyty Samorządowe (New Local Government Notebooks) no. 5 (2000).

Lewandowski, P., Pahl, B.: Wygaśnięcie zobowiązania podatkowego wskutek przeniesienia własności rzeczy lub prawa majątkowego na rzecz gminy (Termination of tax liability due to the transfer of ownership of property or property right to a commune), Finanse Komunalne (Local Self-government) no. 5 (2012).

Morawski, W.: Przeniesienie własności rzeczy i praw majątkowych w zamian za zaległości podatkowe (Transfer of ownership of property and property rights in exchange for tax arrears), Monitor Podatkowy (Tax Review) no. 8 (1998).

Mucha, M.: Umowy o przeniesienia własności rzeczy lub praw majątkowych w zamian za zobowiązania podatkowe (Agreements on the transfer of ownership of property or property rights in exchange for tax liabilities), in: Boć, J., Dziewięcka-Bokun, L. (eds.): Umowy w administracji (Agreements in administration), Wrocław: Kolonia Limited, 2008.

Niemczuk, P.: Pozycja ustrojowo-prawna starosty (Legislative and legal position of the poviat governor), Administracja (Administration) no. 1 (2011).

Nita, A.: Porozumienia w prawie podatkowym. Horyzontalne metody determinacji powinności podatkowej (Agreements in tax law. Horizontal methods of tax liability determination), Warszawa: Wolters Kluwer, 2014.

Olesińska, A.: Glosa do wyroku NSA z dnia 28 sierpnia 2008 r., I FSK 972/07 (Gloss to the judgment of the Supreme Administrative Court of 28 August 2008, I FSK 972/07), Przegląd Orzecznictwa Podatkowego (Review of Tax Jurisdiction) no. 2 (2009).

Siemieniako, J.: Charakter prawny umowy zawartej w trybie art. 66 Ordynacji Podatkowej (Legal character of the contract concluded in the mode of art. 66 of the Tax Code), Finanse Komunalne (Municipal Finance) no. 1-2 (2008).

Ślifirczyk, M.K.: Przeniesienie własności rzeczy lub praw majątkowych na rzecz Skarbu Państwa (gminy) (Transfer of ownership of property or property rights to the State Treasury (community)), Doradztwo Podatkowe (Tax Advisory) no. 4 (1998).

Wołowiec, T.: Przeniesienie własności rzeczy lub praw majątkowych spółki na rzecz wierzyciela podatkowego jako forma wygaśnięcia zobowiązań podatkowych (Transfer of ownership of property or property rights of the company to the benefit of the tax creditor, as a form of 
A Poviat Governor as a Party to the Agreement Transferring the Ownership...

expiration of tax liabilities), Przegląd Ustawodawstwa Gospodarczego (Review of Economic Legislation) no. 8 (2012).

PL: Act of 17 May 1989, on Geodetic and Cartographic Issues, as amended.

PL: Act of 20 June 1997, on Road Traffic Law, as amended.

PL: Tax Ordinance Act of 29 August 1997, as amended.

PL: Act of 5 June 1998, on Poviat Local Government, as amended.

PL: Act of 27 April 2001, on Environmental Protection Issues, as amended.

PL: Act of 13 November 2003, on Revenues of Local Government Units, as amended.

PL: Act of 9 June 2011, on Geological and Mining Issues, as amended.

PL: Supreme Administrative Court: I FPS 2/07.

PL: Supreme Administrative Court: I FSK 501/06.

PL: Supreme Administrative Court: I FSK 434/10.

PL: Supreme Administrative Court: I FSK 1635/10.

PL: Supreme Administrative Court: I FSK 555/13.

PL: Supreme Administrative Court: II FSK 3066/14.

PL: Supreme Administrative Court: II FW 2/14.

PL: Voivodeship Administrative Court: II SA/Łd 1518/03.

PL: Voivodeship Administrative Court: III SA/Wa 2972/05, LEX no. 194038.

PL: Voivodeship Administrative Court: III SA/Wa 861/10.

PL: Voivodeship Administrative Court: I SA/Sz 910/10.

PL: Voivodeship Administrative Court: SA/Po 846/10.

PL: Voivodeship Administrative Court: III SA/GI 1312/12.

PL: Voivodeship Administrative Court: I SA/Po 718/13.

PL: Voivodeship Administrative Court: I SA/Rz 67/14.

PL: Voivodeship Administrative Court: I SA/Sz 1212/14.

PL: Voivodeship Administrative Court: I SA/GI 552/16. 



\title{
PUBLIC INTEREST AS A POSITIVE CONDITION OF APPLYING RELIEFS IN PAYMENT OF NON-TAX PUBLIC LAW LIABILITIES TO STATE
}

\author{
ZBIGNIEW OFIARSKI
}

\begin{abstract}
The subject of this work is the analysis and assessment of applicable legislation concerning the application of reliefs in payment of non-tax liabilities to state, in particular, the condition of "public interest" which justifies such a relief. The works confirm the need to use general clauses including, most of all, the "public interest" clause, which considers universal and generally acceptable values (e.g. justice, safety, equal treatment, building trust in public administration bodies). It is not defined in any act; therefore, it is vague. Using the dogmatic legal method, the normative material, as well as the achievements of the doctrine, have been examined; court rulings have been examined using the empirical method. That enabled the Author to show that public interest is one of two equivalent and disjunctive conditions justifying application of a relief in payment of non-tax liabilities to state. The important interest of the debtor may be the second condition. The fact that any of those conditions is met entitles a competent authority to apply one of the following reliefs in payment: deferred payment date, payment in installments, or remittal of a liability. In each case, the relief may pertain to a part of or the whole liability. It should be assessed in the context of a specific case.
\end{abstract}

\section{Keywords}

State budget; reliefs in payment; public interest; non-tax liabilities to state

\section{JEL Classification: H2, H3, H61}

1 Professor of Finance Law, Head of the Department of Finance Law, Faculty of Law and Administration, University of Szczecin, Poland. The Author of over 550 publications, including 38 books (monographs, students books, and commentaries), articles, studies in joint works, and electronic publications. Specialises in tax law, local government finance law, and banking law. He is a member of Information and Organization Centre for the Research on the Public Finances and Tax Law in the Countries of Central and Eastern Europe. Contact email: zbigniew.ofiarski@usz.edu.pl. 


\section{Introduction}

The purpose of this work is to analyze and assess applicable legislation concerning the application of reliefs in payment of non-tax liabilities to state, in particular, the condition of "public interest" which justifies such reliefs. The legislation in this area is not perfect, as no universal and legal definition of "non-tax liabilities to state" has been formulated, which would not raise doubts as to interpretation, and the condition of "public interest" is a typical general clause used by the legislator. The function of a general clause is an order to modify specific central regulations (i.e. regulations which are within the scope of interest due to their substance), directed at the entity applying the law. This modification results in considering opinions functioning in the society in the process of applying specific regulations (Zieliński, 2002: 126). General clauses are one of the basic ways to make law flexible by referring to a specific system of values and opinions justified in an axiological manner (Wronkowska, Zieliński, 1993: 110).

In public finance law, general clauses (referring to justice, equality, universality, social solidarity, or budget balance) introduce a specific freedom of decision (Münnich, 2013: 149) in solving, by public authorities, specific cases related to creating and distributing public financial resources. Therefore, they ensure flexibility of action depending on changing the political, economic, and legal environment, with no need of introducing frequent changes in legal regulations containing orders or prohibitions (Małecki, 2005: 463).

The issue of applying for reliefs in payment of such liabilities is important from the viewpoint of the current state budget balance as well as its closing balance as at the end of the budget year. What decides about it, most of all is allowable types of reliefs (payment date deferment, payment in installments, and remittal of a part of or the whole liability) as well as the frequency of using them in a budget year in question. Economic consequences of using a specific relief may be short-term and may consist only in a later date of paying a specific amount to the treasury (payment date deferment or payment in installments); they may also be definitive and lead to a reduction of budget receipts (remittal of liability).

Reliefs in payment of non-tax liabilities to the state are important instruments of fiscal policy, which enable flexible reaction of entities collecting budget receipts to needs resulting from a specific situation of an entity obliged to pay such a liability. Reliefs in payment of non-tax liabilities to the state may create a risk of a temporary or definitive disturbance of budget balance; however, if they are not used and the liabilities are strictly enforced from the obliged entity, this may lead to a destruction of a specific source of budget receipts (Ofiarski, 2015: 205). 
Public Interest as a Positive Condition of Applying Reliefs in Payment...

The analysis and assessment of the applicable legislation are supposed to verify the hypothesis that the legislator refers to the general clause of "public interest" in the procedure of using reliefs in payment of non-tax liabilities to state with awareness. The public interest is a vague expression and, at the same time, a directive to respect values common for the whole society, such as justice, security, citizens' trust in public authorities, efficient operation of public administration, and possible correction of its wrong decisions (Gomułowicz, Skoczylas, 2013: 122). Using the premise of "public interest" enables competent authorities to act flexibly when making decisions on applying or refusing to apply for a specific relief in payment of non-tax liabilities to state. However, freedom of such authorities' action must not be complete, as the decisions should respect the universal values referred to above, related to the meaning of public interest.

In this work, the dogmatic legal method (examination of the normative material and the achievements of the doctrine), as well as the empirical methods (examination of court rulings), were used. Firstly, it has been determined that "public interest", which is a positive condition of using a specific relief in payment of non-tax liabilities to state, may form an independent basis for a decision made by a competent authority. That means, that in a specific situation it is not necessary to seek an important debtor's interest as well, as those conditions do not compete with each other. Each of them, separately, may result in a positive (the condition is met) or negative (at least one of the conditions is not met) decision in a case concerning a relief in payment of non-tax liabilities to state.

When examining the issue of using the condition of public interest as a general clause which enables flexible application of statutory regulations concerning reliefs in payment of non-tax liabilities to state, the current achievements of the tax law doctrine concerning payment of tax liabilities were also referred to. Due to certain similarities of legal solutions, those achievements have been found useful in the analysis of regulations concerning non-tax liabilities to state.

\section{Essence and Types of Non-tax Liabilities to State}

The expression "non-tax liabilities to state" is used, most of all, in the Public Finance Act (further: PFA) and the Tax Ordinance Act of 29 August 1997 (further: TOA). In those two acts, the legislator made an attempt at defining the essence of non-tax liabilities to state, listing their main types and even defining them. Art. 60 of PFA lists, in the form of an open catalog, main types of public law non-tax liabilities to state. That catalog is open, as Art. 60 of PFA uses the expression of "including without limitation to", which precedes the list of the most typical liabilities classified into this category. Therefore, the legislator allows a possibility 
of treating other public funds, which were not listed in that regulation directly, as non-tax public liabilities to the state.

Depending on which budget or special state fund the receipts from those sources are supposed to be paid to, they may be divided into three main groups, i.e. those paid to the state budget, those paid to local government budgets, or those paid to special state funds. With a more detailed classification, one may distinguish between nontax liabilities to state which are paid to commune/municipality budgets, poviat budgets, and voivodeship budgets as well as specific special state funds. Non-tax liabilities to the state budget, listed in Art. 60 of PFA, include:

- subsidies to be repaid in events defined in the relevant act;

- liabilities on guarantees and sureties granted by the Treasury;

- the surplus of funds paid by executive agencies;

- payments related to settlements of pre-accession programmes;

- liabilities on repayment of funds allocated to the realization of programmes co-financed by the EU and other liabilities related to the realization of such programmes, including interest on EU funds provided and on those liabilities;

- liabilities on fines imposed by way of a criminal penalty in the proceedings concerning transgressions and proceedings concerning fiscal transgressions;

- income collected by administrative units under separate acts.

Pursuant to Art. 3/8 of TOA, non-tax liabilities to the state are liabilities which are receipts of the state or local government budgets, resulting from public law relationships, excluding taxes and charges. That means that non-tax liabilities to the state have been put in opposition to taxes and charges and are, in consequence, a separate consideration (Huchla, 2014: 258). As a result of Art. 3/8 of TOA, regulations of that Act may be applied to a specific liability to state if it results from public law relationships, which should be understood as an existence of a certain relation between at least two entities, an existence of certain rights and obligations, resulting from specific legal provisions (these may include payments out of profit made by one-man state-owned companies to the state budget (Jamroży, Główka, 2017: 55). "Non-tax public law liabilities" understood in that manner mean liabilities which are a manner of following legal regulations rather than violating them (Supreme Administrative Court: II GSK 1693/13).

From that viewpoint, the status of administrative fines imposed by public administration bodies by way of administrative decisions is being discussed. In general, administrative courts recognize such fines as non-tax public law liabilities (e.g. Supreme Administrative Court: II GSK 1020/10; Supreme Administrative 
Public Interest as a Positive Condition of Applying Reliefs in Payment...

Court: I FPS 2/09; Voivodeship Administrative Court: II SA/Sz 1356/13). Such decisions are verified in administrative proceedings and are subject to control by administrative courts. Furthermore, fines imposed by public administration bodies are subject to administrative enforcement (Act on enforcement proceedings in administration). Administrative fines are also recognized as "non-tax liabilities to state" by some representatives of the doctrine (Drwiłło, 2010: 924; Ślifirczyk, 2007: 347). However, there are also different opinions in the literature, which state that the category referred to above should only include liabilities which are a manner of following legal regulations rather than violating them. As a result, the representatives of that trend do not recognize fines as "non-tax liabilities to state" (e.g. Popławski, 2017: 72; Borodo, 2009: 133).

The polemics concerning the status of fines may be influenced by the provisions of Art. 111/12 of PFA, which state that "other fines" are recognized as "non-tax receipts to state budget" unless other acts state otherwise. Art. 60 of TOA does not mention fines at all; however, as has been mentioned above, the catalog of non-state liabilities to state is open. Here, another issue arises, i.e. Art. 60 of PFA uses the expression of "non-tax liabilities to state", while Art. 111 of PFA mentions "nontax budget receipts". The notions of "liability" and "receipts" are not equivalent; furthermore, they are used by a legislator in different contexts. In Art. 60 of PFA, a liability should be understood as an obligation which already exists and which should be fulfilled by a specific entity by making a payment to the state. In Art. 111 of PFA in conjunction with Art. 110 of PFA, the notion of "receipts" should be understood as a source of receipts, from which incoming payments are made to the budget. Such a source is allocated to the budget; however, it is possible that a specific obligation of payment (amount, entity, payment date) does not exist at the moment concerned.

It should be underlined that administrative courts recognize, as "non-tax liabilities to state", even those liabilities which have been explicitly named charges by the legislator. That issue pertains, in particular, to charges collected for issuing a vehicle history card (Voivodeship Administrative Court: III SA/Kr 574/16; Voivodeship Administrative Court: III SA/Po 1263/13; Voivodeship Administrative Court: III SA/Po 535/13; Voivodeship Administrative Court: III SA/Ld 117/12). Pursuant to Art. 77 of the Road Traffic Act, a vehicle history card for a car other than a new car is issued by the poviat governor (pl. starosta) competent for registration, for a charge and after a payment of a registration charge, upon the first registration of a vehicle in Poland, except for historical vehicles. A duplicate vehicle history card is issued by the competent poviat governor for a charge and after a payment of a registration charge. 
The notion of "non-tax liabilities to state" is also used in Art. $22 \mathrm{~b}$ of the Act of 3 February 1995 on the protection of agricultural lands and forests. A list of such liabilities has been defined but only for the purposes of applying the provisions of that Act. Within the meaning of the Act concerning the protection of agricultural lands and forests, non-tax liabilities to state include voivodeship budget receipts related to excluding agricultural lands from production, which are collected under that Act in the form of various taxes or charges. The list includes liabilities, annual charges, charges for a failure to fulfill the obligation to remove and use the soil humus, charges, and liabilities, and increased annual charges for a failure to fulfill the obligations specified in the Act as well as interest on the liabilities and charges referred above. At the same time, it has been stated explicitly that the receipts referred to above are public law non-tax liabilities to state as understood in the Public Finance Act. With regard to those receipts, the voivodeship governor (pl. marszatek województwa) is a creditor Authorized to apply for reliefs in payment thereof (in the form of remittal, payment in installments, or payment date deferment (Brzezicki, Fisz, 2013: 40) as well as an authority enforcing liabilities on that account. The public law nature of those liabilities justifies the right of claiming the interest in the case of delayed payments, calculated as in the case of tax arrears (Góreczna, Góreczny, 2014: 54).

The notion of "non-tax liabilities to state" is also used in other legal acts; however, its essence or characteristics are not specified in detail. It is present as a component of exemption from various liabilities granted to prison workshops (Art. 6 concerning employment of prisoners) or as a part of a registration and identification obligation referring to entities using a NIP tax id. number (those entities are obliged to provide the NIP no. in documents related to fulfilling obligations on account of non-tax liabilities to state (Art. 11 of the Act on principles of registration and identification of taxpayers and tax remitters). Collection of receipts on account of non-tax liabilities to state is listed in the catalogue of responsibilities of the Polish Fiscal Administration and some of its bodies (Strzelec, 2017: 29), e.g. heads of tax offices and heads of customs and tax offices (Arts. 2, 11, 28, and 33 of the Act concerning National Fiscal Administration).

\section{Forms of Reliefs in Payment of Non-tax Liabilities to State}

Art. 64 of PFA specifies types of reliefs in payment and conditions of applying them with reference to public law non-tax liabilities to state. Reliefs in payment may come in the form of liability remittal, payment date deferment, or payment in installments. In each case, the relief may pertain to a part of or the whole non-tax liability to the state. The legislator has not introduced any restrictions concerning the 
minimum or maximum value of a non-tax liability to state which may be remitted, divided into installments, or paid by a deferred date. The application of a specific relief in payment brings various economic (temporary or permanent) effects. A temporary effect consists only in a later payment of a part of or the whole liability to the state and is related to payment date deferment or payment in installments. In case of applying the relief consisting in remitting (a part of or the whole) liability, the effect is permanent and it involves no receipt of a specific amount by state, one which would have been paid had it not been remitted. Budget receipts reduced in that manner have to be compensated with appropriately increased receipts from other income sources. In case of remittals of large amounts, it is often necessary to use debt instruments, such as bank loans, loans, or issue of Treasury securities; however, in such a situation the borrowed amounts have to be repaid with interest in the following budget years. Therefore, remittals will involve a need for additional spending by the state.

Reliefs in payment of public law non-tax liabilities to the state may be applied by competent authorities representing interests of the state. The expression of "competent authority may" used in Art. 64/1 of the PFA means that an authority is not obliged to apply for a specific relief in payment even if the conditions specified in that provision are met. Granting a relief in payment is a discretionary decision of the competent authority (Kucia-Guściora, 2014: 481). The decision made in such a case is discretionary, however, that does not mean that the authority is completely free to act in any way. On principle, administrative discretion means a possibility to choose, by an authority, a legal consequence in a specific legal and actual situation. In other words, when making a decision using administrative discretion, an authority makes a decision freely, and the final choice concerning the decision should depend on the usefulness and equity; those conditions should be the result of balancing, by the authority, the interest of a party and the public interest, considering applicable legal regulations (Supreme Administration Court: II GSK 2084/12).

Art. 64 of PFA lists several positive conditions of granting, at the obliged party's request, a relief in payment of non-tax liabilities to state. They include an important interest of the obliged party, public interest, social reasons, economic reasons, and payment potential of the obliged party. These are non-specific expressions (general clauses) which refer to certain general socially acceptable values (MalarewiczJakubów, 2014: 145-153). If any condition listed in Art. 64 of PFA is not met, the authority is unable to make a decision concerning the application of a specific relief in payment of non-tax liability to the state. However, it should be emphasized that not all of those conditions are bound, by the legislator, to each of reliefs in payment of non-tax liabilities to state referred to above. 
Public interest and important interest of the obliged party are conditions of remitting whole non-tax liabilities to state. Remitting whole liabilities should be understood as remitting a principal amount as well as accessory liabilities, which usually include interest for delay. Applying reliefs consisting in remittal of a part of a liability, deferment of the payment date of a part of or the whole liability, or payment of a part of or the whole liability in installments is allowable when justified for social or economic reasons, in particular in reference to payment potential of the obliged party.

\section{Authorities Competent for Remittal of Non-tax Liabilities to State}

A diverse catalog of non-tax liabilities to the state has determined the manner of regulating functional and material competences of authorities competent to apply for reliefs in payment of those liabilities, including to remit them. The competences of the authorities are regulated under Art. 61 of PFA. Pursuant to that regulations, authorities of the first instance competent to issue decisions concerning reliefs in payment of non-tax liabilities to the state are a minister, a voivode, other bodies entitled to dispose of budget components, and other managers of state administrative entities. In reference to liabilities from fines imposed by way of a criminal penalty in proceedings concerning transgression and in proceedings concerning fiscal transgressions, authorities of the first instance competent to apply for reliefs in payment of such fines are heads of tax offices.

In case of liabilities related to return of funds allocated for realization of programmes co-financed by the EU and other liabilities related to projects financed in that manner as well as interest on funds granted by the EU and the liabilities, competent authorities include management institutions, the entity responsible for implementing the Connecting Europe Facility, the entity performing the function of a National Contact Point or a National Coordinating Institution, respectively, in programmes financed with funds being aid provided by member states of the European Free Trade Association (EFTA) as well as units of the public finance sector being programme operators, intermediary institutions, and implementing institutions which made a subsidy agreement with a beneficiary if they are duly Authorised by a management institution, the entity responsible for implementing the Connecting Europe Facility, or the entity performing the function of a National Contact Point or a National Coordinating Institution respectively. Appeal authorities include:

a) the Minister of Finance (appeals against decisions issued by a voivode as a first instance authority), 
b) the entity performing the function of a management institution, the entity responsible for implementing the Connecting Europe Facility, or the entity performing the function of a National Contact Point or a National Coordinating Institution respectively (appeals against decisions issued by units of the public finance sector being programme operators, intermediary institutions, and implementing institutions which made a subsidy agreement with a beneficiary),

c) the entity performing the function of an intermediary institution (against decisions issued by implementing institutions if examining appeals against decisions issued by implementing institutions has been entrusted to the intermediary institution by the entity referred to in item b) above),

- director of a fiscal administration chamber (appeals against decisions issued by a head of a tax office as an authority first instance);

- a superior entity (appeals against decisions issued by other entities or other units entitled to dispose of a budget component).

Decisions issued by a minister, a management institution, the entity responsible for implementing the Connecting Europe Facility, and the body performing the function of a National Contact Point or a National Coordinating Institution respectively may not be appealed against; however, a party unsatisfied with a decision may request that the authority which issued the decision to re-examine the case.

Provisions of the Public Finance Act regulate only the competences of authorities of both instances related to issuing decisions concerning public law non-tax liabilities to state; the provisions of the Code of Administrative Proceedings, on the other hand, regulate administrative proceedings, including procedure in specific cases, granting powers of attorney, and issuing decisions (Supreme Administrative Court: II GSK 2374/14). The model of procedure in cases concerning the return of funds allocated for the realization of programmes co-financed by the EU, regulated under the provisions of the Public Finance Act, raises serious doubts as to its consistency with standards of administrative proceedings. The Act not only grants a management institution - a party to a subsidy agreement with competences to inspect the use of funds provided to a beneficiary, but also makes that institution an administrative authority which decides independently whether the subsidy agreement is performed properly. Such a great involvement of the management institution in a subsidy, which enables one entity to examine the same case in administrative proceedings twice, raises justified doubt as to whether a request for re-examining the case settled with a decision issued by a management institution is anything more than a formal appeal measure (Supreme Administrative Court: II GSK 1419/13). 


\section{Essence of "Public Interest" as Condition to Remit a Non-tax Liability to State}

The general clause of "public interest" ensures high flexibility of a legal regulation (Borszowski, 2017: 156; Borszowski, 2013: 47-48). By the doctrine, it is recognized as one of the most important general clauses in Polish legislation, as it is constitutional and is frequently used by the legislator. Most of all, it forms the basis for restricting citizens' rights and freedoms, although it is sometimes a condition to implementing mechanisms for protecting selected values. Therefore, its nature is diverse. The public interest clause introduces multi-aspect relationships between law and social life. Law, in particular, public law, is a result of following a specific policy and a carrier and reflection of values which are socially important. This function is also performed by similar clauses, e.g. "social interest" or "socially justified interest". In the doctrine, those clauses are often treated as interchangeable; however, this is not justified (Żurawik, 2013: 57-69).

The notion of "public interest" as a general clause enables flexible adjustment of a legal regulation resulting from Art. 64/1/2/a of PFA to various situations (Lubelski Voivode: NK.II.0911/241/10). When examining a request for remitting a whole non-tax liability to the state, competent authorities may use the achievements of administrative court case law concerning the meaning of "public interest" (Voivodeship Administrative Court: V SA/Wa 2119/12). As in the case of other general clauses, the notion of "public interest" has not been defined by the legislator. The Public Finance Act does not provide any guidelines or criteria to be used to determine events, situations, or phenomena equaled with public interest either. Therefore, when deciding about a relief in payment of non-tax liabilities to state, consisting in remitting a whole liability, a competent authority should consider the achievements of the judicature and the doctrine and use its own experience derived from previous proceedings concerning such reliefs.

Administrative courts have examined the notion of "public interest" many times. The rulings in that matter are uniform, in principle; however, the emphasis concerning values included in that notion is put on different places. It should be assessed considering values common to the whole society, such as justice, safety, and trust in state authorities (Voivodeship Administrative Court: I SA/Bd 869/13), efficiency of the state apparatus (Voivodeship Administrative Court: I SA/Ke 135/13), and eliminating situations where the payment of a liability will result in encumbering the Treasury with costs of aid. When assessing that notion, one should also consider whether it is justified, in the light of the financial condition of the state, to encumber the state and, what follows, the whole society, with costs of aid provided in that manner. It has been pointed out that it is not an internally 
homogeneous notion and that it consists of a set of generally determined purposes which should be taken into account in the process of applying the law and which should always be referred to the individual situation of the party requesting a relief. It is not possible to define that notion explicitly and, as a result, its meaning may include various aspects of the values referred to above in each individual case (Voivodeship Administrative Court: III SA/Wa 1964/05).

The Constitutional Tribunal has underlined many times that public interest is demonstrated, in particular, in the need to protect the stability of financial interests of the state and maintain the budget balance (Constitutional Tribunal: K 1/12). However, the notion of "public interest" may not be defined too narrowly, e.g. it should not be limited only to "budgetary interest" (Voivodeship Administrative Court: I SA/OI 84/13) or fiscal interest of the state (Voivodeship Administrative Court: V SA/Wa 2614/13), even when a specific liability is a source of budget receipts and it is in public interest that all the obliged parties pay their liabilities to state (Voivodeship Administrative Court: II SA/Bd 727/11). Public interest should be understood not only as a need to ensure the maximum amount of funds on the receipts side of the state budget but also as limiting possible spending e.g. for unemployment benefits or social security (the judgement of the Voivodeship Administrative Court: I SA/Sz 217/13; the judgement of the Supreme Administrative Court: III SA 830/00). There must be no situation where payment of overdue liabilities forces the obliged party, deprived of a possibility to satisfy their essential economic needs, to use state aid (the judgement of the Voivodeship Administrative Court: I SA/Po 595/13; the judgement of the Voivodeship Administrative Court: III $\mathrm{SA} / \mathrm{Ed} \mathrm{496/13).} \mathrm{It} \mathrm{would} \mathrm{not} \mathrm{be} \mathrm{in} \mathrm{the} \mathrm{interest} \mathrm{of} \mathrm{that} \mathrm{citizen} \mathrm{and} \mathrm{neither} \mathrm{would} \mathrm{it}$ be in public interest (the judgment of the Voivodeship Court: I SA/Po 2274/13; the judgment of the Voivodeship Administrative Court: V SA/Wa 2273/10).

\section{Remitting Non-Tax Liabilities to State of Entities Conducting Business Operations}

The public interest as an essential condition for remitting non-tax liability to state of an entity conducting business operations may be applied only with consideration of the regulations under Art. 64/2/5 of PFA. A liability may be remitted only on condition of observing additional standards specified under those provisions (Presnarowicz, 2013: 286). Those standards refer to an obliged entity conducting business operations (regardless from the entity's legal status, organizational and legal form, type of operations and their scale, place of operations, or achieved economic results). That does not mean, however, that if a specific entity conducts business operations, those regulations apply to them in all events. It will be possible 
to apply the regulations only when the entity in question requests for applying a relief in the form of remitting a liability which arose in relation to business operations conducted by that entity. If an obligation of an entity conducting business operations is not related to those operations but to the entity's personal matters, the conditions formulated in Art. 64/2-5 of PFA should not be applied (Voivodeship Administrative Court: I SA/Kr 857/14. At the request of an obliged entity conducting business operations, a competent authority may remit a non-tax liability to state if a relief:

1) is not public aid,

2) is de minimis aid or de minimis aid in agriculture or fishery - within the scope and on the conditions specified indirectly applicable EU legal acts concerning de minimis aid,

3) is public aid:

a) aimed at repairing damage caused by natural disasters or other extraordinary events (separate provisions should specify detailed conditions of providing aid to make it consistent with the principles of the EU common market),

b) aimed at addressing serious economic disturbances (separate provisions should specify detailed conditions of providing aid to make it consistent with the principles of the EU common market),

c) consistent with the principles of the EU common market, specified as acceptable by competent EU authorities, provided for purposes other than listed below (the Council of Ministers may specify, by regulation, the purposes of aid and detailed conditions of granting reliefs, considering the acceptability of providing state aid specified by competent EU authorities).

Therefore, the analysis of the provisions under Art. 64 PFA indicates that entities obliged to pay non-tax liabilities to state, requesting a relief in payment (including in the form of remitting the whole liability), may be divided into two groups. The first group consists of entities which do not conduct business operations; the second group comprises entities which conduct business operations (Kucis-Guściora, 2014: 481). The element common to both groups is the condition of public interest. That condition has to be met for a non-tax liability to the state to be remitted. The difference is that in reference to entities which do not conduct business operations the fact itself that the condition of public interest is met may justify the remittal of a liability. However, if it is an entity conducting business operations that request a relief, even after it has been determined that the condition of public interest is met, it is still necessary to determine whether the application of a relief in payment is acceptable from the viewpoint of standards of public aid for business. 


\section{Conclusions}

The assumed purposes of the work have been achieved, as it has been indicated, based on a detailed analysis of legislation and by identifying dominating trends in administrative courts case law, that the general clause of "public interest" is essential in the procedure of granting reliefs in payment of non-tax liabilities to state. It enables competent authorities to act flexibly and to solve issues of specific obliged entities which expect that form of state aid.

The condition of public interest is one of two conditions specified in Art. 64/1/2/a of PFA. The other condition is the important to interest of the obliged entity, which is also a general clause. Each of those conditions may be an independent basis for applying for a relief in payment of non-tax liabilities to state in the form of payment remittal, subject to meeting the criteria allowing public aid in case of a relief in payment applied with regard to an entity conducting business operations. This conclusion justifies the conjunction "and/or" used by the legislator for joining those conditions in the provision under consideration. In that manner, the interchangeability (disjunctive character) of "public interest" and "important interest of the obliged entity" has been expressed. Those conditions are equal (Dauter, 2002: 48); a competent authority making a decision on remitting a non-tax liability to the state should determine which one prevails and decide to apply for a relief on that basis. Those conditions are not competitive with each other. If it has been determined that at least one of them is met in a specific situation, it means it is not necessary to examine whether the other is met. Meeting one of the conditions may be an independent basis for a positive decision concerning a relief. It may not be assumed that those categories are opposing. A competent authority may determine that the condition of an important interest of a debtor is not met but may notice other expectations expressed by the public interest which make it possible to issue a positive decision concerning the application of a relief in payment (Orłowski, 2001: 87).

The constitutional principle of the state of law results in a balance of individual interest and public interest; public interest restricts a protection of an equitable interest of an individual. Applying discretionary powers with reference to reliefs in payment of non-tax liabilities to state, a competent authority should consider the need of ensuring budget receipts as well as the need to observe the rule of law, citizens' trust to state authorities, and guarantees of social rights and aid provided to people in particularly difficult situations as well as other directives concerning the functioning of the state apparatus (Radzikowski, 2006: 157).

The Public Finance Act does not regulate, in an exhaustive manner, all issues related to applying for reliefs in public law non-tax liabilities to state. Pursuant to 
Art. 67/1 of PFA, the provisions under the Code of Administrative Proceedings of 14 June 1960, the provisions of Chapter III of the Tax Ordinance Act, as applicable, should be applied to all matters concerning those liabilities which are not regulated under the Public Finance Act. The application should consider the systemic and axiological context of the regulations and standards of protecting individuals specified by constitutional principles (Voivodeship Administrative Court: III SA/ $\mathrm{Lu}$ 242/12). Therefore, the provisions of the Code of Administrative Proceedings apply to proceedings concerning public law non-tax liabilities to state, where not regulated by the Public Finance Act, rather than the regulations of Chapter IV of the Tax Ordinance Act (Tax Proceedings) (Dżedzyk, 2012: 3).

\section{References}

Borodo, A.: Glosa do postanowienia NSA z dnia 9 września 2008 r., II GW 4/08 (Commentary on a decision of the Supreme Administrative Court of 9 September 2008, no. II GW 4/08), Orzecznictwo Sądów Polskich (Jurisprudence of Polish Courts) no. 12 (2009).

Borszowski, P.: Określenia nieostre i klauzule generalne jako wyraz elastyczności prawa podatkowego - zarys problematyki (Definitions out of focus and general clauses as an expression of flexibility of tax law - an outline of the issues), Acta Universitatis Wratislaviensis no. 2 (2013).

Borszowski, P.: Określenia nieostre i klauzule generalne w prawie podatkowym (Definitions out of focus and general clauses in tax law), Warszawa: Wolters Kluwer 2017.

Brzezicki, T., Fisz, I.: Należność i opłata roczna za wyłączenie gruntów z produkcji rolnej lub leśnej wymiar i egzekucja (Receivability and annual fee for the exclusion of land from agricultural or forestry production - dimension and enforcement), Casus no. 4 (2013).

Dauter, B.: Nieefektywne sposoby wygasania zobowiązań podatkowych (Inefficient tax liability expiration), Doradztwo Podatkowe (Tax Advisory) no. 6 (2002).

Drwiłło, A.: Inne formy danin niepodatkowych (Other forms of non-tax levies), in: Etel, L. (ed.): System prawa finansowego. Prawo daninowe (Financial Law System. Taxes and Fees), Warszawa: Wolters Kluwer, 2010.

Dżedzyk, J.: W sprawie odpowiedniego stosowania przepisów ordynacji podatkowej oraz przepisów kodeksu postępowania administracyjnego do stosowania ulg w zakresie spłaty zobowiązań publicznoprawnych (On the proper application of the provisions of the Tax Ordinance Act and the provisions of the Administrative Procedure Code for the application of concessions regarding the repayment of public law liabilities), Nowe Zeszyty Samorządowe (New Local Government Notebooks) no. 1 (2012).

Gomułowicz, A., Skoczylas, A.: Prawo podatkowe - aspekt orzeczniczy (Tax law - adjudication), in: Choduń, A., Gomułowicz, A., Skoczylas, A.: Klauzule generalne i zwroty niedookreślone w prawie podatkowym i administracyjnym. Wybrane zagadnienia teoretyczne i orzecznicze (General clauses and phrases that are not specified in tax and administrative law. Selected theoretical and judicial issues), Warszawa: Wolters Kluwer, 2013. 


\section{Public Interest as a Positive Condition of Applying Reliefs in Payment...}

Góreczna, M., Góreczny, G.: Umorzenie należności i opłat rocznych z tytułu wyłączenia gruntów $\mathrm{z}$ produkcji rolnej (Redemption of receivables and annual fees for excluding land from agricultural production), Samorząd Terytorialny (Local Government) no. 9 (2014).

Huchla, A.: Niepodatkowe należności budżetowe w ustawie o finansach publicznych i w ordynacji podatkowej (Non-tax budget receivables in the Public Finance and Tax Law Act), in: Miemiec, W., Sawicka, K. (eds.): Instytucje prawnofinansowe w warunkach kryzysu gospodarczego (Legal funds in the conditions of economic crisis), Warszawa: Wolters Kluwer, 2014.

Jamroży, M., Główka, A.: Korekta deklaracji z tytułu wpłaty z zysku przez jednoosobową spółkę Skarbu Państwa (Correction of declarations from profit for a sole-shareholder company of the State Treasury), Monitor Podatkowy (Tax Review) no. 10 (2017).

Kucia-Guściora, B.: Komentarz do art. 64 (Commentary to art. 64), in: Smoleń, P. (ed.): Ustawa o finansach publicznych. Komentarz (Act on public finance. Comment), Warszawa: C.H. Beck 2014.

Malarewicz-Jakubów, A.: Klauzule generalne i zasady słuszności (General clauses and rules of equity), Białostockie Studia Prawnicze (Bialystok Legal Studies) no. 2 (2014).

Małecki, J.: Refleksje o stosowaniu klauzul generalnych w prawie finansowym (Reflections on the application of general clauses in financial law), in: Zieliński, M.: W kręgu teoretycznych i praktycznych aspektów prawoznawstwa. Księga Jubileuszowa Profesora Bronisława Ziemianina (Within the theoretical and practical aspects of jurisprudence. Book of Jubilee of Professor Bronisław Ziemianin), Poznań: Wydawnictwo Ars boni et aequi, 2005.

Münnich, M.: Zwroty niedookreślone i klauzule generalne w prawie podatkowym. Instrument ochrony praw podatnika czy fundament luzu decyzyjnego organów podatkowych? Wybrane zagadnienia (Undershot phrases and general clauses in tax law. An instrument to protect the taxpayer's rights or the foundations of decision-making decree of tax authorities? Selected issues), in: Wójcicka, E. (ed.): Jednostka wobec władczej ingerencji administracji publicznej (Unit towards imperious interference of public administration), Częstochowa: Wydawnictwo Akademii im. Jana Długosza, 2013.

Ofiarski, Z.: Zasady i przesłanki stosowania z urzędu ulg w zapłacie należności o charakterze cywilnoprawnym przypadających jednostkom samorządu terytorialnego (Rules and conditions for the ex officio use of reliefs in the payment of civil claims due to territorial selfgovernment units), Prace Naukowe Uniwersytetu Ekonomicznego we Wrocławiu (Scientific Works of the University of Economics in Wroclaw) no. 404 (2015).

Orłowski, J.: Przesłanki umorzenia zaległości podatkowych w ordynacji podatkowej (Conditions of extinguishing tax arrears in the Tax Code), Radca Prawny (Legal Counsel) no. 4 (2001).

Popławski, M.: Komentarz do art. 3 (Commentary to art. 3), in: Etel, L. (ed.): Ordynacja podatkowa. Komentarz (Tax Ordinance Act. Comment), Warszawa: Wolters Kluwer, 2017.

Presnarowicz, S.: Komentarz do art. 64 (Comment on art. 64), in: Ruśkowski, E., Salachna, J.M. (eds.): Finanse publiczne. Komentarz praktyczny (Public finances. Practical commentary), Gdańsk: ODDK, 2013.

Radzikowski, K.: Zasady podejmowania i kontroli sądowej decyzji w sprawie umorzenia zaległości podatkowych w świetle uznania administracyjnego (Rules for the taking and judicial review 
of a decision on the cancellation of tax arrears in the light of administrative recognition), Kwartalnik Prawa Publicznego (Quarterly of Public Law) no. 4 (2006).

Strzelec, D.: Kontrola celno-skarbowa dotycząca przestrzegania przepisów prawa podatkowego (Customs and tax control regarding compliance with tax law), Monitor Podatkowy (Fiscal Review) no. 2 (2017).

Ślifirczyk, M.: Niepodatkowe należności budżetowe (Non-tax budget receivables), Gdańskie Studia Prawnicze (Gdańsk Legal Studies) no. 16 (2007).

Wronkowska, S., Zieliński, M.: Problemy i zasady redagowania tekstów prawnych (Problems and rules of editing legal texts), Warszawa: Wydawnictwo Urzędu Rady Ministrów, 1993.

Zieliński, M.: Wykładnia prawa. Zasady, reguły, wskazówki (Interpretation of law. Rules, rules, tips), Warszawa: LexisNexis, 2002.

Żurawik, A.: „Interes publiczny”, „interes społeczny” i ,interes społecznie uzasadniony” (“Public interest", "social interest" and "socially justified interest" An attempt to define concepts), Ruch Prawniczy, Ekonomiczny i Socjologiczny (Legal, Economic and Sociological Movement) no. 2 (2013).

PL: Act of 14 June 1960, Code of Administrative Proceedings, as amended.

PL: Act of 17 June 1966, on Enforcement Proceedings in Administration, as amended.

PL: Act of 3 February 1995, on Protection of Agricultural Lands and Forests, as amended.

PL: Act of 13 October 1995, on Principles of Registration and Identification of Tax Payers and Tax Remitters, as amended.

PL: Act of 20 June 1997, on Road Traffic, as amended.

PL: Act of 28 August 1997, on Employment of Prisoners, as amended.

PL: Tax Ordinance Act of 29 August 1997, as amended.

PL: Public Finance Act of 27 August 2009, as amended.

PL: Act of 16 November 2016, on Polish Fiscal Administration, as amended.

PL: Supreme Administrative Court: I FPS 2/09.

PL: Constitutional Tribunal: K 1/12, OTK-A 2012.

PL: Supreme Administrative Court: III SA 830/00.

PL: Supreme Administrative Court: II GSK 1020/10.

PL: Supreme Administrative Court: II GSK 2084/12.

PL: Supreme Administrative Court: II GSK 1693/13.

PL: Supreme Administrative Court: II GSK 1419/13. 
Public Interest as a Positive Condition of Applying Reliefs in Payment...

PL: Supreme Administrative Court: II GSK 2374/14.

PL: Voivodeship Administrative Court: III SA/Wa 1964/05.

PL: Voivodeship Administrative Court: V SA/Wa 2273/10.

PL: Voivodeship Administrative Court: II SA/Bd 727/11.

PL: Voivodeship Administrative Court: II SA/Łd 117/12.

PL: Voivodeship Administrative Court: III SA/Lu 242/12.

PL: Voivodeship Administrative Court: V SA/Wa 2119/12.

PL: Voivodeship Administrative Court: II SA/Łd 496/13.

PL: Voivodeship Administrative Court: II SA/Ke 135/13

PL: Voivodeship Administrative Court: III SA/Po 535/13.

PL: Voivodeship Administrative Court: I SA/O1 84/13.

PL: Voivodeship Administrative Court: I SA/Sz 217/13.

PL: Voivodeship Administrative Court: I SA/Bd 869/13.

PL: Voivodeship Administrative Court: I SA/Po 595/13.

PL: Voivodeship Administrative Court: III SA/Po 1263/13.

PL: Voivodeship Administrative Court: V SA/Wa 2274/13.

PL: Voivodeship Administrative Court: II SA/Sz 1356/13.

PL: Voivodeship Administrative Court: V SA/Wa 2614/13.

PL: Voivodeship Administrative Court: I SA/Kr 857/14.

PL: Voivodeship Administrative Court: III SA/Kr 574/16.

PL: Lubelski Voivod: no. NK.II.0911/241/10. 



\title{
TAX MOTIVATION AS AN INSTRUMENT PROTECTING PUBLIC FINANCIAL INTEREST
}

\author{
EWA LOTKO
}

\begin{abstract}
This article analyses tax motivation to fulfill tax obligation through the prism of public interest (financial). The starting point for the research presented here are factors shaping taxpayers motivation to comply with tax obligation or evade it. The aim of the article is to determine what values guide taxpayers deciding to pay or evade due taxes as well as what factors shape their tax motivation. The research problem is to establish the answer to the question whether tax motivation may protect the public financial interest. Regarding obtained results of the research identifying factors shaping tax motivation, psychological and ethical factors were selected, with the former proved to be major in having an impact on tax motivation. The main psychological factor negatively influencing tax motivation is the amount of tax and general reluctance towards transferring a part of the earned money.
\end{abstract}

\section{Keywords}

Public interest; tax motivation; tax morale; tax; public financial interest

JEL Classification: A14, H30, H60

\section{Introduction}

Taxpayer's attitudes and beliefs to fulfill tax obligations are the subjects of analysis mainly of social psychologists (Niesiobędzka, 2013: 11-66). They conduct research on the so-called tax morale defined as "attitudes of a group or the whole population

1 Doctor of Law, assistant in the Department of Public Finances and Financial Law on the Faculty of Law University of Bialystok. The Author of a few dozens of publications on public finances including instruments limiting deficit and public debt as well as participatory budgeting. A member of the Center for Information and Research Organisation in Public Finance and Tax Law of Central and Eastern European Countries, Editor-inChief of the research journal "Annual Center Review". Contact email: e.lotko@uwb.edu.pl. 
of taxpayers concerning the issue of complying with or neglecting their duties as taxpayers anchored in tax mentality and the awareness of being a citizen" (Kilchler, 2007: 99). The problem of tax morale is not analyzed through legal sciences which have fundamental importance regarding creation and tightening of the tax system and having special significance to tax gap limitation ${ }^{2}$ (Gemmell, Hasseldine, 2012), as well as to a broad fiscal security of the state and public financial interest. Therefore, the aim of this article is to determine what values taxpayers are guided by when deciding to comply with or evade due taxes and what factors shape their tax motivation. Among moral values indicated by L. Huberts (2014: 85), as public values significant from the perspective of tax compliance may be considered such as public interest, the common good, the interest of the future generations, rule of law, honesty, justice, dignity, ethical awareness and moral standards. The research problem of the article is to establish the answer to the question, essential in the context of paying taxes, whether tax motivation may protect the public financial interest. Given such stated research problem, the hypothesis is formulated in the following way: public financial interest is more protected if taxpayers are ethically motivated to fulfill tax obligations.

Qualitative surveys ${ }^{3}$ were used to verify the hypothesis, conducted on the sample $\mathrm{n}=1300$ inhabitants of Podlaskie and Mazowieckie Provinces, in the age from 18 to 60 , with the return of surveys on the level of $13 \%$. Respondents were asked the following questions including the factors shaping tax motivation both positively $(\mathrm{P})$ and negatively $(\mathrm{N})$ :

1) What motivates entrepreneur to pay taxes? $(P)$

2) What discourages us from using services provided by people or economic entities not paying due taxes? $(P)$

3) Do entrepreneurs honestly pay taxes do so guided by any moral values? If yes then which ones? $(P)$

4) Assuming that your neighbor had their flat renovated by their colleague and did not sign any official agreement evading in this way the payment of taxes, what motivated them? ( $N$ )

5) What motivates us to use services provided by people or economic entities not paying due taxes? ( $N$ )

6) What discourages entrepreneurs from paying taxes? $(N)$

Tax gap is a difference between due taxes which taxpayers should pay in a given time and those which were actually received by the state budget.

3 Preliminary analysis of the presented research results were published by E. Lotko and U.K. Zawadzka-Pąk (2017: 333-343). 


\section{Notion of Public Financial Interest}

According to the lexical definition, the word "interest" may describe "a thing to do" as well as a pursuit to achieve one's own benefit or a benefit for someone else (The Polish language dictionary, 2007: 135). It may be assumed that this benefit is identified with good occurring in a limited amount or directly with material benefits, often financial.

The notion of public interest both in the theory of law and judicial decisions is imprecise and the trials to define it are different depending on the context used or law branches (Wilczyńska, 2009: 50-51; Leszczyński, 2006: 81; Suwaj, 2009: 19; Żurawik, 2013a; Hanusz, Krukowska-Siembida, 2006: 181-184). It may be presumed that the reason for such imprecision is the necessity to consider all circumstances of a given situation every time as well as the need to search for values indicating the scope of individual or public interest and the legislator's intention to implement regulation regarding diverse factual status impossible to formulate in an unequivocal way with the dynamically changing reality (Wilczyńska, 2009: 48). Nevertheless, two different concepts of public interest may be given (Żurawik, 2013: 60). According to the first one, the public interest as opposed to the individual interest. In turn, pursuant to the doctrine of liberal rule of law and the concept of subjective rights, both interests may not only exist parallel to each other but even be connected (Wyrzykowski, 1986: 30-31). Analysing the notion of public interest in the context of taxpayers' behaviors, it is impossible to omit the issues of relations between public and individual interest. There are three models in the professional literature:

- the theory of overriding public interest according to which public interest is superior in relation to the individual interest allowing elimination of minority interest in the process of defining public good;

- common interest theory assuming summing up all individual interests including minority interests;

- unitary conception assuming that the notion of public interest "is founded on the rivalry between competing claims, based however on certain common values accepted in the society and constituting basis for decisions of public authority" (Nawrot, 2009: 67-68).

The notion of public interest may also be determined through the public good, the common good which not always has to correspond to individual good. In the universal apprehension, public interest should be evaluated from the point of view of the common good (society) and the actions of an individual in the aspect of conformity with the interests of other parties (Jakimowicz, 2006: 118). Therefore, discussing acting in the public interest, protection of such values as legal security, 
public order, health care, protection of the environment, protection of liberty and rights of other people as well as fighting frauds and fulfilling tax duties should be taken into account.

In connection with the above, the notion of public financial interest may be understood in two ways: as specific actions in the legal sphere aiming at establishing proper legal provisions allowing to sustain the financial stability of the state or the action of the taxpayers themselves aiming at fulfilling or encouraging to fulfill legal tax duties. For the purpose of this article, the notion of public financial interest is identified with individual reactions of taxpayers to fulfilling tax obligation.

\section{Tax Morale and Tax Motivation}

Tax morale is understood as the internalized obligation (Feld, Frey, 2005) or internal motivation to pay tax liabilities (Alm, Torgler, 2006). On the other hand, taxpayer's morale is understood as an individual reaction to fulfill tax obligation dictated by ethical factors (moral values and attitudes) or psychological factors (reaction of the surroundings / social mentality, legal provisions). Therefore, tax morale and thus taxpayers' behaviors are influenced by their individual financial position, internal beliefs, internal acceptance and recognizing state's fiscal sovereignty (PasternakMalicka, 2013: 92). It needs to be emphasized that tax has always been associated with an unpleasant duty to transfer a part of one's own income to the State Treasury or local government units (Pest, 2010: 107). This obligation may lead to tax resistance (Gomułowicz, Małecki, 2008: 1) which is characterized by a sequence of actions whose aim is to evade paying taxes. Braithwaite (2009: 103) distinguishes two types of resistance against paying taxes, i.e. disrespectful resistance when people think that authorities do not have the right to interfere in the freedom of the individual and attacking resistance meaning opposition to the methods used by the authorities.

It should be unequivocally emphasized that tax resistance results in serious consequences for the financial security of the state and infringes the principle of social justice. It also negatively impacts the fiscal function of taxes and consequently increases the tax gap ${ }^{4}$, because not all public funds which should be transferred are transferred to the state's budget. Therefore, the implementation of the main tax function should be connected with tax motivation in the scope of tax obligations and the phenomenon of social resistance ought to be treated as reprehensible and highly immoral. 4 According to the estimation of PwC, tax gap in the VAT in 2017 in Poland will decrease by about 13 billion PLN
but still, its estimated amount is about 39 billion PLN. 


\section{Analysis of Tax Motivation}

Conducted research was to select factors which positively and negatively shape tax motivation. Answering the first question concerning positive factors shaping tax motivation (among 169 people participating in the research, 159 answered, a part of them gave longer answers from which a few factors were selected, and therefore the number 159 is treated as $100 \%$ ) only $8.1 \%$ of respondents drew the attention to ethical aspects. Occasional answers indicate that respondents have higher values what acknowledge such answers as: "the willingness to conduct responsible business, being perceived as an honest entrepreneur", "the willingness to legally conduct business activity", "honesty towards country and society", "shared responsibility", "honesty", "patriotism". The vast majority of answers considered psychological factors. Respondents indicated that the biggest motivators to pay taxes are: financial penalties for non-payment (50.3\%), fear of fiscal control (6.2\%), own benefits of reductions and tax exemptions (12.5\%) or the possibility "to be creditworthy" in case of a need to obtain a credit (2\%).

Essential factor positively shaping tax motivation, but indicated by only $2.5 \%$ of respondents, are visible effects of the state's activity financed from the tax revenues and the conviction that public funds are well spent. $18.4 \%$ of respondents stated that "nothing" motivates them because paying taxes is a duty imposed by legal provisions. Next question connected with the motivation not to use services provided by people or entities not paying taxes was answered by 147 people (similarly as in the case of the previous question, this number was treated as $100 \%$ ). $78.5 \%$ of respondents showed general reluctance towards such entrepreneurs/frauds, with the main reason for $49 \%$ of respondents being own benefits, because of taxpayers:

- fear the quality of performed service / or its performance at all;

- do not want to be cheated;

- will not have the possibility to complain about the performed service.

$3 \%$ of respondents paid attention to social injustice because "such entrepreneurs enrich at our expense" (3\%). Among common answers (17.7\%) may be noticed and unambiguously judge as positive the tendency of the respondents to abide the law. It is worth mentioning that people who participated in the research indicated also such values as morale, honesty, reluctance to support breaking the law and stealing from the state. However, it is disturbing that only $3.8 \%$ of respondents paid attention to such values. Another question directly concerned moral values guiding entrepreneurs who honestly pay taxes. Answers given by 155 respondents are presented in Figure 1. Especially alarming is the fact that over $29 \%$ of respondents answered that they are not guided by any moral values because it is a duty imposed by law. 


\section{Figure 1 Moral Values Guiding Taxpayers Who Fulfil Tax Obligation}
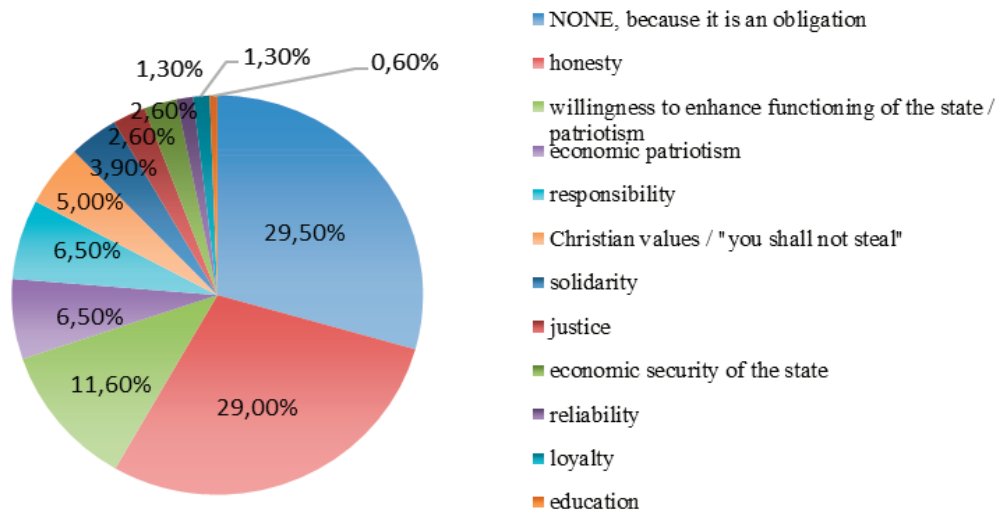

Source: Own elaboration.

Summing up the first three questions, Figures 2 and 3 present collective summaries of factors positively shaping tax motivation with specified psychological and ethical factors. The sum of values for particular factors in both cases exceeds $100 \%$, however calculating percentage value for particular factors, taking into account that each question has the different number of answers or no answers at all, an average of 154 from all answers was assumed and treated as $100 \%$.

Figure 2 Psychological Factors Positively Shaping Tax Motivation

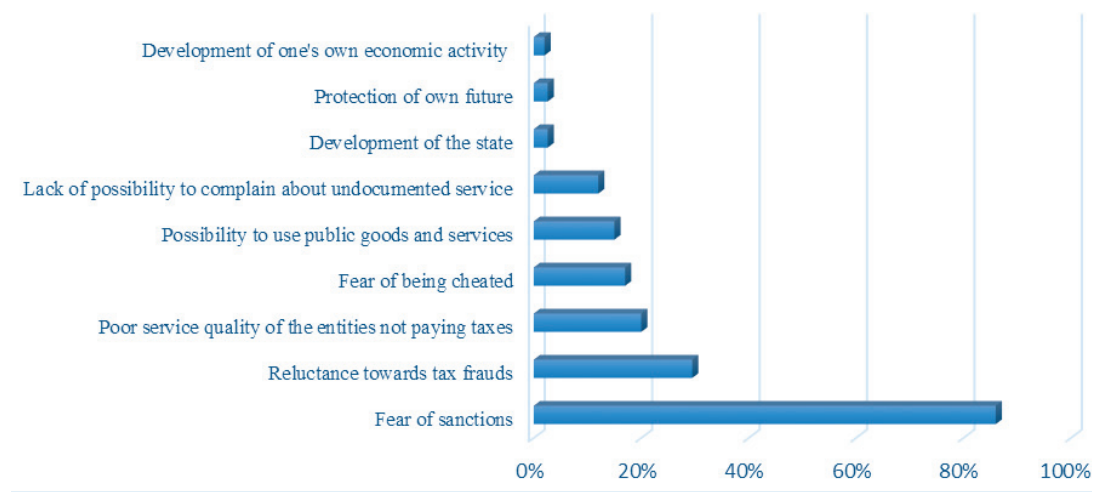

Source: Own elaboration. 
Tax Motivation as an Instrument Protecting Public Financial Interest

Figure 3 Ethical Factors Positively Shaping Tax Motivation

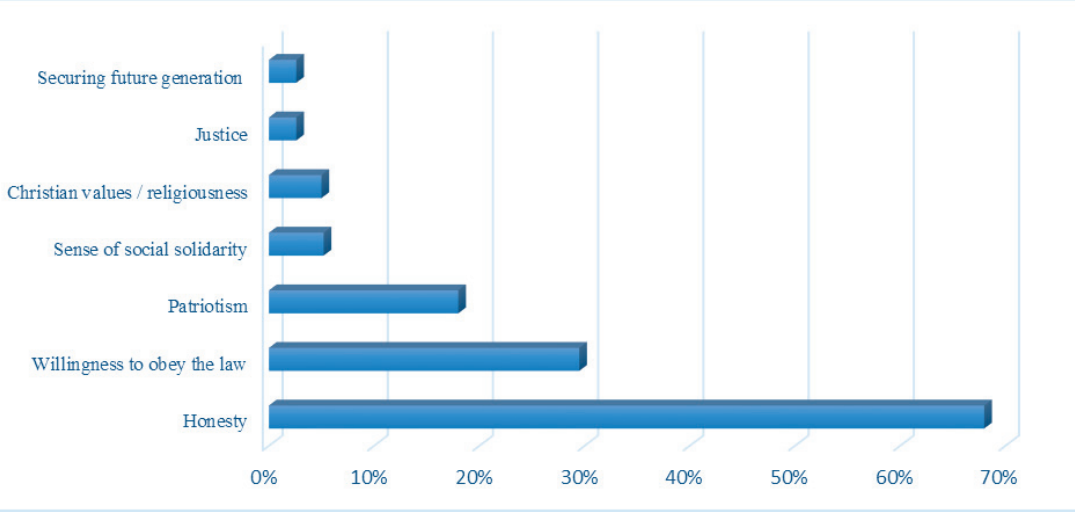

Source: Own elaboration.

Another group of questions allowed to specify the factors which do not motivate taxpayers to pay taxes. The first question was: "assuming that your neighbor had their flat renovated by their colleague and did not sign any official agreement evading paying taxes, what motivated them?" Such asked question was answered by 159 respondents, some of them gave more than one answer to the total sum of answers exceeded $100 \%$. Obtained answers allowed to specify six categories arranged according to their frequency:

1) willingness to save money $-74 \%$,

2) helping a friend $-14 \%$,

3) less formalism and bureaucracy $-10.7 \%$

4) own beliefs / "Polish mentality" $-9.5 \%$

5) lack of knowledge of legal provisions and awareness to enter such agreement $-9 \%$

6) not very friendly state/ attitude of civil servants $-3.8 \%$.

Similar answers regarding the content and frequency were given to the next question concerning taxpayer's motivation to use services provided by people/ entities not paying taxes. Such asked question was answered by 153 respondents. Dominating answers are:

1) lower price connected with the willingness to save $-70 \%$ of respondents,

2) lack of trust to politicians $-23.7 \%$,

3) fast and less formalized service $-3.3 \%$

4) internal reluctance to pay taxes $-3 \%$. 
Whereas among answers to the question about factors discouraging entrepreneurs from paying taxes, four groups of answers were selected from 158 answers:

1) the amount of taxes $-54 \%$,

2) too expanded and complicated tax system $-27 \%$,

3) entrepreneur's attitude/ unwillingness to share $-16.5 \%$

4) the attitude of the state/politicians/ sense of wasting public funds $-8.2 \%$.

The Figures below the present collective summary of the factors negatively influencing tax morale, with division into psychological and ethical. The sum of values for particular factors in both cases exceeded $100 \%$ because the Figures show data from three questions. Calculating percentage value for particular factors, having regard that each question had the different number of answers or no answers at all, an average of 156 answers was assumed and treated as $100 \%$.

\section{Figure 4 Psychological Factors Negatively Shaping Tax Motivation}

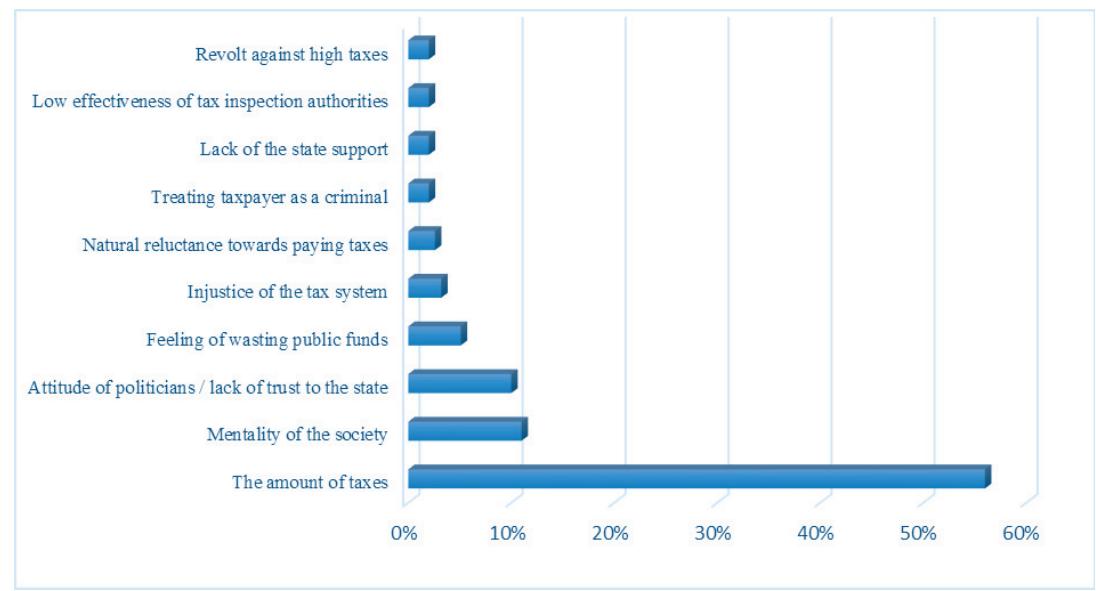

Source: Own elaboration. 


\section{Figure 5 Ethical Factors Negatively Shaping Tax Motivation}

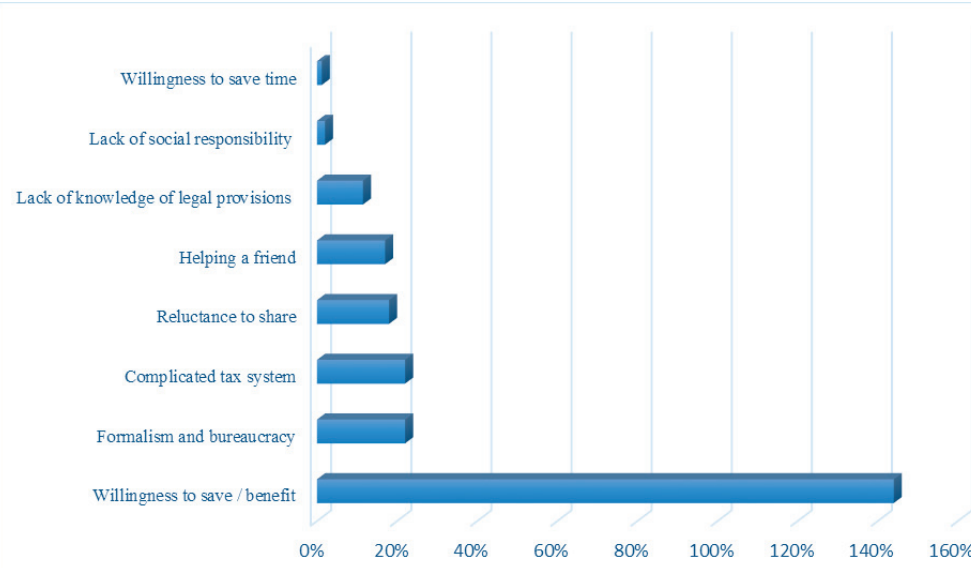

Source: Own elaboration.

\section{Conclusions}

The aim of the article was to determine values which taxpayers are guided by making decision about paying or evading due taxes as well as factors shaping their tax motivation. Regarding obtained results of the research identifying factors shaping tax motivation, psychological and ethical factors were selected, with the former proved to be major in having impact on tax motivation. The main psychological factor negatively influencing tax motivation is the amount of tax and general reluctance towards transferring a part of earned money. The factor deepening negative motivation is the legislator creating the law, who, in the opinion of people participating in the research, does not have a lot of trust from the taxpayers. Additionally, taxpayers (also participating in the research) would like in return for giving away a part of their income to the state see measurable effects of the state activity. Meanwhile, the vast majority of respondents does not perceive reliability, cost-efficiency and purposefulness in using public funds, what in a large extent determines their beliefs and thus behaviour. Among ethical factors negatively shaping tax motivation prevail willingness to obtain own profits and taking care of one's own private interest. Interestingly, respondents on the one hand indicate reluctance towards sharing with the state $(18 \%)$, and on the other hand accept the possibility to help their friend who does not conduct their business in accordance with law (17\%). Also other unethical taxpayers' activities should be highlighted. Mainly, the lack of knowledge of legal provisions, according to respondents, arises from complexity and frequent changes in tax law and not concluding agreements 
and as a result not paying due taxes are justified by too extensive formalism and bureaucracy. Thus, unethical taxpayers' activities are rooted in reluctance to sacrifice own time and in the lack of social and moral responsibility for the state and protection of public financial interest. Among factors positively shaping tax motivation prevail fear from sanctions and uncertainty about the quality of undocumented service. However it is a positively influencing aspect, it is again dictated by own interest of the taxpayer, leaving public financial interest behind. The research also allowed to select moral values which taxpayers are guided by when fulfilling tax obligation. Values such as honesty, willingness to enhance the functioning of the state, justice, patriotism, responsibility and care for common good are present in the taxpayers' awareness. However, as the research indicated, they influence motivation of only $10 \%$ of respondents.

Finally, with regard to the stated research problem, it should be indicated that tax motivation may protect the public financial interest, however, to be an effective instrument, it needs to result from the tax morale. This morale is highly influenced by opinion about the commonness of tax evasion and trust to democratic institutions of the state. The research showed that the actions of the taxpayers themselves as well as the representatives of legislative and executive authorities decide about the will to cooperate and care for common good. Therefore, the connection between tax morale and tax motivation may strengthen tax discipline and consequently public financial interest of the state. However, to make it fully possible, taxpayers should be motivated mainly by ethical factors positively shaping tax motivation.

Moreover, there is a need to increase tax awareness of the society and its education regarding public finances. A society whose members from yearly years learn about the needs of the state, relevance of participating in decisions concerning its functioning and economic processes is a society with high public awareness which impacts shaping of tax morale. It is in the public interest to form tax morale in such a way that taxpayers do not evade tax duties and fulfil them with the sense of acting in public interest. Although legal provisions do not impose priority of any interests because the legislator does not unambiguously define the primacy of one interest over the other, but in the situation of evading taxation public interest should be more significant and valuable. If the obligation to pay taxes arises from legal regulation and pursues to achieve objectives intended by the legislator, protects public financial interest and its amount stays in the proper proportion, then fulfilling tax duties should be treated as s value of supra-individual character. Therefore, in making taxpayers' choice, which are usually profit and loss calculations understood as objective, intended and deliberate choice, not without significance is the level of their tax morale which in consequence decides about tax motivation. 


\section{References}

Alm, J., Torgler, B.: Culture differences and tax morale in the United States and in Europe, Journal of Economic Psychology no. 27 (2006).

Braithwaite, V.: Defiance in Taxation and Governance Resisting and Dismissing authority in a Democracy, Cheltenham, Northampton: Edward Elgar, 2009.

Feld, L., Frey, B.S.: Tax compliance as the result of a psychological tax contract: The role of incentives and responsive regulation, CFRSI Working Paper no. 76 (2005).

Gemmell, N., Hasseldine, J.: The Tax Gap: A Methodological Review, Advances in Taxation vol. 20 (2012).

Gomułowicz, A., Małecki, J.: Podatki i prawo podatkowe (Taxes and tax law), Warszawa: LexisNexis, 2008.

Hanusz, A., Krukowska-Siembida, P.: Ważny interest podatnika i interes publiczny w klauzulach generalnych Ordynacji podatkowej (Important interest of the taxpayer and public interest in general clauses of the Tax ordinance), Annales Universitatis Mariae Curie-Skłodowska Lublin - Polonia no. 2 (2016), DOI 10.17951/g.2016.63.2.181.

Huberts, L. (ed.): The Integrity of Governance, What it is, What We Know, What is Done, and Where to Go, London: Palgrave Macmillan, 2014.

Jakimowicz W.: Wykładania w prawie administracyjnym (Interpretation in administrative law), Warszawa: Wolters Kluwer, 2006.

Kirchler, E.: The economic psychology of tax behaviour, Cambridge: Cambridge University Press, 2007.

Leszczyński, L.: Kategoria interesu w stosowaniu prawa administracyjnego. Przykład art. 7 KPA (The category of interest in the application of administrative law. Example of Art. 7 of the Code of Administrative Proceedings), in: Korybski, A., Kostyckij, M.W., Leszczyński, L. (eds.): Pojęcie interesu $w$ naukach prawnych, prawie stanowionym i orzecznictwie sądowym Polski i Ukrainy (The notion of interest in legal sciences, codified law and judicial decisions of Poland and Ukaraine), Lublin: Wydawnictwo Uniwersytetu Marii CurieSkłodowskiej, 2006.

Lotko, E., Zawadzka-Pąk, U.K.: Psychologiczne i etyczne aspekty w kształtowaniu motywacji podatkowej (Psychological and Ethical Aspects in Shaping Tax Morale), Przedsiębiorczość i zarządzanie w rozwoju ekonomicznym (Entrepreneurship and management in economic development) no. 2 (2017).

Nawrot, J.: Interes publiczny (Public interest), in: Powałowski, A. (ed.): Leksykon prawa gospodarczego publicznego (Lexicon of public economic law), Warszawa: C.H. Beck, 2009.

Niesiobędzka, M.: Dlaczego nie płacimy podatków? Psychologiczna analiza uchylania się od opodatkowania (Why don't we pay taxes? Psychological analysis of tax evasion), Warszawa: Scholar, 2013. 
Pasternak-Malicka, M.: Mentalność i moralność podatkowa a reakcje gospodarstw domowych na obowiązek podatkowy (Mentality, tax morale and reactions of households to tax obligation), Modern Management Review no. 1 (2013).

Pest, P.: Mechanizmy powstawania oporu podatkowego (Mechanisms of tax resistance formation), Studenckie Prace Prawnicze, Administratywistyczne i Ekonomiczne (Students' Legal, Administrative and Economic Works) no. 8 (2010).

Słownik Języka Polskiego (The Polish language dictionary), Warszawa: Wydawnictwo Naukowe PWN, 2007.

Suwaj, P.J.: Konflikt interesów w administracji publicznej (Conflict of interests in public administration), Warszawa: Oficyna a Wolters Kluwer business, 2009.

Wilczyńska, A.: Interes publiczny $\mathrm{w}$ prawie stanowionym $\mathrm{i}$ orzecznictwie Trybunału Konstytucyjnego (Public interest in codified law and judicial decisions of the Constitutional Tribunal), Przegląd Prawa Handlowego (The Merchant Law Review) no. 6 (2009).

Wyrzykowski, M.: Pojęcie interesu społecznego w prawie administracyjnym (The notion of social interest in administrative law), Warszawa: Wydawnictwo Uniwersytetu Warszawskiego, 1986.

Żurawik, A.: Interes publiczny”, „Interes społeczny” i „Interes społecznie uzasadniony”. Próba dookreślenia pojęć ("Public interest", "Social interest" and "Socially just interest". A trial to specify the notions), Ruch prawniczy, ekonomiczny i socjologiczny (Legal, economic and sociological movement) no. 2 (2013).

Żurawik, A.: Interes publiczny w prawie gospodarczym (Public interest in economic law), Warszawa: C.H. Beck, 2013a. 


\title{
THE TAX RULINGS - THE CONFLICT BETWEEN THE PRINCIPLE OF LEGALITY AND THE PRINCIPLE OF LEGITIMATE EXPECTATIONS ${ }^{1}$
}

\author{
WOJCIECH MORAWSKI
}

\begin{abstract}
The key research problem is to determine how the development of the interpretation system can be combined with the principle of legality as far as it is referred to the actions of a public authority. This is particularly important in the situation when it appears that the interpretation was incorrect. In Author's opinion the principle of protection legitimate expectations should be given priority when interpretations obtained by taxpayers motivated them to a particular action, while there were no circumstances undermining their confidence in the accuracy of the interpretation. In the Author's opinion, the principle of legitimate expectations should be given priority when interpretations obtained by taxpayers motivated them to a particular action, while there were no circumstances undermining their confidence in the accuracy of the interpretation. seems to be a rational concept. In Poland, however, the problem with protection of the holder of the interpretation does not lie in the defects of the regulations, but in the defects of the practice of their application.
\end{abstract}

\section{Keywords}

Tax; law; ruling; legality; conflict

JEL Classification: D63, H25, K34

Article prepared under a grant funded by the National Science Center (Poland) no. 2016/21/B/HS5/00187 "Acts of interpretation in tax law - between aid, flexibility and disintegration of system of tax law".

2 Professor in Department of Financial Law, Faculty of Law and Administration, Nicholas Copernicus University in Toruń. Contact email: wojciechmorawski.torun@gmail.com. 


\section{Introduction}

Tax interpretations (tax rulings) are an important part of our "tax life". In different forms, they are used in the vast majority of countries around the world. More and more often, the shortcomings of this institution, are highly noticeable. One of the problems discussed by scholars is the issue of compliance of this legal institution with the principles of law. The small part of this problem - resolving the conflict between the principle of legality and the principle of legitimate expectations of the taxpayer - will be the subject of this article.

\section{Poland - Country of Interpretations}

Undoubtedly, Poland is a country, where official interpretations of tax law (tax rulings) play the great role. It is indicated by the number of issued tax rulings. In 2014, tax administration in Poland issued 37.909 tax rulings, and in 2015 - the number of 37,710. It was not until 2016 when there has been a slight decrease in the number of interpretation to 34.151. It should be added, that the Polish authorities of interpretation in 2016 provided 1,712,804 telephone consultations (www.kis.gov.pl). Such action is not considered as a tax ruling, and a person who obtains information by telephone is not entitled to the same protection as the one who receives the ruling. This study omits the issue of these telephone advice. Issuing tax rulings is regulated in detail, by the provisions of the Tax Ordinance Act of 29 August 1997. In addition to individual interpretations, general interpretations are issued by the Minister responsible for public finances (nowadays: Minister of Finance). Unfortunately, they are issued in rather small quantities (only about 10 per year). Taxpayers affected by the general interpretations use similar protection as holders of tax ruling (individual interpretation). The boundary between individual interpretation (private tax ruling) and general interpretations (general tax ruling) in Poland is becoming less and less noticeable. An application for a private tax ruling can also be made by a group of taxpayers who are in the same actual situation, for example, the parties to the same contract (Tax Ordinance Act, Art. 14n). All applicants may benefit from the protection resulting from this interpretation. Formally, however, it is still an individual ruling.

This system is constantly developing, inasmuch, the legislator introduces new specific legal solutions. On 1 January 2017, a new institution appeared - a tax explanation (Tax Ordinance Act, Art. 14i/1a). To create a kind of simplified interpretation, which would also include examples of the interpreted rules usage was the intention of the legislator, which eventuates form the explanation of the project of the bill. Its regulation is laconic, and in practice, there is only one such 
The Tax Rulings - the Conflict Between the Principle of Legality and the Principle...

tax explanation. Also, since 1 January 2017, the new institution named: "fixed interpretation practice" (Tax Ordinance Act, Art. 14n/5-7) has been existing. It does not rely on issuing another type of interpretive act, but on the fact that taxpayer may point to opinions dominating in individual tax rulings which were obtained by other taxpayers in particular tax period (e.g. year in income taxes, month in the VAT) and 12 months of the preceding period. The taxpayer, who relies on a fixed interpretation practice, is treated as if he had an individual tax ruling.

The above-described interpretations are universal in nature - they may refer to the interpretation of all provisions of tax law (with small exceptions). Apart from them, there are also specialized interpretations in Poland. They touch only selected tax regulations. These are primarily (for many years), advance pricing agreements, subject of which, is the acceptance, by the tax authority, of the method of price calculation in a transaction between related business entities (Tax Ordinance Act, Arts. 20a-20r). The securing opinion is a new kind of interpretation. It is a new sort of interpretation of which launching is connected with the appearance (15 July 2016) in the Polish tax law of general anti-avoidance rule (Tax Ordinance Act, Art. 119a-119zf). The resolution, whether the action planned by the taxpayer, will or will not be considered as an abuse of the tax law, is the subject of this interpretation.

In the case of excise duty, there is specific binding excise information. Only the qualifications of the product as an appropriate type of excise product, not the interpretation of all the excise provisions, is the subject of such interpretations. This interpretation solves indirectly the problem of applying excise duty rates and the application of specific regulations to a given type of excise product. Specialized interpretations will not be the main subject of this study. Individual interpretations are essential for the taxpayer in Poland, and this is the main subject that this study will be focused on.

\section{Principle of Legality}

The principle of legality is the foundation of every modern legal system. It is particularly important in tax law when it comes to imposing public burdens on individuals. In tax law, it is the basic guarantee of the taxpayer's rights and the stability of his legal situation. Its roots reach the time of citizens' resistance to the arbitrariness of absolute monarchy. In France, the scholars usually indicate on Art. 14 of the Declaration of Human and Civil Rights of 26 August 1789 as the first manifestation of this principle in the matter of tax law. This provision stipulated, that citizens through their representatives have the right to determine the shape of the tax system (Lamarque, 2009: 286). It is important that originally this principle was a provision protecting the citizen from the arbitrariness of public authority. 
The similar regulation is in many modern constitutions. Nowadays, according to Art. 170/1 of the Constitution of the Kingdom of Belgium: "Any tax for the State may be imposed otherwise than by bill". Article 172 of this Constitution prohibits the granting of tax privileges, tax reliefs, and tax exemptions. It can be granted only by bill. Here appears the second face of this principle. In the context of the so understood principle of legal interpretation does not grant any tax reliefs or tax exemptions, it can only be - in the literal sense of the word "interpretation". In accordance with Art. 217 of the Constitution of Poland "The imposition of taxes, as well as other public imposts, the specification of those subject to the tax and the rates of taxation, as well as the principles for granting tax reliefs and remissions, along with categories of taxpayers exempt from taxation, shall be by means of statute." Article 99 of the Constitution of the Grand Duchy of Luxemburg prohibits any tax privileges. Tax exemption and the tax reduction may be implemented only by law (fr. en vertu de la loi).

The principle of legality in the context of the application of tax rulings turns out to be less approachable to the taxpayer. Results from the fact, that in the circumstances where a taxpayer has the favorable interpretation, but it is considered to be contrary to law, the tax authority will resolve the case based on the law. On one hand it guarantees that the settlement will not be based on the arbitrariness of authority, which might want to impose a higher tax, but on the other hand, it prohibits the authority taking into account that the taxpayer acted in trust to tax ruling. The principle of legality, therefore, stands for the rigor of tax. Its strict application would make the development of the system of tax ruling, impossible.

\section{Principle of Legitimate Expectations}

In the English and French language literature, the principle of legitimate expectation (pl. zasada ochrony uzasadnionych oczekiwań, fr. le principe de confiance légitime) is usually considered in the connection with the principle of legal certainty (Romano, 2002: 331; Michel, 2009: 286).

In French language literature (both French and Belgian), this concept is often cited with the principle of legal security (fr. le principe de la sécurité juridiques), (Forestini, 2003: 55) or with the principle of legitimate trust (le principe de la croyance légitime) (Geelhand, 1995: 57-105, 259-313, 488-523). It should be pointed out that the literature also, sometimes indicates the differences between these principles (Auby, 2007: 473-492). The principle of legitimate expectations consists in the fact that public authorities are obliged to act in accordance to certain standards that they have previously adopted, using their discretionary powers (Romano, 2002: 331). It is worth noticing, that in some countries the above-mentioned idea, 
The Tax Rulings - the Conflict Between the Principle of Legality and the Principle...

is expressed in a slightly different way. In Italian tax law, protection of the rights of the tax ruling's holder is ensured by the principle of good faith, which derives from civil law (Romano, 2002: 337-340). The legal basis of the principle of good faith has been found in various constitutional provisions, such as those guaranteeing economic initiatives, property rights, or of solidarity principle of Art. 2 of the Italian Constitution (Romano, 2002: 339).

The different sources of the rules, do not lead to significant substantive differences. The analysis of solutions adopted in jurisprudence and doctrine in various countries often shows their strict similarities. Actually, each of these concepts comes down to the issue of trust that an individual should give to the state and all activities of its officers. This is a common feature of all concepts and all ideas can be reduced to the principle of trust in the context of the subject of the study. The taxpayer should be able to trust an official opinion about the tax law interpretation expressed by any public authority. This means, that the taxpayer has the right to be sure that the administration's action based on a current way of interpretation of the tax law is a stable situation and the tax authority will, without any justified reasons, not change it. The Belgian Cour de Cassation in its judgment of 27 March 1992, citing the principle of legal certainty, stated: "the right to legal security implies in particular that a citizen must be able to trust that he will not be treated differently than a settled rule of the functioning of administration, it follows from this principle that public services are obliged to honour legitimate expectations that they created in the citizens" (Peeters, 2009: 9).

Therefore, the principle of legitimate expectation will be an argument emphasizing the value of tax ruling, as well as the basis for formulating doctrinal or juridical views and normative solutions aimed at protecting the interests of a taxpayer acting in confidence in such ruling. It must be stipulated that the scope of impact of the principle of legitimate expectation, is of course much wider, than the protection of trust which the taxpayer grant the tax ruling (Gomułowicz, 2011: 95-11).

\section{Resolution of Conflict of Principles - Compromise or Domination?}

The principles of legitimate expectations and principle of legality in the case of tax rulings seem to be clearly contradictory. If we take into account that the principle of legality is usually a constitutional principle, at first glance, one could say that tax ruling are condemned to liquidation. They should be considered as contrary to the law. At most, it would only be to appreciate as legal such rulings which are not contrary to the law. The problem is that the taxpayer needs protection just when 
he applies the interpretation contrary to the law. It would also be fundamentally unfair if the taxpayer who trusted the State, which issued the tax ruling, was not protected in the situation of state's error. It cannot come as a surprise, that there are no (all around the world) ideas for the complete elimination of tax interpretations. It happens, of course, those different actions are taken to examine the negative aspects of their functioning. For example, the European Parliament set up a special committee to investigate the system of tax interpretations in EU countries in the context of harmful tax competition.

In the Report of the European Parliament's Special Committee on Tax Rulings and Other Measures Similar in Nature or Effects (2015/2066 (INI)) - apart from pointing out some irregularities - it was found that broadly interpreted tax rulings "are not intrinsically problematic since they can, as is their original purpose, provide legal certainty for the taxpayer and reduce the financial risk for honest firms in cases where the tax laws or their particular application in certain circumstances are unclear or subject to diverging interpretations, in particular with regard to complex transactions, and thereby avoid future disputes between the taxpayer and the tax authority".

This committee did not propose the prohibition of issuing tax rulings by the Member States of EU, but only suggested taking actions to create "an EU-wide clearing house system, through which tax rulings would be systematically screened by the Commission so as to increase the system's level of certainty, consistency, uniformity, and transparency and check whether such rulings have a harmful effect on the other Member States". Also, in the preamble of Council Directive (EU) 2015/2376 of 8 December 2015 introducing instruments to combat the use of official tax law interpretations in order to avoid taxation (Council Directive (EU) no. 2015/2376) it was pointed out "rulings concerning tax-driven structures have, in certain cases, led to a low level of taxation of artificially high amounts of income in the country issuing, amending or renewing the advance ruling and left artificially low amounts of income to be taxed in any other countries involved. An increase in transparency is therefore urgently required." In the same document, the advantages of this institution were emphasized: "The issuance of advance tax rulings, which facilitate the consistent and transparent application of the law, is common practice, including in the Union. By providing certainty for business, clarification of tax law for taxpayers can encourage investment and compliance with the law and can, therefore, be conducive to the objective of further developing the single market in the Union on the basis of the principles and freedoms underlying the Treaties" (p. 1.1 preambles).

Among other things, experience related to the using of tax rulings as an instrument of harmful tax competition led to greater transparency (Mischo, 2015: 331). 
The Tax Rulings - the Conflict Between the Principle of Legality and the Principle...

Transparency naturally leads to an increase of importance of legalism in the process of launching them. It is the secrecy of the interpretation that allowed countries such as, Luxemburg, to create solutions (favorable for investors, but harmful to the budgets of other countries), that were not provided by the national tax law. In this unlawful way, Luxembourg enabled striking low taxation to illegally transferred income. However, ruling's transparency does not affect the problem of the ruling's holder protection. In this case, unfortunately, it is necessary to decide what is more important: the principle of legality or the principle of legitimate expectations. It is not a revealing statement, that in various countries this conflict is resolved in various ways.

In Belgium, the constitutional principle of legality seems crucial. In the view of the provisions of the Belgian Constitution cited above, the principle of legitimate expectation does not justify invoking an unlawful ruling before a court (Goyens, 2004: 4; Richelle, 2010: 138). The judge or the tax authority cannot in any way, use tax ruling contrary to the law because they are bound by law, not by the ruling. This solution of the conflict between two eponymous principles was originally the result of the judicial activity of the Belgian courts (Morawski, 2012: 389). Later this solution was transposed to the legal regulation. In Belgium, the tax ruling is, in principle, binding on the tax authority, but is not binging when it is contrary to the tax law. This solution seems unreasonable, also in the opinion of Belgian scholars (Vanhulle, 2005: 121). The Belgian legislator, therefore, prefers the principle of legality at the expense of the principle of legitimate expectation. It is very interesting that the tax authorities do not apply this exception to the binding by the ruling. In turn, in the neighboring Netherlands, this conflict was resolved differently. The Netherland's practice stresses the principle of legitimate expectations, although, in this country, there is no provision that would create for tax administration the effect of binding. The tax authorities, however, feel binding by tax rulings (Filipczyk, 2011: 156).

However, even in this country the principle of legitimate expectations is not automatically applied to every interpretation. In particular, two situations should be distinguished. First of all, if the contents of the ruling were obviously contrary to the tax law, then the taxpayer has no ground to enforce the tax ruling against to the tax law. "If it is not obvious that the ruling violates the law, but it is nevertheless favorable to the taxpayer, the tax authorities cannot simply set it aside. The tax authorities could then inform the taxpayer that, in their view, the ruling is not in accordance with tax legislation. The taxpayer is then entitled to a grace period (usually two years) to restructure his operation in the Netherlands. During that grace period, the tax authorities will respect the ruling" (Romano, 2002: 334). The tax authorities may revoke the ruling retroactively only in the situation when taxpayer 
failed to disclose all the relevant fact or intentionally misled the tax authorities (Romano, 2002: 334).

\section{Poland - to Run with Hare and Hunt with the Hounds}

The conflict of the principle of legality and the principles of legitimate expectations in Poland was resolving in various ways. Unfortunately, the only thing that is certain in Polish tax law is its instability. Before going to the presentation of current legal solutions, it is necessary to pay attention to the judgment of the Constitutional Tribunal (K.4/03). It was issued in the period when the legal regulation of tax interpretations was completely different than at present. However, this judgment indirectly shaped the current tax legislation.

In 2004, general interpretations bound the tax authority. The legal nature of individual interpretation was unclear. It is important that the Constitutional Tribunal has recognized that binding the tax authority by a general interpretation is inconsistent with the Constitution of the Republic of Poland. This was justified by the Tribunal, among other things, the fact that the binding of the tax authorities by interpretation blurs the differences between the creation and interpretation of the law.

This judgment influenced the current shape of Polish tax legislation regarding tax interpretations. Nowadays, no Polish tax interpretations are binding. Formally, the tax authority, which decides that the tax interpretation is against the law, must take a decision in accordance with the law, and therefore, contrary to the interpretation. This does not mean that the taxpayer cannot trust the ruling. Acting in accordance with the interpretation (both individual and general) before its changing must not be detrimental to the taxpayer. If the interpretation concerned events prior to its issue, the taxpayer is exempt from the obligation to pay default interest but is not exempt from paying the tax (Art. 14k Tax Ordinance Act).

If the interpretation concerned actions planned by the taxpayer, then, the taxpayer is entitled to an exemption from the duty to pay the tax in the scope resulting from the event being the subject of the interpretation. This exemption is granted on condition that the tax obligation was not performed properly due to the application of an interpretation that was changed, or which was not taken into account in the resolution of the tax case, and tax consequences connected with the event corresponding to the facts forming the subject of the interpretation occurred after the publication of the general interpretation, or after the delivery of the individual interpretation (Tax Ordinance Act, Art. 14m/1). However, the exemption is applied only at the request of the taxpayer. He must apply to the tax authority in this matter. 
The Tax Rulings - the Conflict Between the Principle of Legality and the Principle...

Similarly, to other countries, Polish law also provides taxpayers with a time of grace. This is a period after changing the interpretation, in which one may benefit from the exemption. Due to the fact, that the reason for the changing interpretation is based on the tax authority's recognition that the interpretation is unlawful, it means that Polish law indirectly accepts the using the interpretation contrary to the law.

The exemption referred shall include:

1) in the case of annual tax settlements - the period until the end of the tax year in which the changed general interpretation was published, the changed individual interpretation was delivered, or a copy of the administrative court's judgment reversing the individual interpretation with a statement of its validity was delivered to the tax authority,

2) in the case of quarterly tax settlements - the period until the end of the quarter in which the changed general interpretation was published, the changed individual interpretation was delivered, or a copy of administrative court's judgment reversing the individual interpretation with statement of its validity was delivered to the tax authority, as well as the following quarter,

3 ) in the case of monthly tax settlements - the period until the end of the month in which the changed general interpretation was published, the changed individual interpretation was delivered, or a copy of administrative court's judgment reversing the individual interpretation with a statement of its validity was delivered to the tax authority, as well as the following month (Tax Ordinance Act, Art. 14m/2).

Polish tax legislation is characterized in this matter by automatism. The reasons for the defectiveness of interpretation are not taken into account at all. As a result, the interest of the ruling's holder is also protected, even though, the taxpayer was fully aware of the obvious defectiveness of the interpretation. This raises the doubt, whether the Polish legislation has gone too far to protect the trust of the taxpayer. A positive aspect of this solution is to minimize potential conflicts related to determining whether the error of the tax authority could be detected by the taxpayer, or not.

However, there are some "traces" of legalism in the Polish legislation. The mechanism of protection is based on granting the exemption to the taxpayer, not on the binding effect of the interpretation. Formally, the tax authorities calculate the tax on the basis of the law and only then will apply for the tax exemption. This is a solution other than the one applicable in the Netherlands. The application of the principle of protection legitimate expectations in the Netherlands is somewhat more flexible, depending on, whether the interpretation was obviously incorrect, or not. In this way, the problems related to the taxpayers who point out to obviously 
incorrect interpretation (issued as a result of the incompetence of the public officials), are omitted. The Dutch practice shows, that the principle of protection legitimate expectations does not necessarily lead to the full binding of the tax authorities by the interpretation. Very good substantive preparation of the Dutch tax authorities and the will to cooperate with taxpayers (more on the functioning of the tax administration in the Netherlands-Alink, 2009) result that the ruling system in the Netherlands functions relatively well.

\section{Conclusions}

The ways of the resolving the conflict between the principles of legality and the principle of legitimate expectations are of course different in various countries. In Belgium, theoretically, an illegal interpretation does not protect the holder. However, in practice, this is not a problem for taxpayers, because the tax authorities act in accordance with interpretations. There is no clear legal regulation in the Netherlands, but in practice, the taxpayer is fully protected when he acts in confidence in interpretation, with exception of the situation when the ruling is obviously incorrect.

The principle of legality wins formally in Poland, but a deeper analysis of the tax legislation leads to the conclusion that the taxpayer is fully protected, more than in Netherland. This protection is, maybe, excessive. When it appears that the interpretation was incorrect, granting taxpayer protection or compensation related to the issuance of an incorrect interpretation seems to be in contradiction with the principle of legality, because it leads to situations in which law regulations will not be applied to the taxpayer. On the other hand, one can not deny that the protection of confidence of the taxpayer to the authority which issued the interpretation has also its essential significance. It is, therefore, necessary to indicate the directives helpful in resolving the conflict of principles. It is not, of course, the matter of a "simple" resolving, which principle is more valid, because in different contexts it seems reasonable to give priority sometimes to one of them, sometimes to the other.

In the Author's opinion, the principle of legitimate expectations should be given priority when interpretations obtained by taxpayers motivated them to a particular action, while there were no circumstances undermining their confidence in the accuracy of the interpretation. seems to be a rational concept. In Poland, however, the problem with protection of the holder of the interpretation does not lie in the defects of the regulations, but in the defects of the practice of their application. In recent years, very often the tax authorities search for small and irrelevant differences between the content of the application for issuing the interpretation and the future business activity of the holder. In practice, this destroys the sense of security of 
The Tax Rulings - the Conflict Between the Principle of Legality and the Principle...

taxpayers. The practice of the operation of tax authorities is more important than the regulations.

\section{References}

Alink, A., van Kommer, V.: The Dutch Approach, Description of the Dutch Tax and Customs Administration, Amsterdam: BFD Publications BV, 2009.

Auby, J.B, Dero-Bugny, D.: Les principes de sécurité uridiques et de confiance légitime (The principles of legal certainty and legitimate expectations), in: Auby, J.B, Dutheil de la Rochère, J. (eds.): Droit administratif européen (European administration law), Bruxelles: Bruylant, 2007.

Ferreira, E., Theurer, M.: Report of the Special Committee on Tax Ruling and Other Mesures Similar or Effect no. 2015/2066(INI) (2015).

Filipczyk, H.: Indywidualne interpretacje prawa podatkowego (Individual tax intepretations), Warszawa: Oficyna Prawa Polskiego, 2011.

Forestini R.: Les accords avec l'administration fiscal (Agreements with the tax authorities), Bruxelles: Larcier Group, 2003.

Geelhand, N.: Le principe de la croyance légitime en droit administratif et en droit fiscal (The principle of legitimate belief in administrative law and tax law), Revue critique de jurisprudence belge (Critical review of Belgian case law) no. 3 (1995).

Gomułowicz A., Małecki J., Podatki i prawo podatkowe (Taxes and tax law), Warszawa: LexisNexis, 2011.

Lamarque, J., Négrin, O., Ayrault, L.: Droit fiscal general (General tax law), Paris: LexisNexis, 2009.

Michel, V.: Brève observations sur l'application des principes de sécurité juridique et de confiance légitime (Brief comments on the application of the principles of legal certainty and legitimate expectations), La gazette du Palais no. 1 (2009).

Mischo, P., Kerger, F.: The New Luxembourg Tax Ruling Procedure, European Taxation no. 7 (2015).

Morawski, W.: Interpretacje prawa podatkowego i celnego - stabilność i zmiana (Tax and custom law interpretation - stability and change), Warszawa: Wolters Kluwer, 2012.

Richelle, I.: Belgium, in: Lang, M., Pistone, P., Schuch, J., Staringer, C. (eds.): Procedural Rules In Tax Law In the Context of European Union and Domestic Law, Oxford: Kluwer Law International, 2010.

Romano, C.: Advance Tax Rulings and Principles of Law Towards a European Tax Rulings System? Amsterdam: International Bureau of Fiscal Documentation, 2002.

Vanhulle, V.: The Belgian Advance Ruling Procedure: Recent Experience and Greater Efficiency and Flexibility from 2015, European Taxation, no. 3 (2015).

Goyens de Heusch F.: La pratique du ruling fiscal en Belgique (The practice of the tax ruling in Belgium). www.goyens.eu. 
Peeters, B.: La relation entre le principe de sécurité juridique et le principe de l'égalité: un processus d'Echternach? (The relationship between the principle of legal certainty and the principle of equality: an Echternach process?), 2009. www.tiberghien.com.

EU: Council Directive (EU) 2015/2376 of 8 December 2015 amending Directive 2011/16/EU as regards mandatory automatic exchange of information in the field of taxation.

PL: Tax Ordinance Act of 29 August 1997, as amended.

PL: Constitutional Tribunal: K.4/03. 


\title{
TRANSFORMATION OF DIRECT AND INDIRECT TAXATION'S CORRELATION AS A NECESSARY CONDITION FOR SOCIAL AND ECONOMIC DEVELOPMENT OF THE STATE
}

\author{
NATALIA A. SOLOVEVA
}

\begin{abstract}
The present study examines the transformation of direct and indirect taxation that has taken place in modern tax systems since the beginning of 2000-is. The study shows that direct and indirect taxation have different fiscal potential and influence the social and economic development of the state differently. On the basis of the carried out analysis, the study proves that in the OECD and EU member States correlation of direct and indirect taxation is constantly changing depending on economic opportunities and aims of the state while tax system of the Russian Federation practically does not shows such tendencies. The purpose of this study is to offer the general recommendation for improving tax policy of the Russian Federation with the aim of stimulating the social and economic development of the state. The purpose of the study predetermined the choice of applied research methods, among which comparative method should be highlighted.
\end{abstract}

\section{Keywords}

Direct taxation; indirect taxation; tax revenues; VAT; income taxes

\section{JEL Classification: H20, H25, K34}

Doctor of Law, Associate Professor at Department of International Economics and International Business Activity, Faculty of International Relations, Voronezh State University, Russia. The Author specializes in tax law and taxation. She is an author of monograph and coauthor of 6 books. She has published more than 50 articles in leading legal journals and conferences papers in Russia and abroad. The Author is a member of Russian Branch of International Fiscal Association and Information and Organization Centre for the Research on the Public Finances and Tax Law in the Countries of Central and Eastern Europe. Contact email: nubiforme@mail.ru. 


\section{Introduction}

Tax systems are constantly and inevitably developing as far as priority functions and tasks of the States changes, public needs, and macroeconomic processes modify. Economic processes taking place in the state at a certain moment of its development primarily influence the change of tax systems. However, when establishing tax payments, social and political processes also play an important role. In the early XX century prof. Ozerov very accurately determined conditions of transformation of tax systems: "Mutually connected complex of taxes established in the state under the influence of all socio-political, economic and financial effects, is called tax system. Each country, each era has its own tax system" (Ozerov, 1905: 82).

Direct and indirect taxation have their own fiscal and regulation functions. Their main advantages and disadvantages lie in the following areas: fiscal efficiency, equity of taxation, tax administration, the possibility of tax evasion, social-political effect. So, only right combination of direct and indirect taxes can establish more or less satisfactory system of taxation, which is able to provide sufficient funds to the state to cover its needs without imposing excessive burden on taxpayers, undermining the welfare of mass of the population and hindering economic development of the country (Vitte, 2011: 528). Obviously, correlation of direct and indirect taxes ensures the realization of their regulatory functions most effectively.

The correlation of direct and indirect taxation is not constant; it is in the process of constant transformation. The main tendencies in changes of mentioned correlation are determined using the examples of the OECD and EU Member States. The study shows that the role of indirect taxation has increased in recent years, in particular, due to the increase of tax rates of excise duties and value-added tax. There is the decrease in rates of corporate taxation and changes in the procedure for calculating of personal income tax. The decline in revenues is compensated by increasing the share of indirect taxes as well as by changing the procedure for calculating income taxes.

On the contrary, tax system of Russia does not demonstrate any significant changes in the correlation of direct and indirect taxation. In a changing economic environment, this suggests that direct and indirect taxation does not perform adequately its regulatory function. Thus, the purpose of this study is to offer the general recommendation for improving tax policy of the Russian Federation with the aim of stimulating the social and economic development of the state. Such recommendations may be subject to further researches with the aim of amending tax legislation of Russia. 
Studying foreign experience we should take into account that many positive features of effectively operating tax system are based on a high level of diversification of the economy whereas Russian economic model has not reached such a level of development and has a focus on the mining and export of natural recourses. At the same time, examples of transformation of foreign tax systems applied methods and achieved results should be carefully reviewed for their adaptation or, on the contrary, exceptions to the application with the aim of improving national tax system for stimulating the social and economic development of the state.

The purpose of the study predetermined the choice of applied research methods, among which comparative method should be highlighted. This method has allowed comparing changes in the correlation of direct and indirect taxation of the OECD, the EU Member States, and the Russian Federation. In addition, a systematic approach has been used that allowed making conclusions on tendencies of direct and indirect taxation's transformation.

In domestic and foreign literature there are many studies of direct or indirect taxation. Some studies relate to their correlation. However, relatively few studies analyze the transformation of such correlation. Therefore, most of the data for analysis was taken from the OECD database, European Commission database, Federal Tax Service of the Russian Federation database and Federal Service of State Statistic of Russia database.

\section{Direct and Indirect Taxation, its Advantages and Disadvantages}

The tax system of any modern state is a combination of direct and indirect taxes. Division of taxes into direct and indirect is applied in taxation from the XVI century. At the end of the XVII century criterion of transposition of taxes became the basis of such a division (Korovkin, 2006: 155). Since the definition of this criterion was given, problems of transposition of taxes have remained the object of study and a subject of debate.

From an economic point of view transposition of taxes can be understood as the change in the price of goods and services caused by the tax in which the payer gets an opportunity to shift tax burden either on his customers or his suppliers (Sokolov, 2003: 93). At the same time, mentioned the interpretation of transposition of taxes makes the division of taxes into direct and indirect quite conditional as modern domestic and foreign research indicate the possibility of transposition of taxes that traditionally are considered as direct taxes. 
It appears that taking into account the prevailing to date defining of taxes as direct or indirect, legal understanding of transposition of taxes obtains decisive importance. In fact, legal understanding reflects the mechanism of levying indirect taxes and can be understood as redistribution of the tax between the juridical subject of the tax (taxpayer) and the actual taxpayer (bearer of tax) (Kudryashova, 2006: 23).

On the basis of the mechanism of a collection of tax and objects of taxation, indirect taxes are taxes on goods, works, and services included in their price and paid by the final consumers. Taxpayer and tax bearer - persons actually paying indirect tax are not the same. Transposition of tax is carried out through a certain increment of the price. Direct taxes are imposed directly on the income liable to pay tax persons or their property and are charged upon receipt of income or property ownership. In this case, taxpayer and tax bearer is the same person.

The advantages and disadvantages of direct and indirect taxation are examined throughout the whole period of existence of the science on taxes. Not stopping at this issue in detail, let us highlight basic points reflecting modern advantages and disadvantages of these types of taxation:

1. Fiscal potential. Indirect taxation meets fiscal interests of the state to a greater extent as it has more significant fiscal efficiency due to vastness and universality of the objects of taxation. Indirect taxation also provides a greater equitability of tax revenues and their stability because indirect taxes are less dependent on changes of economic conditions.

2. Equity of taxation. Unlike indirect taxes, direct taxes can be commensurate to taxpayers' ability to pay and their individual characteristics. As a result, direct taxes largely perform distribution function of taxes. Indirect taxes are less burdensome for taxpayers but they are regressive due to inverse proportionality of taxpayers' ability to pay. So, indirect taxes are more burdensome for poor people.

3. Tax administration. The costs of tax administration of indirect taxes are higher than administration of direct taxes. Direct taxes, especially property taxes and income taxes calculated and paid by tax agents, provide known in advance and, accordingly, guaranteed income of budget.

4. The possibility of tax evasion. Despite the fact that there are a considerable number of schemes of tax evasion for direct and indirect taxes, unlike direct taxes, indirect taxes are difficult to optimize and reduce using lowtax jurisdictions. Moreover, a significant advantage of indirect taxation is that it filters the secondary cash flow and provides receiving by the budget system those revenues that fell out of direct taxation (Turbina, Cheremisina, Cheremisina, 2016: 83). 
5. Socio-political effect. It is rightly pointed out that correlation of direct and indirect taxes directly affects the development of civil society and its control over the financial activities of the state. Imposition of direct taxes demonstrates to citizens that they do maintain the state and promotes among the population the dissemination of legal ideas about the necessity of responsibility of the state and its institutions to society for the expenditure of national resources. Imposition of indirect taxes as a part of the price of goods, works and services is usually imperceptible to the population and does not contribute to the development of institutions of public control over the financial activities of the state (Ivlieva, 2007: 107).

While forming tax system the state uses both direct and indirect taxes on the basis of economic and social objectives, goals and opportunities in a certain period of time. Despite the fact that some studies contain very strong objections to indirect taxation, as a rule, the appropriateness of such combinations is not denied but rather confirmed by scientists for over two centuries.

\section{Correlation of Direct and Indirect Taxation in OECD and EU Member States}

Analyzing correlation of direct and indirect taxation in a number of developed countries of Europe prof. Korovkin noted that for about hundred years the correlation of direct and indirect taxes in tax revenues of the budgets changed almost the contrary. At the end of the $19^{\text {th }}$ century usually, about $2 / 3$ of tax revenues of budgets was formed by indirect taxes. By the end of the $20^{\text {th }}$ century, the share of indirect taxes declined to an average of $1 / 3$. That is, developed countries gave preference to the development of the market leading to the strengthening of the tax base of direct taxes (Korovkin, 2006: 271). Based on the share of indirect taxation in the tax system, all tax systems can be classified into:

- income tax systems, in which the share of indirect taxes in the total tax revenues does not exceed $35 \%$ of the total tax revenues;

- moderately indirect tax systems, in which the share of indirect taxes is between $35 \%$ to $50 \%$ of the total tax revenues;

- indirect tax systems, in which the share of indirect taxes is more than $50 \%$ of the total tax revenues.

If we consider this classification on the example of OECD member States, to date, only two of them - Chile and Mexico - are the countries with an indirect tax system. There are no such countries in the European Union. However, only six EU member States have moderately indirect tax system (Poland, Portugal, Greece, 
Slovenia, Estonia, Hungary). There are only 8 of them in the OECD (New Zealand and Israel in addition to the mentioned EU member States).

In its turn, developing countries and, as a rule, economies in transition are among the countries with indirect tax systems or moderately indirect tax systems that closer to the upper boundary (higher than $45 \%$ of total tax revenues). For example, since the beginning of 2000's, the percentage of tax revenues from indirect taxes in India is averagely $64-66,8 \%$, in Pakistan $-48,5 \%-55.7 \%$, in Brazil $-43.5 \%-$ 46.5\%, in Latin America - 52 - 53\%. Since 1965 the correlation of indirect taxation, income taxes, and property taxes in total tax revenues ${ }^{2}$ on average in the OECD member States changed as shown in Table 1.

Table 1 Correlation of Indirect Taxes, Income Taxes and Property Taxes in Total Tax Revenues (\%)

\begin{tabular}{|l|l|l|l|l|l|l|l|l|l|l|l|}
\hline & 1965 & 1970 & 1975 & 1980 & 1985 & 1990 & 1995 & 2000 & 2005 & 2010 & 2015 \\
\hline $\begin{array}{l}\text { Percentage of } \\
\text { indirect taxes }\end{array}$ & 38.4 & 35.6 & 32.8 & 32.5 & 33.7 & 32.5 & 33.6 & 33 & 32.9 & 30.9 & 32.9 \\
\hline $\begin{array}{l}\text { Percentage of } \\
\text { income taxes }\end{array}$ & 35 & 36.7 & 37.4 & 38.9 & 37.8 & 36.8 & 33.2 & 34.3 & 35.3 & 35.6 & 32.8 \\
\hline $\begin{array}{l}\text { Percentage of } \\
\text { property taxes }\end{array}$ & 7.9 & 7.6 & 6.6 & 5.3 & 5.4 & 5.7 & 5.2 & 5.5 & 5.5 & 5.4 & 5.6 \\
\hline
\end{tabular}

Source: OECD.

It should be taken into account that within the moderately indirect and income taxation systems, the correlation of direct and indirect taxes are often significantly different. For example, the share of indirect taxes in total tax revenues of newer EU member States is comparably higher than the share of indirect taxes in developed EU countries as illustrated in Table 2.

Table 2 Share of Indirect Taxes in Total Tax Revenues (\%)

\begin{tabular}{|c|c|c|c|c|c|c|}
\hline Country & 2000 & 2003 & 2006 & 2009 & 2012 & 2015 \\
\hline Belgium & 25 & 24.3 & 25 & 25 & 25 & 23.8 \\
\hline France & 26 & 25.6 & 25 & 25.2 & 24.5 & 24.4 \\
\hline Austria & 28.7 & 28.6 & 28.1 & 28.2 & 28.2 & 26.9 \\
\hline Hungary & 40.5 & 39.2 & 38.2 & 39.5 & 44 & 43.7 \\
\hline
\end{tabular}

2 It seems that among direct taxes it is more demonstrative to consider income taxes and property taxes as such taxes are collected in all the analyzed countries. The remaining part of tax revenue is social contributions and taxes on the payroll that are charged by significantly different regulations or are not charge at all. 
Transformation of Direct and Indirect Taxation's Correlation as a Necessary Condition...

\begin{tabular}{|c|c|c|c|c|c|c|}
\hline Poland & 35.3 & 37.6 & 38 & 37.2 & 36.6 & 37.1 \\
\hline Slovenia & 37.6 & 36.7 & 34.7 & 36.9 & 38.4 & 39.4 \\
\hline
\end{tabular}

Source: OECD.

With regard to direct taxation, overwhelming share belongs to income taxes, namely personal income tax (hereinafter - PIT), corporate income tax (hereinafter - CIT) and property taxes. In developed countries, the revenues from income taxation of individuals significantly exceed revenues from corporate income taxation. Thus, since the beginning of 2000's in the OECD Member States the revenues from PIT amounted to an average from $8.18 \%$ to $9.1 \%$ of GDP, while revenues from corporate taxation - from $2.72 \%$ to $3.63 \%$ of GDP. For developing countries and economies in transition, there is a converse situation: revenues from the CIT are significantly higher than revenues from the PIT.

Speaking on the changes in the correlation of direct and indirect taxation since the early 2000's in the OECD and the EU Member States, we can identify two following tendencies:

1. There is a certain decline in rates of CIT as well as significant changes in the procedure of calculation of PIT.

Analysis of tax revenues in the countries that have reduced tax burden on the organizations shows an increase of the share of indirect taxes. Such tendency can be demonstrated most clearly on the example of the UK, Sweden, and Hungary (Table 3).

Table 3 Changes of Shares of Indirect Taxes and Income Taxes in Total Tax Revenues (\%)

\begin{tabular}{|l|c|c|c|c|c|c|}
\hline \multicolumn{1}{|c|}{ Country } & \multicolumn{3}{|c|}{$\begin{array}{c}\text { The share of indirect taxes } \\
\text { in total tax revenues }\end{array}$} & \multicolumn{3}{c|}{$\begin{array}{c}\text { The share of income taxes } \\
\text { in total tax revenues }\end{array}$} \\
\hline & 2000 & 2008 & 2014 & 2000 & 2008 & 2014 \\
\hline The UK & 31.87 & 28.86 & 33.13 & 39.83 & 39.99 & 35.02 \\
\hline Sweden & 24.77 & 27.68 & 28.42 & 40.77 & 34.47 & 34.68 \\
\hline Hungary & 40.48 & 37.2 & 43.83 & 24.26 & 25.98 & 16.83 \\
\hline
\end{tabular}

Source: OECD.

It should be noted that despite the quite significant reduction in tax rates and changes in the procedure of taxation of incomes there is often no comparably significant reduction in tax revenues from corporate income taxation. This situation can be 
primarily explained by broadening the tax base and limitation or cancellation of tax incentives. In EU Member States there is also an increase in economic activity that is carried on in corporate forms, in particular, there is the certain transition from individual entrepreneurship and partnerships to the corporate forms (Kari, 2015: 3-5).

2. In the EU Member States, there is a tendency of certain increase of the role of indirect taxes as well as tax revenues from their collection. The moderate increase in excise rates should be marked. The vast majority of the EU member States has raised the standard and (or) reduced VAT rates:

- the average EU standard VAT rate varied from $19.3 \%$ to $19.7 \%$ during the period from 2000 to 2008 . The main increase in rates began in 2008 when the average rate was $19.5 \%$. In 2011 , the average tax rate rose to $20.7 \%$ and in 2014 it was $21.5 \%$. Table 4 gives some examples of courtiers that increased VAT rates.

Table 4 Increase in VAT Rate

\begin{tabular}{|l|c|c|c|c|c|c|}
\hline \multirow{2}{*}{ Country } & \multicolumn{7}{|c|}{ VAT rates (\%) } \\
\cline { 2 - 7 } & \multicolumn{2}{|c|}{2000} & \multicolumn{2}{c|}{2010} & \multicolumn{2}{c|}{2017} \\
\cline { 2 - 8 } & Standard & Reduced & Standard & Reduced & Standard & Reduced \\
\hline Germany & 16 & 7 & 19 & 7 & 19 & 7 \\
\hline Greece & 18 & $8 /-/ 4$ & 23 & $11 / 5.5 /-$ & 24 & $13 / 6 /-$ \\
\hline Spain & 16 & $7 /-/ 4$ & 18 & $8 /-/-$ & 21 & $10 / 4 /-$ \\
\hline Portugal & 17 & $12 / 5$ & 21 & $13 / 6$ & 23 & $13 / 6$ \\
\hline The Nederland & 17.5 & 6 & 19 & 6 & 21 & 6 \\
\hline Finland & 22 & $17 / 8$ & 23 & $13 / 9$ & 24 & $14 / 10$ \\
\hline Lithuania & 18 & 5 & 21 & $9 / 5$ & 21 & $9 / 5$ \\
\hline
\end{tabular}

Source: OECD, Eurostat.

- the average standard VAT rate in the OECD remained almost unchanged from 2000 to $2009(17.5 \%-18 \%)$ and in 2009 it increased to $19 \%$.

- The increasing role of indirect taxes in the formation of state revenues might be understood by two main reasons:

- compensation, i.e. the need to cover budget losses from the decline in revenues from income taxation;

- stimulating - governments promote the investment opportunities of the national capital, pursues the policy of liberalization of income taxations, relies on market self-regulation and encourage private initiatives. 
- Thus, there is a direct relationship between the increasing role of tax methods of stimulating investment activity of businesses and increasing of importance as well as the consequent expansion of the scope of indirect taxes.

\section{Direct and Indirect Taxes in the Russian Federation}

Russian tax system in its present form exists for about 20 years, in contrast to the tax systems of many developed countries that were forming over the centuries. In addition, the formation of Russian tax system occurred in the conditions of high inflation, acute shortage of budgetary funds and high volume of hidden economy. Obviously, indirect taxes satisfied the needs of the state in the best way.

Table 5 Share of Direct and Indirect Taxes in Total GDP (\%)

\begin{tabular}{|l|c|c|c|c|c|c|c|c|c|}
\hline & 2000 & 2006 & 2009 & 2010 & 2011 & 2012 & 2013 & 2014 & 2015 \\
\hline $\begin{array}{l}\text { The share of } \\
\text { direct taxes as } \\
\text { a percentage of } \\
\text { GDP }\end{array}$ & 13.9 & 15.7 & 16.52 & 16.76 & 17.44 & 17.53 & 16.76 & 16.86 & 16.34 \\
\hline $\begin{array}{l}\text { The share of } \\
\text { indirect taxes as } \\
\text { a percentage of } \\
\text { GDP }\end{array}$ & 19.7 & 18.6 & 18.52 & 17.86 & 19.82 & 20.16 & 19.62 & 20.07 & 19.86 \\
\hline
\end{tabular}

Source: Federal Service of State Statistic of Russia.

Russian tax system belongs to countries with the moderately indirect tax system. Despite high fiscal potential and exclusively significant role of indirect taxes, they are rightly considered as constraining factor for the growth of domestic production and investment in fixed assets as well as the cause of inflation. Speaking of indirect taxes, first of all, it should be noted that nowadays VAT in Russia is not only the main indirect tax, but it is among three most important tax sources of revenues of consolidated budget of the Russian Federation (the other two are taxes and payments for using natural resources and revenues from foreign economic activity).

In Russia VAT was introduced in 1992. Initially, the tax rate was too high. At the time of introduction the upper limit was approved at the rate of $28 \%$, then in 1993 , it was reduced to $20 \%$. From 2004 to the present day standard VAT rate is $18 \%$. As for reduced VAT rate, in 1993 it was set at 10\% and since then it had remained unchanged.

As illustrated in Table 6, there is a decrease in VAT revenues in the first half of 2000 's, which was primarily attributable to the reduction of the standard tax rate. In 
further changes in VAT, revenues are insignificant. The growth of VAT revenues in recent years mainly linked to the tightening of tax administration of VAT (extension of tax authorities' powers, putting into service automated control system for VAT, etc.).

\section{Table 6 Share of VAT in GDP, Total Tax Revenues and Consolidated Budget of Russia (\%)}

\begin{tabular}{|l|c|c|c|}
\hline Year & $\begin{array}{c}\text { The share of VAT as a } \\
\text { percentage of GDP }\end{array}$ & $\begin{array}{c}\text { The share of VAT in total tax } \\
\text { revenues }\end{array}$ & $\begin{array}{c}\text { The share of VAT in revenues } \\
\text { of consolidated budget of } \\
\text { Russia }\end{array}$ \\
\hline 2000 & 6.26 & 26.8 & 21.8 \\
\hline 2003 & 6.7 & 27 & 21.3 \\
\hline 2006 & 5.68 & 22.1 & 19.7 \\
\hline 2010 & 5.3 & 16.9 & 17.2 \\
\hline 2012 & 5.67 & 17.2 & 17.3 \\
\hline 2014 & 5.06 & 17.3 & 18.4 \\
\hline 2015 & 5.37 & 17.8 & 18.9 \\
\hline
\end{tabular}

Source: Federal Tax Service of the Russian Federation, Federal Service of State Statistic of Russia.

It appears that collection of VAT in Russia has the exclusively fiscal purpose while regulating potential of this tax is almost never used. Tax with such essential fiscal importance to the state has significantly influenced the overall economic situation in the country. The main instrument of regulation is tax exemptions from the VAT that have to increase payable demand of population, to provide enterprises with enhanced competitiveness and social well being of citizens through a reasonable redistribution of income.

Russian tax legislation fixes a wide range of objects that are excluded from VAT taxation (more than 70 transactions are excluded). It should be noted that exclusion of such a number of transactions from VAT taxation leads to lose control over them and not getting full information on the economic condition in the country. The other negative consequence is the significant shortfall in budget revenues. Thus, since 2010, growth in the shortfall in revenues of the federal budget (tax expenditures) has amounted to $157 \%$ that is hardly justified (Rukina, Denisova, 2016: 44).

Reduced VAT rate applies to certain food products, goods for children, periodicals. If the list of goods taxable at a reduced rate is not questioned, there are no convincing studies about the effectiveness of the application of namely $10 \%$ tax rate 
taking into account foreign experience of levying VAT as well as the impact of VAT on pricing and inflation, it is necessary to carry out studies on the possibility of introducing additional reduced VAT rate and taxation of a number of currently nontaxable operations at a reduced rate. Speaking about the standard VAT rate, since the second half of the 2000's, there have been justified suggestions on its reduction. Obviously, the main objection is the reduction of budget revenues. At the same time, such reduction may be offset by the abolition of inefficient tax exemptions from the VAT, as well as through the introduction of progressive tax rates on the PIT.

As for excise taxation, the share of excise taxes in total tax revenues is small. Since 2010 the share of excise taxes in total tax revenues in Russia varies from $1.76 \%$ to $2.83 \%$. For comparison, since 2010 in Germany and Italy the share of excise duties in total tax revenues varies from $6 \%$ to $7 \%$, in the US - from $3.4 \%$ to $4.2 \%$, in Greece - from $10.6 \%$ to $11.1 \%$. This situation is explained by the fact that in Russia excise rates are significantly lower than in developed countries and the list of excisable goods more narrow. Since the beginning of 2000's the following tendencies are observed:

- certain increase in excise tax rates;

- insignificant extension of the list of excisable goods.

One of the results of the first mentioned tendency is the growth of the hidden economy. For example, according to experts, in 2015-2016 the market of alcoholic products in Russia due to excise taxes consisted of $35 \%$ of legal production, $35 \%$ of surrogates and $30 \%$ of illegal production (Turbina, Cheremisina, Cheremisina, 2016: 84). As excise rates are not too high, combating the negative effects of increasing tax rates lies outside the scope of tax relations and must be implemented by law enforcement authorities.

At the same time, based on the positive foreign experience of excise taxation in foreign countries, the list of excisable goods in Russia should be expanded at the expense of goods that are little elastic for their prices (mainly luxury items). The absence of such goods in the list of excisable goods deprives excise taxation of the function of redistribution of incomes of highly paid levels of population and, consequently, deprives the budget of potential revenues.

Turning to income taxation, in its fiscal value income taxation is comparable to the value of VAT (Table 6, Table 7). It should also be noted that nowadays Russia belongs to the minority of countries that do not use progressive taxation of income of organization and individuals. 
Natalia A. Soloveva

Table 7 Changes of shares of PIT and CIT in GDP of the Russian Federation (\%)

\begin{tabular}{|c|c|c|c|c|c|c|c|c|c|c|}
\hline \multirow{2}{*}{ Tax } & \multicolumn{10}{|c|}{ The share in GDP } \\
\cline { 2 - 12 } & 2000 & 2003 & 2006 & 2009 & 2010 & 2011 & 2012 & 2013 & 2014 & 2015 \\
\hline PIT & 2.4 & 3.3 & 3.4 & 3.8 & 3.9 & 3.3 & 3.4 & 3.5 & 3.5 & 3.4 \\
\hline CIT & 4.1 & 3.4 & 3.7 & 3.86 & 3.83 & 4.06 & 3.76 & 3.1 & 3.08 & 3.52 \\
\hline
\end{tabular}

Source: Federal Service of State Statistic of Russia.

Until 2001 incomes of organizations in Russia were taxed on a progressive scale of taxation. In 2001 one uniform CIT rate in the size of 35\% was introduced. In 2002 it was reduced to $24 \%$. That tax rate existed till 2009 when there was one more reduction to $20 \%$. Calculation of CIT has undergone significant changes: abolishing of tax incentives, changing the procedure of calculation of depreciation, abolishing a number of restrictions on deducting expenses, etc. Thus, changes in levying of CIT in Russia in 2000's can be described as the gradual reduction in the number of tax incentives while reducing tax rates and liberalization of the procedure of formation expenses. Overall, these tendencies correspond to the tendencies in changes of corporate taxation in developed countries.

It seems that among the analyzing taxes CIT performs a regulatory function in the largest extent. One of the reasons for it is that the subjects of the Russian Federation may reduce the tax rate paid to their budgets for certain category taxpayers. There are also such positive aspects as the significant number of tax incentives, including sector-specific, and the possibility of transfer of loss from previous years to the next tax periods. Thus, at the moment CIT is balanced from the point of view of the interests of the state as well as interests of the taxpayer. In the light of the current economic situation, changes of the tax rate or other significant changes of elements of CIT seem inappropriate. As well as in relation to corporative income tax, until 2001 Russia had a progressive taxation of incomes of individuals. In 2001 one uniform PIT rate was introduced that was 13\%. Since 2001 PIT rate has not been changed. Abolition of progressive taxation was motivated by the legalization of incomes of individuals and necessity of increase of tax revenues.

According to experts, the share of informal wages in the total wage was, in particular, $24.6 \%$ in 2002, 28.8\% in 2006, 28.3\% in 2010, 27.3\% in 2015 (Povarova, 2016: 199). These figures indicate that progressive taxation of incomes of individuals is not the main reason for the informal payment of wages. As for increasing of tax revenues (Table 6), it took place only in 2002 and 2003 as the number of taxpayers was extended by officials of the law enforcement authorities and armed forces, as well as by reducing social contributions. After 2003, revenue growth is practically non- 
existent. Thus, the transition to proportional taxation was economically and socially unreasonable, not justified and contradicted world tendencies of development of income taxation of individuals.

Nowadays the PIT rate in Russia is one of the lowest in the world. One of the consequences of it is that GDP per capita in Russia is significantly lower than in countries where there are high rates of the PIT. Proportional taxation of income of individuals does not allow providing an effective and fair system of distributive relations in society. As a result, PIT performs the essentially fiscal function and is poorly used as a measure for influencing social and economic processes. The obvious conclusion is that the current system of taxation of incomes of individuals in the Russian Federation is ineffective.

\section{Conclusions}

The conducted study has shown two main tendencies of changes in the correlation of direct and indirect taxation since the early 2000's in the OECD and the EU member States: the certain decline in rates of CIT as well as significant changes in the procedure of calculation of PIT. At the same time, there is often no comparably significant reduction in tax revenues from corporate income taxation; and the certain increase of the role of indirect taxes as well as tax revenues from their collection. The moderate increase in excise rates should be marked. The vast majority of the EU member States has raised the standard and (or) reduced VAT rates.

The analysis, in particular, shows that if the government intends to implement economic stimulating by reducing one form of taxation, it inevitably leads to an increase in the share of another form of taxation. In the Russian Federation, only corporate income taxation follows the above-mentioned tendencies. In addition, CIT performs a regulatory function in the largest extent.

The study has illustrated that current system of taxation of incomes of individuals in Russia is ineffective mostly due to the proportional tax rate. In the medium term, we need to return to the progressive system of taxation of individual's incomes. The proposed reform of income taxation of individuals will allow, on the one hand, to maintain and even expand the economic conditions, stimulating the capitalization of incomes of individuals, and with another - to minimize social contradictions through a redistribution of tax allocations between the groups of the taxpayer with different social status. This will give the opportunity: to increase significantly budget revenues; to reduce the tax burden on the poor population, thereby contributing to increasing of customer demand and economic growth, and to create conditions for reduction of the high social stratification of Russian society. Indirect 
taxation in the Russian Federation has the exclusively fiscal purpose. In modern conditions, the development vector of indirect taxes can be considered as increasing their regulatory function that will contribute to economic growth and social wellbeing.

It is advisable to reform levying of VAT taking into account foreign experience of levying VAT as well as the impact of VAT on pricing and inflation. Two approaches are possible: radical approach that includes significant reduction of standard VAT rate (to 13-14\%) with simultaneous abolition of reduced tax rate; or moderate approach that includes reducing standard VAT rate to $16 \%$ with the revision and cancellation of larger number of tax incentives in the form of tax exemption (or transfer such objects of taxation to the objects taxing at reduced tax rate).

In respect of excise taxation, the list of excisable goods in Russia should be expanded at the expense of goods that are little elastic for their prices (mainly luxury items). The absence of such goods in the list of excisable goods deprives excise taxation of the function of redistribution of incomes of highly paid levels of population and, consequently, deprives the budget of potential revenues.

\section{References}

Kari, S.: Corporate Tax in an International Environment - Problems and possible remedies: Nordic Tax Journal no. 16 (2015).

Federal Tax Service of the Russian Federation. www.nalog.ru.

Federal Service of State Statistic of Russia. www.gks.ru.

Ivlieva, M.F.: Правовые проблемы косвенного налогообложения в Российской Федерации (Legal Problems od Inderect Taxation in the Russian Federation), Правоведение (Law) no. 11 (2007).

Korovkin, V.V.: Основы теории налогообложения (Fundamentals of the Theory of Taxation), Moscow: Economist, 2006.

Kudryashova, E.V.: Правовые аспекты косвенного налогообложения: теория и практика (Legal Aspects of Indirect Taxation: Theory and Practice), Moscow: Wolters Kluwer, 2006.

Ozerov, I.Kh.: Основы финансовой науки (Fundamentals of Financial Science), Moscow: Tip. T-va I.D. Sytina, 1905.

Povarova, A.I.: Реформирование налога на доходы физических лиц - важнейший фактор стабилизации бюджетной системы (The Reform of Tax on Incomes of Physical Persons

- The Most Important Factor in Stabilization of Budgetary System), Экономические и социальные перемены: факты, тенденции, прогноз (Economic and social changes: facts, tendencies, forecast) no. 6 (2016). 
Transformation of Direct and Indirect Taxation's Correlation as a Necessary Condition...

Rukina, S.N., Denisova, I.P.: Совершенствование косвенного налогообложения в Российской Федерации (Improvement of Indirect Taxation in the Russian Federation), Финансовая аналитика: проблемы и решения (Financial Analytics: Science and Expirience) no. 6 (2016).

Sokolov, A.А.: Теория налогов (Theory of Taxes), Moscow: Cebter UrInfoR, 2003.

Taxation trends in the European Union. www.ec.europa.eu/eurostat.

Turbina, M.V., Cheremisina, T.N., Cheremisina, N.V.: Преимущества и недостатки косвенного налогообложения (Advantages and Disadvantages of Indirect Taxation), Социальноэкономические явления и процессы (Socio-economic Phenomena and Processes) no. 8 (2016).

VAT rates applied in the Member States of the European Union. The situation at the January 2017. www.ec.europa.eu.

Vitte, S.Y.: Конспект лекций о народном и государственном хозяйстве, читанных его императорскому величеству великому князю Михаилу Александровичу в 1900-1902 годах (The Abstract of Lectures on National and State Economy Read to His Imperial Highness Grand Duke Michael Aleksandrovich in 1900-1902), Moscow: Yurait Publishing House, 2011. 



\title{
PROTECTION OF THE PUBLIC INTEREST AND THE TAXPAYER'S INTEREST AS THE GOAL OF TAX ADVISORY IN POLAND
}

\author{
ELŻBIETA A. AMBROŻEJ ${ }^{l}$
}

\begin{abstract}
This article is related to the function of tax advisory in Poland, which is to protect the public interest and the taxpayer's interest. The article shows that it is not possible to clearly define the scope of this function (the purpose of tax advisory), which results from the character of the concepts of "public interest" and "taxpayer interest", which are general clauses. However, the article presents the values recognized in doctrine and judicature that fall within these clauses and are subject to protection. The main aim of the article is an attempt to prove that the current legal model of tax advisory in Poland poses threats both to the taxpayer's interest and public interest, in particular by an improper shape of the principles of tax advising as well as the ones of acquiring the right to exercise it. The research used a dogmatic-legal research method and analysis of the jurisprudence of the Constitutional Tribunal and the judiciary, mainly administrative.
\end{abstract}

\section{Keywords}

Tax advisory; public interest; taxpayer's interest; protection of public interest; protection of the taxpayer's interest

JEL Classification: E62, H24, K34

\section{Introduction}

The Tax Advisory Act to meet social needs, created a new profession of public trust - a tax advisor. As argued in the explanatory memorandum to the draft of this law

1 Doctor of Law, Department of Finance and Accounting, College of Finance and Management in Bialystok, Poland. The author specializes in tax law and tax advisory. The author of numerous articles related to tax law and tax consulting. A member of the Center for Information and Organization of Public Finance Research and Tax Law of the Countries of Central and Eastern Europe. Contact email: elzbieta.ambrozej@gmail.com. 
(Draft no. 1113), providing tax advice and providing taxpayers with assistance in performing their duties (...) by persons without appropriate qualifications poses a threat to both the taxpayer's interests and the interests of the tax office. Misleading information on the existence of a tax obligation or the amount of tax liability exposes him to the consequences set out in the tax law, penal fiscal law and penal code, which, if the tax liability was significant, could lead to a threat of a taxpayer's economic capacity. Considering the above, it was stated that the statutory regulation of the principles of tax advisors' profession becomes, from the social point of view, an extremely important matter, and thus the creation of a new professional group recognized by the state, which would enjoy the great trust and social prestige.

The statutory construction of the tax advisor profession allows to include the profession in the public trust professions referred to in Art. 17/1 of the Constitution of the Republic of Poland. According to its content, the professions of public trust are those for which professional self-government bodies are created by the way of law, as well as representing persons performing them and exercising control over their proper performance, within the limits of public interest and for its protection. Professional corporations, therefore, have two constitutionally defined functions to fulfill. The first one is to represent the people performing such professions both towards citizens and their organizations, as well as against the state authorities. The second function comes down to efforts to ensure proper performance of these professions. It is implemented through supervision over the performance of a particular profession within the limits of public interest and for its protection, including, and perhaps above all, protection of citizens' rights (Constitutional Court: K 37/00).

In practice, the implementation of such a specific tax advisory goal has two main obstacles. The first one is the lack of a statutory definition of the terms "public interest" and "taxpayer interest", which in practice causes problems of interpretation and does not explicitly define the scope of the tax advisory goal ${ }^{2}$. An additional problem is that in the jurisprudence of the Constitutional Tribunal and administrative courts, the term "public interest" is often identified with "fiscal interest", "the interest of the Treasury" or "budgetary interest", which seems to 
Protection of the Public Interest and the Taxpayer's Interest as the Goal...

be a significant narrowing of the scope of the term "public interest". In relation to the notion of "taxpayer's interest", the narrowing of its significance is already highlighted by the Tax Ordinance Act which narrows it to the notion of "important taxpayer's interest" or "important interest of the party", which indicates the different scope of these concepts, and thus the various role of tax advisory in achieving its goal.

The second obstacle can be reduced to the thesis that the Tax Advisory Act, as it currently stands, poses a threat to effective protection of both public interest and taxpayer's interest, in particular through the deregulation of some of tax advisory activities, improper shaping of the rules for acquiring the right to practice as a tax advisor. In order to show the cited threats, it is necessary to attempt to identify the meaning of the terms "public interest" and "taxpayer's interest", their mutual relations, as well as the reference of these concepts to tax advisory institutions.

\section{Notion of Public Interest}

According to the Polish dictionary (www.sjp.pwn.pl), "interest" is a benefit, someone's good and benefits. In the broader, linguistic sense of "interest" the relationship between an objective, current or future state and the evaluation of this state from the point of view of the benefits that it brings or can bring to any individual or social group should be comprehended (Lang, 1972: 98-100). The phrase "public" means, on the other hand, referring to the whole society or some collective bodies, and available or intended for everyone, or related to some office or some kind or a non-private institution (www.sjp.pwn.pl).

In the doctrine of tax law and the jurisprudence of administrative courts, "public interest" is most often understood as a directive of conduct, requiring that the common values of the whole society or local community (territorial self-government unit) are respected, such as justice, security, citizens' trust in the authorities public authority, efficiency of the state apparatus, etc. (Presnarowicz, 2002: 86; Supreme Administrative Court: II FSK1610/13). It is emphasized that these values are not of a permanent nature, hence the content of public interest is variable over time, depending on the will of the democratic majority - but within the limits of the state's obligations expressed in the Constitution and laws (Dębowska-Romanowska, 2002: 20). The unclearness and changeability of the public interest cause that the legislator using this concept transfers the burden of defining its content in a specific case to the authority applying the law, whose duty is to find its content.

The literature also claims that the "public interest" is part of the broader concept of "common good", in the name of which people join and form the state, establish 
a state, (...) the common good is realized in cooperation - that is, co-creation and sharing (Dębowska-Romanowska, 2010: 19). However, it is also necessary to resort to state coercion (Dębowska-Romanowska, 2010: 19-20). This understanding of the public interest forms the basis for limiting freedom and civil rights (Constitutional Court: K.28/01). There are duties and sacrifices here which are connected to the obligation of citizens to pay public levies, including taxes referred to in art. 84 of the Constitution. However (...), the regulations governing the issue of public tributes must be compatible with all of the existing norms and constitutive principles. They cannot lead to any violation of values subject to constitutional protection. In particular, they cannot form a tax obligation in such a way that it would become an instrument of confiscation of property (Constitutional Court: SK.49/06).

With regard to public finances, the Constitutional Tribunal has also repeatedly emphasized that the public interest manifests itself in particular in the need to protect the stability of the state's financial interests and preserve budget balance (Constitutional Court: K.1/12), and case law of Administrative courts formulate the thesis that the public interest is not only the need to provide the necessary income in the budget but also to limit its possible expenses, e.g. for unemployment benefits or social welfare assistance (Supreme Administrative Court: III SA 830/00). In the jurisprudence of the Supreme Court, one can find a view that the notion of public interest should not be directly identified with the economic or fiscal interest of the state (Supreme Court: III ARN 33/93).

Referring to the position of the doctrine in the presented issue, one should also indicate an opinion according to which the public interest also refers to cases where there is a need to withdraw from the legislator's mistakes, resulting in the unpaid tax arrears (Modzelewski, 1997: 79). It is also worth noting that the public interest should also be sought in behaviours aimed at protecting or promoting the principles contained in the Constitution (Zdebel, 2012: 199-200), because in a democratic state of law every attempt to realize constitutional values is in the public interest (Bartosiewicz, Kubacki, 2007: 49). These principles (values) include, in particular, the principle of nullum tributum sine lege (Constitution, 217), which sets the limits of state interference in civil rights and freedoms and is of a guarantee nature, i.e. aimed at protection of individual rights (Supreme Administrative Court: I FSK 871/08). These values should also include all principles resulting from the principle of a democratic state ruled by law, in particular, the principle of protection of trust in the state and its law.

The literature also claims that the "public interest" can be seen as a tool for shaping the situation of the individual, since every state and self-government action is ultimately addressed to a man, hence the public interest can be described 
Protection of the Public Interest and the Taxpayer's Interest as the Goal...

as potentially related to many non-individual recipients treated as common entity (Boć, 2000: 23-24).

\section{Concept of Taxpayer's Interest}

Determining the meaning of the term "taxpayer interest" requires referring to the meaning of the term "individual interest". Considering the dictionary meaning of the phrase "interest" and the meaning of the phrase "individual", i.e. appropriate only to one person or individual, it should be assumed that in an etymological sense individual interest is the benefit, good and gains regarding specific individuals.

In the literature, in particular, with regard to an individual subject, it is argued that the concept of "interest" can be defined as the need, i.e. the desire (pursuit) to achieve an advantage that is able to enable a given entity to survive and develop in a given social environment. In this sense, the benefit means participation in goods that are in a limited quantity, i.e. unevenly distributed. In addition, this concept should include situations in which the purpose is not only to obtain a good but also to avoid the danger of violation of some of its interests (including reducing or preventing losses (Wilczyńska, 2009: 48-49).

Speaking of interest as a legal category, and in particular of the taxpayer's interest, in legal doctrine and jurisprudence, it is most often understood as a certain state of expectation, a specific need to preserve benefits already possessed or to wait for a good to appear (Presnarowicz, 2002: 68 et seq.). This concept should be associated with the dignity of the taxpayer, the possibility of further running a business, ensuring a decent life for himself and the closest family (Etel, 2017: 1472).

In tax legislation, the taxpayer's interest is referred to in particular in the Tax Ordinance Act. However, the subject of its regulation is not every taxpayer's interest, but an interest with specific features. The Tax Ordinance Act uses the phrases "important interest of the taxpayer" 3 and "important interest of the parties" ${ }^{\prime 4}$, which clearly indicates the interest of the taxpayer, which is crucial and of great importance (www.sjp.pwn.pl).

The lack of a normative determination of an important taxpayer's interest and an important interest of the party causes that these concepts are defined mainly in the case-law of administrative courts. Considering, however, that the condition of "important interest of the party" has a broader scope than the criterion

It may concern not only the taxpayer but also the payer, collector, third party responsible for tax arrears and legal successors of the taxpayer, payer, and collector. 
of "important taxpayer's interest", as well as the fact that the assessment of the existence of "important interest of the party" by administrative courts is most often related to the "important interest of the taxpayer", resulting from the substantive law provision constituting the basis of the final decision (Supreme Administrative Court: I GSK 366/136), hereinafter referred only to the concept of "important interest of the taxpayer".

The premise of an "important taxpayer's interest" is defined by administrative courts, in particular on the basis of tax reliefs. Under this concept, administrative courts understand extraordinary and fortuitous situations due to which the taxpayer is unable to regulate its public and legal obligations, and which could upset the taxpayer's existence basis (District Administrative Court: I SA/Wr 735/02). This will include loss of earning opportunities, contingent loss of fortune (Supreme Administrative Court: SA/Sz 850/98). However, when considering whether the taxpayer's interest is important, it is necessary to take into account, in addition to extraordinary (contingent) situations, also his economic situation (Supreme Administrative Court: I FSK 31/08), including the amount of income and expenses (Supreme Administrative Court: II FSK 3139/13), while the notorious lack of cash for payment of tax is not a prerequisite of the taxpayer's interest (District Administrative Court: III SA 2919/03).

An important taxpayer's interest concerns the situation of an individual taxpayer, but his important interest must be so significant and exceptional that its omission would have negative consequences for him (Choduń, Gomułowicz, Skoczylas, 2013: 118).

Analysis of the main thesis of administrative court rulings suggests that the existence of the "important taxpayer's interest" is assessed by the courts through objectified criteria, consistent with the generally approved hierarchy of values to which health and life belong, as well as earning opportunities to obtain means of subsistence of oneself and one's family, and well as the threat to existence. It is also important that the existing circumstances are independent of the taxpayer's behavior or caused by factors beyond the control of the taxpayer (District Administrative Court: I SA/Wr 735/02).

The taxpayer's interest, understood as a state of waiting for a certain advantage or the need to preserve the benefits already possessed or to wait for the emergence of a certain good, can, therefore, be referred to both the sphere of law-making and

6 In the above judgement, The Supreme Administrative Court stated: Admissibility of a change of final decision pursuant to Art. 253a/1 Tax Ordinance Act, except of meeting the conditions defined in this procedural law, depends on the content of this substantive law, on the basis of which the legal situation of a party in a given case is shaped, while both public and important interest of the party are evaluated from the perspective of the substantial law provision constituting the legal basis for the final decision. 
Protection of the Public Interest and the Taxpayer's Interest as the Goal...

application. In the sphere of action, the taxpayer's interest will be in particular the state of expectation that the legislator will create law respecting all constitutional principles, in particular, the principle of the rule of law (Constitution, Art. 7), and all values arising from the principle of a democratic state of law (Constitution, Art. 2). The taxpayer is obliged to fulfill his obligations, including the payment of tax, but only in the amount, time and place resulting from the provisions of tax acts. The special nature of tax law, directly interfering with the sphere of freedom and property of a taxpayer, therefore requires the formulation of tax law in a clear and precise manner, so that the taxpayer can comprehend the content of tax obligations that he is responsible for (fiscal, tax and criminal, and criminal). This interest also includes stability and certainty of tax law, shaping current or future taxpayer behaviour, hence the taxpayer's interest is to provide him with the possibility of appropriate tax planning, which should be expressed in the obligation to introduce a new law with the establishment of appropriate vacatio legis and transitional provisions, is to provide the taxpayer with the protection of "ongoing interests" (Constitutional Court: P 43/07).

In the field of tax law, the taxpayer's interest may be related to the possibility of taking all actions foreseen by law, both during and outside the tax procedure, which may give the taxpayer a certain advantage and thus protect the rights granted to him under the Constitution and tax law, both general and detailed.

\section{Public Interest and Taxpayer's Interest}

In the literature, "public interest" is also defined by comparing it with the concept of "individual interest", by which the taxpayer's interest should also be understood. The combination of these two interests can lead to tensions between them, their competitiveness and collisions (Zimmermann, 2005: 262) 7 .

Currently, in the doctrine and jurisprudence of the Constitutional Tribunal and administrative courts prevails the view that one cannot unequivocally attribute the superiority of the public interest over the interest of the taxpayer, both these interests must be balanced in every situation. This means that sometimes priority will be in the public interest and sometimes it will have to give way to individual interest (Żurawik, 2013: 57). It seems, however, that in a democratic state of law, the task of the administration should be to strive within the framework defined by law

$7 \quad$ It is noticed that there may be various relations between the public interest and the individual interest, which are recognized as overlap (these interests are completely identical); contradiction (disharmony) of public and individual interests (these interests abolish each other); indifference, these interests remain completely neutral with each other - they function on parallel planes, without being in conflict with each other (Wieloński, 2012: 21; Wilczyńska, 2009: 48-55). 
(in particular, the sphere of administrative recognition) to harmonize or reconcile both interests (Kmieciak, 1991). One should also agree with the opinion expressed in the doctrine that the protection of individual interests is in the public interest, that is, institutional securing protection and the possibility of pursuing their interests by individuals serves the collective body (Wieloński, 2012: 21). In this sense, the protection of the taxpayer's interest by the tax advisory institution (tax advisors) is also in the public interest.

\section{Tax Advisory Institution and Protection of Public Interest and Taxpayer's Interest}

Article 84 of the Constitution of RP, imposes on everyone an obligation to bear public burdens and benefits, including taxes specified in the Act. The concept of tax obligation in the light of Art. 84 of the Constitution of RP, has two aspects. The first of these relies on the taxpayer's obligation to meet (pay) the tax benefit (benefits) resulting from specific tax laws and from the general tax law, which may also provide for mandatory liability (co-responsibility) of other people for fulfilling (non-compliance) tax benefit. The second aspect is the personal and, at the same time, the economic obligation of maintaining one's own country. It raises some duties and rights. On the one hand, it is about being ready not only to bear the tax burden, but also other auxiliary duties accompanying it - on the other, to protect the dignity of a taxpayer acting in good faith, as a person maintaining the state, its privacy and the right to help the state to fulfil its duty (Dębowska-Romanowska, 2010: 140-141).

The aspect of tax obligation understood in this way allows to state that one of the forms of state aid in implementing tax obligations imposed on taxpayers is the establishment of a tax advisory institution. The tax advisor acts as a liaison between the taxpayer and the tax authority representing the public-law entity and therefore has two main goals to fulfill. The first one is to lead to the proper implementation of tax obligations incumbent on the taxpayer, including payment of tax in the amount, time and place resulting from the provisions of tax law. This is to protect the taxpayer's interest, in particular by protecting his property rights, as well as to prevent the taxpayer from being liable to tax, criminal-fiscal or criminal liability. Tax advisors, while protecting the taxpayer's interest, consequently protect the public interest as correctly and timely charged and paid taxes to ensure a permanent inflow of funds to the state budget and budgets of local government units necessary for the implementation of public expenditure specified in these budgets. This function is, therefore, the second aspect of tax advisory. A condition for the effectiveness of tax advisory (proper implementation of the tax advisory objective) 
is the existence of such a system of legal norms that will ensure the necessary protection of the tax advisor's rights and interests, public interest as well as the tax advisor's client - the taxpayer's interest.

The Tax Advisory Act on during the 20 years of its implementation has undergone significant modifications. For the most part, these modifications served both the public interest and the taxpayer's interest. The subject-related and subjective scope of tax advisory activities has been extended, which means that the institutional protection of tax advisory covers a wider range of entities and tax matters. Tax advisors were granted a catalog of new rights, such as material immunity, the right to Authorize copies of documents, the right to provide substitution within their own profession and as a lawyer and legal advisor. The protection of the professional secrecy of the tax advisor has been strengthened (it is unlimited in time, and only the court may exempt from the obligation to maintain it). Tax advisors obtained the right to practice in the form of all types of commercial companies, including multidisciplinary involving attorneys, legal advisors, statutory auditors and foreign lawyers, which ensured the possibility of comprehensive customer service in one law firm. The role of the advisors' professional self-government has been strengthened, thus also affecting the practice of tax advisor profession, which fulfilled the directive of the Constitution, Art. 17/1 - ensuring custody over the due performance of the profession, within the public interest and for its protection.

The major change took place with the entry into force of the Act of 9 May 2014 on facilitating access to certain regulated professions, hereinafter referred to as the "deregulation act". This Act, in particular, changed the principles of performing tax advisory activities, the acquisition of rights to practice as the tax advisor, as well as the forms in which this profession can be exercised.

Art. 2/1 of the Tax Advisory Act which had been in force just before the Deregulation came into force, included the following tax advisory activities:

1) providing taxpayers, taxable persons, and collectors with, at their direction or on their behalf, advice, opinions and explanations regarding their tax and customs obligations as well as administrative enforcement related to these duties,

2) keeping, on behalf of and for the benefit of taxpayers, taxable persons and collectors, tax books and other records for tax purposes and providing assistance in this regard,

3) preparing, on behalf of and for taxpayers, taxable persons and collectors, testimonies and tax returns or providing assistance in this respect,

4) representing taxpayers, taxable persons, and collectors in proceedings before public administration authorities and in the scope of judicial review 
of decisions, resolutions and other administrative acts in the matters listed in point $1 .^{8}$

The professional performance of tax advisory activities was reserved only to entities Authorized under the Act, i.e. tax advisors, lawyers, legal advisors, as well as auditors, in the scope specified in the Tax Advisory Act (Art. 2/2) .

In addition, in the light of the Accounting Act also entities providing accounting books were entitled to keep tax books and other records for tax purposes and preparation of tax returns and declarations (Accounting Act, Art. 76a/2). The performance of these activities by certified accountants did not violate the provisions of the Tax Advisory Act, because these activities, although coinciding with tax advisory activities, were not such and were not subject to the tax advisory act. What is important, the condition to acquire the right to provide bookkeeping services was to obtain an accountancy certificate (Accounting Act, Art. 76a/4), issued by the Minister of Finance, after fulfilling by the interested party a number of requirements specified in the $\mathrm{Act}^{10}$.

The deregulation act has liberated two extremely essential, from taxpayer's point of view, tax advisory activities, i.e. keeping tax and other records for tax purposes, and preparing tax returns and declarations. This regulation should be assessed negatively. Significant seems to be here the disturbance of the proportion between the purpose of this regulation and its possible consequences. The legislator, in order to influence the labor market, reduce unemployment, provide easier and wider access to tax advising, while abolishing the accounting certificate, opened the way for the provision of these services by any person, regardless of professional qualifications and personal qualities, with no public supervision whatsoever.

The proper keeping of tax books, their proper storage as well as timely notification of the tax authority about entrusting the keeping of tax books is important for the taxpayer both to determine the tax base and to prepare tax returns, but also to avoid fiscal, criminal and criminal tax liability. Hence, the quality of these books, the security of taxpayers and the protection of their interests depends on the qualifications of the people who maintain them. Transferring the right to maintain them to persons who are not duly prepared for it may lead to incorrect entries in

8 These activities could also be performed for third parties responsible for tax arrears and legal successors of taxpayers, payers or collectors (Tax Advisory Act, Art. 2/1a).

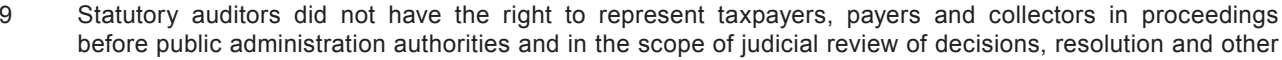
administrative acts.

10 These included full legal capacity, not being convicted by final judgment for particular offenses (including against the credibility of documents, property, business transactions, for criminal-fiscal offenses), professional tertiary education, professional practice, and in relation to persons who did not have a higher education degree passing the exam confirming the qualifications (Accounting Act, Art. 76b). 
Protection of the Public Interest and the Taxpayer's Interest as the Goal...

them, and thus the risk of recognition of the documentation as unreliable arises. This serves to protect neither the taxpayer's interest nor public interest.

Tax advisor's wide range of interdisciplinary knowledge and practical skills is a prerequisite for the proper performance of the profession. The Tax Advisory Act provides in this respect two basic requirements for future tax advisors the obligation to pass an exam to become a tax advisor and to complete an apprenticeship.

Professional training as the last stage of acquiring professional qualifications makes it possible to verify the actual skills of the candidate for the profession. Its completion is necessary to ensure the high quality of services provided, and thus protect the interests of the taxpayer as well as the public interest. Until the entry into force of the deregulation act, the candidate for a tax advisor was obliged to complete a two-year internship ${ }^{11}$ in Poland, which was to prepare him for practicing his profession, familiarize with all aspects of future work, the functioning of tax authorities and tax advisory. Such a purpose of the apprenticeship meant that it took place in the tax authorities, i.e., successively, in the tax office, tax chamber and in the fiscal control office, for a period of two months in each of them, as in a tax advisor or in a tax advisory company for 18 months $^{12}$. The deregulation act has shortened the apprenticeship to 6 months. In principle, its character and purpose have also changed. At present, the purpose of the internship is to familiarize the candidate with the profession of a tax advisor, therefore the employer has consistently limited the place of the apprenticeship to a tax advisor or a tax advisory company (Tax Advisory Act, Art. 21/4). In addition, 8 hours a week work time limit ${ }^{13}$, meaning that the actual internship was reduced to 26 days. It seems that such a far-reaching shortening of the apprenticeship does not ensure the implementation of its statutory goal. It is not possible to learn the practical aspects of this complex and interdisciplinary profession in such a short time. Therefore, it should be recognized that this regulation poses a threat to the clients of tax advisors and the protection of their interests, as it allows the profession to be performed by persons who are not properly prepared for it.

In addition to the apprenticeship, an exam for a tax advisor is part of the process of verifying the candidate's preparation for the profession. Starting from 10 August 2014, the Examination Commission with regards to the principles of conducting

11 The exceptions In this regards concerned natural persons whose qualifications to perform the profession of a tax advisor were recognized on the principles set out in the Act of 18 March 2008 on the principles of recognition of professional qualifications acquired in the European Union Member State.

12 Regulation of the Minister of Finance on 17 November 2010 on apprenticeship of candidates for tax advisors, $\S 2$ (1).

13 Detailed rules of Professional apprenticeship are regulated by the Regulation of Minister of Finance on 5 October 2014, on the professional apprenticeship of the candidate for tax advisors. 
tax advisor examination has obtained a new, extremely important entitlement. In the verification proceedings, university graduates with whom the Examination Commission will conclude the agreement ${ }^{14}$ will be able to take an exam to become a tax advisor on concessional terms, consisting in the possibility of exemption from the written part of the examination. This privilege, however, is limited in time and lasts no longer than two years after graduation (Tax Advisory Act, Art. 25/5 and Art. 25/6) ${ }^{15}$.

This solution should be considered beneficial, both for the development of tax advisory, protection of the taxpayer's interest, as well as the public interest. It creates the basis for shaping the common academic education of candidates for tax advisors. Currently, this profession can be performed by people regardless of the type of higher education they have, which seems not to protect the taxpayer's interest or public interest. It seems that the specificity of this profession requires that the candidate should at least have an economic, legal or specialized education, created for the needs of future tax advisors.

Doubts are also raised by the ban on the profession of a tax advisor as part of employment with an entrepreneur, which was abolished by the Deregulation Act. Characteristics of the employment relationship - subordination and submission of the employer's to the employee may affect the lack of independence and autonomy of the tax advisor in the profession, which violates the essence of the profession of public trust established for the protection of public interest (Constitution, Art. 17/1) and, consequently, also the taxpayer's interest.

\section{Conclusions}

The analysis of the meaning of "public interest" and "taxpayer's interest" led to the conclusion that these concepts do not have a fixed and unambiguous meaning, which imposes on the authorities that exercise law the right to interpret these concepts and look for their meaning in a specific situation. However, they cover certain superior values that require protection. Both doctrine and jurisprudence indicate it. It allows stating that apart from the state and local self-government as well as bodies acting on their behalf, the institution that can protect both these interests is the institution of tax advisory. It seems, however, that this goal is currently not fully implemented. Although tax advisors fulfill their basic function by providing taxpayers with

\footnotetext{
14 These agreements may be concluded only by those universities which organizational units are authorized for the postdoctoral degree in economics or legal sciences and which educational curriculum covers knowledge and skills required in the written part of the examination of a tax advisor. university graduate will become out of date.
} 
Protection of the Public Interest and the Taxpayer's Interest as the Goal...

assistance in fulfilling their tax obligations, incorrectly shaped provisions of the Tax Advisory Act, in particular allowing some tax advisory services to be carried out by persons with unconfirmed formal qualifications, poses serious threats to taxpayers' interests, and protection of their rights. An additional risk is the complete lack of public supervision over the performance of these activities by persons who are not members of professional corporations (people who maintain accounting books). For this reason, it is desirable to amend the provisions of the Tax Advisory Act in the above-mentioned scope, which will contribute to strengthening the protection of the taxpayer's interest as well as the public interest.

\section{References}

Bartosiewcz, A., Kubacki, R.: Ulgi płatnicze w świetle wartości konstytucyjnych (Payment allowances in the light of constitutional values), Monitor Podatkowy (Tax Monitor) no. 12 (2007).

Boć, J. et al.: Prawo administracyjne (Administrative law), Wrocław: Kolonia Limited, 2000.

Choduń, A., Gomułowicz, A., Skoczylas, A.: Klauzule generalne i zwroty niedookreślone w prawie podatkowym i administracyjnym. Wybrane zagadnienia teoretyczne i orzecznicze (General clauses and under-defined phrases in tax and administrative law. Selected theoretical and judicial issues), Warszawa: Wolters Kluwer, 2013.

Dębowska-Romanowska, T.: Zarys prawa. Prawo Finansowe. Część konstytucyjna wraz z częścią ogólną (Outline of law. Financial law. The constitutional part along with the general one), Warszawa: C.H. Beck, 2010.

Etel, L. et al.: Ordynacja podatkowa. Komentarz (Tax Ordinance Act. Comment) Warszawa: Wolters Kluwer, 2017.

Kmieciak, Z.: Glosa do wyroku NSA z dnia 8 stycznia 1988 r., sygn. akt: IV SA 753/87 (Gloss of NSA rulling of January 8, 1988, case ref. II SA 753/87) Orzecznictwo Sądów Polskich (Polish Courts Jurisdiction) no. 7-8, item. 15 (1991).

Modzelewski, W.: Ordynacja podatkowa w pytaniach i odpowiedziach, Tom I (Tax Ordinance Act, questions and answers), Warszawa: Instytut Studiów Podatkowych Modzelewscy i Wspólnicy, 1997.

Presnarowicz, S.: Ulgi i zwolnienia uznaniowe w Ordynacji podatkowej (Discretionary tax exemptions and reductions and in Tax Ordinance Act), Warszawa: Dom Wydawniczy ABA, 2002.

Wieloński, M.: Realizacja interesu publicznego w prawie zamówień publicznych (Realization of public interest in public procurement law), Warszawa: Wydział Dziennikarstwa i Nauk Politycznych Uniwersytet Warszawski, 2012.

Wilczyńska, A.: Interes publiczny $\mathrm{w}$ prawie stanowionym $\mathrm{i}$ orzecznictwie Trybunału Konstytucyjnego (Public interest in the law and case law of the Constitutional Tribunal), Przegląd Prawa Handlowego (The Commercial Law Review) no. 6 (2009). 
Zdebel, M.: Przesłanki umorzenia zaległości podatkowych należnych gminom (Premises for the write-off of tax arrears payable to municipalities), Annales Universitatis Mariae CurieSkłodowska, Sectio H, no. 3 (2012).

Zimmermann, J.: Przepisy ogólne prawa administracyjnego i definiowanie pojęć (General regulations of administrative law and defining concepts), Ruch Prawniczy, Ekonomiczny i Socjologiczny (Legal, Economical and Sociological Movement) no. 2 (2009).

Żurawik, A.: „Interes publiczny”, „interes społeczny”, i „interes społecznie uzasadniony”. Próba dookreślenia pojęć ("Public interest', "social interest" and "interest socially justified". An attempt to define the concepts), Ruch Prawniczy, Ekonomiczny i Socjologiczny (Legal, Economical and Sociological Movement) no. 2 (2013).

Internet Dictionary of Polish Language, Polish Scientific Publisher. www.sjp.pwn.pl

PL: Constitution of Republic of Poland of 2 April 1997, as amended.

PL: Tax Ordinance Act of 29 August 1997, as amended.

PL: Tax Advisory Act of 5 July 1996, as amended.

PL: Accounting Act of 29 September 1994, as amended.

PL: Act of 9 May 2014, as amended on Facilitating Access to Certain Regulated Professions.

PL: Constitutional Court: K.37/00.

PL: Constitutional Court: K.28/01.

PL: Constitutional Court: SK.49/06.

PL: Constitutional Court: P.43/07.

PL: Constitutional Court: K.1/12.

PL: Supreme Court: III ARN 33/93.

PL: Supreme Administrative Court: SA/Sz 850/98.

PL: Supreme Administrative Court: III SA 830/00.

PL: Supreme Administrative Court: I FSK 31/08.

PL: Supreme Administrative Court: II FSK1610/13.

PL: Supreme Administrative Court: II FSK 3139/13.

PL: District Administrative Court: I SA/Wr 735/02.

PL: District Administrative Court: III SA 2919/03. 


\title{
THE NATIONAL FISCAL ADMINISTRATION - CHALLENGES AND EXPECTATIONS
}

\author{
KRZYSZTOF TESZNER ${ }^{l}$
}

\begin{abstract}
The organizational and legal solutions introduced in Poland in 2017, aimed at improving state revenue collection, resulted in establishing the National Fiscal Administration. The adopted solutions have introduced a change in the functioning of the tax administration and a strengthening of its supervision. In the procedural dimension, the administration has been equipped with new tools of control of liable entities. A challenge faced by the National Fiscal Administration is an improved collection of revenue and duties through the introduction of effective audits, prosecution of the tax crime, and undertaking police actions. The expectations that honest taxpayers direct at the administration are a friendly approach to taxpaying entities and assistance and support in their fulfillment of tax obligations. In the Author's opinion, the adopted solutions introduce unequal treatment of liable entities. The assistance and support tool offered to them fails to mitigate the newly-introduced repressive legal instruments. Doubtlessly, when introducing legal solutions in the public interest, the individual interest of taxpayers and entrepreneurs should be taken into consideration to a greater extent.
\end{abstract}

\section{Keywords}

Tax administration; tax bodies; tax due; public interest

\section{JEL Classification: E62, K34, K40}

\footnotetext{
1 Assistant professor at Department of Administrative Law, Faculty of Law, University of Bialystok, Poland; The Author specializes in tax law and administrative law. He is the author of 2 books, and the coauthor of 4 books. He has published more than 120 articles and conference papers. He is a member of Information and Organization Centre for the Research on the Public Finances and Tax Law in the Countries of Central and Eastern Europe. Contact email: k.teszner@uwb.edu.pl
} 


\section{Introduction}

Ensuring the reliability and effectiveness of public institutions resulting from the preamble to the Constitution of Poland has become a principle and a real challenge for employers. This is particularly important in the cases when the legislator, recognizing the constitutional obligation to bear the burdens and public benefits, is guided by the need to protect values such as national financial security. In the area regulated by public law, including administrative law and tax law, public purposes and other values, such as the public interest, public good, or public matters exercised within the limits of the law, must be indicated. The concept of public interest is always dependent on the system of values adopted by the legislator and has a strong axiological basis. A public interest derived from public good has remained among the aims of administration activities, the administration being bound by law in this respect (Boć, 2010: 39).

Hence, acting in the public interest is the main purpose of administration and also its important feature (Zimmermann, 2016: 35). The question arises, however, as to how to achieve reliability and effectiveness of public administration when concentrating its activity on meeting the public interest to the largest possible degree. It seems that in the long-term perspective the aim may be achieved by, first of all, optimizing the administrative structure and, secondly, through adequate separation of tasks among public administration bodies, i.e. in a way that would offset their dysfunction and preclude overlap of competence. Lastly, it becomes important to introduce transparent audit and legal procedures to be applied by public administration.

The aforementioned areas of legal regulations seem particularly important as far as the rise in organized tax crime and the need for tax administration to disclose and prosecute it are concerned. These factors may undoubtedly be the reason for the organizational changes introduced into the tax administration itself, which should act in the public interest, belonging to society at large. The beneficiary of the advantages connected with the closing of loopholes in the tax system and elimination of tax evasion or fraudulent tax returns is society at large. This aim seems possible to attain provided that flexible screening procedures of taxpayers' compliance are accompanied by specific instruments of audit focused on detection and prosecution of tax crime and violations, in addition to Authoritative possibilities for tax administration bodies to make an impact on entities liable to pay tax.

Since 1 March 2017, the National Fiscal Administration has been in operation in Poland. The purpose of its establishment results from the preamble of the act on its establishment, the statutory definition, and the tasks assigned to the administration in question. The aim of this contribution is to present, analyze, and assess the legal solutions regulating the organization and functioning of the National Fiscal 
Administration in the context of the challenges it faces and the expectations of the liable entities. From the very start of the deliberations, an assumption should be made that due to the fact that tax administration is expected to act in the public interest, it must not ignore or be damaging to an individual's interest (Zimmermann, 2016: 39). It is important to introduce such mechanisms of tax administration functioning that would consider public interest together with an individual's interest, retaining possibly relative stability.

\section{Challenges Faced by National Fiscal Administration}

\subsection{General Remarks}

In order to establish the National Fiscal Administration, two acts had to be adopted: the Act of 16 November 2016 on the National Fiscal Administration and the introductory act, i.e. the Act of 16 November 2016 Regulations implementing the Act on the National Fiscal Administration, which introduced changes to over 150 provisions of other acts. The indicated purposes of the introduced changes were: to reduce the scale of tax fraud; to increase the effectiveness of revenue and duty collection; to improve the level of the voluntary character of compliance with fiscal obligations; to ensure a high level of client service; to reduce the operating costs of tax administration, in comparison with the level of the received entitlements; and to develop professional staff. The existing tax administration was considered unable to meet the challenges, due to its fragmented organizational structure, different operating standards, lack of uniform procedures, dispersion and overlap of competence, the competitive character of the undertaken actions, or the lack of a clearly defined career path.

\subsection{Decisive Factors for the Modernization of the Tax Administration in Poland}

In the last 19 years, i.e. since the Tax Ordinance Act of 29 August 1997 came into force on 1 January 1998 (referred to as TOA), no fundamental or systemic reform of the organization of tax administration was made, one that would cover all its segments (Teszner, 2014: 690). The administration, subject to the Minister of Finance until the end of February 2017, was functioning within the framework of three independent organizational divisions:

- Tax Administration (16 tax chambers and 400 tax offices);

- Customs (16 customs offices, 45 customs offices together with 141 customs branches); 
- Fiscal Audit (16 fiscal audit offices).

Thus, the territorial structure of the tax administration was dispersed, while some of the statutory tasks connected with tax and duty collection overlapped. Moreover, there were legal acts in force that regulated the issues of audits carried out by fiscal audit bodies, tax authorities, and customs authorities. In practice, this state of affairs resulted in the taxpayers being subject to different audit procedures. Another aspect that should be mentioned is the lack of uniform supervision. Despite the fact that the whole administration was formally under the Minister of Finance, it was de facto exercised independently by heads of the respective organizational divisions in units of the Ministry of Finance.

It must be assumed that the failure to undertake conceptual work on a comprehensive reform of the tax administration was mainly a result of a lack of political will. A visible change of the tax administration in Poland, on the other hand, was evident in the area of its functions and tasks. This was largely caused by the legislator gradually moving away from the method of the fulfillment of tax obligations based on the amounts established by way of decision and basing the current tax system on taxpayers themselves calculating the amount of the tax due, accompanied by the relevant supporting data required by the tax authorities. The activity of the tax authorities was targeted more specifically at performing checks, tax audits, and verification of the amount of due tax declared by the taxpayer during tax proceedings, as well as detection and taxation of undisclosed income.

The reduced tasks related to the amounts of tax due together with the increased intensity of audits and enforcement activities have had an impact on the increased number of tasks connected with entrepreneur services. The economic reality and the mutual expectations of the tax administration and the applicants, whose scale of activity is increasing within the globalized economy, have changed. Functionally, the tax administration has to some extent received the designation of servicing administration, or even infrastructure administration, as it is currently managing an ICT infrastructure, offering the taxpayers certain products and e-services (Niewiadomski, 2010: 21). At the same time, adapting the organizational units that comprise the tax administration to taking effective actions eliminating aggressive tax optimization in the cross-border aspect has become a real challenge. Tax administration should be capable of taking intense actions aimed at administrative cooperation in the area of taxes and duties, such as exchange of information and mutual assistance in the area of tax evasion and carrying out joint audits, including ones in the presence of tax administration officials from another country. 


\subsection{National Fiscal Administration - Organizational Aspects in Context of the Assigned Tasks}

The aforementioned factors had an undeniable impact on the establishment of the National Fiscal Administration on 1 March 2016, in place of the existing Tax Administration, Customs Service, and Fiscal Audit. The modernization of the tax administration in Poland mainly consisted in the consolidation of the customs and audit divisions, while retaining the existing tax administration units (tax offices and tax administration chambers) virtually unchanged as to their form and numbers. Its effect was the abolition, on the basis of Art. 160 of the NFA introductory act, of: 1) Fiscal Audit authorities conducting audit proceedings, i.e. General Inspectorate of Fiscal Control (GIKS) and the directors of Fiscal Audit offices, 2) the directors of tax chambers and heads of customs offices - Authorized to perform customs audits and proceedings and exercise tax control on the basis of TOA regulations. Within the framework of the National Fiscal Administration, Customs and Fiscal Audit was established, a uniform and uniformed formation consisting solely of officers. Its main task is to perform new customs and fiscal audits. Hence, the consolidation of the existing customs administration and Fiscal Audit has not only led to a resolution of its bodies, but also to an elimination of certain audit procedures.

Art. 11 of the NFA Act lists the newly established NFA bodies. These are: 1) the Minister of Finance, 2) the Head of the National Fiscal Administration, 3) the Director of the National Tax Information, 4) the director of the tax administration chamber, 5) the head of the tax office, and 6) the head of the customs and tax office. The consolidated fiscal administration is subject to the Minister of Finance. Formal and direct supervision of NFA bodies is exercised by the Head of the National Fiscal Administration, appointed by and subject to the Minister of Finance. Moreover, a newly established body, the director of the National Tax Information, was Authorized to issue, throughout Poland, individual interpretations of tax law provisions, on request of the interested entities. The consolidation of the tax administration was carried out simultaneously in two areas, i.e.:

1) at the central level, within the framework of departments in the Ministry of Finance,

2) at regional and local levels: tax chambers and tax offices, fiscal audit offices, customs chambers, and offices - into tax administration chambers as well as tax offices and customs and tax offices.

In the opinion of the legislator, such a model of the National Fiscal Administration will ensure effective tax collection, improve taxpayer service as far as their tax and customs obligations are concerned, ensure efficient administrative execution of claims, reduce the tax gap, and improve the effectiveness and efficiency of 
recovery of claims and taxpayers' audits. Other aims of the introduction of a new organizational model of tax administration is to ensure better communication and cooperation between tax administration bodies, improve the system that provides national financial security and protect the customs border of eastern Poland, and improve the image of the tax administration (National Fiscal Administration Act substantiation document, 2017).

The legislator's belief is that consolidation, even centralization, of organizational and supervisory processes within the framework of a tax administration will bring the expected results. However, as is rightly emphasized, the employer's conviction as to the achievement of these effects is intuition-based wishful thinking as the draft bill considered in the parliament was the deputies', not the government's, it, therefore, did not require preparation and presentation of analyses necessary to assess the regulation's consequences (Gajewski, Nowak-Far, 2016: 8). It is obvious that work on a legislation of such magnitude cannot be performed hastily and remain without consequences in terms of adopting inappropriate solutions, incompatible with other regulations, including the TOA. Introducing serious systemic and organizational solutions to the tax administration requires conceptual work, not to mention a wider discussion on the proposed solutions with experts' participation. It appears that the developments of the administrative and tax law doctrines, whose representatives indicated the deficiencies of the fiscal administration in numerous studies, were not made use of (Kosikowski, 2011: 345-346; Smoleń, 2009: 145146; Teszner, 2012: 408-409; Kulicki, 2014: 209-219). At the same time as the conviction as to the achievement of the expected results was being expressed, no in-depth diagnosis of the existing state of the tax administration was performed and no factors determining the weakness and low effectiveness of the individual segments of the fiscal administration were indicated; in addition, no relevant calculations, including those concerning the costs and benefits of the implemented solutions, were presented. This state of affairs may undermine the viability of the consolidation of the financial audit and the Customs Service in a situation when, in the opinion of the management of the Ministry of Finance, the efficiency of these units was constantly improving, whereas the performed audits brought results in the form of increased state revenues.

The basic regulations of the National Fiscal Administration Act were prefaced with a preamble, which emphasizes both the values that guided the legislator when drafting the law and the objectives to be achieved. These can be described as the challenges brought about by a consolidated tax administration. First of all, a reference to one of the traditional tax rules, one that is constitutionally empowered, i.e. the principle of the generality of taxation (Constitution of Poland, Art. 84), should be noted. This principle implies that the obligation to bear the burdens and 
public benefits, including taxes, as specified in the law, is shared by all entities. Indirectly, the principle is connected with the principle of equality before the law (Constitution of Poland, Art. 32/1) and the principle of tax justice (Kosikowski, 2004: 201). According to the doctrine, it can be assumed that tax burdens should be distributed fairly, therefore tax law should be made according to the principle of the norm of justice (Gomułowicz, 2005: 149-151). The generality of taxation as an expression of social justice has been repeatedly emphasized in the jurisprudence of the Constitutional Tribunal (K.28/98, K.12/94). One of its aspects is not only equal treatment of entities as far as taxation is concerned but also effective tax collection and detection of tax offenses (Oniszczuk, 2001: 149-150). Breach of the principles of justice on the part of liable entities may lead to tax avoidance, the commitment of fraud or tax offenses, and evasion of tax law. In consequence, this would mean a deviation from the constitutional principle of the generality of taxation.

The preamble indicates that when drafting the National Fiscal Administration Act, the legislator was guided by the concern for the "financial security of the Republic of Poland"; it also took into consideration the protection of "safety of the whole customs territory of the European Union". These terms are not explained for the needs of the Act; hence, they do not have the normative effect. They are used again in Art. 1/2 of the Act, defining the National Fiscal Administration, which is described as a specialized governmental administration performing tasks in the area of collection of revenue derived from taxes, customs duties, charges, and non-tax state revenues, protection of the interest of the Treasury, and protection of the whole customs territory of the European Union (Teszner, 2018: 11). The Tax Administration, as a special administration, undertakes actions aimed at the protection of the values indicated by the legislator as important. The fact that the administration acts in the financial public interest, understood as the interest of the public finances, is undeniable. Ensuring financial stability and reducing the tax gap were indicated as the very objective of the modernization of the fiscal administration.

The general scope of the National Fiscal Administration thus defined is detailed in Art. 2 of the Act, which contains a detailed catalog of 20 tasks of the NFA. The catalog has two major disadvantages. Firstly, it is not a closed catalog, which may be understandable due to the objective difficulties inherent in an attempt at a clear and exhaustive inclusion of all tasks realized by the NFA in a single normative act. Secondly, when establishing the National Fiscal Administration, the tasks thitherto realized by the consolidated divisions of the administration organizationally subject to the Minister of Finance were simply transferred to the new act, without their necessary review and verification. This is a serious allegation. It has been a common practice in the last several years to constantly increase the number of tasks assigned to the bodies operating within the framework of the existing 
administration, often without an increase in the overlays necessary for their implementation. For example, the range of tasks performed by the fiscal audit in the final period of its operation was increased to 17. Definitely, only correctly defining the implementation tasks makes it possible to establish an administrative structure that would be necessary for their implementation. This is essential especially as far as the newly-established organizational structure of the administration is concerned (NFA) and is not a common course of action, particularly in the context of undertaking consolidative actions.

\subsection{New Powers and Competencies of National Fiscal Administration Bodies}

In addition to identifying the general tasks of the National Fiscal Administration in Art. 2 of the Act, specific provisions of the Act divide the tasks among the individual bodies of the administration. Hence, the tasks are indicated in the following manner: those assigned to the Director of the National Fiscal Administration in Art. 14; those assigned to the Director of the National Tax Information - in Art. 22; those assigned to the director of the tax administration chamber - in Art. 25; those assigned to the head of the tax office - in Art. 28; those assigned to the head of the customs and tax office - in Art. 33 of the Act. The framework and purpose of this contribution do not allow to discuss all the tasks of the tax administration bodies. It is unclear why typical competences of the bodies, such as, for instance, tax and customs duty amount or making second instance decisions in tax proceedings. The competences of the tax administration bodies as far as forms of implementation of individual tasks are concerned are included in section V of the NFA Act (Art. 54 - Art. 143). It is thus needless to repeat the solutions, especially given that the aforementioned provisions are also not a closed catalog of the tasks of tax administration, which may also result from the provisions of other acts.

One of the tools for the implementation of the tasks of a consolidated National Fiscal Administration is using the existing audit procedure, i.e. the so-called customs and fiscal audit. The statutory assumptions referred to it as "hard audit", as opposed to the tax audit specified in Sec. VI of the TOA. These are two separate and independent control procedures, with tax audit possible to be performed by all first instance fiscal bodies as specified in Art. 13/1/1 of the TOA. The customs and fiscal audit, on the other hand, is a tool that enables fast response on the part of heads of customs and tax offices to fiscal offenses and transgressions.

When specifying the scope of the customs and fiscal audit, the legislator singled out, in Art. 54/1 of the NFA Act, the four major control areas. These pertain to compliance with the following laws: 1) tax law specified in Art. 3/2 of the TOA, 
2) customs legislation, 3) the Gambling Law, and 4) the Foreign Exchange Law. The scope of the customs and tax audit thus drafted is clear and introduces a great deal of flexibility in the area of planning and performance of audits. However, Art. $54 / 2$ of the NFA Act specifies additional instances for actions that are subject to the customs and tax audit, which cover, among others, the type of fuel in the tank of a vehicle, the manufacture and trade of game machines, road traffic, road transport, or export and import of goods subject to import restrictions or prohibitions. It should be thus concluded that the scope of the customs and tax audit is wider and does not overlap with the scope of the tax audit. Yet, in the case when the subject of the customs and tax audit is compliance with tax law, the scopes of both types of audit, as specified in Art. 54/1/1 of the NFA Act and Art. 281/2 of the TOA, clearly overlap. Hence, the criticized dual character of audit has in fact been retained. After all, both norms refer to the tax law regulation specified in Art. 3/2 of the TOA (Teszner, 2016: 209).

When indicating the powers of control of the National Fiscal Administration bodies, the mode of commencement of the customs and tax audit should be noted. According to Art. 62/1 and Art. 62/2 of the NFA Act, the audit is commenced ex officio, on the basis of relevant authorization. Commencement of an audit is no longer preceded by notifying the audited person on the initiation of a customs and tax audit proceeding related to them. Thus, tax administration bodies have been exempted from notifying the audited persons on a planned audit. Moreover, the possibility of performing the audit as a matter of urgency, presenting the service ID, in cases when non-compliance with regulations is suspected and the factual circumstances justify the immediate performance of a customs and tax audit, was foreseen.

The increased powers of the audit of NFA bodies are connected with the clear derogation from the obligation to each time establish the competent local body Authorized to perform the customs and tax audit. According to Art. 61 of the NFA Act, the head of the customs and tax office may perform customs and tax audits on the entire territory of Poland. This does not have to be the competent body for the audited person's domicile or the audited entity's seat, but rather the head of the customs and tax office that first commenced the audit. The consequence of this solution is not only an improvement of the performance of the customs and tax audit but also a consolidation of the competences of the head of the customs and tax office as far as the application of subsequent procedural solutions is concerned as, according to Art. 83/1 of the NFA Act, if a taxpayer fails to correct the tax return after being notified on the audit result and in accordance with the arrangements laid down in the document, then the completed custom and tax audit becomes a tax proceeding (Teszner, 2017: 26). The head of the customs and tax office that prepared 
the customs and tax audit result is thus the competent body Authorized to perform the tax proceedings and issue a decision, according to Art. 83/4 of the NFA Act. This solution was hitherto unheard-of in Polish procedures. What happens here is not a completion of a customs and tax audit and commencement of a separate tax proceeding, due to the fact that the stage of commencement of a tax proceeding is omitted. In this case, the legislator has ruled out the application of Art. 165 of the TOA, which regulates the rules for commencing a tax proceeding. Hence, a tax proceeding is initiated without its commencement but instead through transforming the already completed customs and tax audit.

The significantly broader scope of the customs and tax audit, in comparison with the solutions existing in the previous legal status, has a considerable impact on the place where audit activities are carried out. The provisions of the NFA Act foresee the possibility of performing the activities not only on the audited entity's or the auditing body's premises. Audits are also performed, for example, on public and internal access roads, in seaports and harbors, inland maritime waters, or marketplaces - also as permanent control - in places of manufacture and processing of excise goods and use of excise stamps, as well as in places where gambling is organized and held. Furthermore, in cases of audits performed by a uniformed officer equipped with personal identification markers, audit activities may be performed on border crossings, on the premises of customs and tax offices, or "at other places designated or approved by a relevant NFA body" (Act of NFA, Art. 62/13).

Within the framework of the customs and tax audit, the NFA has been granted broad powers, detailed in Art. 64 of the NFA Act. Some of these, such as the power of access and unrestricted movement on the premises of the audited entity's objects, the power of access to documents, examination, interrogation of the audited person and the witnesses, consultation with experts, securing the collected evidence, or sampling the goods, are similar to those granted to the auditor in other types of control. This provision, however, also foresees special audit powers that are granted exclusively to officers of the Customs and Tax Service. These include performing examination of goods, products, and means of transport, including with the use of technical equipment and police dogs, search of persons, escorting and safeguarding of goods, control of postal items, stopping vehicles and performing other tasks connected with road traffic control, stopping and controlling ships, or performing controls of the type of fuel used by sampling fuel from the vehicle's tank. The range of these prerogatives undoubtedly results from the procedures used by customs bodies and tax audit bodies. Within the framework of performing a customs and tax audit, it is also possible to assure, by way of a decision, the performance of tax and customs obligations over the audited person's assets (Act of NFA, Art. 80). 
Among the numerous powers of audit granted to the tax administration bodies, special attention should be paid to the right to demand from the audited person the files, records, books, and any other types of documents connected with the subject of the customs and tax audit, as well as to produce duplicates, copies, extracts, notes, and printouts, and documented retrieval of data in electronic form. This right also covers the records, books, and documents of any type connected with the subject of the audit for periods other than the period covered by the audit, provided that the period of storage specified in separate provisions has not expired (Act of NFA, Art. 64/3). This power, however, must not be understood as the intention on the part of the legislator for reference periods not covered by the subject of the audit to be subjected to control as part of an audit of a specific reference period.

Within the framework of the customs and tax audit, officers also exercise audit powers that make use of IT tools to a wider extent than previously. Interrogation of the audited person or a witness may be carried out remotely. Art. 76 of the NFA Act indicates that these actions may be performed via technical equipment that enables to carry them out remotely, with simultaneous transmission of sound and vision. The interview is recorded by means of an Audio Visual recording device and the record constitutes an annex to the report from the hearing, which is limited only to the most valid statements made by the participating persons.

Another example concerns the performance of an audit at the audited person's contractor, i.e. the so-called cross-check. This power results from Art. 79/1 and Art. 97/2 of the NFA Act. A significant difference, in comparison with the solutions included in the TOA, is the possibility for the head of the customs and tax office to submit to the audited person's contractor a request for transfer, by means electronic communication media or on an electronic data storage device, an extract from the tax records and accounting records recorded in electronic form. Exercising these powers is conditional on the audited person's contractor keeping tax books with the use of computer software.

\section{Expectations Towards the National Fiscal Administration}

One of the tasks of the National Fiscal Administration is to provide taxpayers and payers with services and support in the area of fulfilling their tax and customs obligations properly (Act of NFA, Art. 2/1/5). In accordance with the intention expressed in the preamble to the Act, ensuring the fulfillment of the obligations is to be modern and friendly. The willingness on the part of the legislator for the tax administration to withdraw in certain situations from the governmental authorities that it exercises in favor of performing taxpayer-dedicated services can be observed here. This approach is consistent with taxpayers' expectations, who wish to fulfill 
their tax obligations on a voluntary basis, with adequate support from the tax administration.

Scientific publications emphasize that, in addition to the traditional forms of operation based on administrative governance, there exist factors that diminish the role of governmental forms of tax administration actions in the process of fulfillment of tax obligations. Among these, the following are mentioned: checks, information campaigns, the tax return correction institution, the tax interpretation institution, or agreements on settlements on transaction prices (Pietrasz, et al.: 2013: 316). These are not, however, instruments that would ensure real support of entities in their fulfillment of tax obligations. The question could thus be raised whether the individual interest of honest taxpayers was also taken into consideration when the legislator was consolidating the tax administration, granting it new powers.

Providing taxpayers and payers with services and support in the area of fulfilling their tax and customs obligations properly is the task of the head of the tax office This body should undertake actions consisting in providing assistance in independent, correct, and voluntary fulfillment of tax obligations, implemented by the service center in the tax office (Act of NFA, Art. 28/1/5 and Art. 28/3) From the very start, an assumption was made that taxpayer services and support do not cover the preparation of applications, opinions, tax statements, or returns. This assumption is accurate as support provided to the taxpayer by the tax administration cannot fall within the activities covered by ${ }^{\text {tax }}$ advisory Art. 29/1 of the NFA Act foresees the following service and support activities:

1) accepting applications and returns, issuing certificates and explanations in the area of tax law, 2) providing guidance on how to complete tax statements and returns, 3) providing a computer workstation with access to the tax portal, 4) providing information on the contact data of the competent authorities together with their ranges of competences.

In the Author's opinion, the elements of service and support indicated above are insufficient. They mostly include the official duties of tax officials that they should be performing in any case, e.g. accepting applications or tax returns. What is lacking, therefore, are real support instruments implemented by offering IT services. An important instrument supporting taxpayers starting their business activity would be, for example, a taxpayer assistant in the initial stage of their activity; an introduction of this solution, however, was eventually rejected. An aspect that deserves a positive assessment, on the other hand, is the possibility to submit a tax return or obtain a certificate in any service center, irrespective of the territoriality of the head of the tax office. 


\section{Conclusions}

The organizational and legal solutions introduced in Poland in 2017, aimed at improving state revenue collection, resulted in establishing the National Tax Administration. In the systemic and organizational dimensions, the adopted solutions have introduced a change in the functioning of the tax administration and a strengthening of its supervision. In the procedural dimension, the administration has been equipped with new tools of control of liable entities.

A challenge faced by the National Fiscal Administration is an improved collection of revenue and duties through the introduction of effective audits, prosecution of the tax crime, and undertaking police actions. The expectations that honest taxpayers direct at the administration are a friendly approach to tax-paying entities and assistance and support in their fulfillment of tax obligations.

In the Author's opinion, the adopted solutions introduce unequal treatment of liable entities. The assistance and support tool offered to them fails to mitigate the newlyintroduced repressive legal instruments. The de facto retained duality of audit results in a serious risk of honest taxpayers and payers also being subjected to "hard audit". Doubtlessly, when introducing legal solutions in the public interest, the individual interest of taxpayers and entrepreneurs should be taken into consideration to a greater extent.

\section{References}

Boć, J.: Prawo administracyjne (Administrative law), Wrocław: Kolonia Limited, 2010.

Gajewski, D.J., Nowak-Far, A.: Krajowa Administracja Skarbowa - propozycja konsolidacji aparatu skarbowego a uszczelnienie systemu podatkowego (The National Fiscal Administration - a proposed consolidation of the fiscal services vs. closing the loopholes in the tax system), Analizy i Studia CASP (CASP Analyses and Studies) no. 2 (2016).

Gomułowicz, A.: Zasada sprawiedliwości podatkowej a prawodawstwo podatkowe (The principle of justice vs. tax legislation), in: Dzwonkowski, H. (ed.): W kręgu prawa podatkowego i finansów publicznych. Księga dedykowana profesorowi Cezaremu Kosikowskiemu w 40-lecie pracy naukowej (Within tax law and public finances. Book dedicated to Professor Cezary Kosikowski for the $40^{\text {th }}$ anniversary of his scientific work), Lublin: Wydawnictwo Uniwersytetu Marii Curie-Skłodowskiej, 2005.

Kosikowski, C.: Finanse publiczne w świetle Konstytucji RP oraz orzecznictwa Trybunału Konstytucyjnego (Public finances in the light of the Constitution of Poland and the Constitutional Tribunal case-law), Warszawa: Wydawnictwo Sejmowe, 2004.

Kosikowski, C.: Naprawa finansów publicznych w Polsce (Improvement of public finances in Poland), Bialystok: Temida 2, 2011. 
Kulicki, J.: Administracja danin publicznych w Polsce (Administration of public levies in Poland), Warszawa: Wydawnictwo Sejmowe, 2014.

Niewiadomski, Z.: Uwarunkowania kształtu współczesnej administracji publicznej (Conditions for the shape of the modern public administration), in: Hauser R., Niewiadomski, Z., Wróbel, A. (eds.): System prawa administracyjnego, T. 1: Instytucje prawa administracyjnego (The Administrative law system. Vol. 1: Administrative law institutions), Warszawa: C.H. Beck, 2010.

Pietrasz, P. (ed.): Siemieniako, J., Wróblewska, E.: Czynniki zmniejszające rolę władczych form działania administracji skarbowej w realizacji zobowiązań podatkowych (The factors that reduce the role of governmental forms of action of tax administration in the implementation of tax obligations), Warszawa-Bialystok: Aspra, 2013.

Smoleń, P. (ed.) et al.: System organów podatkowych w Polsce (The system of tax bodies in Poland), Warszawa: Oficyna Prawa Polskiego, 2009.

Teszner, K.: Administracja podatkowa i kontrola skarbowa w Polsce (Fiscal administration and fiscal audit in Poland), Warszawa: Wolters Kluwer, 2012.

Teszner, K.: Komentarz do art. 1 (Commentary to art. 1), in: Melezini, A., Teszner, K. (eds.): Krajowa Administracja Skarbowa. Komentarz (National Fiscal Administration. Commentary), Warszawa: Wolters Kluwer, 2018.

Teszner, K.: Modernizacja administracji niezespolonej w Polsce na przykładzie reform administracji skarbowej (Modernization of non-combined administration in Poland as exemplified by fiscal administration reforms), in: Sługocki, J. (ed.): Dziesięć lat polskich doświadczeń w Unii Europejskiej. Problemy prawnoadministracyjne, T. I (Ten years of Polish experience in the European Union. Legal and administrative issues Vol. 1), Wrocław: Presscom, 2014.

Teszner, K.: Przekształcenie kontroli celno-skarbowej w postępowanie podatkowe (Transforming the customs and tax audit into a tax proceeding), Procedury administracyjne i podatkowe (Administrative and tax procedures) no. 1 (2017).

Teszner, K.: Wpływ reformy administracji skarbowej na podatkowe postępowanie wyjaśniające (The impact of the tax administration reform on tax investigation), in: Dowgier, R., Popławski M. (eds.): Ordynacja podatkowa w praktyce. Zmiany w ogólnym prawie podatkowym (The Tax Ordinance Act in practice. Changes in general tax law), Bialystok: Temida 2, 2016.

Uzasadnienie projektu ustawy o Krajowej Administracji Skarbowej (The National Fiscal Administration Act substantiation document) no. 826, 2017. www.sejm.gov.pl.

Zimmermann J.: Prawo administracyjne (Administrative law), Warszawa: Wolters Kluwer Polska, 2016.

PL: Constitution of the Republic of Poland of 2 April 1997, as amended.

PL: Tax Ordinance Act of 29 August 1997, as amended.

PL: Act of 16 November 2016, on the National Fiscal Administration, as amended.

PL: Act of 16 November 2016, on Regulations implementing the Act on the National Fiscal Administration, as amended. 
PL: Constitutional Tribunal: K.28/98.

PL: Constitutional Tribunal judgment: K.12/94. 

DOI 10.15290/oolscprepi.2018.42

\title{
THE REASONING ABOUT EVIDENCE IN TAX MATTERS ${ }^{1}$
}

\author{
JOZEF SÁBO
}

\begin{abstract}
The article deals with reasoning about evidence in tax matters. The Author of the article analyses common errors in comprehending of evidence by tax administrators. The Author classifies these errors into two types: incorrect evaluation of burden of proof and incorrect allocation of the burden of proof. The main goal of the article is to examine, how to assess the burden of proof in tax matters. The article examines the rational limitation of the scope of evidence burden that should be respected by tax administrator in tax proceedings. Moreover, the article advocates the application of a rule in dubio mitius in respect to reasoning about evidence.
\end{abstract}

\section{Keywords}

Tax law; errors in reasoning about evidence; burden of proof in tax matters

JEL Classification: D63, K34, K40

\section{Introduction}

Obtaining of evidence is typically divided into three phases: seeking of evidence, taking of evidence and evaluation of evidence (Záhora, 2013:20). Strict division of collection of evidence into these distinct phases is often not needed because of taking evidence and evaluation of evidence often overlap. Therefore we can talk

1 This article presents a partial output of grant project VEGA no. APVV-16-0160 "Tax evasions and tax frauds and legal possibilities of its prevention (by institutes of tax law, commercial law, and criminal law)".

2 Doctor, works as a full-time researcher - post-doctoral in the Department of Financial Law, Tax Law and Economics at the Faculty of Law - Pavol Jozef Šafárik University in Košice. He has participated in scientific research also within projects implementation VEGA č. 1/0375/15, VEGA č. 1/1170/12 and VVGS č. 2013-108. In 2016 he published the scientific monograph on international tax avoidance and tax evasion: "Medzinárodné daňové úniky a metódy ich predchádzania. (International tax avoidance and methods to combat aggressive tax planning)". Contact email: jozef.sabo@upjs.sk. 
about the collection of evidence on one hand and the comprehending of evidence on the other (as a term for taking of evidence and evaluation of evidence).

Collection of evidence includes every activity of the tax administrator which seeks to obtain the source of information (source of evidence) for tax administration. Term comprehending of evidence means every procedural activity which seeks to extract information from the source of evidence, to record information in the legal form and to transform all recorded information into the decision on factual circumstances of a tax case (Babčák, 2015). The factual findings of the tax administrator are recorded in minutes and official records (sect. 19 of Act no. 563/2009 on Tax Administration and on amendments and supplements to certain laws, hereinafter as "Tax Code") or in obiter dictum of a decision (sect. 65/5 of the Tax Code).

We can, therefore, classify errors in the collection of evidence during tax administration into two categories: errors in the collection of evidence and errors in comprehending of evidence. Error in the collection of evidence occurs in the situation when tax administrator does not obtain sufficient sources of evidence for the decision. Errors in comprehending of evidence include two types of errors: incorrect evaluation of burden of proof and incorrect allocation of the burden of proof.

However, various types of errors concerning evidence often do not occur separately. Incorrect evaluation of burden of proof may lead to error in the collection of pieces of evidence. For example, if tax administrators think that burden of proof is on the taxpayer than tax administrators do not obtain evidence about actions of the taxpayer establishing the case for abuse of tax law, although taxpayer provides all evidence needed to prove that taxable transaction actually happened. Therefore tax administrators often make mistake in the assessment of the taxable transaction and incorrectly rule that taxable transaction did not happen. This decision of tax administrators may be declared unlawful by the court. In this stage, the tax administrators cannot repeat tax audit and opportunity for obtaining evidence related to abuse of tax law/ tax evasion is lost afterward.

In the article, we focus our attention on the errors of comprehending of evidence. The main goal of the article is to examine, how to assess the burden of proof in tax matters. In the research presented in this article method of logical analysis, deduction and method of logical synthesis are used. Our conclusions are based primarily on the grammatical and systematic interpretation of legal provisions. 


\section{Incorrect Evaluation of Burden of Proof}

\subsection{Burden of Proof in Tax Administration}

As we mentioned earlier incorrect evaluation of burden of proof constitutes an error in comprehending of evidence. Generally, term objective burden of proof means "a rule which prescribes how the state authority / judge should decide on the merits if the relevant fact of the case is not proved and therefore a state of objective uncertainty occurs" (Macur, 1995: 13). General rule for allocation of burden of proof in tax matter between tax administrator and tax person participating at the tax administration (hereafter "taxpayer") contains section 24 of the Tax Code: taxable payer shall prove facts which have an impact on correct tax determination and facts which it is obliged to state in its tax return or other filings which it is obliged to submit pursuant to special regulations and credibility, correctness and completeness of records which it is obliged to keep (sect. 24/1/a and 24/1/c of Tax Code). On the other hand, tax administrator shall prove (sect. 24/3 of Tax Code) facts regarding actions performed towards the taxable payer which are decisive for correct tax inquiry.

Moreover, the taxpayer shall prove facts which it has been asked to prove by the tax administrator in the course of a tax audit or tax proceedings (sect. 24/1/b of Tax Code). In that regard, the tax administrator has the competence to create the burden of evidence for the tax payer. However such competence of tax administrator is limited by actual circumstances of the tax matter. Therefore tax administrator can only create the burden of evidence concerning facts directly stated by taxpayer (or facts/statements which are included in taxpayers' records) (Kobík, Šperl, 2005: 15).

Notwithstanding such limitation, we recognize further limits in the scope of the burden of evidence in tax matters. The course of taxable event / transaction produces the only certain number of material evidence. Therefore taxpayer is always limited in the scope of possible evidence according to the particular circumstances of taxable event(s) (which is under consideration during tax proceedings). The taxpayer cannot provide more material evidence than actually exists (was created) in a tax matter. Therefore even in cases when the burden of proof is on the taxpayer, there are specific/rational limits for the burden of evidence in each particular tax case.

The assessment of burden of proof depends on the assessment of limits of the burden of evidence. It seems that burden of proof is not the static rule (Svoboda, 2009: 38), but the burden of proof has certain "weight" according to circumstances of the actual tax matter. Tax administrators often do not consider sufficient the evidence that is provided by the taxpayer to prove facts of the tax matter, even in cases when the taxpayer had exhausted / fulfilled his burden of evidence within the 
rational limit. Such incorrect evaluation of burden of proof by tax administrator consequently results in wrong refusal to recognize the tax right of the taxpayer.

We are of the opinion that such evaluation of tax burden is erroneous. In that regard, we may point to the wording of section 24/2 of Tax Code, which states that Tax administrator shall lead the collection of evidence, while it shall make sure that facts necessary for tax administration purposes are identified in their possible entirety, and it shall not be only bound by proposals of taxable entities. From stated legal norm results that evaluation of pieces of evidence always follows the actual circumstances of the tax case. Also, word "possible" implies that collection and evaluation of evidence cannot lead to the situation in which then the taxpayer is obliged to prove facts beyond reasonable possibility. This conclusion is the generalization of the negative theory of evidence, which states that something that did not happen cannot be supported by evidence (because evidence of such event just does not exist). Therefore evidence that does not exist cannot prove something that actually happened. Therefore, proper evaluation of burden of proof always consists of the assignment of "weight" to the burden of proof in particular matter according to types and the possible number of evidence that may/should exist in particular tax case.

\subsection{Different Categories of Evidence}

Tax law (as an independent legal branch) prescribes for tax entities certain evidence that should create/ have to provide to prove facts of the tax case. Such evidence is primarily in the form of records that tax entities should keep. With this in mind, we can classify the source of evidence in tax matters into four categories:

a) sources of information prescribed by law: tax entities have the duty to collect/ create certain sources of information for example accounting document, invoices etc. In case of the tax audit, tax entities are obliged to provide these sources of information to tax administrator as evidence in tax proceedings,

b) sources of information that are usually/ typically created during the business transaction in the normal course of business activities (written contracts etc.). These are not evidenced in the actual tax case but serves as examples of evidence that might occur in connection with the certain business transaction. Tax administration according to his experience can rationally expect certain sources of information created in similar business operations,

c) sources of information that should have been created in the actual tax case,

d) sources of information that taxpayer actually provides as evidence to tax administrator. 
Every absence of the certain source of information that is relevant for decision in tax matter creates the evidential gap that should be addressed by tax administrator in the phase of comprehending of evidence. Even if the sources of information are provided to tax administrator thus forming an evidence of tax case, they may have certain defects. First types of defects are defects in formal requirements. Second types of defects are defects in credibility. Defects in credibility occur when information that follows from the certain source of evidence contradicts information obtained from other sources of evidence. Every defect in the credibility of evidence should be addressed by the tax administrator in the phase of comprehending of evidence.

In case of sources of information falling into category c) - for example contracts, any defect in formal requirements: for example contracts which should be in writing are concluded only orally, might constitute defects in credibility as well. But it is not always the case; defects of formal requirements of evidence do not necessarily constitute the defect in credibility. If the evidence has the defect in formal requirements but it is credible and offers clear information about transaction/ legal relation in question, the tax administrator should not disregard such evidence as invalid (e.g. evidence that is not capable to prove information that such source of evidence should incorporate). This is also true of evidence in category a) e.g. sources of evidence prescribed by tax law (for example invoice).

The situation is different when the taxpayer does not provide prescribed sources of information falling into category a): therefore by his own omission creates the evidential gap. Tax entities have duty prescribed by law to keep track/create sources of information for certain business activities. If the taxpayer does not fulfill this obligation, tax administrator can refuse to recognize some of tax right of the taxpayer.

Often tax administrator expects from the taxpayer to provide certain types of evidence (according to his experience from similar tax matters): for example, if the taxpayer obtains goods, tax administrator may expect that taxpayer has the warehouse for storing goods. Difference between evidence expected by tax administrator due to his experience and evidence that is provided by the taxpayer is an example of contradiction between evidence falling into category b) and evidence falling into category d). However, it is important to mention that this contradiction does not constitute an evidential gap, but serves merely as an indication of potential misconduct on part of the taxpayer. The indication is not evidence, therefore, could not directly prove any fact of the tax matter. If the non-contact taxpayer (e.g. the taxpayer who does not collaborate with tax authority) was one of the taxpayers in the chain of taxable transactions, it indicates that other taxpayers might have participated in tax fraud. But such suspicion cannot automatically lead to the 
conclusion that other taxpayer in fact knowingly participated in tax fraud. Every suspicion of tax administrator must be proved by corresponding evidence: but in that case the burden of proof shifts to the tax administrator.

The most important is a connection between sources of information falling into category c) and sources of evidence falling into category d). Unlike the previous situation, these sources of information are not only "typical" or "possible" but must actually exist for the transaction to ever happen. To know which kind of sources of information should have existed in a certain tax case, the tax administrator must examine actual circumstances of the transaction/event. These circumstances cannot be inferred only from "formal" evidence e.g. from accounting records or tax returns of the taxpayer. Tax administrator should as soon as possible obtain testimony from the taxpayer about actual circumstances of the transaction.

Tax administrator can infer from the circumstance of the business transaction described by the taxpayer in his testimony or in testimonies of other persons working for the taxpayer what sources of information were created during this transaction. For example, if the taxpayer testifies that the goods were dispatched by shipping company then such transaction should have created sources of information in form of contract with the shipping company, contract with the buyer of goods, testimonies of persons acting for shipping company and testimony of persons acting for buyers. Subsequently, tax administrator can ask from the taxpayer to provide these sources of information as evidence for tax audit / tax proceedings. If the taxpayer fails to provide evidence to support his statements about actual circumstances of the business transaction, tax administrator should conclude that the taxpayer does not carry his burden of proof.

Therefore is of vital importance for tax administrators to differentiate between evidence that should have been created (according to the common course of events) and sources of information that according to own statements of the taxpayer were actually created in course of the transaction.

To know actual circumstances of the transaction enables the tax administrator to anticipate rational limit of the evidential burden of the taxpayer. If the taxpayer provides as evidence all sources of information that should have been created by business transaction, the tax administrator should not ask the taxpayer for further evidence. Also, tax administrator cannot ask the taxpayer to provide negative facts. For example to prove, that the taxpayer did not know about tax fraud happening along the chain of transaction.

If taxpayer fulfills his evidential burden then he carries its burden of proof. If suspicions of tax administrator about the misconduct of taxpayer persist then tax 
burden is on the tax administrator to prove that taxpayer participated in tax evasion or acted contrary to the tax legislation otherwise.

\section{Incorrect Allocation of Burden of Proof}

As we mentioned earlier, the term burden of proof stands for rule prescribing how to decide in objective uncertainty about factual circumstances of the case. The situation in reasoning about evidence when this objective uncertainty occurs is called non licet. If evidential reasoning in case reaches non licet stage then the judge should decide against the party/ subject who does not carry the burden of proof (Macur, 1995: 13). This "classical" view on the burden of proof seems not be appropriate in tax matters.

We are of the opinion that majority of evidence in tax matters are formal by nature. Under "formal" we mean sources of information that are predominately in written form and constitute indirect evidence about transactions / taxable events. For example, formal evidence of taxable transaction includes contracts, invoices, and other written documents. At the same time, tax entities often bear the burden of proof about material (e.g. actual) circumstances of the tax case and they should prove that certain transaction really happened.

This may be problematic, because written documents may offer only indirect evidence about past events. If some of these documents have defects (especially defects in credibility) also the reliability of testimony given by taxpayers is questioned. Thus the taxpayers often lack any direct evidence to sustain his claims about nature of the taxable transaction. This is especially the problem for taxpayers in tax matters concerning indirect taxes.

In aforementioned circumstances, the tax administrators often rule that taxpayers fail to prove that taxable transaction actually happened. We consider similar reasoning about evidence incorrect. This constitutes incorrect reasoning about evidence and it is an error in the allocation of the burden of proof.

We are of the opinion that formal evidence should be sufficient to prove material circumstances of the transaction in most cases. This conclusion is based on the rational limit of evidence burden determined by actual circumstances of the past event/ transaction. Reason for this is the fact that majority of the business transaction does not produce any other sources of evidence besides written documents and testimony of the taxpayer.

Tax administrators often do not accept written evidence as sufficient evidence for actual material circumstances of the tax matter. Generally, a defect in the 
credibility of evidence cannot serve as justification for the similar conclusion. Only exceptionally in situations when defects in the credibility of evidence are severe and reach across multiple sources of information tax administrators can conclude that taxable transaction almost certainly did not happen. But generally, when the indication of misconduct of taxpayer exists in the tax case, the burden of proof shifts to tax administration to prove that the taxpayer acted in breach of tax norms. Therefore the burden of proof in tax matters is not static but it is similar to the concept of tactical burden of proof (Walton, 2015: 9; Kazazi, 1996: 24).

Moreover, we think that the rule in dubio pro mitius (Melzer, 2009) should be used also in the assessment of allocation of the burden of proof. This opinion is based on the principle of legality in tax matters (Bujňáková, 2006: 162). We define the rule in dubio pro mitius in respect to reasoning about evidence as following: if defects in credibility of evidence might lead to negative factual findings (e.g. conclusion that something did not happen) or alternatively might cause shift of burden of proof towards tax administrator to prove misconduct on the part of the taxpayer, the burden of proof should shifts towards tax administrator, except in situations when defects in credibility of evidence are severe and reach across multiple sources of information in tax case.

\section{Conclusions}

In the article, we analyzed errors in the evaluation of evidence. Our main concern was errors in comprehending of evidence. We analyzed two variants of these errors: incorrect evaluation of burden of proof and incorrect allocation of the burden of proof.

Our main concern was an allocation of the burden of proof in tax matters and scope of evidential burden. We propose that there is the rational limit in the scope of evidence burden that should be respected by tax administrator in tax proceedings. Moreover, we advocate the application of the rule in dubio pro mitius in respect to reasoning about evidence.

We recognize that it might be very hard for tax administrators to prove situations of tax fraud or tax evasion. Nevertheless, correct assessment of allocation of the burden of proof is essential for tax administration because it is a part of the principle of legality and legal certainty in tax matters. 


\section{References}

Babčák, V.: Daňové právo na Slovensku (Tax law in Slovakia), Bratislava: EPOS, 2015.

Bujňáková, M.: Princípy a zásady v daňovom práve (Principles in Tax law), in: Aktuálne otázky práva (Current questions of Law), Košice: Univerzita P.J. Šafárika v Košiciach, 2006.

Kazaki, M.: Burden of Proof and Related Issues: A Study on Evidence Before International Tribunals, Hague: Kluwer Law International, 1996.

Kobík, J., Šperl, J.: Dokazováni v daňovém řízení (Collection of evidence in tax proceedings), Praha: ASPI., 2005.

Macur, J.: Dukazní břemeno v civilním soudním řízení (Burden of proof in civil proceedings), Brno: Masarykova Univerzita, 1995

Melzer, F.: Metodologie nalézání práva. Úvod do právní argumentace (Methodology of finding the Law. Introduction to the legal argumentation), Praha: C.H. Beck, 2009.

Svoboda, K.: Dokazování (Collection of evidence), Praha: Wolter-Kluwer, 2009.

Walton, D.: Burden of Proof, Presumption and Argumentation, New York: Cambridge University Press, 2014.

Záhora, J. et al.: Dokazovanie v trestnom konaní (Collection of evidence in criminal proceedings 1st. ed.), Praha: Leges, 2013.

SK: Act no. 563/2009 Coll. on Tax Administration (Tax Procedure Code) and on amendments and supplements to certain laws. 



\title{
PROTECTION OF RIGHTS OF TAXPAYERS THAT ARE NOT DEFINED AS PHYSICAL PERSONS IN POLAND
}

\author{
PIOTR WOLTANOWSKI', RÓŻA KOSIŃSKA ${ }^{2}$, JOANNA CZAPSKA ${ }^{3}$
}

\begin{abstract}
Taxpayers, who are not physical persons, mostly use an institution of the Ombudsman or they file a constitutional complaint to Constitutional Tribunal in Poland. Their professional preparation and greater financial strength result in ousting of physical persons - as entities without the satisfactory support of legal advisors - from competition in access to the protection of their rights by the Ombudsman. The problems rather originate from the unsatisfactory level of financing of Polish Ombudsman. Thus, the Ombudsman would avoid commissioning external expert's report and legal opinions and instead would prefer to focus on applications, in which requesting entities provide such documents on their own. In case of the constitutional complaint, the basic difficulty is a lack of professionalism of (surely cheaper) legal counselors and lawyers who serve physical persons. Lately, some works have been initiated to establish a new institution to protect taxpayers' rights - Ombudsman of Taxpayers' Rights. This signalized change is expected to be rather quantitative than qualitative - a new organ is going to double functions of the classical ombudsman.
\end{abstract}

1 Board Member and General Secretary of Information and Organization Centre for the Research on the Public Finances and Tax Law in the Countries of Central and Eastern Europe, Department of Public Finances and Financial Law, Faculty of Law, University of Bialystok. He is the author of over 50 publications in the field of tax administration, human rights, health service finance and social security. Contact email: piotrwoltanowski@ gmail.com.

2 Member of the Audit Committee of Information and Organization Centre for the Research on the Public Finances and Tax Law in the Countries of Central and Eastern Europe, Secretary of Drohiczyn Scientific Society. An experienced practitioner of economics, a long-standing employee of the tax apparatus, an external and internal risk analyst, author of many publications in the field of tax administration. Contact email: rozmark@wp.pl.

3 Member of the Information and Organization Center for the Research on the Public Finances and Tax Law in the Countries of Central and Eastern Europe since 2017. Chief specialist at ARMA (Agency for Restructuring and Modernisation of Agriculture) since 2004. Contact email: joanna.czapska@yandex.com. 


\section{Keywords}

Ombudsman; Constitutional Tribunal; tax law; taxpayers' rights; legal entities

\section{JEL Classification: K38, K34, K40}

\section{Introduction}

The ascription of protected, normative rights seems to be possible with no doubts to entities that are not physical persons particularly in some areas. Che catalog of taxpayer rights of a certain kind could be singled out. However, a scope of these regulations remains controversial and is to be restricted mainly to the area of the economic law. There is a strict association of taxpayer rights and human rights in a law doctrine in Poland. Most of all, this topic-focused literature refers to taxpayers rights who are not physical persons and defined as legal entities. Law act regulations that are aimed to protect e.g. justified taxpayers rights are -at first sight- not adjusted to meet legislative needs of corporations. Particularly roles of Polish Ombudsman and Constitutional Tribunal are concerned in the field of constitutional appeal. The practice of mentioned organs found a different pathway and a number of cases with legal entities is still growing.

\section{Catalog of Taxpayers as Legal Entities}

Rights of taxpaying legal entities and scope of their protection are regulated to a much lesser extent than rights of other taxpayers. Besides constitutional regulations, which protect both groups of taxpayers (physical and legal entities), their rights are ensured also by acts. In Polish practice, rules of this sort are unfortunately scattered in the text of act titled in Polish Ordynacja Podatkowa (Ordinance Act of 27 August 1997) which plays a function of tax codification. ${ }^{4}$ Referral to sentences of constitutional courts has a great significance in this matter, too.

A catalogue of rights granted to legal entities can be divided into fundamental rights which correspond to economical rights acquired by physical persons (they cannot be defined broadly in case of either general rights or civil freedoms of economical sort - because it is impossible to assume that entity, that acquires legal identity, could have been granted any sort of congenital freedoms). In a set of fundamental taxpayer's legal regulations, the greatest significance can be ascribed to rights of proper tax legislation, property right, right to equal treatment, right to

4 Normative constitutional patterns are grounds for $93 \%$ of the control action in the field of tax law by Constitutional Tribunal. 
choice and right to running a business. Mentioned ones are protected by auxiliary rights (guarantee right) - like constitutional regulations: the right to judgment, right to legal proceedings in a court of second, superior instance, right to compensation due to illegal acts of treasury officers.

First, of mentioned laws, a right to proper tax legislation derives from a principle of legality of a democratic state, which is present in the majority of European constitutions. This principle of legality is founded within a catalog of postulates:

1) The postulate of clearness of tax regulations means that each taxpayer should have the possibility to recognize and understand tax law. Respect for this postulate is necessary for proper execution of the law. This can be achieved if only a tax regulation is formulated in clear, precise and easy-to-understand way. If these conditions are not met, actions of state authorities are going to negate the principle of tax stability and trust among a citizen, the law, and the state.

2) Principle of non-retroactivity - a principle of "lex retro non agit" forbids a start of validity for the disadvantageous modifications of law regulations before date of a publication of such a change (Ombudsman of Citizens' Rights: RPO-489470-VI/04/AB; Constitutional Tribunal: P.2/99; Constitutional Tribunal: U.1/86; Constitutional Tribunal: K.1/88; Constitutional Tribunal: K.6/91; Constitutional Tribunal: K.15/95; Constitutional Tribunal: K.15/91). Unfortunately, this rule has been constantly violated at the beginning of system transformation in Poland. For instance Act on income tax of legal entities enacted on 15 February 1992 came into force and was obligatory in recurrent mode from 1 February 1992. An act issued on 26 July 1991 about personal income tax (PIT) contained a part of regulations that were obligatory from 1 July 1991. Moreover, an act on 12 January 1991 about local taxes was binding from 1st January 1991. The Constitutional Tribunal announced that a recurrent mode of the validity of tax law regulations is acceptable and necessary if modifications are justified by the need of introduction of the proper interpretation of existing regulations, whose appliance is hindered by erroneous misunderstandings (Constitutional Tribunal: K.15/95).

3) The postulate of adequate length of vacatio legis. It is essentially important to give to addressees a time to read, understand and prepare to apply novel obligatory regulations of the act. It is indeed outrageous and dramatically confusing to enact acts that oblige from the date of publication. It is a constitutional demand to introduce an adequately long vacatio legis, depending on the complexity of law regulations (Constitutional Tribunal: K.2/94). This period should last at least 14 days according to Constitutional Tribunal (Constitutional Tribunal: W.3/90). Otherwise, citizens will suffer 
from exposition to an abuse of legislative authority. For a plenty of times, the Constitutional Tribunal underlined, that exact law novelties require the period of vacatio legis longer than 14 days. For example tax acts should be provided with at least one month long vacatio legis (Constitutional Tribunal: K.28/95). The Polish Ombudsman postulated that essential changes of annual tax should be announced at least half a year before the date of their entry into force. It is highly reprehensible that novel regulations of Tax Ordination came into force after a month and a half. On the other side, essential public business should be considered each time in perspective of the adequacy of vacatio legis. In the opinion of the Constitutional Tribunal, such an essential public business should be taken into account, for example in case of estimation of legislator's actions that are aimed at tax fraud and abuse (Constitutional Tribunal: K.2/94). According to Polish court, it can exceptionally justify limitation or even giving up the idea of introduction of any period of vacatio legis (Constitutional Tribunal: K.9/92). This essential public business can be characterized very broadly by the Constitutional Tribunal as it even can play a role in case of ensuring of execution of state budget incomes (Woltanowski, 2012: 51).

4) The postulate of avoidance of law modifications during vacatio legis comes from the fact that potential addressees of norm expect that an act in an original shape is going to be binding in a period defined in an act without any later surprising changes during vacatio legis. The legislative route of an act is so extensive, that it covers enactment inadequate mode by parliament, signed by the President of Polish State and in the end publishing in the Act Diary (pl. Dziennik Ustaw). A practice of act modifications during vacatio legis is confusing and causes doubts about the reliability of a legally established order and decreases a respect to legislative authority (Constitutional Tribunal: K.12/03). The Constitutional Tribunal is not consequent and underlines that the period of vacatio legis can be used for correction of errors, discovered after enacting of an act and verification of internal discrepancies. Moreover, vactatio legis can give some time to eliminate solutions evoking conflicts of regulations in the system of law or to prevent negative effects of the introduction of enacted but still not binding regulations (Constitutional Tribunal: K.12/03). According to the Constitutional Tribunal, these effects can particularly occur in the area of public finances. Furthermore, it could be supposed, that the Tribunal can justify similar changes in case of taxes with an argument that boundaries of the reliability of law were defined by the principle of proportionality. Reliability of law was always verified in perspectives of other constitutional values e.g. budgetary balance and state of public finances (Constitutional Tribunal: K.12/03) 
5) Prohibition of modification of tax law during the fiscal year results from two groups of premises. Less important technical premises refer to difficulties of a technical nature due to annuality of taxes. In order to change any element of income tax legislator would have to divide a fiscal year into parts or as it took place in 1993 a lawmaker would have to break a ban of the recurrent mode of law obligation. Arguments of substantial nature are more important than technical ones. One of them states citizens should have an assured right to take care of their interests according to tax duties before the start of fiscal year. Moreover, a constitutional jurisdiction often signalizes that state control is particularly strict in the establishment of tax (Constitutional Tribunal: K.13/93).

6) Right for undisturbed usage of one's property is protected by the state on the ground of both legislation and administration of the law. Tax burdens should differ proportionally and reasonably according to the wealth of taxpayers' groups. Sometimes, the property right is limited on the constitutional level by legislator by means of tax execution duty. In this case, property right and tax duty should be compromised in perspective of the extent of protection of a taxpayer's property. In addition, Polish constitutional court points at the principle of legality of a democratic state as a source of limitations and - originating from it - principles of justice and the common good. It is indispensable to preserve these constitutional values and respecting them together with the requirement of proportionality (Constitutional Tribunal: K.9/95). The essence of this law should not be violated by acceptable limitations deriving from the act (Constitution of Polish Republic, Art. 64/3).

7) Right for equal treatment was mostly expressed in the 32nd article of Polish Constitution. ${ }^{5}$ This article states that "all citizens are equal to the law ..." The present edition of this article (legislator used "all" and "nobody" terms) extends this law over not only physical but also legal entities who are represented not only by Polish citizens. Following detailed indications are the consequence of this article:

- Entities which this article refers to, are equal to the law;

- Entities have a right to equal treatment by public authorities;

- Entities may not be discriminated in any way in public, social and commercial life.

With no doubt, one statement of constitutional tribunal has still been very actual since 1988 and it says that "constitutional principle of equality to the law means that all legal entities (addressees of legal norms) that are characterized by a certain, relevant feature to the same extent, ought to be treated equally, according to the 
same measures with both discriminating a favoring differences." (Constitutional Tribunal: U.7/87) Both considering division of goods the same and in case of distribution of duties, it necessary to apply to differentiate category to make just and fair division among equal entities but separately in each category. Criterions, that determine initial categorization, are most of All: economic effectiveness of taxpayer and social aspects of taxation (Mastalski, 2016: 52). These criterions seem to be meet requirements that are issued by Constitutional Tribunal for exceptions from equal treatment of similar entities (Constitutional Tribunal: K.8/97):

- Criterions of differentiation should be of such a relevant nature, that they should be directly associated with purpose and content of legal regulations (these regulations contain a controlled norm). The criterions are to achieve this purpose and to execute the content of the regulations. Thus introduced differential ought to be rationally justified and they must not be established according to optionally chosen criterion (Constitutional Tribunal: K.3/94).

- A suitable proportion should be preserved with the importance of following interests:

- an interest, that is served by differentiation of legal events of addresses of the controlled norm;

- interests, which are to be violated in course of unequal treatment of similar entities (Constitutional Tribunal: K.8/97).

- Criterions, which determine differentiation of legal affairs of the entities ought to correspond with normative values of Polish Constitution Act that can ground dissimilar treatment of similar entities (Constitutional Tribunal: K.4/95).

The principle of equality is at high risk of being violated according to Constitutional Tribunal if only there is no rational explanation for existing differentiation in other words if this principle is of purely arbitrary nature. In the opinion of the Ombudsman, an example of such unjustified discrimination of some taxpayers was a differentiation in entitlement to decrease of proper excise tax $-\S 18 / 1$ rescript of Ministry of Finances dated 22 March 2002 in case of excise tax (Rescript in case of the excise tax, § 18/1). Precisely, disabling of decrease of excise tax for taxpayers, who started the sale of beer in a certain year, was opposite to with article 32nd in the light of article 84th of the Constitution of Republic of Poland (Ombudsman of Citizens' Rights: RPO-540136-VI/06). Unfortunately, concerning appliance of principle of equality as a constitutional pattern, Constitutional Tribunal expressed opinion of broadly extended freedom of legislator (Constitutional Tribunal: K.12/95) in the area of shaping tax duties (limits are mainly determined by rules of proper 
legislation and a requirement for tax not become a tool for confiscation of property (Constitutional Tribunal: K.8/97)).

8) A right to choice and run of a certain economic activity is sometimes limited by imposing of too high tax duties. It should be underlined that it is permissible to interfere in this law on the ground of constitution of the law e.g. by imposing an excise tax on certain products. However, execution of the law should be autonomic to the high extent in relation to economic and political aims of the state. In my point of view limitation and elimination of disadvantageous objects of economic activity could be regarded as proper and justified if only they are harmful to the environment, public health or if they break other constitutional values. This aim should be accomplished with the system of concessions, permissions or secondary limitations and tax duties (excise tax, differentiation of tax rate on the scale of income taxes). Elimination of economic activity ought not to take place with the use of inland revenues which would function as the machinery of repression. ${ }^{6}$

\section{Protection of Taxpayers' Rights who are not Physical Entities by the Ombudsman}

The scope of protection, assured by the Ombudsman, is varied in legal systems of different states, which support this institution. Initiators of this protection could be different in various states:

- The entity that initiates the control of the Ombudsman can be everybody and every institution (as in Poland, Slovenia, Estonia, and Hungary);

- The control of the Ombudsman can be evoked by entities which are listed in constitutional regulations (Albany - physical persons, personal groups, and non-government organizations);

- Only physical persons can initiate the Ombudsman's control in Bulgaria and Romania;

- In some countries (Cyprus and Malta) it is not precisely determined, which entities may appeal for control of the Ombudsman.

The Constitution of Polish Republic (art. 80) predicts that everybody can appeal to the Ombudsman not only Polish citizen but also foreigner or stateless person on

6 In 2010 to eliminate the distribution of psychoactive substances, Polish offices of treasury control launched a few massive controls in so-called smart shops. The largest one was conducted from 1st to 3rd September 2010 and it covered 849 shops (of total 1800 such all functioning ones). In result, 446 of these shops were subjected to control actions. It seems that authorities should not engage in special tormenting actions with help of Treasury Office and offices of tax control. Instead, authorities should rather execute the restricting law that would limit a distribution of psychoactive substances with Police forces and services in command of Ministry of Health. 
the territory of Poland under the jurisdiction of Polish law. Article $9^{\text {th }}$ of Act dated on 15th July 1987 on the Ombudsman defines that the control of the Ombudsman occurs:

- in the result of the application of citizens;

- in the result of the application of an organization of citizens;

- in the result of the application of bodies of self-government;

- in the result of the application of the Ombudsman of Children's Rights;

- in the result of the own initiative of the Ombudsman.

A term "organizations of citizens" means both legal entities and units without legal personality, though it is lately indicated that the last ones rarely are regarded as subjects of rights and duties. This point of view - may be true on the ground of private law, but it does not work on the ground of financial law.

In spite of the fact, that according to the act, control of the Ombudsman is launched due to the application of organization of citizens, foundations and limited companies turn out to claim for such a kind of protection. Foundations and companies are classified as legal entities, which are characterized by the domination of wealth and property aspect over nature of corporation (Świątkiewicz, 2001: 56).

Housing associations and communities or election committees are examples of entities without legal identity, which are covered by the protection of the Ombudsman. On the other side, it is controversial if protection of the Ombudsman may be accessed by such communities as:

- national minorities (whose rights to preserve their identity is protected on the ground of article 35th of the Constitution);

- local communities (who are granted a right to self-government in article 16th of the Constitution);

- churches and confessional associations (that a privileged with a right of autonomy in Art. 25 of the Constitution).

The Ombudsman's control may be also evoked by organs of self-government, councils of professions, cooperative societies, and councils of economic selfgovernment. The applications, that are directed by such entities, play a great role in the control of constitution and to the lesser extent also in the execution of the tax law.

There is no legally defined requirement of the personal application by the entity, whose rights and freedoms were violated. Application recipient organs and institutions are important sources for collection of information about a violation of rights of taxpayers e.g. Social Ombudsman of Entrepreneurs. Ombudsman of 
Entrepreneurs appeals to proper authorities with the request for the explanation of raised problems, issues a proposal for the start of legal administrative proceeding, participates in the legal proceeding as one side of a party, files complaint to administrative court or postulates modification of law regulations.

There is a debate on the establishment of a separate position of Ombudsman of taxpayer's rights in Poland for last few years. Lately, it has become even more sound in perspective of a project of the act for the appointment of such an organ for 5-years trial period. The project was enthusiastically welcomed by the largest organizations of business representatives. Such an Ombudsman's prerogatives and position in the legal system would be far different from US model of National Taxpayer Advocate. The Polish design of this function is rather a sort of doubling a model of Polish Ombudsman of Citizens' Rights with restriction to the protection of taxpayers' rights. Such an Ombudsman of Taxpayer's Rights (pl. Rzecznik Praw Podatnika, in short, RPP) would be elected by parliament for 5-year cadence being independent of other state authorities and would be supervised only by the lower chamber of Polish Parliament.

These would be entitlements of Ombudsman of Taxpayer's Rights:

- appealing to a certain organ, which violated taxpayers' rights or appealing to its supervising organ;

- evoking a start of a legal administrative proceeding and filing a complaint to administrative court, and participation in these proceedings with rights of the prosecutor;

- filing a complaint to Court of Cassation after legally valid sentence;

- appealing to Ministry of Finances to issue a general interpretation of standard guidelines in given events of tax law reality;

- appealing to Supreme Administrative Court to pass an explaining resolution for legal regulations in order to get rid of any doubts in practice of execution of these regulations and to avoid divergence in official interpretation of this regulations;

- appealing to proper organs with proposals of legislative initiative or issuing or modification of other legal acts in the field of taxpayer's rights;

- informing the Ombudsman of Citizens' Rights about the legitimacy of the appeal of this organ to Constitutional Tribunal.

An initial analysis of activities and results of studies in the Ombudsman's office and organizations of employers give ground for thesis, that a new organ doubles the only function of the Ombudsman of Citizens' Rights (in short RPO). There is also highly probable that such a new organ would easily turn from being the 
ombudsman of All the taxpayers to become the ombudsman of employer's rights. The mechanism of such an appropriation of a qualified ombudsman would probably look similar as in case of RPO. Most likely organizations of employers are going to provide Ombudsman of Taxpayer's Rights a significant part of applications and claims and their applications are going to be more professionally prepared than the others formulated by individual taxpayers. Employers would easily complete such applications with expert's reports and legal opinions on the demand of the Ombudsman of Taxpayer's Rights. If the state is not going to assure enough financial support for proper functioning of the Ombudsman of Taxpayer's Rights in the current era of the crisis of public finances, the Ombudsman's choice of considered cases would be restricted by mentioned financial background. Nevertheless, current experiences indicate that a new organ would be an essential and important part of the protection of institutional taxpayers launching economic activity.

\section{Protection of Taxpayers' Rights who are not Defined as Physical Persons with the Use of Constitutional Complaint}

An analysis of Art. 78 of the Constitution should be a starting point at the approach to the scope of the constitutional complaint. According to this article, "everybody can file a constitutional complaint if his or her constitutional freedoms were violated". It resembles little Austrian regulations, where legislator have not defined precisely circle of entitled subjects to lodge this complaint. ${ }^{7}$ A constitutional term "everybody" should be strictly defined in this area. The constitutional legislator does not use this objective term in a uniform meaning. There are a few application of the same term:

- usage of the term "everybody" as a synonymous for physical person e.g. in article 41 of the Constitution that refers to personal inviolability, in Art. 41 of the Constitution that founds rules of penal liability, in Art. 53 constituting liberty of conscience and religion;

- In broader aspect - "everybody" means also other legal entities than physical persons e.g. in Art. 45 of Constitution that formulated a right to the court proceeding, in Art. 63rd of Constitution - a right to petition and complaint; in Art. 80 giving legal ground to lodge a complaint to the Ombudsman. All these actions are basically defined as petitions. They are characterized by features of actio popularis and they serve as the realization of citizens' right can be filed by the legal entity that is characterized by legal interest or simply citizen. In Spain, this scope is extended to include additionally prosecutor and ombudsman (in form of so-called public complaint). 
to shape actions of public authorities and controlling them in order to protect interests of individuals, groups, and society.

In our opinion, entitled subjects, that file a constitutional complaint, should include physical persons, trade unions, organizations of employers, associations, political parties. Arguments of proposal interpretation, and court protection seem to support this point of view. The constitutional complaint ought to eliminate constitutionconflicting act and protect constitution guaranteed regulations, which refer not only to human beings but also to legal entities, that can use this legal instrument. Article 79 of the Constitution is remarkably placed in the chapter of Constitution titled "Sources of protection of liberties and rights" that also contain rights to reward, to the prosecution of interpretation or legal decisions and to appeal to the Ombudsman. In the establishment of mentioned entitlements, a term "everybody" covers also entities different from physical persons. Thus, it could be assumed that intention of the legislator was to include also such mentioned entities to a class of subjects that are competent to file a constitutional complaint. A right to the legal proceeding is granted also different entities from physical persons. Similarly to the constitutional complaint, a right to the legal proceeding is a kind of procedural guarantee of constitutional laws. In addition, a right to file a constitutional complaint could be acknowledged as a special form of right to the legal proceeding (that is further qualified according to kind of protection and mode of the proceeding). The term "everybody" should mean the same in both of mentioned regulations.

There is a little number of entities not defined as physical persons that file a constitutional file, probably because constitutional liberties and rights refer mainly to human and citizen. The Constitutional Tribunal states that "subjects that are entitled to file the constitutional complaint are - first of all - physical persons. Legal persons may file a constitutional complaint if only they protest against the violation of their rights or liberties. The scope of constitutional complaint is therefore limited by a range of certain constitutional liberties and rights" (Constitutional Tribunal: Ts.148/00). In light of my study of constitutional complaints, I cannot confirm that there is the low rate of constitutional complaints lodged by entities different from physical persons as suggested by reports in Polish literature. Particularly from 1996 to 2013 there was the relatively low rate of constitutional complaints issued by other entities than physical persons. The rate of sentences issued by Constitutional Tribunal in the field of tax law reached the level of $43 \%$ for legal entities. This paradoxically high rate for legal entities could be explained by the specificity of tax law. In generally liberties and tax rights, or economic freedoms refer both to physical persons and to legal entities. In addition, the number of constitutional complaints of physical persons' authorship is radically reduced by in preliminary procedure of formal quality control of filed complaints (approximately much over $90 \%$ of such complaints). There is a really striking disproportion of preliminarily 
rejected complaints of physical person Authorship in comparison to complaints filed by remaining entities - for last decade they have comprised $75 \%$ of all rejected complaints.

\section{Conclusions}

There is no need in the establishment of a quite new and distinct office named the Ombudsman of Taxpayers' rights because such an institution would only double some functions of the Ombudsman of citizens' rights. Instead, district representatives of the Ombudsman's office should be developed and specialized. Moreover, a greater financial support should be allocated for the current activity and the cooperation of the office with external experts and advisors. Thus, protective service of the Ombudsman would be accessible also for indigent taxpayers.

The right to appeal to Ombudsman should be guaranteed for taxpayers that are not physical persons. However, in practice, the Ombudsman should accept complaints that are filed by weaker participants of the economic cycle. A greater professionalism should be aimed at constitutional complaints - a current status of rejection of erroneous constitutional complaints is confusing, especially if complaints with errors are produced by professional representatives.

\section{References}

Mastalski, R.: Prawo podatkowe (Tax law), Warszawa: C.H. Beck, 2016.

Świątkiewicz, J.: Rzecznik Praw Obywatelskich w polskim systemie prawnym (Ombudsman of Citizens' Rights in Polish legal system), Warszawa: Prawo i Praktyka Gospodarcza, 2001.

Woltanowski, P.: Zasady prawidłowej legislacji podatkowej, a ochrona interesu Skarbu Państwa w orzecznictwie Trybunału Konstytucyjnego (The principle of proper tax legislation and protection of the interest of the State Treasury in the jurisprudence of the Constitutional Court), in: Etel, L., Tyniewicki, M. (eds.): Księga jubileuszowa profesora Eugeniusza Ruśkowskiego (Anniversary book of Professor Eugeniusz Ruśkowski), Bialystok: Temida 2, 2012.

PL: Constitution of the Republic of Poland of 2 April 1997, as amended.

PL: Ordinance Act of 27 August 1997, as amended.

PL: Constitutional Tribunal: K.12/03.

PL: Constitutional Tribunal: Ts.148/00.

PL: Constitutional Tribunal: P.2/99.

PL: Constitutional Tribunal: K.8/97. 
PL: Constitutional Tribunal: K.8/97.

PL: Constitutional Tribunal: K.12/95.

PL: Constitutional Tribunal: K.15/95.

PL: Constitutional Tribunal: K.9/95.

PL: Constitutional Tribunal: K.28/95.

PL: Constitutional Tribunal: K.2/94.

PL: Constitutional Tribunal: K.3/94.

PL: Constitutional Tribunal: K.13/93.

PL: Constitutional Tribunal: K.9/92.

PL: Constitutional Tribunal: K.6/91.

PL: Constitutional Tribunal: K.15/91.

PL: Constitutional Tribunal: W.3/90.

PL: Constitutional Tribunal: K.1/88.

PL: Constitutional Tribunal: U.7/87.

PL: Constitutional Tribunal: U.1/86.

PL: Ombudsman of Citizens' Rights: RPO-489470-VI/04/AB.

PL: Ombudsman of Citizens' Rights: RPO-540136-VI/06. 



\title{
REFERENDUM FOR SELF-TAXATION AS A FORM OF PARTICIPATION OF COMMUNE RESIDENTS IN THE SHAPING OF ITS REVENUES
}

\author{
EWA KONIUSZEWSKA ${ }^{1}$
}

\begin{abstract}
The article is devoted to the issue of the referendum on self-taxation as a form of participation of the commune' residents in the shaping of the income level of their self-governing community. The basic objective of the study is to analyze the normative material aimed at answering the question to what extent, and under what conditions, the residents of a commune can realistically create the level of income of their local government units. An equally important problem is the identification of factors determining the initiation of the referendum procedure and affecting its effective course. The considerations undertaken are to justify the thesis that the actual use of the institution of a referendum on self-taxation in local communities is incidental. In the conducted research, a method of analyzing the legal text, the acquis of the jurisprudence and the doctrine was used.
\end{abstract}

\section{Keywords}

Direct democracy; participation; referendum' self-taxation

JEL Classification: D63, H71, K34

\section{Introduction}

The purpose of this paper is to analyze legal regulations defining the conditions for initiating a referendum procedure in the subject of self-taxing of residents of a

1 Doctor of Law, Assistant Professor in Department of Self-Government Law, Faculty of Law and Administration, University of Szczecin, Poland, Member of Center for Information and Research Organization in Public Finance and Tax Law of Central and Eastern European Countries. Contact email: ewa.koniuszewska@usz. edu.pl. 
commune for public purposes and the requirements of its legal course. Attention was paid to factors influencing taking the initiative to conduct a referendum and those decisive as regards the closing of the procedure with a conclusive outcome. The structure of the study has been adapted to the delineated research field. The starting point was a presentation of general issues of an introductory nature. Then, the considerations were made to confirm the thesis that despite the fact that normative foundations of the institution of the referendum on self-taxing have been formed, its actual use is marginal. For the purpose of the conducted research in the indicated scope, the method employed was the analysis of legal acts, judicial and administrative case law and doctrinal views. Research results presented in particular in the following publications were taken into account:

\section{Local Referendum - General Remarks}

A local referendum is one of the forms of direct exercise of power by members of the local government community. Using the institution of a referendum, residents of local government units can exercise their right to participate in the management of public affairs (Olejniczak-Szałowska, 2010: 189). The essence of the referendum is the general and direct participation of members of self-governing communities expressing their will, each of whom has one vote and the will of the majority decides. The legislator introduced a material definition and a formal definition of a local referendum. In material terms, it is an expression in the form of a vote of the residents' will regarding the way of resolving a case concerning this community. On the other hand, in formal terms, this is giving positive or a negative answer on the official ballot to the question or questions asked or making a choice between the proposed variants (Zimmermann, 2005: 216). The literature draws attention to the characteristic features of the institution of a referendum, which include: direct participation of citizens in expressing their views, having only one vote, recognizing the will of the majority of all equal citizens as decisive in the settlement of cases (Mordwiłko, 1998: 176).

The normative shape of the institution of a local referendum is determined by the provisions of Art. 170 of the Constitution of the Republic of Poland (Act of 2 April 1997), Art. $3 / 2$ of the European Charter of Local Self-Government, as well as provisions of constitutional acts (Act on commune self-government, Law on county self-government, Law on voivodship self-government) and the act on the local referendum (Act on the local referendum). Pursuant to the provisions of Art. 170 of the Constitution decisions through a referendum can be made by members of the self-governing community. The right to express their will, which they enjoy, is a public personal right of a political nature, and its essence is the right of every 
resident to participate in the direct exercise of public authority at the local level (Voivodeship Administrative Court: III SA/Gd 183/16). The decision-making right guaranteed to members of the self-governing community can be implemented in matters concerning the given community, including the dismissal of territorial selfgovernment body coming from direct elections. In accordance with the content of Art. 170 of the Constitution, principles of and procedures for conducting a local referendum shall be specified by statute. However, the ordinary legislator may not limit the scope of the local referendum in question, because in reality, it may apply to any matter relevant to the self-governing community. On the other hand, the issue underlying the initiation of a referendum cannot be private, nor can it only be relevant to particular individuals, it should be important for the community (Skoczylas, Piątek, 2016: 947).

The material scope of a local referendum was specified in Art. 2 of the Act on the local referendum. It included: matters of dismissal of the decision-making body of a given unit; the mode of resolving a case concerning this community, falling within the scope of tasks and competencies of the bodies of a given unit; other important matters regarding the social, economic or cultural ties that bind this community. In addition, at the level of the commune, the following matters were included in the material scope of the referendum: dismissal of the commune head (mayor, president of the city); self-taxation of residents for public purposes falling within the scope of tasks and competencies of commune bodies.

The legislator included self-taxation of residents for public purposes in the catalog of issues that may be the subject of a local referendum. A referendum in this matter is obligatory, which is confirmed by the provisions of Art. 54/2 of the Act on commune self-government. According to the aforementioned regulation, the income of the commune may also include inflows from residents' self-taxing. Selftaxation can only take place through a commune referendum.

Referring to the nature of the proceeds from self-taxation as a source of commune's income, it is necessary to recall the views on this subject presented in the doctrine. Representatives of science emphasize that self-taxation cannot be equated with the institution of tax. Tax features include, among others, its mandatoriness and unilateral determination. In the case of self-taxation, these features are difficult to indicate in the strict sense of these concepts. The will of the residents determines the introduction of the institution in question and not the exercise of powers by State authorities. In addition, self-taxation seems to be devoid of legal sanction. In addition, the source of a tax obligation may only be the law, while the source of an obligation in the field of self-taxation is a commune referendum (Brzeziński, 1995: 219). The principle of statutory exclusivity in matters of burdens with the nature of public levies results directly from the Constitution. The problem of 
territorial self-government tax authority must be set out in statutes where the state shares its financial authority with the self-governing community. The admissibility of imposing public fees by the commune authorities is conditioned by the consent of the residents on whom the public fee is to be imposed, previously expressed in a referendum (Gliniecka, 2007: 44). In doctrine, however, a different view was presented, according to which the institution of self-taxation is not compatible with the Constitution because the regulations contained in its Art. 217 determine the exclusivity of the Act in the field of imposing levying burdens (KornbergerSokołowska, 2013: 64).

Self-taxation is treated as the basic local government unit's collection of funds for public purposes important to this local community (Gomułowicz, 2013: 147). In the literature on the subject, public purposes are associated with the performance of tasks, therefore the income from self-taxation of residents must serve the implementation of a specific task. This means that self-taxation cannot have the character of a fixed income for communes. The performance of the task for which funding was obtained using this institution is tantamount to the expiration of this form of communal income (Kryczko, 2013: 756).

The premise justifying the use of the institution of a referendum on selftaxation of residents is fiscal considerations. The commune authorities do not have the possibility to increase the tax burden beyond the maximum statutory level. Therefore, obtaining funds for the implementation of public goals that are important for the basic local government unit may lead its authorities to fall back on this institution. Using the referendum on self-taxation of residents may also be supported by the need to include community members in the implementation of public tasks and, as a result, in the shaping of their responsibility for the functioning of their commune. The introduction of self-taxing solely on the basis of a commune referendum allows performing tasks recognized by the local community as important enough so that it expresses the will to incur additional burdens above those resulting from tax laws (Niezgoda, 2004: 618). A referendum on self-taxation of residents should above all be applied to the implementation of communal tasks which concern the entire local community. Therefore, this institution could be used in the implementation of tasks such as construction of water supply and sewage networks, sewage treatment plants, taking over the duties of property owners as regards commune waste disposal (Palarz, 2015).

\section{Referendum Procedure}

Pursuant to the provisions of Art. 4 of the Act on the local referendum, the initiation of the referendum procedure may take place as a result of a resolution adopted 
Referendum for Self-Taxation as a Form of Participation of Commune Residents...

by the commune council or an application submitted by a group of residents. In the case of the first option, the decision-making and reviewing body shall adopt a resolution on conducting the referendum with an absolute majority of votes of its statutory panel. The resolution must meet the requirements specified in Art. 9/2 and Art. 9/3 of the Act. Therefore, it is necessary for the resolution to include: a question or questions of the referendum, the date of the referendum, a sample ballot paper and sample overlays for ballot papers made in Braille, a calendar of activities related to conducting the referendum. It is also indispensable that the commune council's resolution should indicate the purpose or objectives and the principles of self-taxation. It should be assumed that the resolution should specify: the purpose of the funds collected in this manner, the method of their collection, whether the payment is to be made in a lump sum or paid in installments, possible criteria differentiating the number of payments made. Subsequently, the resolution of the commune's decision-making and reviewing body regarding the holding of the referendum shall be announced in the voivodship official journal, and, in addition, placed immediately on posters or announced in another manner usually adopted in a given local government unit.

In turn, the initiation of a referendum procedure at the request of residents requires, pursuant to the provisions of Art. 11/1 of the Act, that the application is made by a group of at least five citizens who have the right to elect their commune council. It should be noted that the active elective right to elect commune council is afforded, in accordance with Art. 10/1/3 of the Electoral Code of 5 January 2017 to Polish citizens and European Union citizens who are not Polish citizens, who no later than the date of the vote turn 18 years old and permanently reside in the area of this commune. The mentioned entities cannot, however, be: deprived of public rights by a final court decision, deprived of electoral rights by a final decision of the State Tribunal, incapacitated by a final court decision. A group of commune residents entitled to submit a request for a referendum was given an obligation to fulfill statutory obligations, which determine the correct course of the referendum procedure. The first of these consists in a written notification to the executive body of the commune with the intention to put forward a referendum initiative. Then, in accordance with the provisions of Art. 13 of the Act, the initiator of the referendum is obliged to notify, at their own expense, residents of the commune about the subject of the intended referendum. Information about the intended referendum should include the question or questions, as well as the objective or objectives and the principles of self-taxation. In the commune, dissemination of information about the planned referendum takes place in a manner customarily adopted in a given local government unit (it is possible to place the information on the notice board in the commune office, to display posters in places intended for public announcements). The literature points out that burdening residents of self-governing communities 
with the costs of providing information on the subject of the intended referendum is a factor that weakens the ability of community members to initiate a referendum. On the other hand, the need to bear the costs of the announcement may be a barrier to the emergence of various referendum initiatives that will not gain public support (Uziębło, 2008: 69).

Another obligation on the group of residents initiating the local referendum is specified in Art. 14 of the Act. Its essence is the collection of signatures of residents entitled to elect the decision-making commune authority, interested in supporting the initiative. Signatures should be collected on cards, the elements of which were defined by law, within 60 days from the day of notifying the commune's executive body of the intention to put forward a referendum initiative. The time limit is of a preclusion nature, which cannot be restored or extended. However, the case presented to the residents on the cards, while seeking their support, should be equated with the case proposed to be settled by the referendum, as specified in the request for conducting the referendum by means of questions (Supreme Administrative Court: II OSK 825/14).

In addition to the duties assigned to the group of commune residents who are the initiators of the referendum, the legislator regulated in detail the duties of the commune bodies regarding proceeding with the request of the referendum initiator. According to Art. 15/1 of the Act, the executive body of the commune, after receiving the residents' request, shall immediately confirm this fact in writing. Then they pass the request to the chairman of the commune council, in order for the request for a referendum to be verified by the decision-making body. Pursuant to the provisions of Art. 17/1 of the Act, the decision-making body of a local government unit shall adopt a resolution on holding a referendum if the residents' request meets the requirements of the Act and does not lead to decisions contrary to the law. The decision-making body is bound by the content of the request. The manner in which the legislator recognizes the criteria for the assessment of the request means that determining the existence of only one of the two flaws of the request gives a sufficient basis for its rejection (Voivodship Administrative Court: III SA / Lu 689/12). It is not admissible, however, that the authority, rejecting the residents' request regarding the referendum, should be guided by non-normative criteria, such as, for example, the purpose of holding a referendum (Voivodship Administrative Court: III SA/Lu 750/11). A resolution on the holding of a referendum or a resolution on rejecting the residents' request shall be taken by the commune council not later than within 30 days from the date of submitting the request for the initiative of holding a referendum to the executive body of the self-governing community. The resolution is subject to the announcement in the voivodship official journal, 
Referendum for Self-Taxation as a Form of Participation of Commune Residents...

and, moreover, immediate display on posters or announcement in another way customarily adopted in a given commune.

The Act on local referendum sets out the rules, sources, and method of financing a referendum, and the scope of these regulations affects the course and result of the referendum. Representatives of science indicate that the financing of a referendum was based on the principles of transparency, covering costs from public funds (from the budget of a local government unit or from the state budget), covering the expenses of the referendum initiator from own sources, transferring by the initiator of the surplus of obtained funds for referendum purposes to a charity institution (Olejniczak-Szałowska, 2002: 205). Among the listed principles, the most important influence on the frequency of initiating a referendum on self-taxation of residents is the principle of covering the expenses of the initiator of the referendum from own sources. This principle has been expressed in Art. 42 of the Act and covers all activities undertaken by the initiator in the conducted referendum. These include both activities performed in connection with the initiative to hold a referendum, as well as activities carried out as part of the referendum campaign. Expenses incurred in connection with the taking up are to be covered from own sources understood as legally permitted sources of financial contributions (Czaplicki, 2007: 151). The problem of obtaining financial contributions will become apparent when a group of residents of a commune will be the initiator of the referendum. This group will in principle be forced to finance all activities from own resources of natural persons who form that group. It should be noted that the expenses of the initiator of the referendum are relatively large and include, among others, fees for using the mass media, costs of producing and distributing referendum materials, costs of organizing meetings with residents (Olejniczak-Szałowska, 2002: 207). In view of the above, it can be concluded that the regulations adopted in Art. 42 of the Act contribute to the limitation of the referendum initiative. On the other hand, they may be helpful in achieving a state where it would be undertaken when it was supported by the interest of as many of the commune's residents as possible, rather than by the needs of a narrow group of self-governing community members.

The implementation of the principle of transferring the surplus of obtained funds for referendum purposes to a charity institution may also be problematic for the initiator of the referendum. This principle has its normative dimension in the provisions of Art. 46 of the Act. The legislator, obliging the initiator of the referendum to transfer the surplus of funds obtained, also established the requirement to include in the financial statements information on the purpose for which the surplus was transferred. Difficulties related to the implementation of the principle in question may consist in proper identification of the charity institution and in selecting it. In determining which of the existing institutions conduct charitable activities, their 
informal records or registers may prove helpful. The problem may, however, be the choice of such an institution, especially in a situation where a group of residents is the initiator of a local referendum. It would then be reasonable for the persons initiating the referendum procedure to present a common position reached as a result of agreement or vote. The situation is complicated by the fact that people bound by a common referendum goal may have different views on the distribution of surplus funds obtained for activities related to the referendum (Uziębło, 2008: 170-171).

Relatively, the implementation of the principle of transparency should give the initiator of the referendum fewest complications. This principle is embodied in the obligation resultant from Art. 45 of the Act to prepare financial statements on income and expenses related to the referendum. The fulfillment of this obligation rests with the representative of the initiator of the referendum, who is obliged to submit the financial statements to the executive body of the commune within three months from the day of the referendum. The statements are to be drawn upon a form prepared according to an officially agreed template. Then, the executive body makes the statements available to the residents of the local governing community.

The Act on the local referendum regulates the conditions for the validity of the referendum and the recognition of its result as decisive. The legal solutions adopted in this respect seem to have a significant impact on the frequency of initiating referendum procedures in the subject of residents' self-taxation for public purposes. The literature points out that the final result of the referendum is determined by the number of residents of a given local community participating in it and the content of the answers they provide to the questions formulated in the referendum. In the first case, the turnout determines the validity of the referendum. In the second, the manifestation of citizens' expectations as to the subject of the referendum decides whether the result of the referendum will be decisive or not. At the same time, specific legal consequences are triggered only by a valid referendum (Dauter, 2007: 179).

Pursuant to the provisions of Art. 55 of the Act, a referendum is valid if at least $30 \%$ of those entitled to vote took part in it. The number of persons entitled to vote results from the electoral roll. In turn, the number of people who took part in the voting is determined on the basis of the number of valid ballot papers taken out of the ballot box. Therefore, a prerequisite for determining that the referendum has brought about a conclusive result is the right turnout. Only after stating that the conditions for the validity of the referendum have been met is it possible to proceed to determine whether the conditions under which the referendum brings about a conclusive result have been met (Olejniczak-Szałowska, 2002: 218). According to Article 56 of the Act, the result of the referendum is conclusive if more than half 
of the valid votes were cast in favor of one of the solutions in the matter subjected to the referendum. The conclusive result reflects the will of the local community regarding the subject of the referendum, expressed in a direct way during the vote. Each of those entitled to participate in the referendum expresses their will by voting for one of the solutions in the case subjected to a referendum (Dauter, 2007: 181). It should be emphasized that in relation to the local referendum on self-taxation of residents for public purposes, the legislator decided to tighten the criteria determining the conclusive result. Pursuant to the provisions of Art. 56/2 of the Act, the result of the commune referendum on self-taxation is conclusive if at least twothirds of valid votes were cast in favor of self-taxation.

In the subject literature, different views on the legitimacy of establishing higher criteria for a conclusive result of the referendum on self-taxation are presented. Supporters of this regulation argue that the need to establish it is supported by the fact that the subject of the referendum concerns matter which in principle is regulated by law. An additional argument is that the result of the referendum applies equally to all residents of a given self-governing community (Dauter, 2007: 182). It is also indicated that the two-thirds threshold of validly cast votes is too lenient and it is proposed that the threshold of support, and also the threshold of turnout, should be raised. Such a solution would serve to increase the legitimacy of introducing public burdens that are imposed on all members of the self-governing community, and not only on the commune's residents taking part in the voting (Uziębło, 2008: 206). It should be emphasized that the tightening of the criteria determining the conclusive result of the referendum on self-taxation has also been criticized in the doctrine. Its representatives point out that the introduction of strict requirements in relation to the mode of establishing self-taxation makes this institution applicable in practice only exceptionally. One should justify the doubts as to whether the intention of the legislator was to establish a difficult to implement and costly procedure of taking a decision on self-taxation if its consequences were to be residents' nonbinding position as to their will to incur additional costs for the implementation of a public task (Niezgoda, 2004: 621).

Pursuant to Art. 65 of the act, if the referendum ends with a conclusive result in the matter subjected to the referendum, the competent authority of the local government unit shall immediately undertake actions to implement it. If the subject matter of the referendum was self-taxation of residents for public purposes, the commune council will be the Competent authority. It is obliged to undertake actions that bring about the will of the residents. The nature of these actions has not been specified, which should make one conclude that they may be all activities within the scope of the competences of the decision-making body, aimed at the implementation of the referendum decision (Olejniczak-Szałowska, 2002: 253). The deadline for the 
implementation of the referendum decision has not been specified by the legislator. An instructional character is attributed to it due to the lack of sanctions for its violation. Therefore, a de lege ferenda proposal was formulated in the literature that Art. 65 of the Act should be amended in such a way so that the ending date is placed in the norm (Wierzbica, 2014: 150). In the current legal status, guarantees for the implementation of a referendum decision can be sought in the provisions of Art. 101a of the commune self-government act (Olejniczak-Szałowska, 2002: 260). They shape the right of everyone to file a complaint at the administrative court in a situation where the competent commune body does not perform activities prescribed by law.

\section{Conclusions}

The existing legal solutions specify the conditions for initiating a referendum procedure regarding self-taxation of residents for public purposes and its conduct in such a way that it may end in a conclusive result. Although the regulations provide the residents of the commune with the opportunity to personally participate in shaping the income of their self-governing community, the institution of the referendum is relatively rarely used. The referendum initiatives undertaken so far, as a result of which the residents of the commune took on additional obligations for it, concerned: introducing flat-rate fees for the disposal of solid waste, fees for health care. A referendum on self-taxation was often carried out together with voting on other matters - alongside presidential elections, national referendums, parliamentary elections (Piasecki, 2005: 108-109). It may be assumed that the reason for the marginal use of the institution of a referendum are legal solutions establishing for the referendum initiator requirements of informing on the subject of the intended referendum, respecting the rules for financing a referendum, as well as shaping the threshold of turnout or a higher threshold of support. However, it should be borne in mind that a referendum on self-taxation is an expensive, timeconsuming institution, requiring substantial preparation of the commune's residents as to the subject of the vote, and to a large extent causing taxpayers' reluctance to increase their public and legal burdens.

\section{References}

Brzeziński, B.: Glosa do wyroku Naczelnego Sądu Administracyjnego z dnia 21 października 1993 r., SA/Wr 1171/93 (Commentary to the decision of the Supreme Administrative Court of 21 October 1993, SA/Wr 1171/93 ), Przegląd Orzecznictwa Podatkowego (Tax Case Law Review) no. 4 (1995). 


\section{Referendum for Self-Taxation as a Form of Participation of Commune Residents...}

Gliniecka, J.: Opłaty publiczne w Polsce. Analiza prawna i funkcjonalna (Public levies in Poland. Legal and functional analysis), Bydgoszcz-Gdańsk: Oficyna Wydawnicza Branta, 2007.

Kornberger-Sokołowska, E.: Zasada adekwatności w systemie finansów samorządu terytorialnego w Polsce (The principle of adequacy in the system of finance of the territorial self-government in Poland), Warszawa: LexisNexis, 2013.

Czaplicki, K.W.: Komentarz do art. 43 (Commentary to Article 43), in: Czaplicki, K.W. et al. (eds.): Ustawa o referendum lokalnym. Komentarz (Act on local referendum. Commentary), Warszawa: Wolters Kluwer, 2007.

Dauter, B.: Komentarz do art. 55 (Commentary to Article 55), in: Czaplicki, K.W. et al. (eds.): Ustawa o referendum lokalnym. Komentarz (Act on local referendum. Commentary), Warszawa: Wolters Kluwer, 2007.

Gomułowicz, A. et al.: Podatki i prawo podatkowe (Taxes and tax law), Warszawa: LexisNexis, 2013.

Kisielewicz, A.: Komentarz do art. 14 (Commentary to Article 14), in: Czaplicki, K.W. et al.: Ustawa o referendum lokalnym. Komentarz (Act on local referendum. Commentary), Warszawa: Wolters Kluwer, 2007.

Kryczko, P.: Komentarz do art. 54 (Commentary to Article 54), in: Chmielnicki P. (ed.): Ustawa o samorządzie gminnym. Komentarz (Act on commune self-government. Commentary), Warszawa: LexisNexis, 2013.

Mordwiłko, J.: Referendum gminne w świetle prawa i praktyki (Commune referendum in the light of law and practice), in: Piekara, A. et al.: Samorząd terytorialny. Zagadnienia prawne i administracyjne (Territorial self-government. Legal and administrative issues), Warszawa: Wydawnictwo Prawnicze Sp. z o.o., 1998.

Niezgoda, A.: Samoopodatkowanie a bezpośrednie formy sprawowania władzy na szczeblu lokalnym (Self-taxation and direct forms of exercising power at the local level), in: Ura, E. (ed.): Jednostka, państwo, administracja - nowy wymiar (Individual, state, administration - new dimension), Rzeszów: Mitel, 2004.

Olejniczak-Szałowska, E.: Prawo do udziału w referendum lokalnym (The right to participate in a local referendum), Łódź: Wydawnictwo Uniwersytetu Łódzkiego, 2002.

Olejniczak-Szałowska, E.: Referendum lokalne w świetle ustawodawstwa polskiego (Local referendum in the light of Polish legislation), Warszawa: Difin, 2002.

Olejniczak-Szałowska, E.: Referendum lokalne (Local referendum), in: Stahl, M. et al. (eds.): Encyklopedia samorządu terytorialnego, cz. 1, Ustrój (Encyclopedia of territorial self government. Part 1. Regime), Warszawa: Difin, 2010.

Palarz, H.: Przyłączenie do sieci wodociągowo-kanalizacyjnej. Aspekty prawne (Connecting to a water supply and sewage network. Legal aspects), Warszawa: Wolters Kluwer, 2015.

Piasecki, A.K.: Referenda w III RP (Referendums in the Third Polish Republic), Warszawa: Wydawnictwo Naukowe PWN, 2005. 
Skoczylas, A. et al.: Komentarz do art. 170 (Commentary to Article 170), in: Safjan, M. et al. (eds.): Konstytucja RP. Tom II. Komentarz. Art. 87-243 (Constitution of the Republic of Poland. Volume II. Commentary. Articles 87-243), Warszawa: C.H. Beck, 2016.

Uziębło, P.: Ustawa o referendum lokalnym. Komentarz (Law on the local referendum. Commentary), Warszawa: Wolters Kluwer, 2008.

Wierzbica, A.: Referendum i wybory oraz zarządzenia i uchwały jednostek samorządu terytorialnego (Referendum and elections, ordinances and resolutions of local government units), Warszawa: LexisNexis, 2014.

Zimmermann, J.: Prawo administracyjne (Administrative law), Kraków: Zakamycze, 2005.

Council of Europe, European Charter of Local Self-Government of 15 October 1985.

PL: Constitution of the Republic of Poland of 2 April 1997, as amended.

PL: Act of 8 March 1990 on commune self-government, as amended.

PL: Act of 5 June 1998 on county self-government, as amended.

PL: Act of 5 June 1998 on voivodship self-government, as amended.

PL: Act of 15 September 2000 on local referendum, as amended.

PL: Electoral Code of 5 January 2011, as amended.

PL: Supreme Administrative Court: II OSK 825/14.

PL: Voivodship Administrative Court: III SA/Gd 183/16.

PL: Voivodship Administrative Court: III SA/Lu 689/12.

PL: Voivodship Administrative Court: III SA/Lu 750/11. 


\title{
NEW CHALLENGES AND PERSPECTIVES IN CUSTOMS LAW ${ }^{1}$
}

\author{
KARIN CAKOCI
}

\begin{abstract}
In the article, the Author deals with the issue concerning new trends in the area of customs law. The customs law is a sub-branch of financial law, which is the typical branch of public law. Currently, the customs law is confronted with new challenges due to rapid globalization of international trade that creates new opportunities to introduce new customs mechanism. The goal of the article is with standard scientific methods (method of analysis, comparative method, and method of synthesis) to identify new opportunities leading to improvement in effectivity of customs administration. The electronization of customs declaration is regarded as the main measure that may help to improve the effectiveness of customs procedures. It may also secure fast exchange of information between relevant agents as a factor for improvement of the economic environment.
\end{abstract}

\section{Keywords}

Customs law; customs declaration; electronic customs declaration

JEL Classification: H20, H69, O31

\section{Introduction}

The issues of customs, customs sector, as well as their legal aspects in both the substantive and the procedural law systems, have always been at the center of the

$1 \quad$ This paper has been written as a partial output of the research project VEGA 1/0846/17: "Implementation of the initiatives of the EU institutions in the field of direct taxes and indirect taxes and their budgetary law implications", as well as the output of the APVV-16-0160 project: "Tax evasions and tax avoidance (motivation factors, formation and elimination)".

2 Associate Professor of Financial Law and Tax Law at the Department of Financial Law, Tax Law, and Economy, Faculty of Law, Pavol Jozef Šafárik University in Košice, Slovakia. The author specializes in customs law and is the author of more than 50 scientific publications. The author is a member of the Information and Organization Centre for the Research on Public Finances and Tax Law in the Countries of Central and Eastern Europe. Contact email: karin.cakoci@upjs.sk. 
attention of modern civilizations. Ever since its earliest times, every State formation has protected its interests in the movement of goods, persons, labor, etc. The law has in this regard been playing an increasingly decisive and irreplaceable role. No other instrument of social regulation, in particular at present, has its own internal power and ability to better express and protect these interests.

Today, there is little doubt that customs legislation is highly responsive to the socioeconomic development of each country. From this point of view, it is its reflection, but at the same time, it also is its legal expression in that sphere. In contrast to other legal fields, the customs legal regulations are primarily characterized by the flexibility of their being adapted to the economic movement and social practice, primarily due to the objective necessity of regulating newly established social relationships in line with society's needs. In just the same way as social history has been changing over time, new economic and social conditions have been created, customs legislation has adequately been changing.

It should be borne in mind that customs law in the Slovak Republic regulates the rules and procedures for the handling of goods related to the movement of goods between the EU and third countries in the Slovak Republic, with the emphasis being laid on two facts:

- For the assessment of each case, it is necessary to know both the Community rules and the national rules and apply them in their mutual interconnection.

- Priority for the implementation shall be with the EU rules, which means that any contradiction between the legal norms contained in the Customs Code shall be dealt with in accordance with the principle of lex superior derogat legi inferiori in favour of the Union legislation, since higher-order legislation takes precedence over the rule of regulations of lower legal force.

The essence of the customs law is determined by the nature of legal provisions governing a specific area of social relations, in essence, the financial relations arising from the transit of goods through the state or customs border. The customs law regulates these social relations by granting to each of the entities involved in them a precisely defined range of rights and obligations in respect of the transit of goods across the customs border.

The Customs Law (Babčák, 2017: 296) is an integral part of the financial law sector, in which it acts as a relatively separate legal sub-sector. The classification of customs law under the systemic basis of financial law has its historical justification in particular. In addition, this integration also emerges from the very nature and functions that the customs duties fulfill as the oldest financial and legal institution. 
We have to realize that the history of customs and the customs sector as such is inseparably linked to the history of trade. The primary motive for the introduction of customs duties was to provide for state revenues, and later its protective and regulatory roles were added. We could speak of a special kind of charges. This would certainly be a very simplified view, as there is a wide range of opinions in the theoretical sources on the nature of the customs duties, which are in some ways even diametrically opposed. In the earlier period (this is true for this country by around the middle of the 18th century), the customs duty was very often associated with a toll. The toll had been collected as a payment for the means of transport (most often for the wagon, boat or horses). In its essence, the toll was a charge for the use of roads, bridges, embankments, and rivers, and, at the same time, it was a charge for the goods transported, carried, or sailed. The origin of customs duties is usually related to the scots that had been collected for the construction and protection of transport roads and routes. Unlike tolls, which had been collected in particular by private landowners on which trade routes, bridges, and the like were situated, and the basis for which had been the price for the use of a particular route or bridge or a forage to transport the goods, the basis for the assessment of the customs duty by the State was the type, quantity, and price of the goods that had been crossing the border. Some Authors see the origin of the customs duties in payment for a trade permit.

However, we may come across the Institute of customs duty much, much earlier, as late as in the Antiquity. At fixed locations (at borders, streets, etc.), a border charge had been levied for the person in transit and the goods transported in the form of a toll or a charge on the road use; by their function, these charges had come close to the indirect taxation institute. Every Roman province had been considered the customs territory, but larger cities and the Rome-related provinces had also been allowed to levy customs duties. In ancient times, the Egyptians had also been collecting customs duties (Šviderková, 1983: 121), the Greeks, and later also the Romans. However, the customs duties in the form as we know them today only occurred in modern times.

Customs duty originates in the Greek word telos (this had several meanings, such as payment, the period of time, limit, border), the abbreviation of the word telos, tol, later tsol, has completed the formation of this term. As customs duties, the notions like telonium (taloneum, theloneum), douane, customs, pedaticum (Reisegelt), pulveraticum (Wagezoll), navigium (Schiffzoll), rotaticum, saumaticum, pontaticum, from the muta from southern Germany, from the later period Passagezoll, Ortszoll Zoll or Maut (Mauth) or accise (Akzise) and others are translated (Balko, Grún̆, 2001: 18). The following opinions may essentially be accepted with certain reservations: 
- General terms, such as theloneum, zoll, accise, and so on, were terms wider than today's customs duty and included a whole host of different imposts, which were linked to levying them in relation to transport and sale of the goods. Moreover, the term "der Zoll" had on occasions denoted in German history the whole area of market law and is still being translated (if we neglect its understanding as an older measure of length, a coul) as charge or impost. The oldest "customs duties" were not being levied on the value of the goods, as they are today, or on their weight, a number of pieces or other quantitative units, but according to the number of wagons, horses, or persons transporting the goods. If we were to use modern terminology, they had a nature of a toll, i. payments levied on the number of the means of transport used, that is to say, payments for the use of the then-operative road and routes. The actual customs duties came into being only later, and basically, until these days, both of the above types of payments were basically the same ${ }^{3}$.

- The ancient and medieval customs duties had also been distinguished from today's customs duties by their understanding as a certain compensation granted to the State or the ruler for their support to the trade (Fuksa, 1930: 679).

- Social determination of customs duties, denoting their role in the life of society, economy, law, and politics, was also different in the Middle Ages to today's perspective. Customs duties in the Middle Ages served essentially exclusively the fiscal purposes, i.e. as just a means of direct income multiplication (Finanzzoll). The use of customs duties as a tool for influencing the economy largely exceeded the degree of agricultural and craft development that did not as yet required the need for protectionist or protectionist-motivated measures.

- The use of customs duties for attaining political goals was also less frequent than it is today.

The issue of the nature of the customs duties is directly related to the definition of that term. Opinions on the notion of customs duty are not uniform in modern sources, depending on how the relevant Authors perceive the nature of the customs duties, meaning, what they consider to be decisive and dominant for this financiallegal institute. The inconsistency here is largely conditional on the inclusion of the customs duty within the relevant category of State revenue. For example, the Customs Code of 1927, which had been applicable in this country by the year 1953, between them. The designation "toll" (Mauth) initially apparently meant wage, then the reward demanded by an official for their act performed, and later a bribe, pretty obvious as a result of misuse of this entitlement. 
defined the customs duty as "a public levy imposed unilaterally by the State for economic reasons".

Some encyclopedic sources of the 1930s characterized the customs duty as an indirect tax levied on the goods imported into the customs territory; one might, however, argue that the further development did not confirm this view. From among the Authors who understood the customs duties as a cash payment levied by the State when the goods crossed the State or the customs border, one may mention, for example, A. Slovinský and J. Girášek (1985: 133). Some other Authors see the customs duty as a special kind of charge (Spáčil, 1970: 67; Kubicová, 1998: 27). However, this concept had not received much support, and most current Authors do not agree with such an understanding of customs duty.

Customs duty has been perceived by many representatives of the economic sciences in the past few years as a kind of cash payment levied by the State in the crossing of goods across the State border. Defining the customs duty as a certain public impost has found space in a number of available publications in this field, both older and recent (Štěpán, 1963: 17). Among the latest sources, one may mention, for example, the Dictionary of Czech Law (Madar, 1995: 151).

In the foreign professional economic sources, the customs duty is included within taxes, more precisely, within the so-called Trade Taxes - a professional term referring to taxes levied in connection with the trade, more specifically with import or export of the goods. In the current Slovak professional economic sources, the term "Trade Taxes" does not have a relevant representation. Most of the international representatives of economic sciences perceive customs duty as a form of international trade taxation. For example, P.A. Samuelson defines customs duty as the import tax (Samuelson, Nordhaus, 1992: 472). Ch.P. Kindleberger (1978: 123), an American economist dealing with the history of economics, understands the customs duty as a tool for taxing foreign trade. Harold J. Heck (1969: 192) states in his publications that "the customs duties are a form of tax introduced by all countries on imported goods. The customs duty is one of the oldest forms of taxation, one of the reasons for this being ease of choice, as the goods physically cross national borders".

In the Polish sources, some Authors point out that the customs duty has characteristics of a tax, or define the customs duty as a public impost similar to tax (Huchla, 1999: 82), and still others simply identify customs duty with the tax (Kosikowski, Ruśkowski, 1994: 238). K. Lasinski-Sulecki and W. Morawski (2009: 55) point out that at present, it is impossible to identify customs duty and tax in the law of Poland, so that customs duty cannot be understood to cover the tax, too. They justify this fact by claiming that the provisions of the Polish rules, which use 
the term "tax", do not include customs duties. Moreover, they state that taxes are regulated by other legislation and the tax provisions apply to customs duties only if they are expressly referred to by the customs legislation.

The customs duty in the theory of the German financial law, as well as in the theory of economics, is understood as a cash impost levied by the State when crossing the State border or the customs border (www.wirtschaftslexikon.de/Definition). Customs duty is perceived as a tool of the economic policy of the State. As in the vast majority of the EU Member States, especially in relation to the Central and Eastern European region, customs duties are considered to be different payments from tax payments. However, it is stated in professional publications that they perform similarly or even the same functions as excise duties.

In the Czech sources, according to M. Bakeš (1990: 22), the customs duty is characterized by its hybrid nature. As to its content, the customs duty shares with the fees a common payment structure for the services rendered when the goods are being brought into or out of the country. Functionally, especially at the present time, the customs duty passes rather in the tax area, it becomes part of the price of the imported goods, and so it acts equally as indirect or excise taxes. The special status of the customs duty and its (in some cases) hybrid nature had in the past led M. Bakeš (1990: 37) to believe that the customs duty should be regarded as a compulsory sui generis payment, laid down by law, which is levied in direct connection with the crossing of goods across the border from persons, who import or export the goods, or from the persons for whom such goods are imported or exported. Certain identification with this view may also be found in some other publications (Girášek, 1981: 34; Ovečková, 1994: 40; Bakeš, 1995: 244).

With regard to the conceptual definition of customs duty, it should be noted that customs duty, despite its initial and original function, i.e. the fiscal function, has never been the sole or the most significant instrument of exerting any positive influence on the economy of the State in the sphere of foreign trade. It goes without saying that in the period of the persistent trade deficit, as well as the balance of payments and the deficit of the State budget, the State's interest in making the customs duties more effective means of increasing its revenues were more pronounced. In such understanding of customs duty and the entire area of customs policy and practice, customs duty is to be seen as a State instrument of regulation.

At present, the customs duty ranks among the so-called traditional own resources (Treaty on the Functioning of the European Union no. 2012/C 326/01, Art. 311) of the Union budget, which may be characterized as allocations to the EU permanently in order to finance its budget and automatically flowing into that budget without the need for any additional decision by the EU Member States' authorities. Customs 
duties are the result of the use of the Union customs legislation for trading with non-member countries. Out of the total volume of traditional own resources, each Member State retains 20\% of the collection costs. It should be noted that customs duties in mature market economies have always been a relatively low source of State revenue, as the revenues of their State budgets are based on other types of income (in direct and indirect taxes) within their tax systems. On the contrary, especially in the developing and the underdeveloped countries, customs duties are still a priority source of government revenue, resulting from low or lower levels of their economic development.

\section{New Trends in Customs Legislation}

In Slovakia, the customs legislation underwent major transformations mainly during the pre-accession period and in the context of the accession of the Slovak Republic to the EU on $1^{\text {st }}$ May 2004 (Šramková, 2011: 19). The evidence of this was infrequent amendments to the customs legislation or adoption of novel legislation. Prior to joining the EU, the SR had to meet a number of conditions that related to the approximation of our law with the EU law. Harmonizing our national law with the European Community law and the so-called Union law has affected all the legal branches and legal institutes, not leaving aside even the area of customs legislation. This harmonization process was completed by the adoption of Act no. 199/2004 on Customs and on the amendment to certain law acts, which entered into force on 15 April 2004 and was based in full on Council Regulation (EEC) no. 2913/92 of 12 October 1992 establishing the Community Customs Code. However, customs have recently faced a rapidly changing environment, for instance changing industrial and consumer trends, increasing international trade, global threats (e.g. terrorism, organized crime, crisis situations), and various other new dangers (e.g. dangerous goods trade). In this context, it has to be realized that the customs authorities play a key role in this respect. Their mission is to ensure that there is a constant balance between protecting the society and promoting legal trade through the supply chain control, information exchange and cooperation, both at the EU's external borders and within the Customs Union. The customs legislation has had to flexibly respond to new challenges, such as increasing the competitiveness of economic actors operating in the EU, improving the economic environment, notably by ensuring a smooth flow of trade, while at the same time implementing the required level of inspections to protect the health and safety of all the EU citizens. The requirement of aligning all of these requirements to one another was that the procedures and inspection methods need to be modernized and cooperation and exchange of information between customs administrations need to be improved. Customs administrations have information on any movement of goods 
imported into or exported out of the EU, and they have to apply complex systems and inspection methods to a wide range of goods. It is necessary to recognize here that there is no single EU customs administration, but there are 28 national customs administrations which cooperate on the basis of the European strategy and the common legal framework.

In particular, it should be emphasized that the view and look at the fiscal function in the customs area have changed fundamentally. Gradually, the importance of the choice of funds levied has been declining, mainly due to the liberalization of international trade, continuous reduction of tariffs, and the making of new free trade agreements and treaties. More and more customs duties are now shifting to the protection of the EU area and its inhabitants against terrorist threats and other threats to life and human and animal health, environmental hazards, and, last but not least, to the protection of the internal market from anti-competitive practices or those injurious to consumers.

In the area of customs, several measures have been taken to prevent the illegal import, export, and transit of goods in order to protect the economic interests of the EU as a whole. These are a number of regulations of the European Parliament and the Council as basic legislative acts of the EU. In particular, reference should be made in this regard to Regulation (EU) no. 1294/2013 of 11 December 2013 establishing the EU Customs Action Programme for the period between 2014 and 2020 (in short "Customs 2020"). For the purposes of this Regulation, the customs action programme "Customs 2020" was established to support the functioning of the Customs Union covering the period from 1st January 2014 to 31 December 2020. The objective of the programme is to support the functioning and modernization of the customs union, with a view to strengthening the internal market through cooperation between the participating countries, their customs authorities and their officials. In a wider context, reference should also be made to Regulation (EU) no. 1286/2013 of 11th December 2013 laying down the action programme on improving the functioning of the tax systems in the EU for the period between 2014 and 2020 (Fiscalis 2020) and Regulation (EU) no. 250/2014 of 26 February 2014 establishing a programme to support activities in the field of the protection of the EU's financial interests (Hercule III programme). The purpose of these Regulations is to combat corruption, fraud, and any illegal activities detrimental to the EU's financial interests. The aim is to support these objectives through a good exchange of information, by supporting the operational systems of the national authorities, in particular, the customs and law enforcement authorities. The EU framework for the EU financial interest protection certainly belongs to the earlier date of the Council Resolution of 13 December 2011 on the future of the customs law enforcement cooperation, which, although not binding on the individual Member 
States, has shown the direction for the EU to take. In this respect, the resolution outlined a strategy for customs cooperation in the field of law enforcement with a view to identifying the measures to be taken to further develop customs cooperation and cooperation with other authorities in order to strengthen the role of customs administrations in combating organized crime more effectively and to act immediately in response to new threats.

Taking into account these challenges and issues, the European Commission has been working for the modernization of customs rules for several years. The result was the adoption of the Customs Code (Council Directive 952/2013), which is an important milestone in the reform of the EU customs legislation. Its partial effect on the delegation of powers to the European Commission with regard to the development of delegated and implementing regulations took place on 30 October 2013 but was fully effective as of 1 May 2016.

The Union Customs Code has definitively abolished all the existing legal standards relating to customs legislation, in particular the Modernized Community Customs Code (Council Directive no. 450/2008), which has never entered into force, but also the current Community Customs Code (Council Directive no. 2913/92) and its implementing regulation (Council Directive no. 2454/93). These changes are intended to allow as far as possible a uniform and harmonized application of the rules in the EU countries. In this respect, the aim of the Customs Code is to ensure the following:

- Modernizing the customs legislation and regimes as well as the use of customs information systems to facilitate the handling of customs formalities and to ensure risk-free and safe trade in goods in the European Union.

- Streamlining and taking appropriate procedures for customs clearance based on greater clarity and better uniformity of customs legislation.

- Reducing the administrative burden for economic actors by using electronic procedures and storage facilities, thereby reducing the volume of reporting formalities and preparing the conditions for further modernization and better coordination of border management.

- Complete alignment of the EU customs rules with global standards, as well as with further developments at international level, including the EU's major trading partners, thereby simplifying and making trade more efficient, thus generating significant export opportunities for the EU economic actors.

The main objective of the Customs Code and the number of customs tariff reform measures is to improve the functioning of the Customs Union as a whole by extending the application of customs legislation throughout the customs territory of the Union to the national customs administrations of the Member States and to 
streamline and digitize customs regimes in order to achieve their simpler and better structure.

The EU Customs Code itself is based on Art. 6 from the creation of a panEuropean electronic customs system - a customs environment without documents in paper form. "Any exchange of information between customs authorities and economic actors and customs authorities, such as customs declarations, applications or decisions, and the storage of such information in accordance with the requirements of customs legislation, shall be carried out using electronic data processing techniques". Exceptions exist only for the application of the so-called "emergency procedures" and special transport modes. The aim of these measures is to establish an extensive communication network between the customs offices in the EU, between customs and other public authorities with international trade responsibilities, and between public authorities and traders. These steps would enable the customs to keep pace with evolving international trade and making a significant contribution to increasing the EU's economic competitiveness.

Modernization and computerization of customs procedures and the related processes, in line with the EU legislation, will create prerequisites for trade facilitation and support for the digital economy and its better use of online e-Government services (Červená, Románová, 2016: 51) and convenience for the sphere of trade. We expect a better overview of goods flows and trade transactions, faster customs procedures, higher volume of negotiated goods, which may ultimately be reflected in the level of state budget revenues. Thus, it can be said that these developmental tendencies and trends tend to electronize individual processes and services in international trade and to create a fully integrated information environment in this area.

\section{Development in Customs Declarations}

In the next section, I would like to focus my attention on the issue of customs declarations. The adoption of the Union Customs Code in this area has undergone significant changes compared to previous legislation.

The customs procedure begins with the lodging of a customs declaration. From a formal point of view, it is a motion to initiate a procedure, whereby the Customs Code defines a customs declaration as an act by which a person, in the prescribed form and in a prescribed manner, manifests his willingness to release the goods into the proposed customs procedure and, if appropriate, to be applied (see Union Customs Code, Art. 5/12). Without such an incentive, the customs procedure cannot be carried out, application of the principle of official legality in relation to the opening of a customs procedure is not possible. 
The customs declaration may be filed in several ways:

- electronically;

- in paper form;

- in oral form;

- in another (implied) operation.

Filing a customs declaration in paper form was one of the most common and, at the same time, classic ways of filing a customs declaration. However, filing the customs declaration in writing has been on the retreat, since the whole of the Union Customs Code is based on the principle that all the customs and trade transactions are to be carried out electronically and that the information and communication systems for customs operations offer economic operators in each Member State the same opportunities. By 31 December 2020 at the latest, individual Member States are to take effective measures to ensure a paperless customs and business environment. The advantages of the electronic processing system include in particular elimination of the need for paper documentation along with the possibilities of fraud related to the paper form of processing, the possibility of better and more operative monitoring of transit operations, further shortening of the processing time at the customs office, as the customs declaration will be submitted in advance electronically, and the like. The anticipated benefits also include streamlining the inspection, reducing the volume of administration, making better use of resources in physical inspections, stepping up and detecting fraud.

All the goods intended for release for free circulation except for the free zone customs procedure shall be indicated in the customs declaration for the relevant customs procedure. The customs declaration shall contain all the particulars necessary for the application of the rules governing the customs procedure in which the goods are presented in the customs declaration. The declarant or their representative shall be accountable for the accuracy of the information provided in the declaration, for the authenticity of the documents attached, and for the compliance with all the obligations relating to the release of the goods in question into the proposed customs procedure.

All accompanying documents shall be attached to the customs declaration (Union Customs Code, Art. 163) and the documents, the application of which is necessary for the release of the goods into the proposed customs procedure. These documents shall be retained by the customs authorities. Where the declarant so requests, it is necessary for the customs authorities to take certain steps to prevent such documents from subsequently being used for a purpose other than in relation to the quantity or value of the goods for which they remain valid. It is important to remember that each of the proposed customs regimes also requires certain specific documents. 
Most often, the invoice is used to determine the customs value, the documents required for the application of preferential tariff measures or other measures that deviate from the legal provisions applicable to the goods to be logged, or transport documents or the documents relating to the previous customs mode.

The customs declaration shall be lodged at the customs office where the goods were presented. The customs declaration may be lodged together with the goods presented, or even before the declarant submits the goods. In this case, the customs authorities shall set a time limit for the submission of goods. If the goods are not presented within the prescribed period, the declaration shall be deemed not to have been filed either (Union Customs Code, Art. 171).

In special cases, it is possible to lodge a customs declaration by means other than electronic data processing techniques (Union Customs Code, Art. 158/2).

Such exceptions shall include the following:

1. Lodging an oral customs declaration:

- customs declarations for the release for free circulation may be made orally in the case of goods of a non-commercial nature, goods of a commercial nature in personal luggage of travellers, provided that these goods do not exceed the value of either EUR 1,000 or a net weight of 1,000 kg; produce acquired by agricultural actors from the EU on the lots in a third country, and fishery products, fish farming and sport hunting activities exempt from customs duties, etc. (Art. 135 of delegated Commission Regulation (EU) 2015/2446, amending Regulation of the European Parliament and of the Council (EU) no. 952/2013 as regards the detailed rules for certain provisions of the Customs Code);

- interim and re-export customs declarations may be lodged orally in the case of pallets, containers, seafarers' needs for use on board vessels engaged in international maritime transport, etc. (delegated Commission Regulation (EU) 2015/2446, Art. 136);

- customs declarations for the export procedure may be lodged orally in the case of goods of a non-commercial nature, means of transport registered in the customs territory of the EU and intended for re-importation, as well as spare parts, accessories and equipment for such means of transport, products obtained by agricultural producers operating on the land in the EU, which are exempt from customs duties, etc. (delegated Commission Regulation (EU) 2015/2446, Art. 137).

2. Lodging the customs declaration in paper form: 
- customs declaration in paper form may only be lodged by passengers, i.e. not economic actors in relation to the goods they carry when crossing the customs border (see: delegated Commission Regulation (EU) 2015/2446, Art. 143).

3. Lodging the customs declaration for the goods in postal consignments (delegated Commission Regulation (EU) 2015/2446, Art. 144)

- the postal services operator may lodge a customs declaration for release for free circulation containing a reduced data set in the case of goods in postal consignments which meet all of the following conditions:

a) its value does not exceed EUR 1,000,

b) no request for repayment or remission of customs duty is made in respect thereof,

c) it is not subject to any prohibitions or restrictions.

4. Lodging a customs declaration by another (implied) operation ${ }^{4}$ :

- in the case of goods moved to the customs office or any other place designated or approved by the customs authorities:

a) the goods are transported through the green lane labeled "nothing to declare" (this method may only be used at customs offices where the two-stream system - green - red' operates),

b) the goods are transported through the customs territory without a spontaneous lodging a customs declaration (this procedure is used at customs offices where the two-stream system does not work),

c) the goods are transported through the customs clearance space in a passenger motor vehicle which has a "nothing to declare" label affixed to the window (this is the way in which the EU customs legislation entails the possibility of such adaptation by the Member States);

d) crossing the customs frontier in cases where the customs legislation does not require the goods to be transported to the customs office or to another place designated or approved by the customs office.

5. The goods which cannot be placed under the customs procedure orally or in accordance with Art. 141 of the delegated regulation (see: the delegated Commission Regulation (EU) 2015/2446, Art. 142):

- these are the goods in respect of which customs formalities have been completed with a view to obtaining refunds or financial advantages from export on the basis of the common agricultural policy, the goods in which an application for repayment of customs duties or other charges, the 
goods subject to a prohibition or restriction, the goods subject to any other specific formalities laid down in the EU legislation which shall be applied by the customs authorities.

In addition to the aforementioned, substantially standard customs declarations, we may also meet in the customs procedure with declarations which, under simplified procedures $^{5}$ do not contain all the prescribed requirements. Adoption of such a customs declaration

\section{Conclusions}

At present, the EU's total foreign trade amount to about Euro 9.5 billion per day and is expected to increase by $25-40 \%$ by the year 2020 . Obstacles to traffic and trade flow through slow processing of imports or exports can affect the economies of the Member States and the EU. Effective and efficient customs help to speed up trade and promote economic growth, as well as the fight against tax fraud and tax evasion and protect the internal market and public finances.

Modernizing of the cross-border infrastructure and equipment means an opportunity to make a significant contribution to a faster and more efficient flow of goods among countries. The production process is currently trying to reduce inventory and puts the emphasis on fast-moving goods. It is important that logistics services and customs procedures take place quickly, on a top-quality level, and minimize the costs of maintaining the quality. Effective customs administration is crucial for companies that compete in international markets. The new EU legislation on the modernization of the functioning of the Customs Union is at the final stage of adoption, but its implementation and the full use of its potential will depend on the ability of national customs administrations to effectively implement the implementing rules. A decisive factor in this area is the existence of highly efficient and effective national customs clearance systems.

A well-functioning customs administration plays a key role in the security of the population, the protection and security of legal trade, the fight (Bonk, Straková, 2016: 451-463, Popovič, 2016: 72-78) against the unauthorized entry of counterfeit goods into the single market. strengthens the security and safety of European consumers and the protection of the EU's external borders. 


\section{References}

Babčák, V. et al.: Finančné právo na Slovensku (Financial law in Slovakia), Bratislava: Epos, 2017.

Bakeš, M.: Finančně-právni instituty (Financial law institutes), Praha: Vyšehrad, 1990.

Bakeš, M.: Teoretické otázky finančního práva (Theoretical issues of financial law), Praha: UK, 1979.

Bakeš, M. a kol.: Finanční právo (Financial law), Praha: C.H. Beck, 1995.

Balko, L., Grúň, L.: Colné právo - I. diel (komentár) (Customs duty law - I. part - commentary), Bratislava: Epos 2001.

Bonk, F., Straková, I.: Selected Aspects of Local Enquiry in the Slovak Republic, in: Etel, L., Popławski, M. (eds.): Tax Codes Concepts in the Countries of Central and Eastern Europe, Bialystok: Temida 2, 2016.

Červená, K., Romanová, A.: eGovernment ako prostriedok racionalizácie verejnej správy (e-Government as a tool of public administration rationalization), Bratislava: Akadémia Policajného zboru v Bratislave, 2016.

Drwiłło, A.: Zarys prawa dewizowego i celnego (The basics of exchange and customs duty law), Gdańsk: WSM 1991.

Fuksa, J. et al.: Slovník obchodně-technický, účetní a daňový (Dictionary of trade and technique, accountancy and taxes), Praha: Otakar Janáček, 1930.

Girášek, J.: Daňovoprávne vzt’ahy v Československu (Tax law relations in Czechoslovakia), Bratislava: Obzor, 1981.

Heck, H.J.: The international business environment: a management guide, New York: American Management Association, 1969.

Huchla, A. Encyklopedia prawa (The encyclopedy of law), Warszawa: C.H. Beck, 1999.

Kindleberger, Ch.P.: Světová ekonomika (The world economy), Praha: Academia, 1978.

Kubicová, J.: Zdanenie medzinárodného obchodu a transakcií prostredníctvom ciel (Taxation of international trade and transactions through customs), Dane a právo v praxi (Taxes and law in the practice) no. 11 (1998).

Kosikowski, C., Ruśkowski, E.: Finanse i prawo finansowe (Finance and financial law), Bialystok: KiK, 1994.

Lasinski-Sulecki, K., Prawo celne międzynarodowe wspólnotowe polskie (International polish custom duty law), Warszawa: Wolters Kluwer, 2009.

Madar, Z. et al.: Slovník českého práva (The dictionary of czech law), Praha: Linde, 1995.

Ovečková, O. et al.: Slovník obchodného práva (The dictionary of commercial law), Bratislava: Iura Edition, 1994. 
Popovič, A.: Vybrané aspekty vzt’ahu vnútroštátneho daňového zákonodarstva SR a práva EÚ (Selected aspects of relation of national tax law and the EU law), in: Zborník príspevkov z 3. ročníka Jarnej školy doktorandov UPJŠ (Proceedings of the 3rd year of Spring School of Doctoral Students UPJŠ), Košice: Pavol Jozef Šafárik University in Košice, 2016.

Slovinský, A., Girášek, J.: Československé finančné právo (Czechoslovak financial law), Bratislava: Obzor, 1985.

Samuelson, P.A., Nordhaus, W.D.: Ekonómia 2 (Economy 2), Bratislava, 1992.

Spáčil, B.: Teorie finančního práva ČSSR (Theory of financial law in CSSR), Praha: Orbis, 1970.

Šramková, D. et al.: Celní správa v organizačním a funkčním pojetí: vybrané kapitoly (Customs duty administration in organizational and functional understanding: selected chapters), Brno: Masarykova univerzita, 2011.

Šramková, D.: Celní právo v prostredí globalizace (Customs law in the globalization process), Brno: Masarykova univerzita, 2011.

Štěpán, K.: Celní politika v mezinárodním obchodu (Customs duty politics in international trade), Praha: SNTL, 1963.

Šwiderková, A.: Tvář helenistického světa (The helenistic world's face), Praha: Panorama, 1983.

EU: Treaty on functioning of the European Union no. 2012/C 326/01.

EU: Council Directive no. 952/2013, Customs Code.

EU: Council Regulation (EEC) no. 2913/92 establishing the Community Customs Code.

EU: Regulation (EU) no. 1286/2013 laying down the action programme on improving the functioning of the tax systems in the EU for the period between 2014 and 2020 (Fiscalis 2020).

EU: Regulation (EU) no. 250/2014 establishing a programme to support activities in the field of the protection of the EU's financial interests (Hercule III programme)

EU: Regulation (EU) no. 1294/2013 establishing the EU Customs Action Programme for the period between 2014 and 2020 .

SK: Act no. 199/2004 on Customs and on amendment to certain law acts. 
SECTION 3.2

PROTECTION OF PUBLIC INTEREST IN INCOME AND SALES TAXES 



\title{
THE PRINCIPLE OF PROPORTIONALITY IN VALUE ADDED TAX
}

\author{
ARTUR MUDRECKI
}

\begin{abstract}
The principle of proportionality in tax law has a normative character. At the same time, the principle under analysis is of a stipulate nature and should exert significant influence on legislative processes in the construction of a tax system. Standards developed in legal scholarship regarding the principle of proportionality, particularly a test designed to fulfill standards, can be used in the science of tax law. The principle of proportionality is a significant tool employed in the interpretation of tax law applied by the Court of Justice of the European Union and the Polish Constitutional Tribunal. Undoubtedly the case law of the Court of Justice of the European Union and the Polish Constitutional Tribunal impacts the case law of the Polish Supreme Administrative Court in the interpretation of provisions of tax law within the scope of application of the principle of proportionality.
\end{abstract}

\section{Keywords}

Proportionality; value-added tax; Poland

JEL Classification: K19, K34, K49

\section{Introduction}

The objective of the article is to attempt at answering the question of what role is played by the principle of proportionality in value-added tax. This primary objective

1 Doctor, is a professor in the Department of Financial and Tax Law, Kozminski University and a judge of the Supreme Administrative Court in Poland, Head of the Tax Law Department in the Judicial Decisions Bureau of the Supreme Administrative Court. He is also a member of the Fiscal Association Polish Branch and the International Association Centre for Information and Organization of Research on Public Finances and Tax Law of the Countries of Central and Eastern Europe - Association at the Bialystok University, European Association of Tax Law Professors, Faculty of Law and the Financial Law Association AURES in Opole. He specializes in tax law and is an author of over 100 publications, mainly on tax law. Particularly noteworthy is his monograph "Due process in tax proceedings". Contact email: amudrecki@kozminski.edu.pl. 
will be achieved by achieving detailed objectives, understood as finding answers to the following questions:

1. Does the Polish legislator, in the selection of tax law solutions, take the principle of proportionality into account?

2. Does the Court of Justice of the European Union, in issues of value added tax law, employ the analyzed European standard, and are Polish solutions compliant with this European standard?

3. Does the Polish Constitutional Tribunal, in interpreting provisions of tax law, frequently invoke the principle of proportionality?

4. Does the case law of the Polish Supreme Administrative Court, in its interpretation of tax law provisions, employ the principle of proportionality, and do judgments of the Court of Justice of the European Union and Polish Constitutional Tribunal exert the significant impact on the case law of administrative courts in Poland?

The principle of proportionality in tax law is one of the most important principles of law in respect of the rights of the taxpayer, and one of the fundamental general principles of EU law. It should also be pointed out that the indicated standard is strongly anchored in the Constitution of Poland and the case law of the Constitutional Tribunal. It impacts the interpretation applied by the Supreme Administrative Court, which employs a pro-EU and pro-constitutional approach.

The issue of the principle of proportionality has been the object of scientific study in other areas of law, e.g. in the theory of state and law, constitutional law, criminal law, civil law, European law, administrative law, and banking law (Korycka-Zirk, 2012; Szymaniec, 2015; Jasiewicz et al.: 2014). On the other hand, the principle of proportionality in tax law is a subject which has not been explored or elaborated in the scholarly literature. the previous sporadic manifestations in the Polish scholarly literature of legal dogmatic interest in the principle of proportionality in tax law were most generally provoked by controversial rulings of administrative courts, the Constitutional Tribunal, and the Court of Justice of the European Union (LasińskiSulecki, 2016: 46; Lasiński-Sulecki, 2012: 41; Brzeziński, 2014: 10; Brzeziński et al.: 2014: 325; Mączyński, 2017: 88; Etel, Pietrasz, 2011: 32).

In addition, some scholarly works have addressed the case law of the Polish Constitutional Tribunal (Selera 2017: 48; Pomorska et al.: 2011: 139). Some works have been devoted to the analysis of the case law Court of Justice of the European Union (Mikuła, 2014: 31; Mikuła, 2014; Selera, 2013: 77; Litwińczuk, 2011: 557). There have also been individual articles regarding particular tax law institutions concerning their consistency with the principle of proportionality (Kucia-Guściora et al.: 2015: 53). 


\section{Notion of Principle of Proportionality}

\subsection{Notion and Types of Principles of Law}

Before defining the notion of the principle of proportionality, we should indicate the types of principles of law. The term "principles of law" refers to delineating and explaining the sense or character of standards which can be used in the formation of various aspects of particular legal institutions within a system of law, or even entire groups of legal institutions within a system of law (stipulative character). The term "principles of law" is also used to denote norms which, because of their content, are of particular significance in the legal system in force (normative character) (Gomułowicz, Mączyński, 2016: 11).

Principles can have a normative form, or may merely find their expression in scholarship or case law. Normative principles are expressed expressis verbis in tax law provisions. Scholarly principles are an expression of the views of scholars on the shape and functioning of institutions of tax law, particular taxes, and even the tax system in its entirety. In turn, case law principles reflect the position of the judiciary in particular and more or less specific issues, particularly associated with the interpretation of the law (Brzeziński, 2015: 6).

The principle of proportionality appears as a normative and scholarly principle. These principles may impact the case law of the Court of Justice of the European Union, the Polish Constitutional Tribunal, and the Supreme Administrative Court in the interpretation of the provisions of tax law.

\subsection{Principle of Proportionality in Normative Sense}

In the normative sense, the legal basis of the principle of proportionality jest Art. 3b (3 and 4), incorporated into the Treaty on European Union and Treaty Establishing the European Community by the Lisbon Treaty, replacing Arts. 5/4-5) of the Treaty on European Union. Under the adopted solutions and under the principle of subsidiarity, in areas which do not fall within its exclusive competence, the Union shall act only if and in so far as the objectives of the proposed action cannot be sufficiently achieved by the Member States, either at central level or at regional and local level, but can rather, by reason of the scale or effects of the proposed action, be better achieved at Union level. The institutions of the Union shall apply the principle of subsidiarity as laid down in the Protocol on the application of the principles of subsidiarity and proportionality. National Parliaments ensure compliance with the principle of subsidiarity in accordance with the procedure set out in that Protocol (Art. 3b/3). Under the principle of proportionality, the content and form of Union action shall not exceed what is necessary to achieve the objectives of the Treaties. 
The institutions of the Union shall apply the principle of proportionality as laid down in the Protocol on the application of the principles of subsidiarity and proportionality (Art. 3b/4).

Concerning the application of the principles of subsidiarity and proportionality, the Protocol holds that Each institution shall ensure constant respect for the principles of subsidiarity and proportionality, as laid down in Art. 5 of the Treaty on European Union (Art. 1 of the Protocol). The Commission shall forward its draft legislative acts and its amended drafts to national Parliaments at the same time as to the Union legislator. The European Parliament shall forward its draft legislative acts and its amended drafts to national Parliaments (Art. 4 of the Protocol). The Court of Justice of the European Union shall have jurisdiction in actions on grounds of infringement of the principle of subsidiarity by a legislative act, brought in accordance with the rules laid down in Art. 263 of the Treaty on the Functioning of the European Union by the Member States, or notified by them in accordance with their legal order on behalf of their national Parliament or a chamber thereof. In accordance with the rules laid down in the said Article, the Committee of the Regions may also bring such actions against legislative acts for the adoption of which the Treaty on the Functioning of the European Union provides that it be consulted (Art. 8 of the Protocol). The Commission shall submit each year to the European Council, the European Parliament, the Council and national Parliaments a report on the application of Art. 5 of the Treaty on European Union. This annual report shall also be forwarded to the Economic and Social Committee and the Committee of the Regions (Art. 9 of the Protocol).

Under the principle of proportionality, the scope and form of action by the European Union may not exceed that which is necessary for accomplishing the objectives of the Treaty. This principle is a criterion for the activities of EU institutions and is also the basis for assessing actions taken by Member States (Militz et al.: 2013: 145146).

The principle of proportionality was set out in Art. 31/3 of the Constitution of the Republic of Poland of 2 April 1997. This provision establishes that any limitation upon the exercise of constitutional freedoms and rights may be imposed only by statute, and only when necessary in a democratic state for the protection of its security or public order, or to protect the natural environment, health or public morals, or the freedoms and rights of other persons. Such limitations shall not violate the essence of freedoms and rights.

The principle of proportionality is assigned a different meaning in respect of Value Added Tax (VAT). Under Art. 1/2 of the Directive 112 (Council Directive 2006/112/ $\mathrm{EC}$ on the common system of value added tax), the principle of the common 
system of VAT encompasses the application of a general consumption tax exactly proportional to the price of goods and services, irrespective of the number of transactions which occur in the production and distribution process prior to the stage at which the tax is collected. And thus, the principle of proportionality influences the determination of the appropriate tax base (Militz et al.: 2013: 96). The principle of proportionality resulting from Art. 1/2 of the 112 Directive exceeds the scope of this article. This does not, however, mean that the principle of proportionality in a broader sense does not apply in the interpretation of provisions concerning value added tax.

\subsection{Principle of Proportionality in Scholarship}

In the theory of law, R. Alexy points out that there is a direct link between the theory of principles and the principle of proportionality. According to German legal doctrine, the principle of proportionality is described as the relation of the (applied) means to the (intended) objective. This relation, however, should comply with three sub-rules. These criteria, which can be considered a type of test, include the criteria of:

1. usefulness,

2. necessity,

3. proportionality sensu stricto.

The criterion of usefulness is fulfilled when a given measure is useful in achieving a given objective, id est by using that measure it is possible to achieve a stated goal. However, this goal must be legitimized, id est it must be consistent with legally protected values.

The criterion of necessity is fulfilled when a given measure is necessary for achieving a given objective (id est there is no measure which could achieve the stated goal with the same effectiveness, and which would simultaneously be more benign in its effects on legally protected values, principles, objectives).

The criterion of proportionality sensu stricto, in turn, is satisfied when the number of benefits of a given measure is greater than the number of drawbacks; when the balance of a good (value) protected and the good sacrificed is positive; when applied measures are justified by the "weight and nature" of the objective they are to serve, when the proper relationship exists between the benefits derived from achieving the assumed goal and the injury done to a constitutional right resulting from the fact of that objective being achieved (Alexy, 2002: 66; Korycka-Zirk, 2012: 130; Mikuła, 2014: 38). 
In another definition, the principle of proportionality is associated with restraint in the activities of public authorities and minimizing their interference in rights and freedoms. The principle of proportionality is referred to as the principle of commensurability, of restraint, and of adequacy (Etel, Pietrasz, 2012: 27). An adequate comparison of the application of the principle of proportionality is to say that one should not shoot from a cannon in order to hit a sparrow.

\section{Assessment of Application of Principle of Proportionality in Legislative process}

The addressees of the principle of proportionality are the legislative authority, the executive authority, the judiciary. The principle of proportionality as a stipulatory principle of law should be taken into consideration when constructing a tax law system. The analyzed principle takes on a particular significance when considering the fact that it is of a normative character and constitutes both an EU and constitutional standard.

Certain doubts regarding observance of the principle of proportionality are raised by some legislative solutions in effect. The Act of 10 February 2017 on amending the Act - the Criminal Code and other acts introduced a new qualified offence associated with the falsification of invoices and using them for tax-related purposes. Article 270a Criminal Code sets out a punishment of 6 months to 8 years of imprisonment. If the value of the invoices exceeds PLN 5,000,000 or the crime served the perpetrator as a regular source of income, the crime is classified as a qualified offense, and criminal liability then increases to imprisonment from 3 to 8 years. Similar sanctions are set out in Art. 271 Criminal Code for issuing and using invoices in value-added tax. Even harsher penalties are set out in Art. 277a/1 Criminal Code. Under this provision, for commission of the offense set out in Art. 270a/1 or Art. 271a/1 in respect of an invoice or invoices the sum of whose receivables exceeds a figure ten times that which defines property of great value, the potential term of imprisonment is between 5 and 25 years. And thus, if the value of the invoices exceeds PLN 10,000,000, criminal liability can be as great as 25 years of imprisonment: the perpetrator can be given one of the harshest sentences short of lifetime imprisonment. The cost of carrying out such a sentence is PLN 950,000. The question thus arises: will the general preventative objective of these provisions be fulfilled? We may take an example from the history of law reaching back to the Middle Ages, when execution was the punishment for pickpocketing, applied as a way of eliminating the plague of theft. However, during public executions, other thieves pickpocketed the assembled onlookers. This demonstrated that even a very harsh punishment is insufficient to scare people off of committing crimes, as their 
perpetrators do not imagine they can be caught. Similar conclusions can be drawn in respect of adopted legal solutions. Even very harsh penalties are unable to prevent the commission of crimes associated with forging and using the VAT invoices. The procedure for issuing so-called "empty invoices" involves people who are homeless, mentally unstable, or terminally ill as fronts. And thus, those harsh punishments will not be meted out to those who receive the greatest benefits from VAT fraud as its organizers. The most effective means of prevention in respect of such crimes is their effective discovery and inevitability of punishment.

It would also seem that the legal solutions which have been introduced are inconsistent with the principle of proportionality, as they do not meet the three criteria set out in the test. Firstly, in light of the arguments presented above, it is not known whether the applied measure can prevent VAT fraud. Secondly, the application of such harsh punishments is unnecessary in light of the introduction of the mechanisms of the Unitary Control File, reverse charges, split payment of VAT, and the sanctions envisioned in provisions related to the tax, such as for submitting false tax filings, for failure to register turnover in cash registers, and responsibility for "empty invoices" (Art. 108 VAT Act). The indicated measures would seem sufficient to limit abuses associated with VAT fraud. Ultimately, the introduction of long-term imprisonment, in principle equivalent to those for crimes against human health and life, is in contradiction with the principle of proportionality sensu stricto. Even the justified protection of the interests of the State Treasury cannot justify long-term prison sentences. In addition, the financial and social costs of carrying out such a punishment can be exceedingly high. In such a situation, the punishment is inadequate to the crime committed.

\section{Impact of Principle of Proportionality on Case Law of Court of Justice of European Union}

Principles of law can come in jurisprudential form. It cannot be said that the principle of proportionality fulfills the conditions for it to be recognized as jurisprudential doctrine. Nevertheless, it plays an important role in the interpretation of tax law provisions. In the process of interpreting tax law, three directives of interpretation are generally employed: linguistic interpretation, systemic interpretation, and functional interpretation. Additionally, pro-EU interpretation (interpretation favorable to European law) and pro-constitutional interpretation (interpretation consistent with the provisions of the Constitution) are applied. The principle of proportionality as applied in the decisions of international courts, constitutional tribunals, and municipal courts can be considered pro-EU and/or pro-constitutional. 
This is a sort of second-level interpretation supplementary to the primary interpretative principles.

The Court of Justice of the European Union (CJEU) plays an important role in respect of protection of the rights of the taxpayer. On the one hand, it refers in its case law to the standards for human rights protection developed by the European Court of Human Rights within the framework of amicable cooperation, while on the other it does so through the application of pro-EU interpretation, binding on national courts and effectively protecting the rights of the taxpayer. Here it should be emphasized that the CJEU deals with the tax matter, particularly ones concerning taxes subject to harmonization, such as VAT and excise tax (Mudrecki, 2015: 79).

The Court of Justice of the European Union relatively frequently employs the principle of proportionality in the interpretation of European law. In its verdict (CJEU: C-25/07) in the A. Sosnowska case, the CJEU held that Art. 18/4 of the Six Directive 77/388 is inconsistent with domestic regulation which - intending to facilitate the oversight necessary to prevent tax avoidance and fraud - extends from 60 to 180 days (from the day of filing by taxpayers of specified categories of a VAT submission) the period within which a national tax authority may refund surplus VAT payments in the absence of a substantial bond.

The pro-EU interpretation undertaken with regard to infringement of the principle of proportionality, as an EU standard, led to the conclusion that Polish solutions concerning the extension of the right to a VAT refund are overly restrictive, and thus in conflict with EU law. Thus, they demand changes in order to achieve full harmonization of the provisions of tax law. Characteristically, the Court of Justice of the European Union, alongside the principle of proportionality, invokes with the relative frequency the principle of neutrality as a foundation of the value-added tax.

The Court of Justice of the European Union in another verdict (CJEU: 564/15) in the case Tibor Farkas v. Nemzeti Adó-és Vámhivatal Dél-alföldi Regionális Adó Föigazgatósága held as appropriate the loss of the right to claim a deduction in the case of acquisition of goods subject to reverse charge, and pointed to disproportionality in VAT sanctions. In the case under consideration, the purchaser of the goods was deprived of the right to deduct the VAT they had wrongly paid the seller on the basis of an invoice drawn up in accordance with the ordinary VAT regime, where the relevant transaction was subject to the reverse charge mechanism and the seller had remitted the tax to the Treasury. In this ruling, it was pointed out that the provisions of Directive 2006/112, amended via Directive 2010/45, and the principles of fiscal neutrality, effectiveness and proportionality must be interpreted to the effect that, in a situation such as that in the main proceedings, they do not preclude the purchaser of an item of property from being deprived of the right to 
deduct the VAT which he paid to the seller when that tax was not due, on the basis of an invoice drawn up in accordance with the rules of the ordinary VAT regime, where the relevant transaction came under the reverse charge mechanism, and the seller paid that tax to the Treasury. However, if reimbursement of the VAT becomes impossible or excessively difficult, in particular in the case of the insolvency of the seller, the principle of effectiveness may require that the purchaser of the property concerned be able to address his application for reimbursement to the tax authority directly. The principle of proportionality must be interpreted to the effect that it precludes national tax authorities, in a situation such as that in the main proceedings, from imposing on a taxable person, who purchased an item of property the transfer of which comes under the reverse charge regime, a tax penalty of $50 \%$ of the amount of VAT which he is required to pay to the tax authority, where that authority suffered no loss of tax revenue and there is no evidence of tax evasion, this being a matter for the referring court to determine.

Doubtlessly, the principle of proportionality has the significant influence on imposing tax sanctions when the Hungarian Treasury suffered no injury, as the value-added tax due had been paid. Interestingly, the Court of Justice of the European Union denied the right to deduct the assessed tax on the purchaser of goods when the reverse charge mechanism was not applied. However, the Court did indicate that a taxpayer experiencing difficulty in pursuing claims against an insolvent counterparty may apply to the tax authority for a refund.

\section{Principle of Proportionality in Case Law of the Polish Constitutional Tribunal}

The Polish Constitutional Tribunal has relatively frequently taken up the issue of the principle of proportionality. Doubtlessly, the principle of proportionality is one of the most important constitutional standards. Under Art. 8 of the Constitution of Poland, the Constitution is the supreme law of the Republic of Poland. The provisions of the Constitution shall apply directly unless the Constitution provides otherwise. Any limitation upon the exercise of constitutional freedoms and rights may be imposed only by statute, and only when necessary in a democratic state for the protection of its security or public order, or to protect the natural environment, health or public morals, or the freedoms and rights of other persons. Such limitations shall not violate the essence of freedoms and rights. Therefore, every change of legal regulations should consider the necessity of observing the principle of proportionality and impact the legislative process, yet should also influence the interpretation of law applied not only by the Polish Constitutional Tribunal but also 
administrative courts and tax authorities. In determining the constitutionality of legal acts, the Polish Constitutional Tribunal is bound by the constitutional model.

The charge of breaching the principle of proportionality is not always accepted. The Polish Constitutional Tribunal In its verdict of 8 October 2013 (no: SK 40/12), held that Art. 33/2/2 in conjunction with Art. 33/1 of the Tax Ordinance Act of 29 August 1997 as it stood during the period from 1 January 2003 to 31 August 2005, insofar as it made the impounding of tax arrears in the course of audit proceedings dependent on the "justified concern" that a tax obligation would not be performed, was compliant with Art. 45/1 and Art. 64/3 in conjunction with Art. 2 and Art. 31/3 of the Polish Constitution.

However, in many cases, the Tribunal has ascertained a breach of the principle of proportionality. In its verdict of 21 July 2010 (no. SK 21/08) the Polish Constitutional Tribunal held that Art. 72/1/1 in conjunction with Art. 77/1 an Art. 77/2/1 of Tax Ordinance Act of 27 August 1997, in respect of its wording in effect until 4 June 2001, within the scope in which that provision, by determining as an overpayment the sum of overpaid or unduly paid tax with the omission of the sum of unduly paid interest for late payment, deprives the taxpayer of interest on the sum paid in lieu of interest for late payment on unpaid tax arrears paid on the basis of an unlawful tax decision, is incompatible with Art. 77/1 and Art. 64/1 in conjunction with Art. 31/3 of the Polish Constitution.

In the justification to the ruling, the Tribunal recalled that the essence of the regulation contained in Art. 31/3 of the Constitution is an establishment of the preconditions that must be fulfilled in order to impose restrictions on constitutional rights and freedoms. The referenced oversight model establishes as a general principle exclusively statutory grounds for limitation or suspension of rights and freedoms, while simultaneously formulating the restriction that such a limitation can only take place when it is necessary in a democratic state, to ensure the security of the state and/or public order, to protect the environment, public health and morality, or the rights and freedoms of others. These regulations also include in the second sentence a restriction that such limitations cannot violate the essence of rights and freedoms. The Polish Constitutional Tribunal has pointed out on multiple occasions that any and all limitations on the exercise of constitutional rights and freedoms must take account of Art. 31/3 of the Constitution (see judgments P.11/98, P.23/00, P.30/07). The scope of regulation in Art. 31/3 is of a universal character, as it applies to all constitutional rights and freedoms.

The association between statutory limitation on constitutional freedoms and rights of the individual and protection of one of the values enumerated in Art. 31/3 of the Polish Constitution is the necessary condition of ascertaining the permissibility of 
its enactment. The scope of this limitation - pursuant to the first sentence of Art. $31 / 3$ of the Polish Constitution - must satisfy the principle of proportionality, which expresses the conviction that the extent of interference in the legal situation of an individual must be justified by the rank of the public interest protected thereby. In other words, a limitation on the rights of the individual must be appropriate to the object it is intended to serve, and rational. To determine whether in a given case the interference is not excessive, it is necessary to find answers to three questions: Can the adopted legislation actually achieve the intended effects? Is the regulation vital to the protection of the given constitutional value? Are the effects of the adopted regulation proportional to the burdens it imposes on the citizen? (proportionality sensu stricto) (see verdict K.19/01).

In another verdict (SK.14/12), the Polish Constitutional Tribunal ruled that $\S 6 / 5$ in conjunction with $\S 5 / 1$ as worded effective 1 January 2003, and with $\S 12 / 1 / 1$ of the Regulation of the Minister of Finance of 22 March 2002 on Excise tax within the scope it affects cases of unaware acceptance by the seller of a declaration on the destination of purchased fuel oil for heating purposes that contains false information, is incompatible with Art. 64/1 and 3 in conjunction with Art. 2 and Art. 31/3 of the Constitution of Poland. In the text of the decision, it was indicated that the discretion enjoyed by the legislator does not, however, Authorize it to establish conditions impossible for the taxpayer to fulfill. In particular, this entails a violation of the principle of the individual's trust in the state and the law enacted by it, as well as of the principle of prohibition on disproportionate interference in the taxpayer's property rights, associated with the necessity of paying a higher tax bill as a result of the impossibility of taking advantage of preferential tax regulations. It should, however, be emphasized that this impossibility results from conditions which the taxpayer has no influence over.

In a successive verdict (SK.2/10), the Polish Constitutional Tribunal held that Art. 31/1 of the Tax Audit Act of 28 September 1991, as established by the Act of 27 June 2003 on the creation of Provincial Tax Councils and amendments to some other Acts regulating the tasks and competencies of organs and the organization of authorities overseen by the minister responsible for matters of public finance, within the scope in which it excludes the relevant application of Art. 54/1/1 and 7 of the Tax Ordinance Act of 27 August 1997 is incompatible with Art. 84 in conjunction with Art. 641 and 2), Art. 31/3, Art. 32/1 and Art. 2 of the Constitution of Poland.

In the text of the verdict, it was emphasized that in the case at hand - reconstructing the content of the audit standard - Art. 31/3 of the Polish Constitution can also be invoked, as the charge concerns not an interference in property rights consisting in the assessment of a tax, but interference in property rights via additional burdens exceeding the borders of the tax itself. However, with consideration to 
the invocation of Art. 2 of the Constitution, the Polish Constitutional Tribunal reminds us that the principle of proportionality has a broader meaning, as it refers in general to situations in which the state enacts legislation impacting the position of an individual under its authority. In these situations, the charge of the absence of proportionality is assessed without reference to the intersection with a subjective constitutional right (e.g. K.20/01; K.8/07; K.66/07). The Polish Constitutional Tribunal derived three interrelated obligations from the principle of proportionality imposed on the lawmaker: 1) enacting a given regulation only when it is essential to the protection of the public interest associated with it, 2) fashioning a given regulation in a manner that ensures the achievement of the intended objectives (effects), 3) maintaining proportion between the effects of the adopted regulation and the burdens and/or disadvantages for citizens resulting from it. This principle places particular emphasis on adequacy of the objective and the measure employed to achieve it. In other words, from among the potential measures for exerting influence, it is required to select those which would be at once effective in achieving the assumed objectives while imposing the least possible burden on the entities against which it is to be applied, or burdensome to a degree not greater than is necessary for achieving the intended objective.

The rule adopted in the questioned regulation concerning the assessment of interest for tax arrears including also the period during which the performance of the tax obligation was secured against the assets of the taxpayer, when the funds acquired from the security are booked against tax arrears, and for the period starting from the day on which audit proceedings were initiated until the day on which a decision of the organ of the first instance was issued and that decision was not served within 3 months of the day on which the audit proceedings were initiated, puts taxpayers under audit by tax authorities in a worse legal situation than taxpayers under audit by tax authorities against whom interest for those periods is not assessed.

The differentiation present in the questioned provision of the legal situation of taxpayers depending on which tax authority they are being audited by is unjustified, and must be held as an arbitrary choice of the lawmaker. By the same token, the questions regulation places taxpayers under audit by tax audit organs in a worse situation, by depriving them of the right to not have interest assessed for the period during which their assets were secured against tax arrears. There are no grounds to state that such a distinction was justified by the necessity to realize an important public interest. From the presented example verdicts of the Polish Constitutional Tribunal, we may conclude that the three criteria previously developed in the legal scholarship are to be applied in assessing whether the principle of proportionality has been violated. 


\section{Influence of Principle of Proportionality on Interpretation of Provisions of Tax Law in Case Law of Supreme Administrative Court}

The principle of proportionality influences the case law of administrative courts. A certain model for carrying out interpretation of tax law provisions can be found in the case law Court of Justice of the European Union and of the Polish Constitutional Tribunal. It should be emphasized here that it is incumbent upon national courts to apply pro-EU interpretation due to the primacy it enjoys. Pro-constitutional interpretation is also necessary with consideration to the fact that the Constitution is the supreme law of the Republic of Poland. It thereby holds an important place in the interpretation of legislative provisions.

The Supreme Administrative Court in its verdict (I FSK 1278/15), held that for refusal of registration to be considered proportional in respect of an object consisting in preventing tax fraud, it must be based on serious considerations permitting the objective ascertainment of a likelihood that registration of a VAT taxpayer will be abused for purposes of fraud. Such a decision must be based on a comprehensive assessment of all circumstances of a given case, and on evidence collected to verify information supplied by the enterprise.

In its justification, the Court invoked the view expressed in the judgement of the Court of Justice of the European Union (CJEU: C-527/11) in the Ablessio case, in which the latter Court indicated that the measures applied by a state may not exceed what is necessary to achieve the selected objectives, and furthermore they may not undermine the right to deduction, and by the same token neutrality of the tax.

In another verdict, the Supreme Administrative Court (I FSK 1916/15), held that Art. 88/3a/4/b of the VAT Act of 11 March 2004, pursuant to which issued invoices, corrective invoices, and customs documents containing false sums do not constitute grounds for claiming deductions - in respect of those items for which false sums were given - should be interpreted in such a manner that, if the evidence gathered gives the tax authority the possibility to determine the real value of the transaction captured in the inflated sum on the invoice, the taxpayer - with consideration to the principles of neutrality and proportionality - has the right to deduct the tax to the extent it expresses the real value of the transaction.

In another verdict, the Supreme Administrative Court (1536/13), held that in the case of a taxpayer who - having fulfilled all of the conditions set out in Art. 89a/2 of the VAT Act of 11 March 2004 as in effect through 31 December 2012 - submitted a correction to the tax due in an incorrect accounting period, a corrective filing submitted pursuant to the mode set out in Art. 81/1 of tax Tax Ordinance Act of 27 
August 1997 in order to remedy the defect and settle the corrected tax due under Art. 89a/1 VAT Act in the proper accounting period indicated in Art. 89a/3 VAT Act is not limited by the term set out in Art. 89a/2/5 VAT Act, as no fraud nor injury to the state budget.

In a subsequent verdict, the Supreme Administrative Court (I FSK 709/12) indicated that interpretation of Art. 116/6/2 of the VAT Act cannot lead to the violation of the following principles: neutrality of VAT, proportionality as defined under Art. 31/3 in conjunction with Art. 2 Constitution of Poland and Art. 5 Treaty on European Union, and protection of property rights as defined under Art. 21/1 in conjunction with Art. 64/1 Constitution of Poland. In other words, that provision should be interpreted so that the taxpayer remitting a late payment to a flat-rate farmer for acquired products or services and encompassing flat-rate tax refund is not deprived of the right to receive that refund.

\section{Conclusions}

The principle of proportionality in tax law has a normative character. At the same time, the analyzed principle is of a stipulative nature, which should exert significant influence on legislative processes shaping the tax system. The standards developed in legal scholarship concerning the principle of proportionality, and particularly the test serving the fulfillment of standards, can be used in the science of tax law.

The research results presented in this work allow us to formulate the following initial research hypotheses:

1. The principle of proportionality plays a significant role in value-added tax.

2. In the selection of tax solutions, the Polish lawmaker takes insufficient account of the principle of proportionality, which leads to those solutions being incompatible with EU and Constitutional regulations. The adopted solutions are inadequate to the intended effects, at times shooting from a cannon at a sparrow.

3. In tax cases, the Court of Justice of the European Union relatively frequently applies the principle of proportionality alongside other EU principles, in order to ensure the protection of taxpayers' rights. Particularly important rulings concerning the principle of proportionality have been handed down in Polish cases.

4. The Polish Constitutional Tribunal, in interpreting provisions of tax law, frequently invokes the principle of proportionality. The case law of the Polish Constitutional Tribunal influences legislative practice. 
5. The Supreme Administrative Court, in interpreting provisions of tax law, applies the principle of proportionality. The case law of Polish administrative courts is significantly influenced by verdicts of the Court of Justice of the European Union and the Polish Constitutional Tribunal.

\section{References}

Alexy, R.: A Theory of Constitution Rights, Oxford: Oxford University Press, 2002.

Brzeziński, B.: Glosa do wyroku NSA z dnia 17 maja 2013 r. II FSK 1812/11 (Gloss to ruling of SAC of 17 May 2013 II FSK 1812/11), Orzecznictwo Sądów Polskich (Jurisprudence of Polish Courts) no. 2014/1/10 (2014).

Brzeziński, B., Lasiński-Sulecki, K., Morawski, W.: Oświadczenia nabywców oleju opałowego i zestawienia tych oświadczeń a zasada proporcjonalności (Declaration of purchasers of fuel oil, juxtaposition of those declarations and the principle of proportionality), Przegląd Orzecznictwa Podatkowego (Review of Tax Case Law) no. 4 (2014).

Brzeziński, B.: Zasady ogólne prawa podatkowego (General principles of tax law), Toruński Rocznik Podatkowy (Toruń Annual Fiscal Journal) no. 4 (2015).

Etel, L., Pietrasz, P.: Uwagi w przedmiocie konstytucyjności art. 89 ust. 16 ustawy o podatku akcyzowym (Remarks on the constitutionality of Art. 89/16 of the Excise Tax Act), Przegląd Podatkowy (Tax Review) no. 10 (2011).

Etel, L., Pietrasz, P.: Niekompletność świadczeń o przeznaczeniu oleju opałowego a zastosowanie sankcji podatkowej, o której mowa w art. 89 ust. 16 u.p.a. (Incompleteness of declarations on the destination of fuel oil and application of a tax sanction as provided for in Art. 89/16 Excise Tax Act), Zeszyty Naukowe Sądów Administracyjnych (Scholarly Journal of Administrative Courts) no. 2 (2012).

Gomułowicz, A., Mączyński, D.: Podatki i prawo podatkowe (Taxes and tax law), Warszawa: Wolters Kluwer, 2016.

Gomułowicz, A.: Zasada proporcjonalności w orzecznictwie Trybunału Konstytucyjnego a obowiązek podatkowy (The principle of proportionality in the case law of the Constitutional Tribunal and the tax obligation), in: Pomorska, A., Smoleń, P., Stelmasiak, J., Gorgol, A. (eds.): Prawo finansowe w warunkach członkostwa Polski w Unii Europejskiej. Księga jubileuszowa dedykowana Profesor Wandzie Wojtowicz (Financial law in conditions of Poland's membership in the European Union. Anniversary book dedicated to Professor Wanda Wojtowicz), Lublin: Wydawnictwo UMCS, 2011.

Jasiewicz, S., Kulikowski, L., Szpringer, W. (eds.): Zasada proporcjonalności. Przełom w ocenie regulacji (The principle of proportionality. A breakthrough in assessment of regulation), Warszawa: GBPiZS, 2014.

Korycka-Zirk, M.: Teorie zasad prawa a zasada proporcjonalności (Theories of princniples of law and the principle of proportionality), Warszawa: LexisNexis, 2012.

Kucia-Guściora, B., Münnich, M., Zdunek, A. (eds.): Michna, E.: Zasada proporcjonalności w wykładni przepisów dotyczących sankcji podatkowych w świetle orzecznictwa TSUE, 
TK oraz sądów administracyjnych (The principle of proportionality in interpretation of provisions concerning tax law sanctions in light of case law of the CJEU, CT, and administrative courts), in: Stanowienie i stosowanie prawa podatkowego w Polsce. Sankcje i preferencje w prawie podatkowym, (Enacting and applying tax law in Poland. Sanctions and preferences in tax law), Lublin: Wydawnictwo KUL, 2015.

Lasiński-Sulecki, K.: Glosa do wyroku TS z dnia 2 czerwca 2016 r., C-418/14 (Gloss to ruling of CJEU of 2 June 2016, C-418/14), Przegląd Podatkowy (Tax Review) no. 9 (2016).

Lasiński-Sulecki, K.: Glosa do wyroku TS UE z 26 stycznia 2012 r. C-588/10 (Gloss to ruling of CJEU of 26 January 2012 C-588/10), Przegląd Podatkowy (Tax review) no. 3 (2012).

Mączyński, D.: Glosa do uchwały NSA z dnia 24 października 2016 r. I FPS 2/16 (Gloss to SAC resolution of 24 October 2016 I FPS 2/16), Orzecznictwo Sądów Powszechnych (Common Court Rulings) no. 1 (2017).

Mikuła, P.: Zasada proporcjonalności w orzecznictwie TSUE dotyczących podatku od wartości dodanej (The principle of proportionality in the case law of the CJEU as concerns value added tax), Kwartalnik Prawa Podatkowego (Quarterly of Tax Law) no. 2 (2014).

Mikuła P.: Zasada proporcjonalności w podatku od wartości dodanej - analiza orzecznictwa TSUE (The principle of proportionality in value added tax - analysis of CJEU case law), Toruński Rocznik Podatkowy (Toruń Annual Fiscal Journal) no. 2 (2014).

Militz, M., Dominik-Ogińska, D., Bącal, M., Siennicki, T.: Zasady prawa unijnego (Principles of EU law), Warszawa: Wolters Kluwer Polska, 2013.

Mudrecki, A.: Rzetelny proces podatkowy (Fair tax proceedings), Warszawa: Wolters Kluwer, 2015.

Selera, P.: Decyzje wykonawcze Rady odnoszące się do podatku od towarów i usług a traktatowa zasada proporcjonalności (Enforcement decisions of the Council referring to value added tax and the treaty principle of proportionality), Kwartalnik Prawa Podatkowego (Tax Law Quarterly) no. 2 (2013).

Selera, P.: Wpływ unijnej zasady proporcjonalności na polskie regulacje w zakresie podatku od towarów i usług (Impact of the EU principle of proportionality on Polish regulations concerning value added tax), in: Litwińczuk, H. (ed.): Prawo europejskie - 5 lat doświadczeń w polskim prawie finansowym (European law -5 years of experience in Polish financial law), Warszawa: Oficyna Prawa Polskiego, 2011.

Selera, P.: Zasada proporcjonalności w orzecznictwie podatkowym Trybunału Konstytucyjnego (The principle of proportionality in the tax case law of the Constitutional Tribunal), Państwo i Prawo (The state and the law) no. 4 (2017).

Szymaniec, P. (ed): Zasada proporcjonalności a ochrona praw podstawowych w państwach Europy (The principle of proportionality and protection of fundamental rights in the states of Europe), Wałbrzych: Państwowa Wyższa Szkoła Zawodowa w Wałbrzychu, 2015.

EU: Council Directive 2006/112/EC on the common system of value added tax.

EU: Court of Justice of the European Union: no. C- 527/11.

EU: Court of Justice of the European Union: no. C-25/07. 
EU: Court of Justice of the European Union in another verdict: no. CJEU: 564/15.

PL: Act of 10 February 2017 on amending the Act - the Criminal Code and other acts.

PL: Tax Ordinance Act of 27 August 1997, as amended.

PL: Regulation of the Minister of Finance of 22 March 2002 on Excise tax.

PL: Regulation of the Minister of Finance: no. 3/2002 on Excise tax.

PL: Tax Audit Act of 28 September 1991, as amended.

PL: Constitutional Tribunal: SK.40/12.

PL: Constitutional Tribunal: SK.21/08.

PL: Constitutional Tribunal: P.11/98.

PL: Constitutional Tribunal: K.23/00.

PL: Constitutional Tribunal: P.30/07.

PL: Constitutional Tribunal: K.19/01.

PL: Constitutional Tribunal: SK.14/12.

PL: Constitutional Tribunal: SK.2/10.

PL: Constitutional Tribunal: K.20/01.

PL: Constitutional Tribunal: K.8/07.

PL: Constitutional Tribunal: K.66/07.

PL: Supreme Administrative Court: I FSK 1278/15.

PL: Supreme Administrative Court: I FSK 1916/15.

PL: Supreme Administrative Court: 1536/13.

PL: Supreme Administrative Court: I FSK 709/12. 



\title{
ELECTRONIC REGISTRATION OF SALES IN THE CZECH REPUBLIC - THEORY AND PRAXIS ${ }^{1}$
}

\author{
ZUZANA MARETHOVÁ ${ }^{2}$ PETRA SNOPKOVÁ3
}

\begin{abstract}
This contribution analyses the system of electronic registration of sales that has recently been introduced in the Czech Republic. Apart from the analysis, the paper also discusses the types of subjects that need to register their sales, the registration methods, as well as the ways to control if the law is adhered to. Moreover, the paper also deals with the objectives of the new legislation and it offers a brief analysis of what the situation is like in other countries. The paper makes use of methods of analysis, synthesis, and comparison. Analytical methods are used here to analyze the effectiveness of the new legislation and of the electronic registration of sales in the Czech Republic. Then, comparative methods are applied to compare Czech legislation with that of other countries, especially with Croatian legislation. In addition, these methods are employed to compare the expected and the real consequences of the electronic registration of sales. The gathered data is then processed by means of synthesis to outline the future of the electronic registration of sales. The paper hypothesizes that the electronic registration of sales is an effective measure against tax evasion and it thus achieves the intended objectives of the legislation.
\end{abstract}

\section{Keywords}

Tax law; registration of sales; electronic registration

\section{JEL Classification: H25, K34, O31}

1 This article is the outcome of the research projects: MUNI/A/1359/2016 (Reformation of income taxes) and MUNI/A/1387/2016 (Stabilization in financial and tax law).

2 Ph.D. Student at the Faculty of Law, Masaryk University at the Department of Financial Law and Economic. The Author specializes in tax law. Contact email: 344107@mail.muni.cz.

3 Ph.D. Student at the Faculty of Law, Masaryk University at the Department of Financial Law and Economic. The Author specializes in tax law. Contact email: snopkova@mail.muni.cz. 


\section{Electronic Registration - Basic Facts}

\subsection{Description and Legislation}

The electronic registration of sales (hereafter referred to as "registration") was introduced into Czech law by means of Act no. 112/2016 on Registration of Sales, effective from 1 December 2016 (hereafter referred to as the "Act").

Registration is a means of control ensuring that tax obligations applicable to taxable entities are fulfilled. The reason for its introduction was, above all, the desire to prevent tax evasion based on unlawful sales reduction (accepted especially in cash). Unlawful sales reduction is typically committed when a mandatory entry in the registration book states a figure lower than the actual payment. A subsequent inspection, often made several months or even years later, hardly ever reveals such sales reduction. A legal obligation to register every payment online (via the internet) with the Financial Administration of the Czech Republic (hereafter referred to as the "Financial Administration") has thus been introduced with a view to preventing such illegal manipulation (Hajdušek, Vodička, 2017).

Registration can be described in greater detail as a system within which an entrepreneur who has just accepted a payment (typically in cash) sends an instantaneous data message with the transaction details through a device connected to the internet to the Financial Administration, which subsequently sends back a confirmation of receipt with a unique code (called FIC, Fiscal Identification Code). Then, the entrepreneur issues a receipt which, among other legal requirements, also includes the given FIC. The entrepreneur is required to provide the customer with this receipt. The customer may later enter the FIC at the web portal of the Financial Administration, thereby checking that the payment has indeed been registered. Sales registered under the name of a particular entrepreneur may be checked by him or her at the web portal as well. The whole process is aptly illustrated by the following graph from the official Registration website (www.etrzby.cz). 


\section{Graph 1 System functioning of Registration}

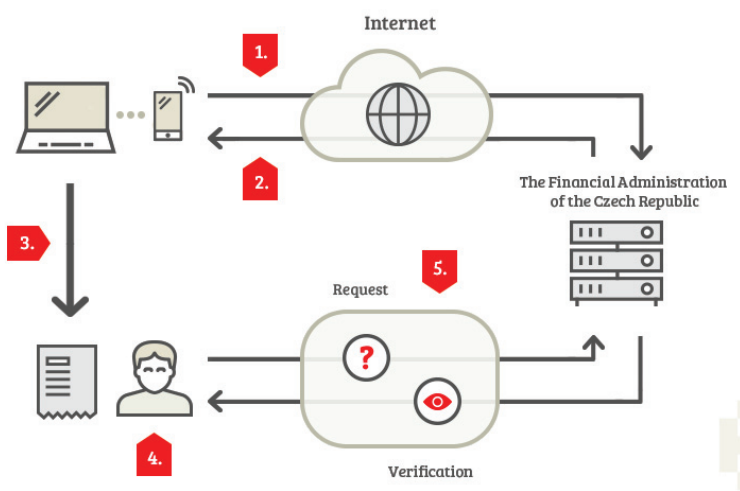

Source: www.etrzby.cz.

\subsection{Subjects of Registration}

The definition of subjects required to register sales is heavily based on Act no. 586/1992 on Income Taxes (hereafter referred to as the "Income Tax Act"). Registration is compulsory for all taxpayers of personal and corporate income tax. Taxpayers of personal income tax are natural persons: those who reside in the Czech Republic (with a permanent address or with a permanent residence permit) as well as tax non-residents. Likewise, taxpayers of corporate income tax are legal subjects (and other subjects as defined by law, e.g. trust funds), regardless of their residence or the residence of their management.

It is noteworthy that the Act did not impose the obligation to register sales on all the subjects at the same time; on the contrary, there are four stages. The first stage (starting on 1 December 2016) made Registration compulsory for entrepreneurs dealing with accommodation and food service activities. The second stage (starting on 1 March 2017) included wholesale and retail trade. The third stage (planned to become effective from 1 March 2018) should involve all subjects excluding those that fall into the fourth stage (starting on 1 June 2018), which should include selected crafts and manufacturing activities (e.g. textile production, furniture production, specialized building activities).

The range of taxpayers obliged to register sales is rather wide. It is estimated that Registration will involve approximately 600,000 entrepreneurial and other subjects and in one way or another, approximately 2 million people will come into contact with it. It is also estimated that around 30 million transactions will be 
registered daily, which means that annually there will be around 11 billion bilateral transactions between the state and taxable subjects. Some even claim the total figure per year might reach 18 billion (Hajdušek, Vodička, 2017). These estimates cannot be tested now since the system of Registration with its four stages does not involve all taxable subjects. In August 2017 the Ministry of Finance registered almost 1.7 billion sales with the total sum of almost 600 billion. By then almost 151000 entities had entered the system and the system at its height processed 1.5 million sales per hour (Žurovec, 2017a).

\subsection{Subject Matter of Registration}

The subject matter of Registration are sales with two important elements:

1. The sale was made in accordance with the conditions stipulated by law (material element),

2. The sale was made using the designated method (formal element) (Explanatory note, Parliamentary press no. 513).

The formal element is accomplished if the payment is made in cash, by a cashless transfer of funds (credit card), by cheque, by the promissory note, or in other forms (virtual currency, food vouchers, and gift vouchers). Transactions made from one bank account to another are thus exempt from Registration.

As far as the material element is concerned, the Income Tax Act was used again. Registration is therefore compulsory for the type of entrepreneurial income that is subject to the income tax. It is not therefore necessary to register income gained by being employed or rental income. Similarly, it is not necessary to register payments that are, given the nature of usually accepted payments, exceptional.

It is also worth pointing out that Sec. 12 of the Act lists payments that are exempt from Registration (e.g. sales achieved by the state, territorial self-governing authorities, banks, insurance companies, from a fare in the public transport, on board an aircraft, or from the operation of public toilets).

If subjects are not sure whether the payment that is being accepted qualifies as a registered sale, they may ask the tax authority for a binding ruling, in which the tax authority states whether the given sale is a registered one or not (Sec. 36 of the Act).

\subsection{Registration Methods}

The most common method is the 'standard regime' described in detail above. Under this regime, a taxable subject sends payment details electronically to the Financial 
Administration, which then sends back an FIC. This code is then printed on the receipt offered to the customer. However, there are also exceptional circumstances that allow a receipt to be printed even without the FIC. Firstly, this is possible under the so-called "simplified regime". Secondly, one may print a receipt without the FIC in case it is not possible (mostly due to technical issues) to connect to the Financial Administration portal; hence the FIC cannot be obtained.

\subsection{Simplified Regime}

The "simplified regime" method of Registration was introduced mainly because of those subjects without continuous access to the internet. Under this regime, only sales stipulated by the Act or in governmental orders can be registered as well as those sales that have been approved (at the request of the entrepreneur) by the tax authority. The Act stipulates that simplified regime can be applied to both sales of goods and services on board of a vehicle during regular public transport and sales whose registration under the standard regime would prevent or significantly complicate the smooth and efficient conduct of the business from which these sales originate.

The simplified regime allows entrepreneurs not to send details of every single sale immediately at the time of the transaction to the Financial Administration portal. The accepted payments are stored in the memory of the device and must be sent to the Financial Administration portal in bulk within five days. The simplified regime is illustrated below.

\section{Graph 2 System functioning of Registration in case of simplified Regime}

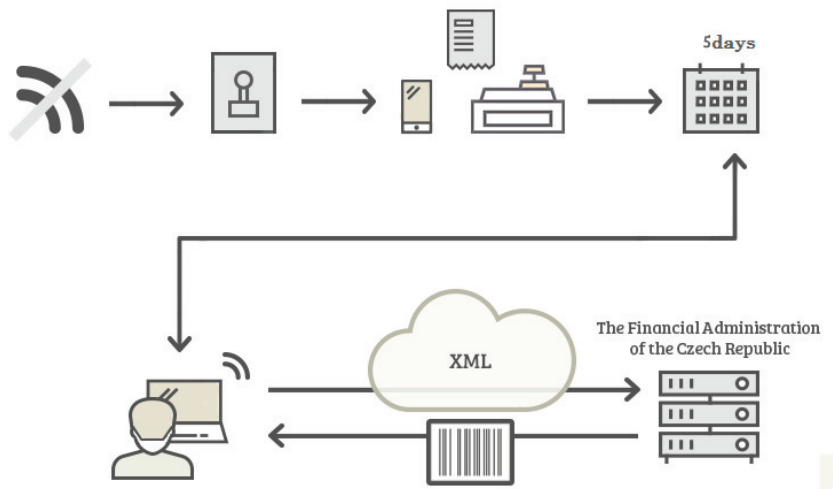

Source: www.etrzby.cz. 


\subsection{Problems with Online Registration}

Problems with online Registration are caused particularly by technological issues (e.g. a short-term internet failure). These prevent immediate connection to the Financial Administration portal; therefore the FIC cannot be obtained. In order to avoid prolongation of a business transaction (which is clearly highly unpleasant and uneconomical for both the customer and the seller), the Act also permits to finish transactions without obtaining the FIC. The FIC is not necessary if the socalled "response time limit" is exceeded. The response time is a period of time between the attempt to send registered sale details from the taxpayer's device and the appearance of the FIC on the same device. The response time limit is set by the registering subject, often with regard to the connection speed and its quality. If the limit is exceeded, the registering subject is permitted to print a receipt even without the FIC, thereby finalizing the transaction without being connected to the Financial Administration portal. The missing payment details must then be sent to the tax authority within 48 hours. This legislative measure should allay the fears that Registration will prolong the amount of time spent in shops and will thus lead to big queues. As regards the response time, the Ministry of Finance claims that the average response time in June 2017 was approximately one-tenth of a second. This figure was also confirmed by independent checks (Žurovec, 2017a). The system described verbally above can be illustrated as follows.

\section{Graph 3 System functioning of Registration in case of problems with online connection}

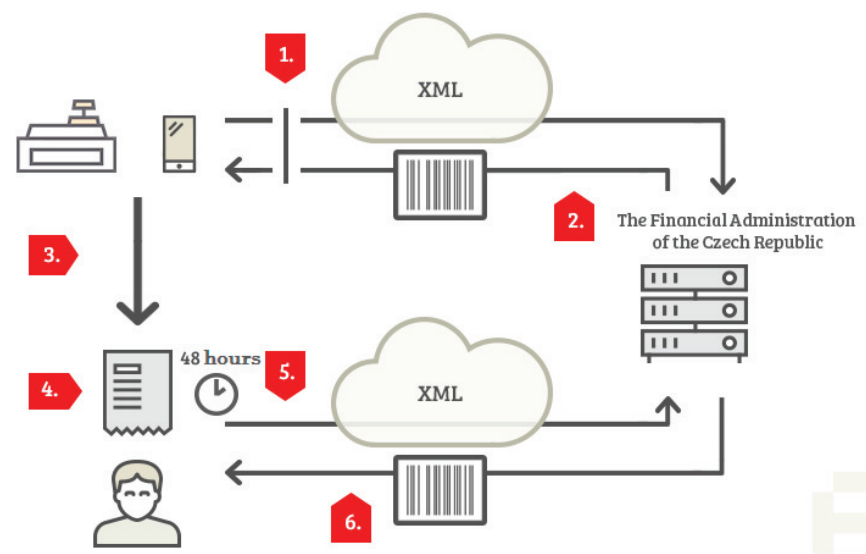

Source: www.etrzby.cz. 
Electronic Registration of Sales in the Czech Republic - Theory and Praxis

\subsection{Supervision of Compliance with Obligations Stipulated by the Act}

Registration is based, among other things, on strict supervision of compliance with obligations. What is rather unusual about Registration is the fact that supervision is not carried out by a public authority only, but also by the public itself.

\subsection{Supervision - the Public}

As has been stated above, every customer holding a receipt with an FIC can then check at the Financial Administration portal whether the sale has indeed been registered with the tax authority by the entrepreneur. Customers' motivation to check registered sales should increase with the arrival of the so-called "receipt lottery", which exists for example in Croatia, Slovenia, and Taiwan. The Act states that the public can enter the lottery by sending in the receipt or by sending the data printed on the receipt (Snopková, 2016: 409-423). In return, the public can win prizes or money. The latest news has it that the lottery should be launched at the beginning of October 2017. Annually, the Ministry of Finance will hand out money and prizes worth CZK 65 million $\left(1^{\text {st }}\right.$ prize: CZK 1 million, $2^{\text {nd }}$ prize: a car worth CZK 400,000, $3^{\text {rd }}$ prize: CZK 300,000) (Vlková, 2017). The lottery will take place every month and it will include receipts from a previously indicated period. The customer may only register one receipt from one seller per day (Žurovec, 2017). The receipt lottery can be regarded as a rather unusual though possibly an effective way to check registered sales. One may ask, however, if the receipt lottery should not give prizes also to subjects that comply with all the obligations connected with Registration.

\subsection{Supervision - State Authorities}

The system of Registration is checked not only by the public but also by state authorities. The Act states that supervisory bodies include the Czech Financial Administration as well as Customs Administration authorities. When carrying out supervision they follow Tax Code, no. 280/2009. Typically, such supervision involves the inspection of data messages with payment details, issuing receipts and putting up information posters. The supervision is carried out by means of a feigned purchase.

Local supervision is performed by officers on location, i.e. where Registration should take place according to the Act (typically in the shop). Such supervision may only involve observation, and if no breach of regulations is revealed, officers may not even reveal their true identity. In such cases, officers simply fill out an official report, which is then filed. Alternatively, officers may feign a purchase, i.e. 
they behave as regular customers and they observe what the entrepreneur does and whether he or she registers the sale. Providing the nature of the feigned purchase allows it, officers may back out of the contract and they should be refunded for the goods they have purchased. This is sometimes not possible: if the back-out goes against the nature of the feigned purchase (typically if the subject matter has been consumed, e.g. getting a haircut at the hairdressers) or if the back-out causes material harm to the taxpayer (if the subject matter is destroyed, e.g. buying food at a takeaway) (Explanatory note, Parliamentary press no. 513). The back-out can be done after the officers have revealed their true identity; the feigned purchase and the local supervision activity are then described in an official report (Hajdušek, Vodička, 2017: 57-58).

The latest data maintains that within the first eight months of Registration almost 50,000 inspections were carried out; $15 \%$ of which discovered some errors (Padla dosud nejvyšší pokuta kvůli EET, 2017).

\subsection{Administrative Misdemeanours}

In case an error has been discovered, the tax authority carrying out supervision initiates an administrative action against the taxpayer accused of committing an administrative misdemeanor. The taxpayer receives an official notice about the action; he or she can then express their opinion and suggest evidence in their favor within a given period (Hajdušek, Vodička, 2017: 60-61).

The Act stipulates relatively only a few elements of the crime, which the Act describes rather vaguely so that a wide range of specific errors can fall within this category. The Act deals in particular with entrepreneurs that completely fail to obey the law: he or she does not register sales, data messages payment details are not sent to the tax authority, receipts are not issued at the time of purchase and posters with information about the need to register sales are not put up. All these misdemeanors (apart from the last one) can result in a fine worth up to CZK 500,000. The Authors are convinced that such a wide range of potential fines along with the vaguelystipulated elements of the crime are rather unfortunate for the tax authority and the entrepreneur alike. As has been indicated above, Registration is a new component in Czech law and, as such, it is a new aspect in the area of administrative penalization. This can pose a problem or two especially for the tax authority, which (if errors are discovered) must be able to levy adequate fines in specific cases, taking into account all the mitigating and aggravating circumstances, the current status of the offender (their prior conduct and their current status) as well as other relevant facts. 
The latest data published by the Financial Administration informs us that the average fine imposed in an administrative action is about CZK 15,000 (Padla dosud nejvyšší pokuta kvůli EET, 2017).

\section{The Registration - Goals and their Fulfilment}

As has been stated above, the Act was approved with the aim 'of leveling unlawful competitive advantage of taxpayers failing to pay taxes properly and of increasing public budgets'. The expected increase of tax collection after the introduction of Registration was derived from the situation in Croatia (whose legislation served as a model for Czech Registration - see below); the explanatory report asserts that the annual increase should reach CZK 12.5 billion (Explanatory note, Parliamentary press no. 513). In January 2017 the Financial Administration announced that in the previous month (December 2016, the first month of Registration) the increase of tax collection was 100\% (Ťopek, 2017). This information is of little value though as the short period of operation only allowed a small sample of entrepreneurs to be involved (approximately 1,600) (Čísla Finanční správy o růstu tržeb se oproti číslům ČSÚ liší, není to překvapivé, 2017). Another partially usable fact is the information that in comparison with the year of 2016, by the end of July 2017 the value added tax (hereafter referred to as the VAT) collection had increased by CZK 14.4 billion (an increase of 11.2\%). Since April 2017 the VAT has been on the increase by double figures, despite the fact that the increase of final consumption (which significantly affects the collection of the VAT) has only been estimated to be at $6 \%$. The Ministry of Finance is convinced that the increase of the VAT has been caused by, among other things, Registration (Žurovec, 2017b). We would like to point out that the aforementioned increase of the VAT collection happened in spite of the fact that the VAT rate in area of food service had been lowered from $21 \%$ to $15 \%$ (like in Croatian law where the VAT had dropped from 25\% to 17\%) (Kudeljan, 2015).

One may agree with the General Financial Director, who asserts that because of the length of the taxable period further analyses of the influence of Registration on the state budget will occur after a longer period of time elapses (Ťopek, 2017). In August 2017 the spokesperson of the Financial Administration announced that the Financial Administration was admittedly analysing the data but it did not have any estimates regarding Registration and its influence.

As far as another objective of Registration is concerned, namely the one regarding the level playing field for entrepreneurs, there is no undisputable data available at the moment. Nonetheless, the spokesperson of the Czech Chamber of Commerce announced in August 2017 that it was certain that Registration had eliminated at least part of the competitive advantages that unfair entrepreneurs had had over 
the ones who obeyed all the regulations. Furthermore, we want to cite the head of the Czech Association of Traditional Commerce, who claims that there has been no dramatic increase in the bankruptcies of small shops, as had been envisaged by some experts. He maintains that only a few dozens of shops have been closed down because of Registration (První měsíce provozu EET přinesly pokuty za devět milionů, 2017).

Apart from increasing the public budget and levelling the playing field for entrepreneurs, the Financial Administration hopes that Registration will help to achieve other positive goals: as the possibility of using the gathered data by entrepreneurs, quicker and more accurate reactions to unfair conduct, lower tax burden in the future, targeting tax inspection at only those subjects that submit dubious data and the subsequent lowering of burden for dutiful taxable subjects (Proč evidence tržeb?). The last of the goals mentioned above has been confirmed by the Minister of Finance, who believes that in the future the number of tax inspections will decrease, because these inspections will focus on dishonest subjects only (Evidence tržeb v praxi. Úvod, 2016). At the moment there is no data available to confirm or refute these proclaimed goals of Registration.

\section{Comparison with Other Countries}

The Czech system of Registration was devised according to the 'fiscalization' model that has been in use in Croatia since 1 January 2013 (Explanatory note, Parliamentary press no. 513). Croatian legislation served as a model for the Registration method itself (sending payment details online to the financial authority, accepting the code, issuing the receipt and checking the registered receipt). There are, however, some differences as well: Croatian legislation insists that the customer accepts the receipt and has it while leaving the shop. This option was weighed up by Czech legislators but it was not accepted eventually (Hornochová, 2015). Some Authors draw attention to the fact that the absence of such an obligation may open the door for evasion based on a mutual agreement between the customer and the seller, or on the same receipt being presented over and over again (Radvan, Kappel, 2016: 334-356). Another difference lies in the amount of data that is required by the Financial Administration (there is much more data required in Croatia). Yet another difference can be found in the system of fines, more specifically in the maximum amount of money that can be imposed in case of a breach of regulations linked with Registration. Both countries can impose fines of up to 500,000 of the local currency (HRK 1 is roughly CZK 3.50) (Fiskalizace v Chorvatské republice: fakta, 2016). One more difference concerns the fact that, unlike Czech law, Croatian law charges the Authorisation certificate for the use of Registration - it costs HRK 300 
for the period of five years (i.e. HRK 60 per year) (Fiskalization, 2012). Finally, the Croatian "simplified regime" of registration is somewhat different as it is based on numbered sheets of paper that are registered in advance by the tax authority and then are filled in by hand by the seller (Hornochová, 2015).

Except for the Czech Republic and Croatia, a certain form of registration of sales is used in other European countries, too: according to the official information about Registration that is available online the following countries use it: Italy, Hungary, Slovakia $^{4}$, Poland, Belgium, Lithuania, Latvia, Malta, Sweden, Romania, Bulgaria, Greece, Cyprus, Austria and Slovenia) (Zkušenosti ze zahraničí, 2016). The most common type is offline cash registers where payment details are entered in an unalterable form; these are not, however, sent online immediately to the financial administration. This system can be found in e.g. Belgium, Poland and Austria. Some legislation (e.g. in Hungary) enable a "hybrid" type of sales registration - data messages are not sent immediately but at regular intervals. Apart from Croatia, the type of electronic sales registration that can be found in the Czech Republic also exists in Slovenia (Smetanková, Palán, 2015).

\section{Conclusions}

This paper deals with Registration that has been in use in the Czech Republic since 1 December 2016. The main focus is on the basic aspects of the system such as the operation of the system, taxable subjects that need to register their sales, registered sales, registration methods and the supervision of compliance with registration obligations. A separate chapter discusses the objectives of the new legislation and the relevant data available to date. From a comparative perspective, this paper briefly described systems of sales registration in other countries, with particular attention drawn to Croatia, which served as the model for the Czech system of Registration.

The Authors believe that Czech legislation took a step in the right direction when it refused certified cash registers that exist in many other countries. As far as the required technology is concerned, a device capable of electronic communication via the internet is the only thing that is needed (it might be e.g. a PC, tablet, mobile phone, cash register, other cash systems, etc.). Such a device must be connected to the internet when a payment is being accepted. It is up to the entrepreneur to choose the optimal type of device along with the most suitable software according

4 A certain type of cash registers was introduced in Slovakia in 1995, since then the Slovakian Financial Administration has been introducing stricter and stricter obligation regarding the Registration. In 2009 Slovakia introduced the obligation to use offline electronic cash registers with a fiscal memory; in April 2015 the system was changed to such an extent that certain service providers can either carry on using the existing cash registers or they can join the "virtual cash register" online (very much like in the Czech Republic). 
to the type of service provided or activity performed. The crucial thing is that data messages with payment details are sent and receipts are issued. In other words, there is no need to buy a specialized certified cash register.

The comparison with Croatian legislation also reveals the fact that Czech legislation opted for an approach that is less demanding for the recipients of the norm. The Czech legislation does not include the obligation for customers to accept receipts, nor does it include the obligation for taxable subjects to pay for certification details. In addition, the amount of data sent to the Financial Administration is not as high as it is in Croatia. On the one hand, such a less strict approach can lead to a certain lack of effectiveness of Registration, but on the other hand, it results in a more positive acceptance of it on the part of the public, and a smoother way of putting the system into practice (it is worth pointing out that in 2016 the Act finished second in the Best Piece of Legislation competition, thanks to the votes from entrepreneurs and the public alike) (Žurovec, 2017a).

The Authors believe that an even more positive acceptance of the system could be ensured by other legislative aspects: the option to print receipts even without being connected to the Financial Administration portal, the simplified regime, lower VAT in the area of food service, the introduction of income tax deduction of up to CZK 5,000 for natural persons as compensation for initial costs connected with the Registration, and the receipt lottery.

The Authors are convinced that all the information above confirms the hypothesis put forward at the beginning (namely that Registration is an effective measure against tax evasion). It is beyond doubt that Registration enables the Financial Administration immediate access to all sales made by taxable subjects. This very fact (providing that the Financial Administration analyses the data correctly) should enable a growing awareness of tax liability of individual subjects. Another indisputable fact is that Registration is a strong preventive measure against unlawful sales reduction by taxpayers. Prevention is also achieved by means of supervisory and enforcing mechanisms included in the Act. The latest data suggest that these mechanisms (a feigned purchase, fines, etc.) are actively used by the Financial Administration, thereby making the system more effective.

The effective operation of Registration is also confirmed by growing VAT revenues. It must be added though that the data is not complete (due to the short period of time since Registration was introduced and due to the gradual four-stage implementation of the system) and the conclusion regarding the increase of revenues in public budgets cannot, therefore, be proved beyond doubt. Similarly, it is rather difficult to predict whether the other intended objectives of Registration will be accomplished 
Electronic Registration of Sales in the Czech Republic - Theory and Praxis

(e.g. a level playing field in the business environment and a sharper focus of tax inspections).

As regards the future of the Registration, we cannot but wait for more complete and relevant data that should enable a more accurate analysis of the system and its effects. It is hoped by the Authors that the Financial Administration in close co-operation with taxable subjects will keep amending legislation to meet the demands of the real-life business environment (lately, the Ministry of Finance has proposed exemption from Registration for the visually impaired until there is a cash device that is technologically suitable for people with such a disability). Nevertheless, it must be stressed that even though future legislative changes will be necessary, the effectiveness of the system will only be ensured if the obligation to register sales will involve as wide a range of taxable subjects as possible. The Authors also maintain that positive motivation for subjects obliged to register sales would be beneficial, too - this could be done, for instance, by their inclusion in the receipt lottery. Another de lege ferenda suggestion is to introduce a more precise specification of the system of fines.

In conclusion, the Authors consider Registration an effective way to monitor the number of sales made by taxable subjects. As long as the Financial Administration keeps conducting inspections and keeps performing systematic data analyses, and as long as the system is not weakened by a great number of exceptions, it may be expected that Registration will fulfill the objectives intended by the legislation.

\section{References}

Hajdušek, T. et al.: První zkušenosti s EET - elektronickou evidencí tržeb (First experience with ROS - registration of sales), Prague: Wolters Kluwer, 2017.

Hornochová, S.: Př́spěvek Simony Hornochové - Konference o EET (Contribution of Simona Hornochová - Conference of ROS), 2015. www.youtube.com.

Kudeljan, V.M.: Příspěvek M.V. Kudeljan - Konference o EET (Contribution of M.V. Kudeljan Conference of ROS), 2015. www.youtube.com.

Radvan, M. et al.: Elektronická evidence tržeb jako nástroj kontroly v berním právu (Registration of Sales as a Control Instrument in Tax Law), in: Mrkývka, P. et al. (eds.): Dohled, dozor, kontrola ve veřejné finanční činnosti (Surveillance, supervision, control of public financial activities), Brno: Masarykova univerzita, 2016.

Smetanková, D. et al.: Právní úprava evidence tržeb ve vybraných zemích EU (Legal registration of sales in selected EU countries). Prague: Parliament Institute, 2015.

Snopková, P.: Uplatnění kontrolních mechanismů $\mathrm{v}$ rámci daně z přidané hodnoty (Apply of Controlling Mechanisms within the Scope of Value Added Tax), in: Mrkývka, P. et al. (eds.): 
Dohled, dozor, kontrola ve veřejné finanční činnosti (Surveillance, supervision, control of public financial activities), Brno: Masarykova Univerzita, 2016.

Ťopek, M.: Z EET si nikdo nebude dělat srandu, říká šéf Finanční správy (No one will be kidding from the ROS, says the head of the Financial Administration), 2017. www.financnisprava.cz.

Vlková, J.: Účtenkovou loterii chce ministerstvo stihnout ještě před volbami (The ministry wants the receipt lottery to run before the election), 2017. www.ekonomika.idnes.cz.

Žurovec, M.: Podnikatelé a odborníci rozhodli: Elektronická evidence tržeb je druhým nejlepším zákonem roku 2016 (Entrepreneurs and experts have decided: Registration of Sales is the second-best law in 2016), Praha: Ministry of Finance, 2017a. www.mfcr.cz.

Žurovec, M.: Státní rozpočet je po sedmi měsících v přebytku 25 mld. Kč (The state budget is in surplus of CZK 25 billion after seven months), Praha: Ministry of Finance, 2017b. www. mfcr.cz.

Žurovec, M.: Účtenková loterie má svého dodavatele (The receipt lottery has its supplier), Prague: Ministry of Finance, 2017. www.mfcr.cz.

Čísla Finanční správy o růstu tržeb se oproti číslům ČSÚ liší, není to překvapivé (The Financial Administration's numbers of revenue growth are different from those of CSO, it's not suprising), 2017. www.etrzby.cz.

Explanatory note to the Bill on Registration of Sales, Parliamentary press no. 513, 2015. www.psp.cz.

Evidence tržeb v praxi. Úvod (Registration of Sales in praxis. Introduction, 2015. www.youtube.com.

Fiskalizace v Chorvatské republice: fakta (Fiscalization in Croatia: facts), 2016. www.etrzby.cz.

Fiskalization in HR: Questions \& Answers, 2012. www.fiscalization.hr.

Padla dosud nejvyšší pokuta kvůli EET (The highest penalty yet has been imposed because of ROS) Úřady proti nepoctivcům přitvrdily (authorities tightened against non-honest people), 2017. www.ekonomika.idnes.cz.

Proč evidence tržeb? (Why registration of sales?). www.etrzby.cz.

První měsíce provozu EET přinesly pokuty za devět milionů (First months of operation of ROS brought fines for nine million), 2017. www.businessinfo.cz.

Zkušenosti ze zahraničí (Experience from abroad), 2016. www.etrzby.cz.

CZ: Tax Code, no. 280/2009, as amended.

CZ: Act no. 112/2016, on Registration of Sales, as amended.

CZ: Act no. 586/1992, on Income Taxes, as amended. 


\title{
“PRE-FACTOR" IN THE TAX ON GOODS AND SERVICES
}

\author{
KATARZYNA KOPYŚCIAŃSKA ${ }^{l}$
}

\begin{abstract}
Since 1 January 2016, there have been new provisions in force of the Act on Tax on Goods and Services, introducing the requirement to use the so-called "prefactor" of the input tax deduction by taxpayers. Already before the amendments, the VAT Act contained provisions on proportional deduction (Art. 90). However, the pre-factor was then applied at a different level. In this paper the essential issue is to establish the right of taxable persons (in particular a self-government unit) to a partial deduction of input tax with respect to mixed costs on the basis of the proportion of sales, referred to in Art 90/3 of the Act on Tax on Goods and Services, as well as to examine the merits of such solutions and to draw attention to possible elements of non-compliance with the rules of the tax while accounting for the CJEU case-law.
\end{abstract}

\section{Keywords}

Value added tax; due tax; deduction; "pre-factor"; active taxpayer

\section{JEL Classification: H23, H25, K34}

\section{Introduction}

Art. 90 of the VAT Act (Act of 11 March 2004 on the Tax on Goods and Services) obligates taxpayers to attribute input tax to a sale which confers the right of deduction and which does not confer this right. When the input tax cannot be unambiguously attributed to one of the above sales categories, the deduction factor is applied. To put it simply, one might say that Art. 90 is predominantly applied when taxpayers,

Associate Professor at the Department of Finance Law, Faculty of Law, Administration, and Economics, University of Wrocław. She is a member of Information and Organization Center for the Research on the Public Finances and Tax Law in the Countries of Centre of Eastern Europe. Contact mail: katarzyna. kopyscianska@uwr.edu.pl. 
within their economic activity, are involved in a sale that is mixed in nature - and that is both subject to VAT and exempt from it. In each case, however, it is still an economic activity that is subject to VAT (Bełdyga, 2014).

\section{Legal Basis for Pre-Factor Regulation}

The provisions cited above of Art. 90/1-3 of the VAT Act constitute the implementation of Art. 17/5 and Art. 19 of the Sixth Council Directive (77/388/EEC - Common system of value added tax) which today correspond to Arts. 173 and 174 of Directive 112 (Council Directive 2006/112/EC on the common system of value added tax). Pursuant to Art. 173/1 of this Directive in the case of goods and services used by a taxable person both for transactions in respect of which VAT is not deductible, only such proportion of VAT as is attributable to the former transactions shall be deductible. The deductible proportion is determined, in accordance with Arts. 174 and 175 for all transactions carried out by the taxable person. However, according to Art. 173/2 the Member States may take the following measures:

a) Authorize the taxable person to determine a proportion for each sector of his business, provided that separate accounts are kept for each sector,

b) require the taxable person to determine a deductible proportion for each sector of his business and keep separate accounts for each sector,

c) Authorize or require the taxable person to make the deduction on the basis of the use made of all or part of the goods and services

In accordance with Art. 174/1, the deductible proportion is made up of a fraction comprising the following amounts:

a) as numerator, the total amount, exclusive of VAT, of turnover per year attributable to transactions in respect of which VAT is deductible pursuant to Arts. 168 and 169;) as denominator, the total amount, exclusive of VAT, of turnover per year attributable to transactions included in the numerator and to transactions in respect of which VAT is not deductible.

Focusing on domestic regulatory enactments, it should be indicated that the provisions of Art. 86/1 and Art. 90 of the VAT Act do not define the meaning of repayment, as contained in Art. 90/1 of the VAT Act - an action in respect to which the taxpayer is not Authorized to lower the tax due, and therefore they do not provide a straight answer as to - how the taxpayer should act in the case when the purchases made involve transactions that are taxed (exempt from tax), as well as transactions that are not subject to the provisions of the VAT Act, while there exists no possibility to attribute the purchases to only one of the categories. As the applicant rightly points out, the repayment was the subject of analysis of the 
domestic courts which recognized that the scope of this repayment did not cover transactions outside the VAT system (not referring to the taxpayer's non-economic activity) which may not exert an influence on the decision on the right of deduction. Thus, in the denominator of the proportion factor of the input tax payment, referred to in Art. 90/3 of the VAT Act, there should be no expenditures on goods and services which are intended for the taxpayer's non-economic activities (Zubrzycki, 2017).

Meanwhile, the new regulatory enactments are applicable when the taxpayer conducts an economic activity as well as other kinds of activities, incurring costs relating to purchasing goods and services used for all of his activities.

According to Art. 86/2a of the VAT Act, the new provisions refer to taxpayers who use goods and services acquired for both economic and non-economic activities. If the taxpayer conducts simultaneously an activity that is subject to VAT (i.e. taxable or exempted from tax) and not subject to VAT (do not fall within the scope of the VAT Act), the input VAT deduction is allowed only to the extent to which the expenditures can be attributed to the activity subject to VAT. The new provisions are supposed to make the implementation of this rule possible.

With respect to the relationship between the new pre-factor of deduction determined on the basis of Art. 86/2a-2h of the VAT Act and the proportional deduction based on Art. 90 of the same act, it is multi-leveled in nature, which means that the taxpayer should first determine the amount of input VAT while accounting for the pre-factor and only then apply the deduction proportion, referred to in Art. 90 of the VAT Act, to the amount, thus determined.

In accordance with the position taken by CJEU in its judgment C- 437/06 in the case when the taxpayer engages in an economic activity, taxable and exempted from tax, and in an activity of non-economic character, which do not fall within the the scope of the Sixth Council Directive 77/388/EEC: a uniform basis of assessment, deduction of the VAT relating to expenditure connected with the issue of shares and atypical silent partnerships is allowed only to the extent that that expenditure is attributable to the taxpayer's economic activity within the meaning of Art. 2/1 of that Directive. In the view of CJEU, "in line with the principle of neutrality, only tax paid on a deductible economic activity should be subject to deduction. There should be no right of deduction for transactions which are not linked to the economic activity. The Member States should implement such provisions which would ensure this objective.

The new paragraph 2a added to Art. 86 of the VAT Act imposes a new obligation on the taxpayer which is relating to the input tax apportionment. In light of this provision: in the case of acquisition of goods and services used for the taxpayer's 
economic activity and for non-economic purposes, with the exception of personal purposes, to which Arts. 7/2 and 8/2 apply, and for purposes referred to in Art. 8/5 in the case, which is referred to in this provision, when it is not possible to attribute these goods and services entirely to the taxpayer's economic activity, the amount of input tax, referred to in Paragraph 2, is calculated in accordance with the method to determine the scope of use of goods and services acquired for business purposes, hereinafter referred to as "the proportion determination method". The method used to determine the proportion should be tailored to the specificity of the taxpayer's activity and acquisitions he makes.

However, attention should be drawn to the content of Art. 86/22 of the VAT Act, in which we read, "Minister competent to public financial matters may establish by Regulation the method of proportion determination considered to be the most suitable for some taxpayers in terms of the characteristics of their activities and acquisitions, and indicate data on the basis of which the input tax amount can be calculated using this method of proportion determination, while taking into account the specificity of some taxpayers' economic activity and economic determinants. The Ministry of Finances applied the legislation contained in the cited Art. and issued on its basis the Regulation of 17 December 2015 addressed to local selfgovernment units which in their calculation of the pre-factor should in the first place learn about the provisions pertaining to the solutions addressed especially to them and try to calculate the pre-factor in accordance with the norms contained therein.

On the basis of the pre-factor regulation cited above, within the local selfgovernment units, the pre-factor is calculated separately for:

- every budgetary unit;

- every budgetary establishment;

- the office providing services to LSGU (city council office, Gmina's office, Marshal's Office, District Governor's Office).

Although those units as a whole form one VAT payer, a local self-government unit is not Authorized to determine one total proportion but it is required to determine a proportion separately for every individual organizational unit. Thus, depending on whether the LSGU carried out the centralization before 1 October 2016 or before 1 January 2017, or possibly before 1 January 2016, unambiguous rules were issued establishing when to deduct the tax charged using the pre-factor and how it should be calculated. The above considerations were confirmed by the individual interpretation (Head of the Tax Chamber of Łódź: no. 1061-IPTPP3.4512.371.2016.3MWj) "Pursuant to Art. 86/2b of the Act, the method determining the proportion corresponds most effectively to the specificity of the activity performed by the taxpayer and his acquisitions if: the method ensures that the tax due is reduced 
by the amount of the tax charged exclusively with respect to the input tax amount, proportionally attributable to a taxable transaction carried out within the taxpayer's economic activity and reflects objectively the portion of expenditures attributable to the economic activity and to other than economic purposes, with the exception of personal purposes, to which Arts. 7/2 and 8/2 apply, and to purposes referred to in Art. $8 / 5$ - in the case, referred to under this provision when it is not possible to attribute all of those expenditures to the economic activity" (Head of the Tax Chamber of Łódź: no. 1061-IPTPP3.4512.371.2016.3MWj). It should be noted that similar to the application of the "classical" proportion arising from the Art. 90 of the VAT Act, the new Art. 86/2a of the Act requires the apportioning of the amounts of the input tax between the economic activity and non-economic activity (...) when attributing those goods and services as a whole to the taxpayer's economic activity is not possible. Thus primacy would be accorded to a direct allocation of the input tax amounts (also for the amounts of input tax which was separated under one invoice, and only if it proved to be impossible (in particular for the so-called general costs), the taxpayer would be required to apply the "pre-factor".

Moreover, in accordance with paragraph 2a added to Art. 86 of the VAT Act, the apportioning of the tax charged within the "pre-factor" is carried out in the case of acquiring services used for purposes of the taxpayer's economic activity (subject to VAT: taxable or exempted) and for other purposes than those relating to his economic activity. The obligation to carry out the above-cited apportioning would thus be referring to VAT payers receiving benefits from an economic activity within the meaning of Art. 15 paragraphs 2 and 3 of the VAT Act and from a noneconomic activity (Namysłowski, Borowski, Sajnaj, 2016: 119).

\section{Apportionment Methods of Tax Charged Using "Pre-factor"}

In light of Art. 86/2c of the VAT Act, while choosing the method to determine proportions the following data may be used in particular:

- The annual average number of persons performing only tasks relating to the economic activity within the annual average number of persons performing tasks within the economic activity and outside it. This method, which is based on the criteria relating to the allocation of persons to perform specific tasks will be of little use in practical terms. In general, a public sector does not divide tasks so strictly (after all, that would have to arise from employment contract/rules, etc.) Persons employed by this type of taxpayers perform a variety of work, and such a strict division of tasks among employees is rarely affected. 
- The annual average number of working hours devoted to tasks relating to the economic activity within the overall annual average number of working hours devoted to tasks relating to the economic activity and outside it. Similar remarks can be cited with respect to this method. A division by working hours is not used by taxpayers, and on top of that, it is difficult to determine and to estimate. Such a key to apportioning would have to draw on corresponding documents/records.

- The annual turnover of the economic activity within the taxpayer's annual turnover from the economic activity increased by the income received from a different activity, including grants, subsidies and other extra donations similar in nature, obtained for the purpose of financing the taxpayer's noneconomic activity. The term "turnover" used in Art. 86/2c/3 of the VAT Act will be interpreted the same as in Art. 90 thereof. Turnover should be understood as the amount due to less VAT. As indicated in the explanatory note on the draft Act: the category "revenue/income" shall also encompass grants, subsidies and other extra subsidies similar in nature which the entity receives to finance his non-economic activity. This category will thus not include grants used for the economic activity (e.g. restricted grant or the socalled cost subsidy, e.g. purchasing a machine to manufacture goods sold by the taxpayer) or grants intended for another entity to perform activity which does not fall within the VAT scope (Namysłowski, Borowski, Sajnaj, 2016: 119). The legislator, however, failed to show how to treat a grant received for "mixed" purposes (e.g. grant received for wages of the staff performing tasks within the economic and non-economic activity). Taxpayers should not treat this kind of grant in its entirety as a grant intended for the activity that does not fall within the VAT scope, for then, in increasing denominator they reduce the scope of the input tax deduction. This kind of grant should be apportioned by taxpayers according to the most adequate, from the point of view of the taxpayer and his activity, apportioning key.

- The annual average surface area used for the economic activity within the overall annual average surface area used for the economic and non-economic activity. Surface area allocation appears to be a method of little use, for not many taxpayers carry out a strict division of surface area (rooms) where they generate income from the economic and non-economic activity. While applying this method, there is also another problem of how to determine and divide the area. What seems the most appropriate in this case is to follow the rules specified under property tax (Selera, 2015).

Based on Art. 86/2d of the VAT Act, in order to calculate the amount of input tax for the purpose of applying the "pre-factor", the data from the last year is used. The taxpayer starting to pursue his economic and non-economic activity in the tax year 
concerned, with a view to calculate the input tax amount so as to apply the "prefactor'adopts data calculated as estimates according to the forecast which has been agreed with the head of a tax office in the form of a report (Art. 86/2e of the VAT Act). Pursuant to Art. 86/2g of the VAT Act, the proportion effective as of 1 January 2016 is determined percentages on an annual basis. This proportion is rounded up to the next whole number. The provisions of Art. 90 paragraphs $5^{2}, 6^{3}, 9 \mathrm{a}^{4}$ and $10^{5}$ of the VAT Act apply respectively.

Moreover, the requirement to correct the pre-factor calculated based on Art. 86/2a of the act is indicated in Art. 90c of the same act (including data for the completed tax year). Particularly complicated will be the method to calculate the deduction scope of the input tax for a property, as here we might have to calculate as many as 3 factors: (a) surface area key based on Art. 86/7b of the VAT Act, (b) pre-factor, (c) factor).

\section{Essential Characteristics of Gmina's Functioning}

Pursuant to Art. 15/2 of the VAT Act an economic activity encompasses any activity of producers, traders or persons supplying services, including entities exploiting natural resources and farmers, as well as the activity of persons engaged in a liberal profession. The economic activity covers in particular activities involving the use of goods or intangible and legal values in a continuous manner for lucrative purposes.

The economic activity is not dependent on a result, and therefore it does not need to bring any noticeable effects, in the first place including the financial ones. The economic activity does not cover an activity in which no economic risk on the part of the seller or service supplier materializes and, thus, there is no liability for damages caused as the result of carrying out this activity. An important aspect is that every task performed within the economic activity has to be verified separately. The economic activity which in the case of LSGU is not of an economic nature is the one linked to the statutory activity. LSGUs are entities which largely carry

2 The turnover, referred to in paragraph 3, does not include the turnover attributable to supplying goods and services, which, based on the provision on the income tax, are classified by the taxpayer as property, as non-current and intangible assets subject to depreciation, and land and the right to perpetual usufruct of land, if they are classified as the taxpayer's non-current assets - used by the taxpayer for the purpose of his business.

3 The turnover referred to in paragraph 3 does not include the turnover attributable to transactions referring to 1) incidental transactions pertaining to property and incidental financial transactions; 2) services listed in Art. $43 / 1$ points 7,12 and $38-41$, to the extent these transactions are incidental in nature.

$4 \quad$ Hile determining the proportion, pursuant to paragraphs 2-6, the tax amount is not included in the turnover.

5 In the case the proportion determined pursuant to paragraphs 2-8: 1) Exceeded $98 \%$ and the amount of the input tax that is not deductible, arising from the application of this proportion, was less than 500 PLN on an annual basis - the taxpayer is authorized to assume that this proportion equals $100 \%$; 2 ) It does not exceed $2 \%$ - the taxpayer is authorized to assume that this proportion is equal to $0 \%$. 
out duties conferred on them. This is to satisfy the collective needs of a local community relating to its daily functioning. It is, therefore, crucial to note that LSGUs have not been established to operate like a classical entrepreneur. The units perform tasks for payment or free of charge to which they have been appointed under the law. The amounts paid by persons using the above-mentioned services are classified as administrative fees, with the provision of those services being considered to be public services. The activity of entities governed by public law is inherently non-commercial in nature. In its principle, their objective is not to sell goods for payment or provide services like it is done within a free market, for their activities are linked to the public law sphere. Therefore, the legislator introduced separate rules for entities from this sector (Sokołowska-Strug 2016: 104).

Pursuant to Art. 15/6 of the VAT Act "public authorities and offices servicing those authorities are not considered to be taxpayers within the scope of tasks conferred by separate provisions of law for the purpose of implementing tasks they have been appointed for, excluding work performed under civil-law contracts".

A local self-government unit providing services by virtue of administrative provisions, and considering the fact that it charges fees in spite of this, after all, it cannot be considered to be a VAT payer in this context. The services the local self-government unit supplies are provided for in law, constituting an activity that is not economic in nature. It should, therefore, be noticed that when the taxpayer, and in this case, it is the LSGU, purchases goods or services, and as the result, it can attribute this purchase to the relevant activity, then if this activity is an activity which:

- is not of economic nature - then the unit does not have the right of the input tax deduction;

- is economic, exempted from VAT - then the unit does not have the right of the input tax deduction;

- is economic that is taxed by VAT - then the unit has the right to the input tax deduction (Sokołowska-Strug, 2016: 104).

\section{Application of Provisions in Practice}

The classification of the costs incurred within the individual types of activities VAT taxable, taxable and VAT exempted and an activity that is outside the VAT scope is what causes the greatest number of problems to LSGUs. An exception to this is when LSGUs have the possibility of attributing expenditures directly - e.g. exclusively to an activity that is taxed by VAT (expenditures incurred in relation to the renovations of rooms which are all rented). However, a given expenditure 
is very likely to be used for the two types of activity carried out by the LSGU (those subject and not subject to VAT). The Head of the Tax Chamber of Bydgoszcz issuing the individual interpretation (no. ITPP2/443-868/13/17-S/RS) contended that "it is possible to apply any kind of apportioning with respect to purchases of goods and services provided that it guarantees the most accurate determination of the amount of input tax to be deducted".

It should be remembered that LSGU's activity is very specific - they implement tasks conferred on them through a number of entities being responsible for separate tasks - they carry out a "fragment" of the LSU's activity that was transferred to them (within this economic activity). The introduction of just one method of calculating the pre-factor applied centrally at the level of the entire LSGU would not account for the specificity of the multi-strand activity of the local self-government as a VAT payer nor for acquisitions made by individual organizational units. To give an example, the scope of the economic activity of LSGU is narrow in educational units, while considerably larger in budgetary establishments involved in water supply infrastructure or utilities.

Attributing the goods and services purchased to the LSU's particular activity and determining the method of the pre-factor calculation should, therefore, be carried out for every organizational unit separately. Adopting this solution is further confirmed by the regulation of the Minister of Finances issued on the basis of Art. 86/22 of the VAT Act (see the legal basis), where the recommended method with respect to the pre-factor calculation has been determined, which should be used by every organizational unit separately.

Moreover, the provisions of the VAT Act provide for the possibility to apply a different method of the pre-factor calculation in the case when the method recommended will not, in the taxpayer's opinion, correspond most accurately to the particularities involved in the taxpayer's activity and acquisitions made.

In the practice of LSGUs, it is extremely difficult to affirm, within the framework of individual tax interpretations, that it is possible to use other methods with respect to pre-factor calculation than the one already recommended (although in the taxpayer's opinion the other method is more suitable to the specific characteristics of the activity). This effectively means that LSGUs cannot use a different method merely because the recommended method is what has been intended for them. The local self-government units may try to defend their different position in this respect before administrative courts, yet many of them simply give up their VAT deductions, for they would rather avoid being involved in a long-lasting dispute.

This negative attitude of the tax authorities with respect to the issue discussed is reflected in the individual interpretation of the Head of the Tax Chamber of Łódź 
(no. 1061-IPTPP1.4512.699.2016.2.AK) in which it is argued that "The method proposed by Gmina with respect to determining the proportion (...) calculated as an annual proportion of the water supplied as represented in the total amount of water supplied to external customers and the proportion of sewage discharged as represented in the total volume of sewage from external consumers is not a method that could be recognized as most accurately corresponding to the specificity of the Gmina's activity and acquisitions made."

Finally, the tax authority contends that "for the local self-government unit, the legislator provided for one method to determine the scope of use in terms of goods and services acquired for the purpose of the economic activity, having recognized it as being suitable to the specificity of those taxpayers' activity and acquisitions made."

One thing is to be concluded from the above: LSGUs theoretically, pursuant to the provisions of the VAT Act, are authorized to apply different methods with respect to the pre-factor calculations, but in practice, it is the recommended method that the tax authorities consider being the most appropriate.

As the result, LSGUs either do not deduct VAT from their expenditures, with respect to which they are required to apply the pre-factor, or they use the method pursued by the legislator which is unfavorable in terms of the amount of VAT deductions, so as not to risk getting involved in a dispute (Zajączkowski, 2016: 26).

\section{Conclusions}

Every organizational unit that is subordinate to a local self-government unit is required to determine by itself the level of the pre-factor and the deduction proportion, and thus every year it is also required to sum up again and to verify data. This is not a small feat for the accounting and record-keeping systems of local self-government units in the context of the changes implemented, and at the same time it brings about a considerable responsibility on the part of an official who carries out those calculations.

The tax and legal effects, although they were forecast considerably earlier by the doctrine, will only be verifiable in a couple of years. At the moment in the context of the changes implemented local self-government units need to establish themselves in the new reality. The new issue which is the application of the pre-factor in the tax on goods and services for the purpose of calculating the input tax amount in relation to the activity carried out by the taxpayers will certainly give rise to doubts 
concerning the interpretation and whose solution will only come with the judicial decisions made by administrative courts.

\section{References}

Bełdyga, T.: VAT w gminach (VAT in municipalities), Warszawa: Wolters Kluwer, 2014.

Namysłowski, R.: Borowski M., Sajnaj B., Centralizacja VAT w jednostkach sektora finansów publicznych (VAT centralization in the public financial units), Warszawa: C.H. Beck, 2016.

Selera, P.: "Prewspółczynnik" w podatku od towarów i usług od 2016 ("Pre-factor" in the Tax on Goods and Services since 2016), Podatki i Rachunkowość (Taxes and Accounting) no. 9 (2015).

Sokołowska-Strug, E.: VAT w jednostkach samorządu terytorialnego (VAT in local government units), Warszawa: C.H. Beck 2016.

Zajączkowski, W.: "Pre-wskaźnik" - podstawowe problemy interpretacyjne ("Pre-factor" basic interpretation problems), Monitor Podatkowy (Fiscal Jounral) no. 5 (2016).

Zubrzycki, J.: Leksykon VAT 2017 (Lexicon VAT 2017), Wrocław: Unimex - Oficyna Wydawnictwo, 2017.

EU: Sixth Council Directive 77/388/EEC - Common system of value added tax.

EU: Council Directive 2006/112/EC on the common system of value added tax.

EU: Court of Justice of the European Union: no. 93968.

PL: Act of 11 March 2004 on the Tax on Goods and Services, as amended.

PL: Regulation of the Minister of Finance of 17 December 2015 on the method of establishing the scope of use for goods and services acquired for business purposes for some taxpayers.

PL: Supreme Administrative Court: I FSK 491/16.

PL: Head of the Tax Chamber of Bydgoszcz: no. ITPP2/443-868/13/17-S/RS.

PL: Head of the Tax Chamber of Łódź: no. 1061-IPTPP1.4512.699.2016.2.AK.

PL: Head of the Tax Chamber of Łódź: no. 1061-IPTPP3.4512.371.2016.3MWj. 



\title{
STRUCTURE OF NATIONAL SOURCES OF FINANCING OF ROAD INFRASTRUCTURE IN LITHUANIA
}

\author{
ERNEST GINCl
}

\begin{abstract}
The functioning of road transport in Lithuania is largely based on internal financing which results from the economic and social function of transport infrastructure. Since 2002, the Road Maintenance and Development Program has been the financing instrument of road infrastructure in Lithuania which finances roads of state importance and partly supports the maintenance and development of roads of local importance. In spite of the many sources of income generated by the Road Maintenance and Development Program, excise tax revenues account for about $90 \%$ of the total budget. However, it should be noted that some of these funds are used to "patch the national budget hole". And there is also the problem of budget losses from excise duty on fuels resulting from the existence of the grey market. Therefore, the reform of road transport financing in Lithuania concerns primarily the improvement of the excise tax system and the increase of its contribution to the Road Maintenance and Development Program.
\end{abstract}

\section{Keywords}

Public expenditure; transport infrastructure financing; road transport toll system; excise tax

JEL Classification: H54, H60, H83

\footnotetext{
1 Assistant of Department of Economics, Faculty of Economics and Informatics, University of Bialystok, Vilnius Branch, Republic of Lithuania. The Author specializes in transport development in Lithuania. Contact email: ernest.ginc@uwb.edu.pl.
} 


\section{Introduction}

It is difficult to question the function and role of transport infrastructure as an engine or even a prime mover for socio-economic development. Infrastructure is a condition for "(...) growth and development processes to take place at all" (Ratajczak, 1999: 76). Therefore, its expansion is essential for the economies of the underdeveloped countries for which one of the main objectives is to rise to the next level of economic development (Kupiec, 2005: 45).

Transport functioning, largely based on the state of the infrastructure, depends primarily on the size of the funding. The economic and social functions of transport are decisive for the financing of infrastructure with the majority of funds from public sources. It is worth pointing out that any attempt to raise private capital is faced with the difficulties of the low propensity of private entities to engage in such investment projects which are characterized by inter alia high capital intensity, long implementation period, and postponement of the effects of expenditures incurred (Bronik, 2009: 19).

This article, by identifying the importance of transport and, in particular, road transport, for the development of the Lithuanian economy, is an attempt to verify the research hypothesis that the Lithuanian State, in order to maintain the pace of socio-economic development towards the leading European Union countries, should provide greater (than before) support for the car transport industry from own funds. Therefore, it is worthwhile to look at the structure of financing of the road transport from internal sources without neglecting the support from EU funds at the same time. This is to identify its strengths and weaknesses and to formulate recommendations to adjust the amount of funding to the growing needs of the modern economy in line with the principle of anticipating transport development in relation to the needs of the economy (Wojewódzka-Król, 2011: 33). The paper will use descriptive research methods based on the analysis of documents regulating the financing of road transport in Lithuania and the statistical tools used to perform quantitative analysis and to formulate conclusions by verifying the hypothesis.

\section{Role and Condition of Road Infrastructure in Lithuania}

The geopolitical position of Lithuania determines the significant role of transit for the socio-economic development of the country. For years the transport and storage sector has been on the third place in terms of contributing to the creation of national added value, second only to the manufacturing and trade sectors. Nevertheless, it is important to underline that its importance is growing which is reflected in a nearly double increase in the share of national added value from $6.3 \%$ in 1995 to $11.7 \%$ 
in 2015. This sector employs nearly $9 \%$ of all people working in Lithuania, with a noticeable growing trend (Gross value added by economic activity). In the branch structure, however, the biggest role is attributable to road transport, where over $60 \%$ of all transport and storage workers are employed (Road Statistics Yearbook, 2016: 14). Passenger transport is clearly dominated by road transport (over $98 \%$ of passenger traffic), while freight transport, although mostly carried out by road transport ( $46 \%$ of total freight by tonnage in 2015), is similar to freight by rail (38\% of total traffic calculated on the basis of the mass of freight by tonnage in 2015). Nonetheless, long-distance transport of goods is carried out mainly by road transport $(65 \%$ of total traffic calculated according to the tonne-kilometer transport work performed) (Transportation of goods and passenger by all types of transport).

The road infrastructure in Lithuania can be considered as sufficiently developed. Taking into account the length of roads per thousand inhabitants, Lithuania is on the third place across the European Union (24.4 km per 1000 inhabitants $^{2}$ ), second only to Estonia and Latvia. The situation is different in the case of the road density index with $1112 \mathrm{~km}$ of paved roads per 1 thousand square $\mathrm{km}^{3}$, which places Lithuania on $17^{\text {th }}$ place in the Community ranking and coincides with the EU average value of this indicator (Statistical pocketbook, 2016: 79; Population on 1 January by age and sex; Land cover statistics). However, it is not sufficient to measure the linear state of the road infrastructure since it is necessary to compare the roadmap broken down into pavement types (see: Table 1 and Graph 1).

In the period from the accession of Lithuania to the European Union until the end of $2014^{4}$, the total number of roads increased by $5703 \mathrm{~km}$ or about $570 \mathrm{~km}$ per year. A large jump was recorded in 2010-2012 because in three years the total number of roads increased by nearly 3 thousand. The greatest influence on this was the growth of dirt roads, which increased by $2485 \mathrm{~km}$ in 2012, resulting in a growth in their share in the total number of roads from $11.5 \%$ in 2009 to $14.1 \%$ in 2012 . The general tendency of dirt roads' growth is the result of the intensive expansion of suburban areas where the process of building paved roads does not follow the

2 Roads with paved surfaces are considered, i.e. in addition to the dirt roads.

3 It should be noted that gravel roads in Lithuania are classified as paved roads.

4 The analysis takes into consideration the period until 2014 since the rules on the quantitative state of roads (in $\mathrm{km}$ ) for roads owned by municipalities have been tightened since 2015 . According to the introduced change, the quantitative state of the roads is to be recorded only on the basis of their thorough inventory, which was not obligatory up to now, and some municipalities deliberately overstated their quantity in order to obtain more funding (Law on the methodology of determination of municipal budgetary revenues of the Republic of Lithuania). This was inter alia due to an audit carried out by the State Control Institution regarding the effectiveness of public funds allocated for the repair and modernization of municipal roads, during which a number of system deficiencies were detected, including: inter alia no reliable information on the actual number and types of municipal roads (Are there any conditions for efficient use of funds for the maintenance and modernization of local roads and streets?). However, on the basis of the data presented in the graph and table, the general tendency for changes in the structure of roads in Lithuania due to the type of pavement can be detected. 
scale of urbanization directly adjacent to cities. It can also be noted that during the period under review, the number of gravel roads continued to fluctuate but remained almost unchanged, thus contributing to their share in the overall structure of roadways decreased from $60.2 \%$ to $55.7 \%$. This is because a relatively small number of dirt roads have been upgraded to gravel roads while the vast majority of gravel roads have been asphalted. The phenomenon of road modernization, including gravel road asphalting, has thus emerged. By evaluating this process, it can be seen that its positive effects are in the form of increasing share of paved roads with improved pavements in the overall structure of the number of roads. It should be noted, however, that this indicator (around 30\%) is far below the average of the EU (87\%), were in as many as $22 \mathrm{EU}$ countries paved roads exceed $60 \%$ of the total number of roads and in 10 countries $-100 \%$ (Roads, paved).

Table 1 Condition of road infrastructure in Lithuania according to the type of road surface in 2004-2014 (in km)

\begin{tabular}{|c|c|c|c|c|}
\hline Years & Paved roads & Gravel roads & Dirt roads & Total \\
\hline 2004 & 22031 & 47741 & 9559 & 79331 \\
\hline 2005 & 22412 & 48137 & 8948 & 79497 \\
\hline 2006 & 22707 & 48228 & 9049 & 79984 \\
\hline 2007 & 23008 & 48293 & 9414 & 80715 \\
\hline 2008 & 23676 & 47887 & 9467 & 81030 \\
\hline 2009 & 23935 & 48013 & 9383 & 81331 \\
\hline 2010 & 24063 & 47985 & 10083 & 82131 \\
\hline 2011 & 24938 & 47384 & 10589 & 82911 \\
\hline 2012 & 25150 & 47147 & 11868 & 84165 \\
\hline 2013 & 25249 & 47342 & 11877 & 84468 \\
\hline 2014 & 25518 & 47331 & 12185 & 85034 \\
\hline
\end{tabular}

Source: Own data processing based on Road length at the end of the year. 


\section{Graph 1 Structure of roads in Lithuania according to the type of pavement in 2004-2014 (\%)}

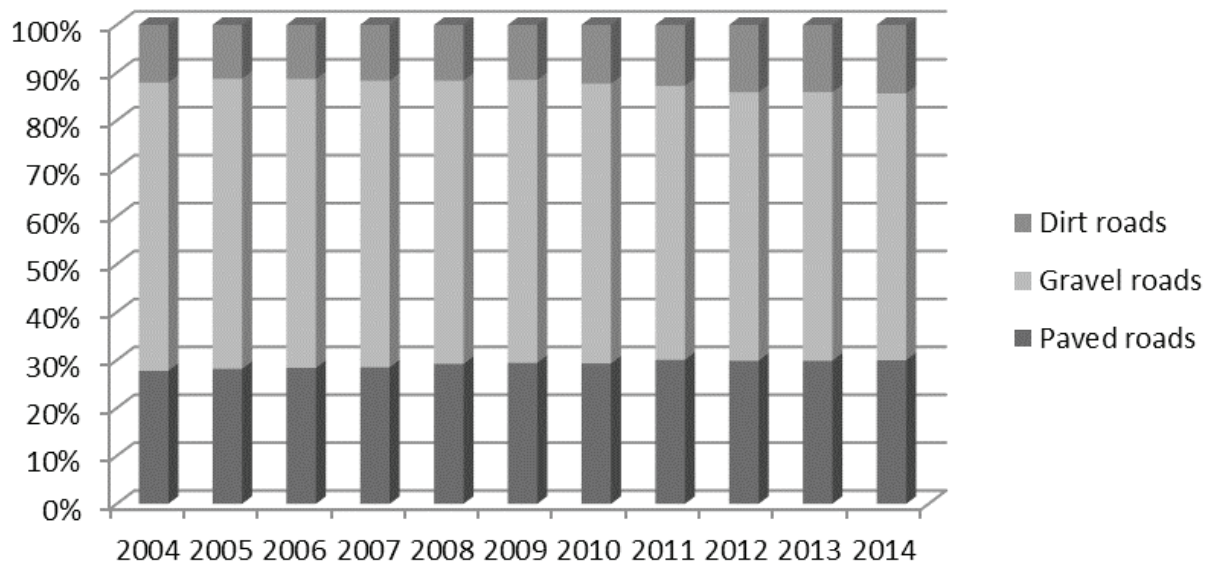

Source: Own data processing based on Road length at the end of the year.

\section{Financing of Road Infrastructure in Lithuania}

Due to capacity and importance for society and the economy, roads in Lithuania are divided into two basic categories: roads of national importance and roads of local importance. This is due to the division of responsibility for their maintenance and development between the Lithuanian Ministry of Transport and Communications and individual local governments (Act no. I-891 on Roads). Since 2002, the Road Maintenance and Improvement Program (Lithuanian: Kelių Priežiūros ir Plètros Programa - KPPP) has been the main financing instrument of the road infrastructure which fully finances roads of national importance and partly supports the maintenance and development of roads of local importance (Law on the Financing of the Road Maintenance and Development Programme of the Republic of Lithuania). It should also be added that roads of national importance are subsidized by EU funds and roads of local importance by municipal budgets as well as a special mechanism of private co-financing ${ }^{5}$. The dynamics of financing road infrastructure in Lithuania in years 2002-2015 is presented in Graph 2.

5 The purpose of the co-financing instrument for the development of road infrastructure from private means is to accelerate the modernization of roads, which usually consists of graveling dirt roads or asphalting gravel roads. Natural and legal persons can benefit from municipal budgets which, depending on the type of investment, can be up to $50-60 \%$, as determined by the documents of local governments. 


\section{Graph 2 Financing of road infrastructure in Lithuania in years 2002-2015 (in million EURO)}

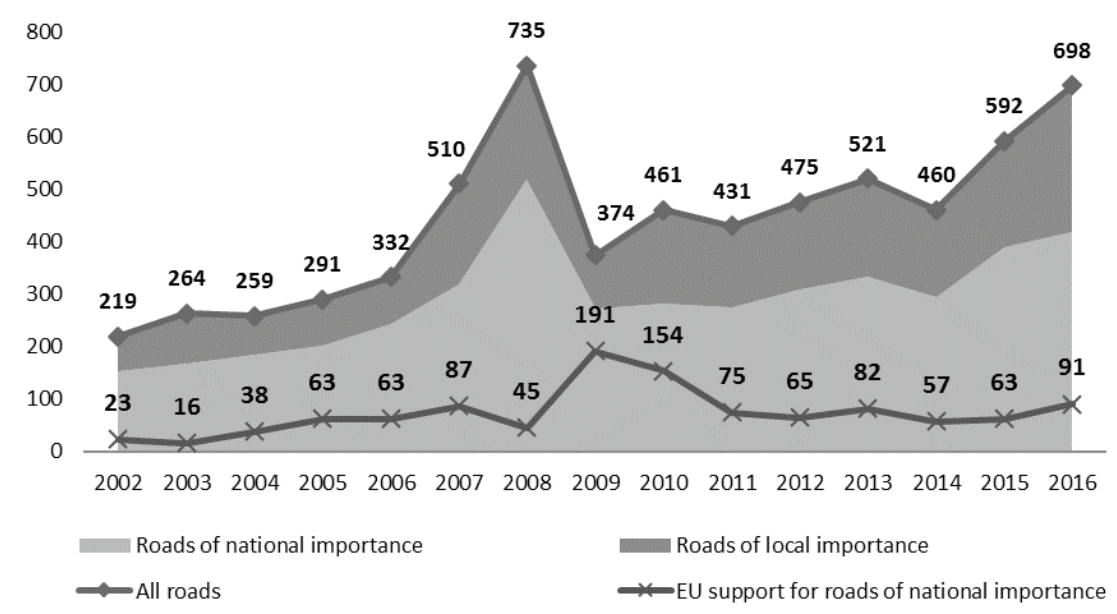

Source: Own data processing based on Expenses of the roads; Financing of national roads.

The cumulative amount of financial resources allocated for the development of road infrastructure in Lithuania in 2002-2015 amounted to nearly EUR 6 billion, of which approx. EUR 1 billion came from EU funds, approximately EUR 1 billion was classified as an expenditure of local governments and the remainder (about 4 billion euro), as a means of the Road Maintenance and Development Program, came from the budget of the State Treasury ${ }^{6}$. The analysis of the dynamics of expenditure on road infrastructure can be divided into two sub-periods, set by the financial and economic crisis, namely the years 2002-2008 and 2009-2015. In 2008, there was more than a threefold increase in expenditure: from EUR 219 million in 2002 to EUR 735 million in 2008. In 2009, a sharp decline in funding was recorded and without EU support, which was at the record level in 2009 with nearly EUR 200 million or around $50 \%$ of total expenditure, the collapse of financing would be acuter. In 2010, thanks to significant EU subsidies, although slightly lower than in the previous year, the overall trend of general pre-crisis transport support was restored. However, it should be emphasized that the increase in domestic finance was accompanied by the decline in the EU aid, with the largest drop seen in 2011, as compared to 2010 with (as much as) 79 million, which was reflected in a decrease in overall transport expenditure in 2011 compared with the year preceding by EUR 30 million. In the highlighted sub-period 2009-2015, the year 2014 can be distinguished, with both EU and domestic support decreasing by EUR 60 million.

6 Calculations based on data of the National Roads Directorate of the Ministry of Transport and Communications of the Republic. www.lakd.Irv.It, access: 30 June 2017. 
Structure of National Sources of Financing of Road Infrastructure in Lithuania

Despite this, the substantial increase in road transport subsidies in 2015 (by EUR 132 million, or nearly $30 \%$ compared to the previous year) brings hope for a further increase in the importance of motor transport for the Lithuanian economy.

In the financing structure of road infrastructure, the majority of funds are allocated to roads of national importance (the average share is about $67 \%$ of total expenditure). Support from the EU funds is of great importance here (the average share is about $18 \%$ of the total expenditure) which is allocated entirely to the development of state roads. Roads of local importance will be supported by an average of $33 \%$ of total road transport subsidies. Talking about the structure of expenditure of the development of road transport, it is worth to once again discuss the breakthrough period of 2008/2009. Namely, in 2009, the financing of state roads from the Treasury budget decreased by (as much as) 82\% (from EUR 473 million in 2009 to EUR 83 million in 2009) but thanks to EU subsidies share in expenditures on state roads which have reached (colossal) $70 \%$, this decrease was mitigated to $47 \%$. Thus, for the first time in 2009, domestic spending on national roads was lower than for local roads which continued throughout another year. Taking into account the importance of transport for the development of the Lithuanian economy, the priority of financing roads of national importance does not raise any objections, however, the deterioration of the state of local roads provokes a difficult discussion on the allocation of budget funds. There is only one answer: "Stretching the quilt will not bring results; the bigger one is needed (Rimkute, 2013: 10-13)". Therefore, it is worthwhile to analyze the existing internal sources of funding of road infrastructure and to consider the possibility of supplementing them.

\section{Internal Sources of Financing of Road Infrastructure in Lithuania}

The financing system of road infrastructure in Lithuania, as noted above, is primarily based on means of the Road Maintenance and Development Program? The source directory of the PURD budget includes (Law on the Financing of the Road Maintenance and Development Programme of the Republic of Lithuania):

1) part of the proceeds from the excise tax on the sale of gasoline, diesel, and biofuels,

2) part of the proceeds from the excise tax on the sale of LPG used by cars,

3) charges for registration of lorries in Lithuania of the total weight equal or exceeding 12 tonnes, 
4) road tolls (vignettes),

5) road user fees for non-standard vehicles (i.e. vehicles or combinations of vehicles whose axle loads and/or unloaded or loaded dimensions are greater than road limits),

6) charges for the temporary limitation of traffic on a given road or its part,

7) purpose funds of natural and legal entities, other organizations or their branches, or foreign states,

8) income from paid or recovered speeding tickets recorded by traffic enforcement cameras on the roads of national importance ${ }^{8}$.

The most significant source of income for the Road Maintenance and Development Program are the excise receipts which account for about $90 \%$ of the total budget (see Graph 3). Another significant source of financial resources is the road toll (the socalled "vignette"), whereby the budget for 2008-2016 was supplemented on average by approximately EUR 28 million with a growing tendency for their volume, although their overall structure is close to $1 / 10$ of revenue. Nearly three times less income supports the PURD budget for the registration of lorries in Lithuania whose total weight is equal to or exceeds 12 tonnes. Since 2012, additional revenue has been generated from paid or recovered speeding tickets but their size, amounting to around EUR 3 million, is of marginal importance for the PURD budget. Other sources constitute only about $0.5 \%$ of income.

\section{Graph 3 Income of the Road Maintenance and Development Program for 2008-2016 (in millions of EURO)}

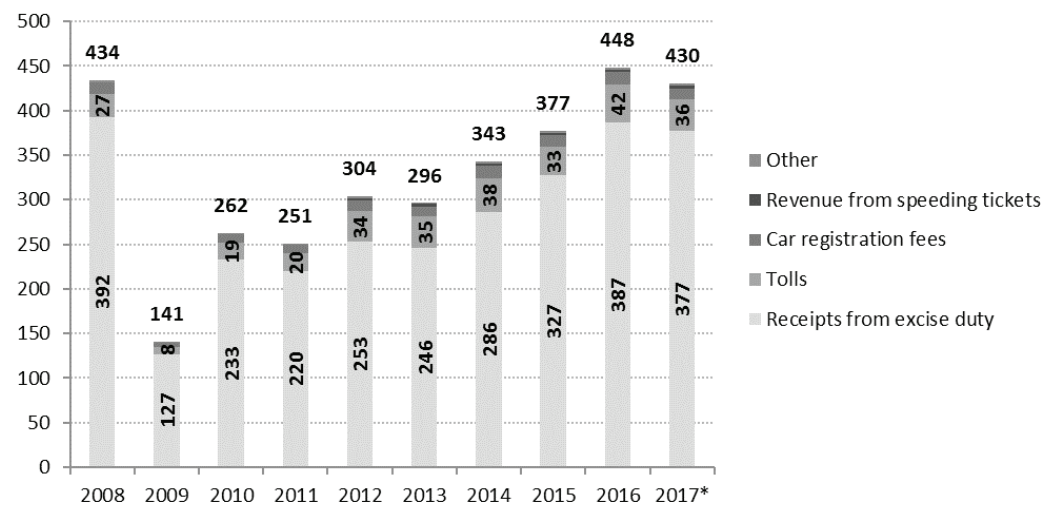

Source: Own data processing based on The funding sources of the road maintenance and development program.

8 Revenue from speeding tickets has been credited to the 2012 Road Maintenance and Development Program budget. 
Structure of National Sources of Financing of Road Infrastructure in Lithuania

Taking into account the dynamics of the size of the PURD budget, it can be seen that it was only possible in 2016 to reach the pre-crisis level. Looking for reasons for such a drastic decrease in income in 2009, it is appropriate to note that in 2008 (as much as) $80 \%$ of the total excise revenue to the State Treasury's budget on the sale of automotive fuels fed the PURD budget, while the collapse of the economy caused by the crisis resulted in the redirection of a significant portion of those funds to patch the state budget hole (see Graph 4). Despite the reduction in the statutory amount of nationwide excise tax receipts onto the PURD account, some money was missing. A particularly elusive distinction between declared and actual value was observed in 2009, which can be explained by the precarious situation of the Lithuanian economy. In the following years, this divergence has subsided, although its continued existence is causing a lack of confidence in national budgetary policy.

\section{Graph 4 The volume of fuel tax receipts to the budget of the Road Maintenance and Development Program for years 2008-2016 (as\% of total revenues from the fuel excise tax to the National Treasury budget)}

$80 \%$

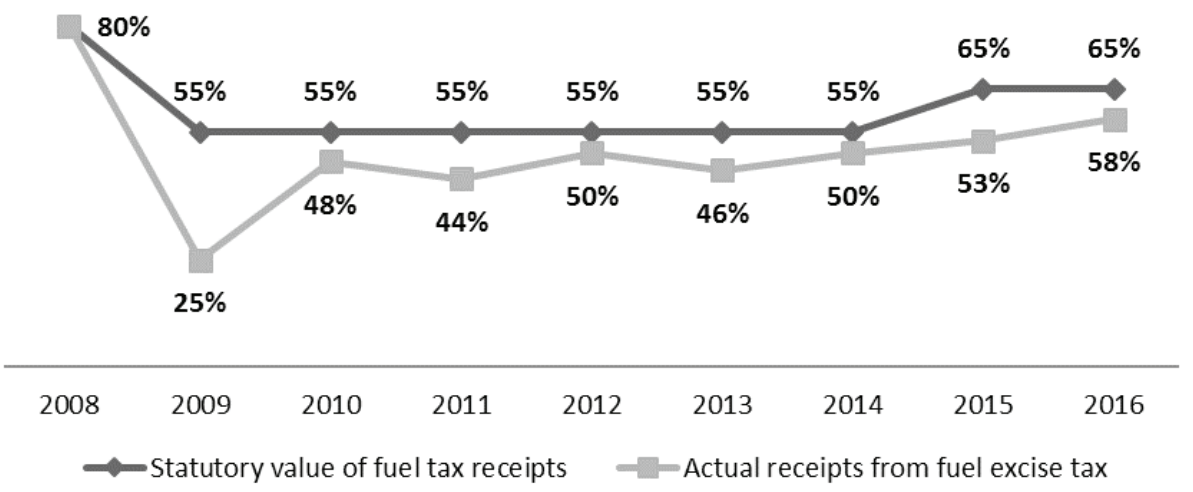

Source: Own data processing based on The funding sources of the road maintenance and development program.

Such radical policy has undoubtedly hampered the development of road infrastructure, which has deteriorated significantly over the last ten years. At present, about $1 / 3$ of the roads of national importance are in poor condition, i.e. they do not meet the minimum quality requirements. There are three main scenarios for financing road investments for the coming years, where it is noted that maintaining the current trend of increasing financial support from national funds will only lead to a deterioration of the situation, while favourable changes in road infrastructure can only be expected with a doubling or tripling of capital expenditures (Lithuanian 
Road Administration under the Ministry of Transport and Communications Director's Order).

\section{Conclusions}

Creating a financing model for transport infrastructure free from defects is in fact impossible. It is worth noting that throughout the European Union there is no way to distinguish the national transport financing system which would perfectly meet the requirements of optimality, productivity and efficiency which is grounded in "the extraordinary complexity of the process of creating and maintaining transport infrastructure, differentiated conditions of its functioning in particular countries, a chronic imbalance between the demand for its potential and its opportunities for growth" (Burniewicz, 2009: 49-50). The approach to the issue of transport charges requires taking into account the complexity of this phenomenon where a proper calculation of the charges which should take into account the marginal cost is crucial (Pawłowska, 2013: 330). It is important, however, to realize that the transport infrastructure will only be used by those users who, after costs, will find that the value of the journey exceeds them (Liberadzki, 2014: 31).

Speaking of recommendations on the reform of the Lithuanian motor vehicle charging system, we should mention the recommendation of the Director of the National Roads Directorate of the Ministry of Transport and Communications of the Republic of Lithuania on the financing of the Road Maintenance and Development Program for the period 2015-2020, which reads as follows (Lithuanian Road Administration under the Ministry of Transport and Communications Director's Order): "Larger State Treasury funding can only be expected to reinforce the Road Maintenance and Development Program from the excise tax on motor fuels up to $80 \%$ of overall excise duty (as was the case in 2008). In addition, in order to achieve the rule of user pays and polluter pays stated in the White Paper, tolls should be introduced not only for lorries but also for passenger cars." An additional remark, presented in the study entitled "Excise tax in Lithuania" is an opinion that the growth of financing of road infrastructure can be expected in the case of reducing the losses of excise tax budget on fuels resulting from the existence of a grey market which is estimated at $15-20 \%$ of the automotive fuel market, and limiting the phenomenon of "patching the budget hole" from the sources of the declared amount of excise tax to the budget of the PURD. As a result, the question remains whether the further decisions and actions of the government will favor the development of road transport in Lithuania. 


\section{References}

Ar sudarytos sąlygos efektyviai nauduoti lèšas, skiriamas vietinès reikšmės keliams ir gatvėms prižiūrèti ir modernizuoti? (Are there any conditions for efficient use of funds for the maintenance and modernization of local roads and streets?), Lietuvos Respublikos Valstybès Kontrole (State Control of the Lithuanian Republic) no. VA-P-20-11-15, 2013.

Bronik, H.: Modele finansowania infrastruktury transportowej (Transport infrastructure financing models), Zeszyty Naukowe Uniwersytetu Szczecińskiego. Seria Ekonomiczne Problemy (Scientific Papers of the University of Szczecin. Series of Economic Problems of Services) no. 32 (2009).

Burniewicz, J.: Wymiana dobrej praktyki europejskiej $\mathrm{w}$ zakresie rozwoju infrastruktury transportowej (Exchange of European good practice in the field of transport infrastructure development), Zeszyty Naukowe Uniwersytetu Szczecińskiego. Seria Ekonomiczne Problemy (Scientific Papers of the University of Szczecin. Series of Economic Problems of Services) no. 32 (2009).

Kupiec, L., Truskolaski, T., Gołębiowska, A.: Gospodarka przestrzenna (Spacial economy), Infrastruktura techniczna (Technical infrastructure), Bialystok: Bialystok University Press, 2005.

Liberadzki, M.: Finansowanie infrastruktury transportowej w Polsce. Innowacyjne instrumenty finansowe. Publiczno-prywatne partnerstwo (Financing transport infrastructure in Poland. Innovative financial instruments. Public-private partnership), Warszawa: The Warsaw School of Economics Press, 2014.

Pawłowska, B.: Zrównoważony rozwój transportu na tle współczesnych procesów społecznogospodarczych (Sustainable transport development on the background of contemporary socio-economic processes), Gdańsk: The University of Gdansk Press, 2013.

Ratajczak, M.: Infrastruktura w gospodarce rynkowej (Infrastructure in a market economy), Poznań: The Poznan University of Economics Press, 1999.

Rimkutè, B.: Painūs finansavimo heliai (Bumpy funding paths), Statyba ir Architektūra (Construction and Architecture) no. 6 (2013).

Road Statistics Yearbook 2016, Brussels: European Union Road Federation, 2016.

Statistical pocketbook 2016: EU transport in figures, Luxembourg: Office of the European Union, 2016.

Wojewódzka-Król, K., Rolbiecki, R.: Infrastruktura transportu (Transport infrastructure), Gdańsk: The University of Gdansk Press, 2011.

Automobilių kelių ilgis metų pabaigoje (Road length at the end of the year), Lihuanian Department of Statistics. www.osp.stat.gov.lt.

Bendroji pridètinè verte pagal ekonomines veiklos rūšis (Gross value added by economic activity, Lihuanian Department of Statistics. www.osp.stat.gov.lt.

Išlaidos keliams (Expenses of the roads), Lihuanian Department of Statistics. www.osp.stat.gov.lt. 
Kelių priežiūros ir plètros programos finansavimo ịstatyme nustatyti programos finansavimo šaltiniai (The funding sources of the road maintenance and development program), Lithuanian Road Administration under the Ministry of Transport and Communications). www.lakd.lrv.lt.

Krovinių ir keleivių vežimas visų rūšių transportu (Transportation of goods and passenger by all types of transport), Lihuanian Department of Statistics. www.osp.stat.gov.lt.

Land cover statistics, in: Eurostat. www.ec.europa.eu.

Roads, paved (\% of total roads). www.tradingeconomics.com/country-list/roads-paved-percent-oftotal-roads-wb-data.html.

Valstybinès reikšmès kelių finansavimas (Financing of national roads), Lithuanian Road Administration under the Ministry of Transport and Communications. www.lakd.lrv.lt.

LT: Act no. I-891 on Roads.

LT: Act. no. VIII-2032, on the Financing of the Road Maintenance and Development Programme of the Republic of Lithuania, as amended.

LT: Act no. XII-2144 on the methodology of determination of municipal budgetary revenues.

LT: Ministry of Transport and Communications Director's Order on 2015-2020 road maintenance and development program of the Lithuanian Republic), no. V(E)-19. 


\title{
PUBLIC INTEREST IN TAXATION OF PROFESSIONAL SPORTSMEN IN THE CZECH REPUBLIC ${ }^{1}$
}

\author{
ROMAN VYBÍRAL ${ }^{2}$
}

\begin{abstract}
This contribution discusses the development of case law relating to the taxation of income from professional sportsmen in the area of collective sports in the Czech Republic. The Supreme Administrative Court has, over time, published a number of controversial decisions, which, instead of clarifying and unifying the existing practice, brought new issues into this area, and it should be pointed out that these are often rather controversial and a question arises whether conclusions arising from those decisions are in public interest.
\end{abstract}

\section{Keywords}

Sport; professional sportsman; income tax; Supreme Administrative Court

JEL Classification: H24, K34, Z23

\section{Introduction}

The field of professional sport has undergone in recent years a very interesting development, which led to the absolute loosening of the rules for taxation of income of professional sportsmen. As a result of this development, the choice of the tax regime is now in the hands of athletes, resp. sports clubs. Currently, there are three basic income tax regimes where athletes can act as employees, as persons running independent profession or as persons carrying on a trade.

1 This paper has been elaborated within the programme "PROGRES Q02 - Publicization of Law in the European and International Context" which is realized in 2018 at the Faculty of Law of the Charles University.

2 Assistant Professor of Financial Law and Financial Science, Department of Financial Law and Financial Science, Faculty of Law, Charles University, Czech Republic. The Author specializes in tax law and insurance law. He is the author or co-author of more than 30 reviewed articles and books. He is a member of Information and Organization Centre for the Research on the Public Finances and Tax Law in the Countries of Central and Eastern Europe. Orcid.org/0000-0002-1112-408X. Contact email: vybiralr@prf.cuni.cz. 
This consequently leads to the fulfilment of the proverb duo cum faciunt idem idem non est. It has to be said that the field of professional sport shows signs of deliberate misinterpretation of the text of the legal norm in order to choose a more advantageous legal regime by the contractual parties. This thesis is directly linked to the concept of tax evasion largo sensu (Almendral, 2005: 560 et seq.).

The main purpose of this contribution is to analyse the relevant case law concerning the status of professional sportsmen in the field of individual income tax, to highlight the fundamental lacks of the individual decisions and, last but not least, to assess whether this case law is in the right course and whether it is in line with the public interest represented here by the interest in the proper taxation of the income of professional sportsmen. The contribution is mainly based on the text of legislation, case law, and research publications.

\section{Triple Standards for Sportsmen}

Dichotomy (nowadays rather trichotomy) in perception of the same conduct or behaviour is not only discouraging for the addresses of legal norms to trust in a uniform and compact legal system, but at the same time such a contradictory situation infringes the principles of legal certainty and foreseeability of law (Constitutional Court: I. ÚS 420/09). In addition, it degrades, vulgarly said, legal norms as a whole to a lower level. Naturally, the law cannot be utterly perfect and indisputable, but if it goes so far that the legal gaps are artificially created, moreover when that happens under the guise of court decisions of the highest judicial instances in the country, the situation is rather alarming.

This very brief and theoretically focused passage stems from the current practice and, if nothing changes, it is expected to be future practice as well, in the area of collective sports when players perform the exact identical activity, yet their tax regime may be divided into more (specifically three) categories. The primary cause of this is the case law, although it is also possible to talk about a few minor mistakes made by the legislator. In the Czech Republic we are still in a space-time where court decisions are not formally binding, however, it is not possible to deny them certain material binding effect, especially if they are so-called constant. In the decision of Supreme Administrative Court of 13 July 2017, no. 6 Afs 278/2016, which will be further analyzed in this text, just a single judgment was enough to make the case law "constant". Apparently, in order to speed up the process of creating constant case law, which would probably, in the current case law of the Supreme Administrative Court regarding taxes, just delay the inevitable conclusion. 
Financial Administration changed its previous practice on the basis of a single decision, when it stated in its opinion of 27 July 2017 that "(...) on the basis of this judgment it adapts its administrative practice of taxation of professional sportsmen, particularly in so-called "collective" sports (football, hockey, handball, etc.), i.e. it will be based on the fact that the activity of a professional sportsman can be performed pursuant to Sec. 7 of the Income Taxes Act, either as a trade, on the basis of the relevant trade license, when the income from this activity represents income from the trade according to Sec. 7 subsection 1 paragraph b) of the Income Taxes Act (...)" (Financnisprava.cz). In other words, the Financial Administration expressly admits the double regime in the taxation of these sportsmen' income.

The question whether a sportsman can officially play for a club also formally in the position of a dependent person seems to be resolved (Morávek, Štefko, 2013: 354 et seq.). In its earlier decision of 29 November 2011, no. 2 Afs 16/2011, the Supreme Administrative Court addressed this issue quite ambivalently, when it de facto stated that due to the inappropriately chosen terminology of the relevant legal regulation, it is up to the contracting parties, i.e. sportsmen and clubs, which regime of taxation they are going to choose. Nevertheless, such approach can only succeed if the legislation is truly unclear. Even if the legislation explicitly provides the choice of several regimes, it is always essential to examine the material nature of the activity in question, not just the formal fulfillment of certain parameters. In other words, if the legislation states that an object may be "green" or "blue", then logically there should not be a situation when the object is materially "blue", but outwardly appears as "green". There is an a priori question whether the case law of the Supreme Administrative Court analyzed below is not in stark contrast to the mentioned principle. Moreover, if this case law reaches a conclusion that the object may be de facto also "red".

\section{Case Law Defining the Dependent Activity}

In the next two chapters, the key decisions of the Supreme Administrative Court will be analyzed. These decisions in their entirety currently create the framework in which sportsmen operate. As indicated in the previous paragraphs, professional sportsmen in the area of collective sports and their clubs have in principle three options how to arrange the internal organization of their relationship, including the tax regime.

I will first mention the judgment of the Supreme Administrative Court of 1 June 2005, no. 2 Afs 176/2004, in which the court dealt with the characteristics common to the employment, service and member relationship. The reason was (and for that matter still is) the diction of the provision of Sec. 6 Subsec 1 par. a) of 
Act no. 586/1992 Coll., on Income Taxes, as amended, which, when determining the so-called dependent activity, also counts with relationships similar to those mentioned above in cases when the taxpayer is obliged to obey the player's orders. Specifically in this context the court states that "this legal relationship arises between the subjects to which it relates, most often on the basis of a bilateral legal act (typically employment contracts), that is to say the same expression of will of the contracting parties (...) it is necessary to always consider its real, by the parties intended and wanted content of the relationship, and not just the outside (...)." This is a manifestation of the principle of material truth, which is nowadays quite standard in the field of tax law.

As another important feature of employment, service and member relationship, the court states that "this relationship is established as a relationship of a lasting nature characterized by the fact that it is not consumed on a one-time basis (...)." At the same time, the court adds that "another significant characteristic of employment, service, and member relationship is that the person, who is providing some specific performance (i.e. in the above-mentioned relationships, certain work activity) is essentially obliged to follow the instructions of the employer or superior. This obligation must be directly established, i.e. as the subject matter of the legal relationship between the two parties."

The Supreme Administrative Court has moved further in this context in its earlier judgment of 31 March 2004, no. 5 Afs 22/2003. The court already clearly distinguishes the term "dependent activity" according to the Income Taxes Act from "dependent labor" under the Labour Code. To this, the court states that "the term dependent activity used in the Income Taxes Act is not identical with the labor law term of dependent labor (hiring labor force for remuneration). The legal relationship from which the income is generated is not decisive for the qualification of income subjected to the provision of Sec. 6 of Act no. 586/1992 Coll. for the purposes of income taxation. The substantial characteristic of dependent activity is the fact that it is not carried out independently, i.e. in one's own name, on one's own account, and on taxpayer's own responsibility, but on the contrary following the instructions of the person, who pays the remuneration for the work provided (the payer)".

The court further discusses the individual characteristics of the dependent activity such as dependence, consideration, economic mutuality etc. (Sluka, 2007: 69 et seq.). The very important conclusion of the court is that "the above-described characteristics must be met simultaneously in a relationship that is supposed to be analogous to the employment, service and member relationship; when just one of the characteristics is absent to a substantial extent in a given relationship, it cannot be considered as analogous to the employment, service and member relationship". It is 
absolutely crucial to use the concept of meeting all the characteristics, although not always to a full extent. The court expressly states that one (or more) characteristics can be overshadowed, but not to a substantial extent (Vybíral, 2013: 12 et seq.).

\section{Case Law Concerning Professional Sportsmen}

I consider the conclusion of the Supreme Administrative Court mentioned in the previous paragraph to be very significant also with regard to the discrepancy between this conclusion and the subsequent case law of the court when the court expressly relativizes the conclusion so that it would achieve the apparently intended goal in its decisions. This turnover in the court opinion is evident especially in the judgment of 29 November 2011, no. 2 Afs 16/2011 and in the judgment of 13 July 2017, no. 6 Afs 278/2016. In both of the mentioned decisions, the court reaches the conclusion that the legal regulation of the status of professional sportsmen is not enshrined uniformly in the Czech Republic and applying the principles of in dubio mitius and in dubiis contra fiscum it is up to the subjects of taxation to decide, which taxation regime is more suitable for them.

In case of the first mentioned decision of the Supreme Administrative Court of 29 November 2011, no. 2 Afs 16/2011, it is necessary to highlight two disputable points. The first disputable point is the statement of the court that "it is obvious that the activity of sportsmen is very close to the conceptual definition of dependent activity, nevertheless it does not achieve its intensity." However, the court did not evaluate the individual aspects of the activity of sportsmen thoroughly enough to establish the degree of intensity. At the same time, it might be that the court did not have in mind the term "dependent activity", but more likely, the term "dependent labor", since it did not refer to any of its previous case law concerning dependent activity. This conclusion is also supported by the statement of the court following the above-mentioned excerpt from the judgment, where the court states that "(a) partial conclusion can be reached that the activity of professional sportsmen is not easily subsumable under the term "dependent labor" pursuant to the Labour Act". I could not agree more with this conclusion, however, the court still does not address the issue of dependent activity, or rather the extent of absence to which the individual characteristics are not met. Therefore, I consider the above-mentioned judgment full of gaps and in many aspects in contradiction with previous case law.

The most current decision of the Supreme Administrative Court in the field of taxation of professional sportsmen' income is the judgment of 13 July 2017, no. 6 Afs $278 / 2016$. This judgment can be perceived as greatly controversial and perhaps even rather absurd. In this judgment, the court is not at all considering the key issue whether the sportsmen in the area of collective sports meet the individual 
characteristics of dependent activity established by the court's previous case law, but is rather concerned with the question whether the status of these sportsmen can be considered a trade. Instead of stabilizing the situation in the area of professional sports in the past twenty years or so, the Supreme Administrative Court allowed for the relevant opening of completely new category primarily by using very problematic and wholly substitutable arguments.

After the court had considered the individual characteristics of trade, it reached quite a Solomonic conclusion when it states that "in the case of a professional football player the individual characteristics of trade are not met in their pure form. However, the legal regulation clearly states that the content of the trading activity operation of sports facilities and organization of sports activities also includes the activity of performing sportsmen carried out independently for profit". It is as if the court indicated by this conclusion that meeting the characteristics of trade is de facto not necessary and it is enough that some activity is close to these characteristics. Moreover, the court preferred form to content when it stated that "in this context, it is important to mention that the respective Trade Licensing Office has in fact issued the authorization to the trade activity Operation of sports facilities and organization of sports activities". Nevertheless, given the scope of this trade activity, we cannot automatically assume that it would also, without further ado, include the performance of sports activity.

The Supreme Administrative Court mentions a wide variety of other arguments that cannot be closely analyzed given the extent of this article. Materially speaking it is quite clear that in this judgment the court gave its blessing to the existence of the so-called "švarcsystém" (i.e. misclassification of employees as independent contractors) in the area of collective sports and took the issue of professional sportsmen' taxation to a different, entirely absurd level.

\section{Conclusions}

I am convinced that the case law analyzed instead of solving the controversial situation in the field of professional sport has brought new controversial issues. The fact that athletes and clubs will be able to choose the tax regime that is the most advantageous for them is undoubtedly not in line with the public interest.

It is only a matter of time when the Czech Republic will incline to the practice of all developed European countries and it will legally explicitly lay down the status of professional sportsmen, for example, in a special legal regulation. The second option is that the Czech Republic will still remain at the level of developing countries and 
the approval of the so-called "švarcsystém" in the field of the sport by the Supreme Administrative Court will expand into wider spheres of human activity.

\section{References}

Almendral, V.R.: Tax Avoidance and the European Court of Justice: What is at Stake for European General Anti-Avoidance Rules, INTERTAX no. 12 (2005).

Gábriš, T.: Športové právo (Sports Law), Bratislava: Eurokódex, 2011.

Križan, L.: Mal by mat' profesionálny futbalista na Slovensku postavenie zamestnanca? (Should be a professioal sportsman an employee in Slovakia?), Bulletin slovenskej advokácie (Bulletin of Slovak Advocacy) no. 3 (2009).

Morávek, J., Štefko, M.: Profesionální sportovec v kolektivních sportech (Professional sportsman in collective sports), Časopis pro právní vědu a praxi (Journal for Legal Science and Practice) no. 3 (2013).

Sluka, T.: Profesionální sportovec: právní a ekonomické aspekty (Professional Sportsman: Legal and Economic Aspects), Praha: Havlíček Brain Team, 2007.

Vybíral, R.: Analýza judikatury vztahující se $\mathrm{k}$ postavení profesionálních sportovců $\mathrm{v}$ oblasti kolektivních sportů v České republice (Analysis of case law concerning the status of professional sportsmen in the field of collective sports), Jurisprudence no. 1 (2013).

Sdělení GFŘ k rozsudku NSS ve věci zdaňování příjmů profesionálních sportovců (Opinion of the GFǨ to the Judgement of the Supreme Administrative Court about taxation of professional sportsmen), 2017. www.financnisprava.cz.

CZ: Act no. 586/1992 Coll., on Income Taxes, as amended.

CZ: Act no. 262/2006 Coll., the Labour Code, as amended.

CZ: Constitutional Court: I. ÚS 420/09.

CZ: Supreme Administrative Court: 5 Afs 22/2003.

CZ: Supreme Administrative Court: 2 Afs 176/2004.

CZ: Supreme Administrative Court: 2 Afs 16/2011.

CZ: Supreme Administrative Court: 6 Afs 278/2016. 



\title{
FORMAL VALUES OF LAW WITH EMPHASIS ON RECENT CASE LAW OF THE TAXATION OF ATHLETES ${ }^{1}$
}

\author{
MICHAL LIŠKA ${ }^{2}$
}

\begin{abstract}
This contribution deals with the problem of taxation of athletes. The hypothesis of this paper is the question whether the tax rules governing the taxation of athletes fulfill the appropriate formal quality of the legal regulation (formal values of law) required in a democratic legal state or not? The methods used for answering this hypothesis are the analysis of the law and selected jurisprudence of the higher courts; a comparison of the legal position of the athletes in the Czech tax law with European soft law model. Throughout the paper, syntax procedures will be used to create partial conclusions for the purpose of the final thesis. Although the position of collective athletes is concerning the matter of tax expenditures surrealistic, nevertheless we can see deep rationality in the motives of Supreme Administrative Court. The hypothesis of the paper needs to be answered positively, the regulation of the taxation of athletes in its current form does not fulfill the formal values of law, especially it fails in the perspective of predictability. Therefore, who knows if the campaign of the courts against the tax rules, which are devoid of formal values, will not continue.
\end{abstract}

\section{Keywords}

Taxation of athletes; formal values of law, income tax

JEL Classification: K34, H71, Z23

\section{Introduction}

Tax law is connecting every individual in the state and through the duty to assess taxes is, on the one hand, realized the will of the people to secure the running of

1 This article is the outcome of the research projects: MUNI/A/1359/2016 (Reformation of income taxes).

2 Postgraduate student at the Faculty of Law, Masaryk University at the Department of Financial Law and Economic. The Author specializes in tax law. Contact email: michaliska@mail.muni.cz. 
their own state (in the most general idea), on the other hand, it faces the principle of democratic state where the majority opinion must prevail. Tax laws should primarily be conceived within a long-term social consensus. Otherwise, it becomes an instrument of the ruling - the instrument justifying the means. A practical application of unstable law always causes serious problems.

As an example, the taxation of professional sportsman performers (athletes) can be used. On 13 July 2017, the Supreme Administrative Court ruled that David Lafata, a former football representative, could claim a $60 \%$ flat-rate tax expenditures as a professional footballer (the Financial Administration hold the view that the athletes of collective sports are allowed to use only the 40 percent of lump-sum rate). The judgment in case Lafata was based on the leitmotif of the previous Supreme Administrative Court's judgment (Supreme Administrative Court: 2 Afs 16/2011), in which the court criticized the absence of precise legal regulation relating to the performance of professional sport. The case law pointed out one of the Czech nuisance - a very complicated and confusing legal tax regulation.

Nowadays, the issue of the taxation of athletes is elaborated particularly in decisions of regional courts and in three judgments of the Supreme Administrative Court, by academic environment the topic was subject of research of M. Radvan (2014: 6070), J. Morávek and M. Štefko (2013: 354-358), T. Sluka (2007: 199) and R. Vybíral (2013: 12-17). However, the hypothesis of the paper was not explicitly "touched" by anyone of them.

\section{Origin and Concept of Formal (Values of) Law}

"Everyone knows what the law is, but no one can define it satisfactorily" (Knapp, 1995: 42). R. Zippelius responds (characteristically to the contemporary attitude of society), in the introduction to his work Das Wesen des Rechts, to the idea of St. Augustine. He proclaims that "(to) discover the law in our world, we do not need to know the a priori definition of law at all" (Zippelius, 1997: 133). Does it right that the system tiding human beings to act somehow was not only discoverable but also define, respectively understandable, doesn't it? Human life is large, if not whole, pervaded and governed by law. According to classics, the law is writhed by an endless war between three pillars of law - purposes of law - justice, legal certainty and effectiveness/purposiveness (Radbruch, 2012: 31). In fact, the main struggle is led between the individual interests represented by justice and the public welfare represented by purposiveness in the form of an effective and reasonable arrangement of things to achieve general well-being (Radbruch, 2003: 216). Legal certainty, hand in hand with the proportionality test in ad hoc cases, balances this clash. 
The application of the test of proportionality in tax law is very limited (Constitutional Court Pl. ÚS 29/08) and so as the main arbitrator in the tilt between the justice of the interests of the individual and the general interest stays legal certainty. Legal certainty is based on the idea of the practical possibility of planning and anticipating the consequences of its future actions - generally speaking, human life (Raz, 1986: 434). Predictability in this purest form has been placed in law from time immemorial, yet the legal certainty itself is connected with the Rule of law. ${ }^{3}$ German legal philosophy and $19^{\text {th }}$-century theory that build solid future foundations for Rechstaat, i.e. the law realistically applicable and practically enforceable, puts emphasis on the formal quality of law from which the fairness of content of the law can be born.

For the purposes of this paper, Jhering's concept of formal law will be used. Formal values of law were considered to be an inseparable part of the democratic Rule of law state, because without these values the very existence of the law, especially its acceptance and applicability, would not be guaranteed (Jhering, 1887: 588). The law, for the purpose of staying law (normative system), contains some immanent (with its nature necessarily tied) values: order, predictability, freedom from arbitrariness, legal equality, legal security and legitimacy (Summers, 2013: 30).

These values are in "law in action" marginally mentioned for example by the Constitutional Court of Czech Republic in its last "tax judgment" (Constitutional Court Pl. ÚS 9/15), specifically in the thought sequence devoted to the proper form of tax regulations. Tax rules "should at the same time be sufficiently precise, intelligibility and applicable in practice (by both taxpayers and body od Financial authorities). The need for practical application of these rules is reflected in the fact that the characteristics of tax structural elements can be adequately typified and flatted by the legislator". Requirements put on law are inspired by the praxis of application of the laws. The aspect of the precise tax law is connected with the restriction of the form of law by principle nullum tributum sine lege. In practice, the intelligibility ${ }^{4}$ is secured by the principle in dubio pro mitius - the guardian of free will and human freedom senso largo. The last requirement is quite indefinite and rather unexplored by legal praxis, even though it is based on the very conditions for enforceability of law 5 .

3 Even the emperor Ferdinand I. used Latin proverb "Fiat iustitia, pereat mundus" in non-ironical robe.

4 The statement of matters of facto $f$ the lawmaker directly (excluding the necessity of inference or argument to arrive at the meaning) and in such appropriate terms, so arranged, as to be comprehensible by a person of common or ordinary understanding.

5 The applicability of law in practice is based on the condition of the Rule of law formed by the will of the majority. If the law was not applicable in practice, it is not "usable" law, and not only for the impossibility of actually carrying out the imposed obligations but above all for the socially unacceptable of the nature of its content. 


\section{Taxation of Athletes in the Czech Republic and UEFA Model}

The Income Tax Act was created in former times when Czechoslovakia was still existing $^{6}$, but its constant changes led to the current state which is best described in the first sentence of the summary and evaluation of the facts of the Supreme Audit Office presented after inspecting aspects of the income tax of natural persons: "The Income Tax Act is unclear..." (Supreme Audit Office: 2017). On the example of the taxation of athletes can be seen how far the possible consequences of the lack of clarity of the law and strong judicial fight against this uncertainty can go.

The taxation of athletes in the European context has very clear outlines. An athlete is an employee of the club. As a textbook example of European standards, we can use Memorandum of Understanding between the Union des Associations Européennes de Football and the Fédération Internationale des Associations de Footballeurs Professionnels "FIFPRO Division Europe" (hereinafter "Memorandum") (Memorandum: 2007).

By the Memorandum on the one side, the club is obliged to ensure salary; other benefits; medical and health insurance for accident and illness; pension fund/social security costs; reimbursements for expenses incurred by the player; paid leave (holidays) $^{7}$ or mandatory insurance coverage for the player for illness and accident and regular medical/dental examination as well as medical/dental treatment with qualified personnel during football duties. On the other side the player is obliged to play matches to the best of his best ability, when selected; participate in training and match preparation according to the instructions of his superior; to maintain a healthy lifestyle and high standard of fitness; comply with and act in accordance with club officials' instructions (reasonable; e.g. to reside where suitable for the club); attend events of the club (sporting but also commercial ones); obey club rules (including, where applicable, club disciplinary regulations, duly notified to him before signing the contract); abstain from participating in other football activities, other activities or potentially dangerous activities not prior approved by the club and which are not covered by clubs' insurance; take care of the property of the club and to return it after termination of the contract; immediately notify the club in case of illness or accident and to not undergo any medical treatment without prior information to the club's doctor (except in emergencies) and to provide a medical certificate of incapacity; not to bring the club or football into disrepute (e.g. media statements); not to gamble or undertake other related activities within football and others.

6 There was a broad public consensus on the creation of basic laws and so their legitimacy is very strong.

7 The minimum is four weeks in each 12- month period. Periods of paid leave must be agreed by the Club in advance and must be taken outside the regular football season. It has to be ensured that at least two weeks are taken consecutively. 
The standardization regulation of the relationship between the player and the employer shows typical signs of dependent work (Liška, 2016: 103-126). The laborlaw protection of athletes in Europe even goes far beyond the protection provided in labor-law relations in the Czech Republic.

The independent work of dependant professions is connected with the misclassification of employees as independent contractors in the Czech legal system, which is a very simplified way supports dependant form of the work as the default form of work. It aimed to maintain the labor-law protection of dependent person against the employer's (cooperators) will.

However, mentioned default setting of the Czech labor-law system (and also taxlaw system) are colliding with tax-law jurisprudence which prefers the "mutual expression of the parties' will" over the content of the contract (material truth) (Šimka, 2014: 6-13). In the legal practice of taxation of athletes, the text of the law has been "bridged" 8 by the mutual expression of will through the "court complaint" against the lack of clarity of the legal regulation (Supreme Administrative Court 2 Afs 16/2011). The Supreme Administrative Court, while leaving the untouched contractual protection of athletes, carries out all the tax-law costs associated with the provision of this protection to the athlete, including "business risk", which is also covered by contract clauses and are typical for labor-law protection connected with the taxation of that dependent work. The only logical explanation for the above mentioned is the lack of formal qualities of tax-law regulation which considers the athlete to be subjects of dependent activity under Sec. 6 of the Income Tax Act.

\section{Formal Values of Law the Case of Income Tax Act v. the People}

The lack of clarity of the legal regulation of the taxation of athletes according to the Supreme Administrative Court (Supreme Administrative Court 2 Afs 16/2011) results from the factual absence of a private-law cause (economic reason) of taxation. Athletes are unclear employment/business category in the civil law and law generally. The Court's approach to the taxation of athletes is based on the following: If you, legislator, do not regulate this, we will accept the tax entity's interpretation, if it is interpretatively achievable. ${ }^{9}$ After the intervention of the court, the legislator has always the choice: he will adjust the certain area or impliedly agree with the opinion of the court, so he will leave the regulation in its current state. In the case of athletes, the Czech legislator approached the second option.

\footnotetext{
8 Although the Income Tax Act does not explicitly mention the taxation of athletes, it is necessary to take into account the material characteristics of the activity.

9 Bounds and interpretative limits of principle in dubio pro liberate. Cf Kokeš and Pospišil, 2009: 312.
} 
Formal values of the Income Tax Act have been questioned, in addition to the aforementioned Supreme Audit Office, by the Constitutional Court in the judgment concerning the VAT control statement, where, among other things, court reminded that the form submission ${ }^{10}$ has no support in the law, respectively requisites of the form are formulated so much widely (the prescribed data necessary for tax administration) that they are unpredictable to the taxpayer.

The taxation of athletes is also related to the predictability of taxation itself. In the case law (Supreme Administrative Court 6 Ads 88/2006) as well as in the legal theory of public law, great emphasis is placed on the predictability of law in the form of the existence of steady administrative practice consisting in the application, respectively non-application of law in a certain way. ${ }^{11}$ If the application is connected to a change in the view on the taxation of a particular subject(s), it is always advisable to ask the question whether this sudden change is predictable or not, respectively made in a predictable manner. For example, in connection with the imposition of a surcharge that is within the meaning of the Court's of Justice of the European Union case-law a criminal sanction (European Court of Human Rights 7356/10), it is always necessary to keep in mind that the requirements of Art. 7 of the Convention are fulfilled only and only if the national regulation of the crime is foreseeable, what means that an individual must be able to meet the meaning of the relevant provisions and to foresee the consequences of its breach (European Court of Human Rights 37571/97; European Court of Human Rights 17862/91 or European Court of Human Rights 32492/96; 32547/96; 32548/96; 33209/96 and 33210/96). Therefore, blank spaces of the law must always be colored before application, either green or red.

\section{Reasons for Additional No-Taxation of Athletes}

It was stated at the beginning that the courts found that in Czech law the taxation of athletes is not clearly defined. This consideration should be enriched by the fact that athletes were not mentioned in the explanatory note to fill out the forms of the tax return, nor was the issue mentioned in the official statement of any of the credible representatives of the "fiscal system". There was no D-instruction before the action "additional taxation of athletes" and the sanction did not meet criteria created by the pan-European principle nulla poena sine lege certa (Klip, 2011: 69). ${ }^{12}$

10 The only form of filing a tax return on the income tax of natural and legal persons acceptable by Financial administration.

11 This creates a law in the material sense (see: Kühn, 2016: 205-213).

12 In the case C-308/06 Intertanko general advocate says: The principle of legal certainty requires, in particular, that rules should be clear and precise, so that individuals may ascertain unequivocally what their rights and obligations are and may take steps accordingly. In connection with criminal offences and penalties it is given concrete expression by the principle of legality (nullum crimen, nulla poena sine lege) [...] This principle implies 
Taxpayers who self-assessing tax-law regulations are common people ${ }^{13}$ to whom the legislator, in part as well as the executive power ${ }^{14}$, has a duty. Duty to create a comprehensible, certain and practically applicable system of rights and obligations. ${ }^{15}$ In the area of the taxation of athletes, state representatives failed in fulfilling abovementioned requirement, even after prior notice by the judicial power.

\section{Some (Unintended) Effects of the Judicial Change of the Taxation Régime}

The taxing of athletes as independents contractors finds justification in formal values of law and their place in Czech tax entropy. However, if the court is going against the profiscal meaning of the law, even for the sake of protection of individuals, the difficulties in the legal application of the issue arise. In the Czech income taxes, troubles are always more or less connected with flat-rate tax expenditures.

Flat-rate tax expenditures have been for a long-term grateful topic in the Czech Republic for political and scientific discussion (Macháček, 2010: 288; Pelc, 2011: 204). Flat-rate tax expenditures could be described as averaging of real expenditures spent in the performance of a certain non-dependent activity in the form of legal fiction. In a case where a typically dependent activity, such as professional football, "reach for" flat-rate tax expenditures, absurd situations can occur.

The $40 \%$ or $60 \%$ tax expenditures covering the same expenses twice, although the expenses have been spent only by one of the contractual party (the player or the club). The player fictitiously uses them for jerseys, air tickets, trainers, masseurs, etc., but in fact, these services are paid by the club. Of course, the situation is related to the wrong wording and setting of the law that does not foresee this situation, since the application of flat-rate tax expenditures is not connected with the obligation to save an audit trail. So there is a place for application of one expenditure twice, respectively by two taxpayers.

that legislation must define clearly offences and the penalties which they attract. That condition is met in the case where the individual concerned is in a position, on the basis of the wording of the relevant provision and with the help of the interpretative assistance given by the courts, to know which acts or omissions will make him [...] liable.

13 In connection with the predictability is talked about criterion the prudent trader (see Court of Justice of the European Union 52/81 or Court of Justice of the European Union 74/74).

14 At this point is no choice but to recall the words of Radbruch: "The will of the lawmaker is not a method of interpretation, but rather the goal of interpretation and the result of interpretation, the expression for an priori indispensability of a systemic concordant interpretation of the whole legal system. It is for that reason possible to declare as the intention of the lawmaker something which was never present as the conscious will of the author of the law. The interpreter must understand the law better than did the person who created it; the law can be wiser than its author - it really must be wiser than its author" (Radbruch, 2003: 107). 
The past praxis, related to the first decision on the taxation of athletes, has created a sort of status quo. Collective athletes "fell to" a flat-rate of $40 \%$, an individual to a flat-rate of $60 \%$. This has solved the ills of diametrically different levels of the real costs of collective and individual athletes, but it is no longer actual nowadays (Radvan, 2017). To what extent new praxis is more likely similar to reality is at the discretion of each of us.

Successive amendments to the Income Tax Act caused that in the Czech Republic was set insurmountable upper rate of the flat-rate tax expenditures to CZK 1,200,000 per year, which particularly limits the possibility of double application of the flatrate expenditures.

\section{Conclusions}

The tax law should be the most transparent branch of law. It should typify the situation, clearly state the reasons for amendments and the sense and purpose of the legal regulation, be helpful and punish the violation of a predictable, intelligible and certain text of the law, not to remain silent and actively "manifest new interpretative view" within the control action - athletes 007 or others. The law has to be adherence, but it must be the law with all its material and formal requirements. The taxation of athletes is unregulated area and there is some open space for taxpayers (athletes) to choose a tax regime limited by an electric fence in the form of a clear text and meaning of the law.

In its decisions on the taxation of athletes, the Supreme Administrative Court forces the legislator to make detailed regulation for many types of occupations that are not regulated by law yet. This requirement is totally meaningless and in the Author's opinion it is enough if the executive power sufficiently specifies the subject matter of taxation in the form of the D-instruction, the Decree of the Ministry or other legitimate expectation ensuring way.

Although the position of collective athletes is concerning the matter of tax expenditures surrealistic, nevertheless we can see deep rationality in the motives of Supreme Administrative Court. ${ }^{16}$ The hypothesis of the paper needs to be answered positively, the regulation of the taxation of athletes in its current form does not fulfill

16 Professional sport is a profession that can be performed only for a limited time. It is a lifelong affair fitted into childhood and productive age. It goes without saying that athletes have to secure themselves for the future in the sport-productive part of their lives. If one day the postman knocked on his door and handed him the Financial administration's call, in which the Financial administration would demand his life savings, the decision is on the human side more than okay, even though purely theoretically the author cannot identify with it (Cf Liška, 2016: 103-126). 
the formal values of law, especially it fails in the perspective of predictability. ${ }^{17}$ Therefore, who knows if the campaign of the courts against the tax rules, which are devoid of formal values, will not continue. ${ }^{18}$

\section{References}

Jhering, R.: Der Zweck im Recht (Purpose in law), Leipzig: Breitkopf \& Härtel,1887.

Klip, A.: Substantive Criminal Law of the European, Antwerpen, Apeldoorn, Portland: Maklu, 2011.

Knapp, V.: Teorie práva (Theory of law), Praha: C.H. Beck, 1995.

Kokeš, M., Pospíšil, I. et al.: In dubio pro libertate. Úvahy nad ústavními hodnotami a právem. Pocta Elišce Wagnerové u př́ležitosti životního jubilea (In dubio pro libertate. Reflections on constitutional values and law. Tribute to Elizabeth Wagner on the occasion of the jubilee), Brno: Masarykova Univerzita, 2009.

Kühn, Z.: Správní řád a problematika ustálené správní praxe. (Administrative Act and the issue of steady administrative praxis), in: Rajchl, J. et al.: Správní řád - 10 let v praxi (Administrative Act - 10 years in praxis), Praha: Univerzita Karlova, 2016.

Liška, M.: Švarcsystém (Misclassification of employees as independent contractors), in: Radvan, M. et al.: Důchodové daně (Income tax), Brno: Masarykova Univerzita, 2016.

Macháček, I.: Daň z př́ijmů fyzických osob 2010. Praktická pomůcka k daňové optimalizaci (Income tax of natural person 2010. Practical guide to tax optimalization), Praha: C.H. Beck, 2010.

Memorandum of Understanding between the Union des Associations Européennes de Football ("UEFA") and the Fédération Internationale des Associations de Footballeurs Professionnels ("FIFPro") "FIFPRO Division Europe", 2007. www.uefa.com.

Morávek, J., Štefko, M.: Profesionální sportovci v kolektivních sportech (Professional athletes in colective sports), Časopis pro právní vědu a praxi (Jurnal for legal science and praxis) vol. 21, no. 3 (2013).

Pelc, V.: Daňové odpisy (Tax depreciation), Praha: C.H. Beck, 2011.

Radbruch, G.: O napětí mezi účely práva (About tension between purposes of law), Praha: Wolters Kluwer, 2012.

Radbruch, G.: Rechtsphilosophie (Philosophy of law), Heidelberg: C.F. Muller Juristischer Verlag, 2003 .

Radvan, M.: Lafatova daňová klička by neměla být přípustná (Lafata tax trick should not be allowed), 2017. www.ceskapozice.lidovky.cz.

Radvan, M.: Sportovci v kolektivních sportech (Professional athletes in collective sports), in: Radvan, M. et al.: Vybrané aspekty př́mých daní a jejich interpretace a aplikace v judicature (Selected aspects of income taxes and their interpretation and application in case law), Brno: Masarykova Univerzita, 2014.

17 Moreover, the tax surcharge imposed on the additional income tax of professional athletes would be in contradiction with European Charter of Human Rights.

18 A new Income Tax Act is currently being prepared. 
Raz, J.: The Morality of Freedom Clarendon, Oxford: Clarendon Press, 1986.

Šimka, K.: Švarcsystém v judikatuře Nejvyššího správního soudu (Misclassification of employees as independent contractors in Supreme Administrative Court case law), Bulletin Komory daňových poradců ČR (Bulletin of the Chamber of tax advisers CZ), no. 4 (2014).

Sluka, T.: Profesionální sportovec: právní a ekonomické aspekty (Professional athlete: legal and economic aspects), Praha: Havlíček Brain Team, 2007.

Summerts, R.S.:. Essays in Legal Theory, Dordrecht, Boston, London: Kluwer Publishing, 2013.

Vybíral, R.: Analýza judikatury vztahující se $\mathrm{k}$ postavení profesionálních sportovců $\mathrm{v}$ oblasti kolektivních sportů v České republice (Analysis of the case law relating to the position of professional athletes in the area of collective sports in the Czech Republic), Jurisprudence no. 1 (2013).

Zippelius, R.: Das Wesen des Rechts (Essence of law), München: C.H. Beck, 1997.

Court of Justice of the European Union: case CNTA v. Commission.

Court of Justice of the European Union: case B.N.O. Walrave, L.J.N. Koch v. Association Union cycliste internationale, Koninklijke Nederlandsche Wielren Unie a Federación Española Ciclismo.

Court of Justice of the European Union: case Christelle Deliège v. Ligue francophone de judo et disciplines associées ASBL.

Court of Justice of the European Union: case Gaetano Donà v. Mario Mantero.

Court of Justice of the European Union: case Intertanko vs Secretary of State for Transport.

Court of Justice of the European Union: case Union royale belge des sociétés de football association ASBL v. Jean-Marc Bosman.

Court of Justice of the European Union: case Faust v. Commission.

European Court of Human Rights: case Cantoni v. France.

European Court of Human Rights: case Coeme and others v. Belgium.

European Court of Human Rights: case Lucky Dev v. Sweden.

European Court of Human Rights: case Veeber v. Estonia.

CZ: Supreme Administrative Court: 2 Afs 16/2011/78.

CZ: Supreme Administrative Court: 6 Ads 88/2006/132.

CZ: Constitutional Court: Pl. ÚS 29/08.

CZ: Constitutional Court: Pl. ÚS 9/15.

Supreme Audit Office conclusion of control action 16/21, 2017. www.nku.cz/assets/kon-zavery/ k16021.pdf. 
SECTION 3.3

IMPACT OF TAX OPTIMALIZATION ON PUBLIC INTEREST 

DOI 10.15290/oolscprepi.2018.52

\title{
OPTIMIZATION OF PUBLIC REVENUES AND EXPENDITURE ${ }^{1}$
}

\author{
MARIE KARFÍKOVÁ2
}

\begin{abstract}
This article concerns public income and expenditure optimization with a focus on legal regulation contained in tax laws. The considered area is particularly legal optimization of duties that are analyzed from a state's point of view, on the one hand, and from tax payer's point of view, on the other hand. The state's main concern is tax evasion which is an unwanted form of optimization from a state's point of view. On the contrary, practice, and articles published by tax advisors, auditors and attorneysat-law show tax optimization as reaching the smallest possible tax burden for the tax payer. Tax evasion is undoubtedly socially harmful and it is necessary to fight it not only by a quality legislature drafting flawless (i.e. simple and well-arranged without a possibility of double interpretation) legal norms but even by criminal procedure. Even though a question connected to an effectiveness of tax system (e.g. an impact of taxes on taxpayers) has been relatively explored - and no one is going to be surprised that if taxes from different social, political, moral or economic reasons should be used for steadier national product redistribution, it is necessary to know impact of such taxes up front. Although the effects of taxes on individual taxpayers have an overall impact on the development of the economy, these aspects are often not given an appropriate attention in terms of tax system development and tax policy as a whole.
\end{abstract}

\section{Keywords}

Public law; tax law; tax laws; optimization of public revenues; optimization of tax expenses

\section{JEL Classification: H20, H60, K15}

1 This paper has been elaborated within the programme "PROGRES Q02 - Publicization of Law in the European and International Context" which is realized in 2018 at the Faculty of Law of the Charles University. Professor of Financial Law and Financial Science, Department of Financial Law and Financial Science, Faculty of Law, Charles University, Czech Republic. The Author specializes in tax law and insurance law. She is the author or co-author of more than 10 books and 80 reviewed articles. She is a member of Information and Organization Centre for the Research on the Public Finances and Tax Law in the Countries of Central and Eastern Europe. Orcid.org/0000-0002-5655-7858. Contact email: karfikov@prf.cuni.cz. 


\section{Introduction}

In common and professional life, we often encounter situations where a number of concepts are defined in general terms, some are defined only for the purpose of a particular law, and some are even used without being defined by law at all. For example, the term immovable property is defined in Sec. 498/1 of Civil Code (hereinafter referred to as the "Civil Code") when at the same time the relevant provision also negatively defines the term of movable property. Just as it was the case in the past, the Civil Code now deals with a definition of movable and immovable property by defining only immovable property, whereby all other things that are not immovable, whether of a corporeal or incorporeal nature, are movable. Every property (thing) is either immovable if it fulfills the legal definition contained in the first paragraph of Sec. 498 or the features contained in the definition are not fulfilled and then it is always movable property. The definition of the immovable property is therefore decisive for defining both categories of things; either is a specific thing an immovable property under this definition, or the features contained in the relevant provision are not met, which means the thing is movable. On the other hand, some concepts are used by law without being defined, such as the term tax. This term has no general definition, only certain tax laws define the subject matter of a tax and thus distinguish each other.

As I have mentioned the concept of tax (the same applies to a fee), then it is interesting for the purposes of interpretation to point out the provision 1811/2/c of the Civil Code which stipulates the following obligation: "If the dealings of the parties aim at concluding a contract and these facts are not evident from the context, the entrepreneur shall, sufficiently in advance before the conclusion of the contract or before the consumer makes a binding offer, provide the consumer with: (...) c) the price of the goods or service, or, where applicable, the method of its calculation including all taxes and fees."

Legal literature commenting on this provision states that information about the price, taxes and fees are required (Pelikánová, 2017). It implies incorporation of the consumer protection included in the Council Directive 93/13/EEC on unfair terms in consumer contracts and within the meaning of Art. 5/1 of Directive 2011/83/EU on consumer rights. The Civil Code imposes the same obligation which is included in the second mentioned directive that states that before the consumer is bound by a contract other than a distance or an off-premises contract, or any corresponding offer, the trader shall provide the consumer with the information about "the total price of the goods or services inclusive of taxes, or where the nature of the goods or services is such that the price cannot reasonably be calculated in advance, the manner in which the price is to be calculated, as well as, where applicable, 
all additional freight, delivery or postal charges or, where those charges cannot reasonably be calculated in advance, the fact that such additional charges may be payable". The meaning of the Czech term "fees" must be interpreted in accordance with the directive as freight, delivery or postage "charges". The Czech provision appears to be stricter in a certain way as it requires the information on "all" taxes and fees, although according the directive it would only be sufficient to provide the consumer with information in a clear and comprehensible manner that additional charges may be payable. Based on a purely grammatical interpretation of this provision, it will be interesting to see how the case law deals with application of this obligation as there is no legal definition of taxes and fees (charges). In particular, it may appear problematic to define the term of a fee which has for the purposes of financial law a different meaning than the one discussed and contained in the above private law provisions.

\section{Optimization}

Somewhat problematic in terms of interpretation might be the concepts used in theory and practice, which, however, are not defined but even explained in the applicable laws. For example, the internet encyclopaedia defines the concept of optimization as follows: "In computer science, program optimization or software optimization is the process of modifying a software system to make some aspect of it work more efficiently or use fewer resources. In general, a computer program may be optimized so that it executes more rapidly, or is capable of operating with less memory storage or other resources, or draw less power. Although the word "optimization" shares the same root as "optimal", it is rare for the process of optimization to produce a truly optimal system. The optimized system will typically only be optimal in one application or for one audience" (www.cs.wikipedia.org). In legislation, the notion of optimization is used in a number of laws without any explanation, for example "optimization of methods for reuse" (Act on Waste), "optimization of water regime" (Act on the Protection of Agricultural Land Fund). The term "optimization" is used in no tax law.

The term "optimization" is on the other hand frequently used in explanatory memoranda to tax laws and also in various specialized articles. For example, in June 2016 has been adopted the Council Directive (EU) 2016/1164 laying down rules against tax avoidance practices that directly affect the functioning of the internal market and which sets common rules for corporate taxation in the European Union. This directive is based on the BEEC (Base Erosion and Profit Shifting) project developed within the OECD and must be implemented by the Czech Republic in its law by 31 December 2018. It primarily affects the tax optimization used by 
companies on the internal market, i.e. among the countries of the European Union. But it also contains rules that have the impact on tax accounting in corporate structures operating only on the domestic market, in particular, it will affect the use of debt instruments and external financing, such as bonds, finance lease payments, but also profits to parent companies or other transactions between members of the group. A number of exceptions might exist from the rules set out in the directive and the directive can also be somewhat mitigated, depending on how precisely the Czech legislator will face this area. At present (30 April 2017) a public consultation on how this directive will be reflected in the Income Tax Act is being held. It is based on a minimum level of protection, so the Member States must use at least the regime set out in the directive, but may opt for a stricter option beyond the directive (as can be seen below in the example of limiting the tax deductibility). In my view, the effects of the new legislation will have to be anticipated and slowly adapted to within corporate structures.

Further, for example, the explanatory memorandum to Act no. 170/2016, on the amendment of certain laws in the field of taxes, states the following: "The proposed legislation is related to efforts on avoiding circumvention of the law and the undesired tax optimization". The explanatory memorandum to Act no. 243/2016, amending certain laws in connection with the adoption of the Customs Act, states: "This step will lead to partial optimization of the activities". Explanatory Memorandum to Act no. 254/2016, amending Statutory Measure of the Senate no. 340/2013, on Tax on the Acquisition of Immovable Property, contains the following: "Further, the aim is to make the necessary clarifications of the current legislation and to eliminate ambiguities, including reducing the potential for undesired tax optimization in this area".

\section{Two Views of Optimization of Public Revenues and Expenditure}

In the light of the above, I would like to begin by pointing out that there are two views on optimization of public spending (expenditure) and public revenues. From the point of view of the state, the aim if focused on preventing circumvention of tax laws and the undesirable optimization. On the other hand, practical life and articles of tax advisers, auditors and lawyers consider optimization in the light of the lowest tax liability.

When talking about amendments to the tax system in the Czech Republic, it has become a tradition that any political representation presents its views on optimizing public revenues and public spending through changes in tax rates. As the larger part of the population is practically not much familiar with the concept and construction of the relevant taxes that are imposed and collected on the territory of the state, it is 
only playing with numbers which easier to understand, and in terms of interest even more acceptable.

Given the fact that the majority population is employed, it is not that much concerned whether small or medium-sized Czech entrepreneurs can still create any values and actually carry out their business despite the challenging and demanding tax administration or whether they are only becoming a new administrative centre that assumes the fulfilment of certain obligations instead of the Czech state without being compensated. This is also because the tax rate is crucial for employees whose salary is the only source of income. Although the tax rate is an interesting measure, it is not the decisive one. Rather, it draws attention from the nature of the problem, which is often the ineffective tax system. It is certainly no secret that for making an overall assessment of the effectiveness of a tax system, it is appropriate to measure the tax rate together with the tax-deductible expenses, however, in the Czech Republic, this tool has not become significant so far. This is also the case because taxes and tax system as such are in most cases subject to social engineering, as the legislator tries to address through tax measures problems falling into the sphere of social law.

To understand the issue of optimizing revenues and expenses, the basic concept needs to be clarified at least very briefly. The key will be to clarify the notion of tax optimization which becomes at a certain moment from the point of view of a public budget a tax evasion. Although there are many definitions, I prefer to consider tax evasion as a criminal act that is to say a behavior considered a criminal offense under criminal law. On the contrary, the European Commission has somewhat redundantly distinguished between the concepts of "tax fraud" ("a form of deliberate evasion of tax which is generally punishable under criminal law; the term includes situations in which deliberately false statements are submitted or fake documents are produced"), "tax evasion" ("generally comprises illegal arrangements where tax liability is hidden or ignored, i.e. the taxpayer pays less tax than he/she is supposed to pay under the law by hiding income or information from the tax authorities") and "tax avoidance" ("defined as acting within the law, sometimes at the edge of legality, to minimise or eliminate tax that would otherwise be legally owed, it often involves exploiting the strict letter of the law, loopholes and mismatches to obtain a tax advantage that was not originally intended by the legislation") (European Commission, 2017). The business environment acknowledges the concept of tax optimization as an activity actually reducing the tax liability within the limits of the law.

As mentioned above, the Ministry of Finance repeatedly argues in its explanatory memoranda that it is proposing amendments to tax laws with the vision of eliminating or limiting unwanted tax optimization. On the other hand, tax 
optimization services leading to the reduction of tax liability are legally offered to taxpayers. The theory of financial law then deals permanently with what leads taxpayers to tax optimization: is it low tax morale, ignorance of legal regulation caused by the complexity of tax legislation? If it is for any of the above reasons, it is sure that taxpayers are trying to get a certain benefit. If there is no violation of law, there is no tax evasion. It is a simple, entirely legal, tax optimization (tax minimization), for which, of course, the taxpayer cannot be penalized.

\section{Optimization of Revenues and Expenses in the Case Law of the Constitutional Court}

The issue of public incomes and spending in tax matters is not so often subject to the Supreme Administrative Court's decisions and even less subject of the Constitutional Court's decisions. One of the interesting rulings of the Constitutional Court is the judgment of the Constitutional Court of 21 April 2009, which was published under no. 181/2009. The judgment was based on a motion of the Supreme Administrative Court (hereinafter referred to as the "SAC") aiming to declare the unconstitutionality of the Secs. 8, 9, 10 and 15 of Act no. 357/1992, on Inheritance tax, Gift Tax and Real Estate Transfer Tax, in the wording before the amendment made by Act no. 420/2003. The question that the Constitutional Court could not avoid is whether the Constitutional Court is actually responsible for assessing the real estate transfer tax from the point of view of the functions of taxes discussed by the economic literature to which the SAC refers in its motion to the Constitutional Court. The SAC's motion suggests that the Constitutional Court should assess the unconstitutionality of taxes in terms of the three basic functions of taxation and the tax system, namely the allocation, distribution and stabilization functions (Musgrave, 1994: 6; Kubátová, Vítek, 1997: 12; Kubátová, 2003: 19 or Peková, 2005: 323).

According to the opinion of the Constitutional Court, any reasoning on taxes in the light of the above criteria falls within the competence of a democratically elected body. If the Constitutional Court approached these considerations, it would enter the field of politics and diverse policies of which rationality cannot be sufficiently assessed from the point of view of constitutionality. The Constitutional Court also does not, as a general rule, examine the effectiveness of taxes, subject to cases where the ineffectiveness of a certain tax would create a clear inequality in the tax burden of the individual citizens. The task of the Constitutional Court is only to examine whether the concerned tax measures interfere with the constitutionally guaranteed property substrate of the owner, i.e. if they can be regarded as arbitrary or unjustifiable opposing the principle of equality. In the Constitutional Court's 
view, it should also be borne in mind that all taxes form one system (see paragraphs 48 and 51 of the judgment). As a result, if the Constitutional Court wanted to address the issue of the legitimacy and rationality of the real estate transfer tax, it would also have to deal with the links between the real estate transfer tax and other taxes. Should the Constitutional Court decide to say whether the transfer tax is an appropriate and necessary element of the tax system, it would enter Authoritatively but without a constitutional justification into a debate, in which the professional economic and legal community itself is not uniform as regards the proposals de lege ferenda. For example, an academic publication on tax policy perspectives considers the change of the budgetary allocation of the real estate transfer tax to be the optimal solution, i.e. the Author prefers to maintain this tax in a modified version as opposed to maintain the current state or its complete abolition (Kubátová, Vybíhal et al.: 2004: 152).

If there is no consensus among the relevant experts, it is not the role of the Constitutional Court to speculate on the right answers. The Constitutional Court is aware of the importance of deciding on the tax system in the context of rival political parties, i.e. in the context of wishes and preferences of members of the political community in relation to the degree of the social status of state policies that find a reflection in election results. It is, therefore, necessary to leave these questions to the political majority that was formed by the elections. Engliš already noticed that "the struggle for political power in the state is a struggle to manage the ideal the state is reaching to, a struggle to manage public welfare. To the same extent as the expenditure structure and the incomes, structure are related, the political struggle is also a struggle for a system of public revenues, especially the tax system" (Engliš, 1929: 101). The Constitutional Court does not intend to enter this political competition and is prepared to intervene only if it finds the unconstitutionality of the tax laws in the above-mentioned scope.

The US Supreme Court decided to abolish tax laws only when the classification of tax subjects and the subject of taxation appeared to be arbitrary, which has occurred only in a limited number of cases. In other words, no legislation may arbitrarily establish discrimination. Comparative studies (Ordower) show that the German Federal Constitutional Court acts far more actively in tax cases and has found many times tax laws being in conflict with constitutional principles, which is quite exceptional in the United States. The reason for such difference is probably to be associated with a different interpretation of fundamental rights in the US and Europe. While in the US, fundamental rights are interpreted only as negative rights (the state is obliged to respect fundamental rights), it is a European standard to interpret fundamental rights as well as positive rights (the state has a duty to protect fundamental rights). The above mentioned is confirmed by the fact that the German 
Federal Constitutional Court found the so-called "nuclear fuel tax" to be illegal. As a result of this decision, energy companies required the return of some EUR 6.3 billion, which they have paid to the German state in recent years.

The Constitutional Court stated in its reasoning that it did not intend to review the consistency of tax policy with other policies, such as housing policy, as proposed by the SAC, because it would find itself on the thin ice of not always conclusive economic analyses of which the results are to be assessed and political consequences deduced only by a democratically elected body which also has to consider whether a tax regulation is appropriate and necessary from this point of view. In its motion, the SAC also stated that the cost of a real estate increases by the amount of the tax, but statistics suggest that there is no such direct relationship between these two variables. Some Authors are even more sceptical about the relationship between real estate transfer tax and restrictions on the housing market, population mobility and other negative social consequences: "It is also not certain that the abolition of this tax must have an impact on housing policy and that would significantly increase population mobility or indirectly reduce unemployment" (Radvan, 2007: 353). Because there are no accurate economic analyses available and the SAC has not submitted any within its motion, the SAC bases its conclusions only on what is to be "apparent from the nature of the case" despite that any statement in the domain of social sciences should be based on a complex of multifactorial explanations. The Constitutional Court did not intend to make an Authoritative decision on the relationship between these and perhaps even other variables. In addition, from the analyses available to the Constitutional Court, it does not imply that the real estate transfer tax would be the main brake on the development of the relevant policies and that its influence on labour mobility, entrepreneurship or the deterioration of the social situation would be somewhat critical (see par. 21). The Constitutional Court shall not substitute the opinion of a democratically elected legislator by its own opinion on the appropriateness of public policies. The democratically elected body has a broad discretion in the sphere of public policies and is politically responsible for the failure of a chosen solution. In other words, the legislation can also take non-rational steps in the domain of taxes, which is, however, not a reason for an intervention by the Constitutional Court. It will intervene only if the property rights limitation gains the intensity of the so-called "smashing effect", or if there is a violation of the principle of equality, in its accessory (in connection with other fundamental rights) or non-accessory form. 


\section{Conclusions}

Optimization of incomes and expenses, i.e. tax evasion, is undoubtedly harmful to society at large and must be tackled not only by good legislation producing perfect legal norms (i.e. simple and clear, applicable without more interpretations) but also in the field of criminal law. Although the question of the effectiveness of a tax system (i.e. the impact of taxes on individual taxpayers), is a relatively historic issue, it is not surprising that if taxes are to be used for social, political, moral or economic reasons in order to achieve a fairer distribution of national income and wealth, it is necessary to know in advance the impact of these taxes. However, it is not possible to avoid the impression that the tax burden is not optimally distributed in the Czech Republic. It has been pointed out earlier that, in relation to the overall concept of tax policy, it is not so important to whom the tax is imposed, but who carries it. Nevertheless, not all of these aspects are given due attention in terms of an overall tax and tax policy developments, although the effects of taxes on individual taxpayers have a large impact on the economy and its development. When assessing the legality of an activity from a taxpayer's point of view, it is necessary to take into account laws connected with other legislation. The taxpayer logically does not try to maximize his tax liability but on the contrary tries to use all available means to pay as little as possible while fulfilling all legal requirements. Due to the complexity of tax laws and their interaction with other rules, it is possible that taxpayers may even unintentionally commit certain illegal practices to reduce their tax liability. Proper tax assessment can be very complex so that assistance of tax advisers is often required, they should know the tax laws and be able to reduce the tax liability within the legal limitations.

\section{References}

Engliš, K.: Finanční věda (Financial Science), Brno: Polygrafie, 1929.

Kubátová, K.: Daňová teorie a politika (Tax Theory and Policy), Praha: ASPI, 2003.

Kubátová, K., Vítek., L.: Daňová politika (Tax Policy), Praha: Codex, 1997.

Kubátová, K., Vybíhal, V. et al.: Optimalizace daňového systému ČR (Optimization of the Czech Tax System), Praha: Eurolex Bohemia, 2004.

Musgrave, P.B.: Veřejné finance v teorii a praxis (Public Finances in Theory and Practice), Praha: Management Press, 1994.

Ordower, H.: Horizontal and Vertical Equity in Taxation as Constitutional Principles: Germany and the United States Contrasted. Bepress Legal Series, Working paper no. 728 (2006).

Peková, J.: Veřejné finance, úvod do problematiky (Public Finances, Introduction), Praha: ASPI, 2005. 
Pelikánová, I.: Commentary to the Civil Code, Praha: ASPI, 2017.

Radvan, M.: Zdanění majetku v Evropě (Taxation of Property in Europe), Praha: C.H. Beck, 2007.

EU: Council Directive 93/13/EEC on unfair terms in consumer contracts.

EU: European Parliament and Council Directive 2011/83/EU on consumer rights.

EU: Council Directive (EU) 2016/1164 laying down rules against tax avoidance practices that directly affect the functioning of the internal market.

CZ: Act no. 357/1992, on Inheritance tax, Gift Tax and Real Estate Transfer Tax.

CZ: Act no. 334/1992, on the Protection of Agricultural Land Fund, as amended.

CZ: Act no. 586/1992, on Income Taxes, as amended.

CZ: Act no. 185/2001, on Waste, as amended.

CZ: Act no. 170/2016, on the amendment of certain laws in the field of taxes.

CZ: Act no. 243/2016, amending certain laws in connection with the adoption of the customs act.

CZ: Act no. 254/2016, amending statutory measure of the Senate no. 340/2013 Coll., on tax on the acquisition of immovable property.

CZ: Constitutional Court: 181/2009.

CZ: Civil Code no. 89/2012, as amended.

European Commission. Taxation and Customs Union. The Missing Part, 2017. www.ec.europa.eu. www.cs.wikipedia.org. 


\title{
CZECH TAX HEAVEN FOR SPORTSMEN
}

\author{
MICHAL RADVAN
}

\begin{abstract}
There is no specific legal regulation of professional athletes in the Czech Republic. In practice, both individual players and team players are mostly self-employment. In case of team players, compared to the legal regulation in other European countries, it is unique. This article deals with the legal regulation of professional team players, especially in the area of taxation. It works with the hypothesis, stated in two judgments of the Supreme Administrative Court, that team players should tax their incomes by the personal incomes tax as self-employed persons, i.e. businesspersons. In 2011, the Supreme Administrative Court stated that team players are not employees of their club and they should pay taxes as from independent activities. The Czech Financial Administration followed this decision and taxed these sportsmen as so-called independent professions. The reason why the Supreme Administrative Court reopened this issue was the case of football player David Lafata, who got a business license (he became a businessperson) as a footballer and claimed that playing football is not an independent profession, but real business. The aim of the paper is to confirm or disprove the hypothesis stated above, analyzing existing legal regulation and case law, and it offers solutions de lege ferenda.
\end{abstract}

\section{Keywords}

Tax; tax law; personal income tax, sportsman

\section{JEL Classification: H24, K34, Z20}

$1 \quad$ Michal Radvan is vice-dean for foreign and external affairs at the Faculty of Law, Masaryk University, Czech Republic, and Associate Professor of Financial Law at the Department of Financial Law and Economics. He specializes in tax law. He is the author of 5 books and the coauthor of almost 45 books. He presented his scientific research in approx. 80 reviewed articles in prestigious journals and conference proceedings. He is a member of the European Association of Tax Law Professors and the Information and Organization Centre for the Research on the Public Finances and Tax Law in the Countries of Central and Eastern Europe. Contact email: michal.radvan@law.muni.cz. 


\section{Introduction}

Sport is an international phenomenon. Sportsmen are moving from one place to another, from one state to another. There is no obstacle to show sporting performance in different places all over the world. Not only individual sportsmen but also team players can earn money by sports activities in different countries and can play for different clubs. In the economic sense of view, it is only a question of supply and demand.

As all sportsmen know, the sports career is relatively short (with the exemption of unique cases like Czech ice hockey player Jaromír Jágr, who is still active in his 45 years playing NHL) and it is necessary to earn enough money to be financially secure for the sports pension. It is crucial to have not only high brut income (what is comparable in all states where the particular sport is popular, with regard to the economic consequences in individual countries) but especially net income, after taxation. This might be an area for tax competition between states. During the last year, we could see many football players moving to two most traditional Czech football clubs Sparta and Slavia. Sparta Prague has signed e.g. Jonathan Biabiany from Inter Milan, Rio Mavuba from Lille OSC, Georges Mandjeck from FC Metz, Semih Kaya from Galatasaray SK, Srdjan Plavšić from FK Crvena Zvezda, Tal Ben Chaim from Maccabi Tel-Aviv, Marc Janko from FC Basel. New players in Slavia Prague are e.g. Tomáš Necid from Bursaspor, Miroslav Stoch from Fenerbahçe SK, Eduard Sobol from Sachtar Doneck, Ruslan Rotaň from Dnepr Dnepropetrovsk, Halil Altintop from FC Augsburg, and Danny from Zenit St. Petersburg. What are their reasons to play in the Czech football league, what is definitely not a prestigious destination compared to Spanish La Liga, Premier League in the UK, German Bundesliga, French Ligue 1 or Italian Serie A? Maybe they want to be a part of a new project to create prestigious European club, maybe they want to live in beautiful and historical Prague, maybe they like Czech girls... or maybe they want to earn good money.

Compared to other European countries, assuming that the brut income would be the same in other countries, the Czech Republic offers better net income. There is no specific legal regulation of professional athletes in the Czech Republic. In practice, both individual players and team players are mostly self-employment. In case of team players, compared to the legal regulation in other European countries, it is unique. This article deals with the legal regulation of professional team players, especially in the area of taxation. It works with the hypothesis, stated in two judgments of the Supreme Administrative Court, that team players should tax their incomes by the personal incomes tax as self-employed persons, i.e. businesspersons. In 2011, the Supreme Administrative Court stated that team players are not employees of 
their club and they should pay taxes as from independent activities. The Czech Financial Administration followed this decision and taxed these sportsmen as socalled independent professions. The reason why the Supreme Administrative Court reopened this issue was the case of football player David Lafata, who got a business license (he became a businessperson) as a footballer and claimed that playing football is not an independent profession, but real business. In both cases, the personal income tax base is created as the difference between income and expenditure. As mostly there are no real high expenditures, Czech legal regulation allows the lump sum expenses: in case of the independent profession $40 \%$, but for business (in this very case) 60\%. The aim of the paper is to confirm or disprove the hypothesis stated above, analyzing existing legal regulation and case law and comparing different approaches of sportsmen taxation. Using the synthetic method, the article offers solutions de lege ferenda.

The existing scientific literature in given area in the Czech Republic is not important at all, it is mostly descriptive (Sluka, 2007) or focused on case law (Vybíral, 2013). The existing legal regulation and case law before the Lafata case were described by Radvan and Neckár (2016) and this paper is partially used in this text (mainly chapters 2 and 5). International scientific literature is at a higher level; there should be mentioned publications by Tetłak (2014), Simpson (2012), or book edited by Loukota and Stefaner (2007).

\section{Individual Sportsmen vs. Team Player}

Individual professional athlete (i.e. tennis player, boxer etc.) mostly (let us disregard team competitions in team sports, e.g. Davis Cup, Fed Cup) acts on his/her behalf and on his/her responsibility. S/he chooses which tournaments to play, during the year $\mathrm{s}$ /he is paid by several subjects (usually by the organizer of a sports event), s/ he bears the costs for a coach, massage therapists, servicemen and other persons in his/her team, s/he chooses when and where s/he trains, etc. (Radvan, Neckár, 2016).

The performance of a team player is highly determined by club rules and regulations in which his/her activity is performed. Team players (typically ice hockey, football, basketball, volleyball players etc.) are in a relationship only with one subject - the club, in which they perform their activity. They do not act on their behalf nor on their own responsibility but only as members of a team or a club. It is also the leadership of the club who determines all duties of its functioning, whether it is the placement in a specific competition (transfer the player during the season with or without the player's consent), training, following the regimen and other individual aspects of its activity. The club itself hires coaches and the whole service team, whereas the player cannot influence it whatsoever. Team players must abide by obligations set 
forth by the leadership and their coaches. It is a paradox that the higher the level of sports activity of a certain club, the higher is the amount of dependence of player's activity on the club (Radvan, Neckár, 2016).

In many European countries, it is quite common that team players are employees of the club. In the Czech Republic, however, professional team players are selfemployed. The player and the club conclude a so-called professional contract, which is considered to be an innominate contract in the Czech legal order (Civil Code, Art. 1746/2). Professional contracts include mutual rights and obligations of the player and the club. Some kind of a model contract is included in the Directive on the evidence of professional and non-amateur contracts (Fotbal.cz, 2014) approved by the Executive Committee of the Football Association of the Czech Republic. It is a paradox that the first article states that "in accordance with the professional contract the player performs the sports activity as his main employment", which means a dependent activity. However, according to the model professional contract in football (Vybíral, 2013: 13) "in the area of income tax, social and health security, the player is considered to be self-employed in accordance with of the Income Tax Act and his income arising from this contract is the income from independent employment which is neither a profession based on a license nor entrepreneurship under special regulations". It is necessary to add that similar contracts are concluded in other team sports; however, any provision of this type in a private contract is for the purpose of public tax law irrelevant (Radvan, Neckár, 2016).

It is apparent that the activity of a professional team player is specific and it is not, therefore, possible to apply without limitations all institutes of labor law guaranteed by the Labor Act. The main aspect, which is the object of disputes between the advocates of employment relationships of athletes and sports clubs, is the possibility of a one-way termination of the employee (the player) without giving any reason; in this case, a player could change clubs without any compensation. We can also state the problem of working hours, overtime and obligatory breaks at work as well as limitations set for the conclusion of fixed-term employment contracts. According to effective legal norms, it is possible to prolong an employment agreement only twice; shall it be prolonged one more time, the employment contract must be concluded for the indefinite time (Radvan, Neckár, 2016).

\section{Tax Issues}

The reason why is the problem of taxation of team player's income repeatedly discussed is the different rate of income taxation in case the athlete taxes his/her income as an income from employment or s/he taxes it as an income from selfemployment. The fact that team players consider themselves as self-employed is 
from the established practice, which is considered favorable not only for themselves but also for the clubs. Athletes receive an unreduced fee and it is their obligation to fill out a tax return and pay taxes as well as social and health security. This obligation is therefore not on the club. This also enables the players to deduct from their incomes costs, which they spend in accordance with their activity. This is not possible with the taxation of employees. Costs spent to reach, secure and maintain incomes, players include for example the washing of uniforms (even though it is done via the club), the cost for travels to European cup matches, diet costs, accommodation, trips to training, etc. Jiří Sabou, not very well known exfootball player of Žižkov and Teplice, stated among his costs a fee for his agent who was supposed to negotiate contracts for him in Manchester United, FC Barcelona, Olympique Marseille or AC Monaco even though none of these teams knew nothing about this average Czech football player. This whole matter was addressed by the European Court of Justice in Luxembourg (ECJ: no. C-276/12) (Radvan, Neckár, 2016).

In terms of taxation of team players' income, the terms which set up the relationship between the player and the club are not essential. It is necessary to determine the characteristics of the player's activity and its subordination under particular provisions of the Income Tax Act. Two basic types of incomes come to mind income from employment and income from self-employment. The main difference is the construction of the tax base.

In case of self-employed sportsmen, the tax base construction is the typical one: the income is reduced by expenditures (costs) necessary to reach the income. Because team players usually do not have high expenditures (the club pays most costs), they are applying so-called lump sum expenses. These lump sum expenses can be $60 \%$ of the income if the sportsman runs a trade, respectively $40 \%$ in case of the independent profession. The maximum amount of the lump sum expenses to be applied in 2016 is CZK 1,200.000 for trade and CZK 800,000 for the independent profession. It must be noted that tax preferences for children and tax relief for the spouse cannot be used as lump sum expenses are applied. On the other hand, the spouse can use tax preferences for children and basic tax relief to lower the family taxation. For the taxable period 2018, the maximum amount of lump sum expenses is lowered to CZK 600,000 for trade, respectively CZK 400,000 for the independent profession, and tax preferences for children and tax relief for the spouse can be applied without any limitations. For the taxable period 2017, the taxpayer has right to choose the regulation valid in 2016 or in 2018 , depending on his/her personal circumstances.

In case of dependent activity (employed sportsman), the super gross wage as a tax base is used. Such a construction is unique in the whole world. Super gross wage 
is a gross wage increased by $34 \%$ of the gross wage as sums of social security insurance premium, contribution to the state employment policy and general health insurance premium that must be paid by the employer. If we accept the social security premiums (or at least social security insurance premium) as taxes, we can talk about the tax on tax, i.e. double taxation.

\section{Case Law}

Until 2011, there was no decision of Czech courts dealing with the taxation of professional team players' incomes. In practice, almost no team players were employed by their clubs. The first ruling was issued in 2011 by the Supreme Administrative Court (2 Afs 16/2011-78). The Court stated that "Even though the activity of professional athletes, although not expressly excluded from entrepreneurship by the Trade Licensing Act, cannot be subordinated under permitted, professional or unqualified trade and neither is an independent profession, many athletes, as well as sports clubs, consider relations arising out of the so-called professional contracts to be of self-employed nature and incomes arising out of these contracts are to be considered as incomes from self-employment".

The Court examined the activity of a professional ice hockey player and concluded that "the activity of a professional athlete cannot be easily subordinated under "employment" in the sense of Labor Act. It cannot be therefore excluded, respectively considered illegal the conclusion of other than labor contracts between players and their clubs". It is disputable, whether it is necessary to interpret the term "employment" and forget to deal with the similar but tax term "employment". This simplification then leads to a faulty conclusion of the Court, which states: "... it is generally accepted in practice that professional athlete may - from a tax point of view - act as self-employed ... To divert from this generally accepted practice, there would have to exist a very strong reason based on for example an explicit change of the legal norms. Otherwise, it is possible to argue by way of certain level of normative power of facticity" (Radvan, Neckár, 2016).

I find this conclusion wrong. Primarily most of the arguments are dealing with the relation between the club and the sportsman from the civil law perspectives. It is apparent that the activity of a professional team player is specific and it is not, therefore, possible to apply without limitations all institutes of labor law guaranteed by the Labor Act. However, in terms of taxation of team players' income, the terms which set up the relationship between the player and the club are not essential. It is necessary to determine the characteristics of the player's activity and its subordination under particular provisions of the Income Tax Act. Moreover, the 
fact that something is happening illegally for a longer period cannot mean that this behavior shall become in accordance with the law.

Czech tax administration, unfortunately, started following the ruling of the Supreme Administrative Court. Team players were taxed as an independent profession, even this term is not defined in Czech law, was never defined by the courts and legal science has never created any definition. Mostly it is accepted that independent profession includes artists. In July 2017 the Supreme Administrative Court in Lafata case (6 Afs 278/2016-54) stated that "the independent activity of a professional athlete can be performed either as a trade or as an independent profession. If the tax subject carries out the activity of a professional football player as a trade on the basis of the relevant trade license, the income from this activity represents income from the trade." I.e. the 60\% lump sum expenses (and not only 40\%) can be applied. Most of the arguments of the Court are connected with the definition of trade: the activity carried out on a continuous basis, independently, on own behalf, on own responsibility, and in order to obtain a profit. The Court stated that some characters (independence, own behalf, and own responsibility) are suppressed, but still decided that the independent activity of a professional athlete can be performed as a trade.

I do agree with the decision that the activity of a professional team player is not an independent profession. However, definitely, it is not a trade, too. The characters of trade are not only suppressed; they are simply not there at all. The Supreme Administrative Court missed the possibility to reopen the issue of team players' taxation from dependent activities and missed the opportunity to change existing unreasonable and unjustifiable practice.

\section{Conclusions}

Certainly, team players do not perform on their behalf and do not make independent decisions. Their income received from the clubs (whether it is for individual matches, in the form of a regular fee for sport or other performance in favor of the club) cannot be considered as income from self-employment (business/trade/ independent profession). The taxpayer is not entitled to reduce this income of the relevant costs spent to reach, secure and maintain incomes as well as $\mathrm{s} / \mathrm{he}$ is not entitled to apply lump costs. However, income from for example advertising activities of the individual player that are not connected with his/her activity for the club could be taxed as an income from self-employment (Radvan, Neckář, 2016).

Income from employment includes payment in the form of an income from present or past employment and similar relationships, in which the taxpayer performing the activity for the employer must oblige orders of the employer. In 2005, the Supreme 
Administrative Court dealt with these terms with the emphasis on the nature of a relationship similar to employment and similar relationships (2 Afs 176/2004-140). It stated that a "similar relationship is a relationship which is not the employment and similar relationships, but which in its nature and role responds to the stated relationships, that means that its main characteristics are the same as with these relationships. Common to employment and similar relationships are first that it is a legal relationship, usually of a private nature but also of a public nature (typically an official relationship)..." When examining whether the given relationship can be subordinated under the term "similar relationship", it is always necessary to examine its actual content intended and wanted by the participants especially if the participants pretend something different than what is the actual content of their legal relationship. The Court emphasized the principle of material justice, respectively the principle of content priority. "When closing the so-called professional contract, it is not important what the title of the contract is and under which legal provisions it was made but what is its content and what are the rights and obligations of the parties" (Radvan, Neckáŕ, 2016).

Another important feature of employment and similar relationships considered by the Supreme Administrative Court is that this relationship is of a long-term character, which is determined by the fact that it is not consumed on a one-time basis by fulfilling a certain obligation. So-called professional contracts also fulfill this definition since they are often concluded for the term of one to five years (Radvan, Neckář, 2016).

Another significant feature of employment and similar relationships not only considered by the Supreme Administrative Court is the fact that the person who provides a certain performance is obliged to follow orders of the person to whom $\mathrm{s} /$ he is bound by the employment and similar relationship. This obligation must be made directly, i.e. it must be the content of the legal relationship between both participants. For example, under the model professional contract, a football player is obliged to fulfill assignments and orders of coaches during training, at training camps and of course during matches (Vybíral, 2013: 12-17). For his performance, the player receives a fee, usually money (Radvan, Neckár, 2016).

It is without a doubt that the so-called professional contracts in the area of team sports fulfill cumulatively all signs of a relationship similar to an employment and other similar relationships and therefore team players' income should be taxed as income from employment (Radvan, Neckář, 2016).

The term "dependent activity" was determined by the Supreme Administrative Court in its previous ruling (2 Afs 62/2004-70). It stated that in order to be considered as a "dependent activity" a person cannot only perform an activity according to relevant 
orders but it must be an activity truly dependent on the employer. Definition of dependency shall be given by the nature of the performed activity (typically an activity performed at one place exclusively for one employer). It shall also be a longterm activity and the employment relationship shall be made in favor of the person performing the activity. It is also important to note that athletes do not perform their activities in one place. However, it is necessary to consider the text of this ruling a bit inaccurate and wrong since undoubtedly many more activities exist with noticeable worker mobility. On the other hand, it is necessary to emphasize the part talking about one employer. Especially with team players, it is unimaginable that for example an ice hockey player or football player would play in one round of a long-term competition in more than one match for one club (Radvan, Neckár., 2016).

Incomes of team players received from the club are undoubtedly incomes taxed as income from employment because the relationship between the player and the club cumulatively fulfills all signs of a relationship similar to employment and other similar relationships. The hypothesis stated in two judgments of the Supreme Administrative Court that team players should tax their incomes by the personal incomes tax as self-employed persons, i.e. businesspersons, was disproved. Until the courts change their incorrect opinion or until the amendment of de lege lata regulation (so that the courts cannot insist on their incorrect case law), the Czech Republic remains a tax haven for professional team players and a specific island not only in Europe, where the incomes from club are taxed as business incomes and not as incomes from dependent activities, i.e. much less than in other countries.

\section{References}

Loukota, W., Stefaner, M.C. (eds.): Taxation of Artistes and Sportsmen in International Tax Law, Vienna: Linde Verlag, 2007.

Radvan, M., Neckář, J.: Taxation of Professional Team Sports Athletes in the Czech Republic, Public Governance, Administration and Finances Law Review in the European Union and Central and Eastern Europe no. 1 (2016).

Simpson, A.: Taxation of Non-Resident Entertainers and Sportsmen: The United Kingdom's Definition of Performance Income and How it Ought to be Measured, Washington University Global Studies Law Review no. 11 (2012).

Sluka, T.: Profesionální sportovec: právní a ekonomické aspekty (Professional Sportsman: Legal and Economic Aspects), Praha: Havlíček Brain Team, 2007.

Tetłak, K.: Taxation of International Sportsmen, Amsterdam: IBFD, 2014.

Vybíral, R.: Analýza judikatury vztahující se $\mathrm{k}$ postavení profesionálních sportovců $\mathrm{v}$ oblasti kolektivních sportů v České republice (The Analysis of the Case Law Relating to the Status of Professional Athletes in Team Sports in the Czech Republic), Jurisprudence no. 1 (2013). 


\section{Michal Radvan}

Directive on the evidence of professional and non-amateur contracts, 2014. www.fotbal.cz.

EU: ECJ: C-276/12 (Jiri Sabou v. Financial Directorate Prague).

CZ: Supreme Administrative Court: 2 Afs 62/2004-70.

CZ: Supreme Administrative Court: 2 Afs 176/2004-140.

CZ: Supreme Administrative Court: 2 Afs 16/2011-78.

CZ: Supreme Administrative Court: 6 Afs 278/2016-54. 


\title{
DEPRECIATION METHODS AND RATES AS AN INSTRUMENT OF OPTIMIZATION OF DIRECT TAXES
}

\author{
WIESEAWA MIEMIEC ${ }^{l}$
}

\begin{abstract}
Depreciation of fixed assets and intangible assets is a crucial instrument having the impact on the structure of costs related to income taxes. Depreciation enables the taxpayer to "regain" money spent on the purchase of used assets. Selection of a suitable depreciation method as well as the right to change the depreciation rate not only enables the taxpayer to have an influence on the duration of the depreciation process but also on the amount of depreciation write-downs determining the amount of the tax base and the amount of tax. In this way, the taxpayer can also legally reduce the tax obligation.
\end{abstract}

\section{Keywords}

Tax-deductible expenses; depreciation of fixed assets; depreciation write-down; depreciation method; depreciation rate

\section{JEL Classification: H26, K34, K42}

\section{Introduction}

In colloquial language "optimization" is understood as the "organization of specific actions, processes so that they resulted in the biggest possible effects and involved the least amount of labor" (Słownik języka polskiego PWN). Polish tax regulations do not define tax optimization. Tax law doctrine helps establish this term. Following one of the ideas, tax optimization is understood as tax planning the aim of which is to create the best solutions as regards tax burdens, related to current or investment business activities taken by taxpayers (Wyciślok, 2013: 29). So, it is

1 Doctor, professor, Department of Financial Law, Faculty of Law, Administration and Economy at the University of Wrocław. Contact email: wieslawa.miemiec@uwr.edu.pl. 
a choice of the variant of completion of a given economic outcome resulting in the legal reduction of tax burdens. Tax optimization is a legal form of reduction of tax burdens provided to the taxpayer by the legislator in order to reduce, among other things, tax burdens (Olesińska, 2013: 26). In practice, they are often connected with institutions avoiding taxes (tax evasion is a legal action of the taxpayer aiming at the decrease in tax burdens, often referred to as the grey market. The taxpayer as part of applicable laws takes specific undertakings leading to the decrease of the final tax below the level treated by the legislator as adequate in relation to specific situation resulting in tax and legal consequences (Kalinowski, 2001: 24; Olesińska, 2013: 27) or evading taxation (tax evasion consists of a situation in which the taxpayer is involved in illegal actions the aim of which is to decrease tax burdens. They include actions of the taxpayer aiming directly at the violation of applicable norms and the fiscal law (e.g. suppression of facts before the tax authority resulting in tax obligation, preparation of forged tax returns). All such behaviors constitute the breach of statutory tax rules and are subject to the penalty pursuant to the Penal and Fiscal Code of 10 September 1999. However, these apparently similar institutions have the different meaning in the tax law system.

For the purpose of this survey, I treat tax optimization as a process that encompasses the elements of planning, anticipating and knowledge of the law and makes use of depreciation of a fixed asset to bring on the legal reduction of tax burdens. First of all, the concept of depreciation of a fixed asset, its functions, and a legal structure have to be explained to discuss methods thanks to which depreciation of fixed assets can contribute to reduce such burden.

\section{Concept and Functions of Depreciation of Fixed Assets in the Corporate Income Tax System}

Depreciation is both an economic and legal category. From the economic point of view, depreciation reflects usage of fixed assets in the process of manufacture and gradual reallocation of its value to new products (Swatler, 1983: 16). The process reflects the pecuniary loss of the value of fixed assets used in business activity as a result of its usage or aging and reallocating it to a newly manufactured or purchased asset. The literature distinguishes its three basic functions, i.e.: amortization function, also referred to as a measure of depreciation of fixed assets, cost function and reinstatement function (Sawicka, 1988: 103).

As the depreciation process moves on through the agency of depreciation writedowns, the amortization function decreases the fair value of a given fixed asset, adjusting it to its current value. The cost function says that depreciation is an element 
of costs of the business activity. In other words, depreciation write-downs are classified together with other expenses as the costs of action in a given accounting period. According to the reinstatement function, depreciation enables to replace used and old fixed assets with the new ones. As the depreciation process moves on, funds are obtained gradually that enable to purchase new elements of fixed assets. All these functions are closely inter-related. As part of the cost function, depreciation is a parameter of economic result that enables to make development decisions.

The depreciation process thus perceived is complex. It comprises a few stages and requires specific record and calculation operations. Apart from reallocating the cost of the tangible asset over manufactured goods, it also covers accounting and booking records of the decrease in the value of the assets, measurement of such decrease in cash in form of depreciation write-downs and collection of funds coming from depreciation write-downs in form of depreciation fund that enables reinstatement of used property (Andrzejczak, Mikina, Rzeźnik, Wajgner, 2010: 107). These stages are referred to in a legal regulation included in the accountancy act (Accountancy Act of 29 September 1994) and the tax regulations. The main purpose of depreciation as part of the balance sheet law consists in defining a real value of tangible assets as at the end of the settlement period. Unlike the balance sheet law, tax depreciation refers to taxpayers of income tax and in a separate legal regime regulated by the act, it enables to reduce tax obligation by way of charging amounts of write-downs to tax deductible expenses. Due to the subject matter of the survey further deliberations are limited to legal and tax aspects of depreciation.

Legal and tax depreciation structure of tangible assets are stipulated in the income tax acts, i.e. Personal Income Tax Act ("PITA") and the Corporate Income Tax Act ("CITA"). These regulations specify as per very similar rules the subject of depreciation, calculation basis and the amount of the depreciation write-downs, depreciation methods and the amount of the applied depreciation rates. However, no legal concept of depreciation has been formulated there. Reference books say that "depreciation is one of the methods of recognizing expenses of the taxpayer incurred on the manufacture or purchase of specific assets, tax-deductible expenses in the profit and loss account" (Mariański, Strzelec, Wilk, 2012: 332).

According to the provisions of both income tax acts, depreciation refers to fixed assets owned or co-owned by the taxpayer with the expected useful life of more than a year, purchased or manufactured on its own, complete and fit for use on the day they have been accepted for use, used by the taxpayer for the purposes connected with its business activity or put into use based on rental, tenancy or financial lease agreement (Art. 22a/1 and Art. 22b/1-3 of PITA and Art. 16a/1 and Art. 16b/1-3 of CITA). The aforementioned acts list the elements of property classified as fixed 
assets that are subject to depreciation, irrespective of the expected useful life, e.g. buildings and structures built on a third party's land (Art. 22a/2 of PITA and Art. 16a/2 CITA). Pursuant to Art. 22b/1 and 2 of PITA and Art. 16a/1 and 2 and Art.16b/11 and $2 \mathrm{~b}$ of CITA, also intangible assets are subject to depreciation. For depreciation write-downs to be made, the requirement referred to in Art. $22 \mathrm{~d} / 1$ of PITA and Art. 16d/1 of CITA is of a great importance, pursuant to which assets with the fair value exceeding 3,500 PLN are subject to depreciation. If the value of an asset is equal or lower than 3,500 PLN, the taxpayer can renounce making depreciation write-downs, and expenses incurred to purchase them can be classified as tax-deductible expenses in a month in which they were put into use (Art. 22d/1 of PITA and Art. 16d/1 of CITA; the literature sometimes defines such possibility as one-off depreciation write-down (Mazur, 2009: 354). The legislator has also created a catalog of tangible assets excluded from depreciation, e.g. land and the right of perpetual usufruct of land (Art. 22c of PITA and Art. 16c of CITA).

Thus, components being subject to depreciation have to fulfill conditions specified by the legislator. As far as the fixed assets are concerned, such conditions include among other things the requirement of the ownership or co-ownership right to be held by the taxpayer, the assets have to be manufactured or purchased internally, the assets have to be complete and fit for use on the date they have been accepted by the user, the expected useful life is to be longer than one year, and used funds are to be allocated for purposes connected with the taxpayer's business activity.

\section{Method, Write-Down and Depreciation Rate}

The depreciation method specifies the manner and speed of collecting cash (depreciation fund) that enables reinstatement of used assets. There are a few depreciation methods: a proportional method, also referred to as a straight-line method, a declining balance method, and a progressive method. In case of the straight-line method, the annual amount of depreciation is calculated on the same basis (i.e. on the gross value of the asset) and with the use of the same depreciation rate (fixed rate). The declining balance method consists in adopting the same rate to calculate due to depreciation write-down but related to the current value of the fixed asset, i.e. to the net value decreased by already made depreciation write-downs. Finally, the progressive method consists in calculating write-downs based on the gross value of fixed assets with the use of variable depreciation rate increasing year by year.

As a result, the taxpayer obtains the information on the amount of depreciation of its fixed assets. The amount expressing such decrease in the value of fixed assets in a specific period of time constitutes the depreciation write-down. Such write- 
down is an instrument directly influencing the amount of tax-deductible expenses, and therefore, the amount of income and tax base as regards income taxes. Pursuant to Art. 22/8 of PITA and Art. 15/6 of CITA, depreciation write-downs include write-downs related to wear and tear of fixed assets and intangible assets that will be recognized as tax-deductible expenses provided that they will be made in accordance with the rules provided for in Arts. 22a-o of PITA, taking account of Art. 23 of PITA and Arts. 16a-m of CITA and Art. 16 of CITA.

The taxpayer choosing a suitable depreciation method should take into account effectiveness of a fixed asset, and the period as well as intensiveness of its operation. It should also not only adjust the speed of physical wear and tear of the fixed asset up to the speed of depreciation but also ensure that depreciation write-downs constituting tax-deductible expenses related to income taxes reached the highest possible level and were also appropriately spread over a period of time taking account of a financial standing of the taxpayer and purposes of its business activity.

The depreciation rate is a percentage value of a fixed asset (on a year-to-year basis) the taxpayer can recognize in a given year as tax-deductible expenses. Due to universality, both acts mentioned herein apply interest rates the name of which as well the amount and the symbol in the Classification of Fixed Assets (Decree of the Council of Ministers dated 3 October 2016 on the Classification of Fixed Assets, Journal of Laws item1864 as amended (CFA) are included in the list constituting an appendix no. 1 to such acts. Thus, the taxpayer can easily establish and assign a given fixed asset to a suitable category, and what follows - to a suitable annual depreciation rate. There are exceptions to the aforementioned general rule that enables the taxpayer, in accordance with statutory requirements, to increase or decrease the rate stipulated in the list. According to Art. 22i of PITA and Art. 16i of CITA, in situations established therein the taxpayer can increase or decrease the depreciation rate in comparison to the amount of the rates provided for in the List of Fixed Assets. It is optional for the taxpayer to use decreased or increased rate but at the same time it involves fulfillment of statutory requirements. As not every fixed asset meets object- and time-related criteria qualifying it within a given group defined in the List of Fixed Assets, the act allows for an individual rate with reference to fixed assets defined in Art. 16j of PITA and in Art. 22j of CITA. In this case, the depreciation period related to such fixed assets is limited pursuant to the act to the period of time specified therein.

The right to change the depreciation rate and to use the individual rate enables the taxpayer to have the impact on increasing the amount of the depreciation writedowns, and thus shortening the depreciation period. It is also a starting point for the preparation of a strategy enabling optimization of income tax burdens. 


\section{Methods of Reducing Income Tax Burdens with the Use of Depreciation}

Appropriate planning of tax burdens and the knowledge of regulations related to depreciation of the taxpayer's assets can result in a legal decrease of tax burdens. Depreciation as a financial and legal institution generating costs can contribute to the application of tax regulations so that the costs were not only optimal but also occurred in a specific time horizon. Taking into account legal rules determining depreciation, it should be assumed that the following can be deemed to be optimization instruments in the analyzed scope:

- the possibility of changing rates in the straight-line method;

- the depreciation with the use of declining balance method;

- the one-off depreciation;

- the depreciation as per individual rates.

These are not all possible methods resulting in the decrease in income tax burdens (tax optimization). There is also the so-called lease back or dwelling premises improved or used before they have been purchased but they are quite rare in practice and therefore they will be skipped in further considerations.

\subsection{Taxpayer's Right to Increase or Decrease the Depreciation Rate in the Straight-Line Method}

The straight-line method is the basic depreciation method provided for in income tax acts. Pursuant to Art. 22f of PITA and Art. 16f of CITA, taxpayers, with the exception of those who do not conduct business activity due to declared bankruptcy covering liquidation of the assets, make depreciation write-downs of the fair value of fixed assets and intangible assets. In Art. 22g of PITA and in Art. 16g of CITA, a normative concept of the fair value was established. In case of a purchase, this value corresponds to the purchase price. In case of internal manufacture, it corresponds to the cost of manufacture. In case of acquisition by way of inheritance, donation or other acquisition free of charge - it is a market value as of the date of purchase unless a lower value has been determined in the contract related to such acquisition free of charge. The act also allows for a possibility of establishing a different fair value of fixed assets by the taxpayer. Pursuant to Art. 22g/1/6 and 7 of PITA and Art. $16 \mathrm{~g} / 1 / 6$ and 7 of CITA, taxpayers who purchased fixed assets by way of performance for them of non-pecuniary obligation in place of the performance of the obligation contract (datio in solutum), can adopt the market value of the assets as their fair value unless the contract for supplementary performance specifies a lower value. Also, foreign taxpayers who conduct business in the territory of Poland 
through the agency of a foreign plant can adopt other value of fixed assets as the fair value. In such case, it is the value of individual elements adopted for tax purposes that results from the books of such taxpayer, however, no higher than the market value of such assets. The provisions of the act provide for a condition that all writedowns in a given tax year cannot exceed the equivalence of 50 thousand EUR.

Pursuant to Art. 22h/44 of PITA and Art. 16h/4 of CITA, taxpayers who apply the straight-line method make depreciation write-downs in equal installments on a monthly or quarterly basis, or on a one-off basis at the end of the tax year. Following this method, depreciation write-downs are made in equal installments depending on the decision made by the taxpayer, on a monthly or quarterly basis, or on a oneoff basis at the end of the tax year. The first month following the month in which a given fixed asset has been put in the records shall be deemed to be the beginning of depreciation, until the end of the month in which the sum of depreciation writedowns is equal to their fair value or in which they were declared bankrupt, sold, or their shortage was stated. The date of putting the fixed asset into use is important as well as the fact whether the asset meets other conditions provided for in the law, e.g. whether it was complete and fit for use on that day.

The straight-line method enables even wear and tear of a given fixed asset during the period of its useful life, based on fixed depreciation write-downs during the whole period of depreciation. In situations indicated in Art. 22i of PITA and Art. 16i of CITA, the taxpayer can bring on increasing or decreasing the amount of the depreciation write-downs and in consequence speed up or slow down the period of depreciation (Małkowska, 2002: 166). Such result can be obtained by way of using the taxpayer's right to change the amount of depreciation rate in comparison to the amount given in the list of depreciation rates. As a result, due to the depreciation rate, the straight-line method can have a form of accelerated or decelerated depreciation (Ożóg, 2000: 93).

Optionality of choice made by the taxpayer should be justified not only by tax optimization but also by financial standing of the taxpayer. Pursuant to Art. 22i/2 of PITA and Art. 16i/2 of CITA, taxpayers can increase basic rates of specific assets that are used in special conditions and establish at the same time the limit for increasing the coefficient of basic rates provided in the list constituting the appendix to the aforementioned acts, i.e.:

- for buildings and structures used in deteriorated conditions - with the use of coefficients not higher than 1.2, or in bad conditions with the use of coefficients not higher than 1.4;

- for machinery, devices and means of transport, with the exception of floating marine fleet, used more intensively in relation to average conditions 
or requiring special technical efficiency - with the use of coefficients not higher than 1.4;

- for machinery and devices classified within groups 4-6 and 8 of fixed assets, being subject to rapid technical development - with the use of coefficients not higher than 2.0.

Explanations attached to the List of rates include open catalogues with examples of situations that enable to apply the increased rate, i.e. deteriorated conditions (a catalogue of such situations is open, section 1 of the explanations says that among other things it is about using fixed assets being under the constant influence of water, steam, significant vibrations or sudden changes in temperature), bad conditions (according to section 2 of the explanations, it concerns fixed assets being under the influence of destructive chemical agents), special technical efficiency (according to section 3 of the explanations, special technical efficiency is understood as facilities which are used on a three-shift work basis, or in field conditions, in the first or under the ground), rapid technical development (according to section 4 of the explanations, rapid technical development is understood as machinery, devices, and apparatus in which microprocessor or computer systems are used).

Possible use of the increased rate is limited by an admissible limit that cannot be exceeded by the taxpayer. One selected coefficient can be applied as regards individual fixed assets. Increased rates mean that the basic rate provided for in the List of rates is multiplied by a given coefficient. Further depreciation writedowns have to be made in accordance with the rules applicable to the straight-line depreciation method. The increased rate in situations provided for in Art. 22i/2 sections 1-2 of PITA and Art. 16i/2/1-2 of CITA can be used starting the month following the month in which circumstances justifying such increase took place. As regards machinery and devices being subject to rapid technical development, taxpayers can increase or stop using them starting the month following the month in which such assets were put in the records or starting the first month of each following tax year. The literature says that after circumstances justifying the taxpayer's right to increase the rate have ceased to exist, the taxpayer shall be obliged to decrease it (Nykiel, Mariański, 2014: 612-613).

Pursuant to Art. 22i/5 of PITA and Art. 16i/5 of CITA, taxpayers can also decrease depreciation rates of individual fixed assets depreciated with the use of the straightline method provided in the List of Fixed Assets. Unlike given situations, the act does not state that the basic rate can be decreased provided that some specific conditions have been fulfilled. There is also no limit as regards the decrease in the rate of a concrete fixed asset and the obligation to meet the acceptable dates for the implementation of such decrease. Following the aforementioned regulations, the rate is changed starting the month in which assets were put in the records or starting 
the first month of each following tax year. The taxpayer can return to previous rates at any time on condition that they do not exceed maximum limits provided for the basic depreciation rates specified in the List. It results from the same wording of the regulations which enable to decrease rates without any additional requirements in this scope.

Thus, the straight-line method can be deemed to be quite flexible and providing for a possibility of changing the depreciation rate during the depreciation period it enables to adjust the amount of depreciation write-downs to current needs and tax burdens of the taxpayer (provided that the rate does not exceed the maximum amount specified in the list of depreciation rates). The use of the increased depreciation rate involves increase in the amount of depreciation write-downs. It results in the increased tax-deductible expenses related to income tax, and in consequence, in the decrease in due and payable obligation on this account. It also results in a shortened depreciation period, faster obtaining of depreciation fund that enables not only reinstatement of used fixed assets but also faster reimbursement of expenses incurred on the fixed assets. The decision on making depreciation stages faster by way of increasing the rate has to be made by the taxpayer after taking account of its financial standing. If the fixed assets are not being as much worn or when the taxpayer suffers financial loss for a longer period of time, the possibility of decreasing the depreciation rate is a useful instrument. When suffering loss, the taxpayer does not generate any taxable income but there might be a risk that it will not make it to deduct the loss from income in the following 5 years pursuant to Art. 9/5 of PITA and Art. 7/5 of CITA (the amount in any of these years cannot exceed $50 \%$ of the amount of loss). Prolongation of the depreciation process enables the taxpayer to decrease income in the next years (Wójtowicz-Janicka, 2012: 207, 210). It has also a positive outcome. The taxpayer can settle the loss in its full amount without losing cost generated by depreciation write-downs. It should be mentioned that the taxpayer can freely choose fixed assets for which the rate will be decreased. The act does not also provide for limits as regards the decrease of the depreciation rate (with the exception of the rate established individually which does not change during the whole depreciation period). Thus, the question if the depreciation rate can approach zero is reasonable. The act does not specify any limits, thus, it should be assumed that it is admissible. Such stance has been adopted in the reference books (Wójtowicz-Janicka, 2012: 211) and in some interpretations of tax authorities (individual interpretation: no. IBPBI/1/423-37/11/ZK, individual interpretation: no IPPB5/423-161/10-2/AM). 


\subsection{Depreciation Made with the Use of the Declining Balance Method}

The principles governing the declining balance method are different. According to Art. $22 \mathrm{k} / 1-13$ of PITA and Art. 16k/1-13 of CITA, the declining balance method can only be used in relation to some assets, i.e. machinery and devices classified within the groups 3-6 and 8 of the Classification of Fixed Assets and to means of transport, excluding buildings and vehicles. This method is characterized by a variable, decreasing base for depreciation write-downs. During the first year, the amount of depreciation write-down is established on the basis of the fair value of a fixed asset according to the rules applicable with reference to the straight-line method. During successive years the amount of depreciation write-down is calculated based on the fair value of the fixed asset decreased by the sum of already made write-downs established at the beginning of successive years of use. So, it is the net value of the fixed asset. Decreasing base causes that also depreciation write-downs decrease, thus, this method is called the declining balance method (wwwsjp.pwn.pl).

Such base constituting the net value of the fixed asset serves as a basis for establishing depreciation write-down calculated with the use of the rate increased by a coefficient not higher than 2.0. The depreciation process would take a lot of time based on such rules, thus, starting the tax year in which the annual amount of depreciation specified based on the aforementioned rules would be lower than the annual amount of depreciation calculated with the use of the straight-line method and basic rates included in the List of depreciation rates, the taxpayer is obliged to make further write-downs with the use of the straight-line method according to Art. 22i/1 of PITA and Art. 16i/1 of CITA. After moving to the straight line method, pursuant to Art. 22i/2-7 of PITA and Art. 16i/2-7 of CITA, the taxpayer can make depreciation write-downs choosing the fixed or variable rate.

The advantage of using the declining balance method consists in a possibility of speeding the depreciation process in the first two years of using the fixed asset, i.e. in the period of its highest efficiency, as well as a possibility of faster use of financial surplus towards which profit and the amount of the depreciation writedowns are applied. Owing to the increased tax-deductible expenses, the payment of income tax is shifted in time. This method also has some defects. In the initial period of use of fixed assets with the use of this method, a higher cost of the activity will be experienced. Thus, profit obtained by the taxpayer will be lower. Depending on the financial standing of the taxpayer, all these consequences should be taken into account. 


\subsection{One-off Depreciation}

The provisions of Art. 22k/7-13 of PITA and Art.16k/7-13 of CITA provide for a possibility of making one-off depreciation write-offs of the fair value of fixed assets classified within groups 3-8 of the Classification of Fixed Assets, i.e. machinery, devices and means of transport, excluding passenger cars. So, fixed assets classified within groups 3-8 can be depreciated on a one-off basis.

Small business taxpayers and taxpayers commencing their business activity (only during the first tax year) have the right to apply (every year) one-off depreciation method) (small business taxpayer in 2017 in accordance with Art. 5a/20 of PITA, Art. $4 \mathrm{a} / 10$ of CITA refers to the taxpayer whose sales income and due VAT in 2014 did not exceed the amount expressed in Polish PLN corresponding to the equivalence of 1.2 million EUR per year). Such possibility can be used by income taxpayers commencing their activity in the tax year during which such assets were put in the records of fixed assets and intangible assets up to the amount not exceeding the equivalence of 50 thousand euro of the total amount of such depreciation writedowns in the tax year (in 2017 the amount was 215 thousand PLN).

Depreciation write-downs made with the use of such preferential method does not apply according to Art. $22 \mathrm{k} / 11$ of PITA to taxpayers that in the tax year and within two years starting the end of the year preceding the year of commencement of activity were conducting business activity independently or as partners of a company not being a legal person or such activity was conducted by a spouse of such person if there was marital community property between spouses. In Art. $16 \mathrm{k} / 11$ of CITA, the act excludes the possibility of making one-off depreciation by the taxpayer that was established as a result of transformation, merger or division of taxpayers or as a result of transformation of the company not being a legal person, or by natural persons who provided their enterprise or assets of such enterprise towards the capital of a new entity with the value exceeding jointly the equivalence in Polish PLN of at least 10.000 EUR.

The possibility of applying this method should be treated as a specific tax relief. Art. $22 \mathrm{k} / 10$ of PITA and Art.16k/10 of CITA treat it as de minimis aid (de minimis aid is a special category of support granted by the state as it is assumed that due to its minor value it does not disturb competition in the EU. Therefore, it is not, in fact, public support within the meaning of Art. 107/1 of TFUE, and in consequence, it is not subject to the obligation of notification of the European Committee. The rules of providing de minimis aid have been defined in the Decree of the Committee (EC) no. 1998/2006 in connection with Art. 87 and 88 of the Treaty to the de minimis aid, Journal of Laws of the EU of 2006, L 379/5). Implementation of such rule causes that the circle of taxpayers applying one-off depreciation method is limited. It can 
only be used by the taxpayers that are entitled to such aid and have not used in full their limit.

The (gross) fair value of fixed assets in the tax year during which they were put in the records is the basis for making depreciation write-downs following this method. This value is established according to the rules included in Art. 22g/1/6 of PITA and Art. $16 \mathrm{~g} / 1 / 6$ of CITA. Selection of the type of method in the following years is also the taxpayer's right. It will have to decide on further depreciation method taking into account not only its own financial standing but also advantages and defects of the straight-line method or declining balance method. Such solution created an investment stimulant for small taxpayers as it contributed to reducing the amount of income tax due in a given year and enabled to use flexible rules for the settlement of depreciation. Due to subject limitations (it was to be used by a small group of taxpayers) and object limitations (it concerned selected assets), as well as the necessity to prepare additional documentation (one-off depreciation write-off constituted de minimis aid) it was not used to a great extent in practice.

On 7 July 2017 another amendment to PITA and CITA was passed, enabling oneoff depreciation to be made in relation to purchased owned or co-owned new fixed assets classified within groups 3-6 and 8 of the Classification of Fixed Assets in the tax year in which these assets were put in the records up to the amount not exceeding the amount of 100,000 PLN in the tax year, covering the sum of depreciation write-downs and payments made by the taxpayer towards the purchase of such fixed assets (Art. 22k/14-21 of PITA and Art.16k/14-21 of CITA). The possibility of applying this preferential method depends on the fulfilment by the taxpayer of conditions provided for in quoted regulations, namely, the fair value of one new fixed asset purchased in the tax year should be at least 10,000 PLN or the aggregate fair value of at least two new fixed assets purchased in the tax year should amount to at least 10,000 PLN and the fair value of each of them should exceed 3,500 PLN (Art. 22k/14-15 of PITA and Art. 16k/14-15 of CITA).

If the activity is conducted by a company not being a legal person, the limit of depreciation write-downs in the amount of 100 thousand PLN refers to all partners of such company (Art.22k/19 of PITA and Art. 16k/19 of CITA). This accelerated depreciation method can be used by taxpayers irrespective of the form of activity in relation to expenses for the purchase of brand new fixed assets, i.e. machinery and devices affected since the beginning of 2017. Expenses on used fixed assets, means of transport, including passenger cars, and expenses on real property have been excluded. It is crucial that as part of the annual limit it is possible to recognize payments (advance payments) for the purchase of a fixed asset meeting the requirements also when such asset will be delivered within the following reporting periods (next month, quarter or year). According to this rule, the taxpayer that 
has exhausted the limit within one tax year and could not recognize the advance payment for the purchase of fixed assets towards tax-deductible expenses, will have the right in the following year to decrease the amount of one-off depreciation writeoff by previously paid advance payment after the fixed asset has been purchased. However, if the delivery is not affected the taxpayer shall be obliged to correct taxdeductible expenses (Art. 22k/21 of PITA and Art. 16k/21 of CITA). This relief is to encourage mainly micro, small and medium-size companies to purchase new machinery and devices that can significantly increase their competitiveness. However, it is hard to assess whether the expected results will be reached. The new regulation has not been implemented yet.

\subsection{Depreciation as per Individual Rates}

The possibility of making depreciation write-downs with the use of individual rates is applied in relation to the straight-line method. It consists in establishing an individual depreciation rate as regards used or improved purchased fixed assets, put for the first time in the records of the fixed assets of the taxpayer (Art. 22j/1 of PITA and Art. 16j/1 of CITA). The possibility of using this method depends on the cumulative fulfillment of two conditions by the fixed assets. First, they have to be considered as used or improved within the meaning of the act (par. 2 and 3 of the aforementioned regulations) and have to be put for the first time in the taxpayer's records. These rates are only limited by the period of depreciation specified in the aforementioned acts. Depreciation period is established for individual types of fixed assets and cannot be shorter than:

1) for fixed assets classified within group 3-6 and 8 of the Classification:

a) 24 months - when their fair value does not exceed 25.000 PLN,

b) 36 months - if their fair value is higher than 25.000 PLN and does not exceed 50.000 PLN,

c) 60 months - in other cases.

2) for means of transport, including passenger cars - 30 months,

3 ) for buildings (premises) and structures referred to in Art. $22 \mathrm{j}$ par.1 section 3 of PITA and Art. 16j/1/3 of CITA - 10 years,

4) for buildings (premises) and dwelling structures for which the basic rate in the List of rates amounts to $2.5 \%$ - 40 years, decreased by a complete number of years that have passed since the date of putting them into use for the first time until the date of putting them in the records kept by the taxpayer, whereas the depreciation period cannot be shorter than 10 years. The aforementioned regulations define separately the concept of used fixed asset (used fixed assets referred to in par. 1 sections 1 and 2 refer to assets if 
the taxpayer proves that they had been used for at least 60 months before they were purchased) and improved fixed assets (improved fixed assets referred to in par. 1 sections 1 and 2 refer to assets if before putting them in the records expenses incurred by the taxpayer for such improvement constituted at least $20 \%$ of the fair value) depending on their type. The act provides also for a possibility of establishing the individual rate for investments in the third party fixed assets accepted for use (Art. 22j/4 of PITA and Art. 16j/4 of CITA).

In practice, individual depreciation rates are used with reference to premises and buildings depreciated with the use of the straight-line method as per low rates, as well as in relation to expensive passenger cars. In the second case, according to Art. 23/1/4 of PITA, depreciation write-downs do not constitute tax-deductible expenses in the part established on the value of the car exceeding the equivalence of 20.000 EUR. Thus, establishing the costs of depreciation write-downs in the records, they should be presented in accordance with Art. 21/1/4 of PITA, in the proportion resulting from the value of the car and the amount of 20.000 EUR. The use of low depreciation rate is cost-effective especially when such car is to be sold. Then the fair value is higher, not covered by depreciation write-downs, constituting costs of paid disposal of the car. The economic result obtained by the taxpayer by way of using individual rates is similar to the result obtained in case of using the declining balance method. It enables to speed up depreciation and accumulation of costs related to depreciation write-downs.

\section{Conclusions}

The aforementioned arrangements show that depreciation methods of individual fixed assets of the taxpayer and a type of applied depreciation rates as well as the amount of the depreciation write-downs have a crucial impact on the level of taxdeductible expenses in a given settlement period. They determine the amount of income reached by the taxpayer as well as the amount of income tax due.

The taxpayer chooses the depreciation method taking account conditions related to the object of depreciation. Thus, the taxpayer has to decide which method provided for in applicable provisions would be the most advantageous solution as regards the taxpayer's financial standing. If the taxpayer assumes that the fixed assets will be worn quickly or its value will decrease rapidly, it has to consider the declining balance method characterized by the increased value of depreciation write-downs at first stages of depreciation. If the taxpayer is in a good financial situation and cares about the fixed amount of depreciation write-downs, it should apply the straight-line method. Systematic depreciation made with the use of the straight-line 
method and a fixed rate enables to lower advance payments for income tax and is more profitable when the taxpayer regularly pays significant amounts of advances on account of the income tax. Selection of the suitable depreciation method and rate is a crucial element of tax planning as regards future tax burdens. Using available legal instruments, the taxpayer can make tax depreciation a significant element of tax optimization.

\section{References}

Andrzejczak, D., Mikina, A., Rzeźnik, B., Wajgner, M.D.: Podstawy działalności handlowej (Basis of commercial activity), Warszawa: WSiP, 2010.

Kalinowski, M.: Granice legalności unikania opodatkowania w polskim systemie podatkowym (Limits of the legality of tax avoidance in the Polish tax system), Toruń: TNOiK, 2001.

Małkowska, D.: Środki trwałe, wartości niematerialne i prawne. Ujęcie podatkowe i rachunkowe (Fixed assets, intangible assets. Tax and accounting aspects), Gdańsk: Ośrodek Doradztwa i Doskonalenia Kadr, 2002.

Mariański, A., Strzelec, D., Wilk M.: Podatek dochodowy od osób prawnych. Komentarz (Corporate tax. Comentary), Warszawa: Wolters Kluwer, 2012.

Mazur, E.: Ustawa o podatku dochodowym od osób prawnych w wyjaśnieniach organów podatkowych. Komentarz. Linie interpretacyjne (Act on corporate income tax in explanations of tax authorities. Comment. Interpretation lines), Warszawa: Wolters Kluwer, 2009.

Nykiel, W., Mariański, A. (eds.): Komentarz do ustawy o podatku dochodowym od osób fizycznych (Commentary to the Act on personal income tax), Gdańsk: ODDK, 2014.

Olesińska, A.: Klauzula ogólna przeciwko unikaniu opodatkowania (General clause against tax avoidance), Toruń: TNOiK, 2013.

Ożóg, I.: Amortyzacja w podatku dochodowym od osób fizycznych i prawnych (Depreciation in personal and corporate tax), Warszawa: Konieczny i Kruszewski, 2000.

Sawicka, K.: Rola instrumentów prawnofinansowych w gospodarce produkcyjnym majątkiem trwałym przedsiębiorstw państwowych (The role of legal and financial instruments in the production economy of fixed assets of state-owned enterprises), Wrocław: Wydawnictwo Uniwersytetu Wrocławskiego, 1988.

Swatler, L.: Amortyzacja i finansowanie remontów a system ekonomiczno-finansowy (Depreciation and financing of repairs and the economic and financial system), Finanse (Finances) no. 5 (1983).

Wójtowicz-Janicka, K.: Amortyzacja ze stawką 0\% u podatnika rozliczającego stratę podatkową (Amortization with a $0 \%$ rate for a taxpayer who settles a tax loss), in: Mazur, Ł.: Optymalizacja podatkowa (Tax optimalization), Warszawa: Wolters Kluwer, 2012.

Wyciślok, J.: Optymalizacja podatkowa. Legalne zmniejszanie obciążeń podatkowych (Tax optimization. Legal reduction of tax burdens), Warszawa: C.H. Beck, 2013. 


\section{Wiesława Miemiec}

Słownik języka polskiego PWN (Dictionary of Polish). wwwsjp.pwn.pl.

EU: Decree of the Committee (EC) no. 1998/2006, on the application of Articles 87 and 88 of the Treaty to State aid to small and medium-sized enterprises active in the production of agricultural products and amending Regulation (EC) no. 70/2001.

PL: Accountancy Act of 29 September 1994, as amended.

PL: Penal and Fiscal Code of 10 September 1999, as amended.

PL: Corporate Income Tax Act of 15 February 1992, as amended.

PL: Personal Income Tax Act of 26 July 1991, as amended.

PL: Decree of the Council of Ministers of 3 October 2016 on the Classification of Fixed Assets, as amended.

PL: Individual interpretation: no. IPPB5/423-161/10-2/AM.

PL: Individual interpretation: no. IBPBI/1/423-37/11/ZK. 


\title{
FEW NOTES ON MEASURES TO PREVENT TAX EVASION AND TAX FRAUD - WHAT IS THE INTEREST OF SOCIETY? ${ }^{1}$
}

\author{
Ivana Štieberová ${ }^{2}$
}

\begin{abstract}
Tax evasion is a very serious and dangerous problem. In recent years, therefore, several measures have been taken to prevent it. The aim of this paper is to determine whether the measures taken to prevent tax evasion are sufficient and whether it is possible, or even more effective, to achieve the intended purpose - to reduce tax evasion to the lowest possible level by other means that shall not burden the taxable entities and will therefore not only for the benefit of state but also for the benefit of taxable entities. We will focus mainly on the moral aspects of preventing tax evasion. We conclude that in the area of tax relations there is a quite significant correlation between legal consciousness and morality. Few problems in society are as sensitive as the relationship of taxable entities to the state or the local government authority in relation to the fulfillment of tax obligations.
\end{abstract}

\section{Key words}

Reduction of public budget revenues; tax law; tax evasion; tax compliance

\section{JEL Classification: H26, K34, K42}

\section{Introduction}

Each State seeks to secure as many funds as possible into the state budget, which are allocated there and subsequently serve to cover the needs of the society which cannot be provided through the operation of the market mechanism. Undoubtedly,

\footnotetext{
1 This article represents a partial output of the grant projects VEGA 1/0846/17: "Implementation of the initiatives of the EU institutions in the field of direct taxes and indirect taxes and their budgetary law implications" and APVV-16-0160: "Tax evasion and tax avoidance (motivation factors, formation, and elimination)".

2 Internal Ph.D. Student, Department of Financial Law, Tax Law and Economy, Faculty of Law, Pavol Jozef Šafarik University in Košice, Slovak Republic. Contact email: ivana.strakova1@student.upjs.sk.
} 
the most important source of the state budget revenues is taxes. Tax revenues represent $75-80 \%$ of the total state budget revenues each year. This revenue side of the state budget is under threat in case the tax evasion occurs. Generally speaking, tax evasion can be considered as tax non-payment in violation of the law (Babčák, 2015: 100).

Tax evasion thus represents a dangerous and serious problem from the economic and fiscal perspective. In the past, paying taxes belonged to and currently belongs to one of the least-favorite activities of taxable entities. There is probably no commercial entity that does not want to minimize its own tax burden.

The highest number of tax evasion and tax fraud may be noticed in the area of value added tax (hereinafter referred to as "VAT"). For this reason, this area is being given the greatest attention, various analyzes are being produced, and the controlling activity focuses mostly on this area. In October 2016, the Financial Policy Institute of the Ministry of Finance of the Slovak Republic (hereinafter referred to as "SR") produced an analysis of operation of the financial administration of the Slovak Republic of October 2016 (Inštitút finančnej politiky Ministerstva financií SR, 2016) where they claim that, according to current estimates, the VAT tax gap ${ }^{3}$ in the year 2015 reached $29.2 \%$ of the potential VAT in the Slovak Republic. In nominal terms, this difference corresponds to 2.2 billion euros, representing $2.8 \%$ of GDP. The European Commission argues that VAT Gap in the European Union (hereinafter referred only as "EU") in 2014 was nearly 160 billion euros lost in uncollected revenues.

It is therefore understandable that states are trying to take measures to prevent tax evasion and tax fraud, to make them as small as possible and thus to make the tax gap as small as possible as well. Therefore, on the territory of the Slovak Republic, successive amendments were drafted to the individual tax legislation, various measures were taken and new institutes were set up to help detect and combat tax evasion. This paper will focus primarily on measures taken to prevent tax evasion and tax fraud on VAT.

Surely, such measures are necessary and several of them have helped achieve the intended purpose of discouraging taxable entities from committing tax evasion. However, it is necessary to take into consideration for how long it is possible to impose new obligations on taxable entities, burdening them with new measures to combat tax evasion, which represent a further administrative burden for them in most cases. estimate of revenue loss due to tax fraud, tax evasion and tax avoidance, but also due to bankruptcies, financial insolvencies or miscalculations. 
Few Notes on Measures to Prevent Tax Evasion and Tax Fraud - What is the...

The aim of this paper is to determine whether the measures taken to prevent tax evasion are sufficient and whether it is possible, or even more effective, to achieve the intended purpose - to reduce tax evasion to the lowest possible level by other means that shall not burden the taxable entities and will therefore not only for the benefit of state but also for the benefit of taxable entities. We will focus mainly on the moral aspects of preventing tax evasion.

In this scientific paper, we will use several scientific methods. Firstly, a systematic and a descriptive method will be used. Also abstraction as an inevitable form of scientific thinking (Knapp, 2003: 65-67). Analysis and synthesis will also be applied, especially in the analysis of selected institutes aimed at preventing tax evasion (such as tax audit and control statement). Of course, we will use a method of induction as a process from special to general. The comparative method will be applied as well. Each method will be used in combination with each other, because only then can we achieve the aim of this paper.

\section{A Few Notes About Institutes and Measures to Prevent Tax Evasion and Tax Fraud}

Many taxable entities (especially "small entrepreneurs") do not consider the measures that are being taken in the area of combating tax evasion in a positive sense. In the event of adopting a measure (for example, some time ago guaranteeing for the value-added tax, a control statement ${ }^{4}$ ) in order to prevent and detect tax evasion and tax fraud, although it is essentially an effective tool to tackle this dangerous issue, such a measure has ultimately an impact on small and medium-sized enterprises that are "paying a price" for it (for example, there is the administrative burden they feel to a greater extent than bigger entrepreneurs).

Take, for example, the control statement. The importance of introducing the VAT control statement is that it represents an important source of information for financial administration. It was introduced for the purpose of cross-checking those data which are subject to VAT and where the tax liability incurs in the Slovak Republic. Due to content of the control statement, that is, the data that the taxpayers are obliged to state, it may be said that it is to serve the tax administrators for the purposes of early detection of risk entities suspected of tax evasion, to better a control of requests for refunding excess VAT deduction, also for early detection of domestic and cross-border carousel fraud and various machinations of invoices.

4 VAT control statement is a detailed summary of information on all VAT payer transactions subject to Slovak VAT. It is a form that is required to submit by each VAT payer in the SR and shall specify details of individual tax obligations of the VAT payer and the individual VAT deductions applied by the VAT payer for the relevant period. For more information, see below. Hereinafter referred to as "control statement". 
This means that the VAT control statement has a control function in taxable transactions within the SR, as well as the recapitulative statement has a control function in intra-community transactions within the EU. The data presented in it is based on tax return data, which are more detailed in the VAT control statement (Jarošová, 2014). The control statement, which is an effective measure to combat tax evasion ${ }^{5}$, represents another non-pecuniary obligation for the taxable entity (the VAT payer).

If we look on the individual measures (VAT guarantee, guaranteeing for the value added tax, control statement) purely from the fiscal point of view, the analysis prepared by the Financial Policy Institute of the Ministry of Finance of the Slovak Republic indicates that has been a VAT gap reduction by as much as one quarter by the measures adopted to prevent tax evasion compared to 2012, when it reached its peak. The reduction of the tax gap was mainly due to the streamlining of the control processes, while by streamlining the control processes we understand the fact that the financial administration of SR has gradually become more and more focused on the tax audits of excess deductions of the VAT. This is more important from the perspective of potential VAT revenues, as detection of fraud with excess deductions of VAT prior to their payment means net savings. On the contrary, in most cases (e.g. if the entity terminates its activities) the additional assessing of tax does not imply an increase in tax revenues.

However, if we look at it only from a fiscal, economic or legal point of view, it may be said that such a profoundly pro-fiscal approach may appear as a form of certain bullying by tax administrators and the state, because 'smaller' taxable entities (small and medium entrepreneurs) feel that large corporations are not affected as much as they are. Thus, the expected effect is different as it should be. This is related to situations where huge tax evasion has been detected, but the responsible entity was ultimately not punished.

\section{Tax Audit and Interest on VAT Refund}

As you may notice another effective tool in preventing tax evasion and tax fraud on VAT is a tax audit (Straková, 2016: 424-442). A tax audit is undoubtedly an effective tool in preventing tax evasion and taxable entities are obliged to tolerate the performance of the tax audit for a certain statutory period. But what if the tax audit exceeds this statutory time limit? What impact does it have on the status of

Only in 2014, based on data from the VAT control statement, were identified schemes of fraudulent behavior at 7,106 entities with a total amount of VAT of 213,044 million euro. However, this tool has also increased the effectiveness of VAT tax audits, namely the specific focus of tax audits. 
Few Notes on Measures to Prevent Tax Evasion and Tax Fraud - What is the...

the taxable entity? The problem arises, in particular, when the payment of taxable entity's funds, such as excess deduction of the VAT, depends on the termination of the tax audit, which is legally carried out but takes longer than usual, and it is concluded that the taxable entity has requested the payment of the funds legally. The issue had arisen due to the context of tax audit performance to verify rightfulness of the claim to refund an excessive VAT deduction or its part and therefore, following the decision of the Court of Justice of the EU of 21 October 2015 in case C-120/15 Kovozber, an interest on VAT refund ${ }^{6}$ has been incorporated into our legal system ${ }^{7}$ since 1 January 2017.

Interest on VAT refund represents a certain compensation for the taxable entity in case the refund of excess VAT deduction was made after the tax audit which exceeded a reasonable period of time ${ }^{8}$. However, it was introduced only on the basis of the decision of the Court of Justice of the EU, which stated in its resolution that "provided the excess VAT deduction is refunded to the taxable person after the expiry of a reasonable period, the principle of fiscal neutrality requires that the financial losses thus incurred to the taxable person, which results from the impossibility of disposing of such amounts, were compensated by the payment of default interest".

The trend among the tax administrators has become the situation in which the taxable entity claims the refund an excess VAT deduction, they initiate the tax audit to verify rightfulness of the claim to its refund ${ }^{9}$, which results from the fact that in recent years there was a huge tax evasion and tax fraud in connection with the unjustified application of excess VAT deductions by taxable entities (VAT payers).

However, if the taxable entity claims the refund of excess VAT deduction rightfully ${ }^{10}$, as demonstrated at the completion of the tax audit, there is a large intervention in the sphere of property of the taxable entity. During the tax audit verifying the rightfulness of the claim to refund an excessive VAT deduction or its part, the taxable entity cannot dispose of funds corresponding to the applied excess deduction. This follows from the fact that if the tax office (the tax administrator) initiate the tax audit within the time period for refunding the excess deduction, the

6 For more details on introducing this interest into our legal order, see for example Bonk (2016: 40-52).

7 Its regulation is in Act No. 222/2004 on Value Added Tax in the wording of later regulations (hereinafter "VAT Act") in Art. 79a "Compensation for VAT refund retained during tax audit".

8 For the length of the tax audit, Cf, for example, Vernarský (2012: 48-60); also Štrkolec (2014: 1354-1363).

9 The annual report of the Financial Administration for 2016 shows that until December 31, 2016, were carried out entirely 7288 tax audits of excess deductions of VAT, which represent $80.4 \%$ of the total tax audits on VAT and $61.6 \%$ of the total number of tax audits carried out on all types of taxes.

10 The taxable entities often try to get the claim of excess VAT deduction by means of various camouflage legal acts. For camouflage legal acts, their difference against an abuse of law and a circumvention of the law, see more e.g.: Popovič (2016: 255-265). 
tax office shall refund the excess deduction within ten days of the completion of the tax audit in the amount determined by the tax office, except for the return of a portion of the excess deduction based on the interim protoco ${ }^{11}$. Thus, it may be observed that if the taxable entity claims a refund of the excess VAT deduction in the relevant taxation period and the tax audit is initiated, there is in some cases a significant extension of the deadline for refund of the excess deduction, namely twelve (or twenty-four months) and even if the tax audit is interrupted, it may also take a longer period of time.

It may be noted that the taxable entity has a primarily fiscal interest in a rapid termination of the tax audit in order to be able to dispose of the funds corresponding to the claimed excess VAT deduction. In many cases, this is not a negligible amount, and the non-payment of excess VAT deduction may be liquidated for the taxable entity. They count on a certain income to be able to continue to pay their liabilities. Of course, it is the right of the tax administrator, in case of doubt, to verify whether the taxable entity applies excess VAT deduction rightfully. However, it is not conceivable for the state to do so whenever a taxable entity asks for the refund of the excess VAT deduction. It affects mainly honest entrepreneurs because the tax administrator is mostly trying to reject the excess VAT deduction or reduce it as much as possible by referring to the general principle of the prohibition of abuse of law ${ }^{12}$, which applies to the area of tax law as well. Retention of excess deduction by the tax administrator in case the subsequent tax audit proves that the claim to refund an excessive deduction or its part was rightful, has a significant interference to the taxable entity's financial freedom and to the violation of VAT neutrality.

Here, it can be noticed, in the case of the tax audit to verify the rightfulness of the claim to refund excess VAT deduction, there is a conflict between the rights of the audited taxable entity which tries to minimize its own tax burden and the fiscal interests of the state or municipality.

The introduction of interest on VAT refund seems to be a significant measure in the interest of the taxable entity, but its regulation in our legal order is not satisfactory. Value Added Tax. The tax administrator could return a portion of the excess deduction before the end of the tax audit in the amount defined in the interim protocol. In particular, this concerns the situations where during the tax audit the tax administrator finds out that a portion of the excess deduction is rightfully applied, but for the remaining portion is needed further investigation, such as getting information through an international exchange of information from another Member State of the European Union, which sometimes takes a long time and therefore it is not possible to terminate tax audit.

12 To introduce this principle into our law, see for example Prievozníková (2015: 161-168); also Sábo (2015: 199207); also Románová (2015: 212-228). 
Few Notes on Measures to Prevent Tax Evasion and Tax Fraud - What is the...

In particular, when regarding the period from which the taxable entity is entitled to such interest $\mathrm{t}^{13}$ and its amount $\mathrm{t}^{14}$.

\section{Tax Compliance as a Tool to Eliminate Tax Evasion?}

Based on the above, it can be stated that the measures taken to prevent tax evasion and tax fraud from the economic and fiscal point of view represent effective measures to prevent tax evasion. Even by the above-mentioned measures, the VAT gap was reduced. If we compare it to the average level in the EU, there is still considerable scope for continuing the fight against tax evasion and tax fraud so far.

As E. Kirchler claims that "tax evasion is a complex phenomenon which is influenced not just by economic motives but by psychological factors as well". In the search for answers to questions on how to prevent tax evasion, it cannot be viewed only from a fiscal point of view, but also from a moral point of view ${ }^{15}$, which is important from the perspective of the individual. Therefore, to find a way to persuade taxable entities to comply with tax regulations, thus not committing tax evasion. Constant audits and fines may cause opposite effects than ensuring compliance. On the contrary, it may interfere with the voluntary compliance (Kirchler, 2009). Although we understand that, at a time when extensive tax evasion occurred, in particular through the unjustified application of excess VAT deductions, it was understandable that tax administrators have carried out tax audits to verify rightfulness of the claim

13 An entitlement to the interest on VAT refund arises if the tax office initiates the tax audit within the time period for refund of the excess VAT deduction and the VAT refund is not paid within six months from the last day of the time period for refund of the excess deduction. This entitlement arises only since the first day after the expiration of the six-month period and is counting until the day of the retained VAT refund. It is apparent from the explanatory memorandum that the legislature modified the entitlement to interest on VAT refund in such a way as to leave the State some time to exercise its power to control the rightfulness of the excess deduction without the entitlement to interest on VAT refund for this period. Interestingly, the taxable entity does not have such a time when he is late with the payment of the tax and is liable to pay interest on late payment. Moreover, the Court of Justice of the EU state that the taxable entity is entitled to interest on refund of excess VAT if the excess VAT deduction is refunded to the taxable entity after the completion of the tax audit which exceeded the reasonable time period and as the starting point should be taken the date on which the excess VAT would have had to be repaid in the normal course of events. It is therefore questionable whether the legislation adopted in the Slovak Republic and in force since 1 January 2017 is in line with what the Court of Justice of the EU. In our opinion, this is not the case, and that the regulation of interest on VAT refund should be defined in the law simpler and more comprehensible and interest on VAT refund should be granted earlier, from the moment when it should normally be returned under the VAT Act.

14 The interest on VAT refund shall be granted in the amount equal to double the European Central Bank interest rate valid on the first day of the calendar year for which the interest is charged. Also if the interest rate of the European Central Bank is below $1.5 \%$, a minimum interest rate is $1.5 \%$. At this point, we would like to note that if the taxable entity is late with the payment of the tax (or other amounts within the meaning of Article 156/1 of the VAT Act), he is obliged to pay interest on delayed payment, which is set at multiple of four of the base interest rate of the European Central bank valid on the date when the tax arrears arose, while if the multiple of four of the base interest rate of the European Central Bank does not reach 15\%, the annual interest rate of $15 \%$ shall be applied. The state is required to pay interest at the rate of $1.5 \%$ and the taxable entity who is late with the payment of the tax interest at the rate of $15 \%$.

15 These connections between taxation, tax evasion and tax compliance is highlighting by several authors. See for example Bujňáková (2015: 61). 
to refund an excessive VAT deduction (or its part) to detect such a breach of tax regulations. However, it is inconceivable that they initiate the tax audit every time the taxable entity asks for a refund of the excess VAT deduction.

Rather than guaranteeing compliance, audits and fines may have opposite effects in a trustful climate and thus corrupt voluntary compliance. Cooperation is essential and such cannot be there without trust. But trust can go downwards to reduced levels when authorities respond to low levels of cooperation with control and punishment. Such an approach consisting of audits and imposing fines may be effective in a completely distrustful climate with the high social distance between authorities and taxpayers. In such a climate with no voluntary compliance, compliance may be enforced by the power of the authorities. However, audits and fines as "the tools" to command and control taxpayers will not be suitable to create a cooperative tax atmosphere (Kirchler, 2009).

In creating a trust between tax administrator and taxable entity, not only the behaviour of the taxable entity is important, but also the behaviour of the tax administrator so that he does not abuse the tax regulations and excessively burden the taxable entity as it happened, for example, in the case of constantly carrying out tax audits to verify rightfulness of the claim to refund an excessive VAT deduction or its part.

In the inspection of the compliance with tax obligations (e.g. within tax audit), tax administrators control small entrepreneurs without focusing on large taxable entities. This is also not supported by the mass media, where there are often various headlines that point to such situations. On the one hand, it is good because we cannot turn a blind eye to such situations and it is necessary to draw attention to them, but for some people this can lead to or encourage a belief that taxes are not necessary, or to raise various questions, especially why they have to pay taxes, when other subjects do not pay taxes and are not sufficiently punished.

\section{Conclusions}

It can be observed that the measures taken to prevent tax evasion are fiscally and legally effective but not sufficient. It is, therefore, necessary to find new ways to prevent this dangerous social phenomenon where, in our opinion, it shall become important in the future to focus on the ethical aspects and the combination of these economic, fiscal, legal and moral measures to find the most effective ways to prevent tax evasion. 
Few Notes on Measures to Prevent Tax Evasion and Tax Fraud - What is the...

Taxpayer's decision whether or not to pay taxes represents a social dilemma where private and communal interests go against each other, as paying taxes is costly for individuals but benefits society: taxation is strongly linked to the provision of public goods and services. These goods governments usually provide for the general public because private individuals would not provide an efficient level of public goods. Taxes are necessary to finance the public provision of these goods and services. Therefore, it seems natural that tax compliance is affected by the quality of publicly provided goods and services. ${ }^{16}$ Experiments have shown that a higher return from public goods leads to increased tax compliance (Blackwell, 2007). Social effects have been widely explored in the laboratory using public good experiments. Tax compliance experiments have tested and confirmed these effects.

Taking into account a moral and psychological point of view, it may be stated that the process of identifying with the fairness of taxation objectively takes decades, and any negative signal from the incorrect use of taxes may disturb it. The taxable entity, in order to believe the meaningfulness of paying taxes, cannot be disturbed and confronted with frequent social annoying phenomena and undesirable practices such as high corruption, a widespread black economy and politicizing management of tax policy, at the expense of stability, maximum expertise, and independent professionalism.

Tax reforms that work on the principle and basis of friendly taxation should dominate in practice. Its essence is based on the fact that the taxable entity is better to be persuaded than coerced. It is related to the ever stronger connection of the economy with psychology. The confidence of the taxable entity to the tax administrator (state) in order to increase the rate of voluntary payment of taxes is achieved by coordination rather than confrontation. If the state fails to do so, it evokes counterproductiveness (thus provoking taxable entities to tax non-discipline, circumvention of tax laws, tax avoidance and other forms of tax evasion) (Burák, 2013).

From the problems and reserves, the tax administrators predominantly have huge reserves in the quality of tax services and at the same time the insufficient level of tax sharing and legal awareness of most taxable entities. It is necessary to increase financial literacy and the related improvement and support of tax education for taxable entities through educational programs for the general public, including in the mass media.

In conclusion, the science of tax law does not pay attention to the research of the relationship between tax law, tax legal awareness, and tax morality. It can be said that in the area of tax relations there is the quite significant correlation between 
legal consciousness and morality. Few problems in society are as sensitive as the relationship of taxable entities to the state or the local government authority in relation to the fulfillment of tax obligations. In relation to commercial entities, this may be extended to fulfill any obligations towards mentioned authorities (in particular, the payment of social security, health insurance, etc.). Research and evaluating of tax legal awareness of society and the related problem of tax morality is thus much more substantial and important than it might seem and also it is important in preventing tax evasion.

\section{References}

Babčák, V.: Daňové právo na Slovensku (Tax law in Slovakia), Bratislava: EPOS, 2015.

Blackwell, C.: A Meta-Analysis of Tax Compliance Experiments, Georgia: Andrew Young School of Policy Studies, Georgia State University, 2007.

Bonk, F.: Fiskálny záujem štátu verzus dížka trvania daňovej kontroly (Fiscal state interest vs. length of the tax audit), in: Mrkývka, P., Czudek, D., Valdhans, J. (eds.): Dny práva 2015 - Days of Law 2015, Brno: Masaryk University, 2016.

Bujňáková, M.: Niekol'ko poznámok k téme daňových podvodov (A few notes about tax fraud), in: Babčák, V., Románová, A., Vojníková, I. (eds.): Tax Law vs Tax Frauds and Tax Evasion: non-conference proceedings of scientific papers, Košice: Pavol Jozef Šafarik University in Košice, 2015.

Burák, E.: Daňová politika a daňová ilúzia (Tax policy and tax illusion), Daňový špeciál (Tax special) no. 3 (2013).

Červená, K., Hučková, R.: Náčrt príčin (ako východísk pre kreovanie opatrení) v kontexte eliminácie daňových únikov (Outline the reasons (as starting points for creating measures) in the context of the elimination of tax evasion), in: Babčák, V., Románová, A., Vojníková, I. (eds.): Tax Law vs Tax Frauds and Tax Evasion: non-conference proceedings of scientific papers, Košice: Pavol Jozef Šafarik University in Košice, 2015.

Inštitút finančnej politiky Ministerstva financií SR (The Financial Policy Institute of the Ministry of Finance of the SR), Analýza prevádzky Finančnej správy SR "Výber daní z našich daní (An Analysis of Operation of the Financial Administration of the Slovak Republic "Collection of Taxes from Our Taxes"), 2016. www.finance.gov.sk.

Jarošová, B.: Kontrolný výkaz na DPH - nová povinnost' pre platitel'ov od 1.01.2014 (VAT control statement - a new obligation for VAT payers from 1 January 2014), Dane a účtovníctvo (Taxes and accounting) no. 1 (2014).

Kirchler, E.: The Economic Psychology of Tax Behaviour, New York: Cambridge University Press, 2009.

Knapp, V.: Vědecká propedeutika pro právníky (Scientific propaedeutic for lawyers), Praha: Eurolex Bohemia, 2003. 
Few Notes on Measures to Prevent Tax Evasion and Tax Fraud - What is the...

Popovič, A.: Zastierané právne úkony pri správe daní (Camouflage of legal action in the tax administration), in: Popovič, A., Románová, A., Straková, I. (eds.): Abuse and Other Forms of Circumvention of Law: reviewed proceedings of scientific papers, Košice: Pavol Jozef Šafárik University in Košice, 2016.

Prievozníková, K.: Implementácia zákazu zneužitia práva do daňového poriadku (Implementation of prohibition of abuse of law to the Tax Procedure Code), in: Babčák, V., Románová, A., Vojníková, I. (eds.): Tax Law vs Tax Frauds and Tax Evasion: non-conference proceedings of scientific papers, Košice: Pavol Jozef Šafarik University in Košice, 2015.

Románová, A.: The new anti-abuse rule in Slovak tax law: Strengthening of legal certainty? in: Radvan, M. (ed.): System of Financial law: System of Tax Law, Brno: Masaryk University, 2015.

Sábo, J.: GAAR (všeobecné pravidlo predchádzania daňovým únikom) v právnom poriadku SR (GAAR (general rule preventing tax evasion) in the law of the Slovak Republic), in: Babčák, V., Románová, A., Vojníková, I. (eds.): Tax Law vs Tax Frauds and Tax Evasion: non-conference proceedings of scientific papers, Košice: Pavol Jozef Šafarik University in Košice, 2015.

Straková, I.: Právne aspekty daňovej kontroly ako nástroja slúžiaceho na elimináciu daňových únikov (Legal aspects of tax audit as a tool to prevent tax evasion), in: Mrkývka, P., Czudek, D., Valdhans, J. (eds.): Dny práva 2015 (Days of Law 2015), Brno: Masarykova univerzita, 2016.

Štrkolec, M.: Prerušenie daňovej kontroly - prípustnost', dôsledky a možnosti procesnej obrany (Interruption of a tax audit - admissibility, consequences and possibilities of a procedural defense), Justičná revue (Judicial review) no. 11 (2014).

Vernarský, M.: Limity daňovej kontroly (Limits of tax audit), Justičná revue (Judicial review) no. 1 (2012).

EU: Court of Justice of the European Union: C-120/15. 



\title{
SECURITY MEASURES IN TAX ADMINISTRATION AS A TOOL TO ELIMINATE TAX EVASIONS ${ }^{1}$
}

\author{
MIROSLAV ŠTRKOLEC ${ }^{2}$
}

\begin{abstract}
The paper focuses on security measures in tax administration and the possibilities of their use as a tool to eliminate tax evasions. The aim of this paper is to define security measures in tax administration, describe their functions and identify the possibilities of the effective application on concrete examples manifesting how to eliminate tax evasions. The Author employed the scientific methods of analysis and synthesis and approached the issue using the method of comparison as well. The Author provides a definition of tax evasion and security measures and describes their legal nature and respective functions. It proves necessary to consider de lege ferenda the possibility to extend the scope of security measures, especially, that of surety as the general security measure in tax administration.
\end{abstract}

\section{Keywords}

Tax evasions; security measures; tax administration

\section{JEL Classification: H26, K34, K42}

\section{Introduction}

The relationship between tax evasions and security measures in tax administration can be characterized as that of undesired consequence and legal measures taken to

1 This paper was written as a partial output from the project VEGA no. 1/0375/15 "Tax evasion and tax fraud and their prevention by legal measures (in the context of Tax Law, Commercial Law, and Criminal Law)" and VEGA no. 1/0846/17 "Implementation of the initiatives of the EU institutions in the area of direct and indirect taxes and their budgetary and legal impacts".

2 Assistant lecturer at the Department of Financial Law, Tax Law and Economy at the Faculty of Law of the Pavol Jozef Šafárik University in Košice, member of The Center For Information And Research Organization In Public Finance and Tax Law Of Central and Eastern European Countries. Contact email: miroslav. strkolec@upjs.sk. 
prevent this consequence. Security measures are regarded to be measured by means of which the legislator seeks to secure timely and proportionate payment of taxes. To put it differently, security measures in tax administration, viewed in terms of their legal delimitation and functions they fulfill, contribute to direct or indirect elimination of tax evasions.

The aim of this paper is to define security measures in tax administration, describe their functions and identify the possibilities of the effective application on concrete examples manifesting how to eliminate tax evasions. The Author employed the scientific methods of analysis and synthesis and approached the issue using the method of comparison as well. The paper builds on up-to-date scholarly papers of the Author in the researched field of security measures (Štrkolec, 2012: 1168; Štrkolec, 2015: 301) and emerges from the works of other Authors who have dealt with the issue either directly or indirectly (Gomułowicz, Małecki, 2013: 392; Karfíková, Karfík, 2015: 255; Babčák, 2015: 101).

\section{Tax Evasions and Security Measures}

Not only tax evasion is a phenomenon but also a problem of our times. The most general way to define tax evasions is to consider it a failure to pay taxes that is contrary to the law (Ryllová, 2007: 13). Understandably, it is not a legal definition, since such a definition is lacking in our legal rules (Karfíková, Karfík, 2015: 255).

This basic definition is by no means exhaustive; in principle, tax evasion must be distinguished from tax avoidance. Whereas tax avoidance consists in, for example, making use of loopholes in the tax system, or decreasing of tax liability that is directly allowed by the law, tax evasion means such acts or omissions that can establish the open or latent violation of tax rules (Babčák, 2015: 101).

Non-payment of taxes contrary to the law amounts to tax evasion. Tax evasion may have different forms.

Those simplest are based on, for instance, a failure to use the electronic cash register, failure to report some income within a taxpayer's taxable income, accounting of fictitious taxable transactions, increasing the actually incurred expenditure or including personal spending within the tax-deductible expenditure. Complicated cases of tax evasion are based, for example, on the use of sophisticated forms of carousel transactions, which, as a rule, have a nature of tax fraud.

Security measures in tax administration play an important role also in cases of elimination of potential loss in tax revenues that are not based on fraudulent acts, but rather on simple insolvency of the taxpayer, or on absence of property that in 
case of realization in executory proceedings could aid to attain the final purpose of tax administration. Such cases can be subsumed under the term of tax evasion, because, in their essence, they amount to the failure to pay taxes contrary to the law.

Viewed from the perspective of revenue into the state budget, it is economically irrelevant to investigate the reasons why such loss of expected tax revenue caused by the failure to pay taxes contrary to the law actually occurs. Such acts or omissions, either intentional or negligent, will have the negative impact on the revenue into the state budget. Despite maintaining the theoretical differentiation between the terms tax evasion and tax avoidance, in practice, these terms can hardly be separated.

\subsection{Conceptual Delimitation of Security Measures in Tax Administration}

The concept of security measures can simply denote such measures which aim to secure the fulfillment of tax liability (Gomułowicz, Małecki, 2013: 392). However, they may also be described by making use of the following defining features:

- these concern measures regulated by tax laws seeking to ensure the payment of taxes in cases when such payment is endangered, prevention of tax evasion (fraud) and elimination of the undesired consequences.

- These concern measures, which, in order to be effectively implemented, usually require the decision of the tax authority or other act of application of the law.

- they may also concern such measures which are not directly connected with the decision-making of the tax authorities, although, they also seek to ensure the immediate securing purpose in connection with the final fiscal function of taxes.

Security measures in tax administration are, therefore, considered to be legal measures taken by tax authorities and implemented by the taxpayers themselves, which are of securing nature in relation to the final purpose of tax administration and actual generation of revenue into the state budgets, and which can contribute to effective prevention of tax evasions (frauds) and eliminate their undesired consequences.

Security measures in tax administration have the potential to prevent tax evasion and tax fraud in a variety of ways. This potential is rather wide in its scope, and when effectively applied, it may be used to prevent the non-payment of taxes contrary to the law. This can be achieved in several ways, for example: 
- by securing property which in the event of failure to pay taxes can be subjected to realization and the proceeds from the realization be used to settle the taxes (liens, seizure of property and forfeiture of a thing);

- by imposing preventive payment obligations on the taxpayer before tax liability commences (security for VAT and excise taxes, securing income taxes);

- by imposing preventive payment obligations after-tax liability commences the amount of which is disputable or which was not awarded (preliminary measures);

- by transferring the subsidiary obligation upon another person which extends the range of obliged persons who may be required to pay the taxes (surety), or

- by preventing the unlawfully claimed tax refund by commencing tax control to detect the eligibility of the claim.

\subsection{Functions of Security Measures in Tax Administration}

Variance in security measures in tax administration and their different legal nature logically induce that individual security measures can fulfill and actually do fulfill different functions. When attempting to generalize, we can state that security measures in tax administration fulfill three different functions: securing, refunding and preventive.

The securing function resides in creating factual and legal guarantees that secure the payment of taxes for the benefit of public budgets in the event when such payment is endangered or uncertain for some reason. The legal framework of security measures in tax administration in various ways seeks to ensure the timely payment of tax, whilst this function is inherent in seizing the property, in preliminary measures, liens, surety, but also in security for individual taxes. Security can be obtained from the property of the taxpayer, property of third persons other than the taxpayer, but also in other specific ways based on different forms of "pre-payment" of taxes by the taxpayer himself, which is common with securing various taxes.

The refunding function of security measures supplements and builds on the security function in such a way that their legal framework usually allows for the payment of taxes in other alternative modes that is determined by the nature of the concrete security measure. In order to attain the final purpose of tax administration, it is essential, that in the event of failure to fulfill tax liability on the part of the taxpayer, the security measures allow for the payment of tax in other alternative ways. These ways of fulfilling the refunding function differ due to variability of security 
measures, for example, realization of the secured property and the subsequent use of proceeds from the realization to settle the payment of taxes, or the use of in advance provided security for tax for the purposes of settling the outstanding payment of tax due later.

The preventive function of security measures is primarily targeted at prevention of unlawful claims of taxpayers in relation to the state budget. Although it sounds paradoxical, taxes are levied for the benefit of the state budget, however, payments are frequently made from the budget back to the taxpayers. In this regard, it is the legal regulation on indirect taxes (especially of VAT) that provides for the taxpayers to assert their monetary claims in compliance with the law. The amount of the finances the state pays to the taxpayers ${ }^{3}$ necessitated that security measures be laid down primarily of preventive nature, which can be exemplified by tax control to detect the eligibility of a claim of excessive VAT refund. Security measures of preventive nature may also include the cancellation of registration for VAT which may, in general, prevent the abuse of the system of the VAT.

\section{General Security Measures}

The category of general security measures comprises security measures which are primarily regulated by the rules of tax procedure stipulated in the Act no. 563/2009 Z. z. (Collection of Acts) on tax administration (Code of Tax Procedure), and characterized by the universality of their application. Universality means that these measures are, in principle, applied towards all taxes, national and local, direct or indirect. The feature of universality has, though, certain limits, and in extraordinary cases, it can be limited in part or excluded from application ${ }^{4}$. General security measures comprise the following:

a) seizure of a thing and forfeiture of a thing,

b) preliminary measures,

c) liens.

The Code of Tax Procedure structurally assigns the seizure of a thing and forfeiture of a thing to the activities of the tax administrator and, in the narrower sense, to the preliminary stage of tax proceedings. In terms of content, this tax-law security measure seeks to attain varied aims which will eventually implement the purpose

3 According to data obtained from the Annual report on the activities of the Financial administration for the year 2016, the amount of excessive VAT deduction refund in 2016 was 6.128 billion EUR, however, in comparison with 2015 it decreased between the years by 110.1 million EUR and in 2015 it was 6.238 billion EUR.

For instance, section 40 subs. 1 of the Tax Procedure Rules stipulates that Tax Office and Customs Office are exclusively competent, not the municipality as the administrator of local taxes, to seize the goods of the entrepreneur who sells goods in the Slovak Republic and fails to use the electronic cash register. 
of tax administration. The seizure of a thing primarily aims to maintain the existing factual condition of a concrete thing and to keep this thing in unaltered condition in pursuit of the purpose to obtain evidence and secure a thing for eventual subsequent sale of the thing and alternative settlement of the monetary claims of the tax administrator from the proceeds of sale of the thing. The valid legal regulation distinguishes between two types of cases when such security measure is taken. Seizure of a thing is used when the manner of acquiring of the thing, the quantity, price, quality or the proper financial arrangements in connection with the import and purchase of it cannot be satisfactorily proven. The Tax Office or the Customs Office can seize the goods of the entrepreneur who sells them in the Slovak Republic and fails to use cash register at the point of sale. The tax administrator will issue a decision on the forfeiture of a thing when the taxpayer fails to eliminate the deficiencies in the statutory period. After the decision on the forfeiture of a thing becomes final, the tax administrator will commence the sale of the thing. The Code of Tax Procedure stipulates three methods of sale of the forfeited thing (i) auction sale, (ii) commission sale and (iii) immediate sale. Proceeds from the sale of the forfeited thing shall be used to settle tax debts and the outstanding tax payments which, as a result, eliminates tax evasions.

The nature of preliminary measures in tax administration is limited by their functions which pursue the final purpose of tax administration. In taxation practice, the use of measures is to be taken into consideration especially when the tax administrator anticipates the taxpayer carry out acts directed at the reduction of his own property, and then his outstanding taxes could not be enforceable in the tax executory proceedings due to the absence of existing seizable property. The tax administrator may decide on preliminary measures when there are reasonable concerns that the undue tax or unlevied tax would not be settled or enforceable, or the exaction or collection of taxes at that time would be accompanied by severe complications. The tax administrator may order the taxpayer to deposit finances onto the account of the tax administrator or not to dispose of the property or other rights set out in the decision. If subsequently tax is assessed, which was not imposed at the time when the preliminary measure was issued, the mandatory preliminary measure will not be effective as of the day of assessment of tax and on condition that the finances set out in the preliminary measure are deposited. In such case, the taxpayer is not obliged to fulfill his tax liability according to the decision on tax assessment, because it would result in double payment of the same tax during one tax period. The transfer of finances to pay this tax represents the refunding function of preliminary measures, and, at the same time, the purpose of the tax administration is attained. Although this legal regulation entered into effect on 1 January 2017, it is seemingly the most effective solution with regards 
to the variability of possible procedures, which we already pointed out in the past (Štrkolec, 2012: 1169).

Liens in tax administration are regulated on similar grounds as liens in private law regulations. In their essence, liens fulfill two basic functions, the securing function, and the refunding function. The securing function of the lien consists in securing the property of the tax debtor and creating options for alternative settlement of the claims of the tax administrator in cases when the outstanding tax is not paid on a voluntary basis. On the other hand, the refunding function of the lien is manifested in the form of realization of lien and using the proceeds from the sale to cover the secured outstanding tax. The refunding function of lien in tax administration takes the form of realization of lien in tax executory proceedings. The lien can be realized in tax executory proceedings, especially, through the sale of personal property, the sale of securities or sale of real property, apartment or non-residential premises.

\section{Special Security Measures}

The category of special security measures encompasses measures applied specifically to selected taxes. Further attention will be particularly devoted to security measures in the VAT. Their full-scope implementation commenced in 2012, when the Government of the Slovak Republic adopted the "Action plan to combat tax fraud" (Governments' Resolution no. 235) measures be taken also in commercial laws and criminal laws.

The first legislative measure was the adoption of the amendment to the Act on VAT no. 246/2012 effective in the majority of new provisions from 1 October 2012. Based on the mentioned amendment, several new security measures in the area of the VAT, including security tax and surety for tax, were incorporated into our legal order.

The measure of security for the tax is by no means considered as new in tax law since it has been used for excise taxes, and with certain limitations, for income taxes for a long time. The legal regulation of security for VAT is grounded on the preventive single liability to pay, which is imposed on a taxable person or on a taxpayer and is of securing nature, and in case the statutory hypothesis is fulfilled, it is also of refunding nature. The tax administrator decides on the security for the tax in the scope from 1000 to 500000 EUR and the rendering of the security is limited for the period of 12 months. The securing function of the security for the tax resides in the indirect effect on the taxpayer towards the proper payment of his own

$5 \quad$ The European Commission submitted its own action plan during the same period under the title Action plan to strengthen the fight against tax fraud and tax evasion COM(2012) 722 final. www.ec.europa.eu . 
future VAT tax. Once the duty to provide a security for the tax is imposed and the security for the tax is provided, legal certainty exists that, in case of failure to settle future obligations of the taxpayer, the tax administrator has an alternative source to settle the outstanding taxes. Security for the tax can be ordered before any payment obligations of the taxpayer arise in relation to the tax administrator which is also safeguarded by its securing nature. The refunding function of the security for the tax is grounded on its possible and admissible use to cover outstanding payments for VAT after the taxable person is registered as a taxpayer.

The mentioned amendment to the Act on VAT has also introduced the measure of surety for tax. Surety represents one of the most typical security measures both in private law and public law. Surety for VAT can be defined as specific legal surety governed by public law method of regulation (Kindl, 2016: 323). The aim of the legal regulation of surety for tax rests in the rules to be set to create accessory payment liability of the surety that commences when the taxpayer fails to fulfill his primary tax liability in the prescribed period. Thus, the surety himself is not the payer of the tax for which he is a surety, rather he is an alternative person whom the tax administrator may request to fulfill the unsatisfied obligation of the primary taxpayer subject to statutory conditions. Accordingly, the features of surety in private law can also be identified in surety for taxes, i.e. accessory and subsidiarity. The accessority of surety implies that it is a secondary relation which wholly depends on the principal debt; and subsidiarity defines the position of the surety as the "auxiliary debtor" in relation to the primary taxpayer (Kohajda, Sejkora, 2014: $8-9)$.

\section{Conclusions}

The limited scope of this paper does not allow for dealing with all of the general and special security measures in tax administration. The aim of the paper was to delimitate the legal nature and the possibilities of implementation to combat tax evasions. The considerations above point to the fact that security measures, when applied effectively, have the potential to eliminate tax evasions caused by failures to fulfill tax obligations in time and in the proper manner. Moreover, it is evident that this potential can be fully exploited only if the necessity of its application is early identified. The tax administrator is obliged to monitor and detect the thread of possible tax evasion especially in connection with the risk-bearing taxpayers in the widest sense and select one measure from the variety of security measures which in concreto appears the most appropriate for the intended purpose. It is only natural that it is the refunding nature that satisfies the importance and purpose of the security measures in the prevention of tax frauds. It proves necessary to consider 
Security Measures in Tax Administration as a Tool to Eliminate Tax Evasions

de lege ferenda the possibility to extend the scope of security measures, especially, that of surety as the general security measure in tax administration.

\section{References}

Babčák, V.: Daňové právo na Slovensku (Tax law in Slovakia), Bratislava: Epos, 2015.

Gomułowicz, A., Małecki, J.: Podatki i prawo podatkowe (Taxes and Tax Law), Warszawa: LexisNexis, 2013.

Karfíková, M., Karfík, Z.: Předcházení daňovým únikům v ČR (Prevention of Tax Evasion in the Czech Republic), in: Daňové právo vs. daňové podvody a daňové úniky (Tax Law vs. tax evasion and tax evasion), Košice: Univerzita Pavla Jozefa Šafárika v Košiciach, 2015.

Kindl, M.: Zajištení a utvrzení dluhů (Assurance and settlement of debts), Praha: C.H. Beck, 2016.

Kohajda, M., Sejkora, T.: Institut ručení v daňové legislativě (Institute of Liability in Tax Legislation), Daně a finance (Taxes and Finance) no 1. (2014).

Ryllová, Z.: Mezinárodní dvojí zdanění (International double taxation), Olomouc: Nakladatelství Anag, 2007.

Štrkolec, M.: Predbežné opatrenia v správe daní (Provisional measures in the Tax Administration), Justičná revue: časopis pre právnu prax (Justice Revue: Legal Practice Magazine) no. 10 (2012).

Štrkolec, M.: Náčrt možností vybraných inštitútov daňového práva v predchádzaní daňovým únikom na DPH (Possibilities of selected tax law institutes to prevent VAT evasion), in: Daňové právo vs. daňové podvody a daňové úniky: nekonferenčný zborník vedeckých prác (Tax law vs. tax frauds and tax evasion: a non-concluding collection of scientific works), Košice: Univerzita Pavla Jozefa Šafárika v Košiciach, 2015.

EU: European Commission no. $\operatorname{COM}(2012) 722$ - Action plan to strengthen the fight against tax fraud and tax evasion.

SK: Act on VAT no. 246/2012.

SK: Governments' resolution no. 235 - Action plan to combat tax frauds for the years 2012 to 2016. 



\title{
ECONOMIC-POLITICAL CAUSES OF TAX EVASION (THEORETICAL BACKGROUND) $^{1}$
}

\author{
KAROLÍNA ČERVENA2, ANNA ROMÁNOVÁ
}

\begin{abstract}
This paper is focused on tax issues, with an emphasis placed on the identification of primary causes of the economic-political nature of the emergence of tax evasion and non-compliance with tax obligations. The aim of the Authoresses is to provide in the context of this paper a brief overview of the economic-political background leading to detection of the real causes of the emergence and existence of tax evasion and non-compliance with tax obligations. In carrying out complex analysis of the causes leading to the emergence of tax evasion and non-compliance with tax obligations, it is necessary to also accept the nature of non-economic determinants. Instability or turbulence of the conditions in the context of the economic milieu (e.g., frequent changes in the tax code) significantly increase the complexity of the disclosure of the real underlying cause of tax evasion and non-compliance with tax obligations. The apparent underlying cause of the emergence and existence of tax evasion is inherently taxation, that is, the introduction of taxes as such and the obligation to pay them. The decisive factors leading to the creation of tax evasion and non-compliance with tax obligations include the factors of economic-political

1 This paper has been written as a partial output of the APVV-16-0160 research project, Tax evasions and tax avoidance (motivation factors, formation and elimination), as well as the output of the VEGA 1/0375/15 research project, Tax evasion and tax frauds and possibilities of their prevention (by means of tax law, commercial law and criminal law).

2 Doctor, Researcher at Pavol Jozef Šafárik University in Košice, Faculty of Law. Within her research and teaching activities, she pays special attention to assorted micro- and macroeconomic issues from the interdisciplinary perspective. She is the author of more than 80 reviewed scientific outputs in the form of articles in journals, chapters in monographs, conference papers. She is a member of the Information and Organization Centre for Research into Public Finances and Tax Law in the Countries of Central and Eastern Europe. Contact email: karolina.cervena@upjs.sk

3 Doctor, Rsearcher at Pavol Jozef Šafárik University in Košice, Faculty of Law. Her specializations are direct taxation, local taxes, and tax administration. She is the author of more than 35 reviewed scientific outputs in the form of articles in journals, chapters in monographs, conference papers. She is a member of International Property Tax Institute, Toronto and Information and Organization Centre for the Research on the Public Finances and Tax Law in the Countries of Central and Eastern Europe, too. Contact email: anna.romanova@ upjs.sk.
\end{abstract}


nature within the meaning of the concept and implementation of the taxation policy as part of the economic policy of the State.

\section{Keywords}

Tax evasion; tax policy; taxation

\section{JEL Classification: D63, H21, H26}

\section{Introduction}

In identifying the causes of the emergence and existence of tax evasion and noncompliance with tax obligations, it is necessary to apply the theoretical knowledge from multiple fields of science with the aim of providing a comprehensive look at this set of issues. The concepts of tax evasion and non-compliance with tax obligations should be understood for the purposes of this paper in the broad sense of the word - which includes both illegal ${ }^{4}$ and legitimate ${ }^{5}$ the action of entities (Stieranka, Sabayová, Simonová, 2016: 78-79). The Authoresses have focused in their paper on finding and describing fundamental and potential sources of the emergence of tax evasion by employing standard methods of scientific research. Within the framework of the examination of these issues, the Authoresses have given priority to applying theoretical (and practical) knowledge from the fields of economics and political economy, partly in interaction with some other pieces of knowledge derived from political science, law, psychology, and ethics. Identification of the causes that exert the real impact on the emergence and persistence of tax evasion and non-compliance with tax obligations is considered the starting point of the subsequent search for alternatives that provide instructions to deal with this phenomenon in the turbulent conditions and the globalizing economic milieu. Mises notes in his monograph that the flourishing of human society depends on two factors: 1. the intellectual abilities of extraordinary people to create sane social and economic theories, and 2. the ability of people to make these ideologies acceptable for the majority of people (Mises, 2006: 775).

\footnotetext{
4 In view of the awareness of one's own actions, intentional illegal tax evasion occurs in life as a result of an open or a hidden breach of applicable law, making use of error, bringing into error, nondisclosure of material facts on frequently shammed or belied actions having the nature of deception and leading ultimately to nonpayment of or reduction in the tax and the unintentional ones - these represent to tax-related actions by the taxable entity, who of carelessness or lack of knowledge of the tax regulations would reduce their own tax base or the tax itself (Stieranka, Sabayová, Šimonová, 2016: 78-79).

5 We do not consider legal tax "evasion" an illegal action, or rather, the result achieved is not related to a violation of law, but is a result of the use of options enabled by the current legal situation in the field of taxation (e.g. making use of alternatives within the framework of taxation legislation, taxation planning, tax liability swapping, etc.) - the macroeconomic effect would subsequently be reflected in the revenue section of the public budget.
} 


\section{Taxation - Selected Knowledge and Experience}

Application of theoretical knowledge and practical experience relating to taxation, originating in economics and political economy, is represented in economic practice by tax policy as part of the economic policy, and practical economic policy is a reflection of the political-economic arrangements of the economy of a particular country (even in the case of a grouping of sovereign states within an economic entity, provided these apply a common economic policy).

In the form of political-economic definition, from the primary historical perspective, there are only two types of organized economy, specifically a free market economy ${ }^{6}$, where isolated economic units come into contact with each other, cooperate through market and competition, and a centrally controlled economy, in which the economic actors are subject to a management center and perform their economic activity by the initiative of the instructions. Modification of the free market economy is represented by social market economy ${ }^{7}$, which is characterized by free pricing, protection of private property, stability of money circulation, competition, economic independence of entities, and the limited functions of the State - the essence of the functioning of the economy of this type is represented by a competitive environment, where the essential economic role of the State is contained in the creation and protection of a competitive environment without the existence of monopolies, as well as other structures controlling the market (e.g. monopson, oligopoly).

Today's reality is that modern types of the economy no longer exist in the form of an "ideal" economic arrangement; what exists are just their combinations or modifications. In the 1960s, a modified model of the social economy appeared in the form of a formed society, where politicians and civil servants were considered entities that pursued their own personal interests ${ }^{8}$ and objectives, and it is, therefore,

6 According to the neoliberals, the ideal free market economy will be realistically approached by those economies where the connection with the market is secured by public institutions. Note. Neoliberalism is a label for the new liberal theories, but also a label for a return to classical liberalism in the form of the teachings of the classical period of economics (A. Smith, D. Ricardo, J. B. Say, and others).

7 The social importance of market economy is linked to the idea that the economic benefit from the increase in the production of the work, rationalization, and innovation, should result in prosperity to all individuals in a society, and the State has to regulate the course of the reproductive process, in particular by the instruments of the monetary-credit nature. The model of the social market economy is based on the principle of subsidiarity, where efficiency and prosperity as a result of the operation of a market economy creates a resource for attaining social objectives, while social responsibility must be based on the individual, and State would only take over the responsibility in case of failure of the individual and the market structures, and also any action of the State in the social domain should be implemented in such a way that it does not compromise the functioning of the market mechanism, but also the social market economy should lead to efficiency and prosperity.

8 In mixed economies, there exist diverse (often differentiated) interests of individuals, private companies, public cooperative and solidary entities of the State. 
necessary to modify their behavior by law in such a way that they are forced to follow the interests of society as a whole (Červená, Čipkár, 2017: 38-50).

In the construction and in the implementation of economic measures, there emerges a conflict between the perception of economic issues in economic and political terms. In that context, it is necessary to contemplate about the question - what kind of impacts or effects of microeconomic and macroeconomic nature the given conflict causes. The optimal setting of the levels of taxation shall be based on and correspond to realistic objectives of economic policy in the long term with a view to the sustainable growth of the economy - the aim of the taxation policy, therefore, should not be maximizing revenues to the State budget, rather, maximizing the aggregate supply. For the economic development, expenses that correspond to the social awareness are definitely far more efficient than those that serve the interests of the planned system. The fiscal policy begins by determining the level of government spending, but there is no guarantee that a combination of expenditure policy and progressive taxation would create a reasonable level of demand (Galbraith, 1984: 423). Fiscal policy may be used to at least a partial correction of revenue inequality (the progressive rate of income tax has a social meaning in a market economy - it is a corrective to the distribution process), but the tax policy should not encourage a process of concentration (for example by turnover tax or special tax for corporations), thus making the business of monopolies more convenient (Eucken, 2004: 338-389).

The possibilities of the fiscal control of the economy by the action of discrete tax policy tools, which policy regulates the income of the population, whereby regulating the resources available for investment, have appeared inadequate or inefficient in recent years. Since the 1960s, the New Economics represents a modification of the Keynesian economic policy9. The possibilities of the fiscal control of the economy by the action of discrete tax policy tools, which policy regulates the income of the population, whereby regulating the resources available for investment, have appeared inadequate or inefficient in recent years. Since the 1960s, the New Economics has represented a modification of the Keynesian economic policy ${ }^{8}$, whose followers recommend to extract the fiscal policy from the principles of restriction, particularly from the principle of equilibrium of the budget, but they also attach great importance to the reduction of taxes for the purpose of stimulating economic growth $\left(\mathrm{Rahn}^{10}, 2007\right.$ : 228-230).

9 The concept of the New Economy is based on the assumption that a cyclic development is not regular, and the aim of the economic policy should be ensuring an equitable growth rate and full employment.

10 Richard W. Rahn served as the Director of the Centre for Global Economic Growth, he also collaborated with the Heritage Foundation, the Discovery Institute, and the Cato Institute, was a member of the Montpelier Society, and in the 1980s he also served as Vice President and Chief Economic Expert of the US Chamber of Commerce and the Chief Editor of the economic journal, Journal of Economic Growth. 
The idea of the representatives of the theory of rational expectations is directed to the recommendation that the national, but today also the transnational economy, be necessarily regulated by publicly known, obvious and understandable economic measures that are to monitor the strategic (long-term), not the ad hoc short-term goals. In this context, the neo-institutionalists ${ }^{11}$ who offer an interdisciplinary approach to examining economic problems in conjunction with other subsystems - political and sociocultural ones - point out that the long-term development of the society is completely different from the static market efficiency (they underline the volatile nature of economic reality). The institutionalists ${ }^{12}$ note that the social costs do not reflect the full extent of the market economy, which may have an impact on the results of the economic measures implemented. It is possible that new institutional theories (the Theory of Constitutional Economics, ${ }^{13}$ the Theory of Public Choice, ${ }^{14}$ the Theory of Property Right ${ }^{15}$ ) can provide guidance on the development and implementation of economic measures for the general beneficiary of economic results in the current globalizing marketing environment.

\section{Taxation in Mixed Economies Under the Influence of Integration and Globalization}

The issue of taxation was in the past and has been in the present dealt with by different groups of experts - economists, political scientists, lawyers, philosophers and others ${ }^{16}$ (Bujňáková et al.: 2015: 408). In addition to the positive views of

11 Neo-institutionalists emphasize the need for the creation of a new economic paradigm based on the synthesis of neoclassical and neo-institutional theories (e.g. publics microeconomics-a new microeconomic theory linked with the State sector and the principles of organization and economic conduct of business entities).

12 The economic direction in which its leaders have traditionally addressed position of power in the social system.

13 It explains the advantages and disadvantages of alternative legal-institutional-constitutional rules, which limit the choice and the activities of the economic and political entities when as a consequence of imperfect functioning of democracies, the executive power is withdrawing from the voters. The leaders of this theory sees the role of the legal rules in their ability to eliminate the abuse of power and competences of the executive branch, and, as their opinion has it, it is necessary to assess the existing alternatives in the construction of the constitutional framework of the society and sort them out according to their level of profitability, which would facilitate the choice of the best alternatives for those who are qualified to deal with legal changes.

14 This theory represents a radical approach to the State administration and the Government in the sense that most of the national activities could be left to the market, or their performance may be carried out by private companies.

15 It based on the idea that the economic system of any society is determined by its proprietary rights, and so if there occurs a change of ownership, it will cause a change in the behaviour of economic entities, which would result in a change in the distribution of income and the allocation of resources, and is also based on the assumption of the existence of economic agents (institutions), who restrict the level of independence of decision-making managers and on the existence of transaction costs, which crucially affect the behaviour of economic entities, while putting emphasis on the relationship between law and economics.

16 Taxation had been a topic for thinkers of the Antiquity (e.g. Aristotle), medieval thinkers (Thomas Aquinas), in the modern era there had existed different view groups (directions) of economists, such as the classical economists (for example, A. Smith, who had formulated four principles of taxation:1. people should contribute in proportion to their income; those who earn more should be paying more; 2 . taxes should be specific, not arbitrary, the maturity period and the method of payment should be clear to all; 3 . The tax maturity should be 
economists to taxation, such as those by the followers of post-Keynesian theories ${ }^{17}$ (Iša, 2006: 853-869), who are advocates of taxation of the affected pension policy (in the meaning that if the private economic entities place burden on the society by extreme costs, the government shall have the right to charge them taxes), we also meet with those in the negative (the leaders of classical economics, monetarists ${ }^{18}$, representatives of the Offer Party Economics ${ }^{19}$ ) notes that taxation constitutes a clear example of seizing private property with its effect on the status of private property and enforcing the right therewith associated.

In today's mixed economies, taxes are considered the most important source of revenue to the State, therefore they are considered important instruments for the implementation of economic policy. In addition to the tasks to be fulfilled directly by the State through the expenditure part of the budget, it is necessary to be taking notice of carrying out the performance of tasks by public territorial self-governments (Románová, 2010: 289-295), which is also funded by taxes (Románová, 2011: 6368 ) and fees, i.e. it uses the funding from the resources coming from individual economic entities on its functioning and the fulfilment of the tasks (which in practice we often perceive as public resources, whereas their economic origin is in fact of private nature). In this context, the setting of the optimal tax system, which would be targeted to and would support the long-term economic growth (whereby the society would be directed to the development of whole society) is essentially a permanent problem, since there exist conflicting opinions and views on the issue of taxation in the scientific and professional communities ${ }^{20}$.

According to Šafránek, taxes are a dynamic value, volatile in time ${ }^{21}$, politically greatly motivated, the issue of taxes ${ }^{22}$ is also one of the redistributive processes. In

benevolent to the payer to meet; 4. taxes should not be more costly than is necessary for the citizen and the State).

17 Post-Keynesianism is a heterogeneous direction of economic thinking, which creatively develops just Keynes' theory, but also builds on other scientific knowledge presented at the 1930 s, refusing any forms of economic liberalism and recommending to complement traditional forms of Keynesian economic policy.

18 They principally reject progressive taxation of revenues - M. Friedman (a significant representative of the Monetarism), rejects progressive taxation of revenues and suggests the introduction of the so-called negative income tax to replace the existing social programmes, while introducing the negative income tax would not require any additional costs, which would eliminate the costs associated with the functioning of the system of social-welfare programmes. An important part of the Monetarian economic and political reform is contained in the tax system and social policy reform.

19 According to the Economics of the Offer Party representatives, taxation policy inhibits the activity of individual economic to work, savings, and investment and, therefore, it is crucial to find such an optimal rate of taxation, which would correspond to the development of the economy as a whole.

20 For example, Prof. Brdlík, who served as the Minister of Agriculture of the Czech Republic in the years 19201921, and also as Minister for the Supply of People, stated that taxes and fees are transferred, either directly or indirectly (in the form of excise duties), in the production and burden, thus restrict competitiveness of the national economy with foreign countries (in Knespl, 1928: 6-7).

21 The long-term stability of the taxes is essential for long-term economic stability or strategic planning on both macroeconomic (national-economic) as well as micro-economic (entrepreneurial or individual) levels.

Departing from a well-known definition that the tax represents the legal, i.e. mandatory, non-refundable and non-specific payment to the public budget, so in this context, we may consider customs and duties, social insurance contributions, and local charges the "tax payment". 
addition to its other functions, the tax system ${ }^{23}$ performs two fundamental tasks: 1. funding the operation of the institutions that protect the citizens, but also the politicians (army, police, emergency services, courts); 2. redistributing the wealth from those who may spare it to those who lack it. With the growth of the wealth in the society, the volume of taxes that the State collects from citizens is growing. But we may assume that alongside with the increasing amount of taxes, the effort of the parties concerned to avoid the payment of taxes is also growing (Šafránek, 2016: 6-7).

Modern tax theory emphasizes two principles, specifically justice ${ }^{24}$ and efficiency ${ }^{25}$ (in addition to equitability and efficiency, the tax should be legally clear and transparent). Technically, the taxes constitute a transfer of funds from natural and legal entities in the public budget. This transfer, however, cannot function without additional costs, which reduce the overall efficiency of the economy. The aim of the tax systems should, therefore, by way of priority, be reducing the inefficiencies to the lowest possible level - in an effort to reduce administrative costs, it is necessary to take into account the interests of both of the parties involved in the tax negotiations; frequent efforts to facilitate work on the part of the public sector at the expense of private taxpayers are unacceptable, just as well as similarly-acting regular changes not reasoned by anybody (e.g. forms and content of the pre-print tax return forms). In relation to the taxpayer, any tax exerts two impacts, specifically: the impact of tax on retirement - it expresses the impact of tax on the taxpayer's net income (according to the amount of the tax, tax reliefs, deductible items, etc.) and the substitution impact - this has an impact on the choice of a taxpayer who has an opportunity to decide between multiple choices, such as goods and services, the factors of production, savings, leisure time (Šafránek, 2016: 9-14).

The current tax policies of most of the democratically developed countries are governed by the proposition that taxes should be levied on every citizen according to their "ability to pay" - the above principle refers to one of the postulates of social

23 In light of the current economic theory, we distinguish three primary functions of taxation: a) the allocation function (active operation with the result of re-allocation of resources); b) redistribution function (redistribution of the wealth of society); c) stabilization function (mitigating cyclical fluctuations).

24 Equitability is associated with the redistribution function of the taxes, and may be based either on the principle of the benefit (the taxpayer pays the tax in an amount that corresponds to their benefit from public services), or to principle of their ability to pay (the taxpayer is to pay as much tax as is their ability to pay). There exist two approaches: 1 . within the meaning of the horizontal equitability, taxpayers with equal equitability are to pay equitable tax; 2 . within the meaning of the vertical equitability, taxpayers with higher ability to pay are to pay higher taxes. According to Ricardo's equivalence, governments are not to finance tax reduction by loans; tax reduction is often considered to be a way of set the economy in motion - if people have more money, they should be spending more; as far as tax reduction is financed by loans, the effect of tax reduction will only be temporary - they will have to be repaid in the future, either by raising taxes or reducing other government expenditure.

25 The principle of effectiveness: its essence is contained in the requirement that taxes be as cheap as possible in terms of costs associated with taxes (administrative costs, costs for the collection of taxes, excessive load - due to high taxes, people cease to work or do business). 
justice. Both fiscal and non-fiscal objectives of taxation are mutually conflicting it is not possible to eliminate this discrepancy. The real nature of the problem of taxation should be recognized in a paradox - the higher taxes we have to be paying, the more they "undermine" the market economy (they are incompatible with the market economy), and thus the system of taxation itself. Taxes as instruments of the interventionist policy may be sorted into three groups: 1 . taxes leading towards a partial or total restriction of the production of certain commodities, which of course leads to intervention in consumption; 2. the tax misappropriating part of the income or wealth; 3 . the tax fully misappropriating the income and wealth. Tax laws often lead to a computational method, by which it seems that the generated profits are higher, in comparison with other methods of quantification of profit (e.g. the accounting method), which essentially leads to "hidden" raising the tax rates. Collection of taxes in order to finance the efficient provision of public services (protection of public order, defense of the country, protecting and securing the rights, etc.) may be considered generally beneficial and not restricting the freedom of individual until such time when taxation begins to cause the destruction of the market economy (e.g. high tax rates). Interventionism as an approach to economic policy is based on the consideration that interference with the property rights does not affect the amount of production; the confiscation interventionism is a negative manifestation - the range of production activities is regarded as given, as something that in no way depends on the form of a social order, that is merely considered random, the role of the Government is to ensure the "equitable" distribution of national income among the citizens; however, in a market economy such as dualism of two separate processes (production and distribution) in fact does not exist. Confiscation taxation leads to a slowing down of economic and technological development not only through its impacts on capital accumulation, it also arises the general trend towards stagnation and preservation of the way of doing business, which in a competitive market of the unrestricted market economy could not sustain. Today, the taxes (and contributions) often drain off a significant portion of the financial resources ${ }^{26}$ of entrepreneurial entities - which restricts their development or the expansion of their business, which exerts an impact on the economy as a whole (Mises, 2006: 194-725).

Taxation policy has always been a symbol of national sovereignty of the State, however, the development of European integration with the aim of forming a single European market requires from the Member Countries cooperation in tax matters (in the form of an exchange of information, harmonization or coordination of their tax systems). According to the claims of some experts on taxation policy 
and tax reform, tax harmonization (in the form of an explicit ${ }^{27}$ or even implied ${ }^{28}$ tax harmonization), in its final effect means higher rates of taxation and also discriminatory and double taxation of income that are saved and invested (Mitchell, 2007: 127-141; Bujňáková, 2013: 27-47). Wallerstein in his publication expressed a view that taxation is constantly growing by the impact of the fact that the world is becoming ever more democratized (Wallerstein, 2006: 58).

More significant changes to the tax systems of a number of the Member States of the European Union have been implemented in the second half of the 1980s in the light of the reform of taxes of the revenue type. A representative of the current French economics, Piketty, states that one of the most important innovations of the $20^{\text {th }}$ century in the field of taxation was the creation and introduction of a progressive income $\operatorname{tax}^{29}$, noting that this institution played a key role in reducing inequality in the previous century, but today it is threatened by tax competition between countries and he also notes that in the $21^{\text {st }}$ century, the role of taxation is shifting toward the idea of taxing financial capital, which should be implemented in the form of a global tax on capital (although the Author himself admits that it is a utopic idea as yet), he considers a global tax on capital an ideal form of regulation, which would preserve economic openness and benefits would be equitably distributed among individual States (Piketty, 2015: 540-567). In the context of ongoing processes, Siroký notes that all the States that are actively involved in international economic activities must respond today to the existence of the tax systems of other countries despite the fact that they have their own tax systems established as derived from their own traditions, their specific terms, policy consensus (Široký, 2010: 350). Schultzová expressed the view that failure to address many tax problems with their direct and indirect impacts on the economy of the State, as well as on the enforced common tax policy in the European Union, create substantial obstacles for the common European market, and according to her opinion, the situation is more complicated in this area in the direction that the fiscal policy of the Member States of the European Union is in fact governed by common principles, but the tax systems of its Member States are also characterized by their own differences mainly in the amount of the tax rates, in recognizing or not recognizing various expenses for tax

27 Explicit tax harmonisation arises, if the representatives of the countries agree to define the minimum or the same tax rates - it is obvious that in this form of tax harmonisation the taxpayers cannot benefit from a better fiscal policy in other countries and governments are not under any pressure from the competitive discipline in the market. 28 Implied harmonization occurs, if governments tax the income earned by citizens in other tax territories - for
example, in the form of the implementation of the "directive on the taxation of savings" basically requiring from the governments the collection of financial information on the investors based outside the country and the delivery thereof to the tax authorities of foreign States - this system of the exchange of information does not ultimately allow the taxpayers to benefit from better fiscal policies in other countries.

29 Progressive income tax and progressive inheritance tax were originally introduced into economic systems as a solution to the crisis in emergencies (e.g. war, conflicts, or natural disasters). 
purposes, in the adjustment of the tax base by attributable tax-deductible items, in depreciation, but even in the redistributive process itself (Schultzová, 2010: 224).

In terms of stabilization, the taxes are the most efficient that are aimed at greater equality (with corporate and personal tax contributing most to the equality of income). The more compact the tax system is, the fewer escape routes it has, the better it serves the principle of equality and stabilization. Stimulation of certain areas of economic activity is a widely recognized aim of special tax bonuses and escape routes. In practice, however, companies or individuals are much more likely to benefit in the planned system than the firms or individuals operating in a market system. In the current economy, it is considered proper to equally treat every form of enrichment, which means to use the standard tax rate, regardless of what follows from it ${ }^{30}$ (Galbraith, 1984: 423-425).

\section{Conclusions}

In carrying out complex analysis of the causes leading to the emergence of tax evasion and non-compliance with tax obligations, it is necessary to also accept the nature of non-economic determinants. Instability or turbulence of the conditions in the context of the economic milieu (e.g. frequent changes in the tax code) significantly increase the complexity of the disclosure of the real underlying cause of tax evasion and non-compliance with tax obligations. The apparent underlying cause of the emergence and existence of tax evasion is inherently taxation, that is, the introduction of taxes as such and the obligation to pay them. The decisive factors leading to the creation of tax evasion and non-compliance with tax obligations include the factors of economic-political nature within the meaning of the concept and implementation of the taxation policy as part of the economic policy of the State.

For a responsible and successful economy, an argument holds true that not just motives matter, what also matters are the outcomes. Taxation subjected entities would, therefore, not be interested in just what taxes and what amounts they are paying, but at the same time for what purposes the tax revenues are used, that is, whether the tasks (including the performance of the tasks of the social, educational, cultural nature) of the State ${ }^{31}$ and whether their performance is productive, whether it is directed to the development, expansion, and promotion of production, thus to

30 Or in the form of income from capital, income, inheritance, gift, etc.

31 State (its political, government representatives) would often try to increase or maintain their popularity in gaining as much as possible of the funds to the State budget, and their use is often uncontrollable effectively (e.g. a quasi "deferred tax", the repayment of the national debt is also necessary to consider - the taxation of future generations due to social and consumer waste - it is essentially a "hidden tax", indirect and progressive in time). 
the development of the national economy - good motives do not guarantee good economy). Successful economic management (both on the micro- and the macro levels) also includes an assessment of not just the intended consequences (e.g. the growth of aggregate supply), but also unintended but often serious side effects (e.g. response of the trade unions in redundancies of employees, environmental pollution, and some more).

Economic motives (sources) of non-performance of tax obligations and tax evasion are, inter alia, represented by high rates of taxation, insolvency, but also the efforts of economic entities (entrepreneurs) to maximize their profits ${ }^{32}$. Actions taken by entities and leading to the implementation of tax evasion contains an entire complex of factors and, therefore, to identify the root causes of tax evasion, taking an interdisciplinary approach is required - in this context, for example, German theorists in business ethics (e.g. K. Homann, H. Steinmann, A. Lohr) agree that they do not absolutely give the profit available to ethics - thus, under certain conditions, they allow priority to be given to profit (even at the expense of the reduction of taxes, non-compliance with tax obligations) - but this is a question for each individual or entity, their morality, and conscience - in that their freedom of expression and business is contained, but for what they carry their personal responsibility (Červená, Čipkár, 2017: 38-50).

An optimal taxation policy is a predominant prerequisite for the elimination of the reasons for the occurrence of tax evasion and non-compliance with tax obligations (at both national and supranational levels), which should be based on the classic principles of taxation and should also work in coordination with the measures to ensuring the elimination of undesirable economic activities of individual entities, including the politicians - the effect of optimization of taxation in practice is also influenced by several factors of a non-economic nature: political will, interest groups, morality of economic entities, the legal status (legal certainty ${ }^{33}$ or

32 In the national economies of the type of market-oriented and mixed economies, the achievement of maximum profit is considered the main motivator of the business and it is more than obvious that any kind of "restriction" (in the form of taxation, levies, etc.) in earning the maximum profit is, from a purely economic point of view, regarded a "brake" for the economic development.

In fact, we are very far from achieving legal certainty today, which stems from the inflation of legislation, as well as from the vast increase in the quasi legislative activities of the Government and the growing powers of the State officials - the paradox of our time is that we are governed by the people not because we are not being governed by law, but precisely because we are being governed by it. Today it seems to be the fate of the freedom of individual that it is protected by economists rather than by lawyers and politicians. The attention of the advocates of the legislation should be turned to the processes leading to final products (law standards) - legislation in democratic societies reflects merely the will of the majority within the group of the representatives of the citizens in the Parliament (legislators), who are often not better educated or "more enlightened" than those who had been outvoted. Another characteristic feature of the legislation in the current democratic societies is the belief that lawmakers in the legislative process represent the "thinking" of citizens. May their own justification be as it is, the fact is that representation, and in fact the legislation, is subject to completely different processes, compared to the ones that result in scientific and technological progress - despite all this, in legislation they constantly adopt decisions in a way different from the scientific realm (Leoni, 1991: 1-6). 
uncertainty, enforcement of law), but also individual and social expectations for the future.

\section{References}

Bujňáková, M. et al.: Dane a ich právna úprava v Slovenskej republike v kontexte daňovej politiky EÚ (Taxes and Their Regulation in the Slovak Republic in Context of Tax Policy of EU), Košice: Univerzita Pavla Jozefa Šafárika v Košiciach, 2015.

Bujňáková, M.: Je v Európe potrebná harmonizácia daní? (Is There A Need For Tax Harmonisation In Europe?) in: Vybrané otázky daňovej politiky Európskej únie a jej členských štátov (Selected Issues of Tax Policy of the EU and Its Member States), Košice: Univerzita Pavla Jozefa Šafárika v Košiciach, 2013.

Cakoci, K., Vojníková, I.: Východiská a prognózy miestnych daní (Bases and Prognoses of Local Taxes), in: Financie, účtovníctvo, dane 2014 so zameraním na súčasné problémy II. (Finance, Accounting, Taxes 2014, Focusing on Current Issues II.), Košice: Ekonomická univerzita v Bratislave, Podnikovohospodárska fakulta so sídlom v Košiciach, 2014.

Červená, K., Čipkár, J.: Etické a ekonomické aspekty hospodárskej politiky s akcentom na zdaňovanie v modernej dobe (The Ethical and Economic Aspects of Taxation in the Present Age), in: Dny práva 2016 - část III Karel Engliš - zdroj inspirace pro rozvoj práva i národního hospodářství (Days of Law 2016 - part III Karel Engliš - Source of Inspiration for Law Development and of the National Economy), Brno: Masarykova Univerzita, 2017.

Čipkár, J.: Daňová harmonizácia a daňová konkurencia (mýty a realita) (Tax Harmonisation and Tax Competition (Myth and Reality)), in: Vybrané otázky daňovej politiky EÚ a jej členských štátov (Issues of Tax Policy of the EU and its Memeber States), Košice: Univerzita Pavla Jozefa Šafárika v Košiciach, 2013.

Epstein, R.: A. Právo, ekonomie a politika (Law, Economics and Politics), Praha: Wolters Kluwer ČR, Cevro institut a liberální institut, 2010.

Eucken, W.: Grundsätze der Wirtschaftspolitik, sechste ausgabe (Principles of Economic Policy, Tübingen: J.C.B. Mohr, 1990), Praha: Liberální institut, 2004.

Galbraith, J.K.: Ekonómia a spoločenské ciele (Economics and the Public Purpose), Boston: Houghton Mifflin Company, 1973; Bratislava: Pravda, 1984.

Iša, J.: Nicholas Kaldor a postkeynesovstvo: teoretická a hospodárskopolitická alternatíva neoklasickej ekonómie (Nicholas Kaldor and Postkeynes: A Theoretical and EconomicPolitical Alternative to Neoclassical Economics), Ekonomický časopis (Journal of Economics) no. 9 (2006). www.ekonom.sav.sk.

Knespl, J.: Reforma daní př́ímých v zemědelství (Reform of Direct Taxes in Agriculture), Praha: Zemědělský ústav účetnicko-spravovědný Č.S.R., 1928.

Leoni, B.: Freedom and the Law, Indianapolis: Liberty Fund, 1991. 
Mitchell, J.D.: Daňová harmonizácia verzus konkurencia v Európskej únii (Tax Harmonization versus Competition in the European Union), in: Na obranu slobodného trhu (In Defense of the Free Market), Bratislava: Konzervatívny inštitút M.R. Štefánika, 2007.

Mises, L.: Lidské jednání: Pojednání o ekonomii (Human Action: A Treatise on Economics), translation Š́ma, J. et al.: Praha: Liberální Institut, 2006.

Piketty, T.: Le capital au xxi siécle (Capital in the 21st Century), Bratislava: Ikar, 2015.

Rahn, W. R.: Kl'úče na ceste k ekonomickému rastu a slobode a úloha vlády (Keys on the Road to Economic Growth and Liberty and the Role of the Government), in: Na obranu slobodného trhu (In Defense of the Free Market), Bratislava: Konzervatívny Inštitút M.R. Štefánika, 2007.

Románová, A.: Význam miestnych daní pre rozpočty územnej samosprávy (Importance of Local Taxes for Municipal Budgets), Miedzynarodowe Studia Spoleczno-Humanistyczne (International Social and Human Studies) no. 1 (2010).

Románová, A.: Miestne dane ako zdroj príjmov rozpočtov územnej samosprávy (Local Taxes as a Source of Local Budget Revenues), in: Verejné financie Slovenskej republiky - vybrané aspekty a tendencie vývoja (Public Finance of Slovak Republic - Selected Aspects and Development Trends), Košice: Univerzita Pavla Jozefa Šafárika v Košiciach, 2011.

Schultzová, A.: Daňové sústavy štátov európskej únie (Tax Systems of the States of the European Union), Bratislava: Ekonóm, 2010.

Stieranka, J., Sabayová, M., Šimonová, J.: Daňové úniky a daňová kriminalita v Slovenskej republike (Tax Evasion and Tax Crime in the Slovak Republic), Bratislava: Epos, 2016.

Šafránek, L.: Daně aneb cesta do otroctví? (Taxes or the Way to Slavery?) Praha: Orego productions, 2016.

Široký, J.: Daně v evropské unii (Taxes in the European Union), Praha: Linde, 2010.

Wallerstein, I.: European Universalism. The Rhetoric of Power, New York, London: The New Press, Praha: Slon, 2008. 



\title{
JURIDICAL INSTITUTE OF "FISCAL REPENTANT"
}

\author{
RICHARD BARTES
}

\begin{abstract}
The contribution deals with the French juridical institute of "fiscal repentant" in the context of the fight against tax evasions. The implementation of new organs and the system of sanctions are related to the mentioned juridical institute. The contribution is conceived interdisciplinary, it deals with issues of the French financial criminal law, as a part of the section of the French public finances. The contribution does not forget to mention one of the most infamous cases related to international tax evasions, so-called Panama Papers and the role of the presented French juridical institute of "fiscal repentant" in this case. Finally, the contribution contains a comparison between the French juridical institute of "fiscal repentant" and the juridical institute of effective penitence under the Czech penal code. The aim of the contribution is to confirm or disprove the hypothesis that the French juridical institute of "fiscal repentant" could be implemented into the Czech legal system. The analytical, comparative, as well as descriptive methods, were used in this paper, too.
\end{abstract}

\section{Keywords}

Fiscal repentant; tax law; tax evasions; tax amnesty

JEL Classification: D63, K34, K42

\section{Introduction}

France - or rather the French National Assembly as the lower chamber of the French Parliament - has adopted a number of laws designed to combat tax evasion

1 Ph.D. student of Financial Law, the Department of Financial Law and National Economy, Faculty of Law, Masaryk University, the Czech Republic. The Author specializes in the branch of French conception of public finance, or rather in the French public finance school which he compares to the Czech model of public finance. $\mathrm{He}$ is a member of the board of directors of the Alliance française in Brno. Contact email: 391896@mail.muni.cz. 
since 2012. These laws strengthen the powers of both the French financial, or customs, administration, as well as the police and the judicial system. The laws further strengthen collaboration between fiscal administration bodies and judicial bodies, as they increase the transparency of enforcement measures imposed by the fiscal administration. At the same time, sanctions against those who commit tax evasion have been consistently becoming increasingly stringent since 2012. All these measures are intended to strengthen the implementation of French public budgets. In the first 18 months alone (since the beginning of 2012), the government has adopted sixty new measures to curtail tax evasion in the area of financial crime.

The initial laws extending the powers of ${ }^{2}$, or the "tax police", introduced a new provision on aggravating circumstances, applicable to the most serious cases of tax fraud, or provisions Authorizing investigators to use "special investigative techniques". The various punishments include a prison sentence of up to seven years. A new institute of "fiscal repentant" was introduced: it involves, aside from the permanent obligation to pay the tax owed, more lenient pecuniary sanctions, provided that the taxpayer itself invokes the institute. This paper is dedicated precisely to this potentially inspiring institute which de facto constitutes a type of tax amnesty.

The aim of this paper is to introduce this juridical institute, including the context of the reasons for its introduction and its outcome which may be encountered by our entrepreneurs focusing on francophone countries in the pursuit of their business. The hypothesis of the paper is defined as "whether the French juridical institute of "fiscal repentant" could be implemented into the Czech legal system". The solution of this hypothesis including arguments is contained in the discussion of the contribution.

The analytical, comparative and descriptive methods were used to write this paper. French articles from reputed French periodicals focusing on economics and law (e. g. Les Echos) were used as sources for this paper. Among a lot of writings dealing with French tax law, it is necessary to mention for example the writing by Prof. Michel Bouvier (2016). Prof. Michel Bouvier is one of the most well-known and the most respected French experts on the French public finances. Finally, the current fiscale, BNRDF), is an investigatory unit under the central directorate of the criminal police of the French Ministry of Interior. It was established pursuant to Directive 2010-1318 of 4 November 2010, and unlike the French tax administration which is bound by bilateral agreements between countries, which impose certain restrictions although they permit exchange of information with foreign tax administrations, BNRDF, together with other departments of criminal police, can investigate (under the supervision of a judge) tax evasion, cooperate with criminal police of foreign states, and is not subject to limitations applicable to bodies of tax administration under the above-referenced agreements. In the course of its activities, it can use tools such as interrogation, seizure of assets, house searches, police custody, phone tapping, and file charges. 
Juridical Institute of "Fiscal Repentant"

data published by the Court of auditors (i.e. fr. Cour des Comptes) were used as a source of statistics used in the presented paper.

\section{Current Situation}

In a addition to their "traditional" statutory duty in the form of annual filing of tax returns, ${ }^{3}$ French taxpayers, if they have an account abroad, are also obliged under the law to disclose such "foreign"accounts to the French fiscal administration, and have other statutory duties in this context.

However, in practice, many taxpayers would not disclose their foreign accounts, and the French fiscal administration was frequently unable to learn of the accounts of such French taxpayers in a reliable manner. As a result, the system of French public budgets would lose several hundred million euros every year. However, it needs to be noted that this is not an exclusively French phenomenon but a phenomenon, the essence, and impacts of which are of a global nature. This was also the reason why in 2014, the Organization for Economic Co-operation and Development created a standard for automatic exchange of financial account information.

\section{3 "Fiscal Repentant" in Practice}

The practical implementation of this multilateral agreement on automatic exchange of financial account information is in progress. Not only France but also the Czech Republic and Slovakia have acceded to the agreement already. Thanks to the agreement, the French fiscal administration (to the full extent since 2018) will be able to obtain facts until then withheld by some of the French taxpayers. It is precisely the existence and actual enforceability of this multilateral agreement that is the key motivation for French taxpayers to reconsider their behavior voluntarily and to start complying with obligations imposed on them under French law (i.e. disclosure of their foreign accounts and the related payment of applicable public levies) for real. Although under the law, the payer does not need to be represented by an attorney in the process of "regularization" of the tax status, it is definitely recommendable to seek legal assistance. The procedure to be followed by the taxpayer is not easy, and includes inter alia the following:

- provision of information on accounts abroad;

- provision of a declaration on the origin of funds; 
- provision of information on income derived;

- an affidavit made in addition to the above.

Since the introduction of the "fiscal repentant" institute in 2013, more than 50,000 applications have been filed by French taxpayers, and the French fiscal administration had to process those. Therefore, in connection with the introduction of the institute, Department for the Processing of Voluntary Disclosures (fr. Service de traitement des déclarations rectificatives, in short STDR), operating throughout France, was set up. Although the French fiscal administration worked literally at full tilt, it was still unable to deal with the onslaught of these (at the time, still coming) taxpayers who suddenly started reporting themselves frantically, and the French fiscal administration was compelled to extend its department and staffing as a result. In the course of two years, the number of STDR's staff was increased by nearly a third.

The expansion of tax administration in this area was also motivated by the statute of limitations (or, to be more precise, by a term of preclusion), which, although it is a term of ten years, commenced running upon the filing of the fiscal repentant's application. While the legalization of the tax situation of the fiscal repentant's results in the obligation to pay all enforceable taxes (in particular income tax, property tax, and inheritance tax), as well as fines assessed, these "tax sinners" will avoid criminal prosecution they would otherwise be faced with. It can thus be noted that this institute, or rather, this procedure helps to "right" a society which has thus far been distorting the freedom of movement, or rather, which has been interpreting same (in a broader sense of the word) overly extensively in the context of the French legal order.

The French fiscal administration, or the law, distinguishes two categories of "fiscal repentants": taxpayers engaging in fraud actively, and taxpayers engaging in fraud passively. The passive ones "only" benefit from accounts previously established abroad (they had established the account while working or living abroad, inherited it or received same as a gift). This group of taxpayers is subject, in addition, to the obligation to pay the concealed tax, to a sanction: originally, $15 \%$, and since 2016 , $2 \%$ of the concealed, and thus unpaid, taxes.

French taxpayers actively involved in fraud were persons who had actively organized their tax evasion and transferred untaxed amounts to their foreign accounts. These were threatened with a sanction of $30 \%$, and now $35 \%$ of the amount of concealed tax (the higher rate applied to tax regularization applications filed after 16 September 2016). 
Although in 2016, the sanctions applicable to French taxpayers engaged in fraud who voluntarily invoked the fiscal repentant institute were increased, even the higher sanctions are still much lower than sanctions to be imposed on taxpayers engaged in fraud who have kept quiet thus far and who will be detected by the French fiscal administration. These other taxpayers engaged in fraud who will be caught and convicted of a violation of the law are faced with a sanction of up to $80 \%$ of the total amount of taxes concealed, and may further be faced with criminal prosecution. Criminal prosecution of such taxpayer may ultimately result in a prison sentence of up to seven years in extreme cases. This more stringent approach, adopted at the initiative of the French finance minister Bercy, reflects a decision of the Constitutional Council of July 2015 (Constitutional Council: 2016/554). The relevant decision prohibited, or found to be anti-constitutional, a provision pursuant to which taxpayers could be given a fixed fine of 5\% of the amount deposited in an undisclosed account abroad, where there was over EUR 50,000 in the account. In its decision, the Constitutional Council described the sanction as "manifestly disproportionate to the gravity of the situation". The newly increased sanctions thus ought to compensate this deficit in income, and was reflected in the 2017 state budget.

\section{4 "Fiscal Repentant" and the Panama Papers}

One of the most interesting issues in the last three years was the case of the Panama Papers. In this case, it would be interesting to make a comparison between French taxpayers and Czech taxpayers, or more precisely the role of the French juridical institute of "fiscal repentant" in this infamous issue.

First of all, it is important to mention in this comparison the huge difference in the number of inhabitants of France and the Czech Republic. In 2016, France had almost 67 million inhabitants, while the Czech Republic had 10,5 million inhabitants in the same year. It means that France had (and still has) 6 times more inhabitants than the Czech Republic. If we focus on the number of persons figuring in the Panama Papers list we can find there 272 Czech persons and 1284 French persons. ${ }^{4}$ At the first sight, these values nearly correspond with the ratio of the number of inhabitants in France to the number of inhabitants in the Czech Republic (it means 6 times more inhabitants in France than in the Czech Republic). But in fact, only 560 French taxpayers of the mentioned total number of French taxpayers (i.e. 1284 in total) have begun checked by French authorities. Another 724 French tax payers also used bank accounts abroad, but they were already known to French fiscal administration,

$4 \quad$ It could be mentioned for a better illustration that in the Panama papers list there are for example 600 persons from Denmark or 108 persons from Iceland. 
who created in 2013 already mentioned STDR. These French taxpayers made use of the opportunity of the juridical institute of "fiscal repentant" and they made a request to the STDR to regularize of their tax situation. Thanks to the utilization of this tax amnesty sui generis these French taxpayers not only saved public funds for their revealing and after that their prosecution but also helped to give concealed taxes back to the state budget sooner.

In other words, more than a half of all French taxpayers concealing their funds abroad voluntarily made use of this tax amnesty and regularized their tax situation (settled owed taxes and paid milder pecuniary sanctions). Thanks to this tax amnesty France reduced the number of fraudsters who are prosecuted nowadays. France gained its public funds quickly, efficiently and "cheaply". This is the best sign of the importance, success, and usefulness of this tax amnesty. In this context, it could be noted that at the beginning of November 2017 we could notice another similar case - the Paradise Papers. ${ }^{5}$ The essence of Paradise Papers is the same as the essence of Panama Papers. A lot of among others famous persons or companies of the world figured on the list of entities linked to tax evasions into tax heavens. Although the Paradise Papers case is later than the Panama Papers case, French entities figuring in the Paradise Papers list could make use of the juridical institute of "fiscal repentant" just as French entities figuring in the Panama Papers list. The deadline for self-reporting to the French fiscal administration (the STDR) is the end of 2018 .

\section{Tax Amnesty or Institute of Effective Penitence?}

It can be noted in this context that this type of tax amnesty does not equal the Institute of effective penitence under Czech criminal law for at least three main reasons.

The first reason is that the effective penitence is the Institute for fraudsters who have already been revealed by the state authority. When the fraudster is charged, he can use the Institute of the effective penitence for the extinction of his penal liability. On the other hand the Institute of "fiscal repentant" consist in selfreporting to the French fiscal administration for the purpose of the regularizing personal fiscal situation at the moment when fraudsters are not yet known to the French fiscal administration.

The second reason why the Institute of effective penitence is different from the Institute of "fiscal repentant" is the fact of diverse course and termination of their 
procedure. When the accused (the taxpayer) decides to make use of the Institute of effective penitence during the penal procedure it means that the penal procedure has already begun and the accused (the taxpayer) pays the sum of money which he has to pay. Afterward, the penal court pronounces the decision not to prosecute. On the other hand in the case where a taxpayer uses the juridical institute of "fiscal repentant", none of the procedures have taken place before. The particular fiscal procedure begins at the moment when the taxpayer applies for the regularization of his fiscal situation. In this case, the fiscal procedure lasts until the taxpayer pays allowed taxes and sanctions.

The last reason, or rather the third difference between the juridical institute of "fiscal repentant" and the Institute of effective penitence under Czech criminal law resides in the breadth of concerning subject. On the one hand, the French tax amnesty only concerns to concealed taxes, on the other hand, the Institute of effective penitence under Czech criminal law relates to not only unpaid taxes but also unpaid social insurance payments or other unpaid similar obligatory payments. ${ }^{6}$ For these reasons, it is not possible to confuse these different juridical institutes, although they seem to be similar at the first sight.

\section{Discussion}

According to the latest statistics, French taxpayers have filed more than 50,000 applications for tax regularization, and nearly EUR 27 billion, currently located abroad and until then not disclosed in any way and, literally, "stepped out of the dark". According to prognoses, this amount will not increase significantly pro futuro; nonetheless, less than 25,000 cases have been processed so far. Of this amount, the French state has to date extracted over EUR 8 billion (EUR 110 million in the course of 2013, EUR 1.9 billion in 2014, EUR 2.6 billion at the end of 2015, EUR 2.7 billion in 2016, EUR 1.2 billion in 2017). 91\% of those funds were located in Switzerland, the balance in countries such as Luxembourg, Hong Kong, Singapore, Andorra, Monaco, USA, and England.

Although the amount "rescued" is considerable, the organization Solidary Public Finance reiterated that tax fraud costs the Republic of France between 60 and 80 billion euro in lost profits. The five biggest, or most serious, cases which involved supranational companies and amounted to EUR 3.3 billion included the giants Apple and Google. While Google agreed on a solution of its situation in England with the British fiscal administration in the spring of 2015, de facto by

6 For example premiums for pension savings, social security contributions, the contribution to the state employment policy, health insurance premiums. 
circumventing English law, the French fiscal administration was contrary to that strict in its application of the law to Google and did not admit any agreements, relief or exemptions. Apple was a little less "lucky" in that; it had to pay outstanding tax not only in France (once again, due to a strict application of the law) but also to the government of Ireland, due to a decision of the European Commission. Pursuant to the decision, Apple had to pay EUR 13 billion for extensive unAuthorized tax relief.

Regarding the hypothesis defined in the abstract (whether the French juridical institute of "fiscal repentant" could be implemented into the Czech legal system), or rather in the introduction of the paper, it is necessary to base on the crucial fact that the Czech Republic has already acceded to the multilateral agreement on automatic exchange of financial account information as France has already done. That is the most important prerequisite for the successful and effective implementation of this tax amnesty in the Czech Republic. If there is no instrument like the automatic exchange of financial account information, it does not worth implementing the tax amnesty like the juridical institute of "fiscal repentant" into the Czech legal system because for one thing a fiscal administration does not get a chance to learn about bank accounts located abroad which means that a fiscal administration cannot claim concealed taxes and for another taxpayers are not motivated to uncover their classified funds or more precisely to pay concealed taxes. The biggest motivation for French taxpayers who were concealing their funds from the French fiscal administration is the opportunity to avoid criminal prosecution, or rather up to seven years imprisonment. Taxpayers who do not pay taxes in accordance with the Czech legal order are liable to the prison sentence up to three years (or even up to ten years if the amount of reduced taxes is higher than 5 million crowns) whereas in France there is a threat of imprisonment up to seven years, if the taxpayer is found guilty. In my point of view the sentences are quite similar to each other in both countries, therefore it could be concluded that the legislature's approach is similar.

Moreover, the regular collecting of public funds should be the major objective of public interest with regard to making budget full. The Czech Republic - or rather the Czech previous cabinet $(2014$ - 2017) has proved this fact during the last three years when the electronic registration of sales or VAT control statements were implemented into the Czech tax legal system. These mentioned measures have helped to return several billions of Czech crowns into the Czech state budget. After the autumn elections in 2017, the Czech general public can expect a continuation of these measures or an implementation of other measures.

In my point of view, conditions and prerequisites for the implementation of the juridical institute of fiscal repentant in the Czech legal system are satisfied. In other words, there is no significant reason why the mentioned juridical institute could not be implemented into the Czech legal system. While there is no doubt that this form 
of tax amnesty is interesting, the question also is whether it is sufficiently effective. Its effectiveness is related to the time that the French fiscal administration has to concentrate on the processing of these cases. And as already mentioned before, there is a statute of limitations period of 10 years. However, this period is not the key aspect playing the primary role in this cases. However, the primary role is the fact that according to hitherto experience and prognoses, the remaining (and more demanding) cases will take 3 to 5 years, while STDR, according to minister Bercy, will cease operating in 2018 already.

It is not unlikely that a more effective solution might be inspired by a different, but also French, tax amnesty. The tax amnesty boasts a rich past because it was introduced by general Charles de Gaulle in 1958. It involved one of the "national loans" bearing the name of A. Pinay - Emprunt Pinay. ${ }^{8}$ Its principle was very simple - property could be "legalized" through a fixed tax (around 5\% at the time) if invested into the national loan. France was able to repay its entire debt to the International Monetary Fund as a result.

\section{Conclusions}

The above description of this type of the French tax amnesty gives rise to the question whether the fiscal repentant institute or perhaps a modified form of tax amnesty, could serve as an inspiration in the enhanced fight against tax evasion in this country in the future. Such legal tool, with the way the applicable sanctions (whether pecuniary or other) is set up at present, could be incorporated into the national legal order because just like France, the Czech and Slovak Republics have also acceded to the multilateral agreement on automatic exchange of financial account information.

If the relevant legislative changes were made, it would be only a matter of time before local taxpayers who have been "rather relaxed" about their tax obligations would start invoking the amnesty voluntarily, contributing their taxes voluntarily to the national public budgets. France is an excellent example illustrating the actual fight against tax evasion, as well as an example showing that tangible results can be attained over a relatively short period of time.

7 national loans have played a relatively important and traditional role in France. A loan of 30 million, approved by the National Assembly in 1789, i.e., during the reign of Luis XVI, can be seen as one of the first loans of this kind. The Republic of Frances used these loans at war times to stabilize public finance and to carry out government projects at times of peace.

8 A loan approved in 1952 by Antoine Pinay, Prime Minister of the IV The French Republic at the time. The loan was guaranteed by gold, bore interest at $3.5 \%$, as compared to the $7-8 \%$ traditional at the time. Interest was exempt from income and inheritance tax. The loan was subscribed in the amount of 428 billion. 
Thus the presented contribution should be the interesting inspiration for (not only) national legislators how to make collecting owed taxes more efficient, quick and inexpensive. The paper also serves as the specialized view of the current situation in the branch of the French tax law and shows to readers new and interesting juridical institute from abroad.

Here we may conclude that the aim of the paper has been fulfilled. The point and the role of the juridical institute of "fiscal repentant" were introduced in the paper. There were presented and discussed and complemented by statistics and experience with this tax amnesty in France.

The contribution showed the significance of the French juridical institute of "fiscal repentant" in one of the most infamous cases in the contemporary world - the Panama Papers. Within the comparison the paper showed the influence of this tax amnesty on the amount of the taxpayers who had their bank accounts abroad and who made use of the opportunity of the juridical institute of "fiscal repentant" and they made a request to the STDR to regularize of their tax situation.

The paper also presented the comparison between the French juridical institute of "fiscal repentant" and the juridical institute of effective penitence under the Czech penal law because these institutes could seem similar at the first sight. In the paper, there were two principal reasons given why it is necessary to distinguish between these institutes.

The hypothesis, which was defined in the abstract, or rather in the introduction of the paper as the "French juridical institute of «fiscal repentant» could be implemented into the Czech legal system", was confirmed. As already mentioned, since the Czech Republic has already acceded to the multilateral agreement on automatic exchange of financial account information, the most important prerequisite for the successful and efficient implementation into the national legal system is satisfied.

With regard to the public interest of each country which (besides other things) focus on making the public budgets full, the implementation of such a tax amnesty into the legal order is to each state's profit.

\section{References}

Bouvier, M.: Introduction au droit fiscal général et à la théorie de l'impôt (Introduction to General Tax Law and Tax Theory), Paris: L.G.D.J., 2016.

Castagnet, M.: Bercy durcit les pénalités pour les repentis fiscaux (Bercy hardens penalties for fiscal repentants), La Croix (2016). www.la-croix.com. 


\section{Juridical Institute of "Fiscal Repentant"}

Monassier, B.: Repentis fiscaux: jouons plutôt la carte de l'amnistie (Fiscal repentance: let's play the amnesty card instead), Les Echos (2016). www.lesechos.fr.

Pirenay, A.: France probes 560 people over Panama Papers tax fraud, The Local (2016). www. thelocal.fr.

Rabreau, M.: Comment Bercy gére l'afflux des repentis fiscaux (How Bercy manages the influx of fiscal repentants), Le Figaro (2016). www.lefigaro.fr.

CZ: Constitutional Council: no. 2016/554. 


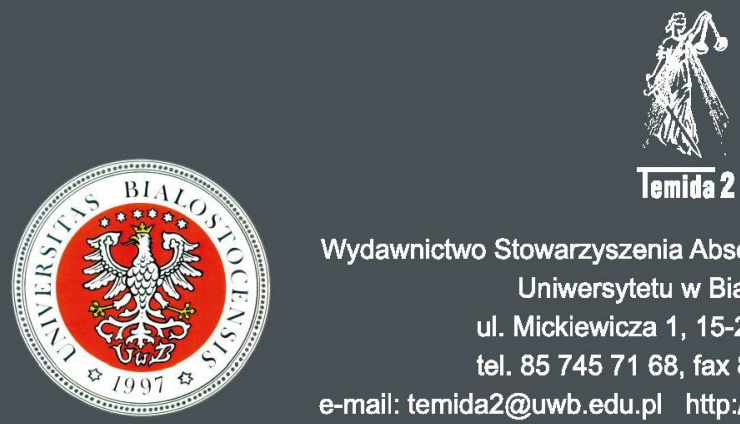

Wydawnictwo Stowarzyszenia Absolwentów Wydzialu Prawa Uniwersytetu w Bialymstoku

ul. Mickiewicza 1, 15-213 Bialystok tel. 857457168 , fax 857406089

e-mail: temida2@uwb.edu.pl http:/www.temida2.uwb.edu.pl

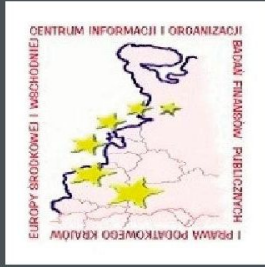

